\title{
Redelijkheid en billijkheid in kapitaalvennootschappen : beschouwingen rond aandeelhouders en bestuurders in rechtsvergelijkend perspectief
}

Citation for published version (APA):

Koelemeijer, M. (1999). Redelijkheid en billijkheid in kapitaalvennootschappen : beschouwingen rond aandeelhouders en bestuurders in rechtsvergelijkend perspectief. [Doctoral Thesis, Maastricht University]. Universiteit Maastricht. https://doi.org/10.26481/dis.19991210mk

Document status and date:

Published: 01/01/1999

DOI:

10.26481/dis.19991210mk

Document Version:

Publisher's PDF, also known as Version of record

Please check the document version of this publication:

- A submitted manuscript is the version of the article upon submission and before peer-review. There can be important differences between the submitted version and the official published version of record.

People interested in the research are advised to contact the author for the final version of the publication, or visit the DOI to the publisher's website.

- The final author version and the galley proof are versions of the publication after peer review.

- The final published version features the final layout of the paper including the volume, issue and page numbers.

Link to publication

\footnotetext{
General rights rights.

- You may freely distribute the URL identifying the publication in the public portal. please follow below link for the End User Agreement:

www.umlib.nl/taverne-license

Take down policy

If you believe that this document breaches copyright please contact us at:

repository@maastrichtuniversity.nl

providing details and we will investigate your claim.
}

Copyright and moral rights for the publications made accessible in the public portal are retained by the authors and/or other copyright owners and it is a condition of accessing publications that users recognise and abide by the legal requirements associated with these

- Users may download and print one copy of any publication from the public portal for the purpose of private study or research.

- You may not further distribute the material or use it for any profit-making activity or commercial gain

If the publication is distributed under the terms of Article 25fa of the Dutch Copyright Act, indicated by the "Taverne" license above, 


\section{REDELIJKHEID EN BILLIJKHEID IN KAPITAALVENNOOTSCHAPPEN}





\section{REDELIJKHEID EN BILLIJKHEID IN KAPITAALVENNOOTSCHAPPEN}

Beschouwingen rond aandeelhouders en bestuurders in rechtsvergelijkend perspectief

\section{PROEFSCHRIFT}

ter verkrijging van de graad van doctor aan de Universiteit Maastricht te Maastricht

op gezag van de Rector Magnificus, Prof.dr. A.C. Nieuwenhuijzen Kruseman volgens het besluit van het College van Decanen, in het openbaar te verdedigen op vrijdag 10 december 1999 om 14.00 uur

door

Marjan Koelemeijer 
Promotores: Prof.mr. H-J. de Kluiver

Prof.mr. C.A. Schwarz

Beoordelingscommissie: Prof.mr. J.H.M. van Erp (voorzitter)

Prof.mr. F.J.P. van den Ingh (Katholieke Universiteit Nijmegen)

Prof.mr. A.L. Mohr (Universiteit van Amsterdam)

Prof.mr. L. Timmerman (Rijksuniversiteit Groningen)

Prof.mr. J.M.F. Wouters 


\section{Voorwoord}

Een proefschrift schrijven is een hele onderneming, maar wel een boeiende en bloeiende onderneming. Zeker als het onderwerp daarvan de redelijkheid en billijkheid in kapitaalvennootschappen betreft.

Graag maak ik van de gelegenheid gebruik om een aantal betrokkenen bij die onderneming te bedanken. Allereerst geldt dit voor mijn promotores, Prof.mr. H.J. de Kluiver en Prof.mr. C.A. Schwarz. Beiden hebben mij in de afgelopen jaren aangemoedigd en gesteund bij het verrichten van het onderzoek. Ik dank Prof.mr. H.J. de Kluiver tevens voor zijn inspirerende begeleiding en de vele uren die hij, ondanks zijn drukke bezigheden, voor mij heeft uitgetrokken. Mijn dank gaat ook uit naar de leden van de leescommissie voor hun bereidheid het manuscript te beoordelen.

Voorts ben ik dank verschuldigd aan de voorzitter van de capgroep Privaatrecht, Prof.mr. G.R. de Groot, op wiens steun ik altijd heb kunnen rekenen en aan Jos Hamers en Stephan Rammeloo, mijn dierbare collega's van de sectie handels- en ondernemingsrecht, die mij vandaag als paranimfen ter zijde staan. Ook gaat mijn dank uit naar Ine Corstjens voor de mooie opmaak van het boek en naar Wies Rayar voor de professionele vertaling van de samenvatting van dit boek in het Engels.

Ten slotte wil ik in het bijzonder bedanken mijn ouders, mijn zus Kitty en Jeroen. Jeroen dank ik voor zijn steun en begrip dat mijn onderzoek zoveel privétijd in beslag heeft genomen. Mijn ouders en mijn zus Kitty zijn onmisbaar. Kitty heeft mijn belangstelling voor het wetenschappelijk onderzoek gewekt. Zij is mijn beste vriendin. Mijn moeder is mijn grootste steun en toeverlaat. Aan mijn ouders draag ik dit boek op.

Het onderzoek werd afgesloten op 1 maart 1999. Hetgeen daarna verscheen aan literatuur en jurisprudentie is slechts incidenteel verwerkt.

Marjan Koelemeijer 



\section{INHOUD}

Lijst van afkortingen

Verkort aangehaalde werken

I Inleiding; voorwerp van onderzoek

II Onderzoekmethode; rechtsvergelijking

III Plan van behandeling

Hoofdstuk 1 De ontwikkeling van de goede trouw in kapitaalvennootschappen in Nederland

1. Inleiding

2. Periode 1838 tot en met 1928: goede trouw in het verbintenissenrecht; een schets

$2.1 \quad$ Artt. 1374, 1375 BW en de contractleer.

2.2 Geringe bijdrage van de wetgever

3. Rechtspraak en doctrine in de periode 1900 tot 1945 nader bezien 10 3.1 Ava: misbruik van meerderheidsmacht en goede trouw 11

3.2 Misbruik van bevoegdheid, goede trouw en bestuur 15

4. Ontwikkelingen in de rechtspraak na 1945: ontkoppeling van verbintenissen- en vennootschapsrecht

4.1 Rond de ava

4.2 Rond het bestuur

5. Goede trouw in de periode van 1976 tot 1992: art. 2:7 BW en art. 2:11 BW

6. De periode na 1992: art. 2:8 BW en 2:15 BW

7. Betekenis en functies van de goede trouw in het verbintenissen- en rechtspersonenrecht

7.1 Betekenis van de goede trouw en (redelijkheid en billijkheid)

7.2 Functies van de goede trouw

8. Betekenis en functie van de redelijkheid en billijkheid na $1992 \quad 28$

9. Redelijkheid en billijkheid, misbruik van recht en misbruik van bevoegdheid

9.1 Misbruik van bevoegdheid

9.2 Billijkheid, misbruik en marginale toetsing 
10. Toetsing in (en aan) jurisprudentie

10.1 Misbruik van recht en misbruik van bevoegdheid in de jurisprudentie

10.2 Redelijkheid en billijkheid in de jurisprudentie

11. Slotbeschouwing

Hoofdstuk $2 \mathrm{BV}$ en NV in vergelijkend perspectief

1. Algemene typering

2. Vennootschappelijke organisatiestructuur 51

3. Reikwijdte, betekenis en functies van de 'goede trouw' 52

3.1. 'Goede trouw' begrippen; terminologie 52

3.2 Reikwijdte toetsing aan redelijkheid en billijkheid 57

4. Toepassing goede trouw beginselen nader bezien 60

$\begin{array}{ll}4.1 & \text { Treupflicht in Duitsland } \\ 4.2\end{array}$

4.2 Fiduciary duties in Engeland 63

4.3 Frankrijk; abus de majorité/abus de minorité 66

5. De rechterlijke mogelijkheden tot ingrijpen 67

5.1 Engeland; section 459 Companies Act 198567

5.2 Frankrijk; 'direct' en 'indirect' ingrijpen door rechter 71

I. 'Direct ingrijpen' 71

II. 'Indirect ingrijpen' 72

$\begin{array}{lll}5.3 & \text { Duitsland } & 75\end{array}$

6. Slotbeschouwing $\quad 77$

DEEL I VERHOUDING MEERDERHEIDSAANDEELHOUDER(S) - MINDERHEIDSAANDEELHOUDER(S)

Hoofdstuk 3 Gedrag en besluitvorming in de algemene vergadering

1. Inleiding

2. Redelijkheid en billijkheid $\quad 82$

3. Rond de oproeping 83

3.1 Bevoegdheid; wettelijke mogelijkheden 84

3.2 Wettelijke mogelijkheden in rechtsvergelijkend perspectief

3.3 Wijze van oproeping 
4. Met betrekking tot de agendering $\quad 90$

5. Tegenvoorstellen en overleg 92

6. Behandeling agendapunten/verdaging van de vergadering 96

7. Besluitvorming 99

7.1 Deelname, spreekrecht, stemrecht en tegenstrijdig belang

7.2 Stemrecht nader bezien

8.1 Herziening stemgedrag

8.2 Heroverweging en intrekking van besluiten

9. Slotbeschouwing

\section{Hoofdstuk 4 Volmacht en stemovereenkomsten}

1. Aandeelhouders en volmacht

1.1 De aandeelhouder/volmachtgever

1.2 Gedrag van de gevolmachtigde

1.3 Gedragsregels gevolmachtigde: informatie- en overlegplicht

1.4 Proxy praktijken in publieke vennootschappen in de Verenigde Staten, Engeland, Duitsland en Frankrijk

1.5 Beoordeling stemgedrag gevolmachtigde in het kader van proxy solicitation

1.6 Rechtsgevolgen stemgedrag gevolmachtigde: toerekenen en afrekenen?

2. Aandeelhouders en stemovereenkomsten

2.1 Stemovereenkomsten tussen aandeelhouders; criteria

2.3 Stemovereenkomsten tussen aandeelhouders en derden nader bezien

2.4 Invloed van stemovereenkomsten op de rechtsverhouding tussen aandeelhouders

2.5 Stemovereenkomsten en (toekomstige) aandeelhouders 


\section{Hoofstuk 5 Statutenwijziging}

1. Inleiding

2. Gevolgen: aantasting belangen minderheid

3. Goede grond of compensatie

4. Duitsland, Engeland en Frankrijk

4.1 Duitsland

4.2 Engeland

4.3 Frankrijk

5. Wijziging blokkeringsregeling

6. Verlies van stemrecht

7. Slotbeschouwing

\section{Hoofdstuk 6 Winstreservering}

1. Inleiding

2. In geding zijnde belangen

2.1 Belang (minderheids)aandeelhouders

2.2 Belang vennootschap

2.3 Afweging van de belangen

3. Criteria in buitenlands recht: belang vennootschap/ bedrijfseconomische positie

3.1 Franse benadering

3.2 Duitse benadering

3.3 Engelse benadering

4. Nederlands recht

5. Andere factoren dan de bedrijfseconomische positie

5.1 Systematisch winst reserveren/'dividend-verleden'

5.2 Verhouding winst - dividend

5.3 Verhouding dividend en directietantième (en andere bestuurdersbeloningen)

6. Vaststelling redelijk dividend: taak voor de rechter? 184

6.1 Opvattingen in Nederland

6.2 Opvattingen in Engeland, Duitsland, Frankrijk en Spanje

I. Een rol voor de rechter

II. Een rol voor de wetgever?

7. Slotbeschouwing 


\section{DEEL II VERHOUDING AVA - BESTUUR}

Hoofdstuk 7 Invloed van en instructie door aandeelhouders

1. Inleiding

2. Relatie ava - bestuur nader bezien: bevoegdhedenverdeling 196

2.1 Duitsland

2.2 Frankrijk

200

2.3 Engeland

3. Instructierecht ava ?

4. Eigen opvatting instructierecht

5. Instructierecht ava bezien naar Engels en Duits recht

5.1 Engeland

5.2 Duitsland

6. Grenzen invloed ava op bestuur; eigen opvatting

7. Aansprakelijkheid voor meerderheidsaandeelhouder?

8. Slotbeschouwing

Hoofdstuk 8 Benoeming van bestuurders

1. Inleiding

2. Wie komt voor benoeming in aanmerking?

3. Bindende voordracht

4. Problematiek rond kwaliteitseisen

5. Invloed van afspraken omtrent benoeming

6. Slotbeschouwing

\section{Hoofdstuk 9 Schorsing en ontslag van bestuurders}

1. Inleiding

2. Ontslag; een betwiste kwestie

3. Arbeidsrecht en vennootschapsrecht

4. Enige opmerkingen over het Engelse, Duitse en Franse recht 244

5. Hoorrecht en stemrecht

5.1 Hoorrecht bestuurder?

5.2 Stemrecht bestuurder? 
6. Toetsing ontslagbesluit aan materiële normen 254

7. IJkpunten voor toetsing schorsingsbesluit 255

8. Vergelijking met ontslagbesluit: discussie $\quad 257$

9. Vergelijking met buitenlands recht 259

10. 'Goede gronden' nader bezien 263

11. Slotbeschouwing 267

\section{Hoofdstuk 10 Bestuurders en Corporate Opportunities}

1. Inleiding

2. Grondslag toetsing corporate opportunities in de Verenigde Staten, Duitsland en Engeland

3. Nederland: art. 2:8 of art. 2:9 BW?

4. Wat is een corporate opportunity?

5. Indeling in categorieën

6. Beoordeling gedrag bestuurders: structuur van de vennootschap 286

7. Geoorloofd gebruik: 'toestemming' of 'goedkeuring' 288

8. Rechtsgevolgen ingeval van ongeoorloofd gebruik corporate opportunities

8.1 Schade, schadevergoeding en acties door aandeelhouders

9. Winstclaim bestuurder?

10. Slotbeschouwing

\section{DEEL III VERHOUDING TUSSEN BESTUURDERS}

\section{Hoofdstuk 11 Besluitvorming en gedrag binnen het bestuur}

1. Inleiding

2. Uitoefening van bevoegdheden binnen bestuur: delegatie, mandaat en instructie

2.1 Taakverdeling en verantwoordelijkheid

2.2 Instructie en collectieve verantwoordelijkheid

2.3 Delegatie en collectieve verantwoordelijkheid

2.4 Mandaat en collectieve verantwoordelijkheid

3. De rol van de bestuursvoorzitter nader bezien

4. Informatie en overleg 
5. Gedrag van bestuurders: afwezigheid ter vergadering 322

5.1 Is een 'bestuurdersvolmacht' zinvol? 323

5.2 Toelaatbaarheid volmacht 324

5.3 Gedrag gevolmachtigde $\quad 325$

6. Schriftelijke besluitvorming 326

7. Slotbeschouwing 327

Hoofdstuk 12 Afsluitende beschouwing

1. Inleiding 331

2. Redelijkheid en billijkheid in rechtsvergelijkend perspectief 331

2.1 Functioneel vergelijkbare rechtsfiguren

3 Verhouding tussen meerderheids- en minderheidsaandeelhouder(s)

3.1 Toetsing van (behoorlijkheid van) besluitvorming 333

3.2 Toetsing van de inhoud van besluiten 334

4 Verhouding ava en bestuur 336

5. Verhouding tussen bestuurders 338

5.1 Betekenis en functie 338

6. Toetsing aan de redelijkheid en billijkheid; relevante factoren 339

6.1 Hoedanigheid van betrokkenen bij een belangenconflict $\quad 340$

6.2 Invloed van betrokkene(n) 341

6.3 Dubbelrollen/tegenstrijdig belang 342

6.4 Aard/inhoud van het besluit 342

6.5 Gevolgen van een besluit c.q. gedraging voor
betrokkene(n)

6.6 Compensatie van de gevolgen van een besluit 343

6.7 Karakter van de vennootschap $\quad 344$

I. Verhouding tussen aandeelhouders 344

II. Verhouding tussen ava en bestuur/bestuurders $\quad 346$

6.8 Aandeelhoudersovereenkomsten 346

$\begin{array}{ll}\text { 7. Afronding } & 347\end{array}$ 
Inhoud

Summary

Geraadpleegde literatuur

Zakenregister

Rechtspraakregister

Curriculum Vitae 


\section{Lijst van afkortingen}

$\begin{array}{ll}\text { AA } & \text { Ars Aequi } \\ \text { ABLR } & \text { Australian Business Law Review } \\ \text { Abs. } & \text { Absatz } \\ \text { AC } & \text { Appeal Cases, House of Lords, Law Reports } \\ \text { AcP } & \text { Archiv für die civilistische Praxis } \\ \text { AG } & \text { Aktiengesellschaft; die Aktiengesellschaft } \\ & \text { (tijdschrift) } \\ \text { A-G } & \text { Advocaat-Generaal } \\ \text { AktG } & \text { Aktiengesetz } \\ \text { al. } & \text { alinea } \\ \text { ALI } & \text { American Law Institute } \\ \text { All ER } & \text { All England Law Reports } \\ \text { ALR } & \text { American Law Reports } \\ \text { Anm. } & \text { Anmerkung } \\ \text { art. } & \text { artikel } \\ \text { ava } & \text { algemene vergadering van aandeelhouders } \\ \text { BB } & \text { Der Betriebs-Berater } \\ \text { Bb } & \text { Bedrijfjuridische berichten } \\ \text { BCC } & \text { British Company law Cases } \\ \text { BCLC } & \text { Butterworth's Company Law Cases } \\ \text { BGB } & \text { Bürgerliches Gesetzbuch } \\ \text { BGH } & \text { Bundesgerichtshof } \\ \text { BGHZ } & \text { Entscheidungen des Bundesgerichtshofs in } \\ \text { BRDA } & \text { Zivilsachen } \\ \text { Bull.Joly } & \text { Bulletin Rapide de Droit des Affaires } \\ \text { BV } & \text { Bulletin mensuel d'information des sociétés } \\ \text { BW } & \text { Besloten Vennootschap } \\ \text { CA } & \text { Burgerlijk Wetboek } \\ \text { Can.Bar.Rev. } & \text { Court of appeal; Companies Act } \\ \text { Cass.com. } & \text { Canadian Bar Review } \\ \text { Ch. } & \text { Cour de Cassation, chambre commerciale } \\ \text { CLJ } & \text { Chancery Division, Law Reports } \\ \text { COB } & \text { The Cambridge Law Journal } \\ \text { Co } & \text { Commission des Opérations de Bourse } \\ \text { curs. } & \text { Corporation } \\ & \end{array}$


D.

DB

Décret

diss.

DLR

DStR

ed.

F.

F. 2d

FS

G

Gaz. Pal.

$\mathrm{GmbH}$

GmbHG

GmbHR

HGB

HR

ICCLR

Inc.

J

JAR

JBL

JCP

JCP, éd. E.

JOR

JZ

KG

L. 1966

LG

Ltd.

LQR

MLR

m.n.

MvT

NCPC

NJ
Recueil de jurisprudence Dalloz/Décret

Der Betrieb

Décret nr. 67-236 du 23 mars sur les sociétés commerciales

dissertatie/dissertation

Dominion Law Reports

Deutsches Steuerrecht

editie/editor

Federal Reporter

Federal Reporter, Second Series

Festschrift

Gesetz

Gazette du Palais

Gesellschaft mit beschränkter Haftung

GmbH-Gesetz

GmbH-Rundschau

Handelsgesetzbuch

Hoge Raad

International Company and Commercial Law Review

Incorporation

Judge

Jurisprudentie Arbeidsrecht

Journal of Business Law

Jurisclasseur Périodique (édition Générale)

Jurisclasseur Périodique (édition Entreprise)

Jurisprudentie Onderneming \& Recht

Juristenzeitung

Kommanditgesellschaft/Kort Geding

Loi nr. 66-537 du 24 juillet 1966 sur les sociétés commerciales

Landgericht

Limited

Law Quarterly Review

Modern Law Review

met name

Memorie van Toelichting

Nouveau Code de Procédure Civile

Nederlandse Jurisprudentie 
NJB

NJW

NV

N.W.

N.W.2d

OK

OLG

RCJB

Rev.Jur.Com.

Rev.trim.dr.com.

Rev.Soc.

RG

RvdW

RW

s.

SA

SARL

SaS

S\&V

t.a.p.

TPR

TRV

TVVS

VW

W.

WLR

WM

WPNR

WvK

ZGR

ZHR

ZIP
Nederlands Juristenblad

Neue Juristische Wochenschrift

Naamloze Vennootschap

North Western Reporter

Idem, Second Series

Ondernemingskamer van het Gerechtshof

Amsterdam

Oberlandesgericht

Revue critique de jurisprudence belge

Revue de jurisprudence commerciale

Revue trimestielle de droit commercial et de droit économique

Revue des sociétés

Rechtsgericht

Rechtspraak van de Week

Rechtskundig Weekblad

section

Société Anonyme

Société à Responsabilité Limitée

Société par actions Simplifiée

Tijdschrift voor Stichting en Vereniging

ter aangehaalde plaatse

Tijdschrift voor Privaatrecht

Tijdschrift voor Rechtspersoon en Vennootschap

Tijdschrift voor Vennootschappen, Verenigingen en Stichtingen

Vennootschappenwet

Weekblad van het Recht

Weekly Law Reports

Wertpapiermitteilungen

Weekblad voor Privaatrecht, Notariaat en

Registratie

Wetboek van Koophandel

Zeitschrift für Unternehmens- und Gesellschaftsrecht

Zeitschrift für das gesamte Handelsrecht und

Wirtschaftsrecht

Zeitschrift für Wirtschaftsrecht und Insolvenzpraxis 



\section{Verkort aangehaalde werken}

Asser-Bregstein

Asser-Van der Grinten-Maeijer

Asser-Hartkamp 4-II

Asser-Maeijer 2-III

Baumbach-Hueck

Cozian-Viandier-Deboissy
Mr. C. Asser's Handleiding tot de beoefening van het Nederlands Burgerlijk recht, bewerkt door M.H. Bregstein, 2e druk 1954.

Mr. C. Asser's Handleiding tot de beoefening van het Nederlands Burgerlijk Recht, 2, Vertegenwoordiging en rechtspersoon, deel II, De Rechtspersoon, 8e druk 1997. door J.M.M. Maeijer.

Mr. C. Asser's Handleiding tot de beoefening van het Nederlands Burgerlijk Recht, bewerkt door A.S. Hartkamp, Verbintenissenrecht, Algemene leer der overeenkomsten 4-II, 10e druk 1998

Mr. C. Asser's Handleiding tot de beoefening van het Nederlands Burgerlijk Recht, 2, Vertegenwoordiging en rechtspersoon, deel III, De naamloze en de besloten vennootschap, le druk 1994, door J.M.M. Maeijer met medewerking van P.J. Dortmond.

A. Baumbach, A. Hueck, Aktiengesetz, Kurzkommentar, 1988 München.

M. Cozian, A. Viandier en Fl. Deboissy, Droit des sociétés, 12e éd, Litec, Parijs 1999. 
Dijk-Van der Ploeg

Farrar's Company Law

Guyon, Droit des affaires

Guyon, Traité des contrats

Handboek

Henn, Handbuch des Aktienrechts

Hicks \& Goo, Cases and Materials

Hüffer, Aktiengesetz

Kölner Kommentar zum Aktiengesetz Kölner Kommentar zum Aktiengesetz door Wolfgang Zöllner, bewerkt door onder meer M. Lutter en H-J. Mertens, Köln 1984-1992.

P.L. Dijk en T.J. van der Ploeg, Van vereniging en stichting, coöperatie en onderlinge waarborgmaatschappij, 3e druk 1997, door T.J. van der Ploeg e.a.

J.H. Farrar \& B.M. Hannigan, Farrar's Company Law, 4e druk, London 1998.

Y. Guyon, Droit des affaires, Economica, t.I, 10e druk Parijs 1998

Y. Guyon, Traité des contrats. Les sociétés, aménagements statutaires et conventions entre associés, LGDJ, 4e druk Parijs 1999.

Mr. E.J.J. van der Heijden, Handboek voor de naamloze en de besloten vennootschap, 12e druk 1992, door W.C.L. van der Grinten, met medewerking van H.J.M.N. Honée en Th.C.M. Hendriks-Jansen.

G. Henn, Handbuch des Aktienrechts, Heidelberg 1994.

A. Hicks \& S.H. Goo, Cases and Materials on Company Law, London 1997

U. Hüffer, Aktiengesetz mit Erläuterungen, München 1995 
Lutter-Hommelhoff

Mayson, French \&

Ryan on Company Law

Mercadal-Janin

Pitlo-Lőwensteyn

Ripert-Roblot

Sanders-Westbroek

Van Schilfgaarde, Van de BV en de NV

Sealy, Cases and Materials

Slagter, Compendium

Wiedemann, Gesellschaftsrecht
M. Lutter, P. Hommelhoff, GmbHGesetz, Köln 1995

S.W. Mayson, D. French \& C.L. Ryan, Company Law London 1997/1998.

B. Mercadal et A. Jauffret, Sociétés commerciales, éd. F. Lefebvre, Parijs 1998.

A. Pitlo, het Nederlands burgerlijk recht, deel 2, Het rechtspersonenrecht, 3e druk 1994, door F.J.W. Löwensteyn (eindtekst M.J.G.C. Raaijmakers).

J. Ripert et R. Roblot, Traité élementaire de droit commercial, t.I, 16e éd, Parijs 1996.

P. Sanders en W. Westbroek, BV en NV, 8e druk 1998, Serie recht en praktijk deel 23, door F.K. Buijn en P.M. Storm.

P. van Schilfgaarde, Van de BV en de NV, 11e druk 1998.

Cases and Materials in Company Law, London 1996.

W.J. Slagter, Compendium van het ondernemingsrecht, 7e druk 1996.

H. Wiedemann, Gesellschaftsrecht. Ein Lehrbuch des Unternehmensund Verbandsrecht, Band I: Grundlagen, München 1980. 



\section{Inleiding; voorwerp van onderzoek}

In het Nederlandse rechtspersonenrecht wordt in de artikelen 2:8 BW en 2:15 lid 1 sub b BW uitdrukkelijk een plaats ingeruimd voor de redelijkheid en billijkheid. Deze norm ziet op gedragingen en besluiten van de rechtspersoon en 'degenen die krachtens wet en statuten bij de organisatie van de rechtspersoon zijn betrokken'. In de praktijk van het rechtspersonenrecht, of beperkter, het vennootschapsrecht blijkt dat de rechter er niet voor terug schrikt om ingrijpende beslissingen op de redelijkheid en billijkheid te baseren. ${ }^{1}$

Bij dit onderzoek beperk ik mij tot de kapitaalvennootschappen NV en de BV en de daarmee vergelijkbare buitenlandse rechtspersonen. Een drietal verhoudingen binnen de organisatie van kapitaalvennootschappen stel ik centraal; de verhouding tussen meerderheids- en minderheidsaandeelhouders, ${ }^{2}$ de verhouding tussen de (algemene vergadering van) aandeelhouders en het bestuur en ten slotte de verhouding tussen bestuurders. Onderzocht wordt hoe gedragingen en besluiten die deze verhoudingen beinnvloeden in het licht van de redelijkheid en billijkheid beoordeeld moeten worden.

Daarbij staan de volgende vragen centraal: Wat is de betekenis van redelijkheid en billijkheid? Welke functie(s) kennen rechters toe aan de redelijkheid en billijkheid? En wat betekent dat vervolgens voor de betrokkenen? Het is mijn doel om de (on)mogelijkheden van de redelijkheid en billijkheid, zoals blijkend uit de wetgeving, rechtspraak en literatuur te inventariseren en mede in het licht van soortgelijke rechtsinstituten in het buitenland te beoordelen.

Behalve het vinden van antwoorden op de hiervoor gestelde vragen, hoop ik daarmee ook een bijdrage te leveren aan de verdere ontwikkeling van het recht en de rechtszekerheid. Een negatief aspect van toepassing van de norm van redelijkheid en billijkheid is immers dat de onzekerheid in het rechtspersonenrecht is toegenomen. ${ }^{3}$

1. Vgl. bijv. President Rechtbank 's-Gravenhage 27 april 1994, KG 1994, 176 en HR 10 maart 1995, NJ 1995, 595 (Janssen Pers).

2. Bij de formulering van art. 2:8 en 2:15 BW (voorheen art. 2:7 en 2:11 BW) stond de Nederlandse wetgever aanvankelijk met name de bescherming van minderheden van aandeelhouders voor ogen.

3. Evenzo Asser-Van der Grinten-Maeijer 2-II, nr. 46: 'In de weinige rechtspraak over redelijkheid en billijkheid in de verhoudingen binnen de rechtspersoon is het tot een samenstel van duidelijke regels van ongeschreven recht tot dusver niet gekomen'. 


\section{Onderzoekmethode; rechtsvergelijking}

In het onderzoek naar de concretisering van de norm van redelijkheid en billijkheid, laat ik mij inspireren door buitenlands recht. Zo'n rechtsvergelijkende benadering van het leerstuk van de redelijkheid en billijkheid in het vennootschapsrecht ligt voor de hand, daar de Europese Gemeenschap met name op het terrein van het vennootschapsrecht een indrukwekkende bijdrage heeft geleverd aan de harmonisatie van het recht. Met het oog op eventueel verdergaande harmonisatie is het wenselijk de overeenkomsten en de verschillen van nationale rechtsstelsels zorgvuldig in het oog te houden.

In dit kader heb ik besloten twee continentale rechtsstelsels, Duitsland en Frankrijk, bij het onderzoek te betrekken. Het Duitse recht is vergelijkbaar met het Nederlandse recht en kan, bij uitstek, dienen als een spiegel daarvoor. Frankrijk heb ik gekozen als vertegenwoordiger van de Latijns-continentale traditie. Slechts een enkele keer zal België bij het onderzoek worden betrokken.

Naast het Duitse en Franse recht omvat het onderzoek ook het Engelse recht. Het is interessant om in het Engelse vennootschapsrecht te onderzoeken hoe omgegaan wordt met het 'goede trouw' beginsel, tegen de achtergrond van het common law systeem. Incidenteel betrek ik daarbij het Amerikaanse recht.

Een functionele benadering van mijn rechtsvergelijkend onderzoek lijkt de meest aangewezen weg. ${ }^{4}$ Deze bestaat immers hierin dat een analyse van problemen voorop staat waarna vervolgens wordt bezien welke 'oplossingen' in de diverse rechtsstelsels worden aangereikt. De in Nederland te hanteren open norm van de redelijkheid en billijkheid biedt de mogelijkheid om, indien wenselijk, oplossingen uit het buitenlandse recht 'over te nemen'. Een voorwaarde voor zo'n functionele benadering is dat de te onderzoeken gevallen qua omstandigheden gelijk zijn. In mijn onderzoek vergelijk ik daarom belangenconflicten die zich zowel in de Nederlandse als in Duitse, Engelse en Franse kapitaalvennootschappen (kunnen) voordoen.

4. Volgens deze methode wordt voor het rechtsvergelijkend onderzoek aangeknoopt bij de functie die een bepaald rechtsinstituut of een bepaalde rechtsregel in een bepaalde rechtsorde vervult en nagegaan welke regels en instituten deze functie in andere rechtsorden vervullen. $\mathrm{Vgl}$. hieromtrent onder meer $\mathrm{K}$. Zweigert-H. Kötz, An introduction to comparative law, Oxford 1992, m.n. p. 31 en J.G. Sauveplanne, De methoden van privaatrechtelijke rechtsvergelijking. Preadvies voor de Nederlandse Vereniging voor Rechtsvergelijking, Deventer 1975, p. 27 e.v. 


\section{Plan van behandeling}

Centraal in mijn onderzoek naar de eisen van redelijkheid en billijkheid stel ik de gerechtvaardigde belangen van de betrokkenen bij een conflict. Om een antwoord te krijgen op de vraag wat die gerechtvaardigde belangen zijn moeten belangenconflicten en het gewicht van de respectieve belangen geanalyseerd worden. ${ }^{5}$

Een factor van belang voor die belangenafweging is welke personen betrokken zijn bij een belangenconflict en in welke hoedanigheid. Van een bestuurder wordt bijvoorbeeld verlangd dat hij zich bij zijn taakuitoefening richt naar het vennootschappelijk belang, terwijl een aandeelhouder in beginsel zijn eigen belang mag nastreven.

In het eerste deel van mijn onderzoek (hoofdstukken $3 \mathrm{t} / \mathrm{m} \mathrm{6}$ ) beoog ik te inventariseren welke conflicten kunnen bestaan in de verhouding tussen meerderheidsaandeelhouder(s) en minderheidsaandeelhouder(s). Ik maak daarbij een onderscheid tussen conflicten rond het besluitvormingsproces van de ava (hoofdstukken 3 en 4) en conflicten met betrekking tot de inhoud van besluiten. In dit kader heb enerzijds gekozen voor een nadere analyse van besluiten tot winstreservering, als 'toonbeeld' van een klassiek conflict tussen aandeelhouders waarbij de financiële belangen van minderheidsaandeelhouders in het gedrang komen (hoofdstuk 6). Daarnaast analyseer ik besluiten tot statutenwijziging daar dergelijke besluiten de kern van de verhouding (en de samenwerking) tussen aandeelhouders raken, en ook de zeggenschapsbelangen van aandeelhouders kunnen aantasten (hoofdstuk 5).

In het tweede deel van dit boek (hoofdstukken $7 \mathrm{t} / \mathrm{m}$ 9) stel ik vervolgens de relatie tussen de ava en het bestuur aan de orde. In hoofdstuk 7 besteed ik aandacht aan de invloed die aandeelhouders kunnen uitoefenen op het bestuur. In de hoofdstukken 8 en 9 neem ik de benoeming, schorsing en ontslag van bestuurders onder de loep. In hoofdstuk 10 stel ik vervolgens de problematiek inzake corporate opportunities centraal.

In het derde, en tevens het laatste, deel (hoofdstuk 11), tracht ik verheldering te brengen in de verhouding tussen bestuurders onderling. Ten slotte sluit ik af met enkele afsluitende beschouwingen (hoofdstuk 12).

Alvorens ik echter toekom aan een uitgebreide behandeling van de onderzoeksproblematiek acht ik het wenselijk om enige aandacht te besteden aan de ontwikkeling van het leerstuk goede trouw in het Nederlandse

5. Vgl. ook J.M.M. Maeijer. 25 jaren belangenconflict in de Naamloze Vennootschap. Zwolle 1989, p. 19 alsmede in De NV 1989, p. 8. 
Plan van behandeling

recht (hoofdstuk 1). Tevens acht ik het, met het oog op de rechtsvergeliking, noodzakelijk om enige aandacht te besteden aan de organisatie van de te onderzoeken buitenlandse kapitaalvennootschappen en de 'goede trouw' beginselen, die deze organisaties in meer of mindere mate beheel. sen (hoofdstuk 2). 


\section{De ontwikkeling van de goede trouw in kapitaal- vennootschappen in Nederland}

\section{§1. Inleiding}

Sinds 1 januari 1992 bepaalt art. 2:8 BW dat een rechtspersoon en degenen die krachtens de wet en de statuten bij zijn organisatie zijn betrokken, zich als zodanig jegens elkaar moeten gedragen naar hetgeen door redelijkheid en billijkheid wordt gevorderd. Hoewel de achterliggende gedachte, dat binnen een georganiseerd verband van een rechtspersoon de goede trouw een rol behoort te spelen, pas in 1976 voor het eerst in de wet werd verankerd in art. 2:7 BW, is deze al veel ouder. Reden voor een terugblik teneinde enig inzicht te krijgen in de verhouding tussen de rechtsbegrippen goede trouw en vennootschappelijk verband.

Uitgebreide historische beschouwingen over de goede trouw in het verbintenissenrecht vindt men in dit hoofdstuk niet.' Slechts voorzover de ontwikkeling van het denken over de goede trouw in het verbintenissenrecht relevant is voor het rechtspersonenrecht, zal hierbij worden stil gestaan.

Aangezien wetgeving voor de ontwikkeling van het goede trouw beginsel in het vennootschapsrecht van beperkte betekenis is geweest, zal die ontwikkeling met name worden geschetst aan de hand van rechtspraak en doctrine.

De ontwikkeling van de goede trouw in het vennootschapsrecht zal worden bezien vanaf 1838 . Als vertrekpunt heb ik 1838 gekozen omdat in het oud BW twee bepalingen werden gewijd aan de goede trouw in het verbintenissenrecht, de artikelen $1374 \mathrm{BW}$ en $1375 \mathrm{BW}$, welke in de praktijk niet alleen een belangrijke functie hebben vervuld in het verbintenissenrecht, maar ook in het vennootschapsrecht. De nadruk zal in dit

1. Voor de ontwikkeling van de goede trouw in het verbintenissenrecht verwijs ik onder meer naar H.C.F. Schoordijk, Redelijkheid en billijkheid aan de vooravond van een nieuw millenium (rede), Zwolle 1996, G.J. Rijken, Redelijkheid en billijkheid, Monografieèn Nieuw BW, Deventer 1994, Asser-Hartkamp II, nr. 300 e.v, P. Abas, Beperkende werking van de goede trouw, Deventer 1972, H.J. de Kluiver, Onderhandelen en Privaatrecht, diss. Deventer 1992, nrs. 31 e.v. (en de daar vermelde literatuur), J. Smits, Het vertrouwensbeginsel en de contractuele gebondenheid, diss. Leiden 1995. Arnhem 1995 en M.W. Hesselink. De redelijkheid en billijkheid in het Europese privaatrecht, (diss. Utrecht) Deventer 1999. 
De ontwikkeling van de goede trouw in kapitaalvennootschappen in Nederland

hoofdstuk echter liggen op de periode na 1900, aangezien in die periode gesproken kan worden over een ontwikkeling van de goede trouw in het vennootschapsrecht. Centraal staat de betekenis van de goede trouw voor het functioneren van algemene vergadering van aandeelhouders en het bestuur.

\section{\$ 2. Periode 1838 tot en met 1928: goede trouw in het verbintenissen- recht; een schets}

\section{\& 2.1. Artt. 1374, $1375 \mathrm{BW}$ en de contractleer}

Sinds 1838 bepaalt art. 1374 BW dat 'wettiglijk' gemaakte overeenkomsten degenen die dezelve hebben aangegaan, tot wet strekken en dat overeenkomsten te goeder trouw ten uitvoer moeten worden gebracht. Ook art. 1375 BW stelt het goede trouw beginsel op de voorgrond: 'Overeenkomsten verbinden niet alleen tot datgene hetwelk uitdrukkelijk bij dezelve bepaald is, maar ook tot al hetgeen dat, naar de aard van dezelve overeenkomsten, door de billijkheid, het gebruik of de wet, wordt gevorderd'.

Deze normen van goede trouw en billijkheid in het verbintenissenrecht vinden in de loop van deze periode ook toepassing op rechtsbetrekkingen binnen naamloze (en na 1970 besloten) vennootschappen en verenigingen. Steun voor die toepassing vindt men aanvankelijk in het standpunt van de Hoge Raad dat de naamloze vennootschap een contractueel karakter heeft. ${ }^{2}$ Uitgangspunt van de Hoge Raad is aanvankelijk dat de oprichtingshandeling van de NV een obligatoire overeenkomst is tussen de oprichters in de zin van art. $1349 \mathrm{BW}{ }^{3}$ Hieruit vloeit voort dat besluitvorming van een orgaan, zoals de algemene vergadering van aandeelhouders, als uitoefening van een contractuele bevoegdheid moet worden

2. Zie reeds HR 27 mei 1898, W. 7128 en HR 18 april 1913, NJ 1913, p. 723 alsmede HR 29 november 1923, NJ 1924, p. 129 en HR 4 april 1924, p. 564. Voor een mooi overzicht van de ontwikkeling van de Naamloze Vennootschap voor de codificatie verwijs ik naar E.J.J. van der Heijden, De ontwikkeling van de Naamloze Vennootschap in Nederland vóór de codificatie, diss. Utrecht, 1908.

3. $\mathrm{Vgl}$. onder meer $\mathrm{G}$. de Grooth, De Naamloze Vennootschap, in de serie recht en praktijk, uitgegeven door G. van Hoften, Rotterdam, 1905, p. 12. Zie tevens de uitspraak van de Hoge Raad 18 april 1913 W. 9500 . De Hoge Raad huldigt hier de opvatting dat de NV een overeenkomst is tussen aandeelhouders. 
beschouwd en derhalve te goeder trouw moet geschieden. ${ }^{4}$ In 1928 bevestigde de wetgever in het gewijzigde Wetboek van Koophandel dit standpunt van de Hoge Raad. ${ }^{5}$ Ook in de doctrine werd deze contracttheorie door vele auteurs aangehangen. ${ }^{6}$

Zie bijvoorbeeld heel duidelijk Van der Heijden, Handboek, 2e druk 1931, in nr. 42: 'Uit het contractuele karakter der NV vloeit voort, dat de bij de oprichtingsovereenkomst toegekende of daarop steunende rechten te goeder trouw, dit is naar redelijke opvatting van billijkheid moeten worden uitgeoefend (artt. 1374, 1375 BW), alsmede in nr. 223 :" Het besluit is uitvoering der in de akte van oprichting neergelegde vennootschapsovereenkomst. Als zodanig moet het naar wijze van totstandkoming en inhoud voldoen niet alleen aan de eischen van wet en statuten, doch ook aan die van de goede trouw. Het moet naar redelijkheid en billijkheid genomen zijn. Voldoet het besluit aan deze voorwaarden niet, dan kan de rechter nietigverklaring uitspreken".

\section{$\S 2.2$ Geringe bijdrage van de wetgever}

De wettelijke regeling die voor de naamloze vennootschap gold in het Wetboek van Koophandel (WvK) van 1838 tot 1928 was uiterst beknopt? en leert ons niets over de werking van het 'goede trouw beginsel' in het vennootschapsrecht.

Ook de vele moeizame pogingen tot wetswijzigingen van de regeling van de naamloze vennootschap tussen 1871 en 1910 dragen niet of nauwelijks bij aan de ontwikkeling van het denken over de werking van het

4. De bestuurders zijn onderworpen aan de bepalingen van artt. 1374 en 1375 BW vanwege het feit dat hun functie veelal op een contractuele betrekking berust (arbeidsovereenkomst, lastgeving). Vgl. N. Okma, Misbruik van recht, diss. Amsterdam 1945 , p. 108.

5. Art. 15 van de Wet van 2 juli 1928 , houdende wijziging van het Wetboek van Koophandel (in werking getreden op 1 april 1929) bepaalde dat de verbintenissen van vennootschappen van koophandel geregeerd worden door de overeenkomsten van partijen.

6. Zie M. Polak, Handboek voor het Nederlandsch handels- en faillissementsrecht 1, Se druk, p. 338 e.v.. Kist-Visser, Beginselen van handelsrecht volgens de Nederlandsche wet. Belinfante 's-Gravenhage 1914, p. 500.

7. $\mathrm{Vgl}$. Molengraaff in zijn afscheidsrede, 'Eene terugblik' (8 juni 1917) Molengraaff Bundel. Zwolle 1978, p. 81: 'Het beste, althans voor de praktijk meest waardevolle van de verouderde regeling van het WvK is wel dit dat deze regeling zo gebrekkig en vol leemten is, dat zij eigenlijk een regeling niet mag heten'. 
'goede trouw' beginsel in het vennootschapsrecht. ${ }^{8}$ Het enige wetsontwerp dat daaraan wel een bijdrage leverde was het ontwerp van minister Nelissen in 1910, waarin voor het eerst als één van de doelstellingen van de wettelijke regeling voor de NV wordt aangenomen de bescherming van minderheidsaandeelhouders. ${ }^{9}$ De achterliggende gedachte was dat deze bescherming met name geboden was in het geval dat de meerderheidsaandeelhouders tevens de belangen van een andere NV vertegenwoordigen. ${ }^{10}$

Het ontwerp Nelissen bood onder meer de mogelijkheid aan houders van ten minste een tiende gedeelte van het geplaatste kapitaal om zich te verzetten tegen besluiten van de NV tot het aangaan van bepaalde belangrijke overeenkomsten. De rechter diende dat verzet niet alleen te honoreren wanneer het besluit streed met de wet, goede zeden of openbare orde, maar ook wanneer bleek dat door het tot stand komen der overeenkomst de belangen van de NV zouden worden geschaad, of dat daardoor éen of meer van degenen die in verzet kwamen, onbillijk zouden worden benadeeld. Dit verzet stond bijvoorbeeld open bij een besluit tot statutenwijziging en bij een besluit tot ontbinding van de vennootschap (artt. 47b en 53b ontwerp). Ook had het bestuur voor het aangaan van enkele door de wet genoemde transacties uitdrukkelijk de machtiging van de ava nodig (art. 43/43a). Daarnaast bood het ontwerp een algemene regeling inzake nietigheid van besluiten (art. 46d/47e) en een recht van enquête. Ten slotte noem ik de regeling inzake décharge (art. 50c). Op grond hiervan konden aandeelhouders die tegen de décharge van bestuurders stemden, ongeacht of de décharge nu wel of niet was verleend, namens de NV de bestuurders aanspreken.

Een vergaande minderheidsbescherming werd door minister Heemskerk (minister in de periode na Nelissen) echter onwenselijk geacht. Hij stelde zich op het standpunt dat de rechter niet op de stoel van de algemene vergadering moet gaan zitten en niet moet beslissen wat in het belang is van de NV, en dat wettige (meerderheids)besluiten nu eenmaal de minder-

8. In het ontwerp Jolles (1871) en het ontwerp van een staatscommissie tot herziening van het wetboek van koophandel (1890) werd onder meer aandacht besteed aan de bevoegdhedenverdeling tussen aandeelhouders, bestuurders en commissarissen. Beide wetsontwerpen hebben geen kracht van wet gekregen. Zie hieromtrent onder meer P.J. Verdam, Nietigheid van besluiten, Zwolle 1940, p. 88-91 en E. Tekenbroek, De verhouding tusschen de aandeelhouders en de bestuurders bij de publieke vennootschap in Nederland, diss. Rotterdam 1923, p. 41.

9. Vgl. Bijlagen Handelingen Tweede Kamer 1909-1910, Wetsontwerp 217.

10. Zie MvT, p. 16. Conform deze gedachte wordt in dit ontwerp (in art. S1e WvK) ook aandacht besteed aan de vertegenwoordigingsproblematiek in geval van tegenstrijdig belang, ook al vindt men deze term niet terug. Pas in het gewijzigd ontwerp van 1925 worden de woorden 'tegenstrijdig belang' opgenomen. 
heid behoren te binden. De heersende opvatting in rechtspraak en literatuur was immers dat in de naamloze vennootschap de hoogste macht toebehoorde aan de algemene vergadering van aandeelhouders. "

In het gewijzigd ontwerp Heemskerk dat uiteindelijk heeft geleid tot de wet van 1928 werden de meeste van de in het ontwerp Nelissen vervatte voorstellen tot bescherming van minderheidsaandeelhouders dan ook verworpen. Slechts op een aantal punten vindt men iets van het ontwerp Nelissen terug, zoals een regeling van het enquêterecht en de bevoegdheid van houders van ten minste $10 \%$ van het geplaatste kapitaal om, desnoods met behulp van de president van de rechtbank, een algemene vergadering te laten plaatsvinden. ${ }^{12}$ Ook bleef de in het ontwerp Nelissen voorgestelde algemene regeling inzake de nietigheid van besluiten in stand en werd deze neergelegd in art. $46 \mathrm{a}$ WvK.

In dit artikel werd een onderscheid gemaakt tussen formele en materièle nietigheid van besluiten. Op een materieel gebrek, voor zover dit kon gelden als strijd met de goede zeden of openbare orde, kon op grond van art. $46 \mathrm{a}$ WvK te allen tijde een beroep worden gedaan, ook bij wijze van verweer. Dit gold ook als sprake was van een formeel gebrek, een gebrek in de totstandkoming van het besluit, dat te kwader trouw was teweeggebracht. Echter, in het geval een formeel gebrek te goeder trouw was ontstaan, kon men zich daarop slechts zes maanden beroepen. ${ }^{13}$

11. Vgl. hieromtrent bijvoorbeeld E. Tekenbroek, De verhouding tussen de aandeelhouders en de bestuurders bij de publieke naamloze vennootschap in Nederland, diss. Rotterdam, 1923, p. 33 en 109 en Kist-Visser, Beginselen van het handelsrecht volgens de Nederlandsche wet, uitgegeven door Gebr. Belinfante 's-Gravenhage 1929, p. 175. Zie tevens H.J.M.N. Honée, De ontwikkeling van het vennootschapsrecht in de bundel: 150 jaar Wetboek van Koophandel: Het verleden en de toekomst, Deventer 1989, p. $39 / 40$.

12. $\mathrm{Vgl}$. hieromtrent JB. Zeylemaker, Verleden, heden en toekomst van de naamloze vennootschap, Zwolle 1947, p. $31-33$ alsmede artt. $43 \mathrm{c}, 43 \mathrm{~d}, 43 \mathrm{e}$ en artt. 53 en 54 WvK (eerste boek, derde afdeling van de derde titel), in Naamloze Vennootschappen, Wet tot wijziging en aanvulling van de bepalingen omtrent de naamloze vennootschap en regeling van de aansprakelijkheid voor het prospectus, van aanteekeningen voorzien door $\mathrm{G}$. Vlug. Rotterdam 1928. Vlug schrijft in zijn 'aanteekeningen': 'Het recht van enquête is het eenige middel dat uit het ontwerp-Nelissen overgebleven is van een aantal middelen dat bestemd was om de minderheid te beschermen tegen de meerderheid. Een regeling van zulk een bescherming heeft uiteraard veel bezwaren aan zich. Men kan toch ook niet de meerderheid aan de minderheid overleveren".

13. Zie hieromtrent P.J. Verdam. Nietigheid van besluiten, Zwolle 1940, p. 164/165 en Kist/Visser, Beginselen van Handelsrecht, $3 e$ druk 1914, p. 504 e.v. 
Minister Heemskerk wilde een inhoudelijke toetsing van besluiten aan de goede trouw slechts toestaan in het kader van een toetsing van de rechtmatigheid van de besluitvorming. De rechter moest niet op de plaats van de algemene vergadering worden gesteld door hem te laten oordelen over de doelmatigheid van een besluit. ${ }^{14}$ Als uitgangspunt werd juist aangenomen dat de doelmatigheid van besluiten slechts ter beoordeling stond van de aandeelhoudersvergadering zelf.

Vgl. ook Visser in de derde druk van Kist/Visser, 'Beginselen van Handelsrecht' (1914): 'waar onze wet niet het tegendeel bepaalt, is er geen enkele macht, die in dit opzicht de besluiten der vergadering kan herzien; de belanghebbenden moeten er zich aan onderwerpen en een toetsingsrecht door den rechter bestaat niet'. is

Een uitzondering maakte de minister met betrekking tot een inhoudelijke toetsing aan de goede trouw van statutenwijzigingen (akte van oprichting). Dit in navolging van de uitspraken van de Hoge Raad (zie hierna § 1.3.).

De minister stelt in de MvA 69, 1 p. 27: 'De bevoegdheid tot wijziging der akte van oprichting is begrensd door de goede trouw. Sedert het arrest van den Hoogen Raad van 29 november 1923, Weekblad van het Recht (W.), nr. 11147, mag zulks worden beschouwd als positief recht'.

\section{§. Rechtspraak en doctrine in de periode 1900 tot 1945 nader bezien}

Aanvankelijk wordt in de periode 1900-1945 de invulling van begrippen strijd met de goede trouw c.q. de openbare orde, in het kader van het denken over (het aantasten van) rechtshandelingen van vennootschappelijke organen, met name gezocht in leerstukken als misbruik van recht en misbruik van (meerderheids)macht.

Invalshoek is dan met name de besluitvorming in de algemene vergadering van aandeelhouders en de verhouding meerderheids-minderheidsaandeelhouders (curs. MK). In de loop van de jaren ' 20 wordt de notie

14. Zie daarover Wijzigingen en aanvullingen van de bepalingen omtrent de Naamloze Vennootschap, uitgegeven door Belinfante, 1929, p. 39.

15. Zie Kist/Visser, Beginselen van Handelsrecht volgens de Nederlandsche wet, Belinfante 's-Gravenhage 1914, p. 503 en in een latere druk in 1929 op p. 208/209. Vgl. ook de uitspraak van de Rechtbank Maastricht op 6 oktober 1932, NJ 1933, p. 420. 
van misbruik van (meerderheids)macht echter verbonden met, en 'geabsorbeerd' door, een denken in termen van (objectieve) goede trouw. ${ }^{16}$

\section{§3.1 Ava: misbruik van meerderheidsmacht en goede trouw}

Misbruik van meerderheidsmacht door (een meerderheid van) aandeelhouders werd aanvankelijk bestreden door zulks in strijd met de wet of een statutaire bepaling te achten danwel in strijd met de openbare orde of goede zeden. Beide kwalificaties leidden tot de nietigheid van het betreffende besluit. ${ }^{17}$ Erkend werd dat een besluit zowel wat betreft de wijze van totstandkoming als naar de inhoud nietig kon zijn.

Zo schrijft Visser in zijn bewerking van het handboek van Kist inzake 'Beginselen van Handelsrecht' (1929) op p. 212: 'Een besluit nu kan oneerlijk zijn wegens de inhoud, indien het bijvoorbeeld sommige aandeelhouders ten koste van anderen onbillijk bevoordeelt, maar ook wegens de wijze, waarop het tot stand is gekomen, indien daarbij misleiding of andere ongeoorloofde middelen als omkoping of geheime beloften zijn gebezigd. Ten slotte zal het besluit eveneens geacht moeten worden de regelen der openbare orde of goede zeden te schenden, indien het berust op misbruik van macht". Machtsmisbruik is volgens Visser aanwezig 'indien de meerderheid haar stemrecht bezigt niet om te bereiken datgene, wat zij te goeder trouw in het belang der gezamenlijke aandeelhouders acht, maar om eigen, egoistische oogmerken, los van het belang van de vennootschap, te verwezenlijken. Dit zal bijvoorbeeld het geval kunnen zijn, indien de meerderheid ten nadeele der minderheid eene vennootschap met een behoorlijk werkend bedrijf tusschentijds ontbindt met het doel dit bedrijf aan zich zelve of aan met haar verbonden personen in handen te spelen of om daardoor den bloei eener andere onderneming, waarbij zij belang heeft, te bevorderen'.

Zeylemaker en in zijn navolging Verdam ${ }^{18}$ pleitten voor de aanvaarding van misbruik van meerderheidsmacht als zelfstandige grond voor ongeldigheid van besluiten.

16. Op een enkele uitzondering na. Van subjectieve goede trouw werd uitgegaan in HR 13 februari 1942, NJ 1942, 360 (eerste Baus/De Koedoe-arrest) en in navolging daarvan Rb. Arnhem 17 januari 1946, NJ 1947, 280.

17. $\mathrm{Vgl}$. P.J. Verdam, Nietigheid van bestuiten, diss. Zwolle 1940, p. 111/112. Zie over de processuele mogelijkheid van de aandeelhouders tot nietigverklaring van een besluit bijvoorbeeld J. Drost, Rechten van aandeelhouders in Naamloze Vennootschappen, diss. Utrecht 1903, p. 9 e.v.

18. Zie Zeylemaker. Het keeren van misbruiken in de onderlinge verhouding van verbonden naamioze vennootschappen, ITR 1932, p. 166 en P.J. Verdam, Nietigheid van besluiten, diss. Amsterdam 1940, p. 25 en 119. 
De ontwikkeling van de goede trouw in kapitaalvennootschappen in Nederland

Zoals hiervoor al ter sprake kwam ( 8 2.2) werd toetsing aan de goede trouw in 1923 aanvaard voor zover toetsing van besluiten tot statutenwijziging van NV's (en coöperatieve verenigingen) aan de orde was. ${ }^{19}$ Dit kan worden verklaard vanuit de opvatting dat de statuten een overeenkomst vormen tussen aandeelhouders. ${ }^{20}$ De Hoge Raad volgt dan, zoals hiervoor in $\$ 2.1$ reeds werd vermeld, de redenering dat een besluit van de algemene vergadering een handeling is ter uitvoering van de statuten, en aldus onderworpen aan art. 1374 BW.

Uitgangspunt is HR 18 april 1913, W. 9500/NJ 1913, p. 723 (imzake Van Roessel/De Posthoorn) waarin de Hoge Raad beslist dat 'de statuten der NV, als wettiglijk gemaakte overeenkomst, degenen die haar hebben aangegaan tot wet strekken' (1374 lid $1 \mathrm{BW}$ ). In navolging daarvan heeft de Hoge Raad in zijn uitspraak van 29 november 1923. W. 11147 voor het eerst art. 1374 lid $3 \mathrm{BW}$ van toepassing verklaard op een statutenwijziging van een coöperatieve vereniging betreffende de verhoging van de ledenbijdrage. ${ }^{21}$ Sindsdien wordt een besluit tot wijziging van de statuten alleen geoorloofd geacht, indien deze naar inhoud en wijze van totstandkomen voldoet aan de 'bij art. 1374 BW gestelde eisch van redelijkheid en billijkheid'. Het enkele scheppen van de mogelijkheid van onredelijke en onbillijke belasting van de leden van een coöperatieve vereniging achtte de Hoge Raad overigens niet in strijd met art. 1374 lid 3 BW. Zie bijvoorbeeld HR 25 april 1929, W. 11979.22

Dit uitgangspunt van de Hoge Raad dat een besluit tot statutenwijziging uitvoering is van een overeenkomst roept echter discussie op. Die discussie omvat ook de vraag hoe de verhouding tussen de goede trouw enerzijds en de goede zeden of misbruik van recht anderzijds moet worden beschouwd.

Over de verhouding tussen goede trouw enerzijds en de goede zeden anderzijds is veel gediscussieerd. Wat betreft de goede zeden zijn de meeste auteurs het er over eens dat dit begrip verschilt van de goede trouw. Paul Scholten bestrijdt op deze grond de contractuele

19. Zie hieromtrent onder meer J.C. van Oven, De Hooge Raad en de artt. 1374 en 1375 BW, NJB 1931, p. 568 e.v, en P.J. Verdam, Nietigheid van besluiten, Tjeenk Willink Zwolle 1940, p. 119/120.

20. Vgl. H.F.A. Völlmar, Nederlands Burgerlijk Recht, tweede druk Zwolle 1952, p. 265/266, M. Polak, Handboek voor het Nederlandsche Faillissementsrecht, vijfde druk Groningen 1935, p. 394.

21. Vgl. hieromtrent J.H.H. Hülsmann, De ongeldigverklaring van meerderheidsbesluiten op grond van wilsgebreken en haar gezag van gewijsde, Amsterdam 1935, p. 3 en P.J. Verdam, Nietigheid van besluiten, Zwolle 1940, p. 99.

22. Zie tevens Van der Heijden, Handboek 1931, nr. 344. 
visie van de Hoge Raad. ${ }^{2}$ Hij heeft met name moeite met de beperkte reikwijdte van de door de Hoge Raad aanvaardde contractleer. ${ }^{24} \mathrm{Kem}$ van zijn betoog is dat de goede trouw van art. 1374 BW slechts verplicht bij het handelen rekening te houden met de belangen van hen, met wie men in contractuele verhouding staat. 'Bij statutenwijziging gaat het echter niet alleen om de belangen van de vereeniging, aldus Scholten, maar ook om die van derden', Volgens Scholten kan nietigheid op grond van strijd met de openbare orde en goede zeden ook bestaan in het geval 'tegen de belangen van derden is gehandeld en zij zich niet kunnen beklagen dat tegenover hen de goede trouw niet in acht is genomen. ${ }^{2 s}$ Voorts voert hij in zijn annotaties bij HR 15 juni 1928, NJ 1928, p. 1626, 6 december 1929, NJ 1930, p. 109 en 9 januari 1941, NJ 1941, 528, alsmede in zijn 'Rechtspersoon', als bezwaar aan dat de goede trouw een 'telkens door de omstandigheden bepaalde wisselende inhoud heeft, die voor ieder lid verschillend kan zijn', terwijl de beslissing over de geldigheid ten aanzien van alle leden dezelfde moet zijn. ${ }^{26}$

Een andere benadering is die van Van der Heijden, ${ }^{n}$ die de goede trouw van art. 1374 BW identificeert met de goede zeden. De meerderheid van de rechtsgeleerde auteurs is echter de mening toegedaan dat de goede trouw en de goede zeden weliswaar beide bronnen zijn van ongeschreven recht, maar dat dit niet betekent dat zij identiek zijn. Het onderscheid uit zich in gelding, werking en effect. ${ }^{2 \pi}$ De goede zeden moeten worden gezien als een complex van ongeschreven dwingende rechtsnormen; algemene maatschappelijke gedragsregels, die in de rechtsgemeenschap zozeer worden ervaren als hoogste norm, dat zij als rechtsnorm wordt gerecipieerd. ${ }^{29}$ De goede trouw is richtsnoer bij de toepassing van contractuele of statutaire normen. Aan normen van openbare orde en goede zeden zijn alle besluiten gelijkelijk onderworpen, terwijl de normerende werking van de goede trouw steeds is toegespitst op de concrete situatie. ${ }^{30}$

23. Gevolgd door P.J. Verdam, Nietigheid van besluiten, Zwolle 1940.

24. Vgl. Asser-Scholten, Personenrecht 1940, p. 140-141 en W.J.M. Noldus, Ongeldigheid van besluiten in de naamloze vennootschap, Deventer 1969, p. 85.

25. $\mathrm{Vgl}$. Asser-Scholten, Personenrecht, 1940, p. 603.

26. Zie in dezelfde zin Van der Heijden, Handboek $3 e$ druk, Zwolle $1936 \mathrm{nr}$. 227. Anders echter Van der Grinten in zijn bewerking van het Handboek in 1955, Zwolle 6e druk, nr. 227.

27. Zie E.J.J. van der Heijden, Natuurlijke normen in het recht, rede Nijmegen 1933, p. 24.

28. W.J.M. Noldus, Ongeldigheid van besluiten in de naamloze vennootschap, Deventer 1969. p. 82.

29. $\mathrm{Vgl}$. Ch.J.J.M. Petit, Overeenkomsten in strijd met de goede zeden, diss. Leiden 1920. p. 35 e.v. en P. Scholten in Asser-Scholten, Algemeen Deel, tweede druk, Zwolle 1934, p. 32. Vgl. ook F.J.W. Lôwensteyn, Wezen en bevoegdheid van het bestuur van de vereniging en de naamloze vennootschap, diss. Amsterdam 1959, p. 188/189 en de daar aangehaalden.

30. Zie Van der Grinten, Nietigheid van besluiten wegens strijd met het ongeschreven recht. De NV 1942, p. 227, N. Okma, Misbruik van recht, diss. Amsterdam 1945, p. 35 en W.J.M. Noldus, Ongeldigheid van besluiten in de naamloze vennootschap, diss. Nijmegen 1969, p. 82. 


\section{De meeste auteurs onderschrijven dan nog de opvatting van de Hoge Raad dat het besluit 'uitvoering is van de overeenkomst', maar de motivering daarvoor verschilt.}

Noldus heeft in zijn dissertatie een drietal visies onderscheiden die in de jurisprudentie en doctrine worden gehuldigd. ${ }^{31}$ De eerste visie, verdedigd door Blaisse en Moes, ${ }^{32}$ ziet het besluit als uitvoering van de overeenkomst van oprichting. De tweede visie, onder meer verdedigd door Van Oven, Bregstein en Van der Heijden, ${ }^{3}$ houdt in dat het besluit uitvoering is van de statuten, die worden gezien als overeenkomst tussen deelgenoten. Volgens de derde visie ten slotte wordt het besluit eveneens gezien als uitvoering van de statuten, maar de statuten vormen een overeenkomst tussen de rechtspersoon en de deelgenoten. Dit standpunt is onder meer ingenomen door Rozendaal, Dorhout Mees en Lōwensteyn. ${ }^{34}$

Overigens blijft de Hoge Raad ook na aanvaarding van deze visie zeer terughoudend met inhoudelijke toetsing van besluiten aan de norm van art. 1374 lid 3 BW. Wel wordt geregeld de totstandkoming van allerlei besluiten bezien in het licht van de goede trouw.

$\mathrm{Vgl}$. voor een inhoudelijke toetsing aan de goede trouw HR 9 jamuari 1941, NJ 1941, 528 (Willink/Ter Kuile). In deze zaak oordeelt de Hoge Raad dat een besluit van twee aandeelhouders/bestuurders, die samen de meerderheid van het aandelenkapitaal vertegenwoordigen, om het bestuurderssalaris vast te stellen op fl.30.000 nietig is wegens strijd met de goede trouw. Enige tijd voordien was namelijk met de andere andeelhouders afgesproken om het salaris vast te stellen op fl.10.000. Uit de jurisprudentie van lagere rechters kan wellicht genoemd worden $R$ b. Rotterdam 20 februari 1911, W, 9183. In deze zaak oordeelde de rechtbank dat een ontbindingsbesluit ongeldig was, omdat de meerderheid daardoor het bedrijf wegens zijn gunstige resultaten ten nadele van de minderheid in andere handen speelt. De ongeldigheid baseerde de rechtbank op het beginsel dat alle aandeelhouders bij liquidatie een gelijk recht hebben op een evenredig deel van de bezittingen. Zie voorts betreffende de

31. W.J.M. Noldus, Ongeldigheid van besluiten in de naamloze vennootschap, Deventer 1969, p. $27 / 28$.

32. H.F. Blaisse en E.A. Moes, Statuten en statutenwijziging, WPNR 1943, p. 137-140 en p. $145-147$.

33. J.C. van Oven, De Hooge Raad en de artikelen 1374 en 1375 BW, NJB 1931, p. 568 e.v., Asser-Bregstein, Personenrecht, tweede druk, Vertegenwoordiging en rechtspersoon, bewerkt door M.H. Bregstein, 2e druk 1954, p. 163 en E.J.J. van der Heyden, Handboek 1e druk 1929, p. 249; 2e druk p. 279.

34. J. Rozendaal, Rechten van derden ten aanzien van ongeldige besluiten en antistatutaire handelingen bij de naamloze vennootschap, diss. Rotterdam 1931, p. 75, T.J. Dorhout Mees, Kort begrip van het Nederlands handelsrecht, 2e druk 1956, p. 225 en F.J.W. Löwensteyn, Wezen en bevoegdheid van het bestuur van de vereniging en de naamloze vennootschap, diss. Amsterdam 1949, p. 93. 
wijze van totstandkoming van besluiten bijvoorbeeld $R b$. 's-Gravenhage 29 oktober 1927, W. II756. Statutair bestond in de vennootschap slechts de verplichting om een algemene vergadering aan te kondigen in een tweetal nieuwsbladen. Een aandeelhouder van een aandelenpakket van f 80000 nominaal had de vennootschap verzocht hem tijdig en persoonlijk op de hoogte te brengen van een vergadering, daar hij in het buitenland verbleef. De rechtbank oordeelde dat op grond van de goede trouw aan dit verzoek gehoor diende te worden gegeven. Zie voor een soortgelijke 'oproepingszaak' Rb. Breda 17 november 1942, NJ 1943 , 463. In Rb. Amhem 12 november 1942, NJ 1943, 846 wordt echter weer gesproken over misbruik van recht. In deze zaak werd een oproeping voor een algemene vergadering van aandeelhouders waarin het ontslag van de enige commissaris, tevens $50 \%$-aandeelhouder, en de benoeming van een vervanger aan de orde zou worden gesteld, geplaatst in het 'Christelijk Sociaal Dagblad de Amsterdammer', Daarmee werd voldaan aan de statuten op grond waarvan oproeping moet worden gedaan in een te Amsterdam verschijnend dagblad. Gezien de beperkte lezerskring van 'de Amsterdammer' bereikt de oproep de commissaris niet. Hij eist daarop met succes nietigverklaring van het ontslag- en benoemingsbesluit. De rechtbank overweegt 'dat het enkel volstaan met een dergelijke oproeping tot een vergadering. waarop zulke ingrijpende voorstellen met betrekking tot de enige commissaris en houder van de helf der aandelen zouden worden behandeld, jegens dezen, zijdens de gedaagde vertegenwoordigende directie was een misbruik maken van die bepaling der statuten, omdat zij daarbij redelijkerwijze heeft moeten begrijpen en kennelijk heeft bedoeld dat juist wat de oproepingsvereisten beogen, niet kon worden bereikt, namelijk dat eiser (commissaris, MK) op de hoogte zou worden gebracht van de voorgenomen vergadering'.

\section{§ 3.2 Misbruik van bevoegdheid, goede trouw en bestuur}

Kwesties omtrent nietigheid en aantastbaarheid van besluiten hebben zich, zoals reeds vermeld in $\S 3.1$, in de rechtspraak aanvankelijk met name aangediend met betrekking tot besluiten van de algemene vergadering. Dit kan mijns inziens onder meer worden verklaard door de heersende contractuele visie met betrekking tot de NV, waarin deze werd gezien als een verenigingsverband van aandeelhouders, verankerd in een contractuele verhouding tussen aandeelhouders. Het bestuur en de raad van commissarissen namen een ondergeschikte positie in. Ook kan gedacht worden aan de omstandigheid dat de wet of statuten voor besluiten van het bestuur en de raad van commissarissen veelal geen regels gaven omtrent de totstandkoming. ${ }^{35}$ Een ander verschil is dat besluiten van de ava van interne aard zijn, terwijl het bestuur naast interne met name ook extern werkende handelingen verricht. Wij bevinden ons dan op het terrein van de vertegenwoordiging.

35. Vgl. W.C.L. van der Grinten, Preadvies over nietigheid van besluiten van organen van de NV, Zwolle 1966, p. 8. 
Echter, tegen het einde van de in deze paragraaf besproken periode (19001945) wordt erkend dat de goede trouw ook besluiten en gedragingen van het bestuur en de raad van commissarissen beheerst. Okma schrijt bijvoorbeeld dat de goede trouw niet alleen richtsnoer is voor de interne, organisatorische handelingen, zoals de wijze van oproeping, maar ook voor het optreden naar buiten (beheer en vertegenwoordiging). ${ }^{36}$

$\mathrm{Vgl}$. reeds $R$ b. Utrecht 30 juni 1920, NJ 1920, p.I139, waarin de rechtbank overwoog dat een 'directeur derhalve gehouden is de hem gegeven last te goeder trouw ten uitvoer $t$ brengen en daaraan slechts de bevoegdheid kan ontlenen tot het verrichten van handelingen. waarvan hij te goeder trouw meent, dat zij in het belang der vennootschap zijn'.

In de literatuur wordt dan (nog) vrijwel eenstemmig betoogd dat bestuurshandelen in strijd met de goede trouw synoniem is met misbruik van (contractuele) bevoegdheden. ${ }^{37}$

\section{\$ 4. Ontwikkelingen in de rechtspraak na 1945: ontkoppeling van verbintenissen- en vennootschapsrecht}

Het kenmerkende van de na-oorlogse periode is dat de 'contractleer' met betrekking tot kapitaalvennootschappen door de Hoge Raad wordt verlaten. De Hoge Raad erkent in de loop van deze periode steeds vaker dat het beginsel van goede trouw ook als richtsnoer kan gelden voor nietcontractuele verhoudingen.

Een belangrijke uitspraak in dit verband is het arrest van de Hoge Raad van 20 december 1946, NJ 1947, 59. Hierin heeft de Hoge Raad beslist dat ook de boedelscheiding door de regels van de goede trouw wordt beheerst. In de literatuur werd naar aanleiding van dit arrest wel aangenomen dat in het algemeen de werking van de goede trouw uitstrekte buiten contractuele kaders. Beekhuis was daarvan overigens niet geheel overtuigd.

36. Zie N. Okma, Misbruik van recht, diss. Amsterdam. Gebr. Zomer en Keunings Uitg. Wageningen 1945, p. 117 en in navolging daarvan F.J.W. Lōwensteyn, Wezen en bevoegdheid van het bestuur van de vereniging en de naamloze vennootschap. Zwolle 1959, p. 164.

37. Vgl. HR 23 juli 1946, NJ 1947, 1, J. Eggens, Over het wezen van misbruik van recht, WPNR 3989, p. 239, N. Okma, Misbruik van recht, p. 30 en 93, Van der Heijden/Van der Grinten, Handboek, derde druk 1936, nr. 224.1. 
In het rechtspersonenrecht wordt de 'eigensoortigheid' van statuten en besluiten benadrukt en 'losgekoppeld' van de oprichtingsovereenkomst. Het besluit wordt gezien als een rechtshandeling van eigen (vennootschapsrechtelijke) aard die als zodanig getoetst dient te worden aan de goede trouw.

\section{$\S 4.1$ Rond de ava}

Wat betreft de verhouding tussen aandeelhouders van een kapitaalvennootschap (en tussen leden en een vereniging) wordt in de naoorlogse periode duidelijk gekozen voor een benadering waarin het accent komt te liggen op de goede trouw als 'norm', losgekoppeld van specifieke wettelijke regels. ${ }^{38}$

De aanzet tot deze ontwikkeling is gegeven door Scholten en Meijers die reeds vanaf de jaren ' 20 benadrukten dat de verhoudingen tussen leden en aandeelhouders onderling en tussen de rechtspersoon en de leden resp. de aandeelhouders van eigen niet-contractuele aard zijn, maar wel geregeerd worden door de goede trouw," Zo schrijft bijvoorbeeld Scholten reeds in $1935^{\circ}$ : Het beginsel der goede trouw 'dringt zich op ook waar het niet een uitdrukkelijke legitimatie van de wetgever ontving'. Vgl. ook Van der Grinten in het Handboek (1946, 4e druk) waar hij in nr. 224.1 schrijft: 'De vraag rijst of dit zoeken naar een rechtsgrond (voor de goede trouw, MK) niet onvruchtbaar is. Waarom kunnen wij niet als norm van ons recht aanvaarden, dat een besluit redelijk en billijk moet zijn, zonder deze uitspraak op een bepaald wetsartikel te gronden?' In de 6e druk van het Handboek in 1955 wordt dan ook, onafhankelijk van art. $1374 \mathrm{BW}$, de goede trouw aanvaard als toetssteen voor besluiten van de ava.

Zeker sinds het Mante-arrest van 1964, HR 30 oktober 1964, NJ 1965, 107 wordt in de doctrine en rechtspraak algemeen aanvaard dat een besluit rechtstreeks getoetst kan worden aan de goede trouw.

38. Zie onder meer J.M. Polak, Inleiding tot het Nederlands rechtspersonenrecht, Groningen 1960, p. 35 en 51 en Asser-Scholten-Bregstein, 1954, p. 150.

39. P. Scholten in Asser-Scholten, Personenrecht, 6e druk 1929, p. 594 e.v. en E.M. Meijers, Individuele en vennootschappelijke rechtsvorderingen, toekomende aan aandeelhouders van Naamloze Vennootschappen, NJB 1927, p. 445-447. Vgl. ook T.J. van der Ploeg. De verbintenis in het rechtspersonenrecht, in de bundel: Met recht verenigd, Arnhem 1986, p. 185.

40. P. Scholten, Rechtsbeginselen, in de serie: mededeelingen der Koninklijke Akademie van Wetenschappen 1934, p. 267. 
In de Mante-zaak vorderde een aandeelhoudster (Mante) die beschikte over een aandelenpakket, dat een zekere zeggenschap in de algemene vergadering meebracht, vernietiging van een besluit tot statutenwijziging wegens strijd met de redelijkheid en billijkheid. $\mathrm{Zij}$ grondde haar vordering op de stelling, dat het besluit tot statutenwijziging in twee opzichten in strijd was met de redelijkheid en billijkheid, namelijk naar zijn wijze van totstandkomen en naar de inhoud. De klacht betreffende de wijze van totstandkomen was dat zij niet per brief voor de vergadering was opgeroepen, hoewel de aandeelhoudster de vennootschap bekend was en deze over haar adres beschikte. De klacht over de inhoud van het besluit betrof het ontnemen van zeggenschap die aan het pakket een meerwaarde (zij het een onzekere) gaf.

De Hoge Raad overwoog onder meer 'dat ook indien aan alle formele vereisten bij wet of statuten voor de wijze van oproeping van een aandeelhoudersvergadering gesteld is voldaan, de eisen van redelijkheid en billijkheid die aandeelhouders jegens elkaar in acht hebben te nemen, onder omstandigheden kunnen meebrengen dat een aandeelhoudersvergadering niet tot het nemen van een besluit aangaande een onderwerp waarbij de belangen van bepaalde aandeelhouders in bijzondere mate zijn betrokken overgaat, alvorens te hebben nagegaan of die aandeelhouders genoegzaam in de gelegenheid zijn gesteld aan de besluitvorming over dit hen in het bijzonder rakende onderwerp deel te nemen'.

Dit is ook het standpunt van het Ontwerp Nieuw Burgerlijk Wetboek in art. $2 \cdot 1 \cdot 8 .^{41}$

\section{$\S 4.2$ Rond het bestuur}

Aanvankelijk, zoals geschetst in $\S 3$ verbindt men in de rechtspraak en literatuur de notie van goede trouw hoofdzakelijk met de toetsing van besluiten van de ava in een NV en van de ledenvergadering in een coöperatieve vereniging. In de naoorlogse periode wordt de blik ook gericht op besluitvorming in andere rechtspersonenrechtelijke organen, zoals het bestuur.

Deze uitbreiding van het blikveld kan worden verklaard door de veranderde visie op de NV. Eerst werd, zoals geschetst, de NV gezien als een verenigingsverband van aandeelhouders. Het bestuur en de raad van commissarissen namen een ondergeschikte positie in. Gaandeweg verandert de benaderingswijze ten aanzien van de kapitaalvennootschap en de vennootschappelijke verhoudingen van contractueel naar institutioneel. ${ }^{42}$

41. Vgl. E.M. Meijers, Ontwerp voor een nieuw burgerijik wetboek, Toelichting eerste gedeelte, 's-Gravenhage 1954, p. 126/127.

42. Dit kan onder meer worden verklaard doordat in de praktijk blijkt dat complexe ondernemersbeslissingen beter genomen kunnen worden door bestuurders, met gespecialiseerde kennis, die leiding geven aan de economische activiteiten. Vgl. onder meer H.J.M.N. Honée, De ontwikkeling van het vennootschapsrecht, in: 150 jaar Wetboek van Koop- 
Deze veranderde zienswijze heeft uiteindelijk geleid tot de aanvaarding van het beginsel van de bestuurszelfstandigheid. ${ }^{43}$

In de jurisprudentie valt deze 'kentering' reeds te bespeuren in de uitspraak van de Hoge Raad op 1 april 1949, 465, NJ 1949, 465 betreffende de Doetinchemse IJzergieterij.

In deze zaak neemt de raad van commissarissen, daartoe statutair bevoegd, een besluit tot uitgifte van nieuwe aandelen, waardoor de meerderheidsaandeelhouder zijn meerderheidspositie verliest. Deze meerderheidsaandeelhouder beroept zich vervolgens op ongeldigheid van het emissiebesluit en stelt zich hierbij op het standpunt dat een vergroting van het kapitaal danwel het verlenen van een voorkeursrecht, niet mag geschieden zonder goedkeuring van de aandeelhouders ook al was dit niet statutair geregeld. De Hoge Raad oordeelt hieromtrent: 'dat, indien de statuten bepalen dat commissarissen over de uitgifte van niet-geplaatste aandelen beslissen, aan dezen de bevoegdheid is gegeven om de plaatsing der aandelen te bewerkstelligen op de wijze als zij in het belang der vennootschap geraden oordelen, en een dergelijke bepaling ingevolge art. 1374 BW partijen tot wet strekt'. Voorts overweegt de Hoge Raad 'dat commissarissen, rechten uitoefenende die hun als orgaan der vennootschap zijn toegekend, zich hebben te richten naar het belang der vennootschap en dit moeten doen overwegen, indien dit naar hun oordeel in botsing komt met belangen van welken aandeelhouder ook'.

Deze uitspraak is sterk bekritiseerd door onder meer Van der Grinten, Löwensteyn en Maeijer. Zij stellen zich op het standpunt dat bij toetsing van het besluit aan de goede trouw 'alle in aanmerking komende belangen tegen elkaar dienen te worden afgewogen' en dat het belang van de vennootschap niet bij voorbaat overwegend is. ${ }^{44}$

Het meest in het oog springt nadien het Forumbankarrest (HR 21 januari 1955, NJ 1959, 43) dat als keerpunt in de ontwikkeling van het denken over het karakter van de NV kan worden beschouwd.

handel, Deventer 1989, p. 40/41.

43. Een uitgesproken voorstander van de institutionele opvatting van de vennootschap is zonder meer Lōwensteyn; zie met name zijn dissertatie Wezen en bevoegdheid van de vereniging en de naamloze vennootschap. Zwolle 1959.

44. Zie W.C.L. van der Grinten, Uitgifte van nieuwe aandelen en voorkeursrecht, NV 27, p. 121 e.v., F.J.W. Lowensteyn, Wezen en bevoegdheid van het bestuur van de vereniging en de naamloze vennootschap, diss. Amsterdam 1959. p. 238 en J.M.M. Maeijer, Het belangenconflict in de naamloze vennootschap, rede Nijmegen 1964, p. 13 alsmede in de NV 1989, p. 1-8. 
Centraal in deze zaak stond de vraag of de ava van een NV geldig een besluit kan nemen, waarbij zij aan het bestur opdraagt een bepaalde gedragslijn te volgen in een aangelegenheid die als zodanig volgens wet en statuten tot de bevoegdheid van het bestuur behoort. Het betrof hier een besluit van twee aandeelhouders, die tezamen de meerderheid in de ava vormden, tot inkoop van eigen aandelen. Het bestuur en de rvc hadden ernstige bezwaren tegen de inkoop, omdat de liquiditeit van de vennootschap daardoor in gevaar dreigde te komen. Een besluit tot inkoop van aandelen achtten zij in strijd met de belangen van de vennootschap en van de andere aandeelhouders. De twee aandeelhouders beriepen zich er onder meer op dat de 'hoogste macht' in de vennootschap bij de algemene vergadering berustte. Het Hof Amsterdam verwierp deze stelling en oordeelde het besluit ongeldig: "het stond de algemene vergadering niet vrij het bestuur instructies te geven op het terrein dat door (de wet en) de statuten aan het bestuur is toegewezen'. De Hoge Raad bevestigde de uitspraak van het hof met de overweging: 'dat ook de algemene vergadering de bij wet en statuten getrokken grenzen harer bevoegdheid niet mag overschrijden'.

Sindsdien wordt het autonome karakter van het bestuur benadrukt. Deze bestuursautonomie vindt echter, zoals Löwensteyn ${ }^{45}$ in zijn dissertatie schrijft, ook haar grenzen in het beginsel der goede trouw.

Zie in de rechtspraak bijvoorbeeld HR 27 januari 1956, NJ 1956, 48 (Unipart-RDM NV). Unipart was houdster van een aantaí oprichtersbewijzen aan toonder, die de Rotterdamse Droogdok Maatschappij had uitgegeven. Deze oprichtersbewijzen gaven recht op een aandeel in de statutaire (over)winst en liquidatiesaldo. Unipart stelde dat het bestuur van RDM, dat statutair bevoegd was inzake de financieringspolitiek van de NV, een aantal jaren te veel winst (ruim fl. 15 miljoen) aan de reserves toevoegde en tevens andere reserves opvoerde, waarvan Unipart nadeel ondervond.

De centrale vraag was in deze procedure of, en zo ja in hoeverre Unipart terzake van wat als reservering kon en mocht worden aangemerkt, gebonden was aan het opstellen van de jaarrekening door het bestuur dan wel de vaststelling daarvan door de algemene vergadering van aandeelhouders. Het hof stelde vast dat het bestuur aangewezen was tot zelfstandige bepaling van de financieringspolitiek in het belang van de NV. Echter, 'dit geeft haar geen vrijbrief om te handelen gelijk haar goeddunkt', aldus het hof. 'Dat immers haar gestie - ook los van andere organen der vennootschap - getoetst kan worden aan de beginseien van redelijkheid en billijkheid'. Het hof overwoog niettemin dat de besluiten om ruim ft. 15 miljoen als reserveringen op te voeren niet strijdig waren met de goede trouw vanwege 'de wens om een sterk door de wereldoorlog gehavend bedrijf zo snel mogelijk op te bouwen en in staat stellen met succes het hoofd te bieden aan concurrentie met andere soortgelijke ondernemingen'. De Hoge Raad bevestigde dit oordeel van het hof.

45. F.J.W. Lowensteyn, Wezen en bevoegdheid van het bestuur van de vereniging en de naamloze vennootschap, Zwolle 1959, p. 159. 


\section{§ 5. Goede trouw in de periode van 1976 tot 1992: art. 2:7 BW en art. 2:11 BW}

Met de invoering van boek 2 van het nieuw BW ${ }^{46}$ in 1976 wordt de opvatting dat de verhoudingen binnen rechtspersonen van eigen niet-contractuele aard zijn gecodificeerd. Art. 2:7 BW bepaalt dan dat de rechtspersoon, de aandeelhouders en degenen die deel uitmaken van haar organen 'zich als zodanig jegens elkander moeten gedragen naar hetgeen door de redelijkheid en billijkheid wordt gevorderd'. 4 De regeling van de vernietigbaarheid van besluiten van organen van rechtspersonen wegens strijd met de 'goede trouw' wordt neergelegd in art. 2:11 jo art. 13 BW. ${ }^{48}$ Daarmee staat vast dat de rechten en verplichtingen voor betrokkenen in de organisatie niet alleen worden vastgesteld door wet en statuten, maar ook door de redelijkheid en billijkheid.

De algemene opvatting is dat art. 2:7 BW betrekking heeft op de aanvullende werking van de redelijkheid en billijkheid, ook al vindt men dit niet met zoveel woorden terug in de wetsgeschiedenis. Als voorbeeld voor dit artikel heeft gediend ant 6.1.1.2 lid 1 NBW (na invoering 6:2 BW) dat bepaalt: 'schuldeiser en schuldenaar zijn verplicht zich jegens elkaar te gedragen overeenkomstig de eisen van de redelijkheid en billijkheid'. Art. 2:11 jo art. 13 BW regelt vervolgens de beperkende of corrigerende werking van de redelijkheid en billijkheid zoals art. 6.1.1.2 lid 2 voor het verbintenissenrecht, inhoudende 'dat een tussen cen schuldeiser en schuldenaar krachtens wet, gewoonte of rechtshandeling geldende regel niet van toepassing is, voor zover dit in de gegeven omstandigheden naar maatstaven van redelijkheid en billijkheid onaanvaardbaar is', $\mathrm{Vgl}$, ook bij de totstandkoming van de vaststellingswet Boek 2, het antwoord van de regering op de vraag inzake het verschil in terminologie tussen art. 2:11 (strijd met de goede trouw) en art. 2:7 BW (strijd met redelijkheid en billijkheid). In art. 2:11 is voor een andere terminologie gekozen dan in art. 2:7 BW, omdat het in art. 2:11 niet gaat over de aanvullende werking van ongeschreven rechtsregels, maar om de vraag of, terwijl men op zich heeft genomen zich te zullen neerleggen bij meerderheidsbesluiten, desondanks deze gehoudenheid kan worden doorbroken met een

46. Bij de Wet van 1960 (Stb. no. 205) werd boek 2 van het nieuwe burgerlijk wetboek vastgesteld. In 1970 werd het ontwerp van de Invoeringswet boek 2 ter vaststelling aan de Tweede Kamer aangeboden (nr. 11005).

47. Overigens werd art. 2:7 BW pas in de eerste nota van wijziging opgenomen in art. 2.1.7b. Zie C.J. van Zeben, Parlementaire geschiedenis van het nieuw burgerlijk wetboek, boek 2 rechtspersonen, p. $135 \mathrm{e} . \mathrm{v}$.

48. Zie art. 2.1.8 Ontwerp-Meijers.

49. Zie C.J. van Zeben, Parlementaire geschiedenis van het nieuw burgerlijk wetboek, boek 2 rechtspersonen, p. 136. 
beroep op de schending van de goede trouw in de zin van misbruik van meerderheidsmacht'.

Overigens wordt algemeen aanvaard wordt dat de begrippen redelijkheid en billijkheid in art. 2:7 BW en goede trouw in de artt. 2:11 en $13 \mathrm{BW}$ gelijk dienen te worden verstaan en dat de artt. 2:11 en $13 \mathrm{BW}$ in het verlengde liggen van art. 2:7 $\mathrm{BW}^{51}$

\section{De periode na 1992: art. 2:8 BW en 2:15 BW}

Met de invoering van het nieuwe vermogensrecht in 1992 is art. 2:7 BW vervangen door art. 2:8 BW en neemt art. 2:15 BW de plaats in van art. 2:11 BW. Art. 2:8 BW schrijft voor dat de rechtspersoon en de daarbij betrokkenen 'zich als zodanig jegens elkander gedragen naar hetgeen door redelijkheid en billijkheid wordt gevorderd'. In aansluiting daarop bepaalt art. 2:8 lid 2 dat een tussen hen 'krachtens wet, gewoonte, statuten, reglement of besluit geldende regel', niet van toepassing is 'voor zo ver dit in de gegeven omstandigheden naar maatstaven van redelijkheid en billijkheid onaanvaardbaar zou zijn'. Daarenboven voorziet art. 2:15 BW er in dat een besluit van een orgaan van een rechtspersoon vernietigbaar is 'wegens strijd met de redelijkheid en billijkheid die door artikel 8 wordt geëist.'

Deze aanpassing bracht drie veranderingen mee. In de eerste plaats wordt met de invoering van het NBW vermogensrecht zowel in art. 2:8 als in art. 2:15 BW gekozen voor dezelfde terminologie, namelijk 'redelijkheid en billijkheid'.

In de tweede plaats wordt de werkingssfeer van de redelijkheid en billijkheid verruimd, doordat in art. 2:8 BW niet meer wordt gesproken van 'organen', maar van 'bij de organisatie van de rechtspersoon betrokkenen'. Hieronder vallen bijvoorbeeld ook houders van met medewerking van een vennootschap uitgegeven certificaten van aandelen daar zij be-

50. Zie J.M.M. Maeijer, De corrigerende werking van goede trouw, in: Goed en Trouw, Zwolle 1984, p. 32.

51. Dit blijkt ook uit HR 17 mei 1991, NJ 1991, 645 (Lampe-Tonnema) nt Maeijer. Zie in de literatuur Handboek, nr. 172.1, P. van Schilfgaarde, Rechtspersonen losbladig, art. 11, aant 14 en J.M.M. Maeijer, De corrigerende werking van goede trouw, in: Goed en Trouw, Zwolle 1984, p. 32. Anders F.J.W. Löwensteyn in Pitlo-Löwensteyn, Rechtspersonenrecht p. 77 e.v. 
paalde rechten binnen het vennootschappelijk verband kunnen uitoefenen. ${ }^{52}$

In de derde plaats wordt in lid 2 van art. 2:8 BW een bepaling opgenomen dat redelijkheid en billijkheid ook bij wet, gewoonte, statuten, reglementen of besluiten gestelde regels opzij kunnen zetten. Deze behoefte bestaat volgens de wetgever omdat een vordering tot vernietiging bij wege van verweer - anders dan in art. 2:11 lid 2 BW niet meer is toegelaten. $^{53}$

$\mathrm{Na}$ het verstrijken van de vervaltermijn van eten jaar (art. 2:15 lid 2 BW) kan het besluit zelf niet meer worden aangetast. 'Een lid of aandeelhouder zou hierdoor kunnen worden gedupeerd, indien hij niet zelf tijdig het initiatief tot vernietiging zou hebben genomen, bijvoorbeeld omdat de rechtspersoon tijdens de termijn het besluit nog niet te zijnen nadele heeft uitgevoerd. De aldus gedupeerde zal dan echter alsnog een beroep op art. 2:8 lid 2 BW kunnen doen, indien aan de vereisten is voldaan; alleen ten opzichte van hem blijft die regel dan buiten toepassing', aldus MvT, p. 57.5 Bovendien kan art. 2:8 lid 2 voor een bepaald lid of een bepaalde aandeelhouder uitkomst bieden in gevallen waarvoor onvoldoende reden voor vernietiging van een besluit bestaat (vgl. MvT TK 17725, p. 56).

Deze derogende werking van de goede trouw in het rechtspersonenrecht wordt overigens niet door iedereen goed ontvangen. ${ }^{55}$

52. Vgl. MvT 17725, p. 56 en M. van Olffen, Vennootschaps- en rechtspersonenrecht en invoering van de boeken 3, 5 en 6 Nieuw BW, Deventer 1991, p. 16.

53. $\mathrm{Vgl}$. MvT 17725, p. 56 alsmede J.M.M. Maeijer, De corrigerende werking van de goede trouw, in het bijzonder binnen rechtspersonen in de bundel: Goed en Trouw 1984. p. 33.

54. Vgl. ook reeds Van der Heijden/Van der Grinten, Handboek 4e druk 1946, nr. 224.1, p, 343: er mag op gewezen worden 'dat besluiten op zich zelf redelijk en billijk kunnen zijn, terwijl hun tenuitvoerlegging tegenover een bepaalden persoon onder omstandigheden onredelijk of onbillijk is".

55. Zie P.L. Dijk, ant. 8 en de identiteit van de rechtspersoon, WPNR 1983, p. 549-552, F.J.W. Lōwensteyn, in: Goed en Trouw, 1984, p. 127 e.v. en T.J. van der Ploeg. De verbintenis in het rechtspersonenrecht, in: Met recht verenigd 1986, p. 202/203. Positief hierover zijn J.M.M. Maeijer, in: Goed en Trouw, 1984, p. 139 en P. van Schilfgaarde, WPNR 1983, p. 73. 


\section{7. Betekenis en functies van de goede trouw in het verbintenissen- en rechtspersonenrecht}

\section{\$ 7.1 Betekenis van de goede trouw en (redelijkheid en billijkheid)}

Over de betekenis en de functie(s) van de 'goede trouw' als bedoeld in art. 1374 lid 3 BW en de 'billijkheid' als bedoeld in art. 1375 BW is veel gestreden in de literatuur. Een aantal auteurs verdedigde bijvoorbeeld dat het begrip 'billijkheid' een andere inhoud heeft dan het begrip 'goede trouw'. ${ }^{36}$

Voorafgaande aan de keuze voor deze terminologie in het nieuwe BW, is flink bediscussieerd of een onderscheid moet worden gemaakt tussen de begrippen goede trouw en redelijkheid en billijkheid. Zo is wel gesuggereerd dat de goede trouw een gedragsnorm zou zijn (bijvoorbeeld aan te leggen ter toetsing van de uitvoering van een rechtshandeling) en dat de rol van redelijkheid en billijkheid beperkt was tot bepaling van de inhoud van (contractuele) verplichtingen. ${ }^{57}$ Met invoering van het nieuwe BW, en de daarin vervatte keuze voor redelijkheid en billijkheid als standaardterm, is die discussie beëindigd. Overigens had ook de Hoge Raad al voor de inwerkingtreding van deze wijzigingen de knoop doorgehakt.

Illustratief is HR 17 mei 1991, NJ 1991, 645 (Lampe Tonnema m. nt. Maeijer), AA 1991, p. 1009-1015, nt. Raaijmakers, TVVS 1991, p. 190-191, nt. Timmerman, in welk arrest de

56. Zo bijvoorbeeld N.J. van de Sande Bakhuijzen, Artikel 6.5.3.1. NBW en goede trouw, WPNR 1977, p. 247 e.v., G.H.A. Schut, Rechtshandeling, overeenkomst en verbintenis, Zwolle 1987, p. 130 en G.E. Langemeijer, De gerechtigdheid in ons burgerlijk vermogensrecht, 1985, p. 111-113. Vgl. hieromtrent H.J. de Kluiver, Onderhandelen en privaatrecht, diss. Amsterdam, 1992 nr. 34 en G.J. Rijken, Redelijkheid en billijkheid, Monografieẽn Nieuw BW, Deventer 1994, p. 2.

57. Voor verwijzingen naar en bespreking van relevante literatuur, alsmede korte historische schetsen, zie men onder meer H.J. de Kluiver, Onderhandelen en privaatrecht, Kluwer Deventer 1992, nr. 34 e.v. en J.M. Smits, Het vertrouwensbeginsel en de contractuele gebondenheid, Gouda Quint - Amhem 1995 p. 81 e.v. Voor het rechtspersonenrecht zie men specifiek F.J.W. Lōwensteyn, Rechterlijke toetsing van besluiten nu en in de toekomst, in: Goed en Trouw (Van der Grinten bundel, 1984) p. 127 e.v. die in de formulering 'strijd met de goede trouw', marginale toetsing las en meende dat de nieuwe formulering een volledige toetsing impliceerde. Anders Maeijer. De corrigerende werking van goede trouw, in Goed en Trouw, Zwolle 1984, p. 31 e.v. 
Hoge Raad oordeelde dat het begrip 'goede trouw' als bedoeld in art. 2:11 lid I sub c BW identiek is aan het begrip 'redelijkheid en billijkheid' als bedoeld in art. 2:7 BW.

In de jurisprudentie van de Hoge Raad worden de termen goede trouw en redelijkheid en billijkheid echter veelal door elkaar gebruikt zonder dat duidelijk is waarom aan de ene of andere term de voorkeur wordt gegeven. Deze normen van goede trouw dienen in beginsel in objectieve zin te worden verstaan. ${ }^{58}$

\section{$\S 7.2$ Functies van de goede trouw}

In het contractenrecht is een onderscheid gemaakt in een drietal functies van de goede trouw, te weten de interpreterende, de aanvullende en de corrigerende functie. Zowel de interpreterende als de aanvullende werking van de goede trouw zijn voor het verbintenissenrecht en het rechtspersonenrecht betrekkelijk gemakkelijk aanvaard. ${ }^{59}$

Ter illustratie van de interpreterende werking van de goede trouw kan het Forumbankarrest worden genoemd (HR 21 januari 1955. NJ 1959, 43). Het bestuur en de raad van commissarissen hadden ernstige bezwaren tegen de inkoop van een groot pakket eigen aandelen van twee aandeelhouders, omdat de liquiditeit van de vennootschap daardoor zeer in gevaar dreigde te komen. Een besluit tot inkoop van die aandelen achtten zij in strijd met de belangen van de vennootschap en andere aandeelhouders. Toch drukten de twee aandeelhouders, die tezamen de meerderheid in de algemene vergadering vormden een besluit tot inkoop door. Op grond van lid 2 van art. 4 van de statuten waren zij daartoe bevoegd. Lid 3 bepaalde dat de vennootschap bevoegd was om aandelen in haar maatschappelijk kapitaal voor eigen rekening onder bezwarende titel te verkrijgen tot ten hoogste de helft van haar geplaatst maatschappelijk kapitaal. Het hof Amsterdam oordeelde op 21 april 1954 het besluit van de ava ongeldig. Het hof interpreteerde de statuten in die zin dat de bevoegdheid van

58. Zie W.J.M. Noldus, Ongeldigheid van besluiten in de naamloze vennootschap. Deventer 1969, p. 171. Van subjectieve goede trouw werd bijvoorbeeld uitgegaan in de uitspraak van de Hoge Raad van 13 februari 1942. NJ 1942, 360 inzake Baus/De Koedoe. Er is sprake van misbruik van meerderheidsmacht wanneer een besluit is genomen 'met de opzet, hetzij om zichzelf of een derde onbillijk te bevoordelen, hetzij om de vennootschap of een derde te schaden'.

59. $\mathrm{Vgl}$. met betrekking tot besluiten van organen van de NV, J.M.M. Maeijer, Matiging van schadevergoeding, diss. Nijmegen 1962, p. 25-28, Van der Grinten, Handelen te goeder trouw, in: Opstelien aangeboden aan Prof.mr B.H.D. Hermesdorf 1965, p. 163. Zie voor de aanvullende werking van overeenkomsten bijvoorbeeld H.F.A. Völimar, Nederlands burgerlijk recht, tweede druk, Zwolle 1952, p. 261. 
art. 4 lid 3 uitsluitend aan het bestuur toekwam. ${ }^{\infty}$ Het Mante-arrest biedt een goed voorbeeld van een leemte in de regels tussen betrokkenen die door de rechter werd opgevuld (zie 8. 4). Het hof oordeelde dat Mante geattendeerd had moeten worden op het plaatsvinden van de aandeelhoudersvergadering. omdat een statutenwijziging aan de orde zou komen die ernstig afbreuk zou doen aan haar positie in de vennootschap. De vennootschap kon niet volstaan met de strikte inachtneming van de normen van de totstandkoming van het besluit tot statutenwijziging gebaseerd op de wet en de statuten. ${ }^{61}$

Echter, de vraag of aan de goede trouw beperkende werking mocht worden toegekend heeft de doctrine lange tijd verdeeld gehouden. Aanleiding daarvoor was een reeks van uitspraken van de Hoge Raad na 1925 waarin uitdrukkelijk werd ontkend dat de rechter de bevoegdheid heeft om op grond van de billijkheid contractuele bepalingen buiten toepassing te laten.

Reeds bij arrest van 10 januari in 1888, W 5518, besliste de Hoge Raad dat gebruik en billijkheid niet de inhoud van een overeenkomst opzij kunnen zetten. In het Sarong-arrest (HR 8 januari 1926, NJ 1926, 203) wordt deze beslissing herhaald. Een katoenmaatschappij verbond zich jegens Stork tot fabricage van een partij sarongs, te leveren in Rangoon. Door belemmeringen van de scheepvaart tijdens de eerste wereldoorlog is de verplichting van de katoenmaatschappij tijdelijk geschorst. Als de nakoming weer mogelijk is, zijn de produktiekosten inmiddels zodanig gestegen dat de ongewijzigde instandhouding van het overeengekomene zal leiden tot een groot verlies voor de katoenmaatschappij. De Hoge Raad oordeelt echter, anders dan het hof, dat art. 1374 lid 3 BW de rechter niet de mogelijkheid biedt op grond van gewijzigde omstandigheden het overeengekomen terzijde te stellen.

Die terughoudendheid ten aanzien van de corrigerende werking heeft ook het ontwerp Meijers voor een nieuw BW beheerst.

Vgl. E.M. Meijers, Ontwerp voor een nieuw burgerlijk wetboek. Toelichting, eerste gedeelte 1954, p. 21: 'Op tal van gebieden geeft de wetgever voorschriften, die hij wil, dat niet door een beroep op een gewoonterecht of op de billijkheid waardeloos kunnen worden verklaard'. Meijers wilde alleen de beperkende werking aanvaarden indien er sprake was van 'misbruik van recht': 'De wet bepale, dat de goede trouw niet alleen de uit overeenkomst en wet voortvloeiende verbintenissen kan aanvullen, maar ook deze onder bijzondere omstandigheden kan doen vervallen of buiten toepassing stellen; echter alleen voor het geval, dat een beroep op het overeengekomene of op het door de wet bepaalde onder de gegeven

60. Zie ook J.M.M. Maeijer, Rumoer rond de Holland-Amerika lijn, De NV 1966, p. 120.

61. Zie hieromtrent J.M.M. Maeijer, De corrigerende werking van de goede trouw, in het bijzonder binnen rechtspersonen, in: Goed en Trouw, Zwolle 1984, p. 40. 
omstandigheden als een misbruik van recht moet worden aangemerkt: ${ }^{2}$ Zoals bekend, heeft het nieuw Burgerlijk Wetboek dat in 1992 van kracht werd, op dit punt een geheel andere opzet dan het ontwerp dat Meijers in 1954 bij zijn dood achterliet.

In het verbintenissenrecht is aan deze controverse een einde gekomen met het arrest inzake Saladin/HBU (HR 19 mei 1967, NJ 1967, 261). Hierin erkent de Hoge Raad de beperkende werking van de goede trouw.

Deze zaak betrof het volgende. Saladin had van zijn bank een beleggingsadvies gekregen en voerde vervolgens overeenkomstig dit advies een transactic uit. Toen Saladin als gevolg hiervan een aanzienlijk verlies leed, sprak hij de bank aan tot schadevergoeding. De bank beriep zich echter op haar exoneratieclausule die deel uitmaakte van haar algemene voorwaarden. Het hof oordeelde dat de bank zich op de clausule kon beroepen, omdat zulks noch in strijd met de goede zeden noch met de goede trouw was. De Hoge Raad bevestigt weliswaar het oordeel van het hof dat in het onderhavige geval het hof heeft kunnen oordelen dat de bank met vrucht een beroep op de bepaling kon doen, maar overweegt wel uitdrukkelijk 'dat het antwoord op de vraag in welke gevallen aan degeen die bij contractueel beding [...] een beroep op dit beding niet vrijstaat, afhankelijk kan zijn van de waardering van tal van omstandigheden', \&s

In de periode na 1967 is de beperkende werking van de goede trouw op alle terreinen van het privaatrecht aanvaard. In dit verband is interessant dat in het rechtspersonenrecht, althans met betrekking tot de toetsing van besluiten de beperkende werking van de goede trouw in de rechtspraak reeds vanaf het begin van de twintigste eeuw kan worden herkend. ${ }^{64}$ Immers wanneer men aanvaardt dat het besluit uitvoering is van de oprichtingsovereenkomst en vervolgens een bepaalde wijze van uitvoering, een bepaald besluit, aan de goede trouw onderworpen acht, kan dit als een

62. Ontleend aan J.W.M. van der Grinten, Misbruik van recht, in: Goed en Trouw, Zwolle 1984, p. 376. Deze opvatting vindt men overigens nog steeds terug in het Belgische recht. Vgl. hierover J.M.M. Maeijer, De goede trouw of de redelijkheid en billijkheid, TPR 1991, p. 5-21.

63. Zie over deze uitspraak onder meer P. Abas, Beperkende werking van goede trouw, Deventer 1972, p. 179-181, Asser-Hartkamp II, nr, 313 e.v. en G.J. Rijken, Exoneratieclausules; Een analyse van de omstandigheden van welker waardering het afhangt of een beroep op een exoneratieclausule vrijstaat, diss. Utrecht, Deventer 1983, p. 86-88.

64. Zie onder meer W.J.M. Noldus, Ongeldigheid van besluiten in de naamloze vennootschap. Deventer 1969, p. 180. 
De ontwikkeling van de goede trouw in kapitaalvennootschappen in Nederland

(aanzet tot) erkenning van de mogelijkheid van beperkende werking van de goede trouw worden gezien. ${ }^{65}$

De volgende arresten zou men als een voorbode kunnen zien van derogerende werking van de goede trouw. In HR 17 juni 1921, W. 10740 (Deen Perlak) $^{\text {66 }}$ werd de directeur van een petroleummaatschappij werd door deze tot schadevergoeding aangesproken op grond dat hij voor een bedrag van circa 4 miljoen gulden aandelen van een andere maatschappij, dic weinig of niets waard waren, verkocht had aan de door hem bestuurde petroleummaatschappij, zodat deze een enorme schade had geleden. De directeur verweerde zich door zich te beroepen op het feit dat de ava hem décharge had verleend over het boekjaar waarin de transactie had plaats gevonden. Uit de jaarstukken bleek echter niets van de onderhavige transactie. De Hoge Raad oordeelde dat de goede trouw meebrengt dat geen beroep op décharge kan worden gedaan ten aanzien van de punten waaromtrent de goedgekeurde jaarstukken geen licht geven. Zie tevens HR 9 januari 1941, NJ 1941, 528 nt. P. Scholten inzake Willink/Ter Kuile. De meerderheid van aandelen was in handen van beide directeuren, die een besluit doordrukten waarbij, hun f 30000 salaris per jaar werd toegekend in afwijking van hetgeen tot dusver, na onderling overieg en na afspraak tussen de twee groepen van aandeelhouders was genoten, namelijk een bedrag van f 10000 . De Hoge Raad oordeelde dat dit besluit in strijd was met de goede trouw vanwege het eenzijdig negeren van de afspraak.

\section{§ 8. Betekenis en functie van de redelijkheid en billijkheid na 1992}

De geschetste aanpassing van de wetgeving, heeft een discussie over de betekenis en functie van de redelijkheid en billijkheid overigens niet beëindigd. In zekere zin wordt een discussie daardoor juist gestimuleerd. De kern van die discussie is, en blijft, hoe en in hoeverre de redelijkheid en billijkheid op basis van de in $\S 6$ besproken wettelijke regels het rechtsoordeel bepaalt. ${ }^{67}$ Om daarop een antwoord te geven is het dienstig eerst een moment stil te staan bij het karakter van de norm 'redelijkheid en billijkheid'.

65. Evenzo W.J.M. Noldus, t.a.p. p. $180 / 181$ en P. Abas, Beperkende werking van de goede trouw, Deventer 1972, p. 286.

66. Zie in dezelfde zin HR 20 juni 1924 W. 11259 , NJ 1924, p. 1107.

67. Ik ga hier voorbij aan de vraag in hoeverre redelijkheid en billijkheid ook zouden gelden als een door een Staat gecodificeerd burgerlijk recht daarin niet zou voorzien. Zie daarover bijvoorbeeld Schoordijk, Redelijkheid en billijkheid aan de vooravond van een nieuw milennium, Zwolle 1996, p. 15 waar hij stelt dat het burgerlijk recht niet geldt omdat de Staat het oplegt, 'maar omdat en voor zover de justiabelen als begrepen door de rechter zich hierin kunnen vinden.' 
De formulering zoals die nu in een aantal sleutelbepalingen van het nieuwe BW (ook buiten boek 2) is vervat, lijkt te indiceren dat redelijkheid en billijkheid als een gedragsnorm moet worden opgevat. ${ }^{\circ 8}$ Zo bepaalt art. 2:8 BW dat de rechtspersoon en alle daarbij betrokkenen 'zich als zodanig jegens elkander [moeten] gedragen naar hetgeen door redelijkheid en billijkheid wordt gevorderd' (curs. MK). Deze formulering acht ik echter misleidend. Redelijkheid en billijkheid missen immers zelfs het minimum aan scherpte en eenduidigheid dat nodig is om als een norm voor gedrag te kunnen fungeren. Wat deze begrippen wel in zich dragen is de opdracht aan en de bevoegdheid voor de rechter, om concrete gedragingen, in het licht van de omstandigheden en de gevolgen daarvan, te toetsen aan achterliggende waarden en (rechts)beginselen. In die zin is niet zozeer sprake van een gedragsnorm, maar van een tot de rechter gerichte 'beslissingsnorm'. ${ }^{9}$ Iets anders is dat wanneer een rechter beslist, deze beslissing bij voorkeur zodanig scherp en eenduidig is dat daaruit wel, voor de toekomst, een gedragsnorm kan worden afgeleid. Sterker nog, ik zou menen dat een rechter er steeds naar moet streven om zijn beslissing omtrent hetgeen de goede trouw in concreto vordert, te formuleren als een norm die in beginsel ook in andere gevallen toepassing kan vinden. ${ }^{70}$ Niet alleen is dat essentieel voor de rechtsontwikkeling, maar ook dwingt zo'n benadering tot gedegen motive in van een beslis-

68. Vgl. J.M.M. Maeijer, De corrigerende werking van de goede trouw, in het bijzonder binnen rechtspersonen, in: Goed en Trouw, 1984 p. 40.

69. Vgl. over 'beslissingsregels' en 'gedragsregels' bijvoorbeeld $\mathrm{H}$. Drion, Functies van rechtsregels in het privaatrecht, in de Bundel Speculum Langemeijer, Zwolle 1973, p. 49 e.v. $\mathrm{Vgl}$. ook Chr. Zevenbergen, Aard en werking der goede trouw in het Romeinsche verbintenissenrecht, Utrecht $3 e$ druk 1942 met name p. 13 en 17 en p. 20 waar hij stelt: 'bona fides dient vóór alles voor den rechter als maatstaf zoodra partijen het oneens zijn over hare rechten en verplichtingen'. Een iets ander accent legt naar mijn gevoel Asser-Hartkamp 4-II nr. 303, en met name nr. 315, die niet wil uitgaan van een bevoegdheid van de rechter, maar van een plicht voor partijen (die door de rechter slechts wordt geconstateerd).

70. Vgl. G.J. Wiarda, Drie typen van rechtsvinding. 3e druk, Zwolle 1988 p. 34 . Zie ook R.J.P. Kottenhagen, Van precedent tot precedent. Over de plaats en functie van het rechtersrecht in een gecodificeerd rechtsstelsel, Gouda Quint - Arnhem 1996 p. 269 die zich keent tegen het door de rechter zelf hanteren van open normen. Het is de taak van de rechter concrete normen te formuleren en niet 'om de problemen heen te lopen.' 
sing waarbij, op grond van de redelijkheid en billijkheid, van een besluit of statutaire regel wordt afgeweken. ${ }^{11}$

Bij deze benadering van redelijkheid en billijkheid verschuift het accent naar de rechtsvinding door de rechter. Die rechtsvinding zal altijd primair worden bepaald door het heersende rechtssysteem. Als hem een geschil wordt voorgelegd zal de rechter allereerst denkend vanuit dat systeem die regels selecteren die 'horen' bij een geschil, en aan de hand daarvan tot een oplossing komen. Welke regels bij een bepaald geschil 'horen' is echter zelfs voor goede en ervaren juristen niet altijd aanstonds duidelijk. ${ }^{2}$ Eén reden voor die onduidelijkheid is dat juist goede juristen, bij het bepalen van de relevante regels mede zullen worden geleid door de uitkomsten die toepassing daarvan zullen genereren en de wenselijkheid daarvan. Altijd is er de spanning tussen 'systeemgebondenheid en concrete billijkheid'. ${ }^{3}$ Hoe zwaar die 'concrete billijkheid' weegt zal mede worden bepaald door de aard en ernst van de bij het geschil betrokken belangen ${ }^{74}$ waarvan het gewicht op haar beurt weer mede wordt

71. Vgl. G.J. Wiarda, Drie typen van rechtsvinding, 3e druk, Zwolle 1988, p. 34. Die rechterlijke motivering is een hoofdthema van J.B.M. Vranken's Algemeen deel in de Asserseric, W.E.J. Tjeenk Willink - Zwolle 1995. Zie onder meer nr. 217 e.v. Zie ook J.M.M. Maeijer, De corrigerende werking van de goede trouw, in: Goed en Trouw, Zwolle 1984, p. 35.

72. Vgl. G.J. Wiarda, Drie typen van rechtsvinding. 3e druk, Zwolle 1988, p. 33. Zo men wil kan men dit keuzeproces van relevante regels ook, met J. Smits, Het vertrouwensbeginsel en de contractuele gebondenheid, diss. Leiden 1995, Arnhem 1995, p. 82 e.v., als een functie van redelijkheid en billijkheid zien.

73. $\mathrm{Vgl}$. aldus J.B.M. Vranken, Le bon juge en onbillijke rechtspraak, in: Met hoofd en hart (Leijten bundel) Zwolle 1991 p. 51 e.v. die zich met name oriênteert aan de Duitse literatuur ter zake. Zie voor een anglo-saxische benadering Dworkin, Law's Empire, London 1986 in wiens 'law as integrity' concept (vgl. met name de hoofdstukken 6 en 7 daaruit) juridische (systeem)gezichtspunten en beginselen een belangrijke rol (blijven) spelen. Vranken accentueert overigens, naar het ons toeschijnt bepaald sterker dan Dworkin, dat recht een 'discursieve grootheid is, dat wil zeggen het altijd voorlopige resultaat van een proces van meningsvorming en overtuiging' is. Deze overtuiging vormt ook het fundament voor zijn reeds vermeld Algemeen Deel (zie o.a. nr. 105 en nr. 169).

74. In de loop van de afgelopen decennia kan men een ontwikkeling in de rechtspraak ontwaren waarin het accent wat minder op de toepassing van regels en wat meer op het afwegen van de bij een bepaalde kwestie betrokken belangen wordt gelegd. Vgl. E.M.H. Hirsch Ballin heeft deze ontwikkeling 'van toepassingsjurisdictie naar belangenjurisdictie' nog eens belicht in de jubileum bundel, 'De Hoge Raad der Nederlanden; De plaats van de Hoge Raad in het huidige staatsbestel', p. 211 en met name p. 219 e.v. 
bepaald door de bestaande regels, fundamentele beginselen en morele gezichtspunten (die samen het 'systeem' vormen).

Art. 2:8 BW impliceert overigens niet dat regels van verbintenissenrecht die betrekking hebben op redelijkheid en billijkheid geen rol meer spelen binnen organisaties van rechtspersonen. Uit de wetsgeschiedenis blijkt dat art. 2:8 BW is bedoeld als een bepaling inzake de redelijkheid en billijkheid naast, respectievelijk in aanvulling op, de basisbepalingen in het vermogensrecht. ${ }^{75}$ Zo moet, gelet op art. 3:12 BW, ook in het rechtspersonenrecht bij de vaststelling van wat redelijkheid en billijkheid eisen, rekening worden gehouden met onder andere algemeen erkende rechtsbeginselen en met de maatschappelijke en persoonlijke belangen die bij het gegeven geval zijn betrokken. ${ }^{76}$

\section{§9. Redelijkheid en billijkheid, misbruik van recht en misbruik van bevoegdheid}

Zoals geschetst in § 3. e.v. werden in de eerste decennia van deze eeuw in de jurisprudentie verschillende grondslagen gehanteerd in het kader van toetsing van rechtshandelingen van vennootschappelijke organen. Die grondslagen, met name misbruik van recht en misbruik van bevoegdheid werden in de loop van de tijd 'geabsorbeerd' door het goede trouw beginsel. Dat betekent echter niet dat deze noties hun betekenis hebben verloren. In het navolgende zal worden onderzocht hoe in de doctrine en in de jurisprudentie de verhouding tussen redelijkheid en billijkheid enerzijds en misbruik van recht c.q. misbruik van bevoegdheid anderszijds, momenteel wordt bezien.

\section{§ 9.1 Misbruik van bevoegdheid}

Misbruik van bevoegdheid is in het BW geregeld in art. 13 van de eerste titel van boek $3 \mathrm{BW}$ dat regels bevat voor het vermogensrecht in het algemeen. Daarin zijn drie maatstaven neergelegd aan de hand waarvan

75. Zie Parl. Gesch. Boek 2, p. 262.

76. Met Raaijmakers meen ik dat art. $2: 8 \mathrm{BW}$ de ruimte laat om 'buiten-corporatieve' elementen mee te wegen. $\mathrm{Vgl}$. Over de rechtsbetrekkingen tussen aandeelhouders in een 'quasi-vof, in: In het nu, wat worden zal 1991, p. 203 e.v. Anders Van der Ploeg. Regels die de betrekkingen binnen de rechtspersoon beheersen, in Nieuw vennootschapsen rechtspersonenrecht, Zwolle 1992, p. 82. 
kan worden getoetst of sprake is van misbruik van bevoegdheid. De eerste is dat een bevoegdheid wordt uitgeoefend 'met geen ander doel dan een ander te schaden'. De tweede luidt dat een bevoegdheid wordt uitgoefend voor 'een ander doel dan waarvoor zij is verleend'. De derde maatstaf ten slotte behelst dat men, "in aanmerking nemende de onevenredigheid tussen het belang bij de uitoefening en het belang dat daardoor wordt geschaad, naar redelijkheid niet tot die uitoefening had kunnen komen'. Het is met name deze derde maatstaf (met als kern het begrip 'onevenredigheid') die vragen oproept. Hoe verhoudt deze zich tot die van redelijkheid en billijkheid? Twee benaderingen zijn hier mogelijk.

De eerste benadering van de verhouding tussen misbruik van bevoegdheid en redelijkheid en billijkheid is dat men de toets van redelijkheid en billijkheid ruimer oordeelt dan de in art. 3:13 BW neergelegde maatstaven. $^{7}$ Verdedigbaar is dat, mede gelet op art. 3:12 BW, de norm van redelijkheid en billijkheid - anders dan misbruik van recht - geen 'negatieve' toets aanlegt, inhoudend dat een redelijk mens gelet op de belangen van direkt betrokkenen tot een beslissing 'niet had kunnen komen', maar een 'positieve' toets in de zin dat een rechtshandeling of besluit slechts als redelijk en billijk geldt als alle betrokken belangen in aanmerking nemende, een redelijk oordelend mens aldus zou hebben besloten. Zoals gezegd zijn ingevolge art. 3:12 $\mathrm{BW}$, voor die afweging relevant 'algemeen erkende rechtsbeginselen, [...], in Nederland levende rechtsovertuigingen [...] en de maatschappelijke en persoonlijke belangen, die bij het gegeven geval zijn betrokken'. Zowel Maeijer ${ }^{78}$ als Van Schilfgaarde ${ }^{79}$ uiten zich enigszins cynisch over deze bepaling. Met Dubbink en Wiarda zou ik dat toch wat genuanceerder willen benaderen. ${ }^{80}$

77. Een dergelijke benadering kan ook worden gelezen in Asser-Vranken, waar hij noteert dat de (beperkende werking van) redelijkheid en billijkheid 'veel verder' gaat dan het leerstuk van misbruik van recht en dit leerstuk om die reden helemaal heeft 'overvleugeld'.

78. Zie Asser-Van der Grinten-Maeijer 2-III, nr. 133: 'Of dergelijke exclamaties het begrip verhelderen mag ernstig worden betwijfeld'. Genuanceerder zie men Maeijer, De corrigerende werking van de goede trouw, in het bijzonder binnen rechtspersonen, in: Goed en Trouw, Zwolle 1984, p. 34 en 42.

79. Van Schilfgaarde, Van de BV en de NV, nr. 96b: 'Erg veel verder brengt deze lyriek ons niet'.

80. Zie voor een genuanceerder betoog met name C.W. Dubbink, De redelijkheid en billijkheid volgens art. 3:12 NBW. WPNR 1990, p. 359-362 en p. 375-378 en G.J. Wiarda, Drie typen van rechtsvinding, 3e druk, Zwolle 1988, p. 108 e.v. 
De tweede mogelijke benadering is dat men toetsing aan misbruik van recht en toetsing aan redelijkheid en billijkheid juist met elkaar verbindt en in elkaar laat opgaan. Een voorstander van zo'n gelijkstelling tussen toetsing aan de goede trouw en aan misbruik van recht toont zich in Nederland Maeijer. Hij betoogt, kort gezegd, dat de beperkende werking van de goede trouw en misbruik van recht (met name benaderd vanuit het onevenredigheidscriterium) ${ }^{81}$ sterk verweven zijn en dat de praktische resultaten van beide doctrines niet ver uiteen zullen lopen. ${ }^{82}$

\section{$\S 9.2$ Billijkheid, misbruik en marginale toetsing}

Het voorgaande bepaalt mede hoe men oordeelt over rechterlijke toetsing van besluiten van organen van rechtspersonen aan redelijkheid en billijkheid zoals voorzien in art. 2:8 en 2:15 BW. In dit verband dient zich onvermijdelijk het begrip 'marginale toetsing' aan. In Nederland wordt zo'n 'marginale' toetsing van besluiten door de meeste beoefenaren van het vennootschapsrecht met overtuiging uitgedragen. Zo lees ik in AsserVan der Grinten-Maeijer 2-II (nr. 133): 'De rechterlijke toetsing van besluiten aan de redelijkheid en billijkheid kan als een marginale toetsing worden aangemerkt. In beginsel heeft de besluitende instantie beleidsvrijheid. De grens van de beleidsvrijheid wordt echter overschreden, indien een besluit tot stand komt dat een redelijk oordelend mens niet voor zijn rekening zou willen nemen. ${ }^{{ }^{83}}$ In gelijke zin zie men Van der Heijden-

81. Vgl. Asser-Vranken, nr. 137 waar het evenredigheidsbeginsel als een aan het gehele privaatrecht ten grondslag liggend 'zedelijkheidspostulaat' wordt gepresenteerd.

82. Opvallend, en mijns inziens (veel) te absoluut, is in dit verband de opvatting van Maeijer (Asser-Van der Grinten-Maeijer nr. 133) dat een besluit 'niet in strijd [is] met de redelijkheid en billijkheid, omdat een ander besluit beter zou zijn geweest.' Juist vanuit een 'onevenredigheids' perspectief wordt echter aangenomen dat een rechtshandeling ook niet door de beugel kan als weliswaar een redelijk belang bestaat bij bevoegdheidsuitoefening, maar een andere wijze van uitoefening daarvan minder nadeel toebrengt aan de ander. Kortom, toepassing van dat criterium brengt mee dat voor de 'minst bezwarende' wijze van uitoefening van een bevoegdheid moet worden gekozen (zo onder meer Rodenburg, Misbruik van bevoegdheid, Deventer 1985, p. 57).

83. Curieus is overigens dat het hier geponeerde slechts ten dele spoort met genuanceerder beschouwingen die Maeijer eerder aan het onderwerp wijdde. Zie bijvoorbeeld zijn mooie bijdrage 'De goede trouw of de redelijkheid en billijkheid' (TPR 1991 p. 5-21) waar hij noteert dat wij bij toetsing aan redelijkheid en billijkheid moeten 'oppassen' met de term 'marginale toetsing' (p. 10 en p. 21) en vervolgt: 'Van marginale toetsing door 
Van der Grinten. ${ }^{84}$ Zo ook Pitlo-Löwensteyn ${ }^{85}$ die het bereik van de 'marginale toetsing' nog iets verder vergroot met het poneren van de stelling dat een in beginsel toepasselijke regel slechts buiten toepassing dient te blijven als deze gevolgen heeft welke 'geen redelijk oordelende betrokkene (...) voor zijn rekening zou nemen'. ${ }^{86}$ In deze zin uit zich

de rechter kan mijns inziens moeilijk worden gesproken; evengoed kan men zeggen dat de rechter door de uitdrukking "onaanvaardbaar" wordt genoopt tot een verscherpte toetsing. Wel hebben de partijen een marge aan vrijheid zich te bewegen binnen het raam van de gevonden toepasselijke regels'. 'Eerst wanneer de grens van het (in verband met de onevenredigheid van belangen) kennelijk onredelijke (art. 13 boek 3) of van het onaanvaardbare (art. 248 boek 6) wordt gepasseerd bestaat die vrijheid niet meer. Door het nagaan en beoordelen van de relevante omstandigheden en de eis dat deze omstandigheden door de feitenrechter ook concreet worden aangeduid, houdt de Hoge Raad in het oog of de lagere rechter niet te vlug concludeert dat die grens is overschreden. In die zin is van marginale toetsing geen sprake.' $\mathrm{Vgl}$. in dit verband Asser-Vranken $\mathrm{nr} .111$ die constateen dat 'vage normen' bijna altijd leiden 'tot een zeer minutieus nalopen. vaststellen en afwegen van relevante feiten en omstandigheden. 'Onthullend is overigens Maeijer's opmerking (op p. 12) waarin hij verklaart zich te verzetten tegen uitleg te goeder trouw omdat hij daarin al snel een 'verdrongen billijkheidscomplex' ontwaart (zo ook reeds Maeijer t.a.p. 1984, p. 37). Recentelijk heeft hij in dat verband zich ook (wederom; zie reeds eerder Maeijer t.a.p. 1984, p. 40/41) uitgesproken tegen het 'rechtsvinderssyndroom' ('Vertrouwen en rechtszekerheid in het overeenkomstenrecht', TPR 1998 p. 5 e.v.). Zie ook nog Maeijer t.a.p. 1984, p. 40/41.

84. Van der Heijden-Van der Grinten, Handboek voor de naamloze en de besloten vennootschap, 12e druk. Zwolle $1992 \mathrm{nr}$. 224.1 waar het heet dat toetsing van besluiten 'een zeker marginaal karakter' heeft. Voor het bepalen van de grens van de beleidsvrijheid wordt ook daar als criterium gehanteerd of sprake is van een besluit 'dat een redelijk oordelend mens niet voor zijn rekening zou nemen.' Zie eerder reeds W.C.L. van der Grinten, Marginale toetsing, in: 'Op de grenzen van komend recht' (Beekhuisbundel) Kluwer/Tjeenk Willink, Deventer/Zwolle 1969 p. 109-123, die zich onder andere beroept op HR 21 mei 1943, NJ 1943, 484 (Baus/De Koedoe) en terughoudendheid met name lijkt te baseren op de stelling dat elke toetsing van de rechter 'een beperking [inhoudt] van een zelfbeschikkingsrecht'.

85. Rechtspersonenrecht, 3e druk Gouda Quint, Arnhem 1994 nr. 1.56-1.59 en eerder reeds Lowensteyn t.a.p. 1984.

86. Hetgeen hij verbindt met 'misbruik van bevoegdheid'. 'Volledige toetsing' acht hij aan de orde als een regel buiten toepassing blijft als deze in de gegeven omstandigheden 'naar het oordeel van de rechter in strijd met de redelijkheid en billijkheid is.' Hij had liever gezien dat de wetgever in plaats van zo'n algemene formulering 'de vrijheid van de burger' had omgeven 'met de waarborg van genuanceerde toetsingsnormen, zoals hij dit met de beleidsvrijheid van de overheid heeft gedaan'. Juist dit laatste is overigens gelet op de zich nog immer ontwikkelende scherpte van toetsing van overheidshandelen niet (meer) zo'n sterk argument. 
ook Timmerman die meent dat een rechter zowel bij toetsing van de inhoud van een besluit als bij de wijze van totstandkoming daarvan, 'marginaal' en niet integraal moet toetsen. ${ }^{87}$ Van Schilfgaarde ${ }^{88}$ is een van de weinigen die een tegenstem laat klinken. 'Ook aan de redelijkheid en billijkheid dienen besluiten integraal te worden getoetst', zo stelt hij. Wel laat de norm van redelijkheid en billijkheid zijns inziens een 'een zodanige marge dat men niet al te snel [...] tot overschrijding daarvan moet besluiten."

Een andere benadering is die van Rodenburg ${ }^{89}$ die toetsing aan misbruik van recht en aan redelijkheid en billijkheid onderscheidt, en deze onderscheiding verbindt met respectievelijk beperkte ('marginale') toetsing in geval van misbruik van recht, ${ }^{90}$ en volledige toetsing als redelijkheid en billijkheid in het geding is. Die 'volledige toetsing' zou zijns inziens inhouden dat een partij de belangen van de wederpartij in beginsel op gelijke wijze in aanmerking te nemen als het eigen belang. Wordt getoetst aan misbruik van recht dan zouden de eigen bevoegdheden en het eigen belang van de handelende primair op de voorgrond treden. Tegen het aldus onderscheiden van marginale en volledige toetsing, keert zich Schoordijk ${ }^{91}$ naar wiens inzicht 'toetsingsmogelijkheden [...] per definitie nooit beperkt' zullen zijn, en een rechtsoordeel steeds zal worden bepaald door de aard van de (rechts)verhouding en de aard van bij uitoefening van rechten betrokken belangen. ${ }^{92}$ In deze controverse schaar ik aan de zijde

87. L. Timmerman in De Monchy-Timmerman t.a.p., p. 85/86.

88. Van Schilfgaarde, Van de BV en de NV, nr. 96 b.

89. P. Rodenburg t.a.p., p. 64

90. Rodenburg o.c. p. 50 . Ook toetsing aan de maatstaf van het met misbruik van bevoegdheid verbonden 'onevenredigheidscriterium' impliceert zijns inziens zo'n beperkte. 'marginale toetsing'. De kernvraag darbij zou dan zijn of de handelwijze ter uitoefening van de bevoegdheid 'in hoge mate onbillijk is, en wel zodanig dat ieder redelijk oordelend mens in het gegeven geval en in de positie van de rechthebbende tot dezelfde conclusie zal komen',

91. H.C.F. Schoordijk, Vermogensrecht in het algemeen naar boek 3 van het nieuwe B.W., Kluwer - Deventer 1986 p. 23 e.v.

92. $\mathrm{Vgl}$. Schoordijk o.c. p. 29 e.v. met name p. 33/34. Men kan het ook zo formuleren dat een toetsing aan redelijkheid en billijkheid steeds vereist te onderzoeken welke ruimte voor appreciatie de bij een bepaald geval betrokken regels en beginselen, gelet op het doel daarvan. laten. Zie in dit verband, naar aanleiding van de vraag of art. 2:8 zich uitstrekt tot toelating van leden tot een vereniging. H.J. de Kluiver, Toelating van betrokkenen bij rechtspersonen, S\&V 1991 resp. p. 35 e.v., p. 63 e.v. met name p. 69. en de daarop volgende discussie met R.F.H. Mertens in S\&V 1991 p. 97-101. Al of niet 
van Schoordijk. Met 'marginale toetsing' wordt de bevoegdheid van een rechter immers reeds bij voorbaat ingeperkt doordat als het ware een gebied wordt afgebakend waarin de rechter niet komen mag. Maar in art. 2:8 BW is nu juist uitdrukkelijk het hele bereik van de verhoudingen tussen rechtspersoon en de daarbij betrokkenen onder het opzicht van de redelijkheid en billijkheid geplaatst en dus, zoals hiervoor door mij verdedigd $(\$ 8)$, onderworpen aan de beslissingsbevoegdheid van de rechter. Anders dan Schoordijk ben ik echter geneigd wel met Rodenburg in te stemmen in die zin dat wanneer rechters misbruik van recht als toetsingscriterium aanleggen zij wellicht (mede) tot uitdrukking brengen dat een handelwijze minder snel rechtens onaanvaardbaar wordt geacht dan in geval van toetsing aan redelijkheid en billijkheid.

Uit het voorgaande kan al worden afgeleid dat de grondslag van de leer van de 'marginale toetsing' in Nederland niet bijzonder sterk is. Weliswaar heeft Borst in de jaren '60 getracht in Nederland diepgravender onderzoek over 'marginale toetsing' te entameren, ${ }^{93}$ maar die poging is in het voorbereidingsstadium blijven steken. Het uitgangspunt van zijn benadering was een 'vrije beleidsvoering' in 'verbanden'. De rechtsgrond voor die beleidsvrijheid zocht hij in 'het gezag over degenen, die tot dat verband behoren'. Dit 'gezag', en het daarop gebaseerde beleid, moeten zowel betrokkenen als de rechter eerbiedigen. Deswege staan een 'verband' en een betrokkene 'niet op gelijke voet' in geval van een geschil, en kan een rechter alleen 'marginaal toetsen', dat wil zeggen ingrijpen bij kennelijke onredelijkheid. ${ }^{94}$

De uitgangspunten van deze redenering doen gedateerd aan en worden, naar mijn inschatting, niet meer in brede kring geaccepteerd. Het betrekt een 'overheidsdenken' (te) sterk op privaatrechtelijke organisaties. Onder

toelating van leden dient, zo was de stelling, te worden getoetst aan het criterium of dit wordt gelegitimeerd door het doel van de rechtspersoon in het licht van de goede trouw. Dat kan men evengoed 'marginale' als 'volle' toetsing noemen maar dergelijke termen verhelderen (dus) niets.

93. Zie met name P. Borst, 'Problemen en perspectieven van de marginale toetsing', in WPNR 5024-5027 [1969].

94. Borst t.a.p., p. 26-28. Zie p. 52/53 voor het onderscheid tussen toetsing aan 'kennelijke onredelijkheid' (welke marginale toetsing impliceert) en toetsing aan de 'gewone redelijkheid'. Het laatste impliceert aldus Borst 'volledige toetsing' waarbij de rechter zijn oordeel over (on)redelijkheid niet ten achter stelt bij dat van anderen. 
meer Timmerman heeft daartegen terecht gewaarschuwd.95 Die waarschuwing kan ook gelden met betrekking tot de theorie van Löwensteyn die overigens een interessant 'changement' doorvoert. Ook hij laat zich inspireren door het publiekrecht. Zijn perspectief is echter niet bestuursrechtelijk maar staatsrechtelijk, waarbij hij aanknoopt bij de regel dat een rechter overheidsregelgeving niet kan toetsen omdat het parlement dat moet doen. Aldus zou ook in de rechtspersoon toetsing van een besluit aan de redelijkheid en billijkheid niet aan de rechter maar aan de algemene vergadering toekomen. Kort gezegd: De algemene vergadering mag geen onredelijke besluiten nemen, maar of een besluit (on)redelijk is maakt zij zelf uit. De rechter is, aldus nog steeds Löwensteyn, slechts tot ingrijpen bevoegd als een bevoegdheid 'disfunctioneel' wordt gebruikt, dat wil zeggen in redelijkheid niet kan dienen ter behartiging van het doel en de belangen met het oog waarop deze gegeven is. ${ }^{96}$

Als men echter, zoals Löwensteyn, vanuit een staatsrechtelijk perspectief redeneert, kan er niet aan worden voorbij gegaan dat de steeds bredere aanvaarding van individuele (grond)rechten de rechter juist steeds meer vrijheid geeft (overheids)regelgeving en (overheids)besluitvorming te toetsen, hetgeen mutatis mutandis dan ook voor besluit- en regelgeving binnen rechtspersonen moet worden aanvaard. Raaijmakers tracht hier aan te ontkomen door te benadrukken dat toetreding tot een privaatrechtelijke organisatie nu eenmaal onderwerping betekent aan de 'meest belangrijke spelregel' van het rechtspersonenrecht; het 'door de wet voorgeschreven meerderheidsprincipe'.97 Maar dit principe, zo zou ik menen, staat er zeker niet aan in de weg dat een concrete beslissing wordt getoetst aan de redelijkheid en billijkheid. En op de vraag hoe die toetsing zou moeten geschieden geeft het evenmin antwoord. Dat geldt eigenlijk ook voor de

95. L. Timmerman, De concretisering van vage normen in het ondernemingsrecht, in: Van vennootschappelijk belang (Maeijer bundel 1988) p. 340/341 waarbij opgemerkt zij dat zijn betoog niet zozeer betrekking heeft op invulling van de norm van redelijkheid en billijkheid maar op die die van 'wanbeleid'. Timmerman benadrukt dat een verschil tussen overheid en private rechtspersoon is dat de laatste moet vechten voor de eigen continuiteit.

96. F.J.W. Lōwensteyn, Rechterlijke toetsing van besluiten nu en in de toekomst, in: Goed en Trouw (Van der Grinten bundel), Tjeenk Willink - Zwolle 1984 p. 127 - 141.

97. M.J.G.C. Raaijmakers, Over toe- en uittreding van leden ingeval van fusie en omzetting van (coöperatieve) verenigingen, in: Van vennootschappelijk belang (Maeijer bundel) 1988 p. 205 e.v. met name p. 210. 
benadering van Maeijer die hiervoor al enige malen aan bod kwam. Hoewel zijn stelling duidelijk is; er is 'beleidsvrijheid' voor vennootschapsorganen en dus moet 'marginaal' worden getoetst, lijkt de dogmatische grondslag daarvoor uiteindelijk toch slechts neer te komen op het postulaat dat dit samenhangt met de, niet verder geëxpliciteerde aard van de rechtsverhoudingen binnen de rechtspersoon en de daarin toegedeelde bevoegdheden. Mijn indruk is dat daarachter rechtspolitieke en 'praktische' argumenten schuil gaan. ${ }^{98}$

Het ontbreken van een, breed aanvaarde, theorie heeft echter geen gevolgen gehad voor de heersende leer met betrekking tot de 'marginale toetsing'. Gelijk geschetst baseert de grote meerderheid van de auteurs zich daarbij op de stelling dat een beslissend orgaan 'beleidsvrijheid' toekomt. Dat is echter mijns inziens het punt niet. De vraag is of dat betekent dat de vrijheid bestaat om onredelijke en onbillijke beslissingen te nemen? De vraag stellen is hem, althans naar mijn inzicht, (ontkennend) beantwoorden. ${ }^{99}$ Iets anders is dat niet te snel moet worden geoordeeld dat een bepaalde beslissing of een bepaald besluit onredelijk of onbillijk is. Daarbij is mede van belang dat de rechter bij gebrek aan kennis op het terrein van commercie en management zo'n oordeel ook niet snel kan vellen. Curieus genoeg echter vloeit zo'n terughoudende benadering juist voort uit een 'volledige toetsing'. Dan immers moeten alle bij een geval betrokken belangen in de afweging moeten worden betrokken. En aangezien er altijd wel belangen zullen zijn die uiteenlopen, zal juist dan betrekkelijk zelden tot een eenduidig oordeel over de redelijkheid en billijkheid van een besluit kunnen worden gekomen. ${ }^{100}$

98. Vgl. J.M.M. Maeijer, De corrigerende werking van de goede trouw, in het bijzonder binnen rechtspersonen, in: Goed en Trouw (Van der Grinten bundel). Tjeenk Willink Zwolle 1984 p. 31 e.v. met name p. 34 - 36 en p. $40 / 41$ waar het er op lijkt dat zijn standpunt ingegeven is door een combinatie van overwegingen zoals de angst voor rechterlijk activisme, gehechtheid aan regels die een soepel rechtsverkeer bevorderen (hetgeen hij op p. 34 als een 'maatschappelijk belang' in de zin van art. 3:12 BW beschouwt) en wantrouwen van het streven naar 'puur individueel bepaalde rechtvaardigheid' die 'naar menselijke maatstaven' toch niet bereikbaar is (p. 36).

99. Zo ook Lowensteyn t.a.p. 1984, p. 129 waarbij echter, zoals hiervoor in de tekst uiteengezet, de belangrijke kanttekening moet worden gemaakt dat dit voor Löwensteyn niet betekent dat de rechter de bevoegdheid tot toetsing toekomt.

100. Vgl. wederom Van Schilfgaarde, Van de BV en de NV, nr. 96 sub b. 


\section{\$10. Toetsing in (en aan) jurisprudentie}

\section{$\$ 10.1$ Misbruik van recht en misbruik van bevoegdheid in de juris- prudentie}

In $\$ 3$ e.v. is geschetst hoe het leerstuk van misbruik van recht, althans in het Nederlandse vennootschapsrecht, in beginsel is 'geabsorbeerd' door de redelijkheid en billijkheid. Op dit beginsel zijn echter zeker uitzonderingen te onderscheiden. Die uitzonderingen zou ik in twee categorieën willen indelen. De eerste categorie betreft de gevallen waarin bij de uitoefening van vennootschapsrechtelijke bevoegdheden derden betrokken zijn die niet gerekend kunnen worden tot de bij de rechtspersoon betrokkenen, en mitsdien buiten het bereik van art. 2:8 BW vallen. In de tweede categorie kunnen die gevallen worden ondergebracht waarin de traditionele maatstaven uit de misbruik van recht doctrine - gebruik van een bevoegdheid louter om een ander te schaden en gebruik van een bevoegdheid voor een ander doel dan waarvoor deze gegeven is - bijzonder 'passend' voorkomt.

Een sprekend voorbeeld van de eerste categorie is de werknemer van een rechtspersoon die door een bestuurder daarvan ontslagen wordt zonder dat voldaan is aan een daarvoor door de statuten gestelde vereiste (bijvoorbeeld een voorafgaand geldig bestuursbesluit of voorafgaande goedkeuring van een ander orgaan).

De Hoge Raad overwoog in zo'n geval ${ }^{101}$ (h. betrot itet ontslag van een werknemer van een stichting die overigens ook lid van het stichtingsbestuur was en uit dien hoofde inzicht had in de besluitvorming) dat wanneer een stichting wordt vertegenwoordigd door krachtens haar statuten daartoe bevoegden, een door hen verrichte rechtshandeling geldt als een rechtshandeling van de stichting. ook als in strijd is gehandeld met de regel dat daaraan een (geldig) bestuursbesluit ten grondslag liggen moet. 'Dit is alleen anders, wanneer onder de omstandigheden van het geval de uitoefening van hun bevoegdheid zonder een daaraan ten grondslag liggend geldig bestuursbesluit tegenover de wederpartij misbruik van bevoegdheid zou opleveren.' Dat dient dan echter wel gesteld te worden en met voldoende feiten te worden onderbouwd. In casu was dat volgens de Hoge Raad niet of onvoldoende gebeurt. ${ }^{\text {to2 }}$

101. HR 5 januari 1979. NJ 1979. 317 Slijkerman-Öldorp.

102. Vergelijkbaar is de situatie dat een, op zichzelf vertegenwoordigingsbevoegde, directeur in een rechterlijke procedure verweer voert zonder daartoe gemachtigd te zijn op basis van de statutaire voorschriften. Dit geval kwam ten toets in HR 9 juli 1990. NJ 
De ontwikkeling van de goede trouw in kapitaalvennootschappen in Nederland

In die eerste categorie zou ik ook willen plaatsen de toepassing die de Hoge Raad aan de idee 'misbruik van recht' heeft gegeven in de context van een beroep op rechtspersoonlijkheid ter afwering van een vordering van derden. Een voorbeeld daarvan biedt HR 9 juni 1995, NJ 1996, 213 (Citco-Krijger).

In dit geval sluit Krijger een overeenkomst met Lorimar NV (een Antilliaanse vennootschap). Deze vennootschap is een bedrag van zo'n $f 85.000$,- verschuldigd aan de Citco Bank. De Bank legt vervolgens beslag onder Lorimar NV en derdenbeslag onder Krijger. Dan gebeurt het volgende. De directeur van Lorimar (Van Ooyen) spreekt met Krijger af dat deze de aannemingsovereenkomst met Lorimar opzegt en vervolgens een nieuwe aannemingsovereenkomst afsluit met Intervorm NV welke het huis zal afbouwen. Intervorm NV wordt ook weer geheel beheerst door Van Ooyen. Een en ander heeft tot gevolg dat de Bank achter het net dreigt te vissen. De Bank tracht nu het tij te keren met de stelling dat in dit geval onder het derden-beslag ook het bedrag valt dat Krijger aan Intervorm NV moet betalen nu de beide vennootschappen, gelet op de rol van Van Ooyen daarin, in feite dezelfde zijn. Het verweer van Krijger is uiteraard dat het hier geheel verschillende rechtspersonen betreft. De vraag is dan uiteraard of Krijger zich op dat verschil kan beroepen. De Hoge Raad overweegt vervolgens 'dat van het identiteitsverschil tussen twee door dezelfde persoon beheerste rechtspersonen misbruik kan worden gemaakt' en dat hetgeen met een dergelijk misbruik wordt beoogd (i.c. het ten nadele van de beslaglegger frustreren van een beslag) 'in rechte niet behoeft te worden gehonoreerd'.

Voorbeelden van gevallen in de tweede categorie, waarin 'misbruik van recht' zich met name aandient onder het gezichtspunt dat een bevoegdheid kan worden gebruikt voor een ander doel dan waarvoor deze is verleend, bieden met name de casus waarin gebruik wordt gemaakt van uitdrukkelijk in de wet verankerde specifieke bevoegdheden. Men denke aan het in art. 2:92a/201a BW gegeven recht om uitkoop van minderheidsaandeelhouders te vorderen als de vorderende aandeelhouder(s) minimaal $95 \%$

1991, 51 (Sluis BV) en Hof Amsterdam (OK) 24 januari 1991, NJ 1991, 224. Overigens is in recente jurisprudentie van de Ondernemingskamer ook in dergelijke gevallen wel getoetst aan 'redelijkheid en billijkheid'. Verdedigd zou echter kunnen worden dat in die situaties wel een vennootschappelijke relatie tussen de betrokkenen bestond. $\mathrm{Vgl}$. Hof Amsterdam (OK) 15 mei 1997, NJ 1998, 517 met betrekking tot de vordering tot het instellen van een enquete bij een dochtervennootschap door de moedervennootschap. Voorts Hof Amsterdam (OK) 5 februari 1998, NJ 1998, 560 waar op een vordering tot kostenverhaal door een directeur werd overwogen dat ingeval een bestuurder van oordeel is dat sprake is van wanbeleid tengevolge van het handelen van de andere bestuurder, op de regel inzake vertegenwoordigings(on)bevoegdheid in redelijkheid geen beroep worden gedaan. 
van de aandelen in een vennootschap houden, en de in art. 2:335 e.v. gegeven bevoegdheid tot vordering van uitkoop van aandeelhouders als het voortduren van aandeelhouderschap 'in redelijkheid' niet kan worden geduld of gevergd.

Een voorbeeld biedt HR 6 oktober 1993, NJ 1994, 300 (Bobel/VEB) waarin cen vennootschap stelde dat een op grond van art. 2:344 BW ingediend enquêteverzoek als een onjuiste wijze van uitoefening van de enquêtebevoegdheid moest worden beschouwd, omdat de verzoekende aandeelhouders dat verzoek baseerden op andere bezwaren dan eerder aan het vennootschapsbestuur waren gemeld. De Hoge Raad overwoog slechts dat de lagere rechter er van uit ging dat het enquêterecht niet voor andere redenen werd gebruikt dan waarvoor het is gegeven en dat de lagere rechter (dus) in voldoende mate had onderzocht of sprake was van 'misbruik van bevoegdheid'. Ook in de sfeer van het gebruik maken van de uitkoopregeling wordt wel eens de stelling betrokken dat dit misbruik van recht inhoudt. ${ }^{103}$

Een duidelijke illustratie van misbruik van bevoegheid biedt ook de jurisprudentie in de jaren 60 en 70 in verband met uitoefening van de emissiebevoegdheid door het bestuur. ${ }^{104}$

$\mathrm{Vgl}$. bijvoorbeeld Pres. Rb. Arnhem 22 september 1967, NV 45, 125 inzake de Veenendaalsche Stoomspinnerij en Weverij NV. In deze zaak had de directie van van de Veenendaalsche Stoomspinnerij onenigheid met de geschorste directeur/aandeelhouder Bottenheim. Enkele dagen voordat over het ontslag van Bottenheim zou worden beslist in een reeds bijeengeroepen aandeelhoudersvergadering emiteen de directie 2095 aandelen à $f 1000$,nominaal bij Staflex International, een belangrijke zakenrelatie. Bottenheim werd hierin niet gekend en hem werd ook geen voorkeursrecht verleend. Door de emissie was er een meerderheid op de aandeelhoudersvergadering om positief te beslissen over het ontslag van Bottenheim. Bottenheim trachtte vervolgens het emissiebesluit aan te tasten wegens strijd met de goede trouw. De Veenendaalsche gaf drie motieven op voor de emissie; onderkapitalisatie van de vennootschap, het belang voor de NV dat Staflex zich financieel interesseerde in de NV en het feit dat het bestuur en commissarissen voor een afdoende meerderheid van stemmen voor hun standpunt wilden zorgen. De president overwoog dat 'kennelijk slechts het laatste motief het beslissende was om op dit ogenblik tot emissie te besluiten'. Hij achtte het echter niet uitgesloten dat 'aan directie en commissarissen geen verwijt kon worden gemaakt dat zij -alle belangen in aanmerking genomen- van een meerderheidsmacht met

103. Zie daarover onder meer het overzicht van jurisprudentie ter zake door W.J. Slagter in TVVS 1997 p. 282 e.v. met name p. $284 / 285$.

104. $\mathrm{Vgl}$. onder meer Scholtens's Aardappeimeelfabrieken, HR 4 januari 1963, NJ 1964, 434. De NV Rubberfabriek Vredestein, Pres. Rb Den Haag 22 mei 1970, NV 48, 51 alsmede Hof Den Haag 15 april 1971, NJ 1971, 301 en Reiss \& Co, Pres. Rb. Amsterdam 1 september 1970, NJ 1970, 401. Zie tevens W.J.M. Noldus, Ongeldigheid van besluiten in de naamloze vennootschap, Deventer 1969, p. 216 e.v. 
De ontwikkeling van de goede trouw in kapitaalvennootschappen in Nederland

behulp van de Staflex-aandelen gebruik wilden maken om Bottenheim als directeur uit te schakelen'.

\section{10.2 Redelijkheid en billijkheid in de jurisprudentie}

Zoals reeds in $\S 2$ is geschetst is de vraag naar de functie, en de uitwerking, van de maatstaf van redelijkheid en billijkheid (voorheen 'goede trouw'), historisch nauw verbonden geweest met de toetsing van besluiten van de algemene vergadering van aandeelhouders in een naamloze (en besloten) vennootschap, en van de vergadering van leden in een coöperatie of vereniging. ${ }^{105}$ In $\S 4.2 \mathrm{kwam}$ echter al aan de orde dat nadien ook de besluitvorming in andere rechtspersonenrechtelijke organen steeds vaker aan rechterlijke toetsing werd onderworpen. ${ }^{106}$ In de volgende

105. Oude rechtspraak in dit verband vindt men vermeld bij Asser-Van der Grinten-Maeijet 2-II nr, 133 en Van der Heijden/Van der Grinten, Handboek nr. 224.1. Als recente, en bekende, uitspraken van de Hoge Raad vermeld ik HR 18 juni 1982, NJ 1983, 200 (De Vries/Biologische Tuinbouwvereniging Elderveld); HR 26 oktober 1984, NJ 1985, 375 Sjardin; HR 9 januari 1987, NJ 1987, 959 (Vecolac/Juliana); HR 19 mei 1989, NJ 1989, 652; HR 17 mei 1991, NJ 1991, 645 (Lampe/Tonnema); HR 10 maart 1995. NJ 1995, 595 (Janssen Pers); Hof Amsterdam (OK) 26 mei 1983, NJ 1984, 481 (inzake aan aandeelhouders voorafgaande aan besluitvorming te verschaffen informatie); Hof 's-Gravenhage 17 maart 1983, NJ 1984, 81 (Reynders/McKinney); Hof Amsterdam 18 mei 1989, NJ 1990, 591 (vernietiging besluit tot ontslag van bestuurder); Rb Almelo 2 augustus 1995/Hof Arnhem 10 september 1996, JOR 1996, 130. Enigszins a-typisch zijn de gevallen waarin een dechargebesluit wordt aangetast (zoals in HR 20 oktober 1989, NJ 1990, 308) en HR 10 januari 1997, NJ 1997, 360 (Van de Ven). Zie voorts in de verhouding tussen aandeelhouders onderling voor de vraag of een aandeelhouder in strijd handelt met de redelijkheid en billijkheid door gebruik te maken van geschillenregeling HR 8 december 1993, NJ 1994, 273.

106. Als uitspraken betreffende besluitvorming van andere organen, zoals het bestuur en de RvC, kunnen onder meer worden vermeld HR 1 april 1949, NJ 1949, 465 (Doetinchemse Uzergieterij); HR 14 mei 1965, NJ 1965, 259 (royementsbesluit door een bestuur); HR 15 juli 1968, NJ 1969, 101 (Wijsmuller); HR 24 september 1976, NJ 1978, 135 (Erdal) waarin bij het toetsen van pakketvergoeding het hof vooropstelde dat degenen die deel uitmaken van de organen zich jegens aandeelhouders niet te goeder trouw hadden gedragen; Hof 's-Gravenhage 14 juni 1985, NJ 1987. 574 (bestuursbesluit ballotage Domburgsche Golfclub). Zie voorts een aantal uitspraken waarin beslissingen tot uitgifte van aandelen in het kader van bescherming tegen vijandelijke overnames werden getoetst. Zie het overzicht bij Asser-Maeijer 2-III nr. 250 e.v. en nr. 450 alsmede H.J. de Kluiver, Machtsstrijd en machtsovername. Opmerkingen over macht, recht en een gegeven paard, Deventer 1996, p. 18 e.v. Overigens laat een en ander onverlet dat een orgaan van een rechtspersoon jegens een 
hoofdstukken kom ik op een en ander uitgebreid terug. Op deze plaats richt ik de blik uitsluitend op enige uitspraken die licht (kunnen) werpen op de hiervoor aan de orde gestelde kwesties en in het bijzonder met betrekking tot (marginale) rechterlijke toetsing. Een goed aanknopingspunt daarvoor biedt HR 18 juni 1982, NJ 1983, 200 (De Vries/Biologische Tuinbouwvereniging Elderveld). In dat arrest was een besluit aan de orde tot royement van een lid van een vereniging door de algemene vergadering. In dit arrest wordt wel gelezen dat de Hoge Raad kiest voor een 'marginale toetsing' van besluiten. Daartegen is echter nog wel iets in te brengen.

Het royementsbesluit werd door rechtbank en hof niet in strijd met de redelijkheid en billijkheid geoordeeld. De Hoge Raad, reagerend op een cassatiemiddel dat 'marginale toetsing' onvoldoende achtte overwoog: 'Het oordeel dat de Vereniging, gezien alle ornstandigheden van het geval, in redelijkheid tot de genoemde besluiten kon komen, impliceen dat deze besluiten naar hun inhoud niet in strijd komen met de goede trouw'. Maeijer ziet hierin een bewijs van zijn stelling dat toetsing aan de goede trouw marginale toetsing is. ${ }^{107}$ Daarbij teken ik echter aan dat in de grieven tegen het vonnis in eerste aanleg, reeds werd geklaagd dat de (president van de) rechtbank 'zich ten onrechte niet heeft begeven in een marginale toetsing'. En dan is het natuurlijk niet verwonderlijk, dat het Hof reeds aanstonds (in r.o. 4) overweegt dat in verband met de 'gezamenlijk te behandelen - grieven onderzocht moet worden of [...] geintimeerde (de vereniging: MK) in redelijkheid tot dit besluit kon komen', en - mede in aanmerking genomen dat het hier een kort geding procedure betreft ook 'voorshands' (r.o 5.13) tot die conclusie komt.

Zou het voorgaande arrest echter al moeten worden begrepen als een principiēle beslissing over 'marginale toetsing', dan meen ik echter dat de Hoge Raad nadien daaraan niet heeft vastgehouden. Mijns inziens kan die visie uitstekend worden onderbouwd met een verwijzing naar HR $17 \mathrm{mei}$ 1991, NJ 1991, 645 (Lampe/Tonnema).

In deze zaak besloot de algemene vergadering tot een statutenwijziging inhoudende dat een blokkeringsregeling werd gewijzigd in die zin dat deze de vorm kreeg van een goedkeuringsregeling. Gevolg, en doel, van deze wijziging was dat een minderheidsaandeelhouder (Lampe) niet in staat was de controle over Tonnema BV over te nemen omdat de (overgrote)

benadeelde aansprakelijk kan zijn indien dit heeft gehandeld in strijd met hetgeen maatschappelijk betaamt (vgl, bijvoorbeeld HR 19 maart 1993, NJ 1994, 92 ).

107. $\mathrm{Vgl}$. zijn noot onder het arrest sub. 3.3 alsmede Asser-Maeijer-Van der Grinten 2-II nr. 133 en 288. Zie ook A.G. Lubbers, Schorsing-in en ontzetting-uit een verenigingslidmaatschap, in: Goed en Trouw (Van der Grinten bundel), Zwolle 1984, p. 141 e.v. 
De ontwikkeling van de goede trouw in kapitaalvennootschappen in Nederland

meerderheid van de aandeelhouders een overdracht van aandelen aan Van Nelle Holding NV goedkeurde. Lampe stelde, in de bewoordingen van de rechtbank, dat het besluit tot wij. ziging van de goedkeuringsregeling 'geen ander oogmerk [had] dan het ongedaan maken van het aan Lampe toekomend voorkeursrecht'. Nu dit een kerncriterium is van misbruik van recht, is dit op zich al een fraaie illustratie van de hiervoor geschetste ontwikkeling waarin misbruik van recht is geabsorbeerd door de goede trouw. Het betrof hier ongetwijfeld een kwestie waarbij de 'marginalen' zouden menen dat slechts marginale toetsing in aanmerking komt. In het arrest van de Hoge Raad blijkt daarvan echter niets. Integendeel; de Hoge Raad toetst nadrukkelijk of de lagere rechter de eisen van de goede trouw 'naar behoren' heeft gemotiveerd (r.o. 3.3) en overweegt even nadrukkelijk dat de lagere rechter 'het belang van Lampe bij het in stand blijven van zijn uit de aanbiedingsregeling voortvioeiende rechten heeft afgewogen tegen de belangen van de overgrote meerderheid der aandeelhouders en van de onderneming, welke afweging ten nadele van Lampe is uitgevallen.' Pas na die overweging (en afweging) concludeert de Hoge Raad: 'Aldus heeft het hof geen rechtsregel geschonden. '(curs. MK)

Uit het Lampe/Tonnema arrest kan worden afgeleid dat in het kader van een afweging van belangen, een besluit waarbij het recht van een (mede)aandeelhouder ongedaan wordt gemaakt, gerechtvaardigd kan zijn. Uiteraard houdt zo'n benadering ook in dat in andere omstandigheden een afweging van belangen mee kan brengen dat zo'n ingreep juist niet gerechtvaardigd is en als 'misbruik' en, bij wege van 'absorptie', in strijd met de redelijkheid en billijkheid kan worden gekwalificeerd. In de kern bezien lijkt mij een illustratie daarvan te vinden in HR 10 maart 1995, NJ 1995, 595 (Janssen Pers).

Onder druk van de Bank was een directeur/grootaandeelhouder (Janssen) gedwongen om de macht in zijn bedrijf te delen met twee commissarissen die, met Janssen, ook bestuurders worden van het administratiekantoor (een stichting) dat de aandelen in het bedrijf controleert. De commissarissen overstemmen vervolgens Janssen, zetten hem als directeur aan de kant, en gaan op zoek naar nieuwe kapitaalverschaffers die zij ook vinden. De bedoeling is dat nieuwe aandelen worden uitgegeven en dat de commissarissen, na die uitgifte, als bestuurders van de stichting zullen terugtreden. Per saldo zal de macht dan zijn overgenomen door de nieuwe aandeelhouders, die een meerderheidsbelang zullen controleren. Er worden emissiebesluiten genomen en de adspirant-aandeelhouders voldoen ook aan hun stortingsverplichting. In de veronderstelling dat alles rond is treden de commissarissen op 1 maart 1993 uit het bestuur van de stichting. $\mathrm{Zij}$ zijn echter vergeten om een en ander in notariële akten vast te leggen, hetgeen een voorwaarde is voor de geldigheid van de operatie. Janssen krijgt aldus de macht weer in handen, ontslaat de directeur, trekt onmiddellijk de eerdere (emissie)besluiten in en snelt naar de notaris om te zorgen dat akten in de door hem gewenste zin worden opgemaakt. De Hoge Raad oordeelt onder deze omstandigheden dat er 'belangrijke aanwijzingen' zijn dat het gebruik maken door Paul Janssen van de vergissing van de commissarissen in strijd is met de redelijkheid en billijkheid. 
In deze sleutel ben ik ook geneigd een plaats te geven aan HR 9 januari 1987, NJ 1987, 959 (Vecolac/Juliana). Aan de orde was hier het besluit van de 'top-coöperatie' Vecolac om zich geheel te onderschikken aan een andere (grote) coöperatie (Coberco). Acht leden van Vecolac verklaarden zich hiervoor, maar het negende lid, Juliana, was daar mordicus tegen.

In deze zaak leverde het Hof Arnhem een mijns inziens fraai en zeer uitgebreid gemotiveerd arrest af waarin het alle belangen van de minderheid nadrukkelijk in ogenschouw nam en woog. Daarbij kwam overigens ook nog de - door het Hof verworpen - stelling van Vecolac aan de orde dat Juliana 'misbruik' makkte van minderheidsmacht c.q. van haar vernietigingsbevoegdheid. Uiteindelijk kwam het Hof tot de conclusie dat 'Vecolac in de omstandigheden van het geval bij behoorlijke afweging van alle betrokken belangen waaronder het belang van Juliana [...] - in redelijkheid niet tot de bestreden besluiten had kunnen komen en mogen komen, en dat deze besluiten derhalve in strijd zijn met de goede trouw', De Hoge Raad herformuleerde dit aldus dat 's Hofs oordeel 'tegen de achtergrond van de daaraan voorafgaande overwegingen, aldus [moet] worden verstaan dat de beide bestreden besluiten te zamen een vorm van samenwerking in het leven roepen welke zodanig ver gaat en van die krachtens de oude statuten van Vecolac zo wezenlijk verschilt, dat zij, welk gewicht ook toekomt aan de belangen welke de meerderheid met die samenwerking beoogde te dienen. naar eisen van redelijkheid en billijkheid aan een zich daartegen verzettende minderheid niet had mogen zijn opgelegd. 'ios

\section{$\S 11$. Slotbeschouwing}

Het leerstuk 'goede trouw' in het rechtspersonenrecht heeft zich tot de invoering van boek 2 BW in 1976 ontwikkeld in de rechtspraak en doctrine. Aanvankelijk werden de normen van goede trouw en billijkheid in het

108. Maeijer spreekt in zijn noot van 'marginale toetsing' (zij het - blijkbaar - als uitkomst van een belangenafweging waarbij de belangen van de minderheid zo overwegend zijn dat zij moeten worden ontzien door de meerderheid). Geiet op de door het Hof en de Hoge Raad gebruikte bewoordingen is dat wel begrijpelijk, maar mijns inziens toch te kort door de bocht. Het Hof had weliswaar de formule gebruikt dat Vecolac bij afweging van alle betrokken belangen in redelijkheid niet tot de bestreden besluiten had kunnen en mogen komen, maar het cassatiemiddel bracht daar tegen in dat het Hof juist in onvoldoende mate een 'een afweging van belangen' had betracht. In het licht daarvan 'verstaat' de Hoge Raad 's Hofs beslissing in de hierboven aangegeven zin. Daaruit kan ons inziens zeker niet worden afgeleid dat bij een minder vergaande aantasting van belangen van de minderheid, belangenafweging achterwege had kunnen blijven. Zie over deze zaak ook M.J.G.C. Raaijmakers, Geschillen in 50/50-verhoudingen, in: Tot vermaak van Slagter, 1988, p. 205 e.v., die een grote terughoudendheid bepleit en een 'veto' van een lid in strijd acht met de (beperkte) corrigerende werking van de goede trouw (zie p. 216). 
De ontwikkeling van de goede trouw in kapitaalvennootschappen in Nederland

verbintenissenrecht toegepast op rechtsbetrekkingen binnen kapitaalvennootschappen. De oprichting van een rechtspersoon werd gezien als een overeenkomst waarvan de statuten de inhoud vastlegde. De statuten maakten deel uit van de oprichtingsovereenkomst. Besluiten werden gezien als uitvoering van die overeenkomst. Partijen bij de oprichting en degenen die zich later bij de rechtspersoon aansloten zoals aandeelhouders en bestuurders, werden geacht mede onderworpen te zijn aan de werking van art. 1374 BW. Dit impliceerde niet alleen voor de partijen dat de statuten in de zin van art. 1374 lid 1 BW tot wet strekte, maar ook dat alle betrokkenen bij hun handelen in de organisatie van de rechtspersoon jegens elkaar de goede trouw in acht dienden te nemen.

In de loop van de jaren 50 kan men vervolgens een ontwikkeling ontwaren waarin het accent komt te liggen op de goede trouw als 'norm' voor alle besluiten en gedragingen binnen een rechtspersoon, losgekoppeld van specifieke wettelijke regels. Deze ontwikkeling kan mede worden toegeschreven aan de veranderde visie op de aard van de naamloze vennootschap in de richting van 'instituut'. ${ }^{109}$ Uiteindelijk heeft een en ander geleid tot de codificatie van de goede trouw in art. 2:7 en art. 2:11 BW voor de betrokkenen bij de rechtspersoon waardoor de band met het verbintenissenrecht definitief werd verbroken. In art. 2:8 BW wordt de betekenis van de goede trouw (dan redelijkheid en billijkheid) in het rechtspersonenrecht nog sterker benadrukt. Geen twijfel bestaat over het feit dat betrokkenen bij de organisatie van de rechtspersoon onderworpen zijn aan de redelijkheid en billijkheid. Bovendien wordt het aan het contractenrecht ontleende onderscheid tussen aanvullende en corrigerende werking van de goede trouw uitdrukkelijk in art. 2:8 BW van toepassing verklaard op de rechtsverhoudingen binnen de rechtspersoon.

Essentieel voor de rechtsontwikkeling is de vraag naar de concrete betekenis van de redelijkheid en billijkheid. In dit kader is een belangrijke taak weggelegd voor de rechtswetenschap. Uiteindelijk moet het doel daarvan zijn te komen tot ontwikkeling van duidelijker regels van ongeschreven recht ook in de verhoudingen binnen rech'spersonen. Daarvan is het, zoals Maeijer terecht noteert, nog niet gekomen. ${ }^{110} \mathrm{Zo}$ ver zal

109. Zie hieromtrent M.J.G.C. Raaijmakers, Rechtspersoon tussen contract en instituut, rede Tilburg 1987 en H.J.M.N. Honée, De ontwikkeling van het vennootschapsrecht. in: 150 jaar Wetboek van Koophandel; Het verleden en de toekomst, Kluwer 1989, p. 40-43.

110. Asser-Van der Grinten-Maeijer 2-II, nr. 46. 
het echter slechts kunnen komen nadat, in de woorden van Schoordijk, ${ }^{\prime \prime \prime}$ de betekenis van de goede trouw in kaart is gebracht vanuit de denkhouding om 'het ongeschreven recht te doorgronden en zo mogelijk op enkele grondnoemers terug te brengen'. In dat verband is een belangrijke rol weggelegd voor de rechtsvergelijking die ons - wederom in de woorden van Schoordijk - bewust kan maken, 'hoe de geest te mobiliseren' aan de hand van 'binnen- en buitenlandse rechtspraak', ${ }^{112}$ en die, zoals Vranken noteert, vaak 'als bron van inspiratie en oriëntatie zeer verhelderend [is]'. Van der Esch schreef reeds in 1953 dat 'de verdieping van het inzicht in het eigen recht alleen te bereiken is door de voortdurende en critische confrontatie van eigen en vreemd recht'. ${ }^{113} \mathrm{Nu}$ het eigen (Nederlandse) recht en rechtsliteratuur met betrekking tot de functie en betekenis van redelijkheid en billijkheid in het rechtspersonenrecht nog vele vragen open laten, geldt dat zeker met betrekking tot het onderwerp van dit boek.

111. H.C.F. Schoordijk, Redelijkheid en billijkheid aan de vooravond van een nieuw millennium, Tjeenk Willink - Zwolle 1996 p. 3.

112. Schoordijk t.q.p., p. 9.

113. Zie Asser-Vranken nr. 214 en B. van der Esch, Vergelijkend vennootschapsrecht, De N.V. naar Engels, Amerikaans, Frans en Belgisch recht tegen de achtergrond van de Nederlandse voorschriften, Tjeenk Willink Zwolle, 1953, p. 2. Overigens tekent Vranken daarbij terecht aan dat dit wel vereist dat men zich rekenschap geeft van verschillen in systeem, cultuur en maatschappelijke constellatie, en zich beperkt tot landen met een vergelijkbaar rechts- en maatschappijsysteem. 



\section{BV en NV in vergelijkend perspectief}

\section{\$1. Algemene typering}

Het Nederlandse recht onderscheidt twee rechtsvormen voor kapitaalvennootschappen; de NV en de BV. De NV wordt veelal gebruikt door grotere ondernemingen die ter verkrijging van financiēle middelen een beroep doen op het beleggend publiek. De BV is veeleer de rechtsvorm van een besloten samenwerkingsverband. Die beslotenheid wordt met name tot uitdrukking gebracht door de regeling omtrent de (beperkte) overdracht van aandelen. Afgezien hiervan makt de Nederlandse wetgever echter nauwelijks onderscheid tussen NV's en BV's. ' Dit betekent niet dat er in de praktijk niet grote verschillen bestaan in de inrichting van de organisatie van deze rechtspersonen. ${ }^{2}$

In het Duitse recht is het uitgangspunt een ander. Hier kan de Gesellschaft mit beschränkter Haftung $(\mathrm{GmbH})$ niet als een variant van de Aktiengesellschaft (AG) worden beschouwd. Dit komt tot uitdrukking in de verschillen in wetssystematiek die wordt gehanteerd voor de AG en $\mathrm{GmbH}$. Het Aktiengesetz (AktG) wordt gekenmerkt door dwingend recht en is vrij gedetailleerd, terwijl het GmbHG-Gesetz juist flexibel en eenvoudig van aard is.

1. Een NV kan worden ingericht als een BV, zie art. 2:235 lid $2 \mathrm{BW}$. Het belangrijkste verschil tussen BV's en NV's vormt de overdraagbaarheid van aandelen, vgl. art. 2:64/175 en art. 2:87/195 BW. Voorts denke men aan de regeling op het gebied van de kapitaalinbreng en kapitaalbescherming. In juridisch opzicht bestaat overigens wel fundamenteel verschil tussen de gewone vennootschappen en de structuurvennootschappen (of zo men wil 'grote' vennootschappen). Vgl. hieromtrent art. 2:153/263 lid 2 BW e.v.

2. Dit wordt mede bepaald door het aantal aandeelhouders, $\mathrm{Vgl}$. hieromtrent C.A. Schwarz, Blokkering van aandelen, (diss.) Deventer 1986 en J.J.A. Hamers, Verpanding van aandelen en de beslotenheid van kapitaalvennootschappen, (diss. Maastricht), Deventer 1996, p. 139 e.v. $\mathrm{Zij}$ maken een onderscheid tussen de intern-besloten vennootschap, de open naamloze vennootschap, de intern-besloten naamloze vennootschap en de naamloze vennootschap met een 'gemengd karakter'. Een andere meer globale indeling geeft bijvoorbeeld Sanders-Westbroek. BV en NV 1998, p. 7/8: het klassieke model waarop de NV is gestoeld, de vennootschap die gekenmerkt wordt door een grote mate van autonomie van de organen van de vennootschap, waarbij de macht van de vele verspreide aandeelhouders zwak is; de vennootschap met één aandeelhouder (eenmansvennootschap of concerndochter) en de joint venture BV. 
Kapitaalvennootschappen in het Franse recht zijn de Société Anonyme (SA) en de Société à Responsabilité Limité (SARL). De SA komt echter in twee vormen (modellen) voor. De 'klassieke' SA kenmerkt zich door een hiërarchische structuur. Hier berust het bestuur en toezicht bij de 'conseil d'administration'. De voorzitter daarvan, de président-directeur général, vervult de sleutelfunctie in de organisatie. In 1966 is naast de reeds bestaande SA de mogelijkheid geschapen voor een nieuwe variant (hierna: nieuwe SA) welke naast een ava (assemblée d'actionnaires) en bestuur (directoire) een raad van commissarissen (conseil de surveillance) kent. De 'nieuwe $\mathrm{SA}^{\text {' }}$ en de SARL zijn vergelijkbaar met de AG en $\mathrm{GmbH}$. Dat is niet verwonderlijk, gezien het feit dat enerzijds voor het ontstaan van de SARL (1925), de GmbH model heeft gestaan en anderzijds voor de nieuwe SA, de AG als voorbeeld heeft gediend. ${ }^{3}$ De praktijk heeft in Frankrijk overigens nog steeds een duidelijke voorkeur voor de 'klassieke' organisatiestructuur van de SA. Aangezien dit nog steeds de meest voorkomende vennootschapsvorm is in Frankrijk, zal ik mij in dit onderzoek met name hierop concentreren.

In het Engelse vennootschapsrecht worden de 'private company' en de 'public company' als varianten beschouwd van dezelfde rechtsvorm, de 'registered company limited by shares'4 en in zoverre functioneel vergelijkbaar met de Nederlandse kapitaalvennootschappen. Aan de public en de private company-regeling ligt, evenals bij de NV en BV, geen fundamenteel onderscheid ten grondslag.

Uitgangspunt van de Companies Act 1985 is de 'public company'. Als gevolg van de tweede EG-richtlijn en de wens van de Engelse wetgever het soepele kapitaalregime voor kleine, besloten vennootschappen te handhaven, werden uitzonderingen gemaakt voor de 'private' company. Met name wat betreft de regels inzake kapitaalbescherming. ${ }^{5}$

3. $\mathrm{Vgl}$. Guyon, Droit des affaires nr. $351 \mathrm{en} \mathrm{nr.} 472$.

4. Deze company kan in drie groepen worden onderscheiden; de 'company limited by guarantee', de 'unlimited company' en de 'registered company limited by shares'. Vgl. Farrar's Company Law, p. 42.

5. Een private company behoeft, in tegenstelling tot een public company niet over een minimumkapitaal te beschikken. De consequentie daarvan is dat de private company het meest voorkomt in Engeland. Er zijn ongeveer een miljoen private companies en 12.000 public companies in Engeland geregistreerd. Zie S. Goulding, The private company in the United Kingdom, in De Kluiver/Van Gerven, The European Private Company? 
Dat er wettelijke verschillen bestaan tussen de private company en public company wordt tot uitdrukking gebracht in section 1 (3) van de Companies Acht 1985 doordat een definitie wordt gegeven van een 'public company' en wordt bepaald dat elke company die daar niet onder valt een 'private' company is. ${ }^{6}$

In de afgelopen jaren is het onderscheid tussen de private company en de public company steeds meer benadrukt. Gestreefd wordt naar versoepeling en deregulering van het recht inzake private companies.

\section{§ 2. Vennootschappelijke organisatiestructuur}

Bij zowel NV als BV is het uitgangspunt van de Nederlandse wetgever een scheiding van aandeelhoudersfunctie en bestuursfunctie. Zoals gezegd in $\S 4.1$, zal die scheiding in de praktijk overigens niet steeds even strikt zijn. In het navolgende zal ik daarop nog regelmatig terugkomen (vgl. met name hoofdstuk 7).

De Duitse AG kent een drieledige organisatiestructuur: naast het bestuur (Vorstand) en de algemene vergadering van aandeelhouders (Hauptversammlung) is ook een raad van commissarissen (Aufsichtsrat) steeds verplicht. Elk van deze organen heeft krachtens het AktienGesetz eigen taken en bevoegdheden. Het zwaartepunt in de organisatie van een AG ligt bij het bestuur. ${ }^{7}$ In de tweeledige organisatiestructuur van de $\mathrm{GmbH}$ daarentegen, vormt de Gesellschafterversammlung de hoogste macht in de vennootschap. De bestuurders ('Geschäftsführer') zijn weliswaar belast met de bedrijfsvoering, maar dit is geen exclusieve bevoegdheid. De Gesellschafterversammlung kan door midddel van juridisch bindende instruc-

Antwerpen/Apeldoorn 1995, p. 57 en Gower's Principles of Modern Company Law, London 1997, p. 13.

6. Section 1 (3) luidt: 'A public company is a company limited by shares or limited by guarantee and having a share capital, being a company - a) the memorandum of which states that it is to be a public company, and b) in relation to which the provisions of this Acht or the former Companies Acts as to the registration or re-registration of a company as a public company have been complied with on or after 22nd December 1980; and a 'private company' is a company that is not a public company'. Zie ook Simon Goulding. Principles of Company Law, London 1996, p. 3 en Mayson, French \& Ryan on Company Law, p. 40.

7. Vgl. \& 76 AktG. Zie ook J. Semler, Leitung und Überwachung der Aktiengesellschaft: die Leitungsaufgabe des Vorstands und die Überwachungsaufgabe des Aufsichtsrats, Köln 1996, p. 5 e.v. 
ties invloed uitoefenen op het bestuursbeleid (zie nader hoofdstuk 7). De structuur van de Franse 'nieuwe' SA en de SARL is vergelijkbaar met respectievelijk de AG en GmbH.

In het Engelse recht komt de aan de Companies Act ten grondslag liggende gedachte van één soort kapitaalvennootschap daarin tot uiting dat zowel de private als de public company een tweeledige structuur hebben; een algemene vergadering (general meeting) en een bestuur (board of directors). De board of directors vertoont in de praktijk kenmerken van zowel het bestuur als de raad van commissarissen, doordat deze samengesteld kan zijn uit 'executive-directors' die belast zijn met het daadwerkelijke bestuur, en 'non-executive directors' die een toezichthoudende taak hebben. ${ }^{8}$

\section{§ 3. Reikwijdte, betekenis en functies van de 'goede trouw'}

Het beginsel dat betrokkenen bij de organisatie van een Nederlandse kapitaalvennootschap zich redelijk en billijk moeten gedragen, ligt ook ter grondslag aan buitenlandse rechtssystemen. Echter, de terminologie, de betekenis en de reikwijdte van dat beginsel verschillen. Zo valt op dat, anders dan in het Nederlandse recht, dit beginsel in het Engelse, Duitse en Franse vennootschapsrecht niet wettelijk is verankerd.

\section{§ 3.1. 'Goede trouw' begrippen; terminologie}

Zoals ik reeds in hoofdstuk $1 \S 6$ heb aangegeven bepaalt in het Nederlandse recht art. 2:8 BW: 'Een rechtspersoon en degenen die krachtens de wet en de statuten bij zijn organisatie zijn betrokken, moeten zich als zodanig jegens elkander gedragen naar hetgeen door redelijkheid en billijkheid wordt gevorderd'.

Wanneer men op zoek gaat naar vergelijkbare beoordelingsnormen voor het gedrag van betrokkenen, stuit men in het Duitse recht op het beginsel van de 'Treupflicht', dat is ontwikkeld vanuit het algemene beginsel van 'Treu und Glauben' ( $§ 242$ BGB). Onder het begrip Treupflicht

8. $\mathrm{Vgl}$. over de rol van de 'non-executive director' het 'Report of the Committee on the Financial Aspects of Corporate Governance (1992) $\$ 4.11$; 'they should bring an independant judgement to bear on issues of strategy, performance, resources, including key appointments and standards of conduct'. Zie eveneens S. Goulding. Principles of company law, London 1996, p. 218. 
wordt wel verstaan; 'die Ausrichtung des internen Gesellschaftsrecht auf ein harmonisches Zusammenwirken aller Beteiligten zur Erreichung des Gesellschaftszwecks'. 9 De Treupflicht in het Duitse vennootschapsrecht is een zgn. 'Generalklausel', die zich in de rechtspraak en doctrine ontwikkelt. ${ }^{10}$ De Treupflicht heeft evenals de redelijkheid en billijkheid in het Nederlandse recht tweeërlei werking: aanvullend en corrigerend. Praktisch gezien betekent dit dat, om tegemoet te komen aan de gerechtvaardigde belangen van betrokkenen, een betrokkene soms 'meer moet doen' of 'minder mag doen' dan hetgeen wet en statuten bepalen en bepaalde gedragingen of handelingen moet verrichten of juist achterwege moet laten.

In het Engelse recht biedt het stelsel van fiduciary duties', die ook binnen de vennootschap kunnen bestaan, vergelijkingsmateriaal. 'Fiduciary law' is ontstaan uit het trust-recht, dat zich in het equity-recht heeft ontwikkeld. " 'Fiduciary law' heeft volgens Finn ${ }^{12}$ als doel 'to impose standards of acceptable conduct on one party to a relationship for the benefit of the other's interests'. In Engeland kan echter niet gezegd worden, zoals in het Nederlandse en (zij het in mindere mate) in het Duitse recht, dat het gehele vennootschapsrecht 'doortrokken' is van het algemene beginsel van 'goede trouw'.

Fiduciary duties bestaan slechts als sprake is van 'fiduciary relationships', welke kwalificatie met terughoudendheid wordt gehanteerd (zie over de reikwijdte hiervan $\S 4.2$ ). Wordt echter eenmaal aangenomen dat sprake is van een fiduciary relationship dan worden daaruit in de jurisprudentie en doctrine wel tal van verplichtingen afgeleid. De belangrijkste

9. Vgl. H. Wiedemann, Zu den Treuepflichten im Gesellschaftsrecht, FS Heinsius 1991, p. 949 en M. Piepenburg, Mitgliedschaftliche Treupflichten der Aktionăre, diss. 1996, Hamburg, p. 7.

10. Vgl. U. Hüffer, Zur gesellschaftsrechtlichen Treupflicht als richterrechtlicher Generalklausel in: FS Ernst Steindorff, Berlin 1990, p. 59. Hier geeft hij een beschrijving van Walter Stimpel weer over de betekenis van de Treupflicht als Generalklausel; 'Wir haben hier einen Fall, in dem sich durch eine Reihe von Einzelentscheidungen allmählich eine richterliche Generalklausel gebildet hat, die nun ihrerseits von Fall zu Fall der Konkretisierung bedarf und sich allmåhlich systematisch in Untergruppen aufzugliedern beginnt'.

11. Vgl. C.AE. Uniken Venema, Law en Equity in het Anglo-Amerikaanse privaatrecht, Zwolle 1990.

12. Zie P.D. Finn, The Fiduciary Principle, in Equity, Fiduciaries \& Trusts, 1989, p. 2. 
BV en NV in vergelijkend perspectief

zijn duties of good faith, duties of loyalty en duties of care and skill. ${ }^{13}$ De vraag tot welke verplichtingen dit in concreto leidt, komt onder meer aan de orde in de rechtspraak ter bescherming van minderheidsaandeelhouders ('fraud on the minority' en met name in procedures waarin wordt onderzocht of sprake is van 'unfair prejudicial conduct' zoals vastgelegd in section 459 Companies Act (CA) 1985.

Op grond van s. 459 lid 1 CA kan een aandeelhouder de rechter verzoeken voorzieningen te treffen 'on the ground that the company's affairs are being or have been conducted in a manner which is unfairly prejudicial to the interests of its members generally or of some parts of its members (including at least himself) or that any actual or proposed act or omission (including an act or omission on its behalf) is or would be so prejudicial'.

Uitgangspunt van s. 459 is dat niet slechts de wettelijke rechten van de minderheidsaandeelhouders beschermd worden, maar ook hun gerechtvaardigde verwachtingen ('legitimate expectations'). ${ }^{14}$ Section 459 CA vervult derhalve de functie van een gedragsnorm. Een aandeelhouder mag van 'zijn' vennootschap bepaald gedrag verwachten en indirect ook van zijn mede-aandeelhouders en de bestuurders. Wordt die norm geschonden, dan heeft de rechter op grond van s. 461 CA vergaande bevoegdheden ${ }^{15}$ (zie hierna in $\S 5.1$ ).

13. Betreft het aandeelhouders dan wordt gesproken over duties of good faith, bij 'directors' gebruikt men duties of loyalty.

14. Zie Re a Company, no. 00477 [1986] BCLC 1986, 376, vgl. ook onder meer R. Hollington, Minority Shareholders Rights, London 1992, p. 57 e.v., Mayson, French \& Ryan on Company Law, p. 568, Gower's Principles of Modern Company Law, London 1997, p. 742 en I.J. Dawson en I.S. Stephenson, Minority shareholders, London 1993. p. 70 .

15. S. 461 (1) CA bepaalt dat de rechtbank 'may make such order as it thinks fit for giving relief in respect of the matters complained of. S. 461 (2) geeft vervolgens aan wat zoal tot de mogelijkheden behoort. Een veel voorkomend bevel van de rechtbank is dat de meerderheidsaandeelhouder verplicht wordt de minderheidsaandeelhouder tegen een redelijke prijs uit te kopen (buy-out). Dit is de enige mogelijkheid voor minderheidsaandeelhouders in kleine besloten vennootschappen om zonder nadeel uit de vennootschap te stappen. Zie hierover A. Hicks \& S.H. Goo, Cases \& Materials on Company Law, London 1997, p. 445-448 en Gower's Principles of Modern Company Law, London 1997, p. 748. 
Ook in Frankrijk ten slotte vervult de 'goede trouw' een rol in het vennootschapsrecht. ${ }^{16}$ In recente doctrine en rechtspraak wordt gesproken over 'devoir de loyauté', het verschuldigd zijn tot loyaliteit, van bestuurders en aandeelhouders. ${ }^{17}$ De grondslag en de invulling van de 'goede trouw' verschilt echter voor aandeelhouders en bestuurders.

De gehoudendheid tot goede trouw (loyaliteit) voor aandeelhouders wordt in de doctrine enerzijds verklaard als een uitwerking van art. 1134 Code Civil dat verplicht om overeenkomsten te goeder trouw uit te voeren. Anderzijds wordt de goede trouw afgeleid van de jurisprudentiële notie van de 'l'affectio societatis'. ${ }^{18}$ Sommige auteurs zijn de mening toegedaan dat l'affectio societatis een toepassing is van de 'bonne foi' (goede trouw). ${ }^{19}$

Wat betreft de grondslag van loyaliteit van bestuurders kan een tweetal benaderingen worden onderscheiden. De eerste benadering is dat art. 1134 Code Civil van toepassing is op het contract dat de bestuurder heeft met de vennootschap ('contrat de mandat'). De tweede benadering is vennootschapsrechtelijk van aard. Centraal staan hier de bevoegdheden die bestuurders zijn toegekend. Bij de uitoefening daarvan moeten zij rekening houden met de belangen van de vennootschap en de daarbij betrokkenen.

16. Zo hebben aandeelhouders bij hun handelen jegens elkaar en jegens de vennootschap een verplichting tot 'bonne foi'. Zie Guyon, Traité des contrats, Les sociétés 1997, nr. 36, J.L. Rives-Lange, L'abus de majorité in het themanummer La loi de la majorité, Rev. Jur.Com. 1991, p. 69 en in datzelfde nummer P. Merle, L'abus de minorité, p. 85.

17. Zie in de jurisprudentie met name de uitspraak van de Cour de Cassation van 27 februari 1996, JCP 1996, ed. G. II, 22665 (Vilgrain) en de uitspraak van 24 februari 1998, JCP ed. E. nr. 17 p. 637, zie hierover $\$ 4.3$. Zie in de literatuur Le Nabasque, Le développement du devoir de loyauté en droit des sociétés, Rev.trim.dr.com 1999, p. 25 e.v., B. Daille-Duclos, Le devoir de loyauté du dirigeant, JCP éd.E 1998, p. 1486 e.v. Bij aandeelhouders wordt veelal gesproken over 'devoir de bonne foi'. Zie bijv. Guyon, Traité des contrats, nr. 36 en L. Godon, Les obligations des associés (thèse Paris), in de serie Droit des Affaires et de l'Entreprise, Parijs 1999, p. 89 e.v.

18. Vgl. Le Nabasque, t.a.p., p. 275 , Godon, t.a.p., p. 89 en Daille-Duclos, t.a.p., p. 1487. Vgl. ook Ghestin in zijn noot bij Cass. com 27 februari 1996, JCP ed. G.II. 22665 (Vilgrain): 'Les associés, en raison de l'affectio societatis qui caractérise les sociétés, se doivent mutuellement une loyauté particulière se traduisant par une plus grande exigence en matière d'information pré-contractuelle'.

19. Zie A. Viandier, La notion d'associé, Parijs 1978, p. 79. 
Le Nabasque opteert voor de tweede benadering. Hij zou de 'verplichting' tot loyaliteil (devoir de loyaute) als volgt willen definiëren: 'l'obligation de ne pas utiliser leurs pouvoirs ou des informations dont ils sont titulaires dans un intérêt strictement personnel et, prejudice oblige, contrairement à l'intérêt de la sociêté ou à celui des associés'. ${ }^{20}$

De invulling van de goede trouw eist wordt, voorzover het gedragingen van aandeelhouders betreft, vorm gegeven in het leerstuk 'abus de majorité' en 'abus de minorité'. ${ }^{21}$

Dit is een uitwerking van 'abus de droit', ${ }^{2}$ (rechtsmisbruik) dat een belangrijk leerstuk in het Franse recht is. De daarop gebaseerde leerstukken van 'abus de majorité' en 'abus de minorite' brengen mee dat bij de uitoefening van de bevoegdheden van meerderheidsaandeelhouders en minderheidsaandeelhouders, de belangen van alle aandeelhouders in acht moeten worden genomen. ${ }^{3}$

Betreft het de toetsing van gedragingen van bestuurders, dan staan veelal de door hen uit te oefenen bevoegdheden voorop en wordt het criterium 'abus de pouvoirs' gehanteerd. ${ }^{24}$

Echter, een nieuwe tendens in recente jurisprudentie is dat gedragingen van bestuurders ook direct getoetst worden aan de 'devoir de loyauté' en dat schending daarvan kan leiden tot aansprakelijkheid van een bestuurder jegens de vennootschap of aandeelhouders. ${ }^{25}$

20. H. Le Nabasque, Le développement de devoir de loyauté en droit des sociétés, Rev. trim.dr.com. 1999, p. 283.

21. Zie bijvoorbeeld L. Godon, Obligations des associés, thèse Paris, 1999. p. 93 e.v., P. Le Cannu. L'abus de minorité, Bull. Joly 1986, p. 429 e.v., Ph. Merle, l'abus de minorité, Rev.Jur.Com., nr. spécial, november 1991, p. 81 e.v., V.J.L. Rives-Lange, l'abus de majorité, Rev.Jur.Com., nr. spécial november 1991, p. 5 e.v. en D. Tricot, Abus de droit dans les sociétés: abus de majorité et abus de minorité, Rev.trim.dr.com. 1994, p. 617 e.v.

22. Vgl. bijvoorbeeld de uitspraak van de Cour de Cassation inzake Piquard, Cour de Cassation 18 april 1961, Dalloz 1961, p. 661 e.v., waarin de meest geciteerde definitie van 'abus de majorité' wordt gegeven en nog gesproken wordt van 'abus de droit'.

23. Zie C. Goyet, Les limites du pouvoir majoritaire dans les sociétés, in La loi de la majorité, Rev.Jur.Com. speciaal nummer november 1991, p. 58 en in dat zelfde nummer J.L. Rives-Lange, L'abus de majorité, p. $65,66$.

24. Vgl. J. Calais-Auloy, L'abus de pouvoirs ou de fonctions en droit commercial francais. in: L'abus de pouvoirs ou de fonctions. Travaux de l'Association Henri Capitant des amis de la culture juridique francais. Tome XXVIII, 1977, Paris 1980, p. 221-230.

25. Vgl. ook B. Daille-Duclos, Le devoir de loyauté du dirigeant. JCP éd. E 1998, p. 1488 en Le Nabasque, Le développement du devoir de loyauté en droit des sociétés, Rev. trim.dr.com. 1999, p. 278. 
De eerste uitspraak waarin de Cour de Cassation aansprakelijkheid van de bestuurder jegens aandeelhouders baseert op schending van de loyaliteit is die van 27 februari 1996, JCP ed. G.II. 22665 (Vilgrain). In deze zaak wordt de president (Vilgrain) van de niet beursgenoteerde SA Compagnie francaise commerciale et financière (CFCF) door een minderheidsaandeelhouder, mevrouw $\mathrm{A}$, benaderd om een koper te vinden voor haar aandelen. $\mathrm{Zij}$ verkoopt vervolgens haar aandelen (ruim 3000) aan Vilgrain en nog drie andere personen (hierna: Vilgrain c.s.) voor $5600 \mathrm{~F}$ per aandeel. Echter, een paar dagen later verkoopt Vilgrain c.s. dezelfde aandelen door voor $8000 \mathrm{~F}$ per aandeel aan de SA Bouyques. Mevrouw A spant vervolgens een procedure aan tegen Vilgrain c.s. teneinde de door haar geleden schade te verhalen. De Cour de Cassation stelt haar in het gelijk. De Cour de Cassation oordeelt dat Vilgrain 'avait manqué au devoir de loyauté qui s'impose au dirigeant d'une société a ' $l$ ' égard de tout associé, en particulier lorsqu'il agit en qualité d'intermédiaire pour le reclassement de sa participation'. Op grond daarvan acht de Cour de Cassation Vilgrain c.s. aansprakelijk. 'Que par ses seuls motifs, procédant à la recherche prétendument omise, la cour d'appel a pu retenir l'existence d'une réticence dolosive (bedriegelijke verzwijging) a I'encontre Vilgrain'.

Ook in Cour de Cassation 24 februari 1998, JCP 1998, ed. E, nr. 17, p. 637 vormt de 'devoir de loyauté' de grondslag van het oordeel van de Cour de Cassation. Een bestuurder van een SA neemt ontslag en richt een nieuwe concurrerende vennootschap op. Een groot aantal werknemers van die SA neemt ontslag om in dienst te kunnen treden van de nieuwe vennootschap. Echter, deze werknemers hadden wel een concurrentiebeding. De Cour de Cassation is van oordeel dat de voormalige bestuurder van de SA een 'obligation de loyauté' heeft jegens de SA en had moeten onderzoeken onder welke voorwaarden de door hem aangenomen werknemers in dienst waren bij de SA. 'Aurait du vérifier les conditions dans lesquelles certains salariés de la société, ultérieurement réembauchés par l'ancien directeur général de cette société, tenu à une obligation de loyauté envers cette entreprise, avaient été déliés par ce directeur général, alors en fonction, de la clause de non-concurrence qu'ils avaient souscrite'.

\section{§ 3.2 Reikwijdte toetsing aan redelijkheid en billijkheid}

Onderwerp van dit onderzoek naar de reikwijdte van het beginsel van redelijkheid en billijkheid, betreft enerzijds de kring van personen tot wie de gedragsnorm zich richt en anderzijds de gedragingen waarop de norm betrekking heeft.

Wat betreft de kring van personen bepaalt de Nederlandse wet dat de redelijkheid en billijkheid in acht moet worden genomen door de rechtspersoon en 'degenen die krachtens wet en statuten bij zijn organisatie zijn betrokken'. Algemeen aanvaard is dat in ieder geval als betrokkenen gelden degenen die zeggenschap binnen de rechtspersoon uitoefenen, zoals aandeelhouders, bestuurders en commissarissen en de organen waarvan zij 
deel uitmaken. ${ }^{26} \mathrm{Ik}$ zou menen dat de redelijkheid en billijkheid ook van toepassing kan zijn op personen die buiten de organisatie van de rechtspersoon staan. Te denken valt dan aan een gevolmachtigde die krachtens de statuten de bevoegdheid heeft gekregen om namens een aandeelhouder te stemmen op een algemene vergadering (waarover ik nader spreek in hoofdstuk 4). ${ }^{27}$

Wat betreft gedragingen, beperkt de norm van art. 2:8 BW zich volgens de Parlementaire Geschiedenis tot 'gedragingen als zodanig jegens elkaar' ${ }^{28}$ Dit impliceert weliswaar dat de norm op interne verhoudingen van toepassing is ${ }^{29}$ maar ik zou willen verdedigen dat de norm niet alleen ziet op 'interne' gedragingen. Ook 'externe' handelingen kunnen gedragingen zijn in de 'sfeer' van de vennootschap en onder art. 2:8 vallen, voorzover dit externe handelen consequenties heeft voor het interne functioneren van de vennootschap en de betrokkenen bij de organisatie. ${ }^{30}$ Dit is bijvoorbeeld het geval wanneer een bestuurder gebruik maakt van corporate opportunities (zie hoofdstuk 10). ${ }^{31}$ Maar dit blijkt ook bij overnamesituaties. Een illustratie biedt de jurisprudentie inzake de overnamestrijd rond het Amsterdamse beursfonds Gucci.

26. L. Timmerman en C,W, de Monchy, De nieuwe algemene bepalingen van boek $2 \mathrm{BW}$, Zwolle 1991, p. 49.

27. Het Engelse leerstuk van 'de fiduciary duty' trekt de grenzen van de kring van betrokkenen scherper. Het toepassingsgebied van de fiduciary duties veronderstelt, zoals gezegd, een 'fiduciary relationship'. Een essentiële vraag in dit kader is derhalve wanneer er sprake is van een 'fiduciary relationship'. Pas daarna rijst de vraag wat 'fiduciary standards' inhouden, en welke 'fiduciary duties' rusten op de fiduciary.

In het Duitse recht kent men een soortgelijk systeem. Het bestaan van een Treupflicht hangt af van de rechtsverhouding. De omvang en intensiteit van de Treupflicht kunnen echter variëren.

28. Parl. Gesch. Aanpassing BW (Inv. 3,5 en 6), p. 157 e.v.

29. Zie evenzo onder meer Van Schilfgaarde in Van de BV en NV, nr. 9 en L. Timmerman en C.W. de Monchy. De nieuwe algemene bepalingen van Boek 2. Preadvies van de Vereniging 'Handelsrecht', Zwolle 1991, p. 49.

30. Anders: L. Timmerman; hij spreekt over gedragingen in de sfeer van de vennootschap en A. F. Verdam, Corporate Opportunities, diss. Deventer 1995, p. 235.

31. Evenzo in het Duitse recht. Zo wordt 'Insider-Handel' en 'Wettbewerb' (concurrentie) ook 'beheerst' door de Treupflicht. Vgl. M. Paschke, Treupflichten im Recht der juristische Personen, FS R. Serick 1992, p. 314/315 en M. Lutter, Die Treupflicht des Aktionărs, ZHR 1989, p. 458 e.v. Anders: A.F. Verdam, t.a.p., p. 235. 
Louis Vuitton Moèt Hennessy SA (LVMH), de Franse fabrikant van onder meer luxe tassen, brillen en wijnen, werpt zich volop in de strijd om de branchegenoot Gucci Group NV (Gucci) over te nemen. Daartoe breidt zij haar belang in Gucci in korte tijd uit van $5 \%$ tot $34,4 \%$. Gucci wenst dat LVHM een openbaar bod uitbrengt op de aandelen in Gucci. LVHM verlangt op haar beurt een vertegenwoordiging in de raad van commissarissen van Gucci. Gesprekken tussen de bestuursvoorzitters van Gucci en LVMH begin 1999 leiden echter niet tot het gewenste resultaat. Gucci besluit daarop - ter voorkoming van door haar niet gewenste belangrijke mate van zeggenschap van LVHM - tot een tweetal maatregelen. Allereerst roept zij de Stichting Belangen Werknemers (stichting) in het leven, waaraan zij vervolgens aandelen emitteert in het kader van een werknemersaandelenplan (Employee Stock Ownership Plan). LVMH probeert hiervoor een stokje te steken door een enquête procedure aan te spannen bij de $\mathrm{OK}$, hetgeen leidt tot de eerste $\mathrm{OK}$ beschikking van 3 maart 1999, JOR 1999, 87, NJ 1999, 350. Op grond hiervan krijgt LVMH een stemverbod voor haar Gucci-aandelen opgelegd. Het doel van de OK was een 'stand still' te bewerkstelligen. ${ }^{12}$ Een en ander pakt echter ongunstig uit voor LVMH.

Gucci sluit namelijk vlak na genoemde OK-beschikking een 'strategic investment agreement' met het Franse detailhandelsconcern Pinault Printemps Redoute (PPR), waardoor deze een belang van $40 \%$ in Gucci verkrijgt. Het aangaan door Gucci van deze samenwerking met PPR leidt tot een verzwakte positie van LVMH. LVMH stelt vervolgens dat het aangaan van de samenwerking van Gucci met PPR in strijd is met de redelijkheid en billijkheid. De OK betrekt de positie van PPR in haar oordeel en overweegt: 'Een en ander heeft geleid tot een exclusieve onderhandelingspositie ten faveure van PPR en in strijd met de verwachtingen die LVMH in redelijkheid en op grond van de gedragingen van Gucci mocht koesteren. Zie de OK in haar beschikking van 22 maart 1999, JOR 1999, 88 (Gucci II r.o. 3.6) en van 27 mei 1999, JOR 1999, 121, NJ 1999, 487 (Gucci IV r.o. 3.24). ${ }^{33}$ De OK schorst in Gucci II (22 maart 1999, JOR 1999, 88) de overeenkomst tussen Gucci en PPR.

Het gedrag van PPR speelt echter ook een rol in het kader van het enquêteverzoek. 'Ook gedragingen van de aandeelhouder die een overwegende of belangrijke mate van zeggenschap wenst te verwerven [..] en gedragingen van een - toekomstige - aandeelhouder die deelneemt aan de gedragingen van het bestuur of de raad van commissarissen' erop gericht te voorkomen dat een hen niet welgevallige aandeelhouder voormelde zeggenschap in de rechtspersoon verkrijgt, kunnen de grondslag vormen voor een enqueteonderzoek, aldus de $\mathrm{OK}$ in Gucci IV (r.0. 3.6).

32. $\mathrm{Vgl}$. S. M. Bartman, De rol van de ondernemingskamer bij overnamegeschillen, Ondernemingsrecht 1999, blz. 139 en M. Brink, Over Gucci en de Ondernemingskamer, Privaatrecht Actueel, WPNR 1999, blz. 465.

33. Zie tevens S.M. Bartman, Enquêterecht, De rol van de ondernemingskamer bij overnamegeschillen, Ondernemingsrecht 1999, p. 248. 
Een strikte scheiding tussen de interne sfeer en de externe sfeer is mijns inziens niet wenselijk voor toepassing van de norm van de redelijkheid en billijkheid. ${ }^{34}$

\section{§ 4. Toepassing goede trouw beginselen nader bezien}

\section{\$ 4.1 Treupflicht in Duitsland}

In het Duitse recht wordt aanvaard dat de verhouding tussen aandeelhouders in een $\mathrm{GmbH}$ en een AG mede bepaald wordt door Treupflichten. Het gaat hier om de zgn. 'mitgliedschaftliche' Treupflichten. ${ }^{35}$

Treupflichten zijn eerst aanvaard in het kader van de $\mathrm{GmbH}$. Dit is te verklaren door de gelijkenis van de structuur van een $\mathrm{GmbH}$ met die van een Personengesellschaft waarin de 'Treupflichten' ontstaan vanwege een 'vom gegenseitigen Vertrauen getragenen Gemeinschaftsverhalltnis'. In de Victoria-uitspraak van het Reichsgericht (RG) van 31 maart 1931 wordt voor het eerst aanvaard dat de stemmenmacht van de meerderheidsaandeelhouders aan banden kan worden gelegd door de 'Treupflicht'.60 In de ITT-zaak (1975) worden Treu-

34. Zie ook een uitspraak van de OK van het Gerechtshof Amsterdam op 16 maart 1995 (JOR 1996, 54 met noot Van den Ingh). In deze zaak beēindigt een $50 \%$-aandeelhouder/ bestuurder de samenwerking met de andere $50 \%$-aandeelhouder/bestuurder en gaat activiteiten ontwikkelen met andere ondernemingen, waardoor de vennootschap concurrentie wordt aangedaan. De $\mathrm{OK}$ acht deze gedragingen in strijd met de redelijkheid en billijkheid jegens de vennootschap en de mede $50 \%$-aandeelhouder.

35. Wiedemann verdedigt dat naast de mitgliedschaftliche Treupflichten ook sprake is van 'mehrheitsbezogene' Treupflichten voor meerderheidsaandeelhouders, op grond waarvan meerderheidsaandeelhouders bij de uitoefening van hun stemmenmacht rekening dienen te houden met de belangen van de minderheidsaandeelhouders. Vgl. Zu den Treuepflichten im Gesellschaftsrecht, in FS Heinsius 1991, p. 950 e.v. Anders: M. Piepenburg, Mitgliedschaftliche Treupflichten der Aktionäre, Hamburg 1996, p. 8. Hij is van mening dat de categorie van 'mehrheitsbezogene' Treupflichten al wordt ondervangen door de 'mitgliedschaftliche' Treupflichten.

36. Zie RGZ 132, p. 149 e.v. Het betrof hier een besluit tot kapitaalvergroting met uitsluiting van het voorkeursrecht. Het RG overweegt; 'aus der Befugnis, im Wege des Mehrheitsbeschlusses auch für die Minderheit zu beschließen und über deren in der $\mathrm{Ge}$ sellschaft gebundene Vermögensrechte zu verfügen, ergibt sich ohne weiteres die gesellschaftliche Pflicht der Mehrheit, im Rahmen des Gesamtinteresses auch den berechtigten Belangen der Minderheit Berücksichtigung angedeihen zu lassen und deren Rechte nicht Gebühr zu verkurzen. Een soortgelijke formulering wordt 45 jaar later gehanteerd door het BGH in de ITT-zaak 'zudem verlangt auch hier insbesondere die für eine Gesellschaftermehrheit bestehende Möglichkeit, durch Einflußnahme auf die Geschăftsführung die gesellschaftsbezogene Interessen der Mitgesellschafter zu beeinträchtigen, als 
pflichten tussen aandeelhouders in een GmbH door het Bundesgerichtshof (BGH) voor het eerst uitdrukkelijk aanvaard." Pas in 1988 wordt in het zgn. Lino-type Urteil de Treupflicht door het BGH van toepassing geacht op aandeelhouders (Aktionăre) in een $\mathrm{AG}{ }^{3}$

Wat betreft de grondslag van de mitgliedschaftliche Treupflicht biedt de rechtspraak geen duidelijkheid. ${ }^{39}$ De functie daarvan is echter wel helder, begrenzing van aandeelhoudersmacht. ${ }^{40}$

Voor aandeelhouders impliceert zo'n mitgliedschaftliche Treupflicht dat: 'die Aktionäre verpflichtet sind, in Ausübung ihrer im Gesellschaftsinteresse begründeten mitgliedschaftlichen Befugnisse diejenigen Handlun-

gegengewicht die gesellschaftsrechtliche Pflicht, auf diese Interessen Rücksicht zu nehmen'. Vgl. onder meer M. Piepenburg. Mitgliedschaftliche Treuepflichten der Aktionăre, Hamburg 1996, p. 18/19; M. Winter, Mitgliedschaftliche Treuebindungen im GmbH-Recht, Mũnchen 1988, p. 40; Zöllner, Die Schranken mitgliedschaftlicher Stimmrechtsmacht bei den privatrechtlichen Personenverbănden, 1963, met name p. 335 e.v. en H. Henze, Materiellrechtliche Grenzen für Mehrheitsentscheidungen im Aktienrecht (Teil I), DStR 1993, p. 1825. Vóór de Victoria-uitspraak achtte het RG de norm van 'Treu und Glauben' van $\S 242$ BGB van toepassing op de rechtsbetrekkingen in een $\mathrm{GmbH}$.

37. Zie BGH 5 juni 1975, BGHZ 65 en H. Wiedemann, Die Bedeutung der ITT-Entscheidung, JZ 1976, p. 392-397.

38. BGHZ 103, zie M. Lutter, Die Treupflicht des Aktionärs. Bemerkungen zur LinotypeEntscheidung des BGH, ZHR 1989. p. 446-471.

39. U. Hüffer, Zur gesellschaftsrechtlichen Treupflicht als richterrechtlicher Generalklausel in: FS Ernst Steindorff, 1990 p. 61 en M. Paschke, Treupflichten im Recht der juristische Personen, in: FS R. Serick 1992, p. 317/318. Sommige auteurs verdedigen dat tussen aandeelhouders een rechtsverhouding bestaat, op grond waarvan de 'mitgliedschaftliche' Treupflichten van de aandeelhouders een behoorlijke samenwerking verlangen. $\mathrm{Vgl}$. H. Wiedemann, $\mathrm{Zu}$ den Treuepflichten im Gesellschaftrecht in FS Th. Heinsius 1991, p. 950, M. Winter. Mitgliedschaftliche Treuebindungen im GmbHRecht, Mũnchen 1988, p. 88 e.v.. Anders: W. Flume, Die Personengesellschaft 1977. \& 7 II 2, p. 211, M. Lutter, Theorie der Mitgliedschaft, AcP 1980, p. 121. Lutter is van mening dat conflicten tussen aandeelhouders steeds de rechtsverhouding tussen aandeelhouders en vennootschap raakt, zodat de 'Treuebindungen' niet afgeleid hoeven te worden van de rechtsbetrekkingen tussen aandeelhouders. Evenzo Zöliner, Die Schranken mitgliedschaftlicher Stimmrechtsmacht bei den privatrechtlichen Personenverbănden, 1963 , p. 355.

40. Evenals in het Nederlandse recht is het beginsel van de 'goede trouw' in de kapitaalvennootschappen tot ontwikkeling gekomen vanuit de gedachte dat het gebruik van meerderheidsmacht, met het oog op bescherming van minderheden, niet onbeperkt mag zijn. 
gen vorzunehmen, die der Förderung des Gesellschaftszwecks dienen, und zuwiederlaufende Maßnahmen zu unterlassen'. ${ }^{4 I}$

Enerzijds gelden voor aandeelhouders 'aktive Förderpflichten'. Men denke bijvoorbeeld aan de verplichting om te stemmen ten behoeve van een bepaald besluit dat in het belang is van de vennootschap ('positive Stimmpflicht'). ${ }^{42}$ Anderzijds wordt van de aandeelhouders loyaal gedrag verwacht jegens de mede-aandeelhouders en de vennootschap. Dit brengt mee dat gedrag dat schade kan veroorzaken aan de vennootschap achterwege moet blijven (passive Förderpflichten; Unterlassungs- und Loyalitätspflichten). ${ }^{43}$

Wel wordt in dit kader onderscheid gemaakt tussen 'Großaktionäre' (meerderheidsaandeelhouders) en 'Kleinaktionäre' ('minderheidsaandeelhouders'). ${ }^{44}$ Onomstreden is in de Duitse doctrine en rechtspraak dat de Treupflicht van toepassing is op gedragingen van een Großaktionär jegens minderheidsaandeelhouders. In de regel wordt de Treupflicht slechts van toepassing geacht op een Kleinaktionär indien door zijn gedrag de belangen van de vennootschap worden geschaad. ${ }^{45} \mathrm{De}$ achterliggende gedachte is dat de mate van invloed die een aandeelhouder kan uitoefenen op de gang van zaken van de vennootschap bepalend is voor de toepassing van de Treupflicht en de intensiteit daarvan. Voor de 'kleine' aandeelhouder strekt de norm in de regel voornamelijk tot 'Unterlassungsplichten'. ${ }^{46}$ Onder omstandigheden kan echter ook een minderheidsaandeelhouder veel

41. Zie M. Piepenburg, Mitgliedschaftliche Treupflichten der Aktionăre, Hamburg 1996, p. en U. Hüffer, Zur gesellschaftsrechtlichen Treupflicht als richterrechtlicher Generalklausel, in FS Steindorff, 1990, p. 69.

42. Zie bijvoorbeeld $M$. Winter, Mitgliedschaftliche Treuebindungen im GmbH-Recht, 1988 p. $168 / 169$.

43. Ook wel genoemd 'Rücksichtspflichte', zie onder meer M. Lutter, AcP 1980, p. 123 e.v. en K-P Martens, Die GmbH und der Minderheitenschutz, GmbHR 1984, p. 267.

44. Waarbij zij opgemerkt dat een 'Kleinaktionär' niet hetzelfde is als een minderheidsaandeelhouder. Een minderheidsaandeelhouder kan namelijk wel invloed uitoefenen door bijvoorbeeld de besluitvorming te blokkeren. Een 'Kleinaktionär' heeft echter zo weinig aandelen dat hij geen invloed kan uitoefenen op de besluitvorming. Dit is slechts anders indien 'Kleinaktionäre' met elkaar samenwerken. Vgl. recentelijk H. Henze, Treupflichten der Gesellschafter im Kapitalgesellschaftsrecht, ZHR 1998, p. 187.

45. Zie Winfried Werner, Zur Treupflicht des Kleinaktionärs, FS Johannes Semmler 1993, Berlin, p. $423 / 424$ en Hartwig Henze, Zur Treupflicht unter Aktionăren, FS Alfred Kellermann, 1990 , p. $151 / 152$.

46. Zie hier met name W. Werner, Zur Treupflicht des Kleinaktionärs, FS Semler 1993, p. 424. 
invloed uitoefenen. Een voorbeeld biedt de hierna nog te bespreken Duitse Girmes-zaak (hoofdstuk 4). Het betrof hier een minderheidsaandeelhouder die zoveel volmachten had verworven dat hij daarmee een besluit van de vennootschap kon blokkeren (zgn. 'Sperrminorität').

De verhouding tussen het bestuur (Vorstand/Geschäftsführer) en de vennootschap wordt eveneens beheerst door Treupflichten. Het betreft hier de 'organschaftliche' Treupflicht. Dit impliceert enerzijds dat een bestuurder zorgvuldigheid in acht moet nemen (vergelijkbaar met de duty of care in het Engelse recht) en anderzijds dat loyaliteit van hem wordt verwacht (vergelijk de Anglo-Saxische 'duty of loyalty').

\section{$\S 4.2$ Fiduciary duties in Engeland}

In de Engelse jurisprudentie en doctrine wordt niet betwijfeld dat bestuurders 'fiduciaries' zijn. ${ }^{47}$ De vraag die wel ter discussie staat is ten opzichte van wie een director fiduciary duties heeft. De traditionele opvatting is dat deze 'duties' alleen bestaan ten opzichte van de 'company', hetgeen volgens de doctrine gelijk kan worden gesteld met de aandeelhouders als groep..$^{48}$

Om de vraag te kunnen beantwoorden of op een aandeelhouder een 'fiduciary duty' rust, moet worden onderzocht wanneer er sprake is van een 'fiduciary relationship'. Kenmerkend voor zo'n relatie zijn vertrouwen ('trust') en kwetsbaarheid ('vulnerability') van de wederpartij. ${ }^{49}$

47. Vgl. Regal Hastings Ltd v Gulliver [1967] 2 AC. Hierin oordeelde Lord Porter; 'Directors, no doubt, are not trustees, but they occupy a fiduciary position towards the company whose board they form'.

48. Zie J.G. MacIntosh, Corporations, Special Lectures of the Law Society of upper Canada, Fiduciary duties, 1990, m.n. p. 189, 193 en 195. Zie tevens P.L. Davies, Directors' fiduciary duties and individual shareholders in Commercial aspects of trusts and fiduciary obligations, Oxford 1992, p. 84/85 en Gower's Principles of Modern Company Law, London 1997, p. 551. Vgl. ook Percival v. Wright [1902] 2 Ch. 421, die als standaarduitspraak geldt.

49. $\mathrm{Vgl}$. Supreme Court of Canada in Frame v. Smith [1987] 42 DLR op p. 99 In deze uitspraak worden drie kenmerken van een fiduciary relationship aangegeven, te weten: 1) The fiduciary has scope for the exercise of some discretion power: 2) The fiduciary can unilaterally exercise that power or discretion so as to affect the beneficiary's legal or practical interests; 3) The beneficiary is peculiarly vulnerable to or at the mercy of the fiduciary holding the discretion or power. Zie ook P.D. Maddaugh, Definition of fiduciary duty, in Special lectures of the Law Society of Upper Canada, 'Fiduciary duties' 
Voorop staat dat een fiduciary handelt in het belang van anderen, waarbij hij zijn eigen belang buiten beschouwing dient te laten. ${ }^{50}$ Klassieke voorbeelden van 'fiduciary relationships' zijn die tussen trustee en beneficiary (begunstigde) en agent (vertegenwoordiger) en principal (vertegenwoordigde).

Uitgangspunt in doctrine en rechtspraak is dat op aandeelhouders geen fiduciary duties rusten jegens de vennootschap, noch jegens andere aandeelhouders. $^{51}$ Op dit uitgangspunt worden echter wel uitzonderingen gemaakt. Dit is met name het geval als de aard van de vennootschap en de samenwerking nauwe onderlinge betrokkenheid impliceert. ${ }^{52}$

Een goede illustratie biedt Ebrahimi v. Westbourne Galleries. ${ }^{53}$ Een vader en zoon, beiden bestuurders en tezamen meerderheidsaandeelhouder van een vennootschap ontslaan de minderheidsaandeelhouder/bestuurder Ebrahimi. Hierdoor raakt Ebrahimi ook al zijn inkomsten kwijt aangezien de winsten van de vennootschap in de vorm van salaris worden uitgekeerd aan het bestuur. Hij vraagt daarop ontbinding van de vennootschap "on the just and equitable ground' van de toen nog geldende section 222 Companies Acht 1948. De House of Lords wijst zijn vordering toe. Lord Wilberforce oordeelt: 'there is room in company law for recognition of the fact that behind it, or amongst it, there are individuals, with rights, expectations and obligations inter se which are not necessarily submerged in the company structure [..]. The 'just and equitable' provision does not [..] entitle one party to disregard the obligation he assumes by entering into a company, nor the court to dispense him from it. It does, as equity always does, enable the court to subject the exercise of legal rights to equitable considerations, that is, of a personal character arising between one individual and

1990, p. 20 en J.R. Maurice Gautreau, Demystifying the fiduciary mystique, The Canadian Bar Review 1989, p. 5.

50. Vgl. Paul Finn, Fiduciary law and the modern commercial world, in Commercial aspects of trusts and fiduciary obligations, Oxford 1992, p. 9: 'A person will be a fiduciary in his relationship with another when and in so far as that other is entitled to expect that he will act in that other's interests or (as in a partnership) in their joint interests, to the exclusion of his own several interest'.

51. De verhouding tusen aandeelhouders wordt veeleer als een contractuele beschouwd. Vgl. bijvoorbeeld Peter's American Delicacy Co Ltd v. Health [1939] 61 CLR 457 (High Court of Australia). Het betreft hier een aantal aandeelhouders die niet meewerkt aan een statutenwijziging. Dixon J oordeelde over de aandeelhouders; 'they occupy no fiduciary position and their shares, which are property, and the right to vote is attached to the share itself as an incident of property to be enjoyed and exercised for the owner's personal advantage'. Zie ook hoofdstuk 5, $\$ 4.2$.

52. Evenzo J.G. MacIntosh, 'Corporations', in Special Lectures of the Law Society of Upper Canada, 'Fiduciary Duties', 1990, met name p. 194 e.v.

53. [1972] 2 All E.R. 492. 
another, which may make it unjust, or inequitable, to insist on legal rights or to exercise them in a particular way'."

Ik wil benadrukken dat in deze zaak met name drie elementen van belang zijn voor de rechter om te oordelen dat niet alleen rekening moest worden gehouden met de rechten, maar ook met de 'legitimate expectations' van Ebrahimi. Op de eerste plaats gaat het om 'an association formed or continued on the basis of a personal relationship'. Op de tweede plaats is er een 'agreement or understanding, that all or some of the shareholders shall participate in the conduct of the business? Op de derde plaats is er sprake van een 'restriction upon the transfer of the members' interest in the company' waardoor een aandeelhouder die als bestuurder wordt ontslagen zijn aandelen niet buiten de vennootschap kan verhandelen.

Met name in het Canadese recht worden fiduciary duties voor aandeelhouders aangenomen." Zie bijvoorbeeld Goldex Mines Ldd. v. Revill (DLR 3d 672 CA) waarin directors/aandeelhouders van de vennootschap de 'proxy rules' overtreden. De Court of Appeal oordeelt: 'The principle that the majority governs in corporate affairs is fundamental to corporation law, but its corollary is also important that the majority must act fairly and honestly. Fairness is the touchstone of equitable justice, and when the test of fairness is not yet met, the equitable jurisdiction of the Court can be invoked to prevent or remedy the injustice which misrepresentation or other dishonesty has caused. The category of cases in which fiduciary duties and obligations arise is not a closed one'.

Van groot belang voor een juiste appreciatie van het Engelse vennootschapsrecht is dat de belangen van individuele aandeelhouders kunnen worden beschermd tegen 'unfair prejudicial conduct' van bestuurders of meerderheidsaandeelhouders op grond van section 459 CA 1985 (zie reeds $\S 3.1){ }^{56}$ De toepassing van deze bepaling is mede gekleurd door de bovengenoemde uitspraak inzake Ebrahimi v. Westbourne Galleries. ${ }^{57}$

54. Vgl. een recente uitspraak van de Court of Appeal inzake Elliot v. Wheeldon [1993]. $B C L C$ 53. In deze zaak aanvaardt de Court of Appeal dat partijen in een joint venture een fiduciary duty jegens elkaar kunnen hebben. Zie hieromtrent Michael Lower, Towards an emerging law of joint ventures: Elliot v. Wheeldon, JBL 1994, p. 507-513.

55. $\mathrm{Vgl}$. Macintosch, t.a.p., p. 195-200.

56. Macintosh kwalificeert dit als een 'fiduciary restraint' waarmee hij wil aangeven dat acties naar aanleiding van belangenconflicten, een bron kunnen zijn voor fiduciary duties, p. 216.

57. Uit statistisch onderzoek blijkt ook dat de meerderheid van de zaken in het kader van een s. 459 procedure, private companies betreft met hooguit vijf aandeelhouders. Het onderwerp van geschil was hier in de meeste gevallen het ontslag van een bestuurder/ aandeelhouder en via s. 459 tracht zo'n ontslagen bestuurder te bewerkstelligen dat hij tegen een 'fair price' wordt uitgekocht. Zie het rapport van the Law Commission, Sharehoider Remedies 1997 , p. 25 en p. $179 / 180$. 


\section{§4.3 Frankrijk; abus de majorité/abus de minorité}

Zoals gezegd wordt ook in het Franse recht aangenomen dat aandeelhouders zich jegens elkaar dienen te gedragen conform de goede trouw. $^{58}$ Hun gedrag wordt echter pas gecorrigeerd door de rechter indien sprake is van misbruik van bevoegdheid, 'abus de majorité' of 'abus de minorité'.

De Cour de Cassation hanteert hiervoor stricte voorwaarden. Volgens vaste jurisprudentie is een sprake van abus de majorité indien het besluit is genomen 'contrairement à l'intérêt general de la société et dans l'unique dessein de favoriser les membres de la majorité au détriment de la minorité'." Andersom is sprake van abus de minorité ingeval van 'une attitude contraire à l'intérêt de la société, dans l'unique dessein de favoriser ses propres intérếts au đétriment de l'ensemble des autres associés'. ${ }^{\infty}$

In de loop van de jaren is dit in de rechtspraak ontwikkelde leerstuk van essentiële betekenis geworden voor de begrenzing van de meerderheid en minderheidsmacht. ${ }^{61}$ Omdat een bestuurder in een SA ook altijd aandeelhouder moet zijn (art. 95 L. 1966), is dit leerstuk ook van groot belang in de verhouding tussen bestuurders en aandeelhouders.

58. Deze notie van goede trouw in het vennootschapsrecht wordt in het Franse recht steeds meer benadrukt. Zie Guyon, Traité des contrats, nr. 36, J.L. Rives-Lange, L'abus de majorité in het themanummer La loi de la majorité, Rev.Jur.Com. 1991, p. 69 en in datzelfde nummer P. Merle, L'abus de minorité, p. 85. Zie ook recentelijk L. Godon, Les obligations des associés, thèse Paris, 1999 , p. 89 e.v.

59. Vgl. Cass. com 18 april 1961, JCP 1961, II, 12164 nt. Bastian, Rev.trim.dr.com. 1961. 634, nt. Houin en 22 januari 1991, Bull. Joly 1991, p. 389, nt. Jeantin. Discussie bestaat over de betekenis van 'T'intérêt general'. In de doctrine wordt gesproken over l'intérêt social. Wat betreft de betekenis hiervan bestaan grofweg twee visies: het belang van de vennootschap als zelfstandige entiteit of de belangen van de aandeelhouders gezamenlijk. De definitie van abus de majorité omvat beide visies. Vgl. Godon, t.a.p., p. 94, D. Schmidt, Les conflits d'intérêts dans la SA, Parijs 1999, p. 188-194 en Cozian-Viandier-Deboissy, nr. 470.

60. Vgl. Cass.com 14 januari 1992, Bull. Joly 1992, p. 273 nt. Le Cannu, Rev. Soc. 1992. 44 nt. Merle (Vitama), 15 juli 1992. Bull. Joly 1992, 1083 nt. Le Cannu, JCP 1992, E, II, 375 nt. Guyon (Six) en 9 maart 1993, Bull. Joly 1993, p. 537 nt. Le Cannu, JCP 1993, E, 448, nt. Viandier (Flandin).

61. Toepassing van deze 'correctie' veronderstelt dat (meerderheids- of minderheids)aandeelhouders invloed kunnen uitoefenen op de gang van zaken in de vennootschap. 
Het Franse recht stelt echter ook zelfstandig eisen aan de loyaliteit van bestuurders. Dit kan worden afgeleid uit een aantal wettelijke bepalingen. ${ }^{62}$ Voorts heeft de Cour de Cassation in recente jurisprudentie uitdrukkelijk beslist dat een bestuurder een loyaliteitsplicht heeft, zowel jegens de vennootschap als jegens aandeelhouders (vgl. § 3.1).

\section{§. De rechterlijke mogelijkheden tot ingrijpen}

In deze paragraaf onderneem ik een eerste verkenning van de rol die rechters in het vennootschapsrecht vervullen en de bereidheid van rechters om werking aan de redelijkheid en billijkheid, en daarmee vergelijkbare leerstukken, toe te kennen.

\section{§ 5.1 Engeland; section 459 Companies Act 1985}

Engelse rechters kenmerken zich van oudsher door een terughoudend optreden in de vennootschap..$^{63}$

Een bekende illustratie van het niet-ingrijpen van de rechter in de vennootschap biedt Foss $v$. Harbottle [1843] 2 Hare $461 \mathrm{Ch}$, waarin wordt vastgehouden aan het meerderheidsbeginsel in de vennootschap. Het betreft hier een procedurele kwestie. Een aantal bestuurders had een stuk grond, dat aan hen toebehoorde, voor een buitensporige prijs aan de vennootschap verkocht. Twee aandeelhouders wilden namens de vennootschap een procedure instellen om de bestuurders aansprakelijk te stellen voor de schade van de vennootschap. De High Court oordeelt echter dat dit recht om een procedure in te stellen slechts toekomt aan de vennoot-

62. Zie bijv, art. 100 en 149 van Loi 1966, betreffende de geheimhoudingsplicht en de strafrechtelijke bepaling inzake 'abus de biens sociaux' (misbruik van goederen van de rechtspersoon/art. 437 L. 1966). Zie ook B. Daille-Duclos, t.a.p., p. 1487.

63. Als belangrijke reden kan hiervoor worden aangevoerd het fundamentele beginsel van het Engelse vennootschapsrecht, inhoudende dat de vennootschap wordt beschouwd als een afzonderlijke rechtspersoonlijkheid ('separate legal entity') afgezonderd van de aandeelhouders. Zie hieromtrent Salomon v. Salomon \& Co. Lid [1897] AC 22, House of Lords. Voorts vloeit de terughoudendheid van de Engelse rechter voort uit het recht met betrekking tot partnerships. Uitgangspunt was dat de rechter niet ingreep in partnerships, tenzij de partnership moest worden ontbonden. Vgl. Wedderburn, Shareholders' Rights and the Rule in Foss v. Harbottle, CLJ 1957, p. 194 e.v. Ten slotte wordt als reden wel aangevoerd dat de leden van de rechterijike macht gedurende hun carrière over het aigemeen weinig contact hebben met de zakenwereld en ook praktisch geen ervaring opdoen met ondernemingsrecht. $\mathrm{Vgl}$. onder meer $\mathrm{A}$. Tunc, 'The Judge and the Businessman', LQR 1986, p. 552. 
schap zelf (en erkent dus geen 'derivative action' voor aandeelhouders). ${ }^{64} \mathrm{De}$ 'regel', dit wordt afgeleid uit Foss v. Harbottle, houdt dus - kort gezegd - in dat indien een vennootschap (en de minderheidsaandeelhouders) schade lijdt door het gedrag van bijvoorbeeld be stuurders of meerderheidsaandeelhouders, een minderheidsaandeelhouder geen mogelijkheder heeft om hiertegen op te treden.

Deze terughoudendheid om zich te bemoeien met de interne organisatie en het beleid var de vennootschap blijkt ook duidelijk uit Burland $v$. Earle [1902]. ${ }^{\text {ss }}$ Lord Davey van dt Privy Council oordeeide; 'it is an elementary principle of the law relating to joint stock. companies that the court will not interfere with the internal management of companies acting within their powers, and in fact has no jurisdiction to do so. Again, it is clear law that if order to redress a wrong done to the company or to recover moneys or damages alleged to be due to the company, the action should prima facie be brought by the company itself.

Tot een soortgelijke uitspraak komt de Privy Council ook in 1974 inzake Howard Smith Ldd v. Ampol Petroleum Lid., [1974] AC 821. Lord Wilberforce overweegt; 'it would be wrong for the court to substitute its opinion for that of the management, or indeed to question the correctness of management' decision, on such a question, if bona fide arrived at'. Ook stelt hij 'there is no appeal on the merits from management decisions to courts of law: nor will courts of law assume to act as a kind of supervisory board over decisione within the powers of management honestly arrived at.'

Afwjiking van deze traditionele opvatting in de common law vindt slechts beperkt plaats, namelijk indien besluiten of gedragingen van de controlerende aandeelhouder(s) leiden tot 'fraud on the minority'. ${ }^{66}$ Dan is er een mogelijkheid voor een minderheidsaandeelhouder om een 'derivative action' in te stellen. Deze mogelijkheid wordt in de praktijk echter nogal bemoeilijkt. Allereerst rust er dan een zware bewijslast op de minder-

64. Het Engelse recht aanvaardt overigens in veel gevallen wel het recht voor een aandeelhouder op een 'personal action' indien de statuten niet worden nageleefd. Dit kan worden gebaseerd op s. 14 CA 1985, dat bepaalt dat de vennootschap en haar aandeelhouders contractueel gebonden zijn aan het memorandum en statuten van de vennootschap, Vgl. onder meer B. Cheffins, Company Law. Theory, Structure and Operation. Oxford 1997, m.n. p. 456.

65. [1902] AC 83.

66. Zie Edwards v. Haliwell [1950] 2 All ER 1064, CA en Prudential Assurance Co Ltd v Newman Industries Ltd [1982] Ch 204. 
heidsaandeelhouder. ${ }^{67}$ Voorts is onduidelijk wat de reikwijdte van 'fraud on the minority' is. ${ }^{\text {s }}$

Een eerste aanzet tot verbetering van de positie van de minderheidsaandeelhouders wordt in 1945 geleverd door de regeringscommissie Cohen. Deze commissie is een voorstander van een wettelijke regeling ter bescherming van de minderheidsaandeelhouders tegen onderdrukking ('oppression') door de meerderheid, hetgeen resulteert in section $210 \mathrm{CA}$ 1948. In de praktijk werpt deze bepaling echter weinig vruchten af. Dit komt onder meer door de terughoudendheid van rechters om deze bepaling toe te passen. De Commissie Jenkins dringt derhalve in het begin van de jaren '70 op hervorming aan. De aanbevelingen van deze commissie worden neergelegd in section 75 CA 1980, dat vervolgens met enige aanpassingen is opgenomen in de huidige section 459 CA 1985 (zie reeds $\S 3.1$ ) waarin als maatstaf geldt of sprake is van 'unfair prejudicial conduct'.

De meeste jurisprudenue die op basis van section 459 is gewezen heeft betrekking op een aandeelhouder in een besloten vennootschap ('closely held company') die opkomt tegen 'unfair prejudicial conduct' van een bestuurder of zijn mede-aandeelhouder(s) ${ }^{69}$ Indien het een 'public company' betreft, getuigt de jurisprudentie echter nog steeds van een zeer terughoudende opstelling van de rechter. ${ }^{70}$

67. Een minderheidsaandeelhouder moet onder meer aantonen dat meerderheidsaandeelhouders ('wrongdoers') een overheersende invloed en macht kunnen uitoefenen in de vennootschap. Dit vormt met name een probleem indien het vennootschappen betreft met een verspreid aandelenkapitaal. Zie hieromtrent bijvoorbeeld S. Goulding, Principles of Company law, London 1997, p. 287.

68. Zie ook The Law Commission (No. 246), Shareholder Remedies 1997, p. 71/72.

69. De statistieken geven aan dat, in de periode tussen januari 1994 en december 1996, ruim $96 \%$ van de procedures rond 'unfair prejudicial conduct' een private company betreft. Het initiatief tot het instellen van die procedure lag in circa $70 \%$ van de gevallen bij minderheidsaandeelhouders en in $24 \%$ ging het initiatief uit van $50 \%$ aandeelhouders. $\mathrm{Vgl}$. The Law Commission, Shareholder remedies, 1997, Appendix J p. 178.

70. Vgl. ook Brian R. Cheffins, Company Law theory, structure and operation, Oxford 1997, p. 464. Teneinde het beleid van public companies aan de kaak te stellen, zijn aandeelhouders derhalve aangewezen op de Department of Trade and Industry. Dit Department heeft de bevoegdheid om 'at any time, if he thinks there is a good reason to do so, give directions to [a company] requiring it, at such time and place as may be specified in the directions, to produce such [documents] as may be so specified' (s. 447 CA 1985). Vgl. Boyle, A.J., Directors' Fiduciary Duties: The Continuing Problem of Effective Enforcement, in: Forum Internationale, 1987, p. 12. 
Ik wijs op een uitspraak van de Chancery Division in 1993 inzake Re Tottenham Hotspur ple." Alan Sugar houdt middels zijn privé vennootschap (Amshold Lud) $48 \%$ van de aandelen in Tottenham en Venables houdt $23 \%$ van de aandelen Tottenham (middels Edennote plc.). In 1991 kopen zij de andere twee aandeelhouders uit en willen samen ook deel gaan uitmaken van het management van de club. Sugar wordt benoemd tot voorzitter van het bestuur en Venables wordt 'chief executive'. Zij spreken vervolgens af dat zij elk voor 50 s deelnemen in de club en dat ook als Venables zijn aandelenbelang zou zien verminderen, hij zijn plaats als chief executive in het bestuur zou kunnen behouden. Reeds in december 1991 investeen Sugar opnieuw in aandelenkapitaal waardoor het belang van Venables in Tottenham afneemt. Er ontstaan conflicten in het management die leiden tot het ontslag van Venables als chief executive. Venables eist (middels Edennote plc.) daarop in het kader van section 459 CA 1985 van Amshold Ltd. de overdracht van de aandelen in Tottenham en een verbod aan het bestuur om uitvoering te geven aan het besluit inzake zijn ontslag. Nicholls I wijst deze vordering echter af en oordeelt: 'Whether Mr Venables' dismissal was in the best interests of Tottenham is not a matter for the court to decide. That is a matter for the Tottenham board to whom this decision is entrusted under the company's constitution'.

De procedure in het kader van section $459 \mathrm{CA}$ is in de afgelopen jaren sterk bekritiseerd. Als belangrijk bezwaar wordt aangevoerd dat deze procedure zeer tijdrovend en kostbaar is voor de (minderheids)aandeelhouders. ${ }^{2}$ In een 'consultation paper' heeft The Law Commission voorstellen gedaan tot wijziging en aanvulling van de huidige regeling om de positie van minderheidsaandeelhouders te verbeteren. ${ }^{73}$

Dit zou moeten geschieden door een aantal wettelijke aanvullingen met betrekking tot sections 459-461 CA. Zo wordt gedacht aan een wettelijke bepaling waarin onder bepaalde voorwaarden 'unfairly prejudicial conduct' wordt vermoed. Hier wordt gedacht aan de situatie in Ebrahimi v. Westbourne Galleries (zie $\$ 4.2$ ). In zo'n geval heeft een aandeelhouder, die als bestuurder wordt ontslagen, het recht om uitgekocht te worden tegen een evenredig deel van de waarde van de vennootschap (pro rata). Tevens wordt voorgesteld een 'winding-up remedy' toe te voegen aan S. $461 \mathrm{CA}$. Overigens wordt ook een nieuwe wettelijke procedure voorgesteld voor een derivative action. Hierdoor wordt duidelijk wanneer aandeelhouders kunnen procederen namens de vennootschap indien deze nadeel lijdt. Het huidige recht hieromtrent, dat wordt beheerst door de uitspraak inzake Foss v. Harbottle en

71. [1994] 1 BCLC 655. Zie hieromtrent ook J.P. Lowry. The irretrievable breakdown of the 'dream ticket'- Re Tottenham Hotspur plc, JBL 1994, p. 606-609.

72. Vgl. bijv. Re Elgirdata Ltd [1991] BCLC 959. Deze procedure duurde 43 dagen en kostte in totaal $f 320.000$. Zie ook Law Commission Report, § 1.6. nr. 14.

73. Zie het rapport van The Law Commission, 'Shareholder Remedies' 1997. Zie hieromtrent ook The Company Lawyer, october 1997 en A. Hicks \& S.H. Goo, Cases \& Materials on Company Law, London 1997, p. 448 e.v. 
de uitzonderingen daarop, is ingewikkeld en blijkt in de praktijk onbevredigend te zijn voor zowel aandeelhouders als de vennootschap. ${ }^{\text {nt }}$

\section{\$ 5.2 Frankrijk; 'direct' en 'indirect' ingrijpen door rechter}

\section{I. 'Direct ingrijpen'}

Anders dan het Engelse recht kent het Franse recht juist een traditie van ingrijpen door de rechter in vennootschappen ter voorkoming van 'misbruik'. 75 Allereerst heeft de rechter de mogelijkheid om 'direct' op te treden door op verzoek van belanghebbenden ${ }^{76}$ besluiten aan te tasten. Art. 360 L. 1966 regelt een tweetal categorieèn van besluiten waarvan de nietigheid kan worden ingeroepen (action en nullité). De eerste categorie heeft betrekking op besluiten tot de oprichting van de vennootschap en besluiten tot statutenwijziging. De tweede categorie omvat alle overige vennootschappelijke besluiten van de ava, bestuur en raad van commissarissen.

Voor wat betreft de eerste categorie van besluiten bepaalt art. 360 lid 1 L. 1966 dat er sprake moet zijn van een schending van een 'disposition expresse de la présente loi of 'de celles qui régissent la nullité des contrats'. ${ }^{n}$ Met andere woorden, de wet moet uitdrukkelijk voorzien in nietigheid. Alle andere besluiten kunnen volgens art. 360 lid 2 L. 1966 worden vernietigd indien sprake is van schending van een 'disposition impérative' (dwingende wetsbepaling) of van 'celles qui régissent les contrats' (dwingende bepalingen met betrekking tot de geldigheid van contracten). Echter, niet duidelijk is wanneer er sprake is van een dwingende wetsbepaling. ${ }^{n}$ 'C'est au juge qu'il appartiendra de dire si telle disposition de la loi doit être considérée comme impérative au sens de l'article 360 al. 2 L. 1966', 79

74. Zie The Law Commission, Shareholders' Remedies 1997, p. 2 en 74.

75. Zie J-C. Marin, La mission du juge dans la prévention des abus, in Rev. Jur. com. 1991, p. 110-121 en A. Guengant e.a., Le rôle des juges dans la vie des sociétés, Parijs 1993, p. 3-6.

76. Elke persoon die een gerechtvaardigd belang (intérêt légitime) heeft bij de nietigheid van een besluit, is belanghebbende. Zie art. 31 Nouveau code de procédure civile (NCPC).

77. Zie Guyon, Droit des Affaires, nr. 442.

78. Zie D. Grillet-Ponton, La Méconnaissance d'une règle impérative de la loi, cause de nullité des actes et délibérations des organes de la société, Rev. Soc. 1984, p. 259 e.v. en Ripert-Roblot, nr. 1221.

79. Zie Mercadal-Janin, Sociétés Commerciales, nr. 3747. 
Vernietiging van besluiten is voorts mogelijk wegens misbruik van bevoegdheid ('abus de majorité' of 'abus de minorité'), of misbruik van recht ('abus de droit') waarover ik reeds sprak in $\S 3.1$ en $\S 4.3{ }^{80}$

Daarnaast heeft de Franse rechter andere instrumenten waarmee hij langs 'indirecte' weg zich kan bemoeien met het functioneren van een vennootschap.

\section{II. 'Indirect ingrijpen'}

Eén van de belangrijkste instrumenten voor de Franse rechter om indirect in te grijpen in de vennootschap is de mogelijkheid om een 'mandataire de justice' te benoemen. Dat kan zijn een 'mandataire ad hoc' of een 'administrateur judiciaire' (ook wel 'administrateur provisoire' genoemd), maar ook een 'observateur de gestion' of een 'enquêteur'. Deze rechtsfiguren kunnen wat betreft hun bevoegdheden grofweg in twee categorieèn worden verdeeld. ${ }^{81}$ De eerste categorie bestaat uit 'mandataires' die tijdelijk bevoegd zijn om de bestuursfunctie te vervullen (administrateur provisoire). De tweede categorie van 'mandataires' hebben die bevoegdheid niet en vervullen veeleer een ondersteunende, niet bestuurlijke taak ten behoeve van het functioneren van de vennootschap. Binnen deze laatste categorie bestaan verschillende gradaties in bevoegdheden. Welke rechtsfiguur door de rechter wordt toegepast, ${ }^{82}$ hangt af van de ernst van de situatie in de vennootschap.

80. Zie onder meer A. Guengant e.a., Le rôle des juges dans la vie des sociétés, Parijs 1993, p. 7 en 12, J.P. Legros, La nullité des décisions de sociétés, Rev. soc. 1991, p. 297 en J. Calais-Auloy, L'abus de pouvoirs ou de fonctions en droit commercial francais, in L'abus de pouvoirs ou de fonctions, Traveaux de l'association Henri Capitant, Paris 1977, p. 221.

81. Vgl. J. Cavallini, Le juge des référés et les mandataires de justice dans us sociétés in bonis, Rev. Soc. 1998, p. 259.

82. Veelal wordt in een kort geding procedure om de benoeming van een 'mandataire de justice' verzocht. Een kort geding rechter heeft namelijk in geval van spoed de bevoegdheid al die maatregelen te nemen 'qui ne se heurtent à aucune contestation sérieuse ou que justifie l'existence d'un différend' (art. 808 en 872 NCPC). Zie Mercadal-Janin, nr. 1497. A. Guengant e.a., Le rôle des juges dans la vie des sociétés, Parijs 1993, p. 38 en J. Cavallini, Le juge des référés et les mandataires de justice dans les sociétés in bonis, Rev. soc. 1998 , p. 250. 
De meest vergaande invloed kan worden uitgeoefend door de 'administrateur provisoire'. De rechter ${ }^{83}$ kan zo'n persoon, op verzoek van een orgaan van de vennootschap, van minderheidsaandeelhouders of zelfs van crediteuren, echter slechts benoemen indien sprake is van een crisissituatie in de vennootschap die het voortbestaan daarvan in gevaar kan brengen en indien het ingrijpen in de vennootschap door een 'administrateur provisoire' gerechtvaardigd wordt door het belang van de vennootschap. ${ }^{84}$ Daarvan is bijvoorbeeld sprake 'si des faits précis conduisent à craindre un abus de droit ou un détournement de pouvoir des majoritaires susceptible de mettre en péril les intérêts de la société' (curs. MK) '. ${ }^{\text {ss }}$ De rechter schuift dan het zittende bestuur terzijde ${ }^{86}$ en kent de 'administrateur provisoire' tijdelijk de bestuursfunctie toe met een tweeledig doel; beslechting van de crisissituatie in de vennootschap en het dagelijks besturen van de vennootschap teneinde het voortbestaan van de vennootschap te verzekeren. ${ }^{87}$ Bij de uitoefening van die taken is hij 'als bestuurder' onderworpen aan zorgvuldigheids- en loyaliteitsverplichtingen en het daaraan gekoppelde aansprakelijkheidsregime. ${ }^{88}$

Als geen aanleiding bestaat voor de benoeming van een 'administrateur provisoire', maar wel sprake is van een conflict in de vennootschap, kan de Franse rechter op verzoek van onder meer aandeelhouders, een 'mandataire ad hoc' benoemen. Ook zo'n verzoek komt alleen voor

83. $\mathrm{Vgl}$. A. Guengant e.a., Le rôle des juges dans la vie des sociétés, Paris 1993, p. 39. Ook de kort geding rechter is hiertoe bevoegd. Vgl. Didier, Droit Commercial 1997, p. $302 / 303$.

84. $\mathrm{Vgl}$. J. Cavallini, Le juge des référés et les mandataires de justice dans les sociétés in bonis, Rev. Soc. 1998, p. 253: 'C'est en effet l'intérêt social qui doit motiver la demande d'intervention du juge et non l'intérêt propre du demandeur'.

85. Conform Cass. com. 17 oktober 1989, Bull.IV nr. 250. Zie Mercadal-Janin, nr. 1496.

86. Teneinde conflicten tussen het zittende bestuur en de administrateur te voorkomen, zie J. Cavallini, Le juge des référés et les mandataires de justice dans les sociétés in bonis. Rev. Soc. 1998, p. 260. Vgl. A. Guengant e.a., Le rôle des juges dans la vie des sociétés, Parijs 1993, p. 39: 'Sa nomination (benoeming van een administrateur, MK) emporte normalement dessaissement des anciens dirigeants'.

87. Zie bijvoorbeeld G. Bolard, Administrateur provisoire et mandat ad hoc, JCP 1995, éd. E. I 509. Vgl. ook bijvoorbeeld de Fruehauf-zaak, Cour d'appel Paris 22 mei 1965 , Rev.trim.dr.com 1965, p. 619-621. De vraag of crediteuren een verzoek tot benoeming van een administrateur kunnen indienen, staat ter discussie. Vgl. Ripert-Roblot, nr. 787.

88. Vgl. Didier, Droit Commercial 1997, p. 302. 
toewijzing in aanmerking als dit in het belang van de vennootschap is." Deze 'mandataire ad hoc' treedt, anders dan een 'administrateur provisoire', weliswaar niet in de plaats van een bestuurder, maar hij kan, doordat de rechter hem ad hoc een specifieke taak toebedeelt, de vennootschap wel (ingrijpend) beïnvloeden. ${ }^{90}$ Men denke met name aan de bevoegdheid om in plaats van de minderheids- of meerderheidsaandeelhouders te stemmen in geval van respectievelijk 'abus de minorité' en 'abus de majorité' (zie hoofdstuk $3 \S 8.1$ ). Andere bevoegdheden die hem kunnen worden toegekend zijn bijvoorbeeld het bijeenroepen van een vergadering in geval van een impasse ${ }^{91}$ (vgl. art. 158 L. 1966 en art. 122 Decr.) of het in rechte optreden namens de vennootschap in geval van tegenstrijdig belang van de bestuurders. ${ }^{92}$ Zie over deze figuur voorts hoofdstuk $3 \S 3.2$ en hoofdstuk $6 \S 2$.1.I.

De rechter kan ook besluiten een 'observateur de gestion' aan te wijzen. Deze kan slechts een ondersteunende rol vervullen. ${ }^{93}$ Hij heeft als taak te voorkomen dat de zittende bestuurders in strijd met het vennootschappelijk belang handelen. ${ }^{44}$

Ten slotte biedt de Franse wet nog andere mogelijkheden om in te grijpen in de vennootschap. Men denke bijvoorbeeld aan de mogelijkheid voor de rechter om op grond van art. 226 L. 1966 (en art. 64-1 L. 1966 voor de SARL) een enquêteur te benoemen, die tot taak heeft bestuurshandelingen te onderzoeken, waarvan betwijfeld wordt of zij met het vennootschappelijk belang stroken (enigzins vergelijkbaar met de Nederlandse enquêteprocedure). ${ }^{95}$ Echter, anders dan naar Nederlands recht, worden

89. Zie bijvoorbeeld Cour de Cassation 19 juni 1990, Rev. Soc. 1990, 621, note Sortais.

90. $\mathrm{Vgl}$. J. Cavallini, Le juge des référés et les mandataires de justice dans les sociétés in bonis, Rev. soc. 1998, p. 273: 'Le cas du mandataire ad hoc est quelque peu spécifique puisqu'il peut être habilité à adopter un acte qui rentre dans la sphere du pouvoir directorial et ainsi se substituer ponctuellement aux dirigeants mais son action se limite à rectifier une position donnée et non à gérer la société; le mandataire ad hoc contribue donc bien à l'encadrement des pouvoirs directoriaux'.

91. Vgl. Rev. Soc. 1989, 485, note Th. Forschbach.

92. $\mathrm{Vgl}$. bijv. Guyon, Droit des Affaires, nr. 450.

93. Zie Cozian-Viandier-Deboissy, nr. 494.

94. $\mathrm{Vgl}$. ook Guyon, nr. 450.

95. Zie Ripert-Roblot, nr. 1330 en nr. 1746, P. le Cannu, Éléments de réflexion sur la nature de l'expertise judiciaire de gestion, Bull. Joly 1988, p. 553, A. Guengant e.a., Le rôle des juges dans la vie des sociétés, Parijs 1993, p. 138-143. en J. Cavallini, Le juge des référés et les mandataires de justice dans les sociétés in bonis, Rev. Soc. 1998, p. 
de taak en bevoegdheden van de 'enquêteur' per geval door de rechter bepaald (art. 64-2 (3) en art. 226 (3) L. 1966). ${ }^{96}$

Deze voorziening is met name van belang voor één of meer minderheidsaandeelhouders die tenminste $10 \%$ van het kapitaal vertegenwoordigen, daar $10 \%$ vereist is voor het mogen doen van zo'n verzoek. ${ }^{97}$

Voor minderheidsaandeelhouders die minder dan $10 \%$ van het aandelenkapitaal vertegenwoordigen biedt art. 145 van de nouveau Code de procédure civile een mogelijkheid om een onderzoek in te stellen naar de gang van zaken in de vennootschap." Deze bepaling luidt: 's'il existe un motif légitime de conserver ou établir avant tout procès la preuve de faits dont pourrait dépendre la solution d'un litige, les mesures d'instruction légalement admissibles peuvent ètre ordonnées à la demande de tout intéressé ou en référé'. Deze procedure heeft, anders dan de procedure op grond van art. $226 \mathrm{~L}$. 1966, veeleer de functie om de feiten uiteen te zetten ten behoeve van een juridische actie. ${ }^{9}$ Een expert kan niet zoals een enquêteur een oplossing voorstellen teneinde een conflict te beslechten. 'L'expert doit, en effet, se contenter de mettre à jour les éléments de fait permettant d'établir la véracité des allegations rapportées sans se prononcer sur les points de droit'. 100

\section{\$ 5.3 Duitsland}

In Duitsland is de mogelijkheid voor de rechter om in te ingrijpen vrijwel beperkt tot de besluitvorming van de vennootschap. Een instrument, vergelijkbaar met het Nederlandse enquêterecht en de Engelse section 459 CA 1985 om het beleid onder de loep te nemen, kent het Duitse recht niet. ${ }^{101}$

Wel kent het Duitse recht de rechtsfiguur van de 'Notgeschäftsführer' in de GmbH, vergelijkbaar met de Franse 'administrateur provisoire', ${ }^{102}$ Echter, deze figuur komt slechts in

275 e.v.

96. Daar staat; 'S'il est fait droit à la demande, la décision de justice détermine l'étendue de la mission et des pouvoirs des experts'.

97. Zie bijv. Cozian-Viandier-Deboissy, nr 487.

98. Vergelijkbaar met de Belgische regeling in art. $191 \mathrm{VW}$.

99. Vgl. A. Guengant, Le rôle des juges dans la vie des sociétés, Parijs 1993, p. 144.

100. Zie J. Cavallini, Le juge des référés et les mandataires de justice dans les sociétés in bonis, Rev. Soc. 1998, p. 275.

101. Vgl. ook M. Lutter. Die Funktion der Gerichte im Binnenstreit von Kapitalgesellschaften - ein rechtsvergleichender Überblick, ZGR 1998, p. 206.

102. Zie over deze figuur H.P. Westermann, Der -Notgeschäftsführer der GmbH - der Mann zwischen den Fronten, in: FS Bruno Kropff, Düsseldorf 1997, p. 683-696. Hij constateert echter dat deze figuur nauwelijks aandacht krijgt in de literatuur en recht- 
beeld indien een GmbH 'bestuurloos' wordt doordat twee (groepen) aandeelhouders ('Ge sellschafter'), die elk $50 \%$ van de aandelen houden, het niet eens kunnen worden over de benoeming van een Geschãftsführer. Evenals een 'administrateur provisoire' wordt zo'n 'Notgeschãftsführer' belast met het tijdelijk besturen van de vennootschap en is hij onderworpen aan bestuurdersaansprakelijkheid. ${ }^{103}$

De rechter kan besluiten slechts aantasten naar aanleiding van de aan de aandeelhouders (en het bestuur) toekomende 'Gesellschafterklagen', bestaande uit 'Nichtigkeitsklagen' en 'Anfechtungsklagen' ( $\$ 241$ e.v. AktG) ${ }^{104} \mathrm{Bij}$ dit laatste gaat het niet alleen om een formele toetsing (indien bij de besluitvorming wettelijke of statutaire voorschriften niet zijn nageleefd) door de rechter, maar ook om een 'materielle Beschlußkontrolle' (zie hierover in dit boek met name hoofdstuk 5 en hoofdstuk 6). ${ }^{105}$ De grondslag van deze materiële toetsing wordt, volgens de heersende opvatting in de doctrine, gevormd door de Treupflicht, waarover reeds $\$ 3.1$ en $4.1 .^{106}$

Zo'n 'Anfechtungsklage' leidt veelal tot vernietiging van een besluit van de ava. Teneinde te bewerkstelligen dat een aanvankelijk afgewezen voorstel wel wordt aangenomen door de ava, kan een (minderheids)aandeelhouder een 'positive Beschlußfeststellungsklage' instellen. Indien de

spraak. Dit heeft er toe geleid, 'daß seine Stellung zwischen der eines - den Dingen etwas vorgreifenden - Totengräbers und eines Retters eines in eine Krise geratenen Unternehmens schwankt', aldus Westermann.

103. Zie H.P. Westermann, t.a.p., p. 691.

104. Dit recht is voor aandeelhouders van een AG wettelijk verankerd in $\$ 243$ AktG. Voor aandeelhouders van een $\mathrm{GmbH}$ wordt in de rechtspraak een analoge toepassing van deze 'Klagebefugnis' aangenomen. Dit geldt overigens ook voor de zgn. 'Nichtigkeitsklage', welke geregeld is $\$ 241$ AktG. Echter, aandeelhouders worden hier wel geconfronteerd met een procesrechtelijke belemmering. daar de bewijslast in de meeste gevallen berust op de 'Klager', die dit bewijs binnen één maand na de besluitvorming moeten leveren (vgl. $\$ 246 \mathrm{AktG}$ ). Vgl. I. Saenger, Minderheitenschutz und innergesellschaftliche Klagen bei der GmbH, GmbHR 1997, p. 112 e.v., T. Raiser, Nichtigkeits- und Anfechtungsklagen, in: 100 Jahre GmbH Gesetz, Köln 1992.

105. Dit wordt overigens door het Europese Hof van Justitie in de zaak 'Siemens' (C. 42/95) in overeenstemming geacht met de tweede EG-Richtlijn.

106. Vgl. bijvoorbeeld Zöliner, Die Schranken mitgliedschaftlicher Stimmrechtsmacht bei privatrechtlichen Personenverbãnden, München p. 349 e.v., H. Wiedemann, Zu den Treupflichten im Gesellschaftsrecht, in FS Heinsius 1991, p. 962 e.v. en M. Piepenburg, Mitgliedschaftliche Treupflichten der Aktionàre, Hamburg 1996, p. 277. 
rechter zo'n 'Beschlußfeststellungsklage' toelaatbaar acht, stelt hij vast dat de ava een bepaald voorstel heeft aangenomen. ${ }^{107}$

In de rechtspraak blijkt, voorzover ik heb kunnen nagaan, dat een 'positive BeschiuBfeststellungsklage' slechts wordt aanvaard in het geval besluitvormingsvoorschriften niet in acht worden genomen. ${ }^{104}$ Zoals bijvoorbeeld in BGHZ 1976, 191 (AG 1980, p. 187 e.v.). Hier had de voorzitter van de ava een voorstel tot wijziging van de statuten afgewezen, aangezien hij er -ten onrechte- van uitging dat een besluit tot statutenwijziging een gekwalificeerde meerderheid behoefde. Het BGH oordeelde: 'Hat in der Hauptversammlung der Vorsitzende zu Unrecht verkûndet, ein Antrag sei wegen Fehlens der erforderlichen Stimmenmehrheit abgelehnt, so kann die hiergegen gerichtete Anfechtungsklage mit dem Antrag auf Feststellung eines zustimmenden Beschlusses verbunden werden'.

\section{§ 6. Slotbeschouwing}

Voorafgaande aan rechtsvergelijkende beschouwingen over de redelijkheid en billijkheid, wordt in dit hoofdstuk bezien hoe in het buitenlandse vennootschapsrecht wordt omgegaan met het 'goede trouw' beginsel. Voorop gesteld kan worden dat in het buitenlandse recht met redelijkheid en billijkheid vergelijkbare beoordelingsnormen voor het gedrag van betrokkenen aanwezig zijn, zij het dat de terminologie, de betekenis en de reikwijdte daarvan verschillen.

In het Duitse recht normeert de 'Treuepflicht' de gedragingen van aandeelhouders en bestuurders. In het Engelse vennootschapsrecht biedt het stelsel van 'fiduciary duties' vergelijkingsmateriaal. Als essentieel daarbij wordt beschouwd dat er sprake is van een 'fiduciary relationship'. Daarnaast wordt, voorzover het gedragingen van (meerderheids)aandeelhouders betreft, door jurisprudentie rond section 459 CA 1985, invulling gegeven aan de 'goede trouw'. In Frankrijk wordt de rol van de 'goede

107. Vgl. I. Saenger, Minderheitenschutz und innergesellschafliche Klagen, GmbHR 1997 , p. 116 en M. Piepenburg. Mitgliedschaftliche Treupflichten der Aktionäre, diss. Hamburg 1996, p. 95 en W. Zöllner, Zur positiven Beschlußfeststellungsklage im Aktienrecht und anderen Fragen des Beschlußrechts, ZGR 1982, 623 e.v.. Indien de rechter vaststelt dat een bepaald besiuit in de ava tot standgekomen is, heeft dit overeenkomstig $\$ 248$ AktG rechtskracht voor de bij de organisatie van de vennootschap betrokkenen. Vgl. M. Winter, Mitgliedschaftliche Treuebindungen im GmbH-Recht, 1988. p. 169.

108. Vgl. M. Winter, t.a.p., p. 168/169, Karsten Schmidt, Gesellschaftsrecht 1994, p. 357 en I. Saenger, Minderheitenschutz und innergesellschaftliche Klagen, GmbHR 1997. p. 116. 
trouw' in het vennootschapsrecht met name vorm gegeven door het leer stuk van 'abus de majorité' en 'abus de minorité' resp. 'abus de pou voirs'.

Ten slotte besteed ik in dit hoofdstuk aandacht aan de rechterlijk! mogelijkheden tot ingrijpen in vennootschappen in Duitsland, Engeland e Frankrijk. 


\section{DEEL I:}

VERHOUDING MEERDERHEIDSAANDEELHOUDER(S) MINDERHEIDSAANDEELHOUDER(S) 



\section{Gedrag en besluitvorming in de algemene vergadering}

\section{§1. Inleiding}

In de regel vindt de besluitvorming van de ava daadwerkelijk plaats in een vergadering. ${ }^{1}$ Een besluit van een meerhoofdig orgaan zoals de ava, komt tot stand door het uitbrengen van stemmen over een voorstel. Daaraan gaat echter nog een aantal fasen vooraf.

Voordat de leden van de ava hun stemmen uitbrengen omtrent een voorstel, vindt er in de algemene vergadering veelal eerst overleg plaats. Aandeelhouders en andere vergadergerechtigden wisselen, als het goed is, over en weer van gedachten omtrent een voorgenomen beslissing en proberen zo invloed uit te oefenen op de besluitvorming. Om de gelegenheid te krijgen aan deze beraadslaging deel te nemen, moeten zij worden opgeroepen tot de algemene vergadering.

De wet en de statuten geven voor iedere fase in het besluitvormingsproces voorschriften, waaraan de meerderheids- en minderheidsaandeelhouders zijn gebonden. In beginsel heeft iedere aandeelhouder belang bij de naleving van deze wettelijke en statutaire voorschriften. ${ }^{2}$ Of dit betekent dat naleving van deze voorschriften de besluitvorming onaantastbaar maakt c.q. niet-naleving de besluitvorming ongeldig doet zijn wordt mede bepaald door de redelijkheid en billijkheid.

1. De wet en de departementale richtlijnen staan echter ook besluitvorming buiten vergadering toe. Vgl. art. 2:128/238 BW en departementale richtlijnen $\$ 11$. Voor besluitvorming buiten de vergadering gelden wel een aantal vereisten. De voorwaarden waaronder besluitvorming buiten vergadering kan geschieden zijn dat: 1) de statuten zulks vermelden en 2) dat er geen aandelen aan toonder of met medewerking van de vennootschap certificaten van aandelen zijn uitgegeven. De wijze waarop besluitvorming buiten vergadering moet plaatsvinden is: 1) schriftelijk, 2) met algemene stemmen en 3) van alle stemgerechtigde aandeelhouders. Voor een historische beschouwing over besluitvorming van aandeelhouders verwijs ik naar S.H.M.A. Dumoulin, Besluitvorming in rechtspersonen (diss. Groningen). Deventer 1999.

2. Anders: W.J.M. Noldus, Ongeldigheid van besluiten in de naamloze vennootschap. Deventer 1969, p. 257. Zie echter Hof Amsterdam 5 januari 1989, NJ 1990, 298: 'Een meerderheidsaandeelhouder die niet bij de dagelijkse gang van zaken is betrokken, heeft in het bijzonder beiang erbij dat de vennootschap zich gedraagt overeenkomstig wet en statuten'. 


\section{§ 2. Redelijkheid en billijkheid}

In elke fase van de besluitvorming kan door het handelen van een meerderheid of minderheid van aandeelhouders een besluit tot stand komen op een wijze die strijdig is met de redelijkheid en billijkheid. Zulk handelen van aandeelhouders kan worden onderscheiden in twee categorieën, namelijk:

- actief handelen;

- passief gedrag. ${ }^{3}$

Bij actief handelen is sprake van een daadwerkelijk handelen doordat een aandeelhouder gebruik maakt van een hem toekomend recht of hem toegekende bevoegdheid (zoals het recht om zich ter vergadering te laten vertegenwoordigen door een gevolmachtigde). Passief gedrag kan zijn het wegblijven van de vergadering of het zich van stemming onthouden. ${ }^{4}$

Er bestaat een voortdurende spanning tussen enerzijds de meerderheidsaandeelhouder of een groep van aandeelhouders die samen een meerderheid vormen, die over het algemeen veel invloed kan uitoefenen op de besluitvorming, en anderzijds de minderheidsaandeelhouder(s).

Geconstateerd moet bovendien worden dat aan de ene kant de zeggenschapsrechten, zoals het recht om aan de beraadslaging en stemming deel te nemen, toekomen aan een individuele aandeelhouder op grond van zijn individuele aandelenbezit. Aan de andere kant maakt hij deel uit van het orgaan 'de algemene vergadering' en oefent derhalve in zijn hoedanigheid van aandeelhouder deze rechten uit. ${ }^{5}$

3. Vgl. J. Ronse en K. Geens, Misbruik van minderheidspositie uit de bundel: Van Vennootschappelijk Belang 1988, p. 228.

4. In het Franse recht gaan sommige auteurs ook van dit onderscheid uit. Men spreekt hiet van l'abus positif en l'abus negatif. Dit onderscheid wordt echter veelal gehanteerd ten aanzien van het gedrag van minderheidsaandeelhouders. Overigens worden aan dit onderscheid wel consequenties verbonden voor wat betreft de sancties die de minderheidsaandeelhouder(s) opgelegd kunnen worden. Vgl. P. Le Cannu, L'abus de minorité, Bull. Joly 1986, p. 429 e.v. en P. Merle, L' abus de minorité, in het themanummer van de Revue de Jurisprudence Commerciale ('La stabilité du pouvoir et du capital dans les sociétés par actions), 1990, p. 82 en 88 e.v.

5. Vgl. ook H.C.F. Schoordijk, De aandeelhouder en zijn stem, Amsterdam 1969, p. 17. waarin hij stelt dat: 'aandeelhouders in algemene vergadering enerzijds als individuen krachtens eigen recht stemmen, anderzijds de NV vertegenwoordigend in kwaliteit 
In dit hoofdstuk staat centraal de vraag wat de redelijkheid en billijkheid in de verschillende fasen van het besluitvormingsproces kan meebrengen in aanvulling op, of in afwijking van, de wettelijke en statutaire regels. Welke factoren spelen daarbij een rol? Als de 'regels' waarnaar de aandeelhouders zich jegens elkaar mede moeten gedragen aldus nader zijn 'ingevuld', komt vervolgens de vraag op wat de consequenties zijn als deze niet in acht worden genomen.

\section{§ 3. Rond de oproeping}

De strekking van een oproeping voor een algemene vergadering van aandeelhouders is dat aandeelhouders in de gelegenheid worden gesteld om deel te nemen aan de besluitvorming, zodat zij invloed kunnen uitoefenen indien zij dat wensen (curs. MK). ${ }^{6}$

In dit kader komt een tweetal vragen op. Allereerst de vraag wie bevoegd is om een ava bijeen te roepen. Deze vraag is mede van belang, aangezien het uitgangspunt in het Nederlandse recht, maar ook in het Duitse, Franse en Engelse recht, ${ }^{7}$ is dat degene die wettelijk of statutair bevoegd is om een vergadering bijeen te roepen, ook de agendapunten voor de vergadering vaststelt en eventueel aanvult (zie § 4). De tweede vraag is op welke wijze dient te worden opgeroepen. ${ }^{8}$

handelen'.

6. Zie ook Wijsmuller HR 15 juli 1969, NJ 1969, 101. Wat betreft de wenselijkheid moet opgemerkt worden dat het een bekend verschijnsel is dat veel aandeelhouders/beleggers niet de moeite nemen om aan de algemene vergadering deel te nemen, gezien de tijd en de kosten die daaraan zijn verbonden.

7. Vgl. voor het Franse recht bijv. Cozian-Viandier-Deboissy, nr. 835 en Mercadal-Jeanin, nr. 1742; vgl. voor het Duitse recht \& 124 AktG en voor het Engelse recht, Gower's Principles of Modern Company Law, London 1997, p. 568.

8. Bijeenroeping en oproeping zijn termen met een verschillende strekking. De bijeenroeping is het besluit van de vennootschap dat de aandeelhoudersvergadering kan worden gehouden; de oproeping is de feitelijke uitnodiging van personen met zeggenschapsrechten om aan de bijeengeroepen deel te nemen. Zie S.H.M.A. Dumoulin, Besluitvorming in rechtspersonen, Deventer 1999. p. 125. 


\section{\$ 3.1 Bevoegdheid; wettelijke mogelijkheden}

Wat betreft de bevoegheid om een vergadering bijeen te roepen, blijkt uit art. 2:109 BW dat deze in het Nederlandse recht in ieder geval berust bij het bestuur en de raad van commissarissen.

In het Engelse recht komt deze bevoegdheid toe aan de 'board of directors' (s. $368 \mathrm{CA}$ 1985). 'Dit geldt ook voor het Franse recht, tenzij het een SA van het 'nieuwe' type betreft; in dat geval is ook de rve (conseil de surveillance) bevoegd (art. $158 \mathrm{~L}$. 1966). Ook voor het Duitse recht geldt dat de Vorstand resp. de Geschäftsführer de algemene vergadering (Hauptversammlung dan wel de Gesellschafterversammlung) bijeenroept ( $\$ 121$ II AktG/ $\$ 47$ III GmbHG). In een AG komt deze bevoegdheid echter ook toe aan de Aufsichtsrat (\$ 111 (3) AktG) onder de voorwaarde dat het belang van de vennootschap ('das Wohl der Gesellschaft') dit vereist.

De statuten kunnen deze bevoegdheid ook aan anderen toekennen. ${ }^{10}$ Een meerderheidsaandeelhouder kan zichzelf bijvoorbeeld via een wijziging van de statuten als oproepend orgaan aanwijzen.

Voor minderheidsaandeelhouders ligt dit anders, tenzij ook zij statutair het recht verkregen hebben om een ava bijeen te roepen. In bepaalde gevallen kunnnen minderheidsaandeelhouders gemachtigd worden door de president van de rechtbank om een vergadering bijeen te roepen.

Een verzoek daartoe is mogelijk indien het bestuur (en eventueel de raad van commissarissen) in gebreke is gebleven een jaarvergadering of een door de statuten voorgeschreven vergadering bijeen te roepen (vgl. art. 2:112/222 BW).

Voorts bestaat deze mogelijkheid indien (één of meer) aandeelhouders tenminste een tiende gedeelte van het geplaatste kapitaal vertegenwoordigen, of een zoveel geringer bedrag als bij de statuten is vermeld (art. 2:110/220 BW). "Voorwaarde is dan echter wel dat een redelijk belang aanwezig moet zijn voor het houden van een vergadering (art.

9. In geval de board of directors in gebreke blijt, is de Secretary of State bevoegd om een algemene vergadering bijeen te roepen (s. 367 (4) en (5)). Vgl. ook Gowers' Principles of Modern Company law, London 1997, p. 567.

10. $\mathrm{Vgl}$. Asser-Maeijer 2-III 1994, nr. 264 en Handboek, nr. 205. Evenzo in het Duitse recht. Hier kan statutair het recht om vergaderingen bijeen te roepen ook worden toegekend aan derden, zoals bijv. stichtingen of verenigingen. Zie U. Hüffer, Aktiengesetz 1995, p. 483.

11. Vgl. het Duitse GmbH-recht $\S 50$ I GmbHG. 
$2: 111 / 221 \mathrm{BW}){ }^{12} \mathrm{Bij}$ de beoordeling of sprake is van een redelijk belang dient blijkens de jurisprudentie mede te worden gelet op het doel dat met het houden van de vergadering wordt nagestreefd. ${ }^{13}$

In een kort geding bij de Rb Breda 12 juni 1979, NJ 1981, 219 (Tilburgse Waterleiding Maatschappij), verzochten aandeelhouders van Lantana beheer, die in het bezit was van 10 à $15 \%$ aandelen van het aandelenkapitaal van de Tilburgse Waterleidingmaatschappij (TWM) een machtiging om een vergadering van aandeelhouders bijeen te roepen, aangezien zij op de agenda onder andere een voorstel tot ontslag van de huidige bestuurders en commissarissen en benoeming van nieuwe functionarissen van TWM, wilden plaatsen. Dit verzoek werd afgewezen, omdat het enige argument voor het bijeenroepen van een vergadering een verschuiving van het aandeelhoudersbestand was waardoor Lantana meer zeggenschap had gekregen. Rekening houdend met de omstandigheid dat de aandeelhoudersvergaderingen doorgaans slecht werden bezocht kwam dit argument neer op de bedoeling de macht over te nemen, aldus de president. ${ }^{14}$

In dezelfde lijn ligt een uitspraak van $R b$ 's-Gravenhage 19 februari $1982, N J$ 1983, 522 waarin wordt overwogen dat minderheidsaandeelhouders en meerderheidsaandeelhouders bij hun streven om een vergadering bijeen te roepen, rekening moeten houden met de belangen van de overige kapitaaldeelnemers die bijvoorbeeld minder hecht georganiseerd zijn en op de aandeelhoudersvergadering slechts ten dele zijn vertegenwoordigd. is

\section{$\S 3.2$ Wettelijke mogelijkheden in rechtsvergelijkend perspectief}

Het Franse, Engelse en Duitse recht, bieden een soortgelijk perspectief voor een minderheidsaandeelhouder. In het Duitse AG-recht kunnen aandeelhouders die samen een pakket van $5 \%$ van het maatschappelijk kapitaal vertegenwoordigen van het bestuur eisen dat dit een vergadering bijeenroept. Desnoods kunnen zij door de rechtbank worden gemachtigd

12. Het gaat hier om het redelijk belang van de verzoekers in hun hoedanigheid van aandeelhouders, certificaathouders of beperkt gerechtigden, zie Asser-Maeijer 2-III, nr. 266 en Handboek, nr. 206.

13. Zie ook Asser-Maeijer 2-III, nr. 266, C.A. Schwarz, Rechtspersonen losbladig art. 1102 en Handboek nr. 206.

14. Instemmend met dit vonnis is Van der Grinten, Handboek nr. 206. Kritisch zijn F.J.W. Lōwensteyn, TVVS 1979. p. 397 en C.A. Schwarz, Rechtspersonen losbladig art. 1102.

15. $\mathrm{Vgl}$. reeds Pres. Rb. 's-Hertogenbosch 20 januari 1959, NJ 1959, 487, waarin wordt overwogen dat de president de belangen van betrokkenen enerzijds en vennootschap anderzijds zal moeten wegen. 
Gedrag en besluitvorming in de algemene vergadering

tot bijeenroeping van een vergadering (122 III AktG). ${ }^{16}$ In een $\mathrm{GmbH}$ kunnen aandeelhouders die gezamenlijk ten minste $10 \%$ van het kapitaal vertegenwoordigen in het geval dat de Geschäftsführer niet ingaat op het met redenen onderbouwde verzoek, zelf de vergadering bijeenroepen. ${ }^{17}$

Het Engelse recht kent een soortgelijke regeling voor aandeelhouders (s. $368(1 / 2) \mathrm{CA}) .^{18}$ Voorts is voor de Engelse rechtspraktijk van belang dat de rechter de bevoegdheid toekomt om een vergadering bijeen te roepen op verzoek van een aandeelhouder of een bestuurder 'if for any reason it is 'impracticable' (onuitvoerbaar) to call a meeting' (371 CA). ${ }^{19}$ Van belang is hierbij dat de vergadering wordt bijeengeroepen, gehouden en georganiseerd 'in any manner the court thinks fit'. Door deze mogelijkheid wordt tegemoet gekomen aan praktische belemmeringen die kunnen bestaan ten aanzien van het bijeenroepen van een algemene vergadering. Ook biedt deze regeling een oplossing in het geval de besluitvorming wordt geblokkeerd (zie hierover $\$ 8.1$ ).

In Frankrijk bestaat voor elke aandeelhouder de mogelijkheid om onder bepaalde omstandigheden de rechter te verzoeken een 'mandataire de justice' te benoemen, die vervolgens de algemene vergadering van aandeelhouders bijeenroept. Deze maatregel is door de wetgever gecreëerd met het oog op bescherming van minderheidsaandeelhouders tegen misbruik van macht door meerderheidsaandeelhouders/bestuurders. ${ }^{20}$

16. Zie onder meer Karsten Schmidt, Gesellschaftsrecht, p. 705 en Hüffer, Aktiengesetz, p. 492.

17. Het gaat hier om het zgn. 'Selbsthilferecht'. Vgl. ook Lutter-Hommelhoff, p. 620.

18. S. 368 ( 1 en 2) CA 1985 luiden: (1) The directors of a company shall, on a members' requisition, forthwith proceed duly to convene an extraordinary general meeting of the company; (2) a members' requisition is a requisition of (a) members of the company holding at the date of the deposit of the requisition not less than one-tenth of such of the paid-up capital of the company as at that date carries the right of voting at general meetings of the company; or (b) in the case of a company not having a share capital, members of it representing not less than one-tenth of the total voting rights of all the members having at the date of deposit of the requisition a right to vote at general meetings.

19. Zie ook onder meer E.S. Magner, Convocation of general meetings in company. reflections on Totex-Adon pty.Itd. and the Companies Act, ABLR 1981, p. 87 en Goulding. Principles of Company Law, London 1996, p. 96 en Farrar's Company Law, p. 312 .

20. $\mathrm{Vgl}$. A. Tunc. The judicial settlement of intra-corporate conflicts in The Cambridge Lectures 1981, p. 73. 
In een SARL mogen slechts aandeelhouders die tenminste de helft van het aantal aandelen houden (of een kwart van de aandelen indien zij tenminste eenvierde van het aantal aandeelhouders uitmaken) van het bestuur eisen dat een vergadering wordt bijeengeroepen. Indien het bestuur weigert een vergadering bijeen te roepen, heeft iedere associé de mogelijkheid om de president van het Tribunal de Commerce te verzoeken iemand te machtigen teneinde een vergadering bijeen te roepen (L. 57 (4) en D. 38 (3)). Deze regeling verschilt enigszins van die betreffende een SA. Hier kunnen alleen houders van aandelen, die gezamenlijk tenminste een tiende gedeelte van het kapitaal vertegenwoordigen, indien het bestuur in gebreke blijft, een verzoek richten tot de rechter om gemachtigd te worden een vergadering bijeen te roepen (L. 158 al 2 en 4$){ }^{21}$ Echter, in het geval er een dringende reden ('cas d'urgence') bestaat om een vergadering bijeen te roepen, kan iedere belanghebbende (tout intéressé), waaronder aandeelhouders met een kleiner pakket dan $10 \%$, de rechter vragen om iemand te machtigen een vergadering bijeen te roepen $(\mathrm{L} .158 /$ 'convocation par mandataire de justice'). ${ }^{2} \mathrm{Zo}^{\prime}$ n dringende reden kan bijvoorbeeld zijn dat het bestuur zodanig in zijn functioneren wordt belemmerd, dat de belangen van de vennootschap ernstig geschaad worden indien geen 'mandataire' wordt benoemd.

Evenals in het Nederlandse recht, blijkt in de Franse jurisprudentie dat een belangrijk toetsingsmoment bij de beoordeling van zo'n verzoek is of een legitiem doel ('but légitime') wordt gediend. Tevens toetst de rechter of de vergadering in het belang van de vennootschap is (l'intérêt social' $)^{23}$

Dit was bijvoorbeeld het geval in Cour de Cassation 19 juni 1990, Rev.Soc. 1990, 621. In deze zaak werden aandeelhouders niet ingelicht over aanvullend overleg dat door bestuurders werd gehouden omtrent kwesties, die ter algemene vergadering nog niet waren opgelost. $\mathrm{Z}_{\mathrm{ij}}$ verzoeken de rechter vervolgens een mandataire aan te wijzen. Zulks geschiedt. De Cour de Cassation verwerpt het cassatieberoep en oordeelt: ${ }^{*}$ La cour d'appel a considéré que c'était dans un but légitime d'information et dans l'intérêt du devenir de la société que la désignation d'un mandataire judiciaire aux fins de convocation d'une assemblée générale, avait été demandée; que cette demande tendait bien à des fins conformes à l'intérêt social'.

21. Vgl. bijv. T.C. Paris 20 februari 1970, Gaz.Pal. 1970-2-J 294, waarin er sprake was van een conflict tussen meerderheidsaandeelhouders en het bestuur over het al dan niet verkopen van een meerderheidsdeelneming in een vennootschap.

22. Zie o.m. Lamy sociétés commerciales 1996, nr. 3426 en A. Guengant e.a., Le rôle des juges dans la vie des sociétés 1993, p. 105.

23. Zie J-C. Marin, La mission du juge dans la prévention des abus in het themanummer van de Revue de Jurisprudence Commerciale 1991 'La stabilité du pouvoir et du capital dans les sociétés par actions, p. 114. 


\section{\$ 3.3 Wijze van oproeping}

Wat betreft de wijze van oproeping kan worden gesteld dat indien de oproeping tot de algemene vergadering geschiedt volgens de eisen die wet en statuten stellen, er niet per se sprake is van een behoorlijke oproeping. De redelijkheid en billijkheid kan met zich mee brengen dat degene die oproept bijzondere maatregelen moet nemen. De vraag die vervolgens opkomt is welke factoren tot zulke maatregelen moeten leiden en wat die maatregelen zijn. Uit de jurisprudentie kan men mijns inziens twee factoren afleiden op grond waarvan een bijzondere maatregel met betrekking tot de oproeping gerechtvaardigd kan zijn.

Allereerst de situatie dat een aandeelhouder intensief bij de vennootschap is betrokken. Men kan dan enerzijds denken aan een aandeelhouder met een bepaald aandelenbelang en anderzijds aan een aandeelhouder die tevens de functie van bestuurder of commissaris bekleedt in de desbetreffende vennootschap. Deze situatie zal zich met name voordoen in besloten vennootschappen met een kleine kring van aandeelhouders. Voorts is van belang welk onderwerp ter vergadering aan de orde wordt gesteld.

Zie hier ter illustratie allereerst HR 30 oktober 1964, NJ 1965, 107 (NV Intermationale Automobiel Maatschappij/Mante). De aandeelhoudster Mante was in het bezit van een aandelenpakket (44 van de in totaal 200 geplaatste en gestorte aandelen), waaraan een zekere machtspositie was verbonden. Die machtspositie bestond hieruit dat voor belangrijke besluiten de medewerking van Mante nodig was. Sommige besluiten konden namelijk slechts genomen worden met een meerderheid van vier vijfde van de uitgebrachte stemmen. Op een vergadering werd zonder de aanwezigheid van Mante besloten tot een wijziging van de statuten, waarbij die machtspositie werd doorbroken.

Het hof oordeelde dat, ook al mocht het zenden van oproepingsbrieven bij de vennootschap in onbruik zijn geraakt, de belangen van Mante bij de statutenwijziging van dien aard waren dat de vennootschap er zorg voor had moeten dragen dat zij van de vergadering op de hoogte was.

De Hoge Raad overwoog in aansluiting hierop: 'dat ook indien aan alle formele vereisten, bij wet of statuten gesteld voor de wijze van oproeping van een aandeelhoudersvergadering is voldaan, de eisen van redelijkheid en billijkheid die aandeelhouders jegens elkander in acht hebben te nemen, onder omstandigheden kunnen meebrengen dat een aandeelhoudersvergadering niet tot het nemen van een besluit aangaande een onderwerp waarbij de belangen van bepaalde aandeelhouders in bijzondere mate zijn betrokken overgaat, alvorens te hebben nagegaan of die aandeelhouders genoegzaam in de gelegenheid zijn gesteld aan de besluirworming over dit hen in het bijzonder rakende onderwerp deel te nemen'.

Bovendien overwoog de Hoge Raad: 'dat ook indien juist mocht zijn dat de wet of statuten individuele oproeping van de aandeelhouders niet dwingend voorschreven, niettemin de 
bijzondere omstandigheden van het geval tijdige verwittiging bepaaldelijk van die aandeelhouders wier belangen in het bijzonder door het te nemen besluit worden geraakt, geboden deden zijn. ${ }^{24}$

Zie voorts Hof 's-Gravenhage 17 maart 1983, NJ 1984, 81 (Reijnders/McKinney), waar het gaat om een besluit tot emissie dat de kem van de samenwerking tussen aandeelhouders raakt. Reijnders en McKinney zijn beiden directeur van Food Concepts BV en de enige aandeelhouders van deze BV, ieder voor vijftig procent (nominale waarde $f$ 12.500.-). Terwijl McKinney met vakantie is in Amerika, roept Reijnders een buitengewone vergadering bijeen met als enig agendapunt de uitgifte van aandelen in de vennootschap. Tijdens die vergadering, waarbij Reijnders als enig aandeelhouder aanwezig is, wordt besloten voor $f$ 10.000,- aan aandelen uit te geven en bij hem te plaatsen. Reijnders had McKinney per brief gericht aan zijn woonadres opgeroepen om deze vergadering bij te wonen.

Het hof overweegt dat de goede trouw welke de verhouding tussen aandeelhouders beheerst, meebrengt dat indien een directeur. tevens houder van vijftig procent van de aandelen, in een aandeelhoudersvergadering constateert dat zijn mede directeur/houder van de overige vijftig procent van de aandelen ontbreekt, hij de vergadering voor wat betreft niet zeer dringende agendapunten dient te verdagen, indien twijfel bestaat of de oproeping voor de vergadering de betrokkene wel heeft bereikt. Het verdagen van een aandeelhoudersvergadering houdt in dat een nieuwe vergadering bijeengeroepen moet worden. Zie omtrent het verdagen van een vergadering $\$ 6$.

De uitspraak inzake Reijnders/McKinney ligt in de lijn van eerdere jurisprudentie. In $R b$ Amhem 12 november 1942, NJ 1943, 846 was sprake van een soortgelijke situatie. Bij afwezigheid van een $50 \%$ aandeelhouder/enig commissaris werd door zijn mede $50 \%$ aandeelhouder/enig bestuurder op een vergadering besloten tot ontslag van de commissaris. Ter vergadering werd tevens een nieuwe commissaris benoemd en werd bovendien besloten aandelen aan hem uit te geven.

De rechter overwoog: 'dat het enkel volstaan met een dergelijke oproeping [op grond van de statuten, MK] tot een vergadering waarop zulke ingrijpende voorstellen met betrekking tot de enig commissaris en houder van de helft van de aandelen zouden worden behandeld, jegens deze [..] een misbruik was van die bepaling der statuten, omdat zij daarbij redelijkerwijze heeft moeten begrijpen en kennelijk heeft bedoeld wat met de oproepingsvereisten niet zou worden bereikt, namelijk dat de eiser op de hoogte zou worden gebracht van de voorgenomen vergadering'. De rechter oordeelde vervolgens dat de oproeping moest worden geacht niet te zijn geschied.

Zie ook Rb Breda 17 november 1942, NJ 1943, 463 (Astarte), waarin de rechter overwoog dat alleen het volgen van de door de statuten voorgeschreven formele wijze van kennisgeving in strijd was met de goede trouw, nu "hiervan met aan zekerheid grenzende waarschijnlijkheid was te verwachten dat eiser van de voorgenomen vergadering onkundig

24. De Hoge raad vernietigde het besluit tot statutenwijziging partieel. Afhankelijk van de aard van het besluit is partiēle vernietiging mogelijk. Het besluit moet voor splitsing vatbaar zijn. De rechter heeft vrijheid om aan de vernietiging van het besluit geheel of ten dele de werking te ontzeggen. De regeling omtrent de nietigheid en vernietiging van rechtshandelingen is immers eveneens van toepassing op de vernietiging van besluiten (art. 3:53). 
bleef. Vgl. ook reeds Pres. $R b$ 's-Gravenhage 26 november 1928, NJ 1929, 1026 (de Econoom) en Rb Amsterdam 20 oktober 1936, NJ 1938, 213 (Dominium Patriae).

\section{4. Met betrekking tot de agendering}

In beginsel worden de agendapunten voor een vergadering vastgesteld door degene die wettelijk of statutair bevoegd is om een vergadering bijeen te roepen. ${ }^{25}$ Ik bepleit echter dat onder omstandigheden op grond van redelijkheid en billijkheid afgeweken mag worden van dit uitgangspunt. Zo biedt de wet (minderheids)aandeelhouders geen rechtstreeks middel om de agenda (mede) te bepalen of ter vergadering de agenda aan te vullen met één of meer nieuwe onderwerpen. De enige wettelijke mogelijkheid voor minderheidsaandeelhouders waardoor zij kunnen bewerkstelligen dat over de door hen, gewenste onderwerpen ter vergadering zal worden beslist, bestaat hierin dat zij door de president van de rechtbank gemachtigd kunnen worden om een vergadering bijeen te roepen.

Mijns inziens kan verdedigd worden dat degene die oproept onder omstandigheden gehouden is om op verzoek van minderheidsaandeelhouders een onderwerp op de agenda te plaatsen, ook indien die minderheidsaandeelhouders minder dan $10 \%$ van het geplaatste kapitaal van de vennootschap vertegenwoordigen. Men denke bijvoorbeeld aan het geval dat gedurende een reeks van jaren geen dividend is uitgekeerd, ondanks de gunstige financiële positie waarin de vennootschap verkeert, terwijl de meerderheidsaandeelhouder/bestuurder wel tantième ontving. ${ }^{26}$ In $z^{\prime}$ 'n situatie is naar mijn mening een verzoek om een voorstel tot winstbestemming op de agenda te zetten gerechtvaardigd. Maar ook kan men in dit kader denken aan publieke vennootschappen met een groot verspreid aandelenkapitaal, waar het verzamelen van een $10 \%$-pakket uiterst moeizaam is.

In het Duitse AG - recht kunnen aandeelhouders die $5 \%$ van het maatschappelijk kapitaal, of minimaal 1 miljoen DM vertegenwoordigen de inhoud van de agenda op een vergadering mede bepalen $(\S 122$ (2) en

25. Evenzo voor het Franse recht, zie art. 160 (1) L. 1966. Zie tevens Lamy sociétés commerciales 1996, nr. 3444, Mercadal-Janin, nr. 1742 en Guyon, Droit des affaires, nr. 293.

26. De toetsing van reserveringsbesluiten aan de redelijkheid en billijkheid wordt besproken in hoofdstuk 6. 
(3) jo $\$ 124$ (1) AktG. $^{27}$ Ook in het Franse recht wordt aan aandeelhouders van een SA die tenminste $5 \%$ van het aandelenkapitaal vertegenwoordigen reeds de mogelijkheid geboden om de door hen geformuleerde voorstellen te laten opnemen in de agenda van de vergadering. ${ }^{28}$

Dit is ook in overeenstemming met het ontwerp vijfde EG-Richtlijn. Indien deze van kracht wordt zullen houders van tenminste $5 \%$ van het geplaatste aandelenkapitaal de bevoegdheid krijgen om een vergadering bijeen te roepen en bovendien de bevoegdheid om de agenda van een reeds opgeroepen ava met één of meer nieuwe onderwerpen aan te vullen (art. 23 en 25 jo. 16 lid 1).

In een SARL kan een associé slechts via tussenkomst van een door de rechter aangewezen 'mandataire' de agenda vaststellen (art. 57 (4) L. 1966). ${ }^{29}$ Zie hiervoor reeds $\S 3.2$. Opvallend is, dat indien in het Franse recht de bijeenroeping van een vergadering van een SA geschiedt via een door de rechter aangewezen 'mandataire' of op verzoek van een of meer aandeelhouders met een aandelenpakket van tenminste $10 \%$, de bevoegdheid tot vaststelling van de agenda ligt bij de rechter (D.122 al. 3). ${ }^{30}$ Op deze wijze kan worden bereikt dat een aandeelhoudersvergadering bijeen wordt geroepen teneinde bijvoorbeeld over kapitaalverhoging of de uitkering van dividend te besluiten.

In het Engelse recht staat een minderheidsaandeelhouder die de agenda mede wil bepalen er minder gelukkig voor. Weliswaar hebben minderheidsaandeelhouders, die tenminste $5 \%$ van het aandelenkapitaal vertegenwoordigen dit recht, maar een vennootschap zal een voorstel alleen honoreren indien aan een aantal voorwaarden is voldaan (s. 377). Zo komen de kosten die zijn verbonden aan het versturen van het voorstel

27. In tegenstelling tot de eis die de wet stelt ten aanzien van het louter verzoeken tot bijeenroeping van een vergadering (een zgn. einfache qualifizierte Minderheit $5 \%$ van het Grundkapital/maatschappelijk kapitaal, zie $\$ 122$ (1) AktG), wordt hier als eis een zgn. einfache Minderheit gesteld (5\% van het Grundkapital/maatschappelijk kapitaal of 1 miljoen DM). Hier is echt sprake van bescherming van de minderheidsaandeelhouders, aldus Henn, Handbuch des Aktienrechts, p. 374, nrs. 793/794. In grote publieke vennootschappen zal sneller aan deze eis kunnen worden voldaan.

28. Zie D. 128 en tevens Ripert-Roblot, nr, 1215.

29. De bevoegde rechter in casu is de président van het Tribunal de Commerce.

30. Zie A. Guengant e.a., Le róle des juges dans la vie des sociétés 1993, p. 105. Dit moet worden beschouwd als een uitzondering op de regel dat degene die de vergadering bijeenroept de agenda vaststelt. Zie recentelijk A. Viandier, Chronique droit des sociétés, JCP éd. G. 1999, p. 1568. 
voor rekening van de minderheidsaandeelhouders, tenzij de vennootschap anders bepaalt (s. 376 (1) en (2). Dit vormt in de praktijk een belangrijke barrière voor minderheidsaandeelhouders om gebruik te maken van dit recht. ${ }^{31}$

\section{§5. Tegenvoorstellen en overleg}

Behalve het verzoek om bepaalde onderwerpen op de agenda te plaatsen, is het van belang voor aandeelhouders dat zij ten aanzien van sommige belangrijke onderwerpen de gelegenheid krijgen om tegenvoorstellen te doen of de agendapunten aan te vullen. In het Nederlandse recht bestaat deze mogelijkheid alleen als dit door redelijkheid en billijkheid wordt gevergd.

Zie $R b$. Leeuwarden 3 februari 1988, KG 1988, 200 (Lampe/Tonnema). Alle aandeelhouders, met uitzondering van Lampe, willen de blokkeringsregeling van Tonnema BV (van oorsprong een familie BV), die de vorm heeft van een aanbiedingsregeling wijzigen in een goedkeuringsregeling zodat de aandelen overgenomen kunnen worden door Van Nelle BV. Aangezien Lampe een groot belang heeft bij het gebruik van de aanbiedingsregeling, kunnen er redenen aanwezig zijn, aldus de President, dat Lampe in de gelegenheid moet worden gesteld om zijn voorstellen met betrekking tot de overname van de aandelen van de overige aandeelhouders aan dezen voor te leggen, voordat de statutenwijziging aan de orde wordt gesteld.

In het Duitse recht biedt een wettelijke regeling daarentegen die mogelijkheid aan iedere aandeelhouder in een AG ( $\$ 126$ (1) AktG). Als eis geldt wel dat het tegenvoorstel betrekking moet hebben op een specifiek agendapunt en dat dit inhoudelijk afwijkt van het bestuursvoorstel. Ook moet de aandeelhouder zelf of middels een gevolmachtigde deelnemen aan de vergadering. ${ }^{32}$ Dit lijkt mij ook relevant voor de 'redelijkheidstoets'. De Franse wetgeving kent aan aandeelhouders van een SARL geen recht toe om voorstellen te doen voorafgaande aan de vergadering, maar dit wordt gecompenseerd doordat aandeelhouders tijdens de vergadering een

31. Vgl. Mayson, French \& Ryan on Company Law, p. $373 / 374$ en Gower's Principles of Modern Company Law, London 1997. p. 575.

32. $\mathrm{Vgl}$. Henn, Handbuch des Aktienrechts, p. 396. 
voorliggend voorstel op een of meer punten kunnen wijzigen. ${ }^{33}$ In het Engelse recht zal vanwege het kostenaspect (zie $\$ 4$ ) enige effectieve oppositie tegen het bestuur slechts gevoerd kunnen worden door institutionele beleggers. ${ }^{34}$

Voorwaarde voor het doen van een tegenvoorstel is mijns inziens dat aandeelhouders tijdig en juist geinformeerd worden over de te behandelen onderwerpen. Alleen dan kan een aandeelhouder zich beraden over het eventueel indienen van tegenvoorstellen en kan hij zijn aandeelhoudersrechten ook zinvol en effectief uitoefenen. In het Nederlandse recht echter, is met name in een NV de verplichting tot informatieverschaffing aan aandeelhouders, in de fase vórafgaande aan de algemene vergadering beperkt.

Voorts regelt de wet slechts dat het bestuur desgevraagd informatie verschaft aan de algemene vergadering van aandeelhouders als zodanig art. 2:107/217 BW. ${ }^{35}$ Inlichtingen kunnen worden geweigerd als een zwaarwichtig belang van de vennootschap zich daartegen verzet. De heersende opvatting is dat een individuele aandeelhouder voor informatie in principe aangewezen is op de algemene vergadering. ${ }^{36} \mathrm{Ik}$ zou menen dat ook buiten de vergadering het bestuur op grond van art. 2:8 BW gehouden is om aan een individuele aandeelhouder informatie te verschaffen, indien deze dat wenst. ${ }^{37}$

33. In een SA hebben slechts aandeelhouders die $5 \%$ van het kapitaal vertegenwoordigen dit recht. Vgl, ook A. Tunc, Minority Shareholders Protection in Private Companies, in: The European Private Company?, p. 210.

34. Zie Gower's Principles of Modem Company Law, London 1997, p. 578. Vaak zal oppositie gevoerd worden door middel van proxy solicitation. Zie hieromtrent hoofdstuk 4.

35. De informatie moet juist en volledig zijn. $\mathrm{Vgl}$. Hof 's-Hertogenbosch 15 mei 1996 JOR 1996, 70 Philips/VEB).

36. Slagter, Compendium, p. 228, Sanders-Westbroek 1998, p. 129: 'mits zij dit recht ter vergadering uitoefenen' en Handboek, nr. 203.1 nemen aan dat een aandeelhouder wel inlichtingen kan vragen, maar uitsluitend ter algemene vergadering.

37. Evenzo B.H.A. van Leeuwen, Beginselen van behoorlijk ondernemingsbestuur, diss. 1990 , p. 94 e.v., Van Schilfgaarde, Van de NV en BV, nr. 64 en L. Timmerman, Het aan ondernemingen toekomende recht op geheimhouding in: Tot Vermaak van Slagter 1988, met name p. 309. 
Anders is dit in het Franse en Duitse recht. Hier wordt het recht van een aandeelhouder op informatie gewaarborgd door wettelijke regels. ${ }^{38}$ In het Franse vennootschapsrecht zijn in dit kader een viertal categorieën te onderscheiden. ${ }^{39}$ In de eerste plaats is het bestuur wettelijk verplicht om de agenda vergezeld te doen gaan van uitgebreide informatie over de voorstellen, zodat de aandeelhouder in staat is zich een helder beeld te vormen van hetgeen ter vergadering zal worden besproken (art. $162 \mathrm{~L}$. 1966/art. 133 Décr. 1967). Dit is met name van groot belang indien een aandeelhouder 'uitgenodigd' wordt om een volmacht te verlenen. In de tweede plaats heeft de aandeelhouder het recht om allerlei informatie van de vennootschap te verlangen, zoals inlichtingen over bestuurskandidaten (vgl. art. 138 jo.135 Décr. 1967). In de derde plaats hebben aandeelhouders het recht om informatie na te slaan die ten kantore van de vennootschap ligt, zoals de aandeelhouderslijst en de lijst van de best gesalarieerde personen. Ten slotte heeft iedere aandeelhouder het recht om schriftelijk vragen te stellen aan het bestuur (art. 56 (3)/162 L. 1966). ${ }^{40}$

In Duitsland regelen de $\$ \S 125-127$ AktG mededelingsplichten van het bestuur aan aandeelhouders, aandeelhoudersverenigingen, kredietinstellingen en commissarissen. Niet alleen de voorstellen van het bestuur, maar ook tegenvoorstellen van aandeelhouders moeten tijdig worden medegedeeld ( $\$ 126$ abs. 2 AktG). ${ }^{4 I}$ Als voorwaarde voor het 'doen' van een tegenvoorstel geldt dat de aandeelhouder zelf of middels een gevolmachtigde de vergadering bijwoont. ${ }^{42}$ Daarenboven heeft een aandeelhouder,

38. Vgl. voor het Engelse recht sect. $376 \mathrm{CA}$ 1985, zie ook S. Goulding. Principles of company law, Londen 1996, p. 95. Zie voor het Duitse recht bijv. F. Kübler, Gesellschaftsrecht, Heidelberg 1994, p. 190.

39. Vgl. ook Guyon, Droit des affaires, nr. 294 e.v.

40. Cozian-Viandier-Deboissy maken een indeling in 'permanente' en 'tijdelijke' informatie. Onder de eerste categorie valt de informatie die ten kantore van de vennootschap ten behoeve van de aandeelhouders ter inzage ligt. Onder de tweede worden onder meer begrepen de tekst en motieven van de voorstellen ten behoeve van de vergadering (vgl. art. 168 L. 1966). Zie Cozian-Viandier-Deboissy, nrs. 822/823.

41. Bij de aankondiging van de agenda van de vergadering moeten de te behandelen onderwerpen zodanig nauwkeurig worden weergegeven zodat de ontvanger van de agenda zich een goed beeld kan vormen van hetgeen aan de orde zal komen op de vergadering. Vgl. H. Meilicke, Das Auskunftsrecht des Aktionârs in der Hauptversammlung, DStR 1992, p. 72. Zie ook LG München, 19-1-1993, GmbHR 1993, p. 664.

42. Vgl. bijv. ook Henn, Handbuch des Aktienrechts, nr, 833. 
met name in beursgenoteerde vennootschappen, een verstrekkend 'Auskunftsrecht' ( $\$ 118$ jo. 131 AktG en $\S 51 \mathrm{a} / \mathrm{b}$ GmbHG).

Via een gerechtelijke procedure wordt beslist of het bestuur informatie moet verschaffen aan andeelhouders ( $\$ 132 \mathrm{AktG} / \$ 51 \mathrm{~b} \mathrm{GmbHG)}$. Die informatie moet in het algemeen worden verschaft, voorzover 'sie zur sachgemäßen Beurteilung des Gegenstands der Tagesordnung efforderlich ist'. Maar ook buiten vergadering kan een recht op informatie bestaan. Op grond van het gelijkheidsbeginsel dient het bestuur de informatie die buiten vergadering is verschaft aan een aandeelhouder ook te verschaffen aan andere aandeelhouders.

Behalve dat een individuele aandeelhouder belang kan hebben bij bepaalde inlichtingen, kunnen er ook omstandigheden zijn waarin een aandeelhouder belang kan hebben bij overleg, voordat bepaalde agendapunten worden behandeld en besluiten ter vergadering worden genomen. Evenals een 'informatierecht' van een aandeelhouder zou mijns inziens ook een overlegrecht c.q. verplichting gebaseerd kunnen worden op art. 2:8 BW. ${ }^{43}$

Blijkens recente jurisprudentie van de Ondernemingskamer van het Gerechtshof Amsterdam bestaat een dergelijke overlegverplichting in ieder geval voor degene die ter beurze een pakket aandelen van enige betekenis verwerft. De achterliggende gedachte is dat een verandering van zeggenschap over de doelvennootschap door de verwerver niet mag geschieden zonder rekening te houden met de belangen van de vennootschap en de belangen van daarbij betrokken personen.

Zie met name de eerste uitspraak inzake LVMH - Gucci, 3 maart 1999, JOR 1999, 87, NJ 1999, 350 (Gucci I), bevestigd door de einduitspraak van de OK 27 mei 1999, JOR 1999, 121. NJ 1999, 487 (Gucci IV) en de uitspraak van de OK 11 maart 1999, JOR 1999, 89 inzake Breevast. Zo overweegt de $\mathrm{OK}$ in beide zaken dat: 'gezien het bepaalde in art. 2:8 BW te gelden heeft dat de verwerver van een pakket aandelen [..] als (behoorlijk) aandeelhouder in verband met en bij gelegenheid van de verkrijging van die aandelen opening van zaken geeft met de vennootschap wier aandelen hij verkrijgt redelijk overleg pleegt en in zijn handelen niet alleen zijn eigen belangen maar ook de belangen van de vennootschap in al haar facetten en de belangen van de bij de vennootschap betrokken personen betrekt'. ${ }^{4}$

43. Vgl. ook B.H.A. van Leeuwen, diss. 1990 op p. 115. Zij ziet zo'n overlegverplichting als een beginsel van behoorlijk ondernemingsbestuur, zie met name p. 113.

44. $\mathrm{V}_{\mathrm{gl}}$. hieromtrent S.M. Bartman, De rol van de ondernemingskamer bij overnamegeschillen, Ondernemingsrecht 1999 , p. 139 en de noot van M. Brink bij Breevast, Gerechtshof Amsterdam (OK) 11 maart 1999, JOR 1999. 89, p. 575/576. 
Brink's meent dat dit standpunt van de OK nog uitwerking behoeft. Zo vraagt hij zich onder meer af wanneer een ter beurze verworven pakket van voldoende betekenis is om de verplichting tot overleg aan te nemen. Mijns inziens is daarvan sprake indien de verwerver een zodanig pakket verkrijgt waardoor de mogelijkheid bestaat om de besluitvorming van de doelvennootschap te blokkeren dan wel te bevorderen. Uiteraard speelt hierbij de mate waarin het aandelenkapitaal is verspreid een rol. De omvang van verplichtingen van een aandeelhouder dient te corresponderen met de mate van invloed die hij kan uitoefenen op de besluitvorming van de (doel)vennootschap. Zie ook mijn betoog in hoofdstuk $4, \& 1.2$ en $\S 1.6$.

Een overlegverplichting kan echter ook bestaan voor het bestuur van de doelwitvennootschap jegens de verwerver van een pakket aandelen.

Zo stelt de OK in Gucci II (22 maan 1999, JOR 1999, 88) voorop dat Gucci gebonden is aan de eisen van redelijkheid en billijkheid als bedoeld in art. 2:8 BW. 'Aan die eisen heeft Gucci zich in zoverre niet gehouden dat zij - anders dan van haar moest worden verwacht op basis van de eerder genoemde beschikking (3 maart 1999, JOR 1999, 87) - de aangevangen althans afgesproken onderhandelingen met LVMH niet behoorlijk heeft gevoerd onderscheidenlijk is begonnen', aldus de OK.

\section{$\S 6$. Behandeling agendapunten/verdaging van de vergadering}

In beginsel zal na de oproeping een vergadering plaatsvinden op een bepaald tijdstip en op een bepaalde plaats, alwaar beraadslaagd zal worden over de agendapunten die naar voren zijn gebracht door het bestuur en, eventueel, (minderheids)aandeelhouders. Ik acht het, afhankelijk van de omstandigheden van het geval, echter mogelijk dat het behandelen van een agendapunt gedurende een aandeelhoudersvergadering in strijd is met de redelijkheid en billijkheid, zowel ten opzichte van de verschenen aandeelhouders als ten opzichte van de niet-verschenen aandeelhouders. Men denke bijvoorbeeld aan een voorstel tot ontbinding of kapitaalvermindering, wanneer daartoe geen enkele aanleiding bestaat ${ }^{46}$ en een meerderheidsaandeelhouder slechts beoogt van zijn macht gebruik (dan wel misbruik) te maken tegenover minderheidsaandeelhouders.

Minderheidsaandeelhouders, wier belangen nauw betrokken zijn bij zo'n voorstel, zouden in een kort geding procedure kunnen betogen dat een te nemen besluit tot ontbinding of kapitaalvermindering in de gegeven

45. M. Brink in zijn noot bij JOR 1999, 89.

46. Zie J. Ronse en K. Geens, Misbruik van minderheidspositie uit de bundel: Van Vennootschappelijk Belang, Zwolle 1988, p. 245. 
omstandigheden wegens strijd met de redelijkheid en billijkheid aan vernietiging bloot zal staan en bij wege van voorlopige voorziening kunnen vorderen dat de meerderheidsaandeelhouder een verbod krijgt opgelegd om zijn stem uit te brengen ten gunste van ontbinding c.q. kapitaalvermindering. Tevens kan worden gevorderd de vennootschap te bevelen het agendapunt niet te behandelen. Denkbaar is echter ook dat de redelijkheid en billijkheid onder omstandigheden kan leiden tot uitstel van de behandeling van een bepaald agendapunt dan wel verdaging van de vergadering.

Wat dit laatste betreft is een punt van discussie allereerst wie bevoegd is tot verdaging te besluiten. In het Engelse, Duitse en Franse recht wordt aangenomen dat in ieder geval de algemene vergadering zelf de vergadering kan verdagen. ${ }^{47}$ Ook wordt de opvatting verdedigd dat degene die de vergadering bijeenroept de bevoegdheid toekomt om de vergadering te verdagen. In Frankrijk heeft ook de rechter onder omstandigheden de bevoegdheid om, voordat de vergadering aanvangt, te besluiten tot verdaging daarvan. Dit geschiedt op verzoek van een of meer aandeelhouders in een kort geding procedure (référé). ${ }^{48}$ In het Franse recht kunnen minderheidsaandeelhouders derhalve een verdaging bewerkstelligen. ${ }^{49}$ Ik zou menen dat dit ook naar Nederlands recht geldt.

Voorts rijst de vraag wanneer er aanleiding bestaat om tot uitstel van behandeling c.q. verdaging van de vergadering over te gaan. Wanneer is het redelijk en billijk om een vergadering te verdagen? Een voorbeeld biedt het in $\S 5$ besproken geval dat de behandeling van een voorstel met betrekking tot een bepaald onderwerp wordt uitgesteld, omdat een minderheidsaandeelhouder eerst de gelegenheid moet krijgen tegenvoorstellen aan de overige aandeelhouders voor te leggen. Dat onbehoorlijke oproeping aanleiding kan geven tot een verdaging van de gehele vergadering of

47. $\mathrm{Vgl}$. voor het Franse recht bijv. Mercadal-Jeanin, nr. 1744. In het Engelse recht komt de bevoegdheid tot verdaging met name toe aan de voorzitter van de vergadering, vgl. Farrar's Company Law, p. 319. Dit is ook het geval in het Nederlandse en Duitse recht. Vgl. W.J.M. Noldus, Verdaging van een aandeelhoudersvergadering. TVVS 1982, p. 81 c.v. en Henn, Handbuch des Aktienrechts, p. 395/396.

48. Een eenvoudige verzoekschriftprocedure is niet voldoende, zie een uitspraak van het Tribunal Commercial Paris op 5 juni 1989, Revue Droit Bancaire 1989, p. 213.

49. $\mathrm{Vgl}$, ook A. Guengant e.a., Le rôle des juges dans la vie des sociétés, Paris 1993, p. $45 / 46$. 
uitstel van behandeling van bepaalde agendapunten, betoogde ik reeds in \&3.3.

Kan ook in het geval dat alle personen wel op correcte wijze voor de vergadering zijn opgeroepen, de vergadering worden verdaagd? In het Franse recht luidt het antwoord bevestigend, mits sprake is van feiten en omstandigheden die een gegronde reden opleveren voor verdaging. In de jurisprudentie wordt daarvoor als criterium le bon fonctionnement de la société' gehanteerd. ${ }^{50}$ Dit wordt geschaad indien er bijvoorbeeld onvoldoende informatie aan aandeelhouders is verschaft. ${ }^{51}$ De rechter kan overigens in deze gevallen (achteraf) ook besluiten de vergadering ongeldig te verklaren (art. 173 (2) L. 1966).

In Cour de Cassation, 21 maart 1974, Rev.Soc. 1974, 471 e.v., werd beslist dat een rechter zich niet mag bemoeien met cen vergadering, indien deze ' $n$ 'est reproché ni la violation des règles relatives à la réunion de l'assemblee, ni celle des droits d'information des actionnaires, ni de leur représentation de la société est normalement assuré par ses organes régulièrement constitués et habilités'.

Ook in het Engelse recht geldt dat er bijzondere omstandigheden aanwezig moeten zijn om een vergadering te verdagen.

$\mathrm{Vgl}$, Byng v, London Life Association Ltd [1989] 1 All ER 560.52 Een buitengewone vergadering van London Life Association Lid zou plaatsvinden om $12.00 \mathrm{u}$ 's-middags in een bioscoop. Echter, aangezien geheel onverwacht zo'n 800 aandeelhouders naar deze vergadering komen, biedt de bioscoop te weinig ruimte. Nog geen uur later besluit de voorzitter de vergadering te verdagen naar een later tijdstip (14.30u) op een andere lokatie (een café op ruim 1 kilometer afstand). Op dat tijdstip konden slechts 600 van de 800 aandeelhouders de vergadering bijwonen. Byng en andere aandeelhouders, die niet in staat waren op die korte termijn gevolmachtigden in te schakelen, beroepen zich op ongeldigheid van de ter vergadering genomen besluiten. De Court of Appeal oordeelde dat de voorzitter "had failed in his duty to take into account all relevant considerations, such as the fact that members who were unable to attend the afternoon meeting could not arrange proxies in the time available, with the consequence that the adjourned meeting would not be representative'. BrowneWilkinson VC overweegt: 'in my judgment there must be very special circumstances to justify a decision to adjourn the meeting to a time and a place where, to the knowledge of the chairman, it could not be attended by a number of the members who had taken the trouble to attend the original meeting and could not even lodge a proxy vote'.

50. Cozian-Viandier-Deboissy, $\mathrm{nr} .850$.

51. Vgl. Rev.trim.dr.com. 1970, p. 150.

52. Ontleend aan Sealy, Cases and materials, nr.86. 


\section{§7. Besluitvorming}

In het navolgende zal de fase waarin het besluit wordt gevormd, worden bezien in het licht van de redelijkheid en billijkheid. Aandeelhouders kunnen in deze fase door middel van deelname aan de discussie trachten de gedachtenvorming van andere aandeelhouders te beïnvloeden. Bij het bezien van deze fase treedt een aantal aspecten naar voren waarbij de redelijkheid en billijkheid een functie kan vervullen.

Allereerst verdient aandacht de vraag naar de deelname van een aandeelhouder aan de beraadslaging en besluitvorming van de ava. Heeft een aandeelhouder wel altijd een recht om de vergadering bij te wonen en aldaar te beraadslagen? Een andere vraag betreft de invloed die een aandeelhouder middels een gevolmachtigde kan uitoefenen op het besluitvormingsproces. Deze kwestie wordt echter niet in dit hoofdstuk besproken, maar aan de orde gesteld in hoofdstuk 4 .

Tenslotte zal aandacht worden besteed aan het stemrecht en stemgedrag van de aandeelhouder.

\section{§ 7.1 Deelname, spreekrecht, stemrecht en tegenstrijdig belang}

Het deelnemen aan de vergadering, het recht daarin het woord te voeren en te stemmen zijn belangrijke zeggenschapsrechten van een aandeelhouder. Deze rechten kunnen de aandeelhouders in beginsel niet worden ontnomen. ${ }^{53}$ Statuten kunnen echter de uitoefening van deze rechten nader regelen ${ }^{54}$ en in sommige gevallen beperken of opschorten. ${ }^{55}$

53. Zie voor het Franse recht art. 58 L. 1966, vgl. bijv. Guyon, Droit des Affaires, nr. 289. $\mathrm{Vgl}$. voor het Duitse recht bijv. Kübler, Gesellschaftsrecht, 1994, p. $189(8) 118$ AktG en $\S 45 \mathrm{GmbHG)}$.

54. Zo kunnen voorwaarden worden gesteld voor toelating tot de vergadering of stemming. zoals voorafgaande inbewaringgeving van bewijsstukken van het aandeelhouderschap of het tekenen van een presentielijst. Zie Handboek, nr. 212.

55. $\mathrm{Vgl}$. Departementale Richtlijnen par. 11. Zo kan op grond van art. 2:118/228 lid 4 BW het stemrecht van een aandeelhouder statutair worden beperkt, mits aan de voorwaarden is voldaan die in dat artikel staan vermeld. Een voorbeeld van opschorting van aandeelhoudersrechten wegens strijd met een wettelijke bepaling is het geval dat houders van aandelen aan toonder na omzetting van een NV in een BV nog niet zijn ingeschreven in een aandeelhoudersregister (vgl. art. 2:183 lid $3 \mathrm{BW}$ ). Opschorting wegens strijd met een statutaire verplichting vindt bijvoorbeeld plaats indien statuten bepaalde kwaliteitseisen stellen aan het aandeelhouderschap en een aandeelhouder niet meer aan deze 
Verdedigbaar is dat onder omstandigheden ook de redelijkheid en billijkheid paal en perk stelt aan het recht van een aandeelhouder om aan de besluitvorming deel te nemen. ${ }^{56} \mathrm{Ik}$ acht het echter niet redelijk en billijk wanneer aan deelname van een aandeelhouder statutair als eis wordt gesteld dat deze een bepaald minimum pakket aandelen moet houden." ledere aandeelhouder moet mijns inziens in beginsel worden toegelaten tot de vergadering. Als uitgangspunt voor de besluitvorming door de algemene vergadering neem ik de 'Wijsmuller-norm', op grond waarvan een besluit van een meerhoofdig orgaan tot stand dient te komen 'als vrucht van onderling overleg'. ${ }^{58}$

De vraag naar het recht op deelname van een aandeelhouder aan de beraadslaging in de ava is mijns inziens met name van belang indien een aandeelhouder een dubbelrol vervult, dat wil zeggen behalve aandeelhouder ook nog bestuurder of commissaris is. ${ }^{59}$ Afhankelijk van de aard van het onderwerp dat in de ava aan de orde is, kan immers door het optreden in twee kwaliteiten sprake zijn van een tegenstrijdig belang.

gestelde eisen voldoet (vgl. Departementale Richtlijnen par. 18). Zie ook D.F.M.M. Zaman, Verdeling, beperking en opschorting van aan aandelen verbonden rechten en besluitvorming door de algemene vergadering. TVVS $1982 \mathrm{nr} .82 / 12$, p. 301/302.

56. Ernst makt in dit kader onderscheid tussen twee systemen van regelingen: niet-flexibele beperkingen, zoals het wettelijke stemverbod, en flexibele beperkingen, zoals misbruik van stemrecht. Ernst pleit met betrekking tot Belgische vennootschappen voor een combinatie van een wettelijke regeling van een niet-flexibele stemrechtsbeperking, in de vorm van een algemeen stemverbod en een flexibele stemrechtsbeperking dat gevonden kan worden in de goede trouw, zie $\mathrm{Ph}$. Ernst, Belangenconflicten in naamloze vennootschappen, Antwerpen 1997, p. 845/846.

57. De Franse wet betreffende een SA staat dit daarentegen wel toe, zij het de eis van een minimumpakket niet hoger mag zijn dan tien aandelen, zie art. $165 \mathrm{~L}$. $1966 . \mathrm{De}$ gedachte achter de toelaatbaarheid van zo'n bepaling is dat aandeelhouders met kieinere pakketten aandelen kunnen bundelen teneinde het vereiste pakket te krijgen, waarbij vervolgens één van hen wordt gevolmachtigd teneinde deel te nemen aan de vergadering. Zie Ripert-Roblot, nr. 1203.

58. Zie HR 15 juli 1968, NJ 1969, 101 (Wijsmuller-arrest). In dezelfde zin F.J.P. van den Ingh. Vergaderrechten bij tegenstrijdig belang. WPNR 1998, p. 269, Dijk-Van der Ploeg, Van vereniging en stichting, coöperatie en onderlinge waarborgmaatschappij. Deventer 1997, p. 139 en Pitlo-Lôwensteyn, p. 83. Anders: W.J. Slagter, Compendium. p. 61 en Besluitvormingsprocessen, in: Miscellanea, Jurisconsulto vero Dedicta. Deventer 1997, p. 384-386.

59. Deze vraag is, zoals Van den Ingh terecht constateert, nog niet uitgekristalliseerd. Zie F.J.P. van den Ingh. Vergaderrechten bij tegenstrijdig belang. WPNR 1998, p. 269. 
De Nederlandse wet (art. 2:12 BW) biedt slechts in enkele gevallen van tegenstrijdig belang de mogelijkheid om een aandeelhouder in de uitoefening van zijn rechten te beperken en dan nog alleen maar met betrekking tot de mogelijkheid om het stemrecht aan een aandeelhouder te ontzeggen. ${ }^{\infty}$ Deze gevallen hebben slechts betrekking op het aan de betrokken aandeelhouder 'toekennen van rechten of kwijtschelden van verplichtingen anders dan in zijn hoedanigheid van aandeelhouder'. Bovendien kan zo'n ontzegging alleen worden gerealiseerd door een statutaire bepaling. Een meerderheidsaandeelhouder heeft echter de mogelijkheid om opneming van 20 'n bepaling in de statuten te verhinderen. Ik ben derhalve van mening dat indien de statuten geen 'tegenstrijdig belang bepaling' bevat, de redelijkheid en billijkheid met zich mee kan brengen dat het stemrecht toch aan een aandeelhouder wordt ontzegd. Men denke aan het geval dat een meerderheidsaandeelhouder zichzelf als bestuurder déchargeert. ${ }^{61}$

Art. 2:12 BW beoogt zuiverheid van de besluitvorming. Echter, de wet biedt geen voorzieningen voor de periode die vooraf gaat aan de stemming. Dit impliceert dat een aandeelhouder aan wie het stemrecht is ontzegd, deel kan nemen aan de beraadslaging en ook meetelt voor de bepaling van het quorum. Het besluitvormingsproces kan dan echter wel op ongeoorloofde wijze worden beïnvloed. De redelijkheid en billijkheid kan naar mijn mening met zich mee brengen dat zo'n aandeelhouder niet deelneemt aan de beraadslaging, indien deze betrekking heeft op een onderwerp, waarbij het tegenstrijdige belang bestaat. Echter, niet in alle gevallen is dit afdoende. Om het risico van beïnvloeding te vermijden, meen ik tevens dat de redelijkheid en billijkheid in sommige gevallen kan meebrengen dat een aandeelhouder niet deel mag nemen aan de voorbereidende besprekingen en ook niet aanwezig mag zijn op de vergadering. Het is immers van belang dat reeds in de voorfase van de besluitvorming voorkomen wordt dat belangen ongeoorloofd verstrengeld raken.

Van den Ingh is dezelfde mening toegedaan. Zijns inziens kunnen 'de dubbelaar' de vergaderrechten worden ontnomen zodra misbruik van bevoegdheid (art. 3:13 BW) van deze

60. Ook de Franse wet regelt een aantal gevallen van tegenstrijdig belang, waarbij het stemrecht van de aandeelhouder wordt uitgesloten, zie bijv. L. 103 en 145.

61. In het Duitse recht is dit wettelijk geregeld, zie $\$ 136 \mathrm{AktG}$ en $\$ 47$ (3) GmbHG. Zie nader H.J. de Kluiver, 'Aansprakelijkheid en décharge. Een paar apart', WPNR 1997. p. 728 . 
rechten dreigt. ${ }^{62}$ Dit lijkt mij minder wenselijk. Ik meen, zoals ik eerder heb aangegeven in hoofdstuk $1 \$ 9.2$ dat een handelwijze op grond van het toetsingscriterium misbruik van recht minder snel onaanvaardbaar wordt geacht dan bij een toetsing aan redelijkheid en billijkheid het geval zou zijn.

In het Duitse en Franse recht is het uitgangspunt dat de betrokken aandeelhouder mag deelnemen aan de vergadering en aldaar beraadslagen over de kwestie waarbij het tegenstrijdige belang bestaat. ${ }^{63}$ Wel voorziet de wet in enkele specifieke gevallen in een stemverbod aan aandeelhouders wegens een belangenconflict. ${ }^{64}$

In het Duitse recht wordt met betrekking tot de 'Stimmverbote' een onderscheid gemaaks tussen twee categorieèn. ${ }^{\text {"S }}$ De eerste is 'Stimmverbote wegen Insichgeschäfts' en de tweede 'Stimmverbote wegen Richtens in eigen Sache'. Onder de eerste categorie valt bijvoorbeeld het stemverbod voor een aandeelhouder bij zijn benoeming als bestuurder. Onder de tweede categorie valt bijvoorbeeld een besluit inzake décharge. De regeling met betrekking tot GmbH's in $\$ 47 \mathrm{GmbHG}$ beslaat beide categorieền. $\S 136 \mathrm{AktG}$ daarentegen ziet slechts op de tweede categorie.

Wat betreft het Franse recht kan bijvoorbeeld gewezen worden op het stemverbod in verband met de bijzondere procedure in het kader van de evaluatie en de toekenning van bijzondere voordelen aan vennoten of derden bij de oprichting (art. 80 e.v. L. 1966) en het stemverbod bij de evaluatieprocedure voor een quasi-inbreng (art. 157 L. 1966). ${ }^{6}$

In het Engelse recht wordt van oudsher aangenomen dat een aandeelhouder aan de beraadslaging en stemming mag deelnemen, ook al betreft het een aangelegenheid waarin hij, bijvoorbeeld als bestuurder, persoonlijk

62. Zie F.J.P. van den Ingh, Vergaderrechten bij tegenstrijdig belang, WPNR 1998, p. 270.

63. Vgl. voor het Duitse recht W. Zöllner, Die Schranken mitgliedschaftlicher Stimmrechtsmacht bei den privatrechtlichen Personenverbänden, München/Berlijn, 1963, p. 187 en voor het Franse recht bijvoorbeeld Hemard, Terre en Mabilat, Sociétes commerciales, 1972 nr. 750 en $\mathrm{Ph}$. Merle, Droit Commercial, Sociétés commerciales. 1992 nrs. 218 en 311. Anders: D. Schmidt, Les droits de la minorité dans la société anonyme, Parijs 1970, p. 105/106.

64. Zie over deze problematiek in het buitenlandse recht ook uitgebreid $\mathrm{Ph}$. Ernst, belangenconflicten in naamloze vennootschappen, Antwerpen 1997, m.n. p. 769-829.

65. Zie Schmidt, Gesellschaftsrecht, p. 501, Wiedemann, Gesellschaftsrecht I, p. 422 en Lutter-Hommelhoff, $\$ 47$ Rdnr 13.

66. Guyon. Droit des affaires, nr. 307. Ripert-Roblot, nr. 1218 en Hemard, Terre en Mabilat, Sociétés commerciales, Parijs 1972, p. 652. 
belang heeft. ${ }^{67}$ Dit is anders voorzover het een beursgenoteerde vennoctschap betreft. ${ }^{68}$

Zoals aangegeven verdedig ik een bredere benadering waarin de redelijkheid en billijkheid alle aspecten van het 'deelnamerecht' reguleren. Zo is het de taak van de voorzitter van de vergadering om ervoor te zorgen dat de vergadering ordelijk verloopt. In de praktijk zal dit een regulering van het spreekrecht kunnen betekenen. Te denken valt in dit kader in ieder geval aan een beperking van de spreektijd van iedere aandeelhouder. ${ }^{69}$

Het spreekrecht is, in tegenstelling tot het stemrecht van een aandeelhouder, niet gerelateerd aan het aandelenbezit. ${ }^{70}$ Een minderheidsaandeehouder kan dus in principe evenveel invloed op de beraadslaging uitcefenen als een meerderheidsaandeelhouder. Deze laatste kan echter docr middel van het inschakelen van meerdere gevolmachtigden, proberen de beraadslaging in de door hem gewenste richting te beïnvloeden. In navilging van het Franse en Duitse recht, meen ik echter dat er op grond van redelijkheid en billijkheid beperkingen kunnen worden gesteld aan het aantal gevolmachtigden dat namens een aandeelhouder het woord kan voeren (zie hieromtrent hoofdstuk 4).

Voorts zou ik willen verdedigen dat een aandeelhouder slechts spreekrecht toekomt voorzover dit betrekking heeft op de geagendeerde onderwerpen. Daarbij meen ik, anders dan Van Solinge, ${ }^{71}$ dat niet als voorwaarde moet worden gesteld dat een aandeelhouder iets nieuws aan het

67. Zie G.K. Morse, Conflicts of interests in English company law, in: De dubbeirol in het vennootschapsrecht, Deventer 1993, p. 47 en P.G. Xuereb, The rights of shareholders, Oxford 1989, p. 91/92.

68. Een Engeise beursgenoteerde vennootschap heeft zich te richten naar 'The Listing Rules of the London Stock Exchange, die een stemverbod kunnen meebrengen voor een aandeelhouder. Zie uitgebreid hieromtrent $\mathrm{Ph}$. Ernst, Belangenconflicten in naamloze vennootschappen, Antwerpen 1997, p. 777-780.

69. In de Duitse literatuur wordt regelmatig aangenomen dat een beperking van de spreektijd tot tien minuten toelaatbaar is. Zie S. Siepelt, Das Rederecht des Aktionårs und dessen Beschrânkung, Die AG 1995, p. 257.

70. Zie eveneens A.G. van Solinge, Vergaderorde in de bundel: Problemen rondom de algemene vergadering. Deventer 1994 , p. $48 . \mathrm{Vgl}$. voor het Duitse recht, S. Siepelt, Das Rederecht in der Hauptversammlung, diss. Kōln 1992, p. 16/17 en J. Lehmann, Mißbrauch des Auskunfts-, Frage- und Rederechts, p. 54.

71. A.G. van Solinge, Vergaderorde, in de bundel Problemen rondom de algemene vergadering, Deventer 1994, p. 46. 
reeds gezegde moet toevoegen. Het komt er immers op aan dat elke aandeelhouder in de gelegenheid moet worden gesteld om actief te debatteren. Wanneer echter, het optreden van zeer veel aandeelhouders berust op een onderlinge afspraak om dezelfde standpunten naar voren te brengen, kan het naar mijn mening naar maatstaven van redelijkheid en billijkheid aanvaardbaar zijn dat de voorzitter een aantal aandeelhouders het woord ontneemt. Men denke hier bijvoorbeeld aan vergaderingen waarin actiegroepen, middels volmachten, hun (vaak politieke) standpunt naar voren trachten te brengen.

\section{§ 7.2 Stemrecht nader bezien}

De jurisprudentie leert ons dat het stemrecht een eigen aan de aandeelhouder toekomend recht is en dat deze in beginsel vrij is om te bepalen op welke wijze, en door wie, hij zijn stemrecht uitoefent. ${ }^{2}$ Dat neemt niet weg dat een aandeelhouder bij de uitoefening van zijn stemrecht onderworpen is aan de norm van redelijkheid en billijkheid, hetgeen impliceert dat een aandeelhouder bij de uitoefening van zijn stemrecht rekening moet houden met de belangen van de overige aandeelhouders en de belangen van de vennootschap. ${ }^{73}$

Een duidelijk voorbeeld biedt de uitspraak van Pres. Rb. Assen 17 december 1993, KG 1994, 90 (Cemex-Zeldenrust). Zeldenrust Beheer BV houdt bijna driekwart van de aandelen in Betonindustrie en Handelsmaatschappij Emmen BV (BHE). De overige aandelen worden gehouden door Cemex BV c.s. Aangezien BHE vanaf 1991 verlies lijdt, stelt Zeldenrust zich hoofdelijk aansprakelijk voor de bankschuld van BHE en verstrekt tevens een achtergestelde lening van 1 miljoen. Als in 1993 blijkt dat de financiële positie van BHE nog steeds niet

72. Men vergelijke hier HR 30 juni 1944, 465 inzake NV Wennex; HR 13 november 1959, NJ 1960, 472 inzake Distilleerderij Melchers en het Aurora-arrest, HR 19 februari 1960. NJ 1960, 473. Vgl. ook M. van Olffen, Ondernemer en ondernemingsvermogen, diss. 1989, p. 274.

73. Vgl. Van Schilfgaarde, Van de NV en BV, nr. 67 'een individuele aandeelhouder zal zijn eigen recht slechts mogen gebruiken onder de afweging van alle bij de vennootschap betrokken belangen, zij het dat zijn eigen belang bij deze afweging een gewichtige rol mag spelen'. In dezelfde zin onder meer ook L. Timmerman, TVVS 1975, p. 246/247 en Slagter, Compendium, die op zijn beurt weer verwijst naar J.L.P. Cahen, De invloed van de belangenverbreding op het handelen van de aandeelhouder uit: Honderd jaar rechtsleven, 1971, p. 71 e.v. De belangenverbreding die in de loop van de tijd heeft plaatsgevonden is ten koste gegaan van de centrale plaats die het aandeelhoudersbelang innam. 
verbeterd is, stelt Zeldenrust aan Cemex voor de vennootschap te ontbinden. Cemex c.s. verzetten zich tegen dit voorstel en willen op hun beurt het aandelenbezit van Zeldenrust overnemen tegen een bij bindend advies vast te stellen prijs. Ten behoeve van de continuiteit van de onderneming van BHE stellen zij voor dat Zeldenrust een overbruggingskrediet verstrekt. Zeldenrust gaat hier niet op in en roept vervolgens een ava bijeen met als agendapunt ontbinding van de vennootschap. Cemex vordert daarop in kort geding een stemverbod voor Zeldenrust.

De president stelt voorop dat 'een aandeelhouder in beginsel het hem toekomende stemrecht uit mag oefenen in zijn eigen belang'. Dit betekent volgens de president echter niet 'dat het hem onder alle omstandigheden vrij staat zich uitsluitend te laten leiden door dat eigen belang. Met name mag de aandeelhouder zich niet uitsluitend door eigen belangen laten leiden ten detrimente van de vennootschap als geheel'. De president overweegt vervolgens dat het plan tot ontbinding van BHE met name berust op fiscale overwegingen. 'Weliswaar heeft de gedaagde aangevoerd dat het de bedoeling is dat de onderneming wordt voortgezet, maar hierover bestaat geen enkele zekerheid; in het algemeen leidt ontbinding van een vennootschap tot verstoring van de continuiteit van de onderneming. Nu eiseressen wel continuiteit van de onderneming beogen en hebben aangeboden om het aandelenpakket van gedaagde over te nemen [..], handelt gedaagde in strijd met de redelijkheid door dit voorstel op voorhand af te wijzen'.

Een aandeelhouder wordt in Nederland niet alleen beschouwd als een belegger die zijn eigen belangen mag nastreven, maar kan soms ook, afhankelijk van het karakter van de vennootschap, gelden als een "beleidsbepaler' van de vennootschap op grond waarvan bij de uitoefening van het stemrecht ook rekening moet worden gehouden met de belangen van de vennootschap. In dit kader is naar mijn mening, zoals reeds vermeld in $\$ 7.1$ verdedigbaar dat in geval van belangenverstrengeling de redelijkheid en billijkheid meebrengt dat een aandeelhouder zijn stemrecht niet mag uitoefenen. Deze visie op de rol van de aandeelhouder vinden we ook terug in andere continentale rechtsstelsels zoals Duitsland, ${ }^{74}$ Frankrijk en België. ${ }^{75}$ Sommige auteurs in Frankrijk en België verdedigen zelfs de opvatting dat het stemrecht van een aandeelhouder een functionele bevoegdheid is.

74. Vgl. bijvoorbeeld $\mathrm{M}$. Winter, Mitgliedschaftliche Treubindungen im GmbH-Recht, Mùnchen 1988, p. 85 e.v. en $\mathrm{H}$. Wiedemann, $\mathrm{Zu}$ den Treupflichten im Gesellschaftsrecht, in FS Heinsius 1991. Berlijn, p. 950 e.v.

75. Zie bijvoorbeeld J. Dabin. Le droit subjectif, Parijs 1952, p. 224-225, W. van Gerven, 'variaties op het thema misbruik', RW 1979-1980, nr. 2476 en P. van Ommeslaghe, Abus de droit, fraude aux droits destiers et fraude à la loi, noot onder Cass. 10 september 1971, RCJB 1976, p. 1318. 
In Frankrijk wordt deze opvatting met name verdedigd door Schmidt. ${ }^{76}$ Hij beschouwt het stemrecht als een 'droit social', bestemd om de belangen van de collectieve vergadering van aandeelhouders te behartigen (intérét collectif) en in mindere mate de eigen belangen van een aandeelhouder. Als een belangrijk bezwaar tegen deze benadering wordt echter aangevoerd dat een functionele bevoegdheid geen ruimte laat voor niet-uitoefening van het stemrecht. Anderen, zoals Ripert-Roblot leggen derhalve de nadruk op het stemrecht als een "droit individuel:, $n$

In het Engelse recht daarentegen overheerst de gedachte dat het stemrecht de aandeelhouder toebehoort ('right of property'). ${ }^{78}$ Dit impliceert dat een aandeelhouder zijn stemrecht in zijn eigen belang mag uitoefenen, zelfs indien zijn belang conflicteert met de belangen van de vennootschap.

Zie in dit verband reeds een uitspraak uit 1887 inzake North-West Transportation Co. Ld. v. Beatry," waarin de Engelse rechter overwoog: "every' shareholder has a perfect right to vote upon such question although he may have a personal interest in the subject-matter opposed to, or different from, the general or particular interests of the company'. In een andere uitspraak van meer recente datum inzake Northern Counties Securities Lid. v. Jackson and Steeple Lid f $^{\circ}$ oordeclde de rechter Walton J: 'when a shareholder is voting for or against a particular resolution he is voting as a person owing no fiduciary duty to the company and who is exercising his own right of property as he thinks fit. The fact that the result of the voting at the meeting will bind the company cannot affect the position that, in voting, he is voting simply in exercise of his own property rights [...] his act therefore in voting as he pleases cannot in any way be regarded as an act of the company'.

\section{§ 8. 'Blokkeren' van besluiten}

Zowel meerderheidsaandeelhouders als minderheidsaandeelhouders kunnen door hun gedrag de besluitvorming frustreren. Bij een meerderheidsaandeelhouder/bestuurder kan men denken aan het niet bijeenroepen van een vergadering, het niet plaatsen van een onderwerp op de agenda, het niet doen van een voorstel, het achterhouden van informatie of het 'blokkeren' van een bepaald besluit. Bij een minderheidsaandeelhouder

76. D. Schmidt. Les droits de la minorité dans la société anonyme, Sirey 1970, p. 55 e.v.

77. $\mathrm{Vgl}$. Ripert-Roblot, nr. 1606 en P. Xuereb, Voting rights: A Comparative Review. The Company Lawyer 1994, p. 20/21.

78. Zie bijv. M. Pickering. Shareholders' voting rights and company control, LQR 1965, P. 250 en 255, S. Goulding. Principles of company law. London 1996, p. 102 en Pender $v$. Lushington (1877) $6 \mathrm{Ch}$. D. 70, 75.

79. [1887] 12 App Cas 589.

80. [1974] 1 WLR 1133/[1974] 2 All ER 625. 
moetmen met name denken aan gedragingen waardoor een quorum of een gekwlificeerde meerderheid benodigd voor een besluit niet wordt gehaalc zoals het niet verschijnen ter vergadering, het zich onthouden van steming of het 'systematisch' tegenstemmen.

Z'n gedraging kan in strijd zijn met de redelijkheid en billijkheid, india de belangen van de vennootschap en de belangen van de overige aandelhouders ernstig worden geschaad bij het achterwege blijven van een epaald besluit. Hoe kan nu worden bewerkstelligd dat zo'n besluit toch ot stand komt?

\section{§ 8. Herziening stemgedrag}

Zowl in het Nederlandse als in het Duitse recht kan van een 'dwarsliggenc' aandeelhouder die zich niet redelijk en billijk gedraagt in rechte woren gevorderd dat hij zijn stemgedrag herziet. ${ }^{82}$ De omstandigheid dat en aandeelhouder stemt overeenkomstig een stemovereenkomst doet daarmijns inziens niet aan af.

Herziening van stemgedrag kan in de praktijk echter nogal wat problemen opleveren.

Een nieuwe vergadering zal moeten worden bijeengeroepen om opnieuw over het voorstel te stemmen. Zijn de veroordeelde (meerderheids)aandeelhouders bevoegd een vergadering bijeen te roepen dan zullen zij waarschijnlijk niet meewerken. De andere aandeelhouders zullen dan de President van de rechtbank moeten verzoeken hen te machtigen zodat zij zelf een vergadering kunnen bijeenroepen. Bij grote vennootschappen kan het aandeelhoudersbestand zich inmiddels hebben gewijzigd en bovendien is er sprake van een groot absenteisme op vergaderingen.

In dit verband kan worden opgemerkt dat herziening van stemgedrag niet de geschikte oplossing is in geval zich aanhoudend verschillen van inzicht

81. Overigens is ook denkbaar dat een blokkering door bijvoorbeeld de minderheid gerechtvaardigd wordt omdat de meerderheid niet wil overieggen omtrent een belangrijk onderwerp. Zie ook J. Ronse en K. Geens, Misbruik van minderheidspositie, in: Van Vennootschappelijk Belang, Kluwer Deventer 1988, p. 232.

82. Vgl. Rb. Roermond 17 mei 1973, NJ 1974, 57 en WPNR 5261 m.nt A. van Oven. In het Duitse recht wordt gesproken over 'positive Stimmpflichten', zie onder meer Karsten Schmidt, Gesellschaftsrecht, p. 506. In het Duitse recht kan een aandeelhouder in een procedure waarin hij een besluit aanvecht (Anfechtungsklage) tevens middels een $\mathrm{zgn}$. positive Beschlußfestellungsklage bewerkstelligen dat een bepaald besluit alsnog wordt genomen. Zie Karsten Schmidt, Gesellschaftsrecht, p. 357. 
voordoen tussen aandeelhouders. De wettelijke voorzieningen inzake de geschillenregeling, de uitkoopregeling en het enquêterecht moeten dan uitkomst bieden. ${ }^{83}$

Het Franse recht biedt een andere, mijns inziens betere, oplossing in het geval de meerderheid in de besluitvorming wordt belemmerd door de minderheid. In een uitspraak van de Cour de Cassation (Com) van 9-31993, Droit des Sociétés 1993, p. 10-12, (nt. Le Nabasque) inzake 'Flandin' werd beslist dat rechters een 'mandataire' mogen aanwijzen teneinde de afwezige aandeelhouders te vertegenwoordigen en namens hen te stemmen ten gunste van de besluiten die in het belang zijn van de vennootschap, maar die niet de legitieme belangen van deze minderheid aantasten.

In de SARL Alarme Service Electronique was in verband met veranderde wetgeving een kapitaalverhoging noodzakelijk tot 50.000 F. Doordat Joseph en Marcel Flandin, die resp. 51 en 50 van de 204 aandelen houden, afwezig zijn op de vergadering, kan niet besloten worden tot een kapitaalverhoging. waarvoor een gekwalificeerde meerderheid vereist is. Enige tjid later wordt nogmaals een vergadering bijeengeroepen met als doel het kapitaal te verhogen tot $500.000 \mathrm{~F}$. Ook deze keer laten deze twee aandeelhouders het afweten.

De Cour d'appel de Pau oordeelt dat sprake is van 'abus de minorité' en besluit dat zijn uitspraak de beslissing van de vergadering inzake de kapitaalverhoging kan vervangen ('que son arrêt valait adoption de la résolution tendant à l'augmentation de capital demandée...) De Cour de Cassation bevestigt dat het besluit tot kapitaalverhoging. althans het besluit dit te verhogen tot $50.000 \mathrm{~F}$, noodzakelijk is voor het overleven van de vennootschap, aangezien de sanctie voor het niet-naleven van de wettelijke bepalingen, ontbinding van de vennootschap is. Niettemin oordeelt de Cour de Cassation dat een rechter niet mag 'se substituer aux organes sociaux légalement compétents' pour ordonner, judiciairement, la résolution litigieuse'. Wel mag een rechter dit indirect, middels het aanwijzen van een 'mandataire': 'qu'il lui (de rechter, MK) était possible de désigner un mandataire aux fins de représenter les associés minoritaires défaillants à une nouvelle assemblée et de voter en leur nom dans le sens des décisions conformes à l'intérêt social mais ne portant pas atteinte à l'intérêt légitime des minoritaires'.

Ook het Engelse recht biedt soelaas in geval van blokkering van de besluitvorming. De rechtbank heeft op grond van section 371 (1) CA, 'if for any reason it is impracticable ('onuitvoerbaar') to call a meeting of a company', de bevoegdheid 'to order a meeting to be called, held and conducted in any manner the court thinks fit'. In dit kader heeft de

83. Zie hierover bijv. M.J.G.C. Raaijmakers, Geschillen in 50/50-verhoudingen in: Tol vermaak van Slagter, p. 211 e.v. 
rechbank ook de bevoegdheid om allerlei instructies te geven. Zo kan de rechbank bepalen dat de algemene vergadering wordt vertegenwoordigd door één aandeelhouder (s. 371 (2) CA). ${ }^{84}$

Men denke met name aan de situatie waarin een bepaald quorum wordt verest voor het laten plaatsvinden van een vergadering en dit niet wordt gehald, doordat de minderheid wegblijft van de vergadering.

Zie biv. Re El Sombrero LAd. [1958] Ch 900 . Hier wilde een aandeelhouder, die in het bezit was un 900 van de 1000 geplaatste aandelen, de twee bestuurders, die ieder 50 aandelen hadder, ontslaan. Het probleem in casu was echter dat als quorum voor een vergadering gold lat twee aandeelhouders aanwezig moesten zijn en de bestuurders weigerden de vergaiering. waarin hun ontslag aan de orde werd gesteld, bij te wonen. Nadat de meerderheidsandeelhouder de rechtbank had verzocht een vergadering bijeen te roepen, beval deze vervogens een vergadering, waarbij het volstond dat slechts éen aandeelhouder aanwezig is.

Ir deze zaak kwam ook de betekenis van het woord 'impracticable' aan de orde (vgl. ook $\{3.2$ ). Wynn-Parry $J$ overwoog hieromtrent: 'It is conceded that the word 'impracticable' is not synonymous with the word 'impossible'; and it appears to me that the question necesarily raised by the introduction of that word 'impracticable' is merely this: examine the crcumstances of the particular case and answer the question whether, as a practical matter, the desired meeting of the company can be conducted, there being no doubt, of course, that it can be convened and held.'

Vgl. ook de uitspraak inzake Re Opera Photographic Ltd [1989] I WLR 634. Ook hier vormde het quorumvereiste een belemmering voor het ontslag van een bestuurder. In deze zak hielden twee bestuurders $51 \%$ resp. $49 \%$ van het geplaatste kapitaal. De minderheidsaandeelhouder/bestuurder woonde de vergadering waarin zijn ontslag aan de orde zou worden gesteld niet bij, waardoor niet werd voldaan aan het quorum. Ook hier slaagde de meerderheidsaandeelhouder/bestuurder er in met succes de rechter te laten bevelen een vergadering bijeen te roepen waarin zijn aanwezigheid zou volstaan. Zie ten slotte Re British Union for the abolition of Vivisection [1995] 2 BCLC 1 (Ch D). In deze zaak werd het door een minderheid herhaaldelijk onmogelijk gemaakt om een vergadering te houden. Het leidde zelfs tot politieoptredens. De rechtbank oordeelde dat de vergadering slechts gehouden moest worden met een commissie van afgevaardigden. Het merendeel van de leden moest schriftelijk stemmen. ${ }^{\text {s }}$

84. S. 371 (2) CA luidt: 'Where such an order (in de zin van s. $371 / \mathrm{MK}$ ) is, made the court may give such ancillary or consequential directions as it thinks expedient; and these may include a direction that one member of the company present in person or by proxy be deemed to constitute a meeting'. Zie ook S. Goulding. Principles of company law. London 1996, p. 96.

85. Overigens mag een rechter op grond van section 371 niet voorbijgaan aan een aandeelhoudersovereenkomst. Zie hieromtrent Harman v. BML Group Limited [1994] 2 BCLC 674. [1994] 1 WLR 893. Court of Appeal. In deze zaak was een geschil gerezen tussen twee groepen aandeelhouders. De aandelen waren verdeeld in twee 'klassen', A en B. De A-aandeelhouders waren in de meerderheid, maar krachtens een aandeelhouders- 


\section{\$ 8.2 Heroverweging en intrekking van besluiten}

Herziening van stemgedrag komt in feite neer op een herziening of heroverweging van een besluit en kan zelfs leiden tot intrekking van een besluit. Het is derhalve niet vreemd dat de Hoge Raad intrekking van besluiten aanvaard.

Deze kwestie kwam aan de orde in HR 10 maart 1995, NJ 1995, 595 (Janssen Pers). In het kader van een financiële reorganisatie verandent de positie van Janssen. Janssen oefent hierdoor niet langer als enig bestuurder van de Stichting Administratiekantoor (AK) (op haar beurt enig aandeelhouder van de moedermaatschappij Janssen Pers Beheer BV) de uiteindelijke zeggenschap uit in de Janssen groep (bestaande uit de moeder, een $100 \%$-dochter Janssen Pers BV en een aantal werkmaatschappijen). Hij moet in het vervolg het AK-bestuur delen met nog twee andere bestuurders. Op een gegeven moment wordt hij geconfronteerd met een aandelenemissie en een ten behoeve daarvan 'op handen zijnde' statutenwijziging. die zijn positie nog verder aantast. Voordat de emissie daadwerkelijk plaats heeft gevonden treden bij vergissing de twee mede-bestuurders van het $\mathrm{AK}$ af. Janssen maakt van deze gelegenheid gebruik door met stemmen van het AK zichzelf te benoemen tot enig bestuurder van Janssen Beheer en besluit, als enig aandeelhouder van Janssen Pers BV, onder meer tot intrekking van de emissiebesluiten. De Hoge Raad overweegt hieromtrent dat 'voor een besluit van de ava tot intrekking van een eerder besluit geen andere vereisten gelden dan voor besluiten van de ava in het algemeen' en indien een besluit van de enige aandeelhouder inhoudt dat eerder genomen besluiten tot statutenwijziging en uitgifte van aandelen worden ingetrokken dan 'staat dat intrekkingsbesluit in de weg aan de geldigheid van de rechtshandelingen strekkende tot uitvoering van die ingetrokken besluiten, ook indien de beoogde verkrijgers van die aandelen en/of degenen die de vennootschap bij die rechtshandeling vertegenwoordigen, nog niet van het intrekkingsbesluit op de hoogte zijn'. Het emissiebesluit was overigens hier nog niet uitgevoerd, waardoor de HR in het midden liet welke rechtsgevolgen deze gang van zaken voor derden teweeg zou brengen.

overeenkomst waren bepaalde rechten toegekend aan de B-aandeelhouder, waaronder het recht dat er pas besluiten kunnen worden genomen indien tenminste een B-aandeelhouder aanwezig is op de vergadering. Het conflict ontstaat al een B-aandeelhouder door Aaandeelhouders beschuldigd wordt van opportunistisch gedrag. De B-aandeelhouder weigert daarop de vergaderingen bij te wonen. Aangezien de besluitvorming daardoor ernstig wordt belemmerd besluiten twee A-aandeelhouders naar de rechter te stappen met het verzoek een vergadering te bevelen op grond van section 371 . Echter zonder succes Dillon J oordeelt: 'It is not for the court to make a new shareholders' agreement and impose it on them'. 
Echter, een besluit tot intrekking zal, als ieder ander besluit, ook moeten voldoen aan de eisen van redelijkheid en billijkheid. ${ }^{86} \mathrm{Om}$ te voorkomen dat 20 'n besluit wordt gebruikt om bestuursdaden te frustreren voelt De Kluiver ${ }^{\text {st }}$ er veel voor om als voorwaarde voor heroverweging of intrekking van besluiten te stellen dat hierbij 'een redelijk belang' bestaat. Dit lijkt mij alleszins verdedigbaar. Men kan hier immers enerzijds een vergelijking maken met het verzoek tot het bijeenroepen van een algemene vergadering en anderzijds met het verzoek tot vernietiging van een besluit. Voor beide moet een redelijk belang aanwezig zijn (art. 2:111/221 en art. 2:15 lid $3 \mathrm{BW}$ ).

\section{§9. Slotbeschouwing}

Conflicten tussen meerderheids- en minderheidsaandeelhouders ontstaan doordat beiden in staat zijn, met (of juist zonder) gebruikmaking van de hen krachtens wet en statuten toekomende (zeggenschaps)rechten en bevoegdheden, het besluitvormingsproces van de ava in meer of mindere mate te beïnvloeden. De gevolgen daarvan kunnen ingrijpend zijn, met name voor minderheidsaandeelhouders. Men denke bijvoorbeeld aan een door de meerderheid genomen besluit tot statutenwijziging of winstreservering (deze besluiten staan centraal in de hoofdstukken 5 en 6).

De norm van de redelijkheid en billijkheid die de verhouding tussen aandeelhouders beheerst kan allereerst worden gezien als een waarborg voor een 'behoorlijke' besluitvorming, in die zin dat de redelijkheid en billijkheid in elke fase van het besluitvormingsproces kan meebrengen dat in aanvulling op, of in afwijking van, de wettelijke en statutaire regels, 'passende' maatregelen ter bescherming van de belangen van (minderheids)aandeelhouders gerechtvaardigd zijn. ${ }^{88}$ Tevens zorgt de redelijkheid en billijkheid voor een besluitvorming, waarbij zowel rekening wordt gehouden met de belangen van individuele aandeelhouders, als ook met

86. Evenzo AG Mok in zijn conclusie bij Janssen Pers (overweging 5.2.2.) en De Kluiver, S \& V 1996, p. 89.

87. H.J. de Kluiver, S \& V 1996, p. 89 en in S \& V 1990, p. 152.

88. Zo dienen aandeelhouders en andere vergadergerechtigden op correcte wijze te worden opgeroepen voor een algemene vergadering. Zie Pres. Rb 's-Gravenhage 29 oktober 1927. NJ 1929, 47, NV 42, 153; Rb. s'-Gravenhage 26 november 1928, NJ 1929, 1026; $\mathrm{Rb}$. Arnhem 12 november 1942, NJ 1943, 846; Rb. Amsterdam 20 oktober 1936, NJ 1938, 213, NV 17, 47; HR 30 oktober 1964, NJ 1965, 107 (Mante). 
het belang van de vennootschap. Deze waarborgen zijn in dit hoofdstuk bij de bespreking van de diverse aspecten van besluitvorming aan de orde gekomen.

Een belangrijke oorzaak van de geringe invloed die met name minderheidsaandeelhouders in het Nederlandse recht op het besluitvormingsproces kunnen uitoefenen is gelegen in de koppeling van de bevoegdheid inzake bijeenroeping tot de algemene vergadering aan de bevoegdheid tot vaststelling van de te behandelen onderwerpen (2:114/224 BW). De minderheidsaandeelhouders missen een rechtstreeks wettelijk middel tot het (mede)-bepalen van de agenda van de vergadering. De enige weg die hiertoe leidt is het verkrijgen van een rechterlijke machtiging tot bijeenroeping. Deze weg kan echter alleen worden bewandeld door aandeelhouders die minimaal $10 \%$ van het geplaatste kapitaal vertegenwoordigen. In dit verband verdedig ik dat de redelijkheid en billijkheid onder omstandigheden er toe kan leiden dat ook aandeelhouders die minder dan $10 \%$ van het geplaatste aandelenkapitaal vertegenwoordigen, via tussenkomst van de rechter een algemene vergadering kunnen afdwingen, alsmede de inhoud van de agenda kunnen bepalen. ${ }^{89}$ Een vergelijking met buitenlandse rechtsstelsels op dit punt leert dat met name het Franse recht een interessante oplossing biedt. Dit moet worden toegeschreven aan de rechtsfiguur van 'mandataire de justice' ('ad hoc', zie hieromtrent hoofdstuk $2 \$ 5.2$.II). Deze houdt, kort gezegd, in dat een door de rechter benoemde persoon een bepaalde taak krijgt toebedeeld teneinde het conflict in de algemene vergadering op te lossen.

Een andere kwestie betreft de deelname van aandeelhouders aan de beraadslaging en besluitvorming. Volgens de meerderheid van de auteurs $^{90}$ geldt ten aanzien van de besluitvorming binnen een algemene

89. De Commissie Corporate Governance vraagt eveneens aandacht voor de positie van aandeelhouders in de besluitvorming. In haar aanbevelingen wordt zelfs gesteld dat verzoeken van kapitaalverschaffers tot agendering van bepaalde onderwerpen in beginsel behoren te worden gehonoreerd, tenzij er sprake is van zwaarwegende omstandigheden die zich daartegen verzetten.

90. Zie onder meer Pitlo-Lōwensteyn, p. 83, F.J.P. van den Ingh, Vergaderrechten bij tegenstrijdig belang. WPNR 1998, p. 269 en Dijk-Van der Ploeg, p. 139. Anders: Slagter, Compendium, p. 61 alsmede in Besluitvormingsprocessen; in de bundel Miscellanea, Deventer 1997. p. 384-386. Slagter vindt de beslissing van de Hoge Raad inzake Wijsmuller weliswaar juist, maar niet altijd in overeenstemming met de werkelijkheid. Volgens Slagter is, naarmate de leden van het besluitvormend orgaan met minder verantwoordelijkheden met betrekking tot de organisatie zijn belast, de kans 
vergidering het Wijsmuller-arrest (HR 15 juli 1968, NJ 1969, 101) waarn de Hoge Raad overwoog dat een besluit binnen een meerhoofdig orgain tot stand dient te komen 'als vrucht van onderling overleg van alle leder van het orgaan die, na daartoe in de gelegenheid te zijn gesteld, aan dat everleg wensen deel te nemen'. Ik sluit mij hierbij aan. Het recht op deelıame van een aandeelhouder aan de beraadslaging staat echter wel ter discıssie op het moment dat zich een tegenstrijdig belang voordoet. Op grond van art. 2:8 lid 2 BW verdedig ik dat de vergaderrechten aan zo'n andeelhouder kunnen worden ontzegd. ${ }^{91}$

Al met al meen ik dat de redelijkheid en billijkheid zowel het actief handelen als het passief gedrag van aandeelhouders zodanig reguleert dat de tesluitvorming 'behoorlijk' geschiedt. Dit komt ten goede aan het funcioneren van de kapitaalvennootschap.

groter dat zij niet bereid zijn hun vooropgezette meningen prijs te geven voor de vrucht van onderling overleg. Dit laat mijns inziens onverlet dat iedere aandeelhouder in de gelegenheid dient te worden gesteld om aan dat overleg te kunnen deelnemen.

91. Zie tevens F.J.P. van den Ingh, Vergaderrechten bij tegenstrijdig belang, WPNR 1998, p. 270. Als andere grondslag voor het ontnemen van de vergaderrechten aan een aandeelhouder die een dubbelrol vervult noemt $V$ an den Ingh misbruik van bevoegdheid (ant, 3:13 BW). Zie daarover en met name over de verhouding tussen redelijkheid en billijkheid en misbruik van recht, hoofdstuk $1 \$ 9.2$. 



\section{Volmacht en stemovereenkomsten}

In het voorgaande hoofdstuk stonden centraal de verschillende fasen van het besluitvormingsproces van de ava en de rol die de redelijkheid en billijkheid hierin kan spelen. De redelijkheid en billijkheid vormt veelal een 'waarborg' voor een 'behoorlijke' besluitvorming in de ava, waarbij rekening wordt gehouden met de belangen van meerderheids- en minderheidsaandeelhouders. In dit hoofdstuk besteed ik nader aandacht aan het normeren van het gedrag van aandeelhouders die door middel van 'stemmenbundeling' meer invloed kunnen uitoefenen op de gang van zaken van de vennootschap dan de omvang van hun eigen aandelenbezit rechtvaardigt. Ik concentreer mij hierbij op volmachten en stemovereenkomsten.

\section{\$1. Aandeelhouders en volmacht}

Voor de gemiddelde minderheidsaandeelhouder is het, gezien de geringe invloed welke hij kan uitoefenen op het besluitvormingsproces, erg kostbaar en onpraktisch om vergaderingen van vennootschappen bij te wonen. De onverschilligheid van deze aandeelhouders ten aanzien van het deelnemen aan vergaderingen, wordt in veel landen als een probleem voor het realiseren van de besluitvorming ervaren, in het bijzonder wanneer wet of statuten quorumeisen stellen voor belangrijke besluiten. In verschillende rechtsstelsels heeft men getracht oplossingen te ontwikkelen voor dit probleem. Men moet in dit verband denken aan voorzieningen die erop gericht zijn de aandeelhouders niet in persoon doch bij gevolmachtigde tegenwoordig te doen zijn. In het Nederlandse recht kan krachtens art. 2:117/227 lid $1 \mathrm{BW}$ iedere aandeelhouder het initiatief nemen om zich te laten vertegenwoordigen door een gevolmachtigde, mits de statuten dit toelaten. ${ }^{1}$ De gevolmachtigde krijgt dan de bevoegdheid om het vergaderen stemrecht op één of meer aandelen van een aandeelhouder uit te oefenen.

1. Het is opvallend dat de mogelijkheid voor een aandeelhouder om zich te laten vertegenwoordigen in het Franse, Duitse en Engelse recht, in tegenstelling tot het Nederlandse recht, dwingend wordt geregeld. In het Nederlandse recht bestaat de mogelijkheid slechts indien de statuten dit toelaten (art. 2:117/227 lid $1 \mathrm{BW}$ ). Zie voor het Franse . recht art. 161 leden 1 en 3 Loi 1966 en art. 58 L. 1966, voor het Duitse recht $\$ 134$ (4) AktG en $\$ 47 \mathrm{GmbHG}$ en voor het Engelse recht art. 372 Companies Act (CA). 
In de Verenigde Staten is een volmacht praktijk ontwikkeld waarbij het initiatief om van een gevolmachtigde gebruik te maken niet uitgaat van de vertegenwoordigde aandeelhouder maar van het bestuur, een vereniging van aandeelhouders of een andere aandeelhouder die (meer) invloed nastreeft. Deze 'volmachtverwerving', in de literatuur vaak aangeduid met de uit Amerika afkomstigde term 'proxy solicitation', is met name in grote publieke vennootschappen niet ongebruikelijk. Ook in Engeland, Duitsland en Frankrijk komen deze 'proxy-voting' praktijken voor.

Naar aanleiding van het debat over 'corporate governance' ziet het et naar uit dat ook in ons land 'proxy solicitation' ingang zal vinden. ${ }^{2}$ Vooralsnog geven in Nederland hieromtrent noch de wet, noch het Reglement van de Vereniging voor de Effectenhandel voorschriften. Dit impliceert dat bij de problematiek rond het verwerven van volmachten de redelijkheid en billijkheid als norm geldt.

Allereerst zullen enkele algemene problemen rond volmacht worden belicht die zich voor kunnen doen in alle 'soorten' vennootschappen. Daarna zal ik stil staan bii 'proxy-voting', praktijken in 'publieke' vennootschappen. In de uitwerking van een en ander concentreer ik mij op het gedrag van de gevolmachtigde. Dit aspect van de volmachtproblematiek is tot nu toe onderbelicht gebleven in de bestaande Nederlandse literatuur. ${ }^{3}$ Het lijkt echter bepaald de moeite waard om op deze kwestie in te gaan. Niet alleen vanwege de ontwikkelingen in het buitenlandse recht, maar ook in verband met de aansprakelijkheidsvraag die rijst wanneer gevolmachtigden worden 'ingeschakeld'.

2. Zie het rapport van de Commissie Corporate Governance betreffende aanbevelingen inzake Corporate Governance, 'De veertig aanbevelingen' 1997, m.n. p. 26. Een werkgroep, bestaande uit vertegenwoordigers van de Vereniging van Effectenuitgevende Ondernemingen, de Amsterdam Exchanges en de Nederlandse Vereniging van Banken, bereidt op dit moment een voorstel voor toepassing van proxy solicitation voor.

3. Zie met name J.J. van de Vijver, 'Proxy Solicitation' in de bundel Jurist in bedrijf, Nederlands Genootschap van Bedrijfsjuristen 1930-1980, Deventer 1980, p. 213 c.v.. W.J. Slagter, Gebundelde actiên in de bundel: Goed \& Trouw, Opstellen voor W.C.L. van der Grinten, Zwolle 1984, p. 235 e.v., J.M.M. Maeijer, Vertegenwoordiging en volmacht in de bundel: Problemen rond de algemene vergadering. Deventer 1994. p. 63 e.v., J.M.M. Maeijer, Proxy Solicitation; beschermingsconstructies in de congresbundel: Ontwikkelingen in het effectenverkeersrecht, Deventer 1995. p. 119 e.v. en M. Koelemeijer, Volmacht en aandeelhouders, in: Onderneming en 5 jaar nieuw burgerlijk recht, serie onderneming en recht, Deventer 1997, p. 21 e.v. 


\section{\$1. De aandeelhouder/volmachtgever}

Eerdr reeds betoogde ik dat een aandeelhouder bij de uitoefening van zijn temrecht onderworpen is aan de norm van redelijkheid en billijkheid. Dit npliceert dat een aandeelhouder bij de uitoefening van zijn stemrecht onde omstandigheden rekening moet houden met de belangen van de overge aandeelhouders en de belangen van de vennootschap. ${ }^{4}$ Dit geldt ook ndien de aandeelhouder op een aandeelhoudersvergadering zijn stem laat itoefenen door een gevolmachtigde.

At. 2:117/227 lid 1 bepaalt dat iedere aandeelhouder bevoegd is om in prsoon of bij schriftelijk gevolmachtigde de algemene vergadering bij te wnen, daarin het woord te voeren en het stemrecht uit te oefenen, mitsde statuten dit toelaten. Deze zin roept een aantal vragen op. Mag een andeelhouder voor ieder aandeel een gevolmachtigde 'naar zijn keus' aanvjzen om hem te vertegenwoordigen? ${ }^{5}$ Is een aandeelhouder bevoegd om bor een gedeelte van zijn aandelen zelf te verschijnen op de aandeel.bouersvergadering en voor een ander gedeelte zich te laten vertegenwoordigen door een gevolmachtigde? ${ }^{6}$

Wat betreft de betekenis van de formulering van lid 1 van art. 2:117/ 227, kan uit de wetsgeschiedenis worden afgeleid dat het woord of moet worden gelezen als en/of. Een aandeelhouder kan dus voor een gedeelte van zijn aandelen zelf stemmen en voor een ander gedeelte een gevolmachtigde laten stemmen. ${ }^{7}$ In het algemeen kunnen op meerdere aandelen

4. Een duidelijk voorbeeld biedt de uitspraak van Pres. Rb. Assen 17 december 1993, KG 1994. 90 (Cemex-Zeldenrust), besproken in hoofdstuk $3 \$ 7.2$. Vgl. onder meer ook de opvatting van Van Schilfgaarde hieromtrent in Van de BV en NV, nr. 67. In het Duitse recht vervult de Treuepflicht dezelfde functie, vgl. bijvoorbeeld W. Timm, Treuepflichten im Aktienrecht, WM 1991, p. 484 en W. Flume, Die Rechtsprechung des II. Zivilsenats des BGH zur Treupflicht des GmbH-Gesellschafters und des Aktionärs, ZIP 1995, m.n. p. $161 / 162$.

5. Met deze vraag hangt samen de vraag of een aandeelhouder überhaupt op verschillende aandelen verschillend mag stemmen.

6. Deze vraag wordt ook gesteld door A.L. Mohr, De aandeelhouder en zijn stemmen, WPNR 1994, p. 237/238 (Privaatrecht aktueel).

7. Vgl. MvA I, PG 2, p. 611. Zie ook Maeijer in Asser-Maeijer 2-III, nr. 279. 
in persoon en bij gevolmachtigde stemmen in verschillende richting worden uitgebracht. ${ }^{8}$

Naar mijn mening is echter verdedigbaar dat de redelijkheid en billijkheid onder omstandigheden met zich kan brengen dat een aandeelhouder niet voor elk aandeel één gevolmachtigde kan laten verschijnen." Het is immers in het belang van zowel de vennootschap als van de aandeelhouders als collectief, dat de aandeelhoudersvergadering goed verloopt. ${ }^{10}$ De aanwezigheid van een zeer groot aantal gevolmachtigden ter vergadering kan leiden tot chaos hetgeen het functioneren van de algemene vergadering van aandeelhouders belemmert. " In enkele andere rechtsstelsels heeft men hiermee rekening gehouden.

Zo gelden in het Franse recht ten aanzien van het verlenen van volmacht reeds zeer stricte regels en is het een aandeelhouder niet toegestaan om zich door meer dan één aandeelhouder te laten vertegenwoordigen (art. 161 L. 1966). ${ }^{12}$ Art. 133 van het Décret uit 1967 bepaalt uitdrukkelijk dat 'l'actionnaire peut donner une procuration à un autre actionnaire ou adresser un pouvoir en blanc à la société' (curs. MK). Ook in het Engelse recht, althans voorzover het een 'private' company betreft,

8. Zie ook J.M.M. Maeijer, Vertegenwoordiging en volmacht uit de congresbundel Problemen rondom de algemene vergadering 1994, p. 76 en 114, Asser-Maeijer 2-III, nr. 279 en Handboek nr. 212. Dit wordt ook aangenomen in het Duitse recht, de zgn. 'gespaltene Stimmabgabe'. Zie S. Siepelt, Das Rederecht des Aktionärs in der Hauptversammlung, Frankfurt am Main 1992, p. 18 en H. Baumann und W. Reiß, Satzungsergänzende Vereinbarungen-Nebenverträge im Gesellschaftsrecht, ZGR 1989, p. 187.

9. Anders: Van Schilfgaarde, Van de BV en NV, p. 191. Hij schrijft daar: 'Ik zou willen aannemen dat een aandeelhouder desgewenst per aandeel een schriftelijk gemachtigde kan aanwijzen, aangenomen tenminste dat de statuten op dit punt geen beperkingen inhouden'.

10. Vgl. Handboek, nr. 213 en O.L.O de Witt Wijnen, Toegang vergader- en stemgerechtigden in de bundel: Problemen rond de algemene vergadering. Deventer 1994, p. 20.

11. Men denke bijvoorbeeld aan de situatie waarbij de lokatie waar de algemene vergadering wordt gehouden te klein blijkt te zijn voor alle aanwezigen. De voorzitter of de algemene vergadering zou naar mijn mening om deze reden de vergadering kunnen verdagen. Een aardig voorbeeld is in dit verband de Engelse uitspraak inzake Byng v. Life Association Ltd [1990] Ch 170, [1989] 1 All ER. Zie Sealy, Cases and Materials, nr. 86.

12. Voor de SARL bevat art. 58 L. 1966 een soortgelijke bepaling, namelijk: 'Il ne peut $s$ faire représenter par une autre personne que si les statuts le permettent'. Echter, anders dan bij een SA kan de gevolmachtigde ook een derde zijn. Zie ook Lamy Sociétés 1996 , nr. 2829, Guyon, Droit des Affaires, nr. 301, Guyon, Traité des contrats, nrs. 84/85 en Cozian-Viandier-Deboissy, nr. 847. 
is het een aandeelhouder niet toegestaan om meer dan één proxy te benoemen voor een vergadering, tenzij de statuten anders bepalen (section 372 2(b) CA). De laatste tijd echter staat deze kwestie ter discussie, vanwege het feit dat het ongunstig kan zijn dat een zgn. 'nominee' company middels welke de meeste particuliere beleggers hun aandelen houden, voor meerdere aandeelhouders optreedt als 'proxy'. 13

Ten slotte bestaat ook in het Duitse recht de opvatting dat een beperking in het aantal gevolmachtigden geboden is. Dit wordt gerechtvaardigd doordat een aandeelhouder zekere 'Rücksichtspflichten' heeft met betrekking tot het belang van de vennootschap. ${ }^{14}$

In dit kader is naar mijn mening ook verdedigbaar dat redelijkheid en billijkheid paal en perk stelt aan wie men als gevolmachtigde kiest. ${ }^{15}$ Wordt een volmacht verleend aan een bestuurder of aan een bank dan bestaat met betrekking tot bepaalde onderwerpen een grote kans op belangenverstrengeling. ${ }^{16}$ Bestuurders en banken vervullen immers vaak tegelijkertijd verschillende rollen.

Een bank bijvoorbeeld, die veelal ook kredietverschaffer/crediteur is, zal in een situatie waarin de continuiteit van de vennootschap wordt bedreigd belang hebben bij een zeer behoudende financierings- en investeringspolitiek, teneinde mogelijke grotere schade voor hem te voorkomen. Zo'n politiek kan echter ertoe leiden dat de aandelen verder in waarde zullen dalen, hetgeen over het algemeen niet zal stroken met de belangen van aandeelhouders. Ook kan men denken aan de uitkering van dividend. De vennootschap (het bestuur) en de bank zullen veelal belang hebben bij winstinhouding teneinde de balansverhoudingen te verbeteren, terwijl aandeelhouders een maximale winstuitkering kunnen prefereren.

Een ander voorbeeld is het verlenen van décharge. Het is naar mijn mening ongeoorloofd dat een bestuurder als gevolmachtigde van een

13. In Engeland worden de particuliere beleggers aangemoedigd hun aandelen te houden middeis nominee companies. $\mathrm{Vgl}$. Shareholder Communication: proposed changes to the Companies Act, The Company Lawyer 1996, p. 189.

14. Zie S. Siepelt, Das Rederecht in der Hauptversammlung, diss. Köln 1992, p. 18.

15. Anders: J.J. van de Vijver. 'Proxy Solicitation' uit de bundel Jurist in bedrijf 1980, p. 233/234.

16. Vgl. hieromtrent ook L.H. Slijkhuis, De bank als kredietverschaffer/aandeelhouder in de bundel: De dubbelrol in het vennootschapsrecht, Deventer 1993, p. 61-71. 
aandeelhouder stemt over een voorstel met betrekking tot zijn décharge. ${ }^{17}$

\subsection{Gedrag van de gevolmachtigde}

Als aandeelhouders zich ter vergadering laten vertegenwoordigen, komt de vraag aan de orde welke 'regels' het gedrag van gevolmachtigden dienen te bepalen. In dit kader worden wij geconfronteerd met de vraag of het gedrag van een gevolmachtigde onderworpen is aan de norm van redelijkheid en billijkheid van art. 2:8 BW. ${ }^{18}$

Het is duidelijk dat een gevolmachtigde de (contractuele) redelijkheid en billijkheid, welke voortvloeit uit de rechtsverhouding volmachtgever/ gevolmachtigde, in acht dient te nemen jegens de gevolmachtigde. Mij gaat het echter om de vraag in welke verhouding een gevolmachtigde staat ten opzichte van andere betrokkenen bij de organisatie, zoals de overige aandeelhouders.

Gelet op de bewoordingen van art. 2:8 BW, meen ik dat de vraag of deze bepaling van toepassing is op gevolmachtigden bevestigend moet worden beantwoord nu het eerste lid van art. 2:8 BW spreekt over 'degenen die krachtens de wet en statuten bij de organisatie zijn betrokken'. Men kan redeneren dat een gevolmachtigde krachtens de statuten een volmacht verkrijgt om bepaalde rechten namens de aandeelhouder uit te oefenen en daardoor bij de organisatie betrokken is. Tevens kan gezegd worden dat de gedraging van een gevolmachtigde plaatsvindt in de interne sfeer van de rechtspersoon.

Wel zou ik menen dat de omvang van de verplichtingen krachtens redelijkheid en billijkheid varieert. Zo verschilt, mijns inziens, de mate van verantwoordelijkheid van een gevolmachtigde, ten opzichte van

17. Zie eveneens het Duitse recht, dat in $\S 136-1$ AktG bepaalt dat een bestuurder of commissaris niet mag stemmen over het besluit inzake hun décharge. Zie omtrent de relatie tussen décharge en aansprakelijkheid van bestuurders, H.J. de Kluiver, Aansprakelijkheid en Décharge: 'een paar apart', WPNR 1997, p. 373-378.

18. Het gaat hier uiteraard om gevolmachtigden die niet reeds uit andere hoofde betrokken zijn bij de vennootschap. Te denken valt bijvoorbeeld aan de Vereniging van Effecten Bezitters (VEB). Vgl. voor het toepassingsgebied van art. 2:8 BW C.W. Monchy en L Timmerman, De nieuwe algemene bepalingen van Boek $2 \mathrm{BW}$, Preadvies van de Vereeniging Handelsrecht, Zwolle 1991, p. $49-52$ en het verslag van de vergadering, $P$. 46-51. Zie tevens hoofdstuk $2 \$ 3.2$. 
andere betrokkenen, in de situatie waarin een volmacht wordt verleend door een kleine aandeelhouder met betrekking tot één agendapunt voor één algemene vergadering van aandeelhouders, van de situatie waarin een gevolmachtigde zelf actief een groot aantal volmachten verzamelt van aandeelhouders, met als doel een bepaalde beslissing te blokkeren dan wel te bevorderen. In het laatste geval kan een gevolmachtigde grote invloed uitoefenen op de besluitvorming. Kortom, ik zou willen betogen dat de verantwoordelijkheid van een gevolmachtigde afhangt van de mate waarin hij invloed kan uitoefenen op de besluitvorming. Hiermee heb ik al een aanzetje gegeven voor het aansprakelijkheidsvraagstuk dat aan de orde zal komen in $\$ 1.6$.

Op basis van het voorgaande zou ik menen dat het gedrag van een gevolmachtigde mede beheerst wordt door de eisen van de vennootschappelijke redelijkheid en billijkheid. Op basis daarvan kan in ieder geval een tweetal gedragsregels worden geformuleerd die een gevolmachtigde in acht dient te nemen. Deze betreffen de mededeling van de gevolmachtigde aan de aandeelhouder/volmachtgever van zijn belangen bij de vennootschap en de verplichting tot overleg met de aandeelhouder/volmachtgever over de wijze waarop de stem zal worden uitgebracht.

\section{$\$ 1.3$ Gedragsregels gevolmachtigde: informatie- en overlegplicht}

In verschillende rechtsstelsels wordt als uitgangspunt aangenomen dat vertegenwoordigers de vergader- en stemrechten moeten uitoefenen overeenkomstig de wensen en belangen van hun opdrachtgevers. In de eerste plaats impliceert dit dat een gevolmachtigde bij een belangenconflict zijn persoonlijke belangen ten achter dient te stellen ten opzichte van zijn opdrachtgever(s). ${ }^{19}$

Om te waarborgen dat gevolmachtigden het stemrecht zodanig uitoefenen dat het strookt met de belangen van hun opdrachtgevers, is een controlemogelijkheid essentieel. Dit kan slechts worden verwezenlijkt

19. Zie voor het Duitse recht bijvoorbeeld M. Henssler, Aktienrechtliche Verhaltenspflichten bei Stimmrechtsausübung. ZHR 1993, p. 101. 
indien de opdrachtgevers over voldoende informatie beschikken ten aanzien van de stemvoornemens van de gevolmachtigde. ${ }^{20}$

Ook dient de gevolmachtigde voorafgaande aan de uitoefening van het stemrecht de aandeelhouder/opdrachtgever te informeren omtrent potentiële belangenverstrengelingen. Aan de hand daarvan kan de aandeelhouder dan alsnog besluiten een steminstructie te geven, een andere persoon een volmacht te verlenen dan wel zelf ter vergadering te verschijnen.

In de tweede plaats mag van de gevolmachtigde worden verlangd dat hij in overleg treedt met de volmachtgever teneinde diens belangen goed te behartigen. Voorzover mogelijk, dient dit overleg niet alleen voorafgaande aan de vergadering, maar ook in de besluitvormingsfase en na afloop van de vergadering plaats te vinden.

Weliswaar zal een aandeelhouder in veel gevallen zijn standpunt omtrent de te behandelen onderwerpen vóór de vergadering hebben bepaald, maar indien zich een verandering van omstandigheden voordoet, moet de aandeelhouder/volmachtgever door de gevolmachtigde, zo mogelijk, in de gelegenheid worden gesteld zijn standpunt te wijzigen. ${ }^{21}$

Wat moet er gebeuren indien er geen tijd is om een nieuwe instructie aan de volmachtgever te vragen? In beginsel mag een gevolmachtigde niet afwijken van instructies die door de aandeelhouder/volmachtgever zijn verstrekt. Echter, de gevolmachtigde kan in een dilemma geraken wanneer zich naderhand omstandigheden voordoen die bij het geven van de instructies of bij de verzending van het verzoek tot volmachtverlening niet bekend waren.

Ik acht het verdedigbaar, dat de redelijkheid en billijkheid meebrengt dat een gevolmachtigde onder omstandigheden kan afwijken van een gerichte volmacht en dus op een andere wijze stemt dan volgens de instructies van de aandeelhouder/volmachtgever. Zo'n omstandigheid zou bijvoorbeeld kunnen zijn dat een voorstel ter vergadering wordt gewijzigd en dit de belangen van de aandeelhouder/volmachtgever ten goede komt.

20. $\mathrm{Vgl}$. hieromtrent ook G. Teubner, Corporate Fiduciary Duties and Their Beneficiaries, in de bundel Corporate Governance and Directors' Liabilities, Berlijn/New York 1985. p. 168: 'Control procedures can function only if sufficient information is made available',

21. In het Duitse recht is een dergelijke regeling neergelegd in $\$ 665$ (2) BGB. Zie ook M. Henssier, Aktienrechtliche Verhaltenspflichten bei Stimmrechtsausūbung. ZHR 157 (1993), p. 104. 
De volmacht strekt immers juist ter behartiging van die belangen. De door de gevolmachtigde uitgebrachte stem moet dan, ondanks de strijdigheid met de instructie, naar mijn mening als geldig worden aangemerkt. $^{22}$

\section{\$1.4 Proxy praktijken in publieke vennootschappen in de Verenigde Staten, Engeland, Duitsland en Frankrijk}

Het voorgaande kan worden beschouwd als een nadere belichting van de problemen rond volmachtverlening die zich voor kunnen doen in alle 'soorten' vennootschappen. Nu is het moment aangebroken om aandacht te schenken aan 'proxy-voting' praktijken die in publieke, beursgenoteerde vennootschappen voorkomen: In deze vennootschappen met een groot gespreid aandelenkapitaal bestaat steeds meer de behoefte om de $\mathrm{zgn}$. 'corporate democracy' te bevorderen en de betrokkenheid van de aandeelhouders bij het vennootschappelijk beleid te vergroten.

\section{Verenigde Staten}

Proxy voting is in de Verenigde Staten thans de belangrijkste methode voor aandeelhouders in public corporations (beursvennootschappen) om te stemmen over zaken die tijdens de aandeelhoudersvergaderingen worden behandeld. Veelal verzoekt het management om proxies. Proxy solicitation is vrij gemakkelijk uitvoerbaar in de Verenigde Staten, aangezien toonderaandelen bij beursgenoteerde vennootschappen nauwelijks voorkomen. ${ }^{23}$ De Securities and Exchange Commission (SEC) is het bevoegde orgaan om proxy solicitations met betrekking tot geregistreerde aandelen te reguleren. Dit geschiedt op basis van section 14 (a) van de Federal Securities Exchange Act 1934 welke een aantal regels bevat die erop

22. Zie ook J.M.M. Maeijer, Vertegenwoordiging en volmacht, in: Problemen rondom de algemene vergadering. Deventer 1994, p. 73 en in Asser-Maeijer 2-III, nr. 280. Mijns inziens kan dit geval worden beschouwd als een impliciete bekrachtiging door de volmachtgever (art. 3:69 BW). Anders Handboek, nr. 225: 'De stem uitgebracht door een vertegenwoordiger in strijd met de hem gegeven instructie zal in het algemeen geldig zijn'.

23. Zie ook J.M.M. Maeijer, Proxy solicitation; beschermingsconstructies in de bundel: Ontwikkelingen in het effectenverkeersrecht, Deventer 1995, p. 120 en J.J. van de Vijver, 'Proxy Solicitation', in de bundel; Jurist in bedrijf, Deventer 1980, p. 215. 
gericht zijn de invloed van aandeelhouders in de vennootschap te waarborgen. Tevens is proxy solicitation in alle jurisdicties van de Verenigde Staten in de wetgeving van de deelstaten geregeld. Toch is, in de afgelopen jaren, het functioneren van het proxy systeem veelvuldig bekritiseerd door, onder meer, institutionele beleggers, aandeelhoudersverenigingen en het US Congress en zijn er voorstellen gedaan om het systeem te veranderen. ${ }^{24}$

\section{Engeland}

Het Engelse systeem van proxy solicitation staat van oudsher dicht bij het Amerikaanse. Evenals in de Verenigde Staten vervult proxy solicitation in de Engelse vennootschapspraktijk, in tegenstelling tot andere landen in Europa, een belangrijke rol indien het gaat om 'registered shares'. ${ }^{25}$

Om te waarborgen dat het stemmen bij volmacht daadwerkelijk strekt ter bevordering van de democratie binnen de vennootschap, heeft de Stock Exchange aan beursgenoteerde vennootschappen het vereiste gesteld dat zgn. 'two-way' proxies moeten worden verzonden aan aandeelhouders op grond waarvan aandeelhouders instructies kunnen geven aan de gevolmachtigde omtrent de uitoefening van het stemrecht. Deze volmachten moeten ook vermelden hoe de gevolmachtigde zal stemmen in het geval dat de volmachten zonder een steminstructie voor de gevolmachtigde worden teruggestuurd naar de vennootschap. ${ }^{26}$

\section{Frankrijk}

In Frankrijk kende men tot 1983 in de praktijk een soortgelijk proxy praktijk als in de Verenigde Staten, in de vorm van 'pouvoirs en blanc' (blanco volmacht). Dergelijke volmachten verleend door aandeelhouders

24. Vgl, hieromtrent onder meer Thomas J. André, The Corporate Governance Reform Act of 1995, The Journal of Corporation Law, p. 89-124; Norma M. Shahara en Anne E. Hoke-Witherspoon, The Evolution of the 1992 Shareholder Communication Proxy rules and their impact on Corporate Governance. The Business Lawyer 1993, p. 327-358 en N. Minow, Proxy Reform: The case for increased shareholder communication, The Journal of Corporation Law 1991, p. 149-162.

25. $\mathrm{Vgl}$. hieromtrent Mayson, French \& Ryan on Company Law, p. 381.

26. Vgl. Gower's Principles of Modern Company Law, London 1997, p. 579/580. Alleen binnen 'private companies' zijn ook blanco volmachten toegestaan. 
stelden de voorzitter van de algemene vergadering in staat gebruik te maken van deze volmachten en stemmen uit te brengen ten gunste van de voorstellen van het bestuur (art. 161 al. 4 L. 1966). De voorzitter van de aandeelhoudersvergadering van een Société Anonyme (SA) is namelijk de president van het conseil d'administration (of de president van de conseil de surveillance in geval van een SA à directoire). In 1983 is echter, teneinde de representativiteit van de algemene vergadering in SA's te verteteren, 'le vote par correspondance' (schriftelijk stemmen door midjel van formulieren) geïntroduceerd (art. 161-I L. 1966/art. 131-I e.v. D. 1967). Deze methode wijkt af van het tot dan toe bestaande proxy systeem, doordat aandeelhouders de mogelijkheid krijgen om tegen voorstellen van het bestuur te stemmen zonder zelf te verschijnen of zich te laten vertegenwoordigen. ${ }^{27}$ Desalniettemin vindt 'voter par correspondance' niet op grote schaal plaats. Een belangrijke reden is gelegen in de ingewikkeldheid van het formulier, waardoor slechts enkele aandeelhouders hiervan gebruik maken. ${ }^{28}$

\section{Duitsland}

Anders dan in het Anglo-Amerikaanse proxy-systeem, wordt in Duitsland de volmachtpraktijk beheerst door banken en financiële instellingen. Twee factoren hebben daartoe geleid. In de eerste plaats tekende zich in Duitsland al vroeg de ontwikkeling af dat aandeelhouders die niet zelf het stemrecht ter vergadering wilden uitoefenen, zich lieten vertegenwoordigen door de banken die hun aandelen bewaarden. In de tweede plaats bieden de banken hun diensten als gevolmachtigde aan hun cliënten aan zonder kosten daarvoor in rekening te brengen. ${ }^{29}$

Het valt te betwijfelen of bestuurders krachtens het Duitse recht wel rechtsgeldig een volmacht kunnen verwerven. In de eerste plaats is het ongeoorloofd dat een bestuurder als gevolmachtigde stemt over een besluit

27. Door middel van 'voter par correspondance' hebben aandeelhouders, in tegenstelling tot het verienen van blanco volmachten, de keus om voor of tegen een voorstel van het bestur te stemmen of zich van stemming te onthouden (D. 131-2 al. 1.) Dit laatste wordt beschouwd ais het uitbrengen van een stem tegen het bestuursvoorstel.

28. Tevens zien vele aandeelhouders het belang van deze stemmethode niet in. Zie Guyon, Traité des contrats, nr. 86.

29. $\mathrm{Vgl}$. ook T. Baums en P. v. Randow, Det Markt für Stimmrechtsvertreter, Die AG 1995, p. 149. 
met betrekking tot zijn décharge ( $\$ 136$ (1) AktG. In de tweede plaats mogen aandeelhouders niet stemmen conform instructies van bestuurders en commissarissen (vgl. $§ 136$ (2) AktG).

Hoewel het zgn. 'Depotstimmrecht', d.w.z. het stemrecht uitgeoefend door banken, gedetailleerd geregeld is in $\S 128$ e.v. AktG, is dit toch niet onomstreden. Als een belangrijk bezwaar wordt aangemerkt dat het gevaar van belangenconflicten tussen de banken en de aandeelhouders steeds aanwezig is tengevolge waarvan een aandeelhouder niet optimaal kan worden vertegenwoordigd. ${ }^{30}$ Voorts is men in de doctrine van mening dat de banken een machtspositie innemen in de algemene vergaderingen van aandeelhouders, die niet in verhouding staat tot het financiële risico dat zij lopen. Tenslotte werken banken vaak samen met het bestuur van de vennootschap en ondersteunen zij bestuursvoorstellen, hetgeen de positie van met name kleine aandeelhouderś verzwakt. ${ }^{31}$ Naar aanleiding van deze kritiek is recentelijk een voorstel gedaan om het Depotstimmrecht van de banken aanzienlijk te beperken. ${ }^{32}$

\section{Nederland}

In Nederland is de proxy praktijk veel minder ontwikkeld dan in de bovengenoemde landen. De proxy solicitation die zich voordoet in Nederland gaat veelal uit van de Vereniging van Effectenbezitters (VEB). Als reden voor het 'achterblijven' van Nederland op dit gebied, wordt in de literatuur genoemd dat men in Nederlandse beursgenoteerde vennootschappen hoofdzakelijk toonderaandelen kent, waardoor de aandeel-

30. De banken spelen dan immers een dubbelrol, namelijk als crediteur en als proxy van aandeelhouders die hun aandelen bij de bank gedeponeerd hebben. Zie voor een heldere beschouwing over de ontwikkeling van het 'Bankenstimmrecht' bijv. Eckhardt in Geßler/Hefermehl $\S 135$, p. 322-325.

31. Vgl. Raiser, Recht der Kapitalgesellschaften 1992, p. 183.

32. Zo wordt voorgesteld dat kredietinstellingen slechts dan aandeelhouders mogen vertegenwoordigen indien de aandeelhouders schriftelijke instructies geven omtrent de agendapunten van de vergadering ( $\$ 135$ (6) ontwerp AktG). Hiermee wordt getracht te voorkomen dat banken overeenkomstig hun eigen voorstellen stemmen. Dit is in het Duitse recht geoorloofd indien de instructies van de opdrachtgever/aandeelhouder achterwege blijven. In de praktijk blijkt dat aandeelhouders slechts in 2 tot $3 \%$ van de gevallen instructies geeft. Zie onder meer H. Hammen, Zur geplanten Neuregelung des Depotstimmrechts, ZIP 1995, p. 1301 e.v. en Th. Baums en Ph. von Randow, Der Markt für Stimmrechtsvertreter, Die AG 1995, p. 145 e.v. 
houders niet bekend zijn. Voorts wordt gewezen op de talrijke beschermingsconstructies, waardoor de zeggenschap van (toevallige) coalities toch al beperkt is. Echter, mede gezien de ontwikkeling van de Europese regelgeving en, onder invloed daarvan, van de Nederlandse regelgeving op het gebied van de bescherming van beleggers/aandeelhouders, ${ }^{33}$ ontkomt naar mijn mening ook Nederland niet aan het nadenken over regulering van 'proxy solicitation'. ${ }^{34}$ Als gevolg van een aanbeveling van de Commissie Corporate Governance buigt een werkgroep zich thans over de mogelijkheid om ook in ons land proxy solicitation te vergemakkelijken. In dit kader wordt gedacht aan het opzetten van een communicatiekanaal, waarbij een onafhankelijke derde als tussenpersoon optreedt tussen de effecten-uitgevende instellingen, haar aandeelhouders en de depotbanken. ${ }^{35}$ Doordat de onafhankelijke tussenpersoon, met medewerking van de depotbanken, de beschikking krijgt over de adressen en namen van de andeelhouders, kunnen de aandeelhouders worden bereikt, terwijl hun anonimiteit gewaarborgd blijft.

In april 1998 is de Stichting Communicatiekanaal Aandeelhouders (SCA) in het leven geroepen teneinde de voor de rechtstreekse communicatie tussen vennootschap en hun

33. Op Europees niveau wordt enerzijds gedoeld op het ontwerp dertiende Richtlijn van de Euopese Commissie inzake vennootschapsrecht, dat onder meer bescherming van minderheidsaandeelhouders beoogt en anderzijds op de ontwerp-vijfde richtlijn waarbij de artikelen 27 en 28 van belang zijn voor proxy solicitation. Voor de Nederlandse rechtsontwikkeling is het wetsvoorstel van de Minister van Financiën inzake beschermingsconstructies van belang. Zie hierover bijv. H.J. de Kluiver, Machtsstrijd en machtsovername in kapitaalvennootschappen. Opmerkingen over macht, recht en een gegeven paard, Oratie Maastricht 1996.

34. Zie daarover H.J. de Kluiver, 'Mag het nog ietsje meer zijn'? NJB 1996, p. 1439-1451. Hij signaleert dat het ontbreken van een 'proxy' regeling bij beursvennootschappen een 'juridisch tekort' oplevert. In verband met de verwezenlijking van een systeem van proxy solicitation is een wetsontwerp ingediend bij de tweede kamer inzake 'record dates' (kamerstuk 26668). Dit houdt in dat de bevoegdheid om een algemene vergadering van aandeelhouders bij te wonen (in persoon of bij gevolmachtigde) en daarin de rechten van aandeelhouders uit te oefenen toekomt aan degene die op een vast tijdstip vóór de vergadering die aandelen houdt en als zodanig geregistreerd is. $\mathrm{Vgl}$. S.E. Eisma, Record dates, Privaatrecht Actueel, WPNR 1998, p. 552 en M. van Olffen, V \& 01999 , p. 90/91.

35. Evenals in Duitsland zijn in Nederland houders van aandelen aan toonder bereikbaar, voorzover die aandelen bij een bank in bewaring zijn gegeven. 
aandeelhouders benodigde infrastructuur te bieden. ${ }^{36}$ De SCA heeft cen 'pilot project' opgezet met een beperkt aantal deelnemende ondernemingen" en een looptijd van drie jaar. Als onafhankelijke tussenpersoon treedt hier op een dochter van de Amsterdam Exchanges NV, de AEX-Intermediary. Naar verwachting zal dit pilotproject de deelnemende ondernemingen en hun aandeelhouders vanaf 1999 de mogelijkheid bieden tot communicatie met inbegrip van proxy voting en proxy solicitation."

In een dergelijk systeem is het gevaar voor een vijandelijke overname echter niet ondenkbeeldig. ${ }^{39}$

\section{\$1.5 Beoordeling stemgedrag gevolmachtigde in het kader van proxy solicitation}

Hoe moet nu het gedrag van een gevolmachtigde worden beoordeeld als deze in grote (beurs)vennootschappen zelf actief volmachten verwerft? Voor de beantwoording van deze vraag is het zinvol om te onderzoeken of het buitenlandse recht aanknopingspunten kan bieden. In de discussies over proxy voting in Engeland en de Verenigde Staten en de bezinning op het Depotstimmrecht in Duitsland zijn de vereiste gedragsnormen van een gevolmachtigde lange tijd onderbelicht geweest. Echter, in de laatste jaren is er in de Verenigde Staten, en met name in Duitsland, sprake van een toenemende belangstelling voor de materiële aspecten van proxy voting. Centraal hierbij staat de vraag of en in hoeverre een gevolmachtigde zelf verantwoordelijk is ten opzichte van andere aandeelhouders en de vennootschap.

In Duitsland is een levendige discussie hieromtrent ontstaan naar aanleiding van de zogenaamde 'Girmes'-zaak. Deze geldt in de Duitse literatuur als schoolvoorbeeld voor de problematiek rond bundeling van stemrechten. Deze zaak stelt niet alleen de contractuele relatie tussen

36. Zie hieromtrent K. Jongsma, Stichting Communicatiekanaal aandeelhouders opgericht. Corporate Governance Nieuwsbrief, p. 6 en J.W. Winter, Stemmen op afstand via het Communicatiekanaal Aandeelhouders, in: Corporate Governance voor Juristen, Deventer 1998, p. 81 e.v.

37. Deelnemers zijn Koninklijke Olie, AKZO Nobel, ABN/AMRO, AEGON, Bols Wessanen, ING, KNP BT, Nedlloyd, Philips en Unilever.

38. Zie G.P.H. Kreijen, Proxy solicitation, V \& O 1998, p. 76/77. D.C. Buijs, Proxy Solicitation uitgesteld. TVVS 1998, p. 82 e.v. en de Kabinetsreactie op het rapport van de Commissie Corporate Governance, De NV 1998, p. 121.

39. Zie hieromtrent ook J.M.M. Maeijer, Proxy solicitation; beschermingsconstructies in de bundel; Ontwikkelingen in het effectenverkeersrecht, Deventer 1995, p. 128. 
volmachtgever(s)/aandeelhouder(s) en gevolmachtigden aan de orde maar tevens de vennootschapsrechtelijke relatie tussen gevolmachtigden en de overige aandeelhouders.

Girnes AG, actief in de textielbranche, verkeert in de jaren tachtig in financiële moeilijkheden. Het bestuur roept in 1989 een buitengewone vergadering van aandeelhouders bijeen tenende een saneringsplan te realiseren. Voor sanering is 108 miljoen DM nodig. De schuideisers zijn bereid om 78 miljoen van de schuld kwijt te schelden. Het restbedrag moet door middel van een kapitaalvermindering, in de verhouding $5: 2$, ten laste van de aandeelhouders worden opgebracht. $\mathrm{Na}$ de bekendmaking van het saneringsplan in december 1988 , roep' de uitgever van het tijdschrift 'Effecten-Spiegel', een tijdschrift dat de belangen van mincerheidsaandeelhouders beoogt te behartigen, de aandeelhouders op een volmacht aan hem te verlenen met het doel tegen het besluit tot kapitaalvermindering te stemmen. Door midcel van volmachten verwerft de uitgever zoveel stemmen (209700 van de 535653) dat ter vergidering het besluit tot kapitaalvermindering, waarvoor een gekwalificeerde meerderheid is vereist, wordt geblokkeerd. Een tegenvoorstel van de uitgever behaalt echter evenmin een meerderheid. Daarop vraagt het bestuur surséance van betaling aan.

Enkele maanden later is het faillissement van Girmes AG een feit. Het gevolg daarvan is dat $c e$ aandelen van Girmes AG niets meer waard zijn. Naar aanleiding hiervan houden niet alleen de aandeelhouders die waren vertegenwoordigd door de uitgever/gevolmachtigde hem verantwoordelijk voor het falen van het saneringsplan van Girmes, maar ook individuele aandeelhouders, die niet tot de kring van volmachtgevers behoren. Dit heeft geleid tot een uitgebreide reeks van procedures ${ }^{40}$ en een levendige discussie in de literatuur.

De discussie spitst zich toe op de vraag of een gevolmachtigde onderworpen is aan een zelfstandige Treuepflicht. ${ }^{41}$ Het BGH 20-3-1995 stelt zich, in navoiging van voorgaande uitspraken, op het standpunt dat op gevolmachtigden geen eigen zelfstandige Treuepflicht

40. $\mathrm{Vgl}$. voor wat betreft de groep van 600 aandeelhouders die middels een vereniging van 'Kleinaktionäre' een proces aanspannen, LG Düsseldorf 4-6-1991 ZIP 1991, 932, OLG Düsseldorf 20-11-1992 ZIP 1993, 347 en BGH 8-11-1993 ZIP 1993, 1708. Zie voor de individuele aandeelhouders LG Düsseldorf 20-5-1992 ZIP 1992, 1155, LG Düsseldorf 22-12-1992 ZIP 1993, 350, OLG Dūsseldorf 17-5-1994 ZIP 1994, 878, BGH 20-3-1995 ZIP 1995, 819 en tenslotte OLG Düsseldorf 14-6-1996 ZIP 1996, 1211. Zie hieromtrent onder meer W. Flume, Die Rechtsprechung des II. Zivilsenats des BGH zur Treupflicht des GmbH-Gesellschafters und des Aktionärs, ZIP 1995, p. 165 e.v. en R. MarschBarner. Treupflicht und Sanierung, ZIP 1996, p. 853 e.v.

41. Een zelfstandige Treupflicht voor de stemrechtverwerver wordt wel aangenomen door onder meer W. Timm, Treuepflichten im Aktienrecht, WM 1991, p. 488 en Schick, ZIP 1989. p. 940, M. Dreher, Die Schadenersatzhaftung bei Verletzung der aktienrechtlichen Treupflicht durch Stimmrechtsausübung, ZIP 1993, p. 334 en R. Marsch-Barner onder de voorwaarde dat de verwerver vrij is om de verworven stemrechten uit te oefenen, zie Treuepflichten zwischen Aktionären und Verhaltenspflichten bei der Stimmrechtsbündelung, ZHR 1993, p. 202. De argumenten voor de aanname van een Treupflicht verschillen bij de auteurs. 
rust. 'Der Stimmrechtsbevollmăchtigte darf das Stimmrecht nur unter denselben aus der Treupflicht folgenden Einschrânkungen ausūben wie der Vollmacht erteilende Aktionắt selbst': 2

Hoe dit ook zij, duidelijk is dat een volmacht niet afdoet aan de Treupflicht van de volmachtgever. De gevolmachtigde zal binnen de daardoor gestelde grenzen moeten opereren. ${ }^{43}$ Een aandeelhouder die zich laat vertegenwoordigen, kan derhalve zijn verantwoordelijkheid niet ontlopen.

Evenals in het Duitse recht kan naar mijn mening in het Nederlandse recht als uitgangspunt bij de beoordeling van het gedrag van gevolmachtigden worden genomen dat de gevolmachtigde binnen de grenzen van de redelijkheid en billijkheid zal moeten opereren. Daarbij zou ik willen aantekenen dat de beantwoording van de vraag waar de grenzen van de redelijkheid en billijkheid liggen, afhangt van de feitelijke machtspositie van een gevolmachtigde.

Bij het bepalen van de machtspositie die een gevolmachtigde inneemt in de vennootschap, moet mijns inziens belang worden toegekend aan factoren zoals: de voorwaarden waaronder de volmacht wordt verleend; wie het initiatief tot het verlenen van de volmacht nam; welk percentage

42. $\mathrm{Vgl}$. ook M. Dreher, Die Schadenersatzhaftung bei Verletzung der aktienrechtlichen Treuepflicht durch Stimmrechtausübung, ZIP 1993, p. 334 en in ZHR 1993, Treuepflichten zwischen Aktionăren und Verhaltenspflichten bei der Stimmrechtsbündelung. $p$. 165/166. Anders echter W. Timm, Treuepflichten im Aktienrecht, WM 1991, p. 489. $\mathrm{Hij}$ is de mening toegedaan dat de gevolmachtigde zelf 'Adressat der gesellschaftlichen Treupflicht is in het geval hij een grote hoeveelheid volmachten heeft verzameld'. In dit kader moet worden opgemerkt dat met betrekking tot minderheidsaandeelhouders in het Duitse recht over het algemeen wordt aangenomen dat zij in beginsel niet onderworpen zijn aan de Treupflicht. In het Lino-type arrest (BGHZ 103, 184, NJW 1988, 1579) heeft het BGH geoordeeld dat 'die Gesellschafterpflichten eines Kleinaktionărs in der Regel nicht von der gesellschaftsrechtlichen Treuepflicht bestimmt werden'. T. Schône is dezelfde mening toegedaan als Timm. Zie Haftung des Aktionärs-Vertreters für pflichtwidrige Stimmrechtsausübung. WM 1992, p. 212. Zie tevens R. Marsch-Barner. Treuepflichten zwischen Aktionären und Verhaltenspflichten bei der Stimmrechtsbündelung. ZHR 1993, p. 182. Dit is anders indien 'Kleinaktionăren' door middel van samenwerking de mogelijkheid hebben om invioed en macht uit te oefenen op de besluitvorming. $\mathrm{Vgl}$. recentelijk H. Henze, Treupflichten der Gesellschafter im Kapitalgesellschaftsrecht, ZHR 1998, p. 187.

43. Zie bijv. R. Marsch-Barner. Treuepflichten zwischen Aktionăren bei Stimmrechtsbündelung, ZHR 1993, p. 182. Dit geldt bijv. ook voor een stemrechtbeperking. dezt beperking geldt ook indien een gevolmachtigde het stemrecht uitoefent, zie Zöllnet. Köllner Kommentar zum AktG, $\$ 134$, nr. 39. 
stemmen de gevolmachtigde verkrijgt; de duur van de volmacht en een eventuele dubbelrol van de gevolmachtigde.

\section{\$1.6 Rechtsgevolgen stemgedrag gevolmachtigde: toerekenen en afrekenen?}

Het voornaamste rechtsgevolg van de volmachtverlening is dat niet de gevolmachtigde, maar de volmachtgever/principaal wordt gebonden (3:66 $\mathrm{BW})$. Echter, moet dit uitgangspunt in de vennootschapsrechtelijke praktijk nu ook worden gehanteerd wanneer door het stemgedrag van een gevolmachtigde feitelijke handelingen of rechtshandelingen worden verricht die rechtsgevolgen voor anderen bewerkstelligen? Twee voorbeelden mogen dit verduidelijken.

Als eerste voorbeeld kan de situatie uit de Duitse Girmes-zaak worden genoemd, welke ik schetste in $\$ 1.5$. Door het gedrag van een gevolmachtigde geraakt een vennootschap in een zodanig slechte financiēle situatie dat de aandelen niets meer waard zijn.

Als tweede voorbeeld vermeld ik de situatie dat tijdens een ava van een NV een onderwerp ter sprake komt dat niet bij de oproeping is aangekondigd, te weten een kapitaalvermeerdering." Veel aandeelhouders hebben zich op deze vergadering laten vertegenwoordigen door gevolmachtigden. Doordat de meeste gevolmachtigden zich van stemming onthouden, kan de vereiste meerderheid niet worden gehaald. Het gevolg hiervan is dat er geen nieuwe aandelen kunnen worden geëmitteerd ten behoeve van institutionele beleggers teneinde een overval af te weren. Vervolgens vindt een overval plaats.

Wie moet in zo'n geval aansprakelijk worden gesteld voor de schade? Is de principaal onverkort aansprakelijk voor de gedragingen van de gevolmachtigde/vertegenwoordiger? Hoever moet men met die toerekening gaan? Of moet behalve met het gedrag van de aandeelhouder/volmachtgever ook rekening worden gehouden met het gedrag van de gevolmachtigde? Kan de aansprakelijkheid misschien worden verschoven naar de gevolmachtigde? ${ }^{45}$

44. Dit is mogelijk op grond van art. 2:114/224 BW.

45. Overigens moet, teneinde het stemgedrag van de gevolmachtigde te kunnen beoordelen, dit wel 'controleerbaar' zijn. Dit is mijns inziens het geval indien onder de gevolmachtigde een zodanige hoeveelheid stemmen is gebundeld, waardoor de gevolmachtigde wezenlijke invloed kan uitoefenen op de besluitvorming. Voorts kan het gedrag van een gevolmachtigde gecontroleerd worden in een vennootschap met een klein groepje aandeelhouders. 
Uitgangspunt in het civiele recht is dat een volmachtgever door daden van een gevolmachtigde wordt gebonden, mits deze de grenzen van zijn vertegenwoordigingsbevoegdheid niet heeft overschreden. Voor deze civielrechtelijke benadering als 'oplossing' van het aansprakelijkheidsvraagstuk in het kader van volmacht in een vennootschap zijn argumenten aan te voeren. Eén argument op grond waarvan men kan verdedigen dat het gedrag van een gevolmachtigde toegerekend moet worden aan de volmachtgever/principaal is dat een aandeelhouder zijn verantwoordelijkheid niet kan ontlopen door een gevolmachtigde aan te wijzen om namens hem te stemmen. In het geval dat het opvolgen van een instructie van de volmachtgever door de gevolmachtigde schade heeft veroorzaakt, lijkt toerekening aan de aandeelhouder/volmachtgever dan ook redelijk.

Ik zou echter willen verdedigen dat toerekening aan de principaal/volmachtgever zeker niet in alle gevallen op zijn plaats is. Allereerst kan zich een praktisch probleem voordoen. Hoe moet de toerekening bijvoorbeeld geschieden indien een derde/gevolmachtigde, bijvoorbeeld de VEB, duizend aandeelhouders vertegenwoordigt?

Voorts meen ik dat het relevant is om een onderscheid te maken tussen de situatie waarin de aandeelhouder het initiatief neemt om een volmacht te verlenen en de situatie waarin de gevolmachtigde zelf de volmachten verwerft met het doel om een bepaalde beslissing tegen te houden dan wel te bevorderen, zoals in de Duitse Girmes-casus. In het eerste geval lijkt toerekening aan de volmachtgever eerder gerechtvaardigd omdat hij een ander de bevoegdheid tot vertegenwoordiging verleent. In het laatste geval is naar mijn mening terughoudendheid geboden. Men kan zeggen dat door 'toedoen' van de gevolmachtigde, te weten de extra handeling bestaande uit het verwerven van volmachten, de schade is ontstaan. Ook de hoeveelheid volmachten die een gevolmachtigde verzameld heeft naar mijn mening invloed op de aansprakelijkheidsvraag.

Ten slotte meen ik dat toerekening minder snel op zijn plaats is indien een gevolmachtigde afwijkt van de door de volmachtgever gegeven instructie en zelfstandig beslist over de inhoud van de stem. De volmachtgever kan in dit geval een beroep doen op schending van de contractuele verbintenis van de gevolmachtigde ten opzichte van hem. Wat zijn echter de mogelijkheden voor de andere aandeelhouders/niet-volmachtgevers, die ook schade hebben ondervonden van het gedrag van de gevolmachtigde? Tot die mogelijkheden behoort mijns inziens het instellen van een actie uit onrechtmatige daad, op grond waarvan schadevergoeding kan worden verkregen. Het in art. 6:162 BW genoemde criterium van 
strijd met de maatschappelijke zorgvuldigheid wordt, gezien de vennootschappelijke context, mijns inziens mede gekleurd door de eisen van redelijkheid en billijkheid van art. 2:8 BW.

\section{\$2. Aandeelhouders en stemovereenkomsten}

Naast het verlenen van volmacht, kunnen aandeelhouders ook een stemovereenkomst sluiten om invloed uit te oefenen op de gang van zaken in de vennootschap. Zo'n stemovereenkomst heeft, evenals het verlenen van volmacht, het meeste nut in een kleine besloten vennootschap met een klein aantal aandeelhouders, alwaar het een bijdrage kan leveren aan een efficiènte besluitvorming. ${ }^{46}$ Een stemovereenkomst kan ook worden gebruikt om een (on)herroepelijke volmacht kracht bij te zetten. ${ }^{47}$

De wet zwijgt weliswaar over stemovereenkomsten, maar uit de jurisprudentie blijkt dat de Hoge Raad in beginsel toelaat dat de uitoefening van het stemrecht de inzet vormt van contractuele afspraken. Echter, onduidelijk blijft waar de grenzen liggen van de geoorloofdheid van stemovereenkomsten en of de naleving daarvan kan worden afgedwongen. ${ }^{48}$ Welke factoren zijn nu van invloed op de geldigheid van een stemovereenkomst?

Toetsing van stemovereenkomsten aan de redelijkheid en billijkheid van art. 2:8 BW lijkt hier de meest aangewezen weg, waarbij (wellicht) oplossingen uit het buitenlandse recht kunnen worden overgenomen. In het buitenlandse recht worstelt men namelijk ook met de stemovereen-

46. Indien het aantal aandeelhouders omvangrijk is, zoals bij een publieke vennootschap, dan is hantering van stemovereenkomsten over het algemeen erg onpraktisch en gecompliceerd. Stemovereenkomsten binden slechts de aandeelhouders die partij zijn. De samenstelling van de aandeelhoudersvergadering verandert in een publieke vennootschap echter voortdurend vanwege de vrijheid die deze aandeelhouders hebben om hun aandelen te verkopen.

47. Aangezien de onherroepelijke volmacht niet privatief werkt zal de gevolmachtigde er behoefte aan hebben dat de aandeelhouder zich verbindt om niet zelf het stemrecht op de aandelen uit te oefenen. Uiteraard rijst hier dan de vraag naar de geoorloofdheid van een dergelijke stemovereenkomst.

48. $\mathrm{Vgl}$. ook met name H.J. de Kluiver, Joint ventures en stemovereenkomsten. Een rechtsvergelijkend perspectief, AA 1995, p. 432-441, A.L. Mohr, Spijkers, Ondernemingsrecht op de breuklijn van praktijk en wetenschap. Arnhem 1993 en B.C.M. Waaijer, Aandeelhoudersovereenkomsten, Deventer 1996, met name p. 8 e.v. en p. 30 e.v. 
komst, zij het dat daar de rechtspraak veelal meer ontwikkeld is dan in het Nederlandse recht.

\section{\$ 2.1 Indeling in categorieën}

In de literatuur wordt veelal een onderscheid gemaakt tussen drie categorieën van stemovereenkomsten. Een eerste categorie betreft stemovereenkomsten van aandeelhouders met de vennootschap. In dit kader kan men denken aan de situatie dat aandeelhouders zich verbinden te stemmen overeenkomstig instructies van het bestuur of de raad van commissarissen om bijvoorbeeld de leiding van een vennootschap van de steun van de algemene vergadering te verzekeren.

Een tweede veelvoorkomende categorie bestaat uit stemovereenkomsten tussen aandeelhouders. Van dergelijke stemovereenkomsten zijn er talrijke varianten. Men denke bijvoorbeeld aan een overeenkomst waarbij aandeelhouders de verplichting op zich nemen om te stemmen conform de uitslag van de voorvergadering of de overeenkomst die dikwijls wordt gesloten door aandeelhouders in een 50/50-situatie om conform de aanwijzing van een derde te stemmen teneinde een impasse in de besluitvorming te voorkomen. ${ }^{49}$

Een laatste categorie van stemovereenkomsten betreft stemovereenkomsten tussen aandeelhouders en derden..$^{50}$ Een voorbeeld hiervan is dat een aandeelhouder met betrekking tot de vervanging van bestuurders of commissarissen stemt overeenkomstig de aanwijzingen van een financier.

Bij de beantwoording van de vraag of een stemovereenkomst geldig is, biedt deze indeling, zowel in het Nederlandse als in het Duitse, Engelse en Franse recht een goede leidraad.

Met de eerste categorie van stemovereenkomsten kan betrekkelijk snel worden 'afgerekend'. In de Nederlandse doctrine bestaat consensus over de ontoelaatbaarheid van dergelijke stemovereenkomsten. De achterliggende gedachte is dat zo'n overeenkomst niet strookt met ons vennootschapsrecht dat gebaseerd is op een scheiding tussen aandeelhouders-

49. Vgl. het Distilleerderij-arrest, HR 13 november 1959, NJ 1960, 472 en het arrest inzake Wennex, HR 30 juni 1944, NJ 1944, 465.

50. Zie onder meer A.M. Brenninkmeijer, Stemovereenkomsten van aandeelhouders. Kluwet 1973, p. 62-67. 
functie en bestuursfunctie. ${ }^{51}$ Mijns inziens kan echter worden betwijfeld of de grenzen tussen het bestuur en de ava wel zo scherp zijn afgebakend (zie hoofdstuk 7 \&5).

Ook in het Engelse recht staat men zeer terughoudend ten opzichte van dit soort overeenkomsten, met name indien het overeenkomsten betreft die voorbijgaan aan de wettelijke bevoegdheden betreffende de structuur van de vennootschap.

Een goede illustratic biedt Russell v Northern Bank Development Corporation Limited. ${ }^{32}$ In het kader van een reorganisatie van twee Limiteds in de bouwbranche worden op advies van de financierende bank deze bedrijven ondergebracht in een holding. Tyrone Brick Ltd. (TBL). In deze holding participeren de vier aandeelhouders/bestuurders van de twee bedrijven met ieder 20 aandelen en de bank met 120 aandelen. Als onderdeel van deze reorganisatic wordt ook cen stemovereenkomst gesloten tussen de vier aandeelhouders/ bestuurders en de bank, inhoudende dat TBL slechts met schriftelijke toestemming van alle aandeelhouders aandelen mag uitgeven. Het conflict in deze zaak ontstaat als de meerderheid van het bestuur van TBL op een ava toch een voorstel doet tot een emissie van aandelen. Eén aandeelhouder, Russell, stapt vervolgens naar de rechter en vordert een stemverbod ten aanzien van de voorgestelde aandelenemissie.

De Court of Appeal stelt Russell in het gelijk en oordeelt dat de overeenkomst ongeldig is wegens een 'improper fetter on the company's statutory power to increase its share capital'. De House of Lords oordeelt weliswaar dat de overeenkomst geen bindende kracht heeft ten opzichte van de vennootschap, maar oordeelt anders dan de Court of Appeal dat deze wel werking heeft tussen aandeelhouders. De boodschap van de House of Lords is duidelijk: 'Do not attempt too much. In particular do not make the company itself a party to the agreement; do not stipulate that the agreement prevails over the company's articles of association and avoid obligations to transfer the shares only subject to similar obligations of the transferee. As long as the agreement is kept 'purely personal' i.e. operating only inter partes, its validity cannot be challenged on the ground that it, in effect, frustrates the operation of mandatory, statutory corporate powers'. 33 De reden waarom de House of

51. Vgl. o.a. Slagter, Compendium, p. 235 en Van Schilfgaarde, Van de BV en NV, nr. 67. p. 201.

52. Northern Ireland Court of Appeal, 16 april 1991, BBC 1991, p. 517-545 en House of Lords 8 april en 11 juni 1992. WLR 1992, p. 588-595. Weliswaar betreft het hier een zaak naar Noord-Iers recht, maar de relevante wettelijke bepalingen zijn identiek aan die in het Engeise recht en derhalve is deze zaak ook voor het Engeise recht van belang.

53. Ik citeer hier een passage van Shapira Giora, 'Voting Agreements and Corporate Statutory Powers', LQR, 1993 p. 214. Zie voorts over deze zaak o.m. C.A. Riley, Vetoes and Voting Agreements: Some Problems of Consent and Knowledge, Northern Ireland Legal Quarterly, 1993, m.n. p. 37 e.v. en B.J. Davenport, What did Russell v. Northern Bank Development Ltd. decide?, LQR 1993, p. 553-572. 
Lords binding van de vennootschap afwijst is gelegen in bescherming van aandeelhouders die geen partij zijn bij zo'n overeenkomst, in het bijzonder toekomstige aandeelhouders. ${ }^{44}$

In het Duitse recht ligt dit, althans wat betreft de $\mathrm{GmbH}$, anders. Weliswaar wordt in $\S 136$ AktG uitdrukkelijk bepaald dat een aandeelhouder van een AG zich niet rechtsgeldig kan verplichten het stemrecht ter algemene vergadering op aanwijzing van de vennootschap of het bestuur uit te oefenen, maar een dergelijke regeling kent het GmbHG niet. Instructies van de ava aan het bestuur zijn hier zelfs wettelijk toegestaan (§ $37 \mathrm{GmbHG).}{ }^{55}$

Wat betreft de stemovereenkomsten waarbij aandeelhouders of derden als partijen betrokken zijn, bestaat in het Nederlandse recht, maar ook in het Engelse en Franse recht de opvatting dat deze in beginsel toelaatbaar zijn. ${ }^{36}$ Ik beperk mij in het navolgende tot stemovereenkomsten waarbij aandeelhouders of derden partijen zijn.

\section{\$ 2.2 Stemovereenkomsten tussen aandeelhouders; criteria}

Met name in het Engelse recht staat men welwillend tegenover stemovereenkomsten tussen aandeelhouders. Dit hangt samen met de traditionele opvatting dat het stemrecht een 'right of property' is dat een aandeelhouder geheel in eigen belang mag uitoefenen. ${ }^{57}$

In Frankrijk en België wordt weliswaar de noodzakelijkheid van dit soort stemovereenkomsten erkend, maar staat men hier toch enigszins terughoudend tegenover. ${ }^{58}$ In de loop van de tijd is in de rechtspraak een

54. Vgl. C.A. Riley, Vetoes and Voting Agreements, Northern Ireland Legal Quarterly, 1993, m.n. p. 48 en A.P. Rutabanzibwa, Shareholders' agreements in corporate joint ventures and the law, The Company Lawyer 1996, p. 197.

55. $\mathrm{Vgl}$. Lutter-Hommelhoff, GmbHG $\$ 37$.

56. Ook uit de jurisprudentie van de Hoge Raad valt niet af te leiden dat er een onderscheid wordt gemaakt al naar gelang de persoon van degene aan wie toezeggingen zijn gedaan aandeelhouder of buitenstaander is. Vgl. bijv. de Aurora-procedure, HR 19 februari 1960, NJ 1960, 473. Zie voor het Franse recht bijv. Guyon, Traité des contrats, nr. 290.

57. Recentelijk is dit bevestigd in Russell v. Northern Bank Development Corporation Limited, zie $\$ 2.1$.

58. In de Franse rechtspraak komt regelmatig naar voren dat waarde wordt gehecht aan de discussie en het overleg ter algemene vergadering. Het komt voor dat het aandeelhouders niet is toegestaan om zich te verplichten hun stem op een bepaalde manier uit te brengen. Zie bijvoorbeeld Carelles et Hirsch v. Compagnie Francaise des tramways du 
aantal criteria ontwikkeld waaraan zo'n stemovereenkomst moet voldoen, ongeacht de vorm waarin de stemovereenkomst is gegoten. Zo wordt als belangrijk criterium voor de geoorloofdheid van stemovereenkomsten 'het belang van de vennootschap' gehanteerd. ${ }^{59}$ Ook in de Nederlandse doctrine wordt hieraan belang gehecht. ${ }^{\infty}$

Echter, wanneer is een stemovereenkomst in strijd met het belang van de vennootschap? Een duidelijk geval van strijd met het belang van de vennootschap is bijvoorbeeld de situatie waarin het voortbestaan van een vennootschap wordt bedreigd. Zo kan mijns inziens worden verdedigd dat een stemovereenkomst ongeoorloofd is indien deze wordt gesloten met

Douai et la Bienhoa, waarin de Cour d'appel van Parijs op 22 februari 1933, Dalloz 1933 , p. $528 / 529$ overwoog dat het belang van de vennootschap vereist dat elke aandeelhouder in vrijheid zijn stem uitoefent, nadat hij door gedachtenwisseling in de algemene vergadering is ingelicht over de belangrijkheid, bruikbaarheid en mogelijke gevolgen van het voorgestelde besluit voor de vennootschap.

59. In het Belgische recht is dit sinds juli 1991 zelfs wettelijk vastgelegd, vgl. art 74 ter VW voor NV's dat in art. 136 van overeenkomstige toepassing is verklaard voor BV's. Vgl. F. Hellemans, Stemovereenkomsten naar Belgisch recht, in: Beginselen van vennootschapsrecht in binationaal perspectief. Vergelijkende beschouwingen naar Belgisch en Nederiands recht, Antwerpen 1998, p. 185 e.v. Daarvoor werd dit reeds aangenomen in de jurisprudentie. Vgl. D. van Gerven, Shareholders' Agreements under Belgian Law, ICCLR 1991, p. 212 en J. Lievens, De Reparatiewet Vennootschapsrecht, nr. 215. Zie voor het Franse recht onder meer M. Jeanţin, Les Conventions de vote in het themanummer van de Rev.Jur.Com. ('La stabilité du pouvoir et du capital dans les sociétés par actions), p. 129, A. Viandier, Observations sur les conventions de vote, JCP 1986. I 3253, S. Prat, Les pactes d'actionnaires relatifs ou transfert de valeurs mobilières, Parijs 1992, p. 202 (nr. 232), G. Parléani, Les pactes d'actionnaires, Rev.Soc. 1991, p. 28 en Guyon, Traité des contrats, nr. 289. Overigens worden in art. 355 L. 1966 (dat een definitie geeft van een beheersovereenkomst) en art. 356 L. 1966 (dat ziet op melding van aandelenbelang) stemovereenkomsten impliciet erkend.

60. Dit houdt uiteraard verband met de veranderde visie op het gebruik van het stemrecht door de aandeelhouder. Vgl. Van Schilfgaarde, Van de BV en NV, nr. 67. Hij acht de aandeelhouder verplicht zijn stemrecht te gebruiken onder afweging van alle bij de vennootschap betrokken belangen, waarbij het eigen belang wel een gewichtige rol mag spelen. Zie in dezelfde zin ook L. Timmerman, TVVS 1975, p. 246/247. Zie ook J.M.M. Maeijer, De stemovereenkomst van aandeelhouders in de bundel Recht zo die gaat, Zwolle 1976, p. 100 . 'Naar mijn inzicht kunnen besluiten van de algemene vergadering van aandeelhouders worden aangetast wegens flagrante strijd met of totale verwaarlozing van het vennootschappelijk belang, bijvoorbeeld in het geval dat men een bestuurder benoemd die naar aan ieder bekend is of redelijkerwijze bekend kan zijn voor zijn functie totaal ongeschikt is'. 
een aandeelhouder of een derde die een belang heeft dat tegengesteld is aan het belang van de vennootschap.

Uit het Franse en Italiaanse recht blijkt dat het belang van de vennootschap kan worden geschaad door de zgn. 'syndicat de blocage', waarbij een aantal aandeelhouders zich verplicht ter algemene vergadering te stemmen conform de afspraken die in een voorvergadering zijn gemaakt. ${ }^{61}$

Een andere voorwaarde, die met name in de Franse en Belgische rechtspraak, maar ook in de Engelse rechtspraak gesteld wordt voor de geldigheid van een stemovereenkomst is de beperkte duur daarvan. ${ }^{62} \mathrm{De}$ achterliggende gedachte van dit criterium is evident. Hierdoor wordt voorkomen dat een aandeelhouder systematisch wordt belemmerd om deel te nemen aan de besluitvorming. In de Franse jurisprudentie blijkt dat van deze voorwaarde kan worden afgeweken. Echter, een stemovereenkomst van onbeperkte duur kan hier slechts worden gerechtvaardigd door een 'intérêt legitime', zoals het belang van de vennootschap. ${ }^{63}$

Voorts vindt men onder meer in het Engelse, Amerikaanse en Franse recht de notie dat een aandeefhouder zich niet mag binden in ruil voor speciale voordelen of gunsten. ${ }^{64}$

Bovengenoemde criteria kunnen naar mijn mening ook gehanteerd worden als aanknopingspunten bij de beoordeling van stemovereenkomsten in het Nederlandse recht, zij het dat ik terughoudendheid zou willen betrachten ten opzichte van het criterium dat de overeenkomst een beperkte duur dient te hebben. Uit de jurisprudentie van de Hoge Raad blijkt niet dat de

61. Zie M. Jeantin, Les conventions de vote, in het themanummer van de Rev.Jur.Com. (La stabilité du pouvoir et du capital dans les sociétés par actions) 1990, p. 128.

62. Uitgangspunt is dat altijd durende stemovereenkomsten in beginsel niet geldig zijn. Een stemovereenkomst voor een periode van 15 of 20 jaar wordt in het Belgische recht echter wel mogelijk geacht, zie B.C.M. Waaijer, Aandeelhoudersovereenkomsten, Deventer 1996, p. 11.

63. Zie onder meer S. Prat, t.a.p., p. 28.

64. Zie voor het Anglo-Saksische recht bijvoorbeeld P. Finn, Shareholder Agreements, ABLR 1978, p. 99/100, voor het Amerikaanse recht Cary/Eisenberg p. 259. Zie voot het Franse recht art. 440 L. 1966. In zekere zin zijn er altijd 'voordelen' verbonden aan het gebruik van stemovereenkomsten. Vgl. Guyon, Traité des contrats, nr, 288. Vgl. ook H.J. de Kluiver, t.a.p. p. 105/106. Het gaat hier om speciale voordelen waarvoor een aandeelhouder zich bindt, maar dat niet wordt gerechtvaardigd door het gelijkheids. beginsel dat tussen aandeelhouders geldt. 
duur van de stemovereenkomst een factor van betekenis vormt voor de geldigheid daarvan. ${ }^{65}$

Wel blijft mijns inziens gelden het door de Hoge Raad gehanteerde algemene criterium dat een stemovereenkomst niet mag leiden tot maatschappelijk onbetamelijke gevolgen.

Voorts zou ik menen dat op de geoorloofdheid van een stemovereenkoms: mede van invloed is of alle aandeelhouders, of slechts een deel daarvan, daarbij als partij betrokken zijn. Met name indien niet alle aandeelhouders partij zijn bij de stemovereenkomst, bestaat er gevaar van onderdrukking van de minderheid van aandeelhouders en kan de stemovereenkomst mijns inziens ongeoorloofd zijn. Bijvoorbeeld indien een stemovereenkomst wordt gehanteerd door partijen met de bedoeling om andere aandeelhouders schade te berokkenen.

\section{\$2.3 Stemovereenkomsten tussen aandeelhouders en derden nader bezien}

In de praktijk is het soms wenselijk dat uitoefening van het stemrecht wordt bepaald door een ander dan de aandeelhouder. Men denke bijvoorbeeld aan een pandhouder of een geldschieter die een economisch belang heeft bij de aandelen.

Hier kan de vraag worden opgeworpen of een aandeelhouder zich tegenover iedere derde mag verplichten om zijn stem in een bepaalde richting uit te brengen. In $\S 1.1$ heb ik verdedigd dat de redelijkheid en billijkheid paal en perk stelt aan de keuze van een gevolmachtigde door een aandeelhouder. Ik meen dat dit ook geldt bij het aangaan van een stemovereenkomst. Zo'n stemovereenkomst is naar mijn mening ongeoorloofd indien deze wordt aangegaan met een derde die zelf niet mag stemmen (vanwege stemrechtbeperking of ontzegging van stemrecht), maar door middel van aanwijzingen toch (meer) invloed kan uitoefenen op de besluitvorming.

65. $\mathrm{Vgl}$. het Melchers-arrest, HR 13 november 1959, NJ 1960, 473. Hier overwoog de Hoge Raad dat 'het geen verschil maakt, voor welke duur een aandeelhouder zich mocht hebben verbonden'. Zie eveneens H.J. de Kluiver, t.a.p. p. 107. 
Anderzijds heb ik, met De Kluiver, ${ }^{66}$ geen problemen met de situatie waarin een stemovereenkomst wordt gesloten op grond waarvan een aandeelhouder bij de uitoefening van zijn stemrecht de aanwijzingen van een geldschieter moet opvolgen, mits deze geldschieter een economisch belang heeft dat strookt met het belang van de vennootschap, bijvoorbeeld het gezond maken van het bedrijf. Met andere woorden evenals bij stemovereenkomsten tussen aandeelhouders wordt mijns inziens de grens hier mede bepaald door het belang van de vennootschap. ${ }^{67}$

Voorts wordt in de literatuur veelal verdedigd dat een overeenkomst op grond waarvan een aandeelhouder voortdurend overeenkomstig de aanwijzing van een derde moet stemmen nietig is. De achterliggende gedachte is dat zo'n overeenkomst lijkt op een niet geoorloofde vervreemding van het stemrecht. Dit leidt ons tot de vraag of 'vervreemding' van het stemrecht eigenlijk wel in strijd is met het Nederlandse recht. Ik zou dit niet willen onderschrijven.

Het feit dat een aandeelhouder een tegenprestatie ontvangt voor een toezegging aangaande de uitoefening van zijn stemrecht, leidt er mijns inziens op zichzelf niet toe dat de overeenkomst tot maatschappelijke onbetamelijke gevolgen zal leiden. Dit is anders indien zo'n stemovereenkomst beoogt een statutaire of wettelijke blokkeringsregeling te ontduiken. ${ }^{68}$

\section{\$ 2.4 Invloed van stemovereenkomsten op de rechtsverhouding tussen aandeelhouders}

Zoals ik reeds eerder heb verdedigd, staan aandeelhouders tot elkaar in een rechtsverhouding die niet alleen beheerst wordt door de wet en

66. H.J. de Kluiver, Joint ventures en stemovereenkomsten. Een rechtsvergelijkend perspectief, AA 1995, p. 105.

67. Hier doemt een vergelijking met het Duitse recht op. Sommige auteurs achten stemovereenkomsten met derden slechts dan toelaatbaar indien degene die aanwijzings. bevoegdheid verkrijgt voldoende met het belang van de vennootschap is verbonden, en de aanwijzingen niet betrekking hebben op de structuur van de vennootschap. Zie hieromtrent H.J. de Kluiver, Joint ventures en stemovereenkomsten. Een rechtsvergelijkend perspectief, AA 1995, p. 108 en de daar aangehaalden.

68. Ook in de Duitse literatuur wordt algemeen erkend dat langdurige (dauerhafte) stemovereenkomsten die strijdig zijn met de blokkeringsregeling ontoelaatbaar zijn en nietig of grond van $\S 138$ BGB. Vgl. Flume, Die juristische Person, 1983, p. 243 en Karsten Schmidt, Gesellschaftsrecht 1994, p. 457. 
statuten, maar ook door redelijkheid en billijkheid. Indien aandeelhouders een geldige stemovereenkomst sluiten, komt de vraag op in hoeverre deze van invloed is op hun rechtsverhouding. Tevens ontkomt men niet aan de vraag hoe zo'n stemovereenkomst zich verhoudt met de statutaire regeling van een NV of BV. Veelal betreffen die stemovereenkomsten immers onderwerpen die ook statutair geregeld kunnen worden, c.q. aanvullingen op zo'n statutaire regeling.

Voorop staat mijns inziens dat de redelijkheid en billijkheid van art. 2:8 BW met zich brengt dat aandeelhouders hun gedrag mede moeten laten bepalen door de afspraken (waaronder stemovereenkomsten) die zij, buiten de statuten om, met elkaar hebben gemaakt. De rechter zal bij de invulling van de norm van de redelijkheid en billijkheid rekening kunnen houden met afspraken van aandeelhouders. ${ }^{69}$

Een goede illustratie biedt President Rechtbank 's-Gravenhage 9 oktober 1987, KG 1987. 454 Nevesbu. Een aantal werven, Wilton-Feijenoord (WF), de Rotterdamse Droogdokmaatschappij (RDM) en de Koninklijke Maatschappij de Schelde (KMS) richtten een tekenbureau op, genaamd Nevesbu, die zich bezighoudt met het ontwerp- en constructie tekenwerk voor marineschepen. Vanaf haar oprichting heeft Nevesbu het karakter van een joint venture en is dienstbaar aan de oprichtende venootschappen die tevens haar aandeelhouders zijn.

WF vraagt Nevesbu hulp bij het uitwerken van een voorstel met betrekking tot de aanbouw van een ontwerp-onderzeeboot bestemd voor Canada. Nevesbu laat WF in de eerste plaats weten dat zij een exclusieve samenwerkingsovereenkomst is aangegaan met RDM om een nieuwe generatie onderzeeboten te ontwikkelen. In de tweede plaats stelt Nevesbu dat het aanvaarden van de opdracht van WF afhankelijk is van beraad in de algemene vergadering van aandeelhouders. WF eist in een kort geding procedure dat Nevesbu een bevel krijgt om

69. De uitspraak van de OK van 9 maart 1989, rekestnr. 55/88 wijst ook in die richting. De ondernemingskamer overweegt dat: 'indien een andere of andere aandeelhouders aan een wijziging van die afspraak niet wensen mee te werken, dat afhankelijk van de omstandigheden een onredelijk dan wel onbillijk gedrag kan opleveren'. Een andere relatie die mede beheerst wordt door de redelijkheid en billijkheid is de relatie tussen ondernemer en ondernemingsraad, ook al is dit niet expliciet vermeld in de Wet op de Ondernemingsraden (WOR). Vgl. onder meer het IKON-arrest, OK 26 november 1987, NJ 1989. 271. De Sociaal Economische Raad (SER) is van oordeel dat de 'redelijkheid en billijkheid onder meer met zich meebrengt dat ondernemer en ondernemingsraad, behoudens bijzondere omstandigheden, over en weer van elkaar moeten kunnen verlangen dat zij zich zullen houden aan vrijwillig gemaakte afspraken en toezeggingen, voorzover althans deze zich verdragen met de inhoud en het rechtskarakter van de wettelijke bepalingen.' 
teken- en rekenopdrachten van WF te aanvaarden, of aandeelhouders daarmee nu instemmet of niet.

Deze eis wordt door de president verworpen, daar voor rechtshandelingen waarvan he: belang of de waarde van de vennootschap de grens van tweehonderdvijftigduizend gulden te boven gaat, zoals het aanvaarden van opdrachten als die van WF, de statuten machtiging o goedkeuring van de algemene vergadering vereisen.

Eén van de verplichtingen die voor de aandeelhouders uit het samenwerkingsverban voortvloeien, bestaat uit het bevorderen dat Nevesbu teken- en rekenopdrachten var aandeelhouders aanvaardt. De omstandigheid dat Nevesbu een exclusieve overeenkomst heef gesloten met RDM doet daar niet aan af, volgens de president. Hij overweegt: "het staa Nevesbu en RDM in hun verhouding tot de andere aandeelhouders niet vrij inbreuk te maker op rechten van aandeelhouders op aanvaarding van hun opdrachten. Die rechten zijn sterker dan de rechten en verplichtingen van Nevesbu en RDM uit hun exclusieve overeenkomst (curs. MK).

Het is alleszins verdedigbaar dat indien uit het samenwerkingsverband van aandeelhouders rechten en verplichtingen voortvloeien, aandeelhouders daar niet ten nadele van één van hen mogen afwijken door middel van het sluiten van een overeenkomst. Dat levert strijd op met de redelijkheid en billijkheid die aandeelhouders onderling moeten betrachten. ${ }^{70}$

Overigens heef mijns inziens een stemovereenkomst oak in de rechtobetrekking van een aandeelhouder met een derde invloed. Het in art. 6:162 BW genoemde criterium van de maatschappelijke zorgvuldigheid wordt mede ingevuld door overeenkomsten.

\section{§ 2.5 Stemovereenkomsten en (toekomstige) aandeelhouders}

Met De Kluiver"1 ben ik van mening dat stemovereenkomsten het zicht op de werkelijke machtsverhoudingen kunnen versluieren, en dus onduidelijkheid kan creëren bij andere aandeelhouders en bij derden die overwegen in een BV te participeren. Teneinde dit risico te beperken, geeft De Kluiver in overweging dat het bestaan van stemovereenkomsten tussen aandeelhouders, waarbij niet alle aandeelhouders zijn betrokken, inclusief stemovereenkomsten met derden, dienen te worden gemeld bij het handelsregister. Indien het gaat om stemovereenkomsten waarbij alle aandeelhouders partij zijn, dan dienen, volgens De Kluiver, de potentiële

70. Zie ook H.J. de Kluiver in: Verslag van de vergadering van de vereniging 'Handelsrecht' op 26 april 1991 over De nieuwe algemene bepalingen van boek 2 BW, p. 49.

71. H.J. de Kluiver, Joint ventures en stemovereenkomsten. Een rechtsvergelijkend perspectief, AA 1995, m.n. p. 106 en 113. 
aandelhouders over het bestaan en de inhoud van de stemovereenkomst te worden geïnformeerd. Ik ben met dit voorstel niet helemaal gelukkig.

Weliswaar kan ik met De Kluiver instemmen dat publiciteit inzake stemvvereenkomsten gewenst is voorzover met name potentiële aandeelhouders trachten een belang te verwerven bij de vennootschap, maar een zodanige wettelijke voorziening roept ook vragen op. Allereerst kan men zich afvragen of zo'n voorziening wel wenselijk is met betrekking tot BV's. In hoeverre kunnen minderheidsaandeelhouders hun positie in de ava nog versterken indien zij stemovereenkomsten openbaar moeten maken? Anders is dit in publieke (beursgenoteerde) vennootschappen. Met name bij dit soort vennootschappen zullen stemovereenkomsten veelal worcen gesloten met het doel een belang te verwerven bij de vennootschap en is transparantie van de verhoudingen binnen de vennootschap mijns inziens wenselijk. Ik meen dat hier een vergelijking kan worden getrokken met de meldingsplicht in het kader van de Wet Melding Zeggenschap. ${ }^{n}$ Men kan mijns inziens immers betogen dat ook het verwerven van invloed in de vennootschap langs contractuele weg, zonder gelijitijdige participatie in het kapitaal van de vennootschap, openbaar moet worden gemaakt. Deze gedachte vindt men terug in het Franse recht. $^{73}$

Voorts kan men zich afvragen hoe bijvoorbeeld op de nakoming van de verplichting tot aanmelding zal moeten worden toegezien? ${ }^{74}$

In het Engelse recht maakt section 380 (5) Companies Act 1985 het niet aanmelden van stemovereenkomsten tot een strafbaar feit waarvoor een boete wordt opgelegd aan de vennootschap en aan diegenen die de overeenkomst moeten aanmelden. Dit doet echter niet af aan de geldigheid van de stemovereenkomsten. In het Franse recht kan de rechtbank van koophandel (tribunal de commerce) op verzoek van het openbaar ministerie, de Président van de vennootschap, een aandeelhouder of de Commission des óperations de bourse (COB)

72. Zie hieromtrent H.M. Vletter-van Dort, Meldingsplicht voor beursvennootschappen, Deventer 1994.

73. In het Franse recht bestaat een meldingsplicht van aandelenbelang in geval er sprake is van een 'action de concert' in de zin van art. 356-1-3 L. 1966. In de daar beschreven gevallen wordt een stemovereenkomst vermoed. $\mathrm{Vgl}$. ook art. 5-1-1 van de OPA (Offres Publiques d'Acquisition). Zie hieromtrent onder meer P. Le Cannu. L'action de concert, Rev.Soc. 1991 , p. 675 e.v.

74. Zie in dit verband ook A.M. Brenninkmeijer, Stemovereenkomsten van aandeelhouders, Kluwer 1973, p. 219. 
beslissen dat de aandeelhouder die zijn belang niet aanmeldt, geschorst wordt in de uitoefe. ning van zijn stemrecht (art. 356-4 L. 1966).

Om de naleving van de melding van stemovereenkomsten te verzekeren zou men, voorzover het beursvennootschappen betreft, kunnen denken aan een overeenkomstige toepassing van de regeling van de WMZ.

Krachtens art. 13 lid 4 WMZ kunnen op verzoek van de vennootschap of één of meer aandeelhouders die alleen of ten minste $5 \%$ van het geplaatste kapitaal vertegenwoordigen door de rechtbank civielrechtelijke sancties worden opgelegd, zoals schorsing van het steinrecht.

\section{§ 3. Slotbeschouwing}

Aandeelhouders maken in de praktijk veel gebruik van volmachten en stemovereenkomsten. Wat betreft de volmacht heb ik enerzijds aandacht besteed aan de problemen rond de volmachtverlening die zich voor kunnen doen in alle soorten vennootschappen. Anderzijds heb ik, gezien de Nederlandse ontwikkelingen inzake de invoering van 'proxy solicitation', stil gestaan bij praktijken rond volmachtverwerving in publieke beursgenoteerde vennootschappen. Bij het bezien van de problemen die zich kunnen afspelen rond het verlenen en verwerven van volmachten heb ik mij met name geconcentreerd op het gedrag van een gevolmachtigde.

Het 'inschakelen' van gevolmachtigden roept de vraag op welke normen het gedrag van een gevolmachtigde beheersen. Met de voorziene komst van 'proxy solicitation' in ons land rijst tevens de vraag of het actief werven van volmachten door een gevolmachtigde gevolgen heeft voor de aansprakelijkheid. In dit hoofdstuk heb ik getracht een aanzet tot beantwoording van die vragen te geven.

De (contractuele) redelijkheid en billijkheid welke geldt in de rechtsverhouding tussen de gevolmachtigde en de volmachtgever leidt mijns inziens tot een tweetal gedragsregels. De eerste regel is dat de gevolmachtigde in geval van een mogelijk tegenstrijdig belang de gevolmachtigde hieromtrent dient te informeren voorafgaande aan de uitoefening van de vergader- en/of stemrechten. De tweede gedragsregel is een overlegverplichting van de gevolmachtigde jegens de volmachtgever. Deze gedragsregels dragen bij aan de uitoefening van de vergader- en stemrechten conform de wensen en belangen van de opdrachtgever.

In mijn optiek is het gedrag van een gevolmachtigde ook onderworpen aan de redelijkheid en billijkheid van art. 2:8 BW. Dit impliceert dat de 
gevolmachtigde ook rekening dient te houden met de belangen van de overige betrokkenen bij de organisatie. De mate van verantwoordelijkheid hangt af van de invloed die een gevolmachtigde kan uitoefenen op het besluitvormingsproces. Hoe meer invloed, hoe meer verantwoordelijkheid en, daaraan gekoppeld, aansprakelijkheid. Een aantal factoren bepalen die invloed. Een belangrijke factor is het actief verwerven van volmachten. Indien nadien schade ontstaat door 'toedoen' van de gevolmachtigde, kan het verdedigbaar zijn om 'af te rekenen' met de gevolmachtigde zelf.

Voorts heb ik in dit hoofdstuk getracht criteria te formuleren voor de beoordeling van stemovereenkomsten. Het nut daarvan staat buiten kijf. ${ }^{75}$ De problematiek inzake de geoorloofdheid van stemovereenkomsten wordt, bij gebrek aan een wettelijke regeling, beheerst door de norm van redelijkheid en billijkheid. Een aantal criteria dat in het buitenlandse recht gehanteerd wordt voor de geoorloofdheid van stemovereenkomsten, kan als aanknopingspunt dienen bij de beoordeling van stemovereenkomsten in het Nederlandse recht. Het gaat dan met name om het belang van de vennootschap. Dit past ook bij de heersende visie dat een aandeelhouder ook andere belangen dan zijn eigen belang in zijn stemoverweging dient te betrekken. ${ }^{76}$

Wel zal naar mijn mening mede in aanmerking moeten worden genomen of alle aandeelhouders, of slechts een deel daarvan, betrokken zijn als partij bij een stemovereenkomst. Hier rijst ook het gevaar dat de werkelijke machtsverhoudingen in een kapitaalvennootschap voor sommige aandeelhouders en derden, die, overwegen te participeren in de vennootschap, verborgen blijven. Een wettelijke meldingsplicht verbonden aan stemovereenkomsten zou hiervoor een oplossing kunnen bieden, zoals bijvoorbeeld in Frankrijk het geval is. Vooralsnog meen ik echter dat een meldingsplicht alleen wenselijk is indien het stemovereenkomsten betreft in beursgenoteerde vennootschappen.

75. $\mathrm{Vgl}$. onder meer A.L. Mohr, Spijkers. Ondernemingsrecht op de breuklijn van praktijk en wetenschap, (oratie Amsterdam), Arnhem 1993, p. 8 e.v., B.C.M. Waaijer, Aandeelhoudersovereenkomsten, Deventer 1996, p. $2 / 3$ en Asser-Maeijer 2-III, nr. 286.

76. Zie Van Schilfgaarde, Van de BV en NV, nr 67, L. Timmerman, TVVS 1975, p. 246/247. J.M.M. Maeijer, De stemovereenkomst van aandeelhouders, in: Van der Ploeg-bundel 'Recht zo die gaat', p. 101/102. Th.C.M. Hendriks-Jansen, Stemovereenkomsten, De NV 1982, p. 6 e.v. en J.L.P. Cahen, De invloed van de belangenverbreding op het handelen van de aandeelhouder, in: Honderd jaar rechtsleven, Zwolle 1970, p. 71 e.v. 



\section{Statutenwijziging}

\section{\$1. Inleiding}

Statuten leggen de identiteit en de structuur van de vennootschap vast en regelen, binnen de grenzen die de wet toelaat, de bevoegdheden, rechten en verplichtingen van de organen van de vennootschap en de houders van aandelen en andere effecten jegens elkaar. Een statutenwijziging kan dus een ingrijpende wijziging in de organisatie bewerkstelligen. Voorts kunnen statuten nadere eisen stellen aan de wijze van totstandkoming van besluiten. De bevoegdheid tot wijziging van de statuten berust bij een BV en NV uitsluitend bij de ava (vgl. artt. 2:121/231 BW). Zij kan op deze wijze de door haar gewenste invloed uitoefenen op de structuur van de vennootschap.

In beginsel zijn de minderheidsaandeelhouders onderworpen aan de beslissingen van de meerderheid.' Bescherming vinden zij echter in toetsing door de rechter van een besluit tot statutenwijziging aan wet, statuten en redelijkheid en billijkheid. Eventueel kan zelfs de weigering van een meerderheidsaandeelhouder om mee te werken aan een statutenwijziging, afhankelijk van de omstandigheden, jegens een minderheidsaandeelhouder in strijd zijn met de redelijkheid en billijkheid en/of wanbeleid opleveren in de zin van art. 2:350 lid $1 \mathrm{BW} .^{2}$

1. Ongeacht of de minderheidsaandeelhouders al dan niet aan de statutenwijziging hebben meegewerkt. Aanvankelijk heerste de gedachte dat statutenwijziging alleen mogelijk was indien men gezamenlijk de statuten wijzigde; men zag de statuten als een obligatoir contract. Dit standpunt werd in de jaren ' 50 verlaten, zie W.J.M. Noldus, Ongeldigheid van besluiten in de naamloze vennootschap, Deventer 1969. Vergelijk de jurisprudentie met betrekking tot coöperatieve verenigingen HR 29 november 1923, NJ 1924, p. 129 , en HR 3 november 1927, NJ 1928, p. 397: 'de leden zijn gebonden aan de statutenwijziging onverschillig of zij al dan niet aan die statutenwijziging hebben meegewerkt'. In de statuten kan echter wel een bepaling worden opgenomen waarbij de statuten slechts bij unaniem besluit van de ava kunnen worden gewijzigd. Waaijer bepleit zulks voor de BV in zijn dissertatie Statuten en statutenwijziging, Deventer 1993, p. 72.

2. HR 9 juli 1990, NJ 1991, 51 (Sluis BV), besproken door M.J.G.C. Raaijmakers in AA 40 (1991), p. 83. Zie ook Th.S. Usselmuiden in TVVS 1990, p. 314-316. Zie ook hoofdstuk $6 \& 4$. Het omgekeerde is ook mogelijk. Gedragingen van een (gegadigde) minderheidsaandeelhouder die zeggenschap heeft binnen de vennootschap of wenst te verkrijgen, kunnen de grondslag vormen voor twijfel aan een juist beleid. Vgl. Gerechtshof Amsterdam (OK) 27 mei 1999, JOR 1999, 121, NJ 1999, 487 (Gucci IV). 
Bij de toetsing van een besluit tot statutenwijziging aan de redelijkheid en billijkheid staat voorop dat rekening moet worden gehouden met de 'gerechtvaardigde' belangen van betrokkenen. De financiële en/of zeggenschapsbelangen van de minderheid kunnen door een statutenwijziging zodanig in het gedrang komen dat de meerderheid deze moet ontzien. Maar de belangen van de meerderheid kunnen een statutenwijziging ook juist rechtvaardigen. In dit hoofdstuk tracht $\mathrm{ik}$, met name aan de hand van jurisprudentie, enig inzicht in deze problematiek te verschaffen.

\section{§ 2. Gevolgen: aantasting belangen minderheid}

Voor de beantwoording van de vraag of de belangen van de meerderheid een besluit tot statutenwijziging rechtvaardigen is naar mijn mening van groot belang of de wijziging van de statuten meer of minder ingrijpende gevolgen voor de minderheidsaandeelhouder(s) met zich meebrengt. Hierbij moet naar mijn mening in de beschouwing worden betrokken dat statutenwijzigingen minderheidsaandeelhouders op verschillende wijzen kunnen benadelen.

Enerzijds zijn er statutenwijzigingen die de rechtspositie van een aandeelhouder direct ongunstig kunnen beïnvloeden als deze een wijziging in de rechten en verplichtingen van een aandeelhouder meebrengen of een wijziging in de onderlinge verhouding van de rechten verbonden aan de verschillende soorten aandelen (aantasting formele positie). Men kan dan bijvoorbeeld denken aan een statutenwijziging in een NV met op naam genoteerde aandelen waarbij alsnog een blokkeringsregeling wordt opgenomen, of aan een statutenwijziging in een BV waarbij de kring van personen aan wie aandelen zonder inachtneming van de blokkeringsregeling kunnen worden overgedragen, statutair beperkt of zelfs uitgesloten wordt.

Anderzijds zijn er besluiten tot statutenwijziging die formeel geen wijziging brengen in de rechten en verplichtingen van aandeelhouders, maar dezen feitelijk wel direct kunnen benadelen. Indien aandeelhouders bijvoorbeeld volgens de statutaire bepalingen omtrent de winstverdeling recht hebben op een bepaald percentage dividend, blijft dit recht onaangetast door een statutenwijziging waardoor voortaan vóór uitkering aan aandeelhouders eerst een reserve moet worden aangelegd. Een feitelijke vermindering van dividend is echter wel het gevolg (aantasting materiële 
positie). ${ }^{3}$ Men denke ook aan een besluit tot statutenwijziging dat nadeel toebrengt aan aandeelhouders, doordat bijvoorbeeld de mogelijkheid wordt geschapen voor een emissie of een fusie.

In het geval dat de minderheid nadelige gevolgen ondervindt van een statutenwijziging, verdedig ik hierna dat als uitgangspunt kan gelden dat daarvoor een 'goede grond' aanwezig moet zijn. Dit is mijns inziens anders wat betreft statutenwijzigingen waarbij de belangen van minderheidsaandeelhouders niet in het gedrang komen, zoals wijziging van de statutaire naam van een vennootschap. Zo'n statutenwijziging is ook zonder 'goede grond' niet onredelijk en onbillijk. Hetzelfde zou ik willen verdedigen ten aanzien van statutenwijzigingen die weliswaar aandeelhouders 'benadelen', maar waarbij zij vervolgens financieel of anderszins worden gecompenseerd (curs. MK)."

\section{\$3. Goede grond of compensatie}

Bij de beoordeling van de geoorloofdheid van een door de meerderheid genomen besluit tot statutenwijziging verdedig ik, gelijk gezegd, dat uitgangspunt zou kunnen zijn dat, wanneer de belangen van de minderheid daadwerkelijk worden aangetast, de beslissing van de meerderheid moet berusten op een 'goede' grond. De vraag rijst dan natuurlijk wat een 'goede' grond is. Deze vraag is niet eenvoudig te beantwoorden.

Uit de rechtspraak kan worden afgeleid dat in ieder geval sprake is van een goede grond voor een besluit tot, statutenwijziging indien wezenlijke belangen van de vennootschap daartoe aanleiding geven. ${ }^{5}$ Aanpassing aan maatschappelijke veranderingen en economische ontwikkelingen, die vaak een ingrijpende wijziging in de organisatie van de vennootschap vereisen, kan een statutenwijziging noodzakelijk maken. Zo kan een statutenwijziging de mogelijkheid openen voor een fusie of een uitbreiding van de werkzaamheden van de vennootschap (beide bijvoorbeeld door vergroting van het maatschappelijk kapitaal). De meerderheidsaandeelhouders kunnen ook besluiten de statutaire doelstelling van de vennootschap of een

3. $\mathrm{Vgl}$. G. Suetens-Bourgeois, De verhouding meerderheid minderheid in de naamloze vennootschap, Gent-Leuven 1970, p. 51.

4. Zie over compensatie ook M.M. Mendel, Stemrecht, minderheidsaandeelhouders en ongelijkheidscompensatie, in: Ongelijkheidscompensatie als roode draad in het recht, Deventer 1997, p. 207 e.v.

5. Vgl. bijv. Rb Leeuwarden 3 februari 1988, KG 1988, 200 (Lampe/Tonnema). 
statutaire blokkeringsregeling te wijzigen, indien zij menen dat dit met het oog op de continuiteit en voortbestaan van de vennootschap nodig is. ${ }^{6}$

Een goede grond kan bijvoorbeeld ontbreken indien de meerderheid bij het nemen van het besluit tot statutenwijziging uitsluitend rekening houdt met het eigen belang' of het besluit tot statutenwijziging de strekking heeft de belangen van een meerderheidsaandeelhouder eenzijdig te dienen. ${ }^{8}$

Voorts ontbreekt mijns inziens een goede grond voor een statutenwijziging indien deze als maatregel wordt gebruikt ter oplossing van een conflict tussen aandeelhouders, terwijl daarvoor andere geschikte middelen aanwezig zijn. ${ }^{9}$

6. Opgemerkt moet worden dat een statutenwijziging vaak geschiedt op voorstel van het bestuur of de raad van commissarissen. De ava heeft het recht wijzigingen in zo'n voorstel aan te brengen, maar die wijzigingen moeten dan wel in verband staan met het voorstel tot wijziging van de statuten dat aan haar door het bestuur of de raad van commissarissen is voorgelegd (vgl. \&4 Departementale Richtlijnen).

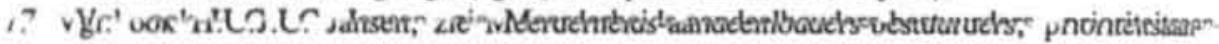
deelhouders en fusie, in De NV 1973, p. 4. Als voorbeeld kan dienen Hof Amsterdam 22 februari 1940, NJ 1940, 779. Het hof overweegt: 'dat blijkens de overwegingen van het vonnis het groepsbelang, dat de Rechtbank op het oog heeft, het belang is van commissarissen tevens houders van een belangrijke portie aandelen, terwijl onder het eenzijdig dienen van dat groepsbelang klaarblijkelijk is verstaan de opoffering, in strijd met de eisen van goede trouw en betamelijkheid, van de belangen der overige aandeel. houders en zelfs van de vennootschap aan de inhaligheid van bedoelde groep, als gevolg van een door machtsmisbruik van deze groep tot stand gekomen besluit der vergadering van aandeelhouders'.

8. Een goede grond ontbreekt uiteraard ook indien sprake is van misbruik van recht, c.q. misbruik van bevoegdheid. Men denke aan het geval dat de statutenwijziging plaatsvindt met als enig doel het frustreren van de rechten van de minderheidsaandeelhouder. Vgl. Pres. Rb Haarlem 8 mei 1990, KG 1990, 247, ook besproken door W.J. Slagter in TVVS 1991, p. 102. Art. 3: 13 lid 2 BW bepaalt onder meer dat een bevoegdheid kan worden misbruikt door haar uit te oefenen met geen ander doel dan een ander te schaden. $\mathrm{Vgl}$. ook hoofdstuk 1 \$ 9 . Als criterium voor misbruik van recht wordt in de rechtspraak en literatuur ook aanvaard het ontbreken van 'enig redelijk belang'. Het bepalen van de 'redelijkheid' van het belang hangt onder meer af of er sprake is van een 'redelijk' motief; zie P. Rodenburg. Misbruik van bevoegdheid, Serie Monografieth NBW, deel 4A. Deventer 1985, p. 45-47.

9. Deze gedachte blijkt bijvoorbeeld uit Hof 's-Gravenhage 17 maart 1983, NJ 1984, 81 (Reijnders/McKinney), reeds besproken in hoofdstuk 3 \& 3 . Het gaat hier weliswaar niet om een statutenwijziging. maar wel om een emissiebesluit dat de kern van de samenwerking raakt en is in zoverre met een statutenwijziging te vergelijken. In deze zaak besluit de directeur $/ 50 \%$-aandeelhouder Reijnders op het moment dat zijn mede-aandeel- 
Voc het beantwoorden van de vraag of het ontbreken van een goede grot voor een besluit tot statutenwijziging strijd oplevert met de redelijkheicen billijkheid is mijns inziens mede van belang of en in hoeverre minerheidsaandeelhouders worden gecompenseerd. ${ }^{10}$ Een en ander han! samen met de mate waarin minderheidsaandeelhouders in hun belagen worden aangetast en of het financiële en/of zeggenschapsbelangen betreft. Een nadeelcompensatie voor verlies aan zeggenschap zou bijvorbeeld kunnen inhouden dat aandeelhouders het recht krijgen om tege een goede prijs te worden 'uitgekocht' of het recht krijgen om tegen een antrekkelijke prijs aandelen te kopen."

Menkan hier een vergelijking maken met het wetsontwerp beschermingsconstructies. Volgis dit wetsvoorstel kan een aandeel- c.q. certificaathouder die tenminste $70 \%$ van het kapitl verschaft, de Ondernemingskamer verzoeken maatregelen te treffen die erop gericht zijn eschermingsconstructies ongedaan te maken. Art. $359 \mathrm{~h}$ lid 2 van het wetsontwerp bepat dat de ondernemingskamer aan de toewijzing van het verzoek voorwaarden kan verbiden. Een voorbeeld van zo'n voorwaarde is dat de verzoeker de gezamenlijke andere aandlthouders een bod doet tot verwerving van hun aandelen (zie lid 2). Een ander

houder van de overige $50 \%$, McKinney, op vakantie is een vergadering bijeen te roepen teneinde aandelen uit te geven en bij hem te plaatsen waardoor hij de macht verkrijgt. Het hof oordeelt dat Reijnders de vergadering had moeten verdagen, aangezien het geen dringend agendapunt betrof.

10. Dit was een factor van belang in de enquêteprocedure LVMH - Gucci waarbij onder meer de Vereniging van Effecten Bezitters (VEB) en haar Franse equivalent Association Pour La Défense Des Actionnaires Minoritaires (ADAM) zich als belanghebbenden hebben gevoegd. De minderheidsaandeelhouders stelden ernstig in hun belangen te zijn geschaad, daar geen openbaar bod plaatsvond door LVMH of PPR. De OK overwoog echter op 27 mei 1999, JOR 1999, 121, NJ 1999, 487: 'Hoewel niet valt uit te sluiten dat indien overeenkomstig hun wens de voorziening zou worden getroffen dat zowel LVMH als PPR een openbaar bod zouden dienen te doen op alle uitstaande aandelen van Gucci Group NV hun (onder meer financieel) belang het meest zou worden gediend, niettemin valt op te merken dat de gedragingen van LVMH en het aangaan door Gucci van een strategisch samenwerkingsverband met PPR in ieder geval (mede) oorzaak zijn geweest van een hogere beurskoers van de aandelen in Gucci Group NV en daarmee van enig financieel voordeel voor alle (minderheids)aandeelhouders. Dit vermag de door VEB en ADAM voorgestelde voorzieningen niet te rechtvaardigen, aldus de $\mathrm{OK}$.

11. In dit kader neem ik de stelling in dat in een publieke vennootschap met een groot verspreid aandelenkapitaal slechts een financièle compensatie mogelijk en haalbaar is. In besloten vennootschappen kan dit anders zijn. Men zou in het kader van een samenwerking (fusie) een minderheidsaandeelhouder bijvoorbeeld het recht kunnen toekennen om een bindende voordracht te doen voor de benoeming van één of meer bestuurders. 
voorbeeld is dat degene die door een maatregel wordt getroffen schadeloos wordt gesteld door de verzoeker. ${ }^{12}$

Alvorens ik een en ander aan de hand van besluiten tot wijziging van een blokkeringsregeling en wijzigingen met betrekking tot het stemrecht illustreer, begeef ik mij op het terrein van het buitenlandse recht.

\section{§ 4. Duitsland, Engeland en Frankrijk}

\section{§4.1 Duitsland}

Ook in Duitsland vindt men de gedachte dat besluiten die de belangen van de minderheid raken een rechtvaardiging behoeven. Aangenomen wordt dat voor meerderheidsbesluiten, die een wijziging van de statuten of structuur van de vennootschap ten gevolge hebben, een 'sachliche Grund' vereist is.

Als uitgangspunt voor een inhoudelijke toetsing van besluiten geldt in het Duitse recht de uitspraak van het BGH inzake Kali \& Salz. ${ }^{13}$ Naar aanleiding van deze zaak is in Duitsland de discussie ontstaan omtrent de reikwijdte van de 'Sachkontrolle' van meerderheidsbesluiten. $^{14}$ In Kali \& Salz wordt een besluit tot uitsluiting van het voorkeursrecht van bestaande aandeelhouders in het kader van een kapitaalverhoging getoetst. Het BGH oordeelt dat een besluit dat zwaar ingrijpt in de rechtspositie van de aandeelhouders een 'sachliche rechtfertigung' behoeft en overweegt; 'das der Ausschluß des Bezugsrechts bei einer Kapitalerhöhung nur zulässig ist, wenn er aus der Sicht im Zeitpunkt der Beschlußfassung auch bei gebührender Berücksichtigung der Folgen für die ausgeschlossenen Aktionäre durch sachliche Gründe im Interesse der Gesellschaft gerechtfertigt ist'. Dit betekent dat zo'n

12. Zie S.E. Eisma, Wetsontwerp beschermingsconstructies (II), WPNR 1998, p. 99. Kritisch daarover juist vanuit het perspectief van minderheidsbescherming is H.J. de Kluiver in zijn oratie Machtsstrijd en machtsovername in kapitaalvennootschappen, Deventer 1996, p. 40 e.v.

13. BGH 13-3-1978, BGHZ 71, p. 40. Zie in navolging hiervan OLG München 24 maart 1993, die AG 1993, 283 (Siemens).

14. De heersende opvatting in het Duitse recht is dat de 'Treupflicht' de grondslag vormt voor de toetsing van de inhoud van besluiten. Vgl. onder meer W. Zöllner, Die Schranken mitgliedschaftlicher Stimmrechtsmacht bei privatrechtlichen Personenverbânden, München 1963, p. 349 e.v., M. Lutter, Theorie der Mitgliedschaft, AcP 1980, p. 124. H. Wiedemann, $\mathrm{Zu}$ den Treuepflichten im Gesellschaftsrecht, in: FS Heinsius 1991, p. 962, M. Piepenburg, Mitgliedschaftliche Treupflichten der Aktionăre, Hamburg 1996, p. 285 en M. Winter. Mitgliedschaftliche Treuebindungen im GmbH-Recht. München 1988, p. 130 e.v. 
besluit gerechtvaardigd moet zijn met het oog op het belang van de vennootschap. Het BGH formuleert vanuit dat perspectief twee criteria waaraan het besluit tot uitsluiting van voorkeursrecht moet worden getoetst, te weten de 'erforderlichkeit' en 'verhältnismäßigkeit'. Het eerste criterium impliceert dat het besluit het enige geschikte middel is om het doel te bereiken. Het tweede criterium komt neer op een afweging tussen enerzijds de voordelen van het besluit voor de vennootschap (dus het belang van de vennootschap) en anderzijds de gevolgen van het besluit voor de minderheidsaandeelhouders. Een besluit is niet verhalttnismäßig indien de nadelen van het besluit voor (minderheids)aandeelhouders onevenredig groter zijn dan de voordelen die het besluit oplevert voor de vennootschap.

Deze uitspraak van het BGH inzake Kali \& Salz heeft in de literatuur de discussie geïntensiveerd over de vraag welke besluiten een 'sachliche rechtfertigung' behoeven. Twee visies kunnen worden onderscheiden. ${ }^{\text {is }}$ De eerste visie is dat elk meerderheidsbesluit met betrekking tot een wijziging van de statuten of structuur van de vennootschap (zgn. Strukturänderungen) 'erforderlich' en 'verhältnismäßig' moet zijn. ${ }^{16}$ De tweede visie gaat uit van een tweedeling in de zgn. 'structuurbesluiten'. Enerzijds wordt dan verdedigd dat er besluiten zijn die getoetst moeten worden aan de door het BGH geformuleerde criteria en anderzijds dat er besluiten zijn die krachtens de wet of wegens de inhoud daarvan zijn vrijgesteld. ${ }^{17}$ Tot de laatste categorie behoort bijvoorbeeld een ontbin-

15. Vgl. hieromtrent onder meer H. Henze, Materiellrechtliche Grenzen fur Mehrheitsentscheidungen im Aktienrecht (Teil II), DstR 1993, p. 1867/1868; M. Winter, Mitgliedschaftliche Treuebindungen im GmbH-Reoht, Munchen 1988, p. 133 e.v. en M. Piepenburg, Mitgliedschaftliche Treupflichten der Aktionare, Hamburg 1996, p. 276 en p. 280-284.

16. $\mathrm{Vgl}$. met name $\mathrm{H}$. Wiedemann, $\mathrm{Zu}$ den Treuepflichten im Gesellschaftsrecht, in FS Th. Heinsius, 1991, p. 952 en in Rechtsethische Maßstăbe im Unternehmens- und Gesellschaftsrecht, ZGR 1980, p. 157; K-P. Martens, Zum Interesse an wirtschaftlicher Selbständigkeit, FS Fischer, 1979, p. 445; Th. Bischoff, Sachliche Voraussetzungen von Mehrheitsbeschlüssen in Kapitalgesellschaften, BB 1987, p. 1057 en W. Zöllner, Die Schranken mitgliedschaftlicher Stimmrechtsmacht bei privatrechtlichen Personenverbănden, München 1963, p. 318. Wiedemann is hierbij de mening toegedaan dat voor wat betreft de bewijslast wel een onderscheid gemaakt moet worden tussen besluiten die direct dan wel indirect ingrijpen in de rechtspositie of deelname van de minderheidsaandeelhouders. Hij stelt voor om in het geval dat besluiten direct ingrijpen in de positie van de minderheid, zoals stemrechtbeperkingen, de bewijslast bij de meerderheid te leggen. Vgl. FS Heinsius p. 964 e.v.

17. Zie M. Lutter, Zur inhaltlichen Begründung von Mehrheitsentscheidungen-Besprechung der Entscheidung BGH WM 1980, 378, ZGR 1981, p. 171 e.v. en W. Timm. Der Mißbrauch des Auflösungsbeschlusses durch den Mehrheitsgesellschafter, JZ 1980, p. 665 e.v. Naast de twee visies zijn er ook nog andere afwijkende meningen. Hirte 
dingsbesluit. Als argument daarvoor wordt onder meer gebruikt dat in dit kader reeds wettelijke regels bestaan met het oog op bescherming van minderheidsaandeelhouders. ${ }^{18}$ Ook kan men denken aan een besluit tot statutenwijziging, waarbij de belangen van minderheidsaandeelhouders niet in het gedrang komen, zoals een zetelverplaatsing. In geval van dergelijke besluiten kan slechts worden getoetst of sprake is van misbruik van recht of strijd met het gelijkheidsbeginsel. ${ }^{19}$

\section{\$ 4.2 Engeland}

Krachtens het Engelse common law vindt slechts een beperkte toetsing van besluiten tot statutenwijzigingen plaats. Als uitgangspunt bij de beoordeling van een statutenwijziging geldt het dictum van Lindley MR in Allen v. Gold Reefs of West Africa Ltd ${ }^{20}$ dat deze 'must be exercised, not only in the manner required by law, but also bona fide for the benefit of the company as a whole'.

De statuten van de vennootschap bevatten een bepaling die toestond dat de vennootschap een pandrecht verkreeg op niet-volgestorte andejen van aandeelhouders, die schulden hadden jegens de vennootschap. Zuccani had zowel niet volgestorte aandelen als volgestorte aandelen. Aangezien na zijn overlijden bleek dat de nalatenschap onvoldoende was om alle crediteuren te voldoen, besloot de ava de statuten zo te veranderen dat ook op volgestorte aandelen een pandrecht verkregen werd. De erfgenamen van Zuccani stelden dat er sprake was van een 'oppressive' besluit en dat zij hierdoor benadeeld werden. Zuccani was namelijk de enige aandeelhouder met volgestorte aandelen. Lord Lindley oordeelde hierover dat weliswaar 'the power thus conferred on companies to alter the regulations contained in their articles is limited only by the provisions contained in the statutes and the conditions

bijvoorbeeld is van mening dat alleen besluiten die ingrijpen in de machtsverhoudingen van een vennootschap een toetsing aan de 'erforderlichkeit' en verhältnismäßigkeit behoeven. Zie H. Hirte, Bezugsrechtsausschluß und Konzernbildung. Minderheitenschutz bei Eingriffen in die Beteiligungsstruktur der Aktiengesellschaft, Köln 1986, p. 138 e.v.

18. Zo kan een minderheidsaandeelhouder aanspraak maken jegens de moedervennootschap op 'Abfindung' (uitkoop) of 'Ausgleich' in geval hun vennootschap wordt opgenomen in een concern. $\mathrm{Vgl}$. de regeling in $\S 305 \mathrm{AktG}$. Zie tevens T. Sonnenberg, Die Änderung des Gesellschaftszwecks, Frankfurt am Main 1990, p. 143/144.

19. Het gelijkheidsbeginsel is overigens alleen wat betreft de AG verankerd in de wet $(\$ 53$ a AktG), voor GmbH's wordt dit beginsel in de jurisprudentie aangenomen op grond van de Treupflicht. Vgl. M. Winter, Mitgliedschaftliche Treuebindungen im GmbH-Recht. München 1988, p. 82 en p. 134/135.

20. [1900] $1 \mathrm{Ch}, 656$ (p. 671). Zie tevens Sealy, Cases and materials, nr. 58 en Hicks \& Goo, Cases \& Materials, p. 191 e.v. 
contained in the company's memorandurn and articles of association', maar hij stelde evenetns dat de bevoegdheid tot statutenwijziging, zoals elke andere bevoegdheid 'must be exercised subject to those general principles of law and equity which are applicable to all powers conferred on majorities and enabling them to bind minorities. It must be exereised, not orly in the manner required by law, but also bona fide for the benefit of the company as a whde'. In casu wordt de statutenwijziging overigens toelaatbaar geacht, daar deze in het belang van de vennootschap was.

Nadien is in een aantal uitspraken dit criterium gehandhaafd. In latere jurisprudentie wordt zelfs van een 'subjectieve' benadering uitgegaan. Het wordt dan in beginsel aan de meerderheidsaandeelhouder(s) overgelaten om te beoordelen of een statutenwijziging in het belang van de vennootschap is. ${ }^{21}$ Dit is slechts anders indien hun handelen niet berust op een 'reasonable ground' of in ernstige mate 'oppressive' is ten opzichte van minderheidsaandeelhouders. ${ }^{2}$

Vgl. Shuttleworth v. Cax Brothers \& Co. (Maidenhead) Ltd. [1927] 2 KB 9, CA. In deze zaak worden de statuten gewijzigd teneinde het ontslag van een voor het leven aangestelde bestuurder mogelijk te maken. Bankes LJ oordeelt: 'the test is whether the alteration of the articles was in the opinion of the shareholders for the benefit of the company. By what criterion is the Court to ascertain the opinion of the shareholders upon this question? The alteration may be so oppressive as to cast suspicion on the honesty of the persons responsible for it, or so extravagant that no reasonable man could really consider it for the benefit of the company: 23

21. Dit illustreert de terughoudende opstelling van de Engelse rechter om in te grijpen in de vennootschap (zie ook hoofdstuk $2 \$ 5.1$ ). Vgl. Atkin LJ in Shuttleworth v. Cox Brothers \& Co.[1927] 2 KB p. 26; 'It is not a matter of law for the Court whether or not a particular alteration is for the benefit of the company; nor is it the business of a judge to review the decision of every company in the country on these questions.

22. Met andere woorden: meerderheidsaandeelhouders moeten zich bij hun handelen laten leiden door objectieve minimumeisen. De rechter mag ingrijpen indien de meerderheidsaandeelhouders 'te kwader trouw' handelen. Vgl. Scrutton LJ op p. 23 van Shuttleworth v. Cox Brothers \& Co Ltd [1927] 2 KB 9 CA: 'The absence of any reasonable ground for deciding that a certain course of action is conductive to the benefit of the company may be a ground for finding lack of good faith or for finding that the shareholders, with the best motives, have not considered the matters which they ought to have considered. On either of these findings their decision might be set aside'.

23. Zie tevens Mayson, French \& Ryan on Company Law, p. 102/103 en Gower's Principles of Modern Company Law, London 1997, p. 710/711. 
De hiervoor weergegeven uitspraken zijn in de literatuur en rechtspraak veelvuldig bekritiseerd. ${ }^{24}$ Zo biedt het criterium 'benefit of the company' niet altijd een oplossing voor statutenwijzigingen die alleen betrekking hebben op belangenconflicten tussen aandeelhouders onderling. Men denke bijvoorbeeld aan een statutenwijziging waardoor de rechten en verplichtingen van een aandeelhouder ingrijpend gewijzigd worden. In zo'n geval moeten andere criteria worden gehanteerd. ${ }^{25}$

$\mathrm{Vgl}$. de uitspraak van de Court of Appeal inzake Greenhalgh v. Aderne Cinema's Ld. ${ }^{26}$ In deze uitspraak wordt een statutaire bepaling, inhoudende dat een aandeelhouder een reflectierecht heeft op aandelen die een mede-aandeelhouder wil verkopen, zodanig gewijzigd dat elke aandeelhouder aan iedere persoon, waaronder buitenstaanders, aandelen mag verkopen mits de ava bij gewoon meerderheidsbesluit daarin toestemt. Een 'aanbiedingsblok. kade' wordt dus omgezet in een 'goedkeuringsblokkade'. De managing director van Ademe Cinemas wil aldus bewerkstelligen dat hij zijn meerderheidsbelang aan een buitenstaander kan verkopen. Dit tot ongenoegen van minderheidsaandeelhouder Greenhalgh. Bij de beoordeling van deze statutenwijziging acht de Court of Appeal van belang of een statutenwijziging een discriminatoire werking heeft ten opzichte van meerderheids- en minderheidsaandeelhouders: 'an alteration of articles would be liable to be impeached if the effect of it were to discriminate between the majority and the minority shareholders, so as to give the former an advantage of which the latter were deprived'. In casu oordeelt het hof dat dit niet het geval is, onder meer omdat de buitenstaander een redelijk ('fair') bod heeft gedaan op alle aandelen.

In dit verband wijs ik ook op twee Australische uitspraken. In Peters' American Delicacy Co. Ltd. v. Heath ${ }^{27}$ wordt op advies van bestuurders een einde gemaakt aan een inconsistentie in de statuten. Enerzijds wordt namelijk dividend uitgekeerd aan aandeelhouders naar evenredigheid van het voor de aandelen betaalde bedrag, terwijl anderzijds bonusaandelen worden verdeeld naar evenredigheid van de nominale waarde van de gehouden aandelen. Door de statutenwijziging geschiedt de uitkering van bonusaandelen voortaan conform de uitkering van dividend. Enkele houders van niet volgestorte aandelen maken hiertegen bezwaar. Latham $\mathrm{CJ}$ oordeelt dat de statutenwijziging geldig is, maar acht de 'test' uit Allen v. Gold Reefs in casu niet geschikt: 'The benefit of the company as a corporation cannot be adopted as a criterion which is capable of solving all problems in this branch of the law [...] in cases where the question which arises is simply a question as to the relative rights of different classes of shareholders the problem cannot be solved by regarding merely the benefit of the corporation'. In plaats daarvan moet de statutenwijziging

24. Zie met name F.G. Rixon, Competing Interests and Conflicting Principles: An examination of the power of alteration of articles of association, MLR 1986, p. 451.

25. Vgl. onder meer F.G. Rixon, t.a.p., p. 469 en Gower's Principles of Modern Company Law, London 1997, p. 712 e.v.

26. [1951] 1 Ch 286, (1950) 2 All ER. 1120 (CA).

27. [1939] 61 CLR 457 (High Court of Australia). Zie eveneens Sealy, Cases and Materials. nr. 62 . 
aan een redelijkheidstoets worden onderworpen: 'As there is no evidence of oppression, and as the alteration cannot be described as extravagant, so that reasonable men could not regard it as a fair alteration to be made, the case of the plaintiff fails. The resolution involved no oppression, no appropriation of an unjust or reprehensible nature and did not imply any purpose outside the scope of the power'.

In 1995 velt de High Court of Australia zijn oordeel in de zaak Gambotto v. WCP Ld.. ${ }^{2 a}$ warbij het criterium 'benefit of the company as a whole' helemaal buiten beschouwing wordt gelaten. In deze zaak houdt een vennootschap direct en via verbonden vennootschappen $99.7 \%$ van de aandelen in WCP. De meerderheidsaandeelhouder stelt voor om de statuten zodanig te wijzigen dat aandeelhouders die $90 \%$ of meer van de aandelen houden minderheidsaandeelhouders, waaronder Gambotto, kunnen uitkopen. De statutenwijziging zou belastingvoordelen en besparingen op het administratieve vlak opleveren voor de vennootschap, daar deze een $100 \%$-dochter zou worden. De Court of Appeal van New South Wales oordeelt aan de hand van het criterium 'bona fide in the interests of the company' dat sprake is van een geldige statutenwijziging. De High Court is echter een andere mening toegedaan en oordeelt dat - omdat het uitkopen van minderheidsaandeelhouders een bijzondere situatie vormt - de statutenwijziging aan de hand van een tweetal criteria moet worden getoetst; namelijk dat een bevoegdheid wordt uitgeoefend 'for a proper purpose and exercising the power would not be oppressive to the minority'. De High Court oordeelt vervolgens dat de belastingvoordelen voor de meerderheidsaandeelhouder geen 'proper purpose' opleveren. Men moet echter bedenken dat de uitspraken inzake Peters' American Delicacy en Gambotto met name van belang zijn voor het Australische recht. In het Engelse recht zal de geldigheid van een statutenwijziging moeten worden getoetst aan de vage criteria van 'interest of the company', waarbij zoals blijkt uit de Shuttleworth case 'oppression' een rol van betekenis speelt, of 'discrimination'. 29

Voor minderheidsaandeelhouders is een procedure in het kader van s. 459 $\mathrm{CA}$ e.v. het aangewezen middel indien zij door een statutenwijziging in hun belangen worden aangetast. ${ }^{30} \mathrm{De}$ rechter kan dan, mits voldaan is aan de voorwaarden van s. $459 \mathrm{CA}$, een door hem geschikt geacht

28. [1995] 127 ALR (High Court), [1992] 8 ALSR 141 (Court of Appeal), zie ICCLR 1992. p. C-203/204.

29. Zie ook Mayson, French \& Ryan on Company Law, p. 105.

30. Deze procedure, die wordt besproken in hoofdstuk $2 \& 5$, is onderwerp van discussie in de Law Commission Consultation Paper inzake 'Shareholder Remedies' (1997). De Law Commission van de Department of Trade and Industry tracht hervormingen aan te brengen in de procedure, zodat een en ander eenvoudiger en efficienter kan geschieden. $\mathrm{Vgl}$. D. Sugarman, Reconceptualising company law: reflections on the Law Commission's consultation paper on shareholder remedies: Part 1, The Company Lawyer 1997. p. 226 e.v. 
rechtsgevolg verbinden aan het besluit tot statutenwijziging. ${ }^{31}$ Behalve ongedaanmaking van de statutenwijziging zou dat ook het 'uitkopen' van de minderheidsaandeelhouder kunnen zijn (vgl. s. 461 (2) sub d CA 1985).

\section{§4.3 Frankrijk}

In het Franse recht brengt toetsing van statutenwijzigingen aan de criteria van 'abus de majorité en 'abus de minorité' mijns inziens mee dat ook daar rekening wordt gehouden met de aanwezigheid van een goede grond voor het besluit en de gevolgen voor de aandeelhouders.

Van 'abus de majorité is op grond van jurisprudentie sprake als een besluit genomen is 'contrairement à l'intérêt général et dans l'unique dessein de favoriser les membres de la majorité au détriment de la minorité'. Met betrekking tot abus de minorité heeft de Cour de Cassation in de Six-zaak (Bull. Joly 1990, p. 755) als criteria geformuleerd ; "une attitude contraire à $\mathrm{I}^{\prime}$ intérêt de la société et dans l'unique dessein de favoriser ses propres intérêts au détriment de l'ensemble des autres associés' ( $\mathrm{vgl}$. ook hoofdstuk $2 \S 4.3$ ). Een en ander kan het beste geillustreerd worden aan de hand van uitspraken met betrekking tot besluiten tot statutenwijzigingen gericht op verhoging van het kapitaal. Deze hebben veelal betrekking op minderheidsaandeelhouders die zo'n besluit blokkeren. De tendens in deze jurisprudentie is dat wanneer de reden voor een kapitaalverhoging/kapitaalvermindering gelegen is in de continuilteit van de vennootschap (dus een goede grond heeft) een blokkering door de minderheid veelal 'abus de minorité' oplevert. ${ }^{32} \mathrm{Vgl}$. bijvoorbeeld Cour d'appel de Pau 21 januari 1991 inzake Flandin c. SARL Alarme Service. ${ }^{33} \mathrm{Om}$ te voldoen aan het wettelijk vereiste minimumkapital (ingevolge de wet van 1 maart 1984) van 50.000 FF besluit de ava op 24 mei 1985 het kapitaal van de vennootschap te verhogen van $20.400 \mathrm{FF}$ tot $50.000 \mathrm{FF}$. Joseph en Marcel Flandin, beiden aandeelhouders met 50 resp. 51 aandelen (van de 204) stemmen tegen deze kapitaalverhoging. In een volgende vergadering besluit de ava het kapitaal zelfs te vergroten tot $500.000 \mathrm{FF}$. De twee genoemde aandeelhouders schitteren door afwezigheid. Ten aanzien van de eerste kapitaalverhoging oordeelt de Cour de Cassation dat sprake is van 'abus de minorité' omdat deze 'était légalement requise et était nécessaire à la survie de la société'. Wat betreft de tweede kapitaalverhoging tot $500.000 \mathrm{FF}$ oordeelt de Cour de Cassation echter anders, daar deze kapitaalverhoging niet noodzakelijk

31. Vgl. s. 461 (1) CA: 'If the court is satisfied that a petition under this Part is well founded, it may make such a order as it thinks fit for giving relief in respect of the matters complained of.

32. $\mathrm{Vgl}$. P. Le Cannu, Le minoritaire inerte (observations sous l'arrêt Flandin), Bull. Joly 1993, p. 541, Merle, Abus de minorité in het themanummer van de Revue de Jurisprudence Commerciale 'La Stabilité du pouvoir et du capital dans les sociétés par actions' 1991 , p. 86 en M. Boizard, Rev. Soc. 1988, p. 374.

33. Rev. Soc. 1992, p. 46 e.v. en Bull. Joly 1993, p. 547 e.v. 
is voor de vennootschap, want 'les résultats de la société sont bons et celle-ci (de vennootschap, MK) est prospère'.

Bovendien moet blijken dat zo'n kapitaalverhoging een geschikt middel is ten behoeve van de continuiteit van de vennootschap en dat het niet tot onevenredige benadeling leidt voor (minderheids)aandeelhouders. Zie een recente uitspraak van de Cour d'Appel Paris 24 januan 1997. Bull. Joly 1997, p. 405. In deze zaak weigert een minderheidsaandeelhouder in te stemmen met een kapitaalverhoging, aangezien dit voor hem een aanzienlijke verlies aan zeggenschap betekent (van $32 \%$ naar 2,53\%) De Cour d'appel oordeelt daarover dat een kapitaalverhoging ' $n$ 'était pas et n'est toujours pas indispensable à sa survie'. Hiermee geeft het hof aan dat er ook nog andere middelen geschikt zijn om de vennootschap uit zijn erbarmelijke financiële situatie te halen. ${ }^{34}$ Voorts overweegt het hof dat de minderheidsaandeelhouder, in verband met de ernstige aantasting van zijn zeggenschap, goede redenen had om tegen het besluit te stemmen;" qu'elle ne participerait pas à une augmentation de capital qui serait décidée, sans que cette abstention puisse, de quelque manière, être regardée comme fautive, observe à juste titre que sa participation serait fortement diluée en cas d'une augmentation'.

\section{§ 5. Wijziging blokkeringsregeling}

De statuten van een BV moeten een blokkeringsregeling bevatten. Een $N V$, waarvan de statuten voorzien in aandelen op naam, kan een blokkeringsregeling in de statuten opnemen. ${ }^{35}$ De blokkeringsregeling kan een aanbiedings- of goedkeuringsregeling bevatten. De Departementale Richtlijnen staan ook combinaties toe van deze varianten. De wet laat de vennootschap vrij om de vrije kring waarbinnen aandelen zonder inachtneming van de blokkeringsregeling kunnen worden overgedragen, statutair te beperken en zelfs uit te sluiten. ${ }^{36}$ De blokkeringsregeling heeft als doel het handhaven van het besloten karakter van de vennootschap. ${ }^{37}$

Dezelfde functie wordt in het Duitse recht vervult door zgn. 'Vinkulierung' ( $\$ 15 \mathrm{GmbHG} /$

$\$ 68 \mathrm{AktG}$ ). In een $\mathrm{GmbH}$ zijn vele varianten van statutaire blokkeringsregelingen mogelijk. Zo kan de overdracht van aandelen afhankelijk zijn van toestemming van één aandeelhouder. In een AG mogen de statuten echter alleen een goedkeuringsregeling bevatten ( $\$ 68$ II (1) AktG.). Goedkeuring of toestemming van de raad van commissarissen (Aufsichtsrat) of van

34. Vgl. B. Saintourens in zijn noot bij deze uitspraak, Bull. Joly 1997, p. 407.

35. $\mathrm{Vgl}$. art. $2: 87 \mathrm{BW}$. Indien tevens de statuten van zo'n NV niet toelaten dat met medewerking van de vennootschap certificaten aan toonder worden uitgegeven, is de geschillenregeling van toepassing, vergelijk art. 2:335 lid $2 \mathrm{BW}$.

36. $\mathrm{Vgl}$. $\$ 21,22$ en 23 Departementale Richtlijnen met betrekking tot de BV en $\$ 32,33$ en 34 met betrekking tot de NV.

37. $\mathrm{Vgl}$. over de geschiedenis met betrekking tot de totstandkoming van de blokkeringsregeling C.A. Schwarz, Blokkering van aandelen, Deventer 1986, p. 1-4. 
de ava (Hauptversammlung) kan hier een voorwaarde voor overdracht van aandelen zijn." Het Franse recht kent een wettelijke regeling met betrekking tot zgn. 'clauses d'agrément' (toestemmingsregeling, zie artt. 47/274 L. 1966). Echter, in literatuur en rechtspraak word. aanvaard dat ook 'clauses de préemption' (aanbiedingsregeling) statutair kunnen worden vastgelegd. ${ }^{30}$ In de praktijk worden dergelijke regelingen vaak buiten-statutair, in aandeel. houdersovereenkomsten, overeengekomen. Een reden hiervoor is dat de wet een blok. keringsregeling niet toestaat in het geval van aandelentransacties tussen bestaande aandeel. houders, ${ }^{40}$ Evenals in het Duitse recht kunnen de statuten van beursvennootschappen bepalen dat de raad van commissarissen toestemming moet verlenen voor een overdracht, ${ }^{4}$ In het Engelse recht is een beperking in de verhandelbaarheid van aandelen van beursvennootsvennootschappen op grond van de Stock Exchange's Listing Rules niet mogelijk. ${ }^{2}$

Een blokkeringsregeling kan in het belang zijn van (de meerderheid van) aandeelhouders, maar ook juist tegen hun belangen ingaan. Men denke aan het geval dat een in de statuten opgenomen blokkeringsregeling een aanbiedingsplicht resp. reflectierecht kent en de meerderheid van aandeelhouders zijn aandelen wil vervreemden aan een derde terwijl de minderheidsaandeelhouder(s) niet aan die transactie wil(len) meewerken, omdat zij zelf de aandelen wil(len) verwerven. Een statutenwijziging, waarbij de statutaire aanbiedingsregeling wordt vervangen door een goedkeuringsregeling, waarbij de ava aangewezen wordt als goedkeurend orgaan, kan dan een oplossing bieden. De omzetting van een anbiedingsregeling in een goedkeuringsregeling heeft echter tot gevolg dat een minderheidsaandeelhouder zijn reflectierecht verliest, hetgeen verlies aan zeggensmacht impliceert.

38. $\mathrm{Vgl}$. omtrent de blokkeringsregelingen in het GmbH-Recht, Lutter-Hommelhoff, GmbHGesetz, Köln 1995, $\S 15$, met name p. 215 e.v. en voor het AG-Recht, Hưffer, Aktiengesetz, $\$ 68$, met name p. 271.

39. Vgl. J. Moury, Des clauses restrictives de la libre négociabilité des actions, Rev.trim. dr.com. 1989, p. 191/192 en Guyon, Droit des Affaires, nr. 746.

40. Aandeelhouders trachten door middel van buiten-statutaire afspraken te ontkomen aan de beperkingen en voorwaarden die de wet stelt inzake de verhandelbaarheid van aandelen (artt. 274-277 L. 1966). Zie Guyon, Traité des contrats, nr. 217.

41. $\mathrm{Vgl}$. art. 4 van $\mathrm{L} .1$ augustus 1986 dat van toepassing is op beursvennootschappen; 'toute cession d'actions est soumise à l'agrément du conseil d'administration ou de surveillance'. Zo'n regeling in beursvennootschappen is niet, zoals bij besloten vennootschappen gericht op bescherming van de beslotenheid maar op bescherming tegen vijandige overnames. $\mathrm{Vgl}$. J-L. Beaufort, Le droit d'agrément dans la sociétés de pressé, Rev. Soc. 1994, p. 436.

42. Zie S. Goulding. Principles of Company Law, London 1996, p. 176. 
Vergelijk HR 17 mei 1991. NJ 1991, 645 (Lampe/Tonnema). Tonnema BV was een 'familievennootschap' met 9600 stemgerechtigde aandelen. Lampe behoorde tot die familie en bezat 150 aandelen. Tijdens een ava van Tonnema BV was in beginsel besloten onderzoek te doen naar de mogelijkheid van verkoop van aandelen aan een derde. Op een bijeenkomst van het bestuur, de rad van commissarissen en een door de ava ingestelde 'contactcommissie', werd besioten cen bank te belasten met een onderzoek naar de mogelijke verkoop van de aandelen. Uitgangspunten waren: optimale prijs, waarborgen van de continuilteit en van de werkgelegenheid in de vestigingsplaats Sneek, handhaving van de merkenpositie en handhaving van het Nederlands karakter van de onderneming. Van Nelle Holding NV bleek bereid een bod uit te brengen van 26 miljoen dat voldeed aan de uitgangspunten. Alle aandeelhouders behalve Lampe gingen akkoord met de verkoop van aandelen en zij verstrekten vervolgens een machtiging om namens hen te onderhandelen, een koopovereenkomst te tekenen en de aandelen te leveren. Lampe beriep zich op de in de statuten van Tonnema BV opgenomen aanbiedingsregeling waardoor op de aandeelhouders de verplichting rust om bij voorgenomen verkoop van hun aandelen aan een derde deze eerst aan te bieden aan Lampe. De raad van commissarissen en het bestuur bereidden daarop een statutenwijziging voor om de aanbiedingsregeling te vervangen door een goedkeuringsregeling. De meerderheid in de ava stemt vervolgens voor deze statutenwijziging.

Het hof overweegt in deze zaak dat de meerderheid door met bovenstaande belangen rekening te houden 'respectabele, redelijke en derhalve aanvaardbare motieven' (curs. MK) had om tot wijziging van de blokkeringsregeling te besluiten. Ook de omstandigheid dat de minderheidsaandeelhouder Lampe onzekere plannen had met de vennootschap vormde volgens het hof een redelijk motief voor de meerderheid om tot wijziging van de statuten over te gaan. De meerderheid van aandeelhouders, de ondernemingsraad en de vakorganisaties hadden geen vertrouwen in de plannen van Lampe. De Hoge Raad oordeelt dat 'het hof geen blijk heeft gegeven van een onjuiste opvatting omtrent de eisen van de goede trouw' en onderstreept de opvatting van het hof. Belangrijk is dat de Hoge Raad zich aansluit bij de opvatting van het hof waarin dit uitdrukkelijk overweegt dat 'een aandeelhouder vanaf de aanvang van zijn aandeelhouderschap rekening'heeft te houden met de mogelijkheid van wijziging van de aanbiedingsregeling bij meerderheidsbesluit. Het hof overwoog dat de meerderheid van aandeelhouders vrij was om tot de onderhavige statutenwijziging te besluiten daar een afweging van het belang van Lampe bij het in stand blijven van zijn uit de aanbiedingsregeling voortvloeiende rechten en de belangen van de overgrote meerderheid van aandeelhouders en van de onderneming ten nadele van Lampe was uitgevallen. Een belangrijke factor daarbij was dat de statutenwijziging een noodzakelijk middel vormde om het eigenlijke doel- de beoogde overdracht van de aandelen aan een derde - bereikbaar te maken'.

In gelijke zin, zij het in een andere situatie zie men $R b$ Utrecht 16 februari $1989, K G$ 1989. 156. De grootaandeelhouders van de BV Centraal Op- en Overslagbedrijf 'Utrecht' (COBU) wilden reeds lang hun aandelen vervreemden. Eind 1987 begin 1988 ontstonden echter problemen omdat twee minderheidsaandeelhouders, Van Vliet en Krijn Coppoolse BV beiden alle (resp. zoveel mogelijk) aandelen in Cobu wilden verwerven en daartoe tegen elkaar opboden. De geldende statuten gaven voor die situatie geen passende regeling. De grootaandeelhouders besloten daarop op 17 juni 1988 de statuten te wijzigen in die zin dat de aanbiedingsregeling werd vervangen door een blokkeringsregeling met goedkeuringsvereiste van de ava. Daarbij werd een overgangsbepaling opgenomen dat die wijziging pas in 
werking zal treden indien en zodra een afschrift van deze akte ten kantore van het handelsregister zal zijn neergelegd krachtens een besluit van de ava. ${ }^{43}$

De rechtbank oordeelt: 'een dergelijke ziens- en handelswijze van de (groot)aandeelhouders kan geredelijk in het belang van Cobu worden geacht nu daardoor de eenheid van beleid in Cobu en daarmee haar continuiteit beter kan worden gewaarborgd, dan in het geval de aandelen verdeeld zouden worden over twee aandeelhouders, die kennelijk elkaar beconcurreren (curs., MK). Nu vermelde problemen nog steeds voortduren, valt niet in te zien dat gedaagden (grootaandeelhouders $\mathrm{MK}$ ) in strijd met de jegens Krijn Coppoolse in acht te nemen goede trouw zouden handelen door [...] te besluiten tot het in werking doen treden van voormelde statutenwijziging en vervolgens aan overdracht van aandelen aan de hoogstbiedende mee te werken'.

\section{In het Engelse recht is in $R e$ a company no. 005685 of 1988 (Ring- tower $)^{44}$ sprake van een soortgelijke situatie als in Lampe/Tonnema.}

In Ringtower Holding, een 'public' company wordt $80 \%$ van de aandelen gehouden door de vennootschap GMDC, $5,25 \%$ door A en M, $5 \%$ door S en zijn zoon en de resterende aandelen door enkele andere minderheidsaandeelhouders. De statuten bevatten een regeling op grond waarvan voor overdracht van aandelen toestemming van alle aandeelhouders vereist is. De meerderheidsaandeelhouder wil zijn aandelen verkopen aan een door A en M opgerichte vennootschap. Alle aandeelhouders, behalve $S$ en zijn zoon, stemmen toe in die verkoop. Daarop wijzigt de meerderheid van de aandeelhouders de statuten zodanig dat de public company omgezet wordt in een private company, en dat voortaan de verkoop van aandelen de toestemming behoeft van de directors. S en zijn zoon eisen op grond van section 459 en 461 CA 1985 ongedaanmaking van de statutenwijziging. De rechter wijst de vordering af. Weliswaar kan sprake zijn van nadeel voor de minderheidsaandeelhouder, aldus de rechter, maar 'unfair' is de besluitvorming niet, omdat deze de mogelijkheid heeft om zijn aandelen aan de nieuwe mede-aandeelhouder over te dragen.

In Re Kenyon Swansea Ltd ${ }^{\text {ts }}$ sluit de meerderheidsaandeelhouder/oprichter Kenyon (K) van de vennootschap, een overeenkomst met de bestuurder/minderheidsaandeelhouder Mitchell $(\mathrm{M})$. dat deze het recht heeft om het controlerende aandelenpakket van $\mathrm{K}$ te kopen. $\mathrm{K}$ is echter niet tevreden met de door $\mathrm{M}$ geboden prijs voor de aandelen en besluit in een bijzondere algemene vergadering tot schrapping van de blokkeringsbepaling, waardoor hij zijn aandelenpakket aan buitenstaanders kan verkopen. De rechter oordeelt dat sprake is van 'unfair prejudice' jegens $\mathrm{M}$; 'having regard to the expectations to which the past relationship between $\mathrm{Mr}$ Mitchell and $\mathrm{Mr}$ Kenyon has given rise and on which $\mathrm{Mr}$ Mitchell has relied in. for example, arranging for the purchase of the new factory by his family company, it would be unfairly prejudicial to him that $\mathrm{Mr}$ Kenyon should now exercise his voting control in

43. De statuten mogen bepalen dat een statutenwijziging slechts in werking zal treden indien en wanneer een afschrift daarvan ten kantore van het handelsregister is neergelegd, vgl. $\S 2$ Departementale Richtlijnen.

44. [1989] BCLC, p. 427.

45. [1987] BCLC, p. 514 e.v. 
general meeting either by passing resolutions which will restore day-to-day control of the affairs of the company to him [...] or by deleting the pre-emption provisions in the article thereby enabling him to sell his controlling interest to an outside purchaser'.

Een andere kwestie in dit verband is in hoeverre het al dan niet goedkeuren door de meerderheidsaandeelhouder(s) van een overdracht van andelen jegens minderheidsaandeelhouder(s) strijd met de redelijkheid en billijkheid oplevert. Verdedigbaar is mijns inziens dat in het algemeen een weigering door de meerderheid redelijk en billijk is, zolang een (minderheids)aandeelhouder geen nadeel lijdt. Dit betekent bijvoorbeeld dat in het geval meerderheidsaandeelhouders een goede prijs bieden voor de aandelen van de minderheidsaandeelhouder, dat wil zeggen een prijs conform de waarde van de aandelen, ${ }^{46}$ de weigering om de aandelentransactie door de minderheidsaandeelhouder goed te keuren niet snel aantastbaar is. ${ }^{47}$

Dit kan mijns inziens anders zijn in het geval dat een aandeelhouder wel nadeel lijdt, doordat hij in zijn zeggenschapsbelangen wordt aangetast

46. Een blokkeringsregeling mag er immers niet toe leiden dat de aandeelhouder minder ontvangt dan de waarde van de aan te bieden aandelen, vastgesteld door één of meer onafhankelijke deskundigen (art. 2:195 lid 5 BW).

In de literatuur en in de praktijk bestaat overigens onzekerheid omtrent de maatstaf die moet worden gehanteerd voor de prijsbepaling van aandelen die krachtens een blokkeringsregeling worden aangeboden. Art. 2:195 lid 5 bepaalt: 'De blokkeringsregeling dient zodanig te zijn dat de aandeelhouder, indien hij dit verlangt, van degenen die als gegadigden in de zin van het derde lid worden opgegeven of aan wie ingevolge de blokkeringsregeling als bedoeld in het vierde lid moet worden aangeboden een prijs ontvangt gelijk aan de waarde van zijn aandeel of aandelen, vastgesteld door een of meer onafhankelijke deskundigen'. Over de vaststelling van die waarde van die aandelen in een blokkeringsregeling bestaan verschillende opvattingen. Enerzijds bestaat de opvatting dat de 'pro rata parte waarde' gehanteerd moet worden, dat is de waarde van de aandelen in de marktwaarde van de vennootschap in haar geheel. Deze waarde is voor alle aandelen gelijk, ongeacht de omvang en/of machtspositie van aandelenpakketten. Anderzijds bestaat de opvatting dat de waarde de 'pakketwaarde' betreft, ofwel de marktwaarde van het aandelenpakket van de verkoper. Een mede-bepalende factor bij deze waarde is de prijs die een mede-aandeelhouder of een derde bereid is te betalen. Deze laatste opvatting vinden we terug in de onderhavige uitspraak. Zie omtrent deze discussie W.F.C. Blom, Blokkering van BV-aandelen: tegen welke blokkeringsprijs?. Maandblad De NV 1992, p. 140-144 en A. Voûte, Prijs van de derde kan blokkeringsprijs van BV-aandelen zijn, Maandblad De NV 1992, p. 168-169.

47. $\mathrm{Vgl}$. ook $\$ 243$ AktG (2) op grond waarvan aandeelhouders hun bevoegdheid om een besluit 'aan te vechten' verliezen indien zij hun schade vergoed krijgen. 
en daarvoor geen 'passende' compensatie verkrijgt. Onder omstandig. heden kan een weigering door de meerderheid echter worden gerechtvaardigd door belangen van de vennootschap.

$\mathrm{Vgl}$. ook het Duitse $\mathrm{GmbH}$ recht waarin wel wordt aangenomen dat de uitoefening van de bevoegheid om al dan niet aandelentransacties goed te keuren moet worden getoetst aan de Treupflicht. Dit brengt mee dat de weigering niet toelaatbaar is 'wenn die Versagung det Zustimmung durch unsachliche, nicht dem Vinkulierungsinteresse entsprechende Gründe motiviert ist'. ${ }^{48}$ Een weigering moet 'erforderlich' en 'verhältnismäßig' zijn. Dit is bijvoorbeeld niet het geval indien de toestemming aan een verkopende aandeelhouder wordt onthouden om redenen die niet gebaseerd zijn op het belang dat de vennootschap heeft bij het in stand houden van de blokkeringsregeling. ${ }^{49}$

\section{Indien de meerderheid de blokkeringsregeling 'opheft' waardoor een} buitenstaander de zeggenschap verwerft, zonder dat dit gerechtvaardigd wordt door belangen van de vennootschap, moeten in mijn visie de minderheidsaandeelhouders gecompenseerd worden.

Vgl. ook in het Franse recht Cour de Cassation 21 juni 1982, Rev. Soc. 1982, p. 852 (Cassegrain-Saupiquet). In deze zaak heft de meerderheidsaandeelhouder/bestuurder de blokkeringsregeling geldend voor Cassegrain SA op, waardoor de zeggenschap in de vennootschap Cassegrain in handen komt van de concurrent Saupiquet SARL. De minderheidsaandeelhouders stellen dat er sprake is van 'abus de majorité', daar zij menen dat de continuiteit van de vennootschap in gevaar wordt gebracht. De Cour de Cassation stelt hen uiteindelijk niet in het gelijk. Van belang acht de Cour de Cassation dat Saupiquet een bod heeft uitgebracht op alle aandelen, zodat niet kon worden vastgesteld dat het besluit ten detrimente van andere aandeelhouders was genomen. De redelijkheid en billijkheid (en het gelijkheidsbeginsel) brengen mijns inziens mee, ook los van specifieke regels zoals vervat in bijvoorbeeld de SER Fusiecode, dat een aandeelhouder de mogelijkheid moet hebben zijn aandelen van de hand te doen tegen een prijs die de overnemer heeft betaald voor de andere aandelen. ${ }^{50}$ Vergelijk voor uitgebreide beschouwingen hieromtrent H.J. de Kluiver, Machtsstrijd en Machtsovername in Kapitaalvennootschappen, Deventer 1996, met name p. 22 e.v.

48. Vgl. M. Piepenburg, Mitgliedschaftliche Treupflichten der Aktionãre, Hamburg 1996, p. 374 en J. Reichert en M. Winter, Vinkulierungsklauseln und gesellschafterliche Treupflicht in de bundel 100 Jahre GmbH-Gesetz 1992, p. 222/223.

49. Vgl. met name J. Reichert en $\mathrm{M}$. Winter, Vinkulierungsklauseln und gesellschafterliche Treupflicht, in: 100 Jahre GmbH Gesetz 1992, p. 220 e.v. en J. Reichert, Das Zustimmungserfordernis zur Abtretung von Geschalftsanteilen in der $\mathrm{GmbH}$, diss. Heidelberg 1984, p. 233 e.v.

50. $\mathrm{Zij}$ het dat wel in acht moet worden genomen dat voor een controlerend pakket een pakketvergoeding niet onredelijk is. Vgl. HR 24 september 1976, NJ 1978, 135 (Erdal). 
Een andere vraag die opkomt is of een aandeelhouder zijn aandelen aan een derde mag overdragen indien deze meer biedt dan het bod van de reflecterende mede-aandeelhouders, die bereid zijn de intrinsieke waarde van de aandelen te betalen.

Vergelijk een Duitse uitspraak van het BGH op 7 november 1987, WM 1987, 174. Een andeelhouder van een familie-AG was vanwege zijn erbarmelijke financiēle positie gedwongen tot verkoop van zijn aandelen. De meerderheidsaandeelhouders vrezen 'binnendringers' in hun vennootschap en weigeren hun toestemming aan de aandeelhouder om zijn aandelen te verkopen aan een derde. Een aantal aandeelhouders is vervolgens wel bereid om de aandelen over te nemen. De prijs die zij aanbieden aan de aandeelhouder ligt echter aanzienlijk onder het aanbod van de derde. Het BGH is van oordeel dat van de aandeelhouder verwacht mag worden dat hij zijn aandelen aan de mede-aandeelhouders overdraagt. voorzover deze een 'passende' ('angemessene') prijs bieden, vastgesteld door experts. M.a.w. weliswaar moet rekening worden gehouden met de belangen van de verkopende aandeelhouder, maar het belang van de vennootschap bij de blokkering staat voorop. Dit is ook de heersende opvatting in de literatuur. ${ }^{31}$

Ook naar Nederlands recht kan mijns inziens worden aangenomen dat de prijs die een derde biedt niet als maatstaf mag gelden voor de waardering van aandelen.

\section{§. Verlies van stemrecht}

Een besluit tot statutenwijziging kan er niet alleen toe leiden dat een aandeelhouder over minder zeggenschap beschikt doordat hem rechten als het reflectierecht worden ontnomen, maar kan ook bewerkstelligen dat een aandeelhouder zijn stemrecht grotendeels 'verliest'. ${ }^{52}$ Het 'verlies' van stemrecht betekent voor de aandeelhouder dat hij geen invloed meer kan uitoefenen op de besluitvorming met betrekking tot belangrijke bevoegdheden die aan de ava toekomen, zoals vaststelling van de jaarrekening en statutenwijziging. Dit verlies aan zeggensmacht kan ook nadelige financiële gevolgen voor de aandeelhouder hebben, bijvoorbeeld omdat hij de hoogte van het dividend niet meer direct kan beïnvloeden. Bovendien zal

51. Zie bijvoorbeeld Hüffer. Aktiengesetz $\S 68 \mathrm{Rn} 15$ en M. Lutter, Die AG 1992. p.370 e.v.

52. Eigenlijk zou gesproken moeten worden van beperking van stemrecht omdat een statutaire bepaling waardoor een aandeelhouder uitgesloten wordt van stemrecht niet is toegestaan, art. 2: 118 lid $1 \mathrm{BW}$ bepaalt immers dat iedere aandeelhouder tenminste één stem heeft. 
het aandelenpakket van de aandeelhouder aan waarde kunnen inboeten." Van een rigoureuze inbreuk op het stemrecht is sprake indien bijvoorbeeld in de statuten een zgn. x\%-regeling wordt opgenomen al dan niet in combinatie met het stellen van kwaliteitseisen. ${ }^{54}$

De $x \%$-regeling kent in de praktijk verschillende verschijningsvormen. ${ }^{55}$ Een veel voorkomende vorm is een regeling die een verbod inhoudt voor een aandeelhouder om meer dan het in de statuten vermelde maximum percentage aandelen te houden (vaak 1\%), veelal gecombineerd met een verplichting tot certificering van aandelen die een belang van $x \%$ overschrijden. Statuten van een vennootschap mogen ook eisen stellen waaraan aandeelhouders moeten voldoen, bijvoorbeeld de eis dat slechts natuurlijke personen aandeelhouders kunnen zijn. Daarbij kunnen de statuten bepalen dat een aandeelhouder die niet (meer) aan de gestelde eisen voldoet, de verplichting heeft de aandelen aan te bieden c.q. over te dragen. Dit laatste gebeurt in de praktijk regelmatig in het kader van vererving van aandelen, daar een blokkeringsregeling in de NV of BV dan niet van toepassing is. De statuten mogen bepalen dat zolang de aandeelhouder niet aan de gestelde eisen of aan de verplichting tot aanbieding c.q. overdragen voldoet, deze het vergaderrecht en het stemrecht niet kan uitoefenen en dat het recht op uitkeringen wordt opgeschort (vergelijk Departementale Richtlijnen \& 24),

Volgens Slagter is de door middel van een statutenwijziging in te voeren $x \%$-regeling, waarbij een minderheid van aandeelhouders de verplichting krijgt opgelegd om aandelen verkregen boven het in de statuten vermelde percentage aandelen om te wisselen in certificaten in strijd met de goede trouw, tenzij een vitaal belang van de vennootschap op het spel staat dat

53. Zie C.A. Schwarz, Blokkering van aandelen, Deventer 1986, p. 75. Een aandelenpakket ontleent zijn waarde voor een groot deel aan de omstandigheid dat de medewerking van de houder van dat aandelenpakket nodig is voor bepaalde besluiten. Dit zal met name gelden voor een groter pakket (een 'overnemer' zal bereid zijn een extra vergoeding voor zo'n pakket te betalen).

54. Een ander minder rigoureuze wijze van stemrechtbeperking is een statutaire bepaling waardoor het aantal stemmen dat een aandeelhouder kan uitbrengen aan een maximum is gebonden, hetzij door een degressief stemrecht, hetzij door fixering van het aantal stemmen per aandeelhouder. Voorts gaat een statutenwijziging waarbij het nominal bedrag van de aandelen wordt verminderd zodat een kapitaalvermindering word verwezenlijkt, gepaard met vermindering van stemrecht, in beginsel naar evenredigheid op alle aandelen (van dezelfde soort).

55. Zie voor een uitgebreid overzicht R.P. Voogd, Statutaire beschermingsmiddelen bi beursvennootschappen, Deventer 1989, p. 139 e.v. Zie tevens W. Bosse, $1 \%$-regelingen. TVVS 1991, p. 141-146. 
een dergelijke statutenwijziging rechtvaardigt, zoals het voorkomen van 'Überfremdung' van de vennootschap. ${ }^{56}$

Niet in strijd met de goede trouw is volgens Slagter de situatie waarbij de omwisseling geschiedt op basis van vrijwilligheid. ${ }^{77}$ De medewerking van de aandeelhouders kan worden verkregen doordat de omwisseling antrekkelijk wordt gemaakt, bijvoorbeeld door het bieden van een financieel voordeel. Slagter noemt als voorbeeld een statutenwijziging waarbij aandelen op naam worden omgewisseld in certificaten aan toonder, zodat de verhandelbaarheid van de effecten wordt vergroot.

Een voorbeeld van een statutenwijziging waardoor aandeelhouders hun rechtspositie als aandeelhouder verloren biedt Hof Amhem 24 april 1917, NJ 1917, p. 634. De ava van de NV tot exploitatie van het hotel Groot Berg en Dal te Beek besloot tot een statutenwijziging die onder meer leidde tot afschrijving van het gehele bestaande aandelenkapitaal en tot een verplichting voor aandeelhouders hun aandelen om te wisselen in winstbewijzen. Dit had tot gevolg dat de aandeelhouders niet alleen hun stemrecht en medezeggenschap bij het bestuur en beheer van de NV verloren, maar ook een groot financieel nadeel leden doordat zij in plats van het hun bij de oprichting toegekende percentage in de winst slechts winstbewijzen ontvingen, waarbij zij gerechtigd waren tot veel lager dividend. Het hof was van mening dat de statutenwijziging 'de wezenlijke haar kenmerkende grondslagen van de NV aantast en zij zulk een verstrekkende verandering en verkorting aanbrengt dat zij - nu zij niet met algemene bewilliging - tot stand kwam - niet als een geoorloofde kan worden beschouwd' (curs. MK)."

56. W. J. Slagter, Degradatie van aandeelhouders of wijziging van hun rechten? TVVS 1965 , p. $130 / 131$. Door een statutenwijziging van de NV Gerofabriek werd aan bestaande aandeelhouders de verplichting opgelegd hun aandelen (voorzover het bezit meer dan $5 \%$ van het geplaatste kapitaal bedraagt) te verwisselen in certificaten. Volgens Slagter leidt deze situatie tot een gedwongen 'degradatie' van aandeelhouders en is dat strijdig met de goede trouw.

57. Zie eveneens R.P. Voogd, Statutaire beschermingsmiddelen bij beursvennootschappen, 1989, p. Hij is de mening toegedaan dat de invoering van een $x \%$-regeling niet in strijd is met de goede trouw indien bestaande aandeelhouders de keuze wordt gelaten om hun aandelen te verwisselen in aandelen op naam.

58. $\mathrm{Bij}$ de beantwoording van de vraag of een besluit tot wijziging van de statuten geoorloofd is, acht Slagter in tegenstelling tot het Hof Arnhem echter niet zozeer beslissend de wezenlijke grondslag van de vennootschap of het ontnemen van voorrechten, maar het bestaan van een vitaal belang. 


\section{§ 7. Slotbeschouwing}

Statuten leggen de identiteit en de structuur van de vennootschap vast en regelen de rechten, bevoegdheden en verplichtingen van de organen van de vennootschap en van de houders van aandelen en andere effecten jegens elkaar, een en ander met inachtneming van het vennootschapsrecht en van de vennootschappelijke orde. ${ }^{59}$ Of zoals het Handboek ${ }^{60}$ stelt: De statuten zijn de eigen fundamentele organisatieregels van de individuele vennootschap. Het gaat hier dus onder meer om regels die gelden tussen aandeelhouders en weergeven hetgeen tussen aandeelhouders op een bepaald moment is afgesproken ten aanzien van hun onderlinge verhouding. ${ }^{61}$ Weliswaar kunnen daarnaast overeenkomsten zijn gesloten tussen aandeelhouders, maar dit laat de werking van de statuten jegens iedere aandeelhouder onverlet.

Minderheidsaandeelhouders moeten vanaf de aanvang van hun aandeelhouderschap rekening houden met de mogelijkheid dat een meerderheid(saandeelhouder) de statuten kan wijzigen. ${ }^{62}$ Echter, de meerderheid heeft niet steeds de vrijheid daartoe. ${ }^{63}$ Vergelijking met het Engelse, Duitse en Franse recht leert ons dat ook daar statutenwijzigingen aan een 'redelijkheidstoets' worden onderworpen.

In dit hoofdstuk heb ik verdedigd dat die vrijheid kan worden beperkt indien de minderheid nadelige gevolgen ondervindt van een statutenwijziging. Voor toetsing van zo'n besluit tot statutenwijziging aan de redelijkheid en billijkheid meen ik dat in zo'n geval als uitgangspunt kan gelden dat een goede grond daarvoor aanwezig moet zijn. Dit impliceert naar mijn mening dat een statutenwijziging in het belang van de vennootschap moet zijn.

Beantwoording van de vraag of een besluit tot statutenwijziging strijd oplevert met de redelijkheid en billijkheid, wordt aldus mede bepaald door de omstandigheid of 'benadeelde' aandeelhouders een voor het door hen geleden nadeel 'passende' compensatie verkrijgen.

59. $\mathrm{Vgl}$. Slagter, Compendium 1996, $\S 11$.

60. Handboek nr. 149.

61. Vgl. HR 9 juli 1990, NJ 1991, 51 (Sluis BV).

62. $\mathrm{Vgl}$. bijv, de formulering van de Hoge Raad in het Lampe-Tonnema arrest (NJ 1991.

645). Zie ook M.J.G.C. Raaijmakers in zijn noot bij dit arrest, A.A 1991, p. 1009 e.v.

63. Zie ook B.C.M. Waaijer, Statuten en statutenwijziging, Deventer 1993, p. 16-19. 


\section{Winstreservering}

\section{$\S 1$. Inleiding}

De uitgangspunten van het dividend-/reserveringsbeleid van een vennootschap blijken uit haar statuten. ${ }^{\prime}$ Meestal bepalen de statuten dat de algemene vergadering van aandeelhouders beslist welke bestemming aan de winst moet worden gegeven. Het besluit tot winstbestemming kan inhouden een uitkering van dividend ten laste van de winst van het desbetreffende boekjaar, of ten laste van niet-gebonden reserves, zoals die blijken uit de vastgestelde jaarrekening van het desbetreffende boekjaar. ${ }^{2}$ Ook kan echter worden besloten tot een reservering van die winst. Met name dit laatste leidt in de praktijk geregeld tot conflicten.

Het opbouwen van reserves door vennootschappen is uiteraard uit financieel-economisch oogpunt zinvol en noodzakelijk. Aan de andere kant leidt het stelselmatig reserveren van (het grootste gedeelte van) de winst in de praktijk er toe dat aan (minderheids)aandeelhouders geen of een gering dividend uitgekeerd wordt (men spreekt wel van 'uithongering' of 'uitpersing'). De centrale vraag die dan rijst is binnen welke grenzen een besluit tot reservering van (een groot gedeelte van) de winst gerechtvaardigd is. In het navolgende buig ik mij over die vraag alsmede over de vraag in hoeverre aandeelhouders recht hebben op dividend. Bij het beantwoorden van die vraag vormen redelijkheid en billijkheid de maatstaf om de betrokken belangen te bepalen, te wegen en te verenigen.

1. Indien in de statuten niets geregeld wordt, volgt uit de wet dat de winst ten goede komt aan de aandeelhouders (artt. 2:105/216 lid 1 BW).

2. J.B. Huizink, Iets over dividend, De NV $70 / 6$ juni 1992, p. 137. Uitkeringen aan aandeelhouders zijn slechts toegestaan voorzover het eigen vermogen van de vennootschap groter is dan het gestorte en opgevraagde deel van het kapitaal vermeerderd met de reserves die krachtens de wet of de statuten moeten worden aangehouden (gebonden reserves), aldus het tweede lid van artt 2:105/216 BW.

Vergelijk het Engelse recht. Hier bepaalt s. 263 (3)(1) CA dat 'a company shall not make a distribution except out of profits available for the purpose. S. 263 (3) CA bepaalt vervolgens dat winsten die uitgekeerd kunnen worden zijn "its accumulated, realised profits, so far as not previously utilised by distribution or capitalisation less its accumulated, realised losses, so far as not previously written off in a reduction or reorganisation of capital duly made'. 


\section{§ 2. In geding zijnde belangen}

De toetsing van een besluit tot reservering van de winst aan de redelijk. heid en billijkheid komt neer op een afweging tussen enerzijds het belang dat de vennootschap heeft bij interne financiering en een financieel sterke positie, en anderzijds van het belang dat (minderheids) aandeelhouders hebben bij een uitkering van dividend. ${ }^{3}$

\section{\$ 2.1 Belang (minderheids)aandeelhouders}

Uitkering van dividend is om verschillende redenen van groot belang voor met name minderheidsaandeelhouders. ${ }^{4}$ In de eerste plaats omdat deze aandeelhouders voor het genieten van de winst uit de resultaten van de vennootschap veelal uitsluitend op het uit te keren dividend zijn aangewezen. Dit zal over het algemeen met name van toepassing zijn op minderheidsaandeelhouders van een besloten vennootschap. Een (minderheids)aandeelhouder van een beursgenoteerde vennootschap heeft immers de mogelijkheid om te allen tijde de waarde van zijn aandelen te realiseren middels verkoop. Deze mogelijkheid is voor minderheidsaandeelhouders in een BV echter zeer beperkt. Voor meerderheidsaandeelhouders ligt dat anders en bovendien kunnen zij bij verkoop van hun beleidsbepalend pakket profiteren van een pakketvergoeding. ${ }^{5}$

In de tweede plaats brengt winstinhouding onzekerheid mee voor enerzijds de reeds bestaande aandeelhouders, daar zij nog maar moeten afwachten of de ingehouden winst op een gunstige wijze binnen de onderneming wordt aangewend (en zal leiden tot een koersstijging van het desbetreffende aandeel) en anderzijds voor de potentiële belegger/koper, die het niet uitkeren van dividend als een signaal kan opvangen dat de toekomstperspectieven van de vennootschap niet gunstig zijn.

3. Vgl. voor het Duitse recht P. Hommelhoff, Ergebnisverwendung in der GmbH, ZGR 1986, p. 426.

4. Dit is uiteraard anders indien minderheidsaandeelhouders nog een rol vervullen in de vennootschap en op grond daarvan beloning krijgen.

5. In de Nederlandse doctrine wordt van derden niet geèist om alle aandeelhouders gelijk te behandelen, zie onder meer H.J.C. ter Kuile, Gelijkheid van aandeelhouders in Quid luris bundel, Deventer 1977, p. 68 en B.H.A. van Leeuwen, Beginselen van behoorlijk ondernemingsbestuur, Deventer 1990, p. 166. 


\section{\$2.2 Belang vennootschap}

Het belang van een vennootschap bij haar dividendpolitiek wordt bepaald door een aantal factoren, zoals:

- de (bedrijfs)economische positie van een vennootschap, in het bijzonder de omvang van de algemene reserve en dividendreserve en de hoogte en looptijd van financiële verplichtingen;

- de algemene economische toestand van de marktsector waarin de vennootschap zich bevindt;

- de prognoses omtrent die marktsector;

- de plannen van de vennootschap. ${ }^{6}$

\section{$\S 2.3$ Afweging van de belangen}

In dit verband rijst de vraag hoeveel gewicht er aan het belang van aandeelhouders en het belang van de vennootschap (met name de financieel sterke positie daarvan) moet worden toegekend. Het antwoord daarop zal afhangen van de omstandigheden van het geval en de waardering daarvan door de rechter. In het navolgende probeer ik in het licht van de redelijkheid en billijkheid aan de hand van Nederlandse en buitenlandse rechtspraak een aantal criteria te formuleren die wellicht houvast kunnen bieden bij de beoordeling van reserveringsbesluiten. Voorts zal ik trachten de belangen van aandeelhouders en het belang van de vennootschap te concretiseren.

\section{Criteria in buitenlands recht: belang vennootschap/bedrijfseco- nomische positie}

In het buitenlandse recht, met name in het Franse recht maar ook in het Engelse en Duitse recht, vormt het belang van de vennootschap een belangrijk aanknopingspunt bij de beantwoording van de vraag of het reserveringsbesluit al dan niet gerechtvaardigd is.

6. $\mathrm{V}_{\mathrm{gl}}$. ook D. Joost, Beständigkeit und Wandel im Recht der Gewinnverwendung in de bundel 100 Jahre GmbH Gesetz, Köln 1992, p. 300 en P. Hommelhoff. Ergebnisverwendung in der GmbH, ZGR 1986, p. 426. 


\section{§ 3.1 Franse benadering}

In Frankrijk wordt de onderhavige kwestie met name getoetst aan het leerstuk van 'abus de majorité' als de meerderheid van aandeelhouders een besluit neemt dat ten koste gaat van minderheidsaandeelhouders. In een standaardarrest van de Cour de Cassation van 18 april 1961, D. 1961 $J$ 166, waarin de algemene vergadering van aandeelhouders beslist om de winst van het voorafgaande jaar geheel te reserveren, heeft de Cour de Cassation beslist dat een besluit misbruik oplevert indien dit is genomen; 'contrairement à l'intérêt général et dans l'unique dessein de favoriser les membres de la majorité au détriment de la minorité'. Sindsdien heeft deze formule veel aandacht en navolging gekregen. ${ }^{7}$ Zie bijvoorbeeld de uitspraak van de Cour de Cassation van 22 januari 1991, Rev. Soc. 1992, p. 345 e.v. nt. Y. Chartier.

Deze uitspraak betreft de wederwaardigheden van de uit vier aandeelhouders bestaande SARL Pyrénées Diesel. De minderheidsaandeelhouder, Francois Grenet, die $45 \%$ van de aandelen houdt in de SARL, vecht drie besluiten aan van de aandeelhoudersvergadering. Twee besluiten die zijn genomen door de ava op resp. 12 augustus 1986 en 30 juni 1987 . betreffen de toevoeging van de winsten van 1985 en 1986 aan de reserves. Het derde besluit, genomen tijdens een buitengewone vergadering van aandeelhouders op 17 december 1988 . betreft het omzetten van reserves in kapitaal. De Cour d'appel Pau vernietigt de besluiten van 1987 en 1988 na de overweging dat de reserveringen een behoorlijk niveau hadden bereikt en dat de overige aandeelhouders direct of indirect voordeel behalen bij de winstreserveringen in de vorm van salaris. De Cour de Cassation wijst dit echter van de hand met de overweging dat de motieven die de Cour d'appel aangeeft slechts 'simples affirmations' zijn en niet precies genoeg om vast te stellen dat sprake is van 'abus de majorité (de tels motifs constituent de simples affirmations impropres à préciser en quoi les résolutions litigieuses avaient été prises contrairement à l'intérêt général de la société dans l'unique dessein de favoriser les associés majoritaires au détriment du demandeur').

Echter, bij de beoordeling van de winstreserveringen, vereist de Cour de Cassation niet dat deze voorwaarden cumulatief moeten zijn vervuld. Een besluit tot reservering van de winst kan enkel en alleen wegens strijd met

7. Zie ook J.L. Rives-Lange, L'abus de majorité in het themanummer van de Rev. Jur. Com. 1991, p. 67 en D. Tricot. Abus de droits dans les sociétés/abus de majorité et abus de minorité, Rev.trim.dr.com. 1994, p. 619. 
het 'intérêt général' 'abus de majorité' opleveren. ${ }^{8}$ Een goede illustratie biedt hier Cour de Cassation van 22 april 1976 inzake S.A.R.L. Etablissements Langlois et Peter c/Roizot. ${ }^{9}$

Twee aandeelhouders, die gezamenlijk $95 \%$ van het kapitaal van bovengenoemde S.A.R.L. in handen houden, besluiten al twintig jaren achtereen om de totale winst te reserveren. Zij ontvangen als bestuurder van de SARL wel salaris en andere 'beloningen'. Sinds 1968 bedraagt de reserve elk jaar een enorm bedrag, bestaande uit zo'n tweederde van de omzet, waarmee niet wordt geinvesteerd. De minderheidsaandeelhouder is geheel aangewezen op dividend, aangezien hij geen functie vervult binnen de vennootschap en het hem niet lukt om een koper te vinden voor zijn aandelen. Tijdens de jaarlijkse vergaderingen van 1970 tot 1974, wordt wederom met meerderheid van stemmen besloten om de gehele winst aan de buitengewone reserve toe te voegen. Daarop vordert de minderheidsaandeelhouder vernietiging van deze besluiten. De Cour de Cassation oordeelt hierover dat de besluiten tot reservering van de winsten 'n'a répondu ni à l'objet ni aux intérêts de la société. Que par ces motifs l'arrêt à relevé le premier l'élément dont l'existence est nécessaire, sinon suffisante, pour caractériser l'abus du droit de majorité'.

Overigens lijken de Franse rechters zeer terughoudend om 'abus de majorité' aan te nemen in geval van winstreservering, aangezien bij de beoordeling van een reserveringsbesluit met name in ogenschouw wordt genomen of dat wordt gerechtvaardigd op grond van (bedrijfs)economische redenen.

Een goede illustratie biedt hier Cour d'appel de Versailles 7 december 1995, Bull. Joly 1996, p. 197. In deze zaak vecht een minderheidsaandeelhouder van de SA Panol, Nigron, de winstreserveringsbesluiten van 1989 en 1990 aan wegens 'abus de majorité' en eist dat de vennootschap hem een bepaald bedrag aan dividend uitkeert. Hij stelt dat de reserveringen niet kunnen worden gerechtvaardigd door het beleid van de vennootschap.

Het Tribunal de Commerce te Nanterre wijst een deskundige aan om een en ander te onderzoeken. Op grond van het verslag van de deskundige stelt het Tribunal de minderheidsaandeelhouder in het ongelijk. Het Cour d'appel de Versailles wijst de vordering van de minderheidsaandeelhouder opnieuw af op grond van een tweetal overwegingen. Allereerst dienden de reserveringen ten behoeve van diversificatie, de ontwikkeling van nieuwe produkten en het investeren in een industrieel project in Hongarije, aldus de Cour d'appel. Voorts overweegt de Cour d'appel dat in voldoende mate duidelijk is geworden dat de

8. Zie J.L. Rives-Lange, L'abus de majorité in Rev.Jur.Com. 1991, p. 67. Het intérêt général speelt, zoals al uit de gebezigde formule blijkt, een belangrijke rol bij het leerstuk 'abus de majorité', vgl. M. Cabrillac, De quelques handicaps dans la construction de la theorie de l'abus de minorité, Bull.Joly 1992, p. 114. Zie ook hoofdstuk $2 \S$ 4.3 .

9. Rev.Soc. 1976, p. 479 e.v., nt. Schmidt. 
reserveringen gemaakt zijn 'dans l'intérêt général de l'ensemble des actionnaires', daar door deze reserveringen de waarde van het kapitaal van de vennootschap is gestegen en daarmet ook de waarde van de aandelen.

De benadering van de Cour d'appel in deze uitspraak ligt in de lijn van eerdere jurisprudentie. Vgl. bijv. Cour d'appel de Limoges 26 juni 1995, Juris Data nr. 95-43884. Op initiatief van de bestuurders/meerderheidsaandeelhouders werd gedurende een periode van vijf jaar de gehele winst gereserveerd. Ook hier oordeelt de Cour d'appel dat van 'abus de majorité' geen sprake is omdat dit reserveringsbeleid 'sage et prudente' (verstandig en zorgvuldig) is, 'puisque cette prudence avait favorisé d'après le rapport d'expertise, la rentabilitée l'entreprise, et avait permis d'affronter une période de crise'. Maar ook omdat de beslissingen tot winstreservering 'ont contribué à sauvegarder la valeur de leurs parts sociales'. Zie ten slotte ook Cass. Com. 23 juni 1987, BRDA 1987, nr. 14 p. 17 waar de meerderheidsaandeelhouders gedurende acht jaren besloten om de winst aan de reserve toe te voegen. De Cour de Cassation oordeelt hierover dat er geen sprake is van misbruik ondat het een zorgvuldig beleid betreft (politique prudente) en omdat deze besluiten hebben bijgedragen tot 'une progression de la valeur des actions qui profite à tous les actionnaires'.

Zoals uit bovengenoemde uitspraken blijkt, wordt met name aan twee argumenten belang toegekend. Allereerst dat winstreservering tot het voeren van een zorgvuldig beleid van de vennootschap behoort. ${ }^{10}$ Voorts wordt geargumenteerd dat winstreservering bijdraagt aan een waardestijging van de aandelen, waarvan alle aandeelhouders profiteren. Dit laatste argument acht ik echter, gelet op de vaak geringe verhandelbaarheid van de aandelen, weinig overtuigend.

\section{$\S 3.2$ Duitse benadering}

Ook in het Duitse recht vormt het belang van de vennootschap een belangrijk toetsingsmoment bij de beoordeling van winstreserveringen. In dit verband worden twee criteria centraal gesteld.

Winstreservering moet in de eerste plaats 'erforderlich' zijn voor het belang van de vennootschap. Dit is het geval indien andere financieringsvormen, die minder belastend zijn voor minderheidsaandeelhouders, niet voorhanden zijn. " In de tweede plaats moet er sprake zijn van

10. Winstreservering is immers een wettige manier om de vennootschap in zijn financièle behoeften te voorzien, zie onder meer J.L. Rives-Lange, t.a.p. p. 13 en Lamy societés commerciales 1996, nr. 2427.

11. Zie onder meer M. Dreher, Die gesellschaftliche Treupflicht bei der GmbH, DStR 1993, p. 1634 en M. Winter, Mitgliedschaftliche Treubindungen im GmbH-Recht. München, p. 284. 
'verhältnißmäßigkeit', dat wil zeggen dat niet zoveel winst mag worden gereserveerd dat het in geen verhouding meer staat tot het niet-uitgekeerde dividend. ${ }^{12}$

Deze criteria vindt men ook terug in $\S 254$ AktG, dat een aanknopingspunt biedt voor de beoordeling van een reserveringsbesluit. ${ }^{13}$ Volgens deze bepaling is een meerderheidsbesluit tot reservering van de winst aanvechtbaar wanneer een reservering 'bei vernünftiger kaufmännischer Beurteilung' nicht notwendig ist um die Lebens- und Widerstandsfähigkeit der Gesellschaft für einen hinsichtlich der wirtschaftlichen und finanziellen Notwendigkeiten übersehbaren Zeitraum zu sichern und dadurch die verteilte Dividende unter $4 \%$ des Grundkapitals sinkt' (curs. MK). Een dergelijke bescherming tegen 'uithongering' van minderheidsaandeelhouders, biedt de wetgeving met betrekking tot het GmbHG niet ( $\$ 29$ GmbHG). Wel worden op grond van de 'Treupflicht' in de rechtspraak voor $\mathrm{GmbH}$ 's dezelfde criteria gehanteerd. ${ }^{14}$

Men zie hier bijv, een uitspraak van het OLG Hamm van 3 juli 1991, GmbHR 1992, p. 458/BB 1992, p. 33. Het conflict betreft hier een besluit van de ava, genomen met 149 stemmen voor en 148 stemmen tegen, om $65 \%$ van de winst te reserveren. In de jaren daarvoor werd steeds $50 \%$ van de winst gereserveerd. De meerderheidsaandeelhouders beroepen zich op de statuten waarin een reservering van $75 \%$ van de winst wordt toegestaan 'wenn dieses erforderlich ist'. Dit impliceert volgens het OLG Hamm dat de statutaire bepaling slechts dwingt tot uitkering van $25 \%$ van de winst. Voor het overige wordt ruimte gelaten aan de ava om een besluit te nemen omtrent de winst. Daarbij zijn meerderheidsaandeelhouders onderworpen aan de Treupflicht en moeten zij rekening houden met de belangen van minderheidsaandeelhouders. Het OLG oordeelt dat bij afweging van enerzijds de economische en financiële positie van de vennootschap en anderzijds het belang van minderheidsaandeelhouders bij uitkering van winst, 'eine Rücklagenbildung nur dann zulässig ist, wenn sie nach verstăndiger kaufmănnischer Beurteilung erforderlich ist, wobei allerdings ein weiterer unternehmerischer Ermessensspielraum einzuräumen ist'. In dit geval oordeelt het OLG dat de economische positie van de vennootschap een reservering van $65 \%$ niet vereist.

12. M. Winter, Mitgliedschaftliche Treuebindungen im GmbH-Recht, München 1988, p. 284.

13. Zie bijv. Baumbach-Hueck, GmbHG $\$ 29$, nr. 74, Raiser, Recht der Kapitalgesellschaften, München 1992, p. 434 en F. Kübler, Gesellschaftsrecht, Heidelberg 1994. p. 203.

14. Zie bijv. Scholz, Kommentar zum GmbH- Gesetz. Bewerkt door o.a. V. Emmerich. H-J. Priester en Karsten Schmidt, Gesellschaftsrecht, Anm. 122 e.v., D. Joost, Beständigkeit und Wandel im Recht der Gewinnverwendung in de bundel 100 Jahre GmbH-Gesetz, Köln 1992, p. 299 en P. Hommelhoff, Ergebnisverwendung in der GmbH, ZGR 1986, p. 427. 


\section{§3.3 Engelse benadering}

De grens van de 'majority power' in geval van winstreservering komt in Engeland aan de orde in de specifieke procedures van s. 459 CA 1985 waarin getoetst wordt of sprake is van 'unfair prejudicial conduct'. In de Engelse jurisprudentie wordt benadrukt dat een winstreserveringsbesluit een commerciële beslissing is en dat slechts onder bepaalde omstandigheden de rechter mag ingrijpen. ${ }^{15}$

Als illustratie kan dienen $\operatorname{Re}$ Lundie Brothers (1965) 1 WLR 10S1. In de betreffende vennootschap was het gebruikelijk om winsten te verdelen over de bestuurders. In feite werd er nooit dividend uitgekeerd aan aandeelhouders. Toen een aandeelhouder hierover een procedure aanspande wegens 'onderdrukking' van de minderheidsaandeelhouders (op grond van sect. 210 CA 1948 vergelijkbaar met de huidige sect. 459 CA 1985) overwoog Plowman J: 'Its policy has been substantially to divide its profits between directors [..] but no case is either pleaded or had been established for concluding that the company's failure was oppressive to the shareholders of the company and indeed there may well have been sound commercial reasons for not declaring any dividend' (curs. MK). In Re Sam Weller \& Sons Lid. [1986] BCLC 430 (CA) weigeren de bestuurders/meerderheidsaandeelhouders om het dividend te relateren aan de winst, terwijl hun tantième wel evenredig stijgt. Peter Gibson J overweegt dat over het algemeen voorzichtigheid moet worden betracht met het ingrijpen in vennootschapsrechtelijke beslissingen. In deze situatie meent Gibson echter dat de besturders/meerderheidsaandeelhouders niet 'bona fide' hebben beslist met betrekking tot de dividenduitkering. Hierbij is van belang dat het een besloten vennootschap betreft waarbinnen sprake is van een vertrouwensrelatie tussen aandeelhouders. In zo'n vertrouwensrelatie dienen de gerechtvaardigde verwachtingen van aandeelhouders te worden gerespecteerd.

\section{§ 4. Nederlands recht}

Ook in het Nederlandse recht kan het belang van de vennootschap een essentiële rol spelen bij de belangenafweging rond het besluit tot winstreservering.

Zo kan uit een tweetal uitspraken rond de Uniwest Group BV worden afgeleid dat de bedrijfseconomische positie van de vennootschap, een grond kan opleveren om een besluit tot winstreservering te vernietigen.

De ava van Uniwest Group BV beslist op grond van haar statutaire bevoegdheid een aantal jaren achtereen om de gehele winst toe te voegen aan de algemene reserves. Dit was mogelijk omdat de enig directeur van Uniwest, in het bezit van de meerderheid van de

15. Vgl, ook R. Hollington, Minority shareholders'rights 1992, p.67. 
aandelen, steeds als aandeelhouder voor deze besluiten stemde. Twee minderheidsaandeelhoudes (ex-werknemers van Uniwest) vorderen, onder andere, de vernietiging van de bestuien om de winst te reserveren en een veroordeling alsnog een dividend betaalbaar te stellen

De Rb. Zutphen 17 januari 1991 (WPNR 6001, 1991, p. 246 met nt. J.W. Winter/ TVVS 1991, p. 160, met nt. W.J. Slagter) overweegt daaromtrent dat voldoende is dat de bedrijseconomische positie van Uniwest geen beletsel vormt voor een dividenduitkering en dat de ava ook overigens geen redelijke gronden heeft om de winstgerechtigde aandeelhoudes dividend te onthouden. ${ }^{16}$ De tweede uitspraak van de Rb. Zutphen van 30 september 1993 is in feite een herhaling van de eerste. Hier betreft het de besluiten over de winstbestemming over de jaren 1989-1991.

Voors dient hier de jurisprudentie op het gebied van het enquêterecht te worden vermeld zoals bijvoorbeeld het arrest van de Hoge Raad van 9 juli 1990, NJ 1991, 51 inzake Sluis BV en, als het vervolg daarop, $O K 24$ janucri 1991, NJ 1991, 224.

In Slus BV, een familie-beleggings BV, bestaat het aandelenkapitaal uit aandelen A en aandelen B. Een administratiekantoor houdt één aandeel A en één aandeel B. Directeur K.S. houdt 500 aandelen B; zijn broer S.sr. tevens directeur, houdt één aandeel A, terwijl de overige 499 aandelen A gehouden worden door zijn vijf kinderen. De statuten van Sluis BV bepalen dat naast de dividendreserves A en B ook een algemeen reservefonds in stand wordt gehouden. Krachtens een statutaire bepaling moet telkens $50 \%$ van de jaarwinst aan dat fonds worden toegevoegd.

Er ontstaat een conflict tussen aandeelhouders A en aandelhouders B. Aandeelhouders A zijn namelijk van mening dat het niet meer in het belang is van de BV of van de aandeelhouders om het vermogen van S BV in huidige omvang te handhaven. Zij stellen derhalve een statutenwijziging voor, waarbij deze bepaling wórdt geschrapt, zodat de vrijkomende gelden toegevoegd kunnen worden aan de dividendreserves. De directeur/grootaandeelhouder K.S. weigert mee te werken aan de statutenwijziging, waardoor de in casu verèiste tweederde meerderheid niet wordt gehaald.

In dit geschil rijst de vraag of het gedrag van de directeur, de weigering om mee te werken aan de wijziging van de afspraak (die in de stauten is verankerd) terzake van de reservering van de gemaakte winst, onder het begrip 'beleid' valt. De Hoge Raad overweegt dat onder omstandigheden sprake kan zijn van gegronde redenen om aan een juist beleid te twijfelen indien de vennootschap gedurende een aantal jaren, zonder dat het belang van de vennootschap zulks rechtvaardigt, geen of in verhouding tot de gemaakte winst gering dividend uitkeert en tevens indien de vennootschap op grond van een statutaire bepaling gedurende een reeks van jaren de door haar gemaakte winsten niet of slechts in geringe mate bij wege van dividend uitkeert zonder dat zulks (nog langer) door het vennootschappelijk

16. Een dividenduitkering moet dan ook in verhouding staan tot de bedrijfseconomische werkelijkheid, zie een uitspraak van Rb. Alkmaar van 15 december 1976, NJ 1977, 319. 
belang gerechtvaardigd wordt, en zij niet aan wijziging van die statutaire bepaling wenst met te werken.

De OK, waarnaar de Hoge Raad het geding terugverwijst, overweegt dat aan de beweegredenen van K.S. om niet mee te werken aan de statutenwijziging geen gefundeerde economische motieven ten grondslag lagen. De OK komt tot de conclusie dat het gedrag van K.S. is gebaseerd op zuiver persoonlijke, uit verstoorde familieverhoudingen voortvloeiende overwegingen en dat dit geen rechtvaardiging kan vormen om de statutaire bepaling omtrent de winstbestemming te handhaven. Onder deze omstandigheden, aldus de OK, is er sprake van gegronde redenen om aan een juist beleid te twijfelen.

Uit de voorgaande uitspraken blijkt dat (bedrijfs)economische motieven een beslissende rol kunnen spelen bij de belangenafweging. Dat geldt enerzijds in geval van een riante financiële positie, anderzijds natuurlijk ook in geval van (dreigende) economische moeilijkheden. Echter, indien ten tijde van de aandeelhoudersvergadering de moeilijkheden niet concreet voorzienbaar zijn, legt het belang dat de vennootschap heeft bij het bewaren van een sterke financiële positie van het bedrijf 'relatief minder gewicht in de schaal'. ${ }^{17}$

Vgl. Hof s'-Gravenhage 1 oktober 1982, NJ 1983, 393. ${ }^{18}$ De NV waarop deze uitspraak betrekking heeft, is gespecialiseerd in de bouw van baggermateriaal, een tak van scheeps. bouw, waarvoor sombere vooruitzichten bestaan. Op het moment dat tijdens een ava het besluit wordt genomen om de 'restant-winst' toe te voegen aan de reserves zijn et echter geen duidelijke aanwijzingen dat ook voor dit bedrijf concrete moeilijkheden dreigen.

De NV is een familievennootschap met drie bestuurders, waarbij één van die drie bestuurders de meerderheid van de aandelen in handen heeft. In de statuten van de NV is bepaald dat de 'restant-winst' (d.w.z. de na een aantal statutair verplichte uitkeringen resterende winst) ter beschikking staat van de ava die dit geheel of ten dele kan verdelen over de aandeelhouders en/of kan bestemmen voor extra reservering of afschrijving. In de loop van de tijd ontstaat het gebruik dat de ava in geval van 'restant-winst' steeds $50 \%$ als extn dividend uitkeert aan de aandeelhouders.

Tijdens een aandeelhoudersjaarvergadering van 3 december 1972 weigert een minder. heidsaandeelhouder mee te werken aan een besluit tot omzetting van de vennootschap in een BV, waarvoor een gekwalificeerde meerderheid vereist is. De meerderheidsaandeelhovder/bestuurder heeft daarop een duidelijk dreigement geuit, inhoudende dat dit 'repercussies zal hebben voor deze tak van de familie, zowel voor hen die in het bedrijf als buiten bet bedrijf werkzaam zijn'.

17. Zie bijv, ook Rb. Roermond 17 mei 1973, NJ 1974, 57. In die zaak werd geoordeeld dat de meerderheidsaandeelhouder concreet had moeten aangeven waarom hij de vaststelling van de jaarrekening verhinderde.

18. Vgl. W.J. Slagter. TVVS 1983, p. 105. 
In de jaren daarna keert de ava in verhouding tot de winst slechts een gering dividend uit. Op een aandeelhoudersjaarvergadering van 3 december 1975, waarbij de jaarrekening van 1974 wordt vastgesteld, wordt zelfs besloten om de gehele 'restant-winst' aan de reserves toe te voegen en geen dividend uit te keren. Daaruit leidt de minderheidsaandeelhouder, die geen deel uitmaakt van de directie af dat het doel van de meerderheidsaandeelhouder kennelijk is om hem 'uit te hongeren' en daardoor te bewegen zijn aandelen te verkopen. ${ }^{19}$ De minderheidsaandeelhouder vecht het besluit aan wegens strijd met de goede trouw. Tegen de achtergrond van de vermelde omstandigheden laat het hof in casu het belang van de minderheidsaandeeihouder zwaarder wegen dan het belang dat de vennootschap heeft bij het bewaren van een financieel sterke positie van het bedrijf.

\section{\$5. Andere factoren dan de bedrijfseconomische positie}

In het voorgaande werd met name één factor, te weten de bedrijfseconomische positie van een vennootschap belicht. Veelal zullen echter meerdere factoren in aanmerking worden genomen om te concluderen of een besluit tot winstreservering al of niet strijdig is met de redelijkheid en billijkheid. Zowel de Nederlandse als de buitenlandse jurisprudentie kan dat illustreren.

\section{\$5.1 Systematisch winst reserveren/'dividend-verleden'}

Het systematisch, jaren achtereen, reserveren van winsten kan een aanwijzing vormen voor rechters om aan te nemen dat een besluit tot winstreservering onredelijk en onbillijk is. Zowel in Nederlandse als in buitenlandse rechterlijke uitspraken met betrekking tot winstreservering wordt rekening gehouden met het element van de herhaling. Dit is echter op zichzelf niet voldoende om tot de conclusie te komen dat strijd met de redelijkheid en billijkheid aanwezig is. Zulke winstreserveringen kunnen immers gerechtvardigd worden door gefundeerde bedrijfseconomische motieven. ${ }^{20}$

19. H. Prins noemt en vergelijkbaar voorbeeld: 'the majority approve a dividend policy aimed at inducing the minority to sell their shares at too low a value', zie Protection of the minority shareholders in a limited company, Leiden 1972, p. 55.

20. Zie in het Nederlandse recht bijv. Hof 's-Gravenhage 1 oktober 1982, NJ 1983, 393. reeds besproken in $\$ 4 . \mathrm{Vgl}$. voor het Engelse recht bijv. Re Lundie Brothers [1965] 1 WLR 1051. Met name in het Franse recht wordt het element van de herhaling overheerst door de bedrijfseconomische motieven. Een goede illustratie biedt bijv. CaC 22 avril 1976 (Rev. Soc. 1976, p. 479 e.v. besproken in \$ 3.1.). De Cour de Cassation overweegt hier dat: 'la société sans distribuer pendant vingt ans aucun dividende, avait mis en réserve des sommes considérables dont l'accumulation avait chaque année depuis 


\section{$\$ 5.2$ Verhouding winst - dividend}

Bij het beantwoorden van de vraag of een reserveringsbesluit gerechtvaardigd is zal de verhouding tussen de gemaakte winst en het dividend meewegen.

In het Nederlandse recht wordt reeds in oude jurisprudentie bepaald dat het vaststellen van dividend dat niet in 'redelijke verhouding' staat tot de in de voorafgaande jaren behaalde winsten strijd met de goede trouw (redelijkheid en billijkheid) oplevert omdat daarmee een gedragslijn wordt gevolgd, die geen redelijk handelend vennootschap ten opzichte van haar winstgerechtigden (waaronder aandeelhouders, MK) kan volgen. ${ }^{21}$ In een recentere uitspraak van de Hoge Raad van 9 juli 1990, NJ 1991, 51 (Sluis BV), op het gebied van het enquêterecht, reeds besproken in $\S 4$, zie ik een bevestiging hiervan. In het Duitse recht wordt, zoals ik in $\S 3.2$ reeds heb besproken, de reserveringsbesluiten getoetst aan de 'Verhältnismäßig. keit'

Ook in het Franse recht vormt het percentage van de winst dat wordt gereserveerd een aanwijzing voor de rechter bij de beoordeling van de noodzakelijkheid van een winstreservering. ${ }^{22}$

Vgl. bijv. de uitspraak inzake SARL Huber et compagnie van de Cour de Cassation (Com) van 9 juni 1990, Rev.Soc. 1990, p. 606 e.v., nt. Y. Chartier. Het gaat hier om een klassieke situatie waarin aanzienlijke winsten van de vennootschap geheel worden gereserveerd, terwijl twee meerderheidsaandeelhouders in hun functie als bestuurder forse salarissen toebedeeld krijgen.

De Cour de Cassation oordeelt dat er sprake is van 'abus de droit de majorité' onder meer overwegend dat 'depuis la création de la société Huber, tous les bénéfices d'exploitztion avaient été affectés entièrement aux réserves, portant le montant de celles-ci vingt deux fois celui du capital, sans que cette mise en réserve n'ait eu aucun effet sur la politique d'investissement de l'entreprise, tandis que les deux associés détenant les $4 / 5$ du capital social disposaient de rémunérations importantes dont la croissance a été normalement rapide et qui ont permis en particulier au gérant de réaliser des investissements personnels se

1968 un chiffre supérieur aux deux tiers du chiffre d'affaires [..] et que cette affectation systématique de la totalité des bénéfices à la réserve extraordinaire avait constitué une thésauration pure et simple'. M.a.w. de Cour de Cassation oordeelt dat sprake is van een 'gewone' winstreserveringspolitiek, ondanks het feit dat twintig jaar geen dividend is uitgekeerd en de vennootschap goede omzetcijfers behaalde.

21. Zie HR 21 mei 1943, NJ 1943, 484 en Rb Utrecht 15 mei 1953, NJ 1954, 337.

22. Zie ook Bull. Joly 1991, doctrine et jurisprudence, p. 888. 
substituant à ceux qui auraient dù être réalises normalement par la société Huber s'agissant des immeubles qu'elle occupait et dont elle devait payer le loyer au gérant [..].

\section{Ten slotte kan nog worden verwezen naar het Engelse recht.}

Re Sam Weller \& Sons Ldd [1990], reeds besproken in $\$ 3.3$ kan opnieuw als illustratic dienen. In deze zaak had een familievennootschap gedurende 37 jaar het dividend niet verhoogd, terwijl de vennootschap het in de loop der jaren erg goed deed. In 1985 werd bijvoorbeeld van de 36,000 pounds winst slechts 2,520 pounds uitgekeerd als dividend. Voor de minderheidsaandeelhouders was dit de enige bron van inkomsten van de vennootschap. Dit in tegenstelling tot de enige bestuurder, Sam Weller. Peter Gibson J oordeelt: 'the facts are striking because of the absence of any increase in the dividend for so many years and because of the amount of accumulated profits for so many years and the amount of cash in the hand". Hij oordeelt 'as their (de minderheidsaandeelhouders) only income from the company is by way of dividend, their interests may not be only prejudiced by the policy of low dividend payments, but unfairly prejudiced' (curs. MK).

\section{\$5.3 Verhouding dividend en directietantième (en andere bestuur- dersbeloningen)}

Een andere factor die bij de belangenafweging rond winstreservering en dividenduitkering een rol kan spelen is, zoals reeds aangegeven in bovenvermelde Franse uitspraak, de verhouding tussen de ontwikkeling van het dividend en het directietantième. Voor de beantwoording van de vraag wanneer deze factor een rol speelt, biedt het Hof 's- Gravenhage in de reeds in $\$ 4$ besproken zaak Scheepsbouw/Van Rees (NJ 1983, 393) een aanknopingspunt.

Het hof overweegt daaromtrent: 'dat het directietantième niet in alle gevallen een rol hoeft te spelen bij de vaststelling van het dividend, doch wel in het gegeven geval van een familievennootschap met werkende en niet-werkende aandeelhouders, met name indien zich, zoals hier, het geval voordoet dat één van de directeuren tevens de meerderheid van de aandelen bezit en aldus in staat is om door zijn stemgedrag een hoog dividend te blokkeren terwijl zijn tantième daarentegen relatief stijgt'.

Zijn de financiële omstandigheden van een vennootschap gunstig dan is een hoger directietantième op zich niet ongeoorloofd. ${ }^{23}$ Is echter sprake

23. Zie bijv. W.J.M. Noldus, Ongeldigheid van besluiten in de naamloze vennootschap. Deventer 1969, p. 106. Tantième wordt wel omschreven als: elke beloning die afhankelijk is van de resultaten van de vennootschap, zie Handboek, nr. 252. 
van een ongelijke verhouding tussen enerzijds het (stijgende) directietantième en anderzijds een stagnerend dividend dan kan dat ertoe leiden dat een besluit tot winstreservering onredelijk en onbillijk is. ${ }^{24}$

Het voorgaande als uitgangspunt nemende, meen ik overigens dat het vaststellen van een 'redelijk' directietantième op zijn beurt mede bepaald dient te worden door de ontwikkeling van het dividend. Steun voor mijn opvatting vind ik met name in de Anglo-Saksische landen, waar niet alleen in literatuur en rechtspraak, maar ook in de dagbladen veel aandacht wordt besteed aan de vraag of bestuurders 'reasonable remuneration' betaald krijgen.

In het Anglo-Saksische recht is het niet moeilijk cases te vinden waarin is beslist dat een buitensporige beloning ('excessive renumeration') aan bestuurders/meerderheidsaandeelhouders kan worden beschouwd als onderdrukking ('oppression') van minderheidsaandeelhouders.

In Australië zie men de uitspraak van de Supreme Court of New South Wales in Sanford v Sanford Courier Services Pry Lid. ${ }^{23}$ De aandelen in Sanford Courier Services worden voor gelijke delen gehouden door drie aandeelhouders, waarvan twee tevens bestuurder zijn. In 1984 wordt door de vennootschap een dividend uitgekeerd van \$ 3,000. Voor de salarissen van de twee bestuurders werd een bedrag van \$ 169,000 uitgetrokken. Een bedrag van $\$ 9,714$ bleef als winst over. In 1985 wordt meer dan $\$ 182,000$ betaald aan de twee bestuurders en wordt geen dividend uitgekeerd aan de minderheidsaandeelhouder, terwijl er na belastingen en uitkering van de salarissen nog een bedrag van \$ 78,679 als winst overblijft. Het argument dat de twee bestuurders aanvoerden, te weten dat zij als oprichters persoonlijk garant staan voor het kapitaal door middel van door hen aan de vennootschap verstrekte leningen, werd door de Supreme Court van tafel geveegd. De buitensporige salarissen, welke de vennootschap aan de twee bestuurders betaalt, impliceert "oppression' van de minderheidsaandeelhouder.

Een soortgelijk resultaat werd bereikt in Roberts $v$ Walter Developments Pry Ldd, ${ }^{x}$ in deze zaak is de minderheidsaandeelhouder tevens bestuurder van Walter Developments, een vennootschap welke huizen verhuurt, die zich bevinden op haar grond. Op dat grondgebied bevindt zich ook een herberg. Deze herberg wordt beheerd door een partnership, waarin onder meer de minderheidsaandeelhouder, zijn vrouw en andere bestuurders van de vennootschap deelnemen. Aangezien de kapitaaldeelname van de partners in de partnership dezelfde zijn als de belangen in de vennootschap, wordt overeengekomen dat de partnership slechts nominale rente hoeft te betalen aan de vennootschap. De bestuurders van de

24. Eveneens in het Franse recht, zie bijv. Cour d'appel Aix en Provence 29 juni 1995. Juris data nr. 95-45922, zie tevens E. Lepoutre, Autofinancement des entreprises et abus de majorité, Bull. Joly 1996, p. 194.

25. (1987) 5 ACLC 394.

26. (1992) 10 ACLC 804. 
vennootschap ontvangen op dat moment elk slechts 1000 dollar per jaar aan salaris van de vennootschap. Door een conflict tussen minderheids- en meerderheidsaandeelhouders houdt het partnership echter op te bestaan. Het gevolg daarvan is dat de herberg voortaan een commercieel rentepercentage gaat betalen aan de vennootschap. De winst die voorheen werd gemaakt door het partnership komt nu in handen van de vennootschap. In 1989 besluiten twee bestuurders/meerderheidsaandeelhouders om $\$ 60.000$ aan salarissen uit te betalen aan bestuurders waarvan éen bestuurder $\$ 55.000$ krijgt, vanwege het belangrijke werk dat hij heeft verricht in de vennootschap. De Court of Appeal is van mening dat deze handelwijze 'oppressive' is ten opzichte van de minderheidsaandeelhouder/bestuurder:

'The resolution points unequivocally to an intention on the part of the second defendants to recoup for themselves a substantial part of the additional rental being paid by the partnership to the company [..]. In effect, \$ 12,000 (representing $20 \%$ of the directors'fees) which would otherwise have been available as a dividend in respect of the plaintiffs shareholding was, instead distributed to the majority shareholders by way of directors' fees'.

In het Engelse recht kan dergelijk gedrag van bestuurders/meerderheidsaandeelhouders bestempeld worden als 'unfairly prejudicial' in de zin van s. $459 \mathrm{CA} 1985 .{ }^{27}$

Een goed voorbeeld biedt Re Cumana Ld. [1986] BCLC 430 CA. Een bestuurder kreeg hier meer dan 300.000 pounds aan bonussen en pensioenvoorzieningen. Vinelott J. oordeelde: 'The remuneration paid to [the respondant/bestuurder] was plainly in excess of anything he had earned and was so large as to be unfairly prejudicial.' Vgl. ook Re a Company [1986] 2 BCC 99, 453 en 2 BCC 99. 495 (appeal). In deze zaak was het salaris dat aan de bestuurder/meerderheidsaandeelhouder werd betaald zo omvangrijk, dat dit beschouwd kon worden als 'oppressive of the minority shareholder'.

Bij het voorgaande teken ik echter aan dat, mijns inziens, wel voorzichtigheid is geboden om aan de onevenredig stijgende beloning de conclusie te verbinden dat een reserveringsbeluit onredelijk en onbillijk is. Ik acht de verhouding bestuurdersbeloning en dividend alleen niet beslissend bij de beoordeling van reserveringsbesluiten. Veelal zal het een combinatie van factoren zijn die tot de conclusie voert dat een besluit tot winstreservering strijd met de redelijkheid en bilijkheid oplevert. ${ }^{28}$ Voorts acht ik van belang in het oog te houden dat bestuurders/meerderheidsaandeelhouders zich ook op andere manieren dan door toekenning van tantième kunnen

27. $\mathrm{Vgl}$. S. Goulding. Principles of company law, London 1996, p. 295.

28. Zie voor het Franse recht bijv. D. Tricot, Abus de droits dans les sociétés abus de majorité et abus de minorité, Rev.trim.dr.com. 1994, p. 619. 
bevoordelen ten detrimente van minderheidsaandeelhouders. Men denke bijvoorbeeld aan het benutten van een 'corporate opportunity'. ${ }^{29}$

\section{§ 6. Vaststelling redelijk dividend: taak voor de rechter?}

Uit het voorgaande kan worden afgeleid dat (minderheids)aandeelhouders recht hebben op een billijk dividend. Echter, wat is een billijk dividend en hoe kan worden bewerkstelligd dat dit wordt uitgekeerd? De enkele vernietiging van besluiten tot reservering van de winst, langs de weg van art. 2:8 jo. art. 2:15 lid 1 sub b BW of via het enquêterecht, leidt daar immers niet toe.

Er is nu een drietal mogelijkheden denkbaar. Eén mogelijkheid, die met name in Nederland steeds uitgangspunt is van wetenschappelijke discussies, is om het vaststellen van een redelijk dividend aan de rechter over te laten. Een andere mogelijkheid is dat de wetgever een 'redelijk' (minimum) dividend bepaalt. Ten slotte is een combinatie van beide mogelijkheden denkbaar.

\section{§6.1 Opvattingen in Nederland}

In het Nederlandse recht wordt over het algemeen erkend dat het een rechter is toegestaan om in te grijpen in het geval dat een vennootschap geen of slechts een gering dividend uitkeert. Echter, in de huidige Nederlandse literatuur en rechtspraak bestaan wel verschillende opvattingen over de vraag hoe en in hoeverre dat kan en moet geschieden.

De meest vergaande opvatting in de jurisprudentie is dat de rechter zelf een besluit tot uitkering van een dividend van een bepaalde omvang vaststelt. Deze oplossing is verkozen in de uitspraak van Hof Arnhem 26 mei 1992, NJ 1993, $182^{30}$ als vervolg op Rb. Zutphen 17 januari 1991. ${ }^{31}$ Daarin overweegt het hof dat:

'niet valt in te zien waarom niet de rechter na vernietiging van een besluit omtrent de winstbestemming de vennootschap zou kunnen veroordelen tot betaalbaarstelling en mitsdien betaling van het dividend dat naar zijn oordeel behoort te worden uitgekeerd'.

29. Hiervoor verwijs ik naar hoofdstuk 10. Overigens kan men bij beursgenoteerde vennookschappen ook bijvoorbeeld denken aan deelname van bestuurders aan optieregelingen.

30. Zie ook L. Timmerman, TVVS 1993, p. 105.

31. L. Timmerman, t.a.p., p. 105/106. 
Slagter, ${ }^{32}$ Van Schilfgaarde, ${ }^{33}$ Timmerman, $^{34}$ Maeijer $^{35}$ en Bart$\operatorname{man}^{36}$ onderschrijven deze opvatting. Zo'n opvatting impliceert dat het recht op dividend door aandeelhouders rechtstreeks tegen de vennootschap kan worden ingeroepen. Van Schilfgaarde ${ }^{37}$ onderbouwt dit met de stelling dat een aandeelhouder die recht op dividend heeft, dat vordert als schuldeiser van een vennootschap. De aandeelhouder kan dan rechtstreeks vorderen dat de vennootschap een bepaald dividend betaalt, zonder dat de ava tevoren een besluit hieromtrent hoeft te nemen.

Aan deze opvatting is een aantal voordelen verbonden. Zo wordt het vaak moeizame proces rond het bijeenroepen en de besluitvorming van de ava vermeden. Bovendien, zo schrijft Van Schilfgaarde, kan aan een vordering tot betaling van een geldsom een vordering tot betaling van rente worden gekoppeld. ${ }^{38}$

Echter, het bezwaar van deze visie is, zoals Winter" betoogt, dat $z o^{\prime} \mathrm{n}$ vordering van een aandeelhouder neerkomt op vervanging van een vennootschappelijk besluit door een rechterlijk vonnis en dit is naar zijn mening slechts mogelijk indien de wet dit uitdrukkelijk bepaalt. Een vennootschap kan zijns inziens wel worden veroordeeld een besluit te

32. W.J. Slagter in zijn noot bij Hof 's-Gravenhage 10 oktober 1982, NJ 1983, 393 (Scheepsbouw/Van Rees, TVVS 1983, p. 106.

33. P. van Schilfgaarde, Tegenstrijdig belang in het vennootschapsrecht uit de congresbundel: De dubbelrol in het vennootschapsrecht, 'Deventer 1993, p. 30-32.

34. L. Timmerman in zijn commentaar bij Hof Amhem 26 mei 1992, NJ 1993, 182 in TVVS 1993, p. 105. Timmerman pleit zelfs voor een nieuw wetsartikel 2: 8a BW op grond waarvan de rechter de bevoegdheid verkrijgt om voor een rechtspersoon een besluit vast te stellen, indien deze in gebreke blijft. Zie $\mathrm{L}$. Timmerman, Dient de rechter voor een rechtspersoon besluiten te kunnen vaststellen? in de congresbundel: Knelpunten in de vennootschapswetgeving, Deventer 1995, p. 23 e.v.

35. J.M.M. Maeijer in zijn noot onder de uitspraak van Hof Amhem 26 mei 1992, NJ 1993 , 182. Maeijer is echter van mening dat reële executie op grond van art. 3:300 BW slechts kan worden toegepast in bepaalde gevallen, namelijk indien de aard van de rechtshandeling zich daar niet tegen verzet.

36. Volgens Bartman vloeit dit voort uit de bewoordingen van art. 2:105/ 216: 'Voor zover bij de statuten niet anders is bepaald, komt de winst de aandeelhouders ten goede'. Zie S.M. Bartman, Onderneming in (kort) geding 1994/1995, Arnhem 1996, p. 27.

37. P. van Schilfgaarde, Tegenstrijdig belang in het vennootschapsrecht in de congresbundel: De dubbelrol in het vennootschapsrecht, Deventer 1993, p. 32.

38. Bij een veroordeling tot betaling van een geldsom is uitvoerbaarverklaring bij voorraad mogelijk, zie art. 52 RV.

39. J.W. Winter in WPNR 1991, 6001, p. 246-248. 
nemen tot dividenduitkering en tot onmiddelijke uitvoering van 20 'n besluit.

\section{§ 6.2 Opvattingen in Engeland, Duitsland, Frankrijk en Spanje}

\section{Een rol voor de rechter}

Hoe kijkt men in het buitenland aan tegen de rol van de rechter in het geval de vennootschap geen of een gering dividend uitkeert?

Het Engelse vennootschapsrecht kent weliswaar een lange traditie van niet-ingrijpen door de rechter in de vennootschap,,$^{40}$ maar onder omstandigheden kan hier nalatigheid van de vennootschap om een redelijk dividend te betalen aan minderheidsaandeelhouders in een besloten vennootschap toch aanleiding geven tot optreden van de rechter. $\mathrm{Z}_{0}$ kan dergelijk gedrag een reden opleveren tot ontbinding van de vennootschap door de rechter 'on the just and equitable ground' (s. 124 Insolvency Act 1986) of gekwalificeerd worden als 'unfair prejudicial conduct' in de zin van s. 459 CA $1985,{ }^{41}$ waarbij de rechter sancties kan opleggen die vergelijkbaar zijn met hetgeen in het Nederlands recht na enquête mogelijk is.

Het niet uitkeren van dividend kan 'unfairly prejudicial conduct' zijn in het geval een deel van de aandeelhouders in hun belangen wordt geschaad. Vgl. Re Sam Weller \& Sons Ld BCLC [1990] 80,42 waarin Peter Gibson J. overweegt (p. 816): 'It may well be in the interests of the other shareholders, including the petitioners, that a more immediate benefit should accrue to them in the form of larger dividends. As their only income from the company is by way of dividend, their interests may not be only prejudiced by the policy of low dividend payments, but unfairly prejudiced'. En in Re a company [1988] 4 BCC 506 heeft de rechter beslist dat onder bijzondere omstandigheden een dividendbeleid waarbij geen rekening wordt gehouden met de belangen van alle aandeelhouders aanleiding kan geven tot een zgn. 'winding up order'.

40. Zie J. Hill, Protecting minority shareholders and reasonable expectations, Company and Securities Law Journal, 1982 p. 87. Vgl. ook Burland v. Earle [1902] AC (Privy Council).

41. $\mathrm{Vgl}$. N. Hawke, Legal control of directors' dividend discretion, Business Law Review 1989, p. 3/4.

42. Zie tevens Sealy, Cases and materials, nr. 253. 
In de Franse doctrine is het van oudsher wel toegestaan dat een rechter ingrijpt in de vennootschap, zij het via door hem benoemde personen, zoals een 'administrateur provisoire', een 'mandataire ad hoc', een 'observateur de gestion' of een 'expert de gestion'. De rechter kan met name aan een 'administrateur provisoire' vergaande bevoegdheden geven tot het ingrijpen in het functioneren van de vennootschap (vgl. hoofdstuk $2 \S 5.2) .3$

Minderheidsaandeelhouders kunnen verzoeken om de benoeming van zo'n administrateur of mandataire ad hoc. ${ }^{44}$ De rechters zijn echter wel terughoudend in het toekennen van deze verzoeken. ${ }^{45}$ Pas wanneer het gaat om ernstige feiten welke leiden tot een 'abus de droit' van meerderheidsaandeelhouders, waarbij het belang van de vennootschap in gevaar komt, zal de rechter zo'n verzoek inwilligen. ${ }^{46}$ Wat betreft de bevoegdheden van zo'n mandataire ad hoc, wordt in de jurisprudentie aangenomen dat hij mag stemmen in plaats van een meerderheid of minderheid van aandeelhouders, mits dit wordt gerechtvaardigd door het 'intérêt social'. 4 ?

\section{Een rol voor de wetgever?}

Zoals gezegd, is een andere mogelijkheid dat de wetgever het 'redelijk' dividend (mede) bepaalt. Een goed voorbeeld biedt hier Duitsland. $\S 254$ AktG biedt een zekere waarborg tegen 'uithongering' van minderheidsaandeelhouders van AG's door te eisen dat in beginsel $4 \%$ van het maatschappelijk kapitaal ('Grundkapital') als dividend moet worden bestemd

43. Zie onder andere Ripert-Roblot, nr. 1156/1157, Mercadal-Janin, nr. 1499 en J. Cavallini, Le juge des référés et les mandataires de justice dans les sociétés in bonis, Rev. Soc. 1998, p. 260 e.v.

44. Vaak geschiedt dit in een kort geding procedure. Zie Mercadal-Janin, nr. 1497.

45. Vgl. bijv. J. Mestre, Réflexions sur les pouvoirs du juge dans la vie des sociétés, Rev. Soc. 1985 , p. 86.

46. Mercadal-Janin, nr. 1496.

47. Vgl, bijvoorbeeld Cass. com. 9 maart 1993, Rev. Soc. 1993, 403 (m.nt Ph. Merle). Zie tevens J. Cavallini, Le juge des référés et les mandataires de justice dans les sociétés in bonis, Rev. Soc. 1998, p. 274. 
voor de aandeelhouders, tenzij al een gehele reservering om economische redenen noodzakelijk is. ${ }^{48}$

Het besluit tot winstbestemming kan krachtens \& 254 AktG worden aangevochten door minderheidsaandeelhouders, 'wenn die Hauptversammlung aus dem Bilanzgewinn Betrăge in Gewinnrücklagen einstellt oder als Gewinn vortrăgt, die nicht nach Gesetz oder Satzung von der Verteilung unter die Aktionăre ausgeschlossen sind, obwohl die Einstellung oder der Gewinnvortrag bei vernünftiger kaufmănnischer Beurteilung nicht notwendig ist, um die Lebens- und Widerstandsfahigkeit der Gesellschaft für einen hinsichtlich der wirtschaftlichen und finanziellen Notwendigkeiten übersehbaren Zeitraum zu sichern und dadurch unter die Aktionäre kein Gewinn in höhe von mindestens vier vom Hundert des Grundkapitals abzüglich von noch nicht eingeforderten Einlagen verteilt werden kann'.

Echter, deze regeling is ook onderwerp van kritiek. Zo zal dit minimumdividend de minderheidsaandeelhouder niet kunnen beschermen tegen excessieve reserveringen. Bovendien is het bedrag vaak niet toereikend om de vermogensbelasting, die geheven wordt voor het aandelenbezit, te betalen. $^{49}$

In het $\mathrm{GmbHG}$ is, in tegenstelling tot het AktG, geen wettelijke regeling opgenomen. ${ }^{50}$ Betreft het een $\mathrm{GmbH}$ dan moet de rechter het besluit van de meerderheidsaandeelhouder(s) steeds toetsen aan de 'Treupflicht', hetgeen neerkomt op afweging van het belang van de vennootschap en het belang van de aandeelhouders, waarbij alle omstandigheden in aanmerking moeten worden genomen. Omdat het zo moeilijk is voor een rechter om een oordeel te vellen over het dividendbeleid van een vennootschap, laat bescherming van de minderheidsaandeelhouders in de praktijk echter te wensen over.

Hommelhoff pleit derhalve voor een systeem van 'behoorlijke' ('ordentliche') winstreservering, waarbij de meerderheidsaandeelhouder(s) in

48. Overigens is $\S 254 \mathrm{AktG}$ alleen van toepassing in het geval de ava een besluit tot winstreservering neemt, het ziet dus alleen op $\S 58$ abs. 3. $\mathrm{Vgl}$. Huffer, Aktiengesetz $\S 254$, II, nr. 4 .

49. Zie M. Winter, Mitgliedschaftliche Treuebindungen im GmbH-Recht, München 1988, $p$. 290.

50. In $\S 42$ h van het ontwerp van het nieuwe GmbHG was wel een regeling analoog aan die van de AktG opgenomen. De gedachte achter het niet overnemen van het voorstel was dat dit niet stroken met de financieel geheel anders geaarde $\mathrm{GmbH}$. Zie hieromtrent bijv. Ehlke, DB 1987, p. 677 en D. Joost, Beständigkeit und Wandel in Recht der Ge winnverwendung in de bundel 100 Jahre GmbH Gesetz. Otto Schmidt Verlag Köln 1992, p. 302. 
beginsel mogen besluiten een bepaald gedeelte van de winst te reserveren ten behoeve van de vennootschap zonder rekening te hoeven houden met belangen van andere aandeelhouders (Hommelhoff denkt aan $60 \%$ ). Indien de vennootschap boven die $60 \%$ nog winst wil reserveren dient wel een belangenafweging plaats te vinden (zgn. 'Sockeltheorie'). ${ }^{51}$ Dit brengt volgens Hommelhoff mee dat de overige $40 \%$ van de winst bestemd zal worden voor dividenduitkering. In de literatuur staat men hier over het algemeen echter sceptisch en soms regelrecht afwijzend tegenover. ${ }^{52}$

Ook in Spanje heeft men in een wetsvoorstel (Proyecto de Ley de Sociedades de responsabilidad limitada) met betrekking tot de besloten vennootschap in art. 87 de uitkering van een bepaald minimum-dividend willen verzekeren. Deze bepaling geeft aan aandeelhouders, die tenminste $5 \%$ van het aandelenkapitaal vertegenwoordigen de mogelijkheid om van de vennootschap uitkering van tenminste een derde van de totaal voor uitkering beschikbare winst te eisen met uitzondering van de eerste drie levensjaren van de vennootschap.

Echter, vanwege de vele kritiek op deze regeling heeft men in Spanje uiteindelijk besloten om van deze regeling af te zien. Zo werd als argument aangevoerd dat zo'n regeling de vrijheid van dividendpolitiek en daarmee de financieringspolitiek van de vennootschap aantast. Voorts was men van mening dat deze regeling niet veel voordeel zou opleveren en zou afwijken van belangrijke trends, bezien vanuit rechtsvergelijkend perspectief..$^{53}$

Opmerkenswaard is dat in Frankrijk het niveau van 'een redelijk dividend' mede wordt bepaald door de 'trouw' van aandeelhouders. De wet van 12 juillet 1994 heeft art. 347-2 toegevoegd aan de wet van 24 juillet 1966, waarin aan een beursgenoteerde SA wordt toegestaan om aan aandeelhouders, die tenminste $5 \%$ van het geplaatste kapitaal in handen

51. P. Hommelhoff, Ergebnisverwendung in der GmbH, ZGR 1986, m.n. p. 427-433. Ter onderbouwing van deze theorie, kijkt Hommelhoff onder andere naar $\$ 58$ abs. 2 AktG. Hierin wordt bepaald dat indien het bestuur en de rve de jaarrekening vaststellen, zij de helft van de winst kunnen reserveren.

52. Zie bijv. D. Joost, Bestăndigkeit und Wandel im Recht der Gewinnverwendung in de bundel 100 Jahre GmbH Gesetz, Köln 1992, p. 302, Ehlke, DB 1987, p. 677 e.v. en Baumbach/Hueck $\$ 29 \mathrm{~m} .31$.

53. De informatie heb ik ontleend aan F.M. Sanz, The private company in Spain, a short overview in de bundel The European Private Company? ed. H.J. de Kluiver, W. van Gerven, Maklu 1995, p. 142. 
hebben en tenminste twee jaar aandeelhouder zijn, extra dividend uit te keren met een maximum van $10 \%$. Deze bepaling is niet van toepassing op de SARL. ${ }^{54}$ Een bezwaar van zo'n regeling is naar mijn mening dat het gelijkheidsbeginsel dat tussen aandeelhouders geldt wordt geschonden.

\section{§ 6.3 Eigen opvatting}

Een wettelijke regeling in het Nederlandse recht met betrekking tot een minimumdividend of een extra dividend lijkt mij om een aantal redenen niet wenselijk. Een belangrijke reden is mijns inziens dat het bijzonder moeilijk is om vast te stellen welk percentage van de winst als minimum. dividend zou moeten worden uitgekeerd. Bovendien is een wettelijke regeling te weinig flexibel en tast, zoals reeds vermeld in $\S 6.2$., de dividendpolitiek van de vennootschap en daarmee de financieringspolitiek aan. Het is overigens wel voorstelbaar dat met name in besloten vennootschappen minderheidsaandeelhouders en meerderheidsaandeelhouder(s) middels aandeelhoudersovereenkomsten afspraken met elkaar maken met betrekking tot het uit te keren dividend.

Gelet op het voorgaande, is naar mijn mening voor wat betreft de vaststelling van een redelijk minimum-dividend een belangrijke taak weggelegd voor de rechter. Wat betreft de vraag welke rol de rechter moet vervullen, gaat mijn voorkeur in beginsel uit naar de mogelijkheid voor een 'indirect' ingrijpen door de rechter. Met andere woorden de rechter kan, indien de omstandigheden daartoe nopen, een bevel opleggen aan de vennootschap om een bepaald minimum dividend uit te keren. Voor de overige bestemming van de winst behoudt de ava dan haar beslissingsbevoegdheid.

Echter, ik ben wel gevoelig voor het bezwaar dat aan deze aanpak verbonden is. De ava kan, ondanks een veroordeling, nalatig blijven met het nemen van een dividendbesluit. In zo'n geval, acht ik het wenselijk dat er een mogelijkheid bestaat om een besluit aan de rechtspersoon op te leggen. De methodiek die daarvoor in het Franse vennootschapsrecht wordt gebruikt spreekt mij aan. Ook voor het Nederlandse recht zou ik

54. Zie Ph. Engel en P. Troissière, La prime de fidélité aux actionnaires par attribution d'une majoration de dividende, JCP ed. E, p. 55-57, F. Peltier, L'attribution d'un dividende majoré a l'actionnaire stable, Bull. Joly 1995, p. 153 e.v. en Y. Guyon, La Loi du juillet 1994 sur le dividende majoré, Rev. Soc. 1995, p. 7. 
willen verdedigen dat er een mogelijkheid zou moeten bestaan om een deskundige persoon of instantie aan te wijzen die de bevoegdheid heeft om over uitkering van de winst te besluiten. Men zou hier kunnen denken aan de Ondernemingskamer. ${ }^{55}$

\section{Slotbeschouwing}

In dit hoofdstuk staat de problematiek rond winstreserveringen centraal. Winstreserveringsbesluiten, veelal genomen door meerderheidsaandeelhouders, leiden in de praktijk geregeld tot conflicten. Met name de minderheidsaandeelhouder loopt hierdoor winstuitkeringen mis terwijl de meerderheidsaandeelhouder (bijvoorbeeld als hij tevens bestuurder is) zichzelf kan ontzien door het innen van een (riant) salaris of tantième.

In dit verband rijst de vraag wanneer (minderheids)aandeelhouders recht hebben op dividend. Voor de beoordeling van reserveringsbesluiten c.q. dividendbesluiten meen ik, in aanmerking genomen de in dit verband gepubliceerde rechtspraak, dat aan een aantal criteria/factoren belang toekomt. Het gaat dan enerzijds om de bedrijfseconomische positie van de vennootschap en anderzijds om het 'dividend-verleden' van de vennootschap, de verhouding winst-dividend en de verhouding dividend-bestuurdersbeloningen (vgl. § 5).

Voorts komt de vraag op hoe kan worden bewerkstelligd dat een 'redelijk' dividend wordt uitgekeerd. Men kan in dit kader denken aan een wettelijke regeling die een bepaald minimum-dividend voor minderheidsaandeelhouders garandeert. Zo'n regeling is echter, met het oog op de dividendpolitiek en financieringspolitiek van een vennootschap, naar mijn mening te weinig flexibel. Een vergelijking met buitenlandse stelsels waarin een rol voor de wetgever is ingeruimd, zoals in Duitsland, geeft geen aanleiding om de hier verdedigde visie te wijzigen.

Een andere mogelijkheid is dat een rol wordt toebedeeld aan de rechter. Dit vormt een punt van juridische discussie. Hoever reikt de bevoegdheid van de rechter? Blijkens de Nederlandse jurisprudentie kan de rechter een bevel geven aan de vennootschap tot de uitkering van een bepaald dividend. Gewezen kan worden op de uitspraak van de Hoge Raad van 21 mei 1943, NJ 1943, 484 (Baus-de Koedoe), Hof 's Graven-

55. Zie ook Maeijer in het verslag van de discussie, in: Knelpunten in de vennootschapswetgeving, Deventer 1995, p. 137. 
hage 1 oktober 1982, NJ 1983, 393 (TVVS 1983, p. 105 m.nt. Slagter) en van de Rechtbank Zutphen van 17 januari 1991 (WPNR 6001, p. 246) en in hoger beroep Hof Arnhem 26 mei 1992, NJ 1993, 182.

Timmerman stelt - mijns inziens terecht - voorop dat boek 2 BW aan de rechter niet de bevoegdheid geeft om in plaats van de ava een besluit tot dividenduitkering te nemen. Ook Winter is deze mening toegedaan. Vervanging van een vennootschappelijk besluit is naar hun mening in het huidige recht slechts mogelijk als de wet dit uitdrukkelijk bepaald (zoals in het enquêterecht). ${ }^{56}$ Timmerman is wel een voorstander van een direct ingrijpen door de rechter en stelt voor, in een nieuw in te voeren art. 2: $8 \mathrm{a}$, een wettelijke grondslag te creëren voor de bevoegdheid van rechters om, in geval van verzuim door de vennootschap, zelf het besluit vast te stellen. ${ }^{57}$

Een en ander in aanmerking genomen zou ik, geỉnspireerd door het Franse recht, het meest wenselijk achten, wettelijk de mogelijkheid op te nemen dat de rechter een deskundige persoon of instantie kan benoemen die de bevoegdheid verkrijgt, om besluiten vast te stellen.

56. Zie J.W. Winter, Recente rechtspraak in WPNR 6001 en L. Timmerman, Dient de rechter voor een rechtspersoon besluiten te kunnen vaststellen?, in: Knelpunten in de vennootschapswetgeving, Deventer 1995, p. 26 alsmede in Nietigheden in het nv- en bvrecht, RM Themis 1992 , p. 148.

57. Zie L. Timmerman, t.a.p., p. 23 e.v. 


\section{DEEL II:}

VERHOUDING AVA - BESTUUR 



\section{Invloed van en instructie door aandeelhouders}

\section{\$1. Inleiding}

In dit hoofdstuk, dat nauw aansluit bij het vorige, concentreer ik mij op conflicten die kunnen voortvloeien uit de verhouding die tussen ava (aandeelhouders) en bestuur (bestuurders) in een NV of een BV bestaat. Deze machts- en rechtsverhouding, die in elke vennootschap aanwezig is, vindt grotendeels regeling in de wet en in de statuten.

Als uitgangspunt voor mijn beschouwingen omtrent de relatie tussen de ava en het bestuur, neem ik de stelling in dat deze verhouding moet worden bezien in het licht van de redelijkheid en billijkheid. Er bestaat onderling een verplichting tot loyaliteit, aangezien de ava en het bestuur binnen de organisatie van de vennootschap moeten samenwerken om het doel daarvan te kunnen realiseren. ${ }^{1}$

Bij de beoordeling van belangenconflicten in deze verhouding moet voorop worden gesteld dat het bestuur bij het vervullen van zijn taak zich uitsluitend moet richten naar het belang van de vennootschap en de daarmee verbonden onderneming terwijl een aandeelhouder in beginsel mede het eigen belang centraal mag stellen.

In het navolgende wordt getracht een aantal belangentegenstellingen te belichten die bestaan tussen de ava en het bestuur en die tot uitdrukking (kunnen) komen in kwesties als het instructierecht, benoeming en ontslag van bestuurders en last but not least de problematiek rond 'corporate opportunities'.

Alvorens te bespreken welke mogelijkheden de redelijkheid en billijkheid biedt bij de oplossing van conflicten in de verhouding ava bestuur, acht ik het van belang om het concrete functioneren van de ava en het bestuur nader te bezien.

1. Zie over 'loyaal samenwerken' in een vennootschap ook H.J. de Kluiver, Onderhandelen en privaatrecht, Deventer 1992, p. $46 / 47$ en p. 55. 


\section{§ 2. Relatie ava - bestuur nader bezien²: bevoegdhedenverdeling}

De visie die men heeft op de meest aangewezen bevoegdhedenverdeling binnen een kapitaalvennootschap heeft invloed op de belangenafweging in conflictsituaties. Daarbij moeten natuurlijk wel de grenzen in het $00 \mathrm{~g}$ worden gehouden die wet en statuten stellen. Voorop gesteld dient te worden dat, krachtens de Nederlandse wet en statuten, zowel de ava als het bestuur eigen bevoegdheden hebben met daaraan verbonden eigen verantwoordelijkheden.

Het bestuur is dwingendrechtelijk belast met het besturen van de vennootschap, zij het behoudens beperkingen in de statuten (vgl. art. 2:129/239 BW). Anderzijds kent de wetgever ook aan de ava dwingendrechtelijk een aantal bevoegdheden toe. ${ }^{3}$ Daarenboven behoren de ava alle bevoegdheden toe die niet bij wet of statuten aan anderen zijn toegekend (art. 2:107/217 lid $1 \mathrm{BW}$ ).

De vraag rijst wat onder het 'besturen' van de vennootschap moet worden verstaan. De functieomschrijving die de wet in art. 2:129/239 BW verschaft, werkt niet uit welke bevoegdheden en taken het bestuur concreet zijn toebedeeld. Aangenomen mag worden dat in ieder geval tot de bestuurstaken behoren:

- het voorbereiden, vaststellen en uitvoeren van ondernemingsbeleid: het bepalen van her beleid kan worden beschouwd als het meest elementaire onderdeel van de bestuurstaak;

het beheer van het vermogen van de vennootschap;

de vertegenwoordiging van de vennootschap, zowel in als buiten rechte (vgl. art. 2:130/240 BW);

- de uitvoering van besluiten van andere organen."

2. Opgemerkt dient te worden dat er niet gesproken kan worden van één relatie tussen ava en bestuur. De juridische positie van de ava en het bestuur verschilt per vennootschap. Een en ander hangt onder meer af van de aard van de vennootschap en de statutaire regeling. Hetzelfde kan gezegd worden over de positie van een aandeelhouder en een bestuurder.

3. Deze bevoegdheden zijn: benoeming, schorsing en ontslag van bestuurders en commissarissen (tenzij het structuurregime van toepassing is op de vennootschap); vaststelling jaarrekening: statutenwijziging en ontbinding van de vennootschap.

4. Zie ook R. van den Vijver, Besluitvorming in besturen van vennootschappen in: Recht zo die gaat, Zwolle 1976, p. 170.

5. Zie hieromtrent Handboek nrs. 231/232, Rechtspersonen losbladig art. 129, aant. 2 e. v. en F.W.Z. Löwensteyn, Wezen en bevoegdheid van het bestuur van de vereniging en de naamloze vereniging (diss.). Zwolle 1959, p. 113 e.v. 
Meer in het algemeen is aanvaard dat het bestuur tot taak heeft alles te doen dat bijdraagt tot het bereiken van het doel van de rechtspersoon. ${ }^{6}$

$\$ 9$ van de Departementale Richtlijnen bepaalt dat daartoe onder meer behoren beslissingen over:

samenwerking met en deelneming in andere rechtspersonen;

investeringen:

benoeming en ontslag van werknemers.

De beslissingsbevoegdheid van het bestuur hoeft echter niet altijd exclusief te zijn. Sommige besluiten zijn onderworpen aan de goedkeuring van een ander vennootschapsorgaan (bijvoorbeeld de ava of de raad van commissarissen) of kan het bestuur slechts nemen op voorstel van een ander orgaan. $^{8}$

Voorts kunnen de statuten - binnen de grenzen die de wet daartoe laat - de bevoegdhedenverdeling nader regelen. Zo kunnen statutair bijvoorbeeld de bevoegdheid tot emissie van aandelen en de bezoldiging van bestuurders en commissarissen worden overgeheveld naar het bestuur (zie art. 2:96/206 lid 1 en art. 2:135/245 BW). ${ }^{9}$

Het uitoefenen van bevoegdheden door bestuurders wordt naar mijn mening, behalve door de wet en de statuten, begrensd door de redelijkheid en billijkheid. ${ }^{10}$ Door de aanvaarding van de benoeming ontstaat tussen bestuurder en vennootschap immers een organisatierechtelijke rechtsbetrekking en is de bestuurder onderworpen aan de normen van art. $2: 8$ en $2: 9$ BW.

6. Zie bijvoorbeeld Rechtspersonen losbladig, art. 129 aant. 3.

7. Voor juridische fusies echter, is een belangrijke beslissingsbevoegdheid toegekend aan de ava.

8. Dit is met name het geval bij structuurvennootschappen. Art. 2: 164/274 BW noemt een aantal besluiten dat onderworpen is aan goedkeuring van de raad van commissarissen. Opgemerkt dient te worden dat dergelijke goedkeuringsbepalingen wel een beperking inhouden van de bevoegdheid van het bestuur, maar ze ontnemen het niet zijn bestuurstaak, zie bijv. Dijk-Van de Ploeg, p. 156.

9. Bij deze categorie van besluiten op het terrein van het bestuur die tot de competentie van cen ander orgaan worden gebracht is het gevaar van 'uitholling' van bestuursbevoegdheden aanwezig. Vgl. Asser-Maeijer 2-III, nr. 300 en A.G. van Solinge, Instructiebevoegdheid in concernverhoudingen, in: Goed en trouw, Zwolle 1984, p. 260.

10. $\mathrm{Vgl}$. ook F.J.W. Löwensteyn, Wezen en bevoegdheid van het bestuur van de vereniging en de naamloze vennootschap. Zwolle 1959, p. 159. 
De redelijkheid en billijkheid kan enerzijds er toe leiden dat bijvoorbeeld een bepaalde statutaire beperking van de bestuursbevoegdheid onder omstandigheden niet geldt en de bestuurstaak derhalve uitgebreid wordt. Anderzijds echter kan de redelijkheid en billijkheid onder omstandigheden meebrengen dat bevoegdheden niet mogen worden uitgeoefend (en dus de bestuurstaak wordt beperkt), dan wel slechts met medewerking van een ander orgaan, zoals de ava. Dit is mijns inziens bijvoorbeeld het geval indien een besluit zeer ingrijpende gevolgen heeft voor de aandeelhouders of de structuur van de vennootschap betreft. Men denke aan een overdracht van (een essentieel deel van) de onderneming of de zeggenschap daarover in het kader van een bedrijfs -of aandelenfusie of een 'sterfhuisconstructie'." Te denken valt ook aan een splitsing van de vennootschap. ${ }^{12}$ Steun voor dit standpunt kan ook gevonden worden in het Duitse recht.

\section{§ 2.1 Duitsland}

De Duitse wetgever legt wat betreft de AG een sterk accent op het 'autonome' karakter van de drie verplichte organen van de AG, te weten de Vorstand (bestuur), de Aufsichtsrat (rvc) en de Hauptversammlung (ava). Op grond van $\S 76 \mathrm{AktG}$ is de Vorstand belast met de leiding van de $A G$ en de daarmee verbonden onderneming, waarbij als leidraad fungeert het 'Gesellschaftsinteresse' of 'Unternehmensinteresse'. ${ }^{13}$ De

11. Evenzo H.J.M.N. Honée, de NV 1984, p. 16-19 en Van Schilfgaarde, Van de BV en NV, nr. 42. Vgl, ook recentelijk Gerechtshof Amsterdam (OK) 27 mei 1999, NJ 1999, 487 (Gucci IV): 'Zeer wel denkbaar is - en het kan wenselijk zijn - dat het recht de regel zou inhouden dat emissies op een schaal als deze in het onderhavige geval (aan de Stichting, MK) vanwege GUCCI GROUP hebben plaatsgevonden, de instemming van de algemene vergadering van aandeelhouders dienen te hebben althans dat zij niet zouden mogen plaatsvinden zonder dat daaromtrent het oordeel van de algemene vergadering van aandeelhouders wordt gevraagd'.

12. De wet inzake splitsing van vennootschappen voorziet hierin alleen in het geval de splitsingsakte bepaalt dat de onderscheiden aandeelhouders van de splitsende vernootschap aandeelhouder worden van onderscheiden verkrijgende vennootschappen (art. 2:334cc BW),

13. De heersende opvatting is dat het bestuur rekening moet houden met een complex van deelbelangen. $\mathrm{Vgl}$. Th. Raiser, Das Unternehmensinteresse, FS R. Schmidt, 1976, P. 101 e.v. en G. Teubner, Unternehmensinteresse -das gesellschaftliche Interesse des Unternehmens - 'an sich'?, ZHR 1985, p. 470 e.v. Vgl. bijvoorbeeld $\$ 121$ (1) AkG De Hauptversammlung moet bijeen worden geroepen 'wenn das Wohl der Gesellschat 
Aufsichtsrat houdt toezicht op het bestuur ( $\$ 111$ abs 1. AktG) en de Hauptversammlung beslist slechts in de door de wet en statuten toegelaten gevallen ( $\$ 119$ abs. 1 AktG). Wel voorziet $\S 119$ abs. 2 AktG dat de Hauptversammlung kan beslissen over bestuursaangelegenheden, als de Vorstand dit wenst. ${ }^{14}$

In dit verband is van groot belang de uitspraak van het BGH inzake het 'Holzmüller-Fall', 's naar aanleiding waarvan een levendige discussie is ontstaan over de verhouding tussen ava en bestuur. De discussie spitst zich toe op de vraag of de ava naast de wettelijke en statutaire bevoegdheden ook nog andere bevoegdheden kan toekomen en zo ja, op welke grond. In het Holzmüller-Urteil geeft het BGH in algemene bewoordingen weer dat op grond van $\S 119$ abs. 2 AktG niet alleen een recht, maar ook een verplichting voor het bestuur kan bestaan om de ava te raadplegen (zgn. 'Vorlagepflicht')! ${ }^{16}$

In Mûllet \& Sohn AG, welk bedrijf zich van oorsprong bezig hield met de houthandel, ontwikkelde zich in de loop der jaren het 'Seehafenbetrieb' tot het meest waardevolle onderdeel. In 1972 besluit de AG dit onderdeel onder te brengen in een aparte, speciaal daartoc opgerichte $(100 \%)$ dochtervennootschap, Holzmüller KGaA. Vervolgens besluit de 100\% aandeelhouder het kapitaal van Holzmüller te vergroten. De minderheidsaandeelhouders van de moedervennootschap zijn echter de mening toegedaan dat het bestuur hen voor de verzelfstandiging en kapitaalvergroting om toestemming had moeten vragen.

Het BGH oordeelt hieromtrent; 'daß es grundlegende Entscheidungen gibt, die durch die Außenvertretungsmacht des Vorstandes, seine gemãß $\S 82$ abs. 2 AktG begrenzte Geschāftsführungsbefugnis, wie auch durch den Wortlaut der Satzung formal noch gedeckt sind, gieichwohl aber so tief in die Mitgliedsrechte der Aktionäre und deren im Anteilseigennum verkörpertes Vermögensinteresse eingreifen, daß der Vorstand vernünftigerweise nicht annehmen kann, er dürfe sie in ausschließlich eigener Verantwortung treffen, ohne die Hauptversammlung zu beteiligen'(curs. MK).

es fordert'. $\$ 49(2)$ GmbHG stelt hiervoor als eis 'wenn es im Interesse der Geselischaft erforderlich erscheint".

14. $\$ 119$ abs. 2 AktG luidt als voigt: 'Über Fragen der Geschäftsführung kann die Hauptversammlung nur entscheiden, wenn der Vorstand es verlangt'.

15. BGH 25 februari 1982, zie Die AG 1982, p. 158-164, E. Sünner, Aktionärsschutz und Aktienrecht, Die AG 1983, p. $169-173$ en D. Joost, 'Holzmuller 2000' vor dem Hintergrund des Umwandlungsgesetzes, ZHR 1999, p. 164 e.v.

16. Vór het Holzmuller - Urteil werd de kwestie of de ava naast de wettelijke bevoegdheden ook nog andere bevoegdheden op grond van ongeschreven recht kon toekomen in de literatuur en rechtspraak benaderd in het kader van de concernproblematiek. Zie W-G. Freiherr von Rechenberg. Die Hauptversammlung als oberstes Organ der Aktiengeselischaft, Heidelberg. 1986, p. 125/126. 
Het BGH oordeelt dat de ava ten aanzien van beide besluiten geraadpleegd had moeten worden. Dit is wat betreft de verzelfstandiging van een bepaalde activiteit in een daartoe opgerichte dochtervennootschap vereist omdat dit grote veranderingen teweeg brengt voor zowel de structuur van de onderneming als voor de relatie tussen de vennootschap en de aandeelhouders. Met betrekking tot de kapitaalvergroting gebruikt het BGH het argument da een kapitaalvergroting kan leiden tot verwatering van de deelname van aandeelhouders en uitholling van hun voorkeursrechten. ${ }^{17}$

Het BGH zegt dus eigenlijk dat het redelijk en billijk ('vernünftig') is dat het bestuur in situaties waarin zijn besluiten de rechten van aandeelhouders ingrijpend aantasten, zoals het vervreemden van delen van de onderneming, de ava raadpleegt. In casu ging het om een 'Ausgliederung' (verzelfstandiging) van een bedrijfsonderdeel en een kapitaalverhoging van de dochtermaatschappij. Beide zijn zgn. 'Strukturmaßnahmen'. Het BGH laat door zijn formulering de mogelijkheid open dat ook bij andere ingrijpende besluiten zo'n plicht kan bestaan. ${ }^{18}$

Anders dan in een AG, wordt het 'autonome' karakter van het bestuur in een $\mathrm{GmbH}$ naar de achtergrond verschoven door de overheersende positie van de Gesellschafterversammlung (ava). Hier kan de ava een grote invloed uitoefenen op het bestuursbeleid, onder meer vanwege het haar toekomende instructierecht jegens het bestuur ( $\$ 37 \mathrm{GmbHG}$ ). Ik bespreek dit verder in $\S 5.2$.

\section{$\S 2.2$ Frankrijk}

In Frankrijk wordt, met name ten aanzien van de SA, niet alleen in de doctrine maar ook in de rechtspraak het beginsel van 'machtenscheiding' van de vennootschapsorganen strikt toegepast. ${ }^{19}$ De wet van 1966 geeft

17. Vgl. E. Sünner, Aktionärsschutz und Aktienrecht. Die AG 1982, p. 170 en 172.

18. $\mathrm{Vgl}$. ook Die AG 1982, p. 163. In dit kader rijzen vragen van procedurele aard, zoals het moment waarop de ava geraadpleegd moet worden en met welke meerderheid de ava moet beslissen. Zie W. Groß, Vorbereitung und Durchfuhrung von Hauptversammlungs. beschlüssen zu Erwerb oder Veräußerung von Unternehmensbeteiligungen. Die AG 1996, p. 112, M. Lutter, Zur Vorbereitung und Durchführung von Grundlagenbeschliussen in Aktiengesellschaften, FS Fleck 1988, p. 170-172 en D. Joost, t.a.p., p. 199.

19. Dit geldt overigens niet voor de Société par Actions Simplifiée (SAS), sinds 3 januan 1994 geregeld in art. 262 L. 1966. De aandeelhouder(s) kunnen naar vrijheid statutait vormgeven aan de organisatie en de besluitvorming (262-6). Als enige eis stelt de wet dat een Président aanwezig moet zijn (art. 262-7). Zie hieromtrent bijvoorbeeld $Y$ Guyon, Rev. Soc., 1994, p. 207 e.v, en M. Jeantin, Les associés de la SAS, Rev. soc 
\$ 2. Relatie ava - bestuur nader bezien: bevoegdhedenverdeling

echter geen duidelijk beeld van de bevoegdhedenverdeling binnen een $\mathrm{SA}^{20}$

Enerzijds bepaalt art. 155 al. 1 L. 1966 (enigszins vergelijkbaar met art. 2:107/ 217 lid $1 \mathrm{BW}$ ), dat de ava bevoegdheden toekomen, die de wet niet aan andere organen toekent. Anderzijds kennen de artt. 98 al. 1 en 113 al. 2 L. 1966 daarentegen het bestuur (de conseil d'administration of het directoire) uitgebreide bevoegheden toe met uitzondering van de bevoegdheden die de wet uitdrukkelijk aan de ava toebedeeld. ${ }^{21}$

In de rechtspraak wordt het hierarchische karakter van de SA benadrukt. Statutenwijzigingen waardoor een verschuiving plaatsvindt van bevoegdheden tussen de organen zijn omstreden, daar als uitgangspunt geldt dat de verschillende organen elkaars bevoegdheden dienen te respecteren. $^{2}$

Reeds in 1946 oordeelde de Cour de Cassation": 'La société anonyme est une société dont les organes sont hiérarchisés et dans laquelle l'administration est exercée par un Conseil élu par l'assemblee générale d'empiéter sur les prérogatives du Conseil en matière d'administration'.

In dezelfde lijn liggen recentere uitspraken van het Cour de Cassation op 18 mei 1982 . Rev.Soc. 1983, p. 71 en van het Cour d'Appel Aix-en-Provence op 28 september 1982 , Rev.Soc. 1983, p. 773 e.v. In deze laatste zaak was aan de orde of aandeelhouders een bestuurscommissie kunnen oprichten. Pillard, de oprichter van de SA Enterprise générale de Chauffage Industriel Pillard' (EGCI), sloot drie jaar nadat hij de meerderheid van de andelen in de SA had verkocht aan Babcok en Wilcox, met dezen een overeenkomst teneinde zijn rechten als minderheidsaandeelhouders te beschermen. Om dit te bewerkstelligen werd onder meer een bestuurscommissie' opgericht. Teneinde de organisatie en het functioneren van de commissie mogelijk te maken werd, op aanbeveling van het bestuur, door de ava in de statuten een bepaling opgenomen die voorziet in de instelling van zo'n

1994, p. 223 e.v. Deze vennootschapsvorm laat ik verder buiten beschouwing.

20. Vgl. hieromtrent ook Guyon, Traité des contracts, $\mathrm{nr}, 177$.

21. Wat betreft de bevoegdheid van het conseil d'administration bepaalt art. 98 lid 1: 'Le conseil d'administration est investi des pouvoirs les plus étendus pour agir en toute circonstance au nom de la société; il les exerce dans la limite de l'object social et sous réserve de ceux expressément attribués par la loi aux assemblées d'actionnaires'. Art. 113 ziet op de bevoegdheden van de president: 'Sous réserve des pouvoirs que la loi atrribue expressément aux assemblées d'actionnaires ainsi que des pouvoirs qu'elle reserve de facon spéciale au conseil d'administration, et dans la limite de object social, le président est investi des pouvoirs les plus étendus pour agir en toute circonstance au nom de la société.

22. Zie Cozian-Viandier-Deboissy, nrs. 703 en 710 en Guyon, Droit des Affaires, nr. 279.

23. Cour de Cassation 4 juni 1946, JCP 1947.II.3518, note D. Bastian. 
commissie. De commissie functioneert van 1969 tot het moment in 1973 warop etn wettelijke vertegenwoordiger van de vennootschap van oordeel is dat de commissie in strijd is met de wet. ${ }^{24}$

Het Cour d'Appel overweegt hieromtrent dat doordat art. 90 al. 2 van het Décret \& bevoegdheid tot het instellen van een commissie uitdrukkelijk voorbehoudt aan het bestuur, het besluit van de ava betreffende de statutenwijziging nietig is. Het is een ava immers niet toegestaan 'd'empieter sur le rôle dévolu au conseil d'administration, celui-ci ne peut se dépoullier de ses attributions propres'.

Wat betreft de SARL ligt dit anders. Hier hebben aandeelhouders krachtens de wet (artt. 49-55 L. 1966) de mogelijkheid om naar wens her bestuur te organiseren. ${ }^{25}$

\section{\$2.3 Engeland}

Het Engelse recht is, wat betreft de regels met betrekking tot bevoegdhe. denverdeling, flexibeler dan de meeste West-Europese landen. ${ }^{26}$ In beginsel zijn slechts de statuten (articles of association) bepalend. Enig houvast bij de inrichting daarvan biedt Table A behorend bij de Com. panies Act 1985 (waarover hierna in $\S 5.1$ ), welke standaardbepalingen van toepassing zijn op private en public companies, tenzij de statuten anders bepalen.

Niettemin wordt ook in het Engelse recht als uitgangspunt aangenomen dat het bestuur en de ava, binnen de door de statuten getrokken grenzen van hun bevoegdheden, in principe autonoom opereren. ${ }^{27}$

Aanvankelijk worden bestuurders in de rechtspraak louter beschouwd als 'agents' die zich bezig houden met de uitvoering van managementtaken en in het kader hiervan instructies van de aandeelhoudersvergadering moeten opvolgen ${ }^{2 s}$. Deze opvatting wordt in Automatic Self-

24. Zie over de figuur van wettelijke vertegenwoordiger in het Franse recht ('administrateur judiciaire') hoofdstuk $2 \S 5.2$.

25. Zie ook Guyon, Traité des contrats, nr. 171.

26. Vgl. G. R. Sullivan, The relationship between the board of directors and the general meeting in limited companies, LQR 1977, p. 570/571.

27. Vgl. Mayson, French \& Ryan on Company Law, London $1997 / 98$, p. 454/455 en P Xuereb. The Rights of Shareholders, London 1991, p. 55/56. Overigens is er in de doctrine ook veel kritiek op dit uitgangspunt. Zie met name G.R. Sullivan, The relationship between the board of directors and the general meeting in limited cont panies, LQR 1977, p. 569 e.v.

28. Vgl. Isle of Wight Rly Co v Tahourdin [1883] 25 Ch D 320, zie ook S. Goulding. Principles of Company Law, London 1996, p. 111. 
Cleansing Filter Syndicate Co. Lid. v. Cunninghame [1906] 2 Ch. 34, voor het eerst verlaten. In deze zaak wordt beslist dat de aandeelhouders van een vennootschap niet de bevoegdheid hebben om met een gewoon meerderheidsbesluit het bestuur te instrueren om eigendommen te verkopen. 20

Recenter zie men bijvoorbeeld de uitspraak van de Court of Appeal inzake Howard Smith Ld v. Ampol Petroleum [1974] AC 821 die het beginsel van 'seperation of powers' als uitgangspunt neemt. Lord Wilberforce oordeelt; 'The constitution of a limited company normally provides for directors, with powers of management, and shareholders, with defined voting powers having power to appoint the directors, and to take, in general meeting, by majority vote, decisions on matters not reserved for management [...] it is established that directors, within their management powers, may take decisions against the wishes of the majority of shareholders, and indeed that the majority of shareholders cannot control them in the exercise of these powers while they remain in office'.

\section{Instructierecht ava ?}

Het voorgaande leidt ons onontkoombaar naar de vraag of er een instructierecht van de ava bestaat waarnaar het bestuur zijn taakuitoefening heeft te richten en, zo ja, wat dan de grenzen van zo'n instructierecht zijn.

De vraag van toekenning en/of uitoefening van instructiebevoegdheid staat in de literatuur uitgebreid ter discussie. Hierbij wordt veelal een onderscheid gemaakt tussen een zelfstandige vennootschap en een vennootschap die als afhankelijke maatschappij deel uitmaakt van een groep.

Wat betreft het aanvaarden van een instructierecht wordt op basis van het Forumbank-arrest, (HR 21-1-1955, NJ 1959, 43) wel aangenomen dat bij de enkelvoudige vennootschap de ava niet bevoegd is om instructies te geven aan een ander orgaan van de vennootschap (zoals het bestuur) indien de ava daarbij haar, bij de wet of de statuten getrokken, bevoegdheidsgrenzen zou overschrijden. De achterliggende gedachte is dat het andeelhoudersbelang niet altijd doorslaggevend dient te zijn en dat het bestuur, zich richtend naar het vennootschappelijk belang, ook andere

29. Evenzo in navolging van Automatic, Gramophone \& Typewriter Ltd. v. Stanley. Het betreft hier de aansprakelijkheid van een Engelse vennootschap met betrekking tot de dividendbelasting van een $100 \%$ Duitse dochteronderneming. Buckley J. oordeelt hier: 'The directors are not servants to obey directions given by the shareholders as individuals they are not agents appointed by and bound to serve their shareholders as their principals.' 
belangen in ogenschouw moet nemen, zoals de belangen van minderheids. aandeelhouders en werknemers. ${ }^{30}$

Over de juistheid van deze regel wordt in de literatuur niet gestreden." Echter, onduidelijk blijft wel waar de grenzen liggen die de ava in acht heeft te nemen. In het Forumbank-arrest wordt slechts in het algemeen verwezen naar wet (art. 2:129 BW/art. 47WvK oud) en statuten. ${ }^{32}$ Wel duidelijk is dat de zelfstandigheid van het bestuur van een enkelvoudige vennootschap moet worden gerelativeerd. De ava kan immers doot wijziging van de statuten veranderingen aanbrengen in de bestuursmacht en bepaalde bestuursbevoegdheden kunnen daardoor aan het bestuur worden onttrokken. Wel zal het bestuur in beginsel steeds bevoegd blijven de vennootschap te vertegenwoordigen. Bovendien kunnen de statuten, zoals reeds is vermeld in $\S 2$ instemmings- of goedkeuringsbepalingen bevatten. Blijkens de tekst van art. 2:139/239 BW zijn dergelijke statutaire beperkingen niet verboden.

Anderzijds is men het erover eens dat het bestuur niet zodanige beperkingen kunnen worden opgelegd dat er daardoor sprake is van een volledige uitholling van de bestuurstaak. ${ }^{33}$ Deze opvatting vindt men ook terug in $\S 9$ van de Departementale Richtlijnen. Het is geoorloofd dat een ander orgaan de bevoegdheid heeft om het bestuur aanwijzingen te geven mits een statutaire grondslag aanwezig is en die aanwijzingen niet verder

30. Met name F.J.W. Low wensteyn verdedigt deze opvatting. Hij is van mening dat het bestuur zelfstandig is zowel in een enkelvoudige vennootschap als in concernverhoudingen. Zie zijn proefschrift Wezen en bevoegdheid van het bestuur van de vereniging en de naamloze vennootschap, Zwolle 1959, p. 57 e.v. Zie ook J.B. Huizink, Bestuurders van rechtspersonen, Deventer 1989, p. $27-29$ en M.P. van Achterberg. De juridische definitic van het economische verschijnsel concern, Deventer 1989, p. 91/92.

31. Vgl. H.L.J. Roelvink, Bestuurszelfstandigheid in concernverhoudingen, in: Piercing Van Schilfgaarde, Deventer 1990, p. 47.

32. Zie W, Westbroek, Zijn wettelijke bepalingen gewenst in verband met concernverhovdingen, Praeadvies Vereniging Handelsrecht, p. 66. M.J.G.C. Raaijmakers in o.a. zijt dissertatie Joint ventures, Deventer 1976, p. 88 en AA 1993, p. 277. M.P. van Achterberg. De juridische definitie van het economische verschijnsel concern. Deventet 1989, p. 86.

33. Zie bijv. B.H.A. van Leeuwen, Beginselen van behoorlijk ondernemingsbestuut. Deventer 1990, p. 6 en Handboek, nr. 231. 
gaan dan de algemene lijnen van het te voeren economische, financiële en sociale beleid. ${ }^{34}$

De meningen omtrent de betekenis van het Forumbank-arrest voor de instructiebevoegdheid in concernverhoudingen lopen nogal uiteen. ${ }^{35}$ Volgens de meerderheid van de schrijvers lijdt de Forumbank-regel uitzondering in concernverhoudingen. $\mathrm{Zij}$ kennen, al dan niet binnen zekere grenzen, een bevoegdheid toe aan de moedervennootschap om het bestuur van een dochter bindende concrete instructies te geven. Het bestuur is volgens de meeste auteurs in beginsel verplicht deze instructies op te volgen, tenzij dit in strijd is met het belang van de vennootschap. Schrijvers als Timmerman, ${ }^{36}$ Roelvink, Van Schilfgaarde, Van Solinge, Huizink en Westbroek stellen daarbij wel de eis dat de instructiebevoegdheid een statutaire grondslag moet hebben.

Ook in de rechtspraak wordt het Forumbank-arrest gerelativeerd. In een aantal rechterlijke uitspraken is aangenomen dat de afwezigheid van een statutaire voorziening die de instructiebevoegdheid regelt binnen concernverhoudingen geen belemmering vormt voor het bestaan van deze instructiebevoegdheid. ${ }^{37}$

$\mathrm{Na}$ het Forumbank-arrest is de kwestie van de bevoegdheid om het bestuur van een enkelvoudige vennootschap instructies te geven, bij de Hoge Raad pas weer aan de orde gekomen in het Meijers/Mast-arrest, HR

34. $\mathrm{Vgl}$. ook wetsontwerp 26277. Bepaald kan worden volgens het nieuwe art. 2:239 lid 3 BW dat het bestuur zich dient te gedragen 'naar de aanwijzingen van een orgaan van de vennootschap die de algemene lijnen van het te voeren beleid op nader in de statuten aangegeven terreinen betreffen'. Zie M.J.A. van Mourik, Herziening van het preventief toezicht, WPNR 1999, p. 103.

35. Voor een uitgebreid overzicht van de verschillende opvattingen verwijs ik naar M.P Achterberg, De juridische definitie van het economische verschijnsel concern, Deventer 1989, p. 114-119 en S.M. Bartman-A.F.M. Dorresteijn, Van het concern, Arnhem 1996, p. $97-102$.

36. L. Timmerman, De NV 1990, p. 138 en in: Over multinationale ondernerningen en medezeggenschap van werknemers (diss. Groningen), Deventer 1988, p. 65 waar hij schrijft: 'Als een instructierecht van een bepaalde reikwijdte wordt aanvaard, dan zal dit steeds een basis dienen te hebben in de wettelijke of statutaire regeling van de bevoegdheden van de desbetreffende organen van de NV of BV'.

37. $\mathrm{Vgl}$. Hof Amhem 9 oktober 1974, NJ 1976, 42 (Makelaarskantoor Van E.); OK 18 maart 1976. NJ 1978, 317 (Batco); Rb's-Hertogenbosch 11 maart 1983, NJ 1984, 394 (Kuiken Brabant) en Pres. Rb Amhem 28 december 1987. NJ 1988, 699 (Amstelland). 
4 december 1992, NJ 1993, 271. ${ }^{38}$ Uit deze uitspraak kan impliciet afgeleid worden dat ook in geval van een enkelvoudige vennootschap een instructiebevoegdheid kan bestaan zonder dat in de statuten een bepaling is opgenomen als volgens $\& 9$ van de Departementale Richtlijnen is toegestaan.

In Meijers/Mast Holding $B V$ is sprake van een machtsstrijd tussen een bestuurder en de ave. Alle aandelen worden gehouden door mevr. Mast-Meijers. $Z_{i j}$ is tevens directie-voorzitter. Daarnaast zijn nog andere personen lid van het bestuur van de vennootschap. Op 1 januari 1986 benoemd mevr. Mast-Meijers haar broer, Meijers, tot enig statutair bestuurder van Mast Holding BV. Daarvoor was hij directiesecretaris. Op 12 augustus 1987 wordt hij door de ava ontslagen. De redenen voor dit ontslag zijn:

- ontevredenheid met het bestuursbeleid van de afgelopen jaren;

- de weigering van Meijers om het beleid uit te voeren dat door enig aandeelhoudster mevr. Mast-Meijers wordt gewenst en waaraan een advies van een onafhankelijk organisatieadviseur ten grondslag ligt.

Meijers vordert schadevergoeding op de grond dat het hem verleende ontslag in de zin van art. 7A:1639 s BW kennelijk onredelijk is. De Hoge Raad is echter van oordeel dat: "de weigering van een bestuurder van een vennootschap om een door de algemene vergadering van aandeelhouders gewenst beleid uit te voeren een redelijke grondslag voor ontslag kan zijn' (curs. MK). Of die weigering in concreto een redelijke grond oplevert, hangt af van de aard van het door de algemene vergadering gewenste beleid en van de overige omstan. digheden (curs. MK).

In het onderhavige geval betrof het door de algemene vergadering voorgestane beleid de naleving van de aanbevelingen in een rapport van een organisatieadviseur, dat is opgesteld in verband met de financiēle positie van de vennootschap, welke wordt gekenmerkt door een jarenlange, verliesgevende situatie en een slechter wordende solvabiliteitspositie. Gelet op die omstandigheden, geeft het oordeel van het Hof, dat hier geen sprake is van een kennelijk onredelijk ontslag, niet blijk van een onjuiste rechtsopvatting, aldus de Hoge Raad.

\section{§ 4. Eigen opvatting instructierecht}

Het is de vraag of men in het kader van de instructiebevoegdheid een onderscheid moet maken tussen een enkelvoudige vennootschap en een vennootschap die deel uitmaakt van een concern. Noch in de wet (arth. $2: 107,129 / 217,239 \mathrm{BW})$ noch in het Forumbank-arrest vindt men mijns inziens enig aanknopingspunt daarvoor. ${ }^{39} \mathrm{De}$ in het Forumbank-arrest gehanteerde regel dat de ava bij de wet en statuten getrokken grenzen van

38. Zie omtrent deze uitspraak ook M.J.G.C. Raaijmakers, AA 1993 p. 275-281 en L. Timmerman, TVVS 1993, p. 45-46.

39. In gelijke zin, Lôwensteyn, Rechtspersonen art. 129, aant. 13. 
haar bevoegdheid niet mag overschrijden, geldt naar mijn mening ook niet onverkort voor een enkelvoudige vennootschap.

Wat kan men nu immers uit het Forumbank-arrest afleiden? Het Forumbank-arrest heeft betrekking op een enkelvoudige vennootschap die het bankbedrijf uitoefende waarbinnen het bestuur de instructie kreeg tot een zodanige inkoop van eigen aandelen dat de liquiditeitspositie van de bank in gevaar zou komen. ${ }^{40} \mathrm{De}$ instructie was in casu evident in strijd met het vennootschappelijk belang en (dus) met de redelijkheid en billijkheid. En daar nu ligt mijns inziens het kernpunt van het arrest. Vanuit dit perspectief is er onder omstandigheden niet zoveel bezwaar tegen instructies door de ava. Met name als deze wordt geïnitieerd door één of enkele aandeelhouders met invloed. Naarmate het controlerend belang van de meerderheidsaandeelhouder groter is, zal de zelfstandigheid van het bestuur tegenover aandeelhouders in betekenis afnemen en heeft de ava een wezenlijke invloed op het door het bestuur te voeren beleid.

Zoals gezegd heeft dit echter consequenties voor de belangenafweging in het kader van toetsing aan de redelijkheid en billijkheid. ${ }^{41}$ Naarmate de invloed van de ava of aandeelhouders op het bestuur groter is, dienen aandeelhouders zich mijns inziens bij het aanwenden van hun invloed wel meer te richten op het belang van de vennootschap en de daarmee verbonden onderneming. ${ }^{42}$

40. Zie ook M.J.G.C. Raaijmakers, diss. Joint Ventures, Deventer 1976, p. 84/85 en dezelfde in AA 1993, p. 281. Hijmans v.d. Bergh is, in zijn noot bij het Forumbankarrest (NJ 1959, 43), de mening toegedaan dat de ava niet door opdrachten de bevoegdheden van de directie moet doorkruisen en uithollen, daar 'dit in strijd zou zijn met de sociaal-economische werkelijkheid'. Deze opvatting is mijns inziens inmiddels verouderd.

41. Een andere consequentie kan naar mijn mening betrekking hebben op de aansprakelijkheid van het bestuur/de bestuurders. In $\$ 7 \mathrm{zal}$ ik enige aandacht aan dit aspect besteden.

42. Evenzo J.B. Huizink, Bestuurders van rechtspersonen, Deventer 1989, p. 33. 


\section{§ 5. Instructierecht ava bezien naar Engels en Duits recht}

\section{§5.1 Engeland}

Wat betreft de instructieproblematiek, kan in het Engelse recht worden aangeknoopt bij s. 70 Table A behorend bij CA $1985 .{ }^{43}$ Deze luidt als volgt:

'Subject to the provisions of the Act, the memorandum and the articles and to any directions given by special resolution, the business of the company shall be managed by the directors who may exercise all the powers of the company [...]'

Hieruit kan afgeleid worden dat de ava weliswaar instructies kan geven aan het bestuur, maar slechts 'by special resolution', dat wil zeggen met drievierde meerderheid. ${ }^{44}$ De achterliggende gedachte is dat aandeelhouders de bevoegdhedenverdeling ook kunnen beïnvloeden door middel van een statutenwijziging waarvoor eveneens een drievierde meerderheid is vereist. ${ }^{45} \mathrm{~S} .70$ van Table A is in de plaats gekomen van het 'oude' s. 80 van Table A behorend bij CA 1948. Deze bepaling en de jurisprudentie daaromtrent is echter nog steeds van toepassing op de vele duizenden vennootschappen die zijn opgericht voordat de CA 1985 van kracht werd. ${ }^{46}$

Art. 80 CA 1948 luidde: 'The business of the company shall be managed by the director who may [..] exercise all such powers as are not by the Act or by these regulations, required to be exercised by the company in general meeting. subject nevertheless, to any of such regulations, to the provisions of the Act and to such regulations being not inconsistent with the aforesaid regulations or provisions as may be prescribed by the company in general meeting'.

De interpretatie van s. 80 CA 1948 is in de rechtspraak niet eenduidig. In de doctrint zijn twee visies te onderscheiden. De eerste visie gaat er van uit dat een special resolution

43. Vgl. L.S. Sealy, Power of the general meeting to intervene, CLJ 1989, p. 26 en P. Xuereb, p. 53 c.v.

44. Zie ook F. Chomely Bischoff, Comparative Law Yearbook of International Business, Shareholders' liability 1993, p. 101.

45. $\mathrm{Vgl}$. Mayson, French \& Ryan on Company Law, p. 454: 'It might be argued that a direction given by special resolution should be construed as altering art. 70 so as to giv the directors powers of management except on the subject-matter of the direction, and being by special resolution this would be an effective alteration under CA, s. 9'.

46. Zie bijv. Wedderburn of Charlton, Control of corporate actions, t.a.p., p. 405. 
vereist is voor bemoeienis van de ava met bestuursaangelegenheden." De autonomie van de ava en het bestuur staat dan voorop. De tweede visie houdt in dat een gewoon meerderheidsbesluit (ordinary resolution) van de ava voldoende is voor een instructic aan het bestuur. "

De jurisprudentie is niet eenduidig. De eerste visie strookt bijvoorbeeld niet met de vitspraak inzake Marshall's Valve Gear Ltd. v. Manning. Wardle Ltd. [1909] I Ch. 267. In deze zaak wil de bestuurder/meerderheidsaandeelhouder van Marshall's een procedure beginnen tegen Manning wegens inbreuk op een patent. De bevoegdheid om te procederen is echter krachtens de statuten toebedeeld aan het bestuur en de overige drie bestuurders stemmen tegen. Neville J. stelt de bestuurder/meerderheidsaandeelhouder in het gelijk. 'The majority of shareholders in the company at a general meeting have a right to control the action of directors so long as they do not effect to control it in a direction contrary to any of the provisions of the articles which bind the company'.

De tweede visie lijkt in strijd te zijn met Scott v. Scott [1943] (CA) All ER 582. In deze rak worden besluiten van de ava, inhoudende instructies aan het bestuur om interim dividend uit te keren, vernietigd. De bevoegdheid tot uitkering van dividend was volgens de statuten voorbehouden aan het bestuur. Lord Clauson oordeelt: 'The thing which is to be managed by the directors and with which the company may interfere only by removing the directors or by having an investigation under the statutory provisions is the management of the business of the company. How can you manage a business without managing its finance, how can things be carried out if at any moment the company can interfere and say to the directors 'you must keep a balance at the bank although you have demands coming forward in a week or two; you must let out that money on loan because that will bring you more interest:

In recente rechtspraak lijkt de eerste visie, uitgaande van het $\mathrm{zgn}$. beginsel van 'separation of powers', algemeen aanvaard te zijn (vgl. ook $\S 2.3$ ). Men zie hier met name de uitspraak. inzake Breckland Group Holdings Ltd. v. London \& Suffolk Properties Ltd. ${ }^{49}$

Crompton Enterprises Led. (C) houdt een belang van $51 \%$ in London \& Suffolk Properties Ltd. (L). De overige $49 \%$ zijn in handen van Breckland Group Holdings Ltd. (B). Avery (A) is meerderheidsaandeelhouder van B en managing director van L. C, de meerderheidsaandeelhouder van $\mathrm{L}$ wil namens deze een actie instellen tegen $\mathrm{A}$. Echter, $\mathrm{C}$ begint een actie zonder dat een bestuursbesluit is genomen door $\mathrm{L}$ en dit is krachtens de statuten een vereiste voor het instellen van procedures. Harman J oordeelt dat zolang er geen bestuursbesluit is,

47. $\mathrm{Vgl}$. bijv. Wedderburn of Charlton, t.a.p., p. $401-408$ en Sullivan, 'The relationship between the board of directors and the general meeting in limited companies, LQR 1977 , p. $569-580$.

48. Vgl. G. D. Goldberg, Article 80 of Table A of the Companies Act 1948, MLR 1970, p. $177-183$.

49. [1988] Ch. div, 4 BCC 542. Zie ook Andrew Hicks \& S.H. Goo, Cases \& Materials on Company Law, London 1997, p. 223 en Farrar's Company Law, p. 366. 
geen bevoegdheid toekomt om een procedure in te stellen. 'The principle is, as I see it, the art. 80 confides the management of the business to the directors and in such a case it is no for the general meeting to interfere'.

\section{\$ 5.2 Duitsland}

In de Duitse doctrine en rechtspraak is het leerstuk van de instructiebevoegdheid, zeker in vergelijking met Engeland en ons land, betrekkelijk sterk ontwikkeld.

Allereerst blijkt dat uit de wettelijke regeling van het AG-concernrecht en de ontwikkeling van het Duitse groepsrecht in de rechtspraak, doctrine en rechtspraktijk. Voorts wordt volgens de heersende opvatting aangenomen dat de ava van een enkelvoudige $\mathrm{GmbH}$ te allen tijde instructiebevoegd. heid (Weisungsbefugnis) toekomt jegens het bestuur. Dit laatste verdient, gelet op de door mij gestelde vraag, meer aandacht.

Een instructiebevoegheid van de ava wordt daarentegen niet aangenomen in de context van een AG. De ava heeft hier, zoals ik reeds aangaf in $\$$ 2.1, geen directe invloed op het bestuursbeleid. Het bestuur van een AG heeft een onafhankelijke positie en is zelf verantwoordelijk voor de vervulling van de leidinggevende taken ( $\S 76 \mathrm{AktG}),{ }^{51}$ zij het wel onder toezicht van de Aufsichtsrat ( $\$ 111 \mathrm{AktG}$ ).

Het bestaan van een instructierecht van de ava in een $\mathrm{GmbH}$ kan worden verklaard aan de hand van de ontstaansgeschiedenis van de $\mathrm{GmbH}$ en de aard van de organisatiestructuur. Een belangrijk wettelijk aanknopingspunt voor dit instructierecht wordt gevonden in $\$ 37 \mathrm{I} \mathrm{GmbHG.?}$ Deze bepaling brengt tot uitdrukking dat in de interne verhouding tussen bestuur en ava in een $\mathrm{GmbH}$ de ava de hoogste macht heeft. Dit impliceert wel dat een instructierecht in beginsel slechts toekomt aan de aandeelhoudersvergadering als zodanig, en dus op een besluit van de ava

50. In navolging van Club Flotilla Ltd. v. Isherwood [1987] 12 ACLR 387. New South Wales, waarin Needham $\mathbf{J}$ oordeelde, 'This particular company [...] has vested in is committee (board of directors (MK) full powers of management of the company and, in my opinion, it is only the committee which may give instructions for the institution of proceedings in which that company has an interest'.

51. Vgl. bijv. Mertens in Kölner Kommentar zum Aktiengesetz $\S 76$, nr.4.

52. $\$ 37$ I GmbHG luidt:'Die Geschăftsfuhrer sind der Gesellschaft gegenüber verpflichtel. die Beschränkungen einzuhalten, welche für den Umfang ihrer Befugnis, die Geselischat zu vertreten, durch den Gesellschaftsvertrag oder, soweit dieser nicht ein anders bestimmt, durch die Beschlūsse der Gesellschafter festgesetzt sind". 
zal moeten berusten. Opvallend is dat, in tegenstelling tot het Engelse recht, een gewone meerderheid voor een instructiebesluit in een $\mathrm{GmbH}$ volstaat.

Wat betreft de omvang van het instructierecht in een $\mathrm{GmbH}$ kan worden opgemerkt dat deze, op enkele dwingendrechtelijke bevoegdheden van het bestuur $\mathrm{na}^{33}$ onbegrensd is. ${ }^{54} \mathrm{De}$ ava kan in principe alle bestuursaangelegenheden naar zich toe trekken, waardoor het bestuur als het ware wordt gedegradeerd tot een uitvoerend orgaan." Dit heeft tot gevolg dat de meerderheidsaandeelhouder(s) in feite het belang van de vennootschap concretiseren. ${ }^{56}$

Weliswaar wordt een instructierecht in een $\mathrm{GmbH}$ algemeen aanvaard, maar in de literatuur bestaat wel de opvatting dat grenzen kunnen bestaan voor wat betreft de inhoud van instructies. Deze grenzen worden in een GmbH bepaald door de Treuepflicht."

Het ITT-Urteil van het BGH van 5 juni $1975^{58}$ geldt op dit gebied als standaardarrest. In dat ITT-arrest, oordeelt het BGH dat een meerderheidsaandeelhouder, die de mogelijkheid heeft om invloed uit te oefenen op het bestuur en daardoor de minderheidsaandeelhouders kan benadelen, niet alleen rekening dient te houden met het belang van de vennootschap maar ook met de belangen van deze minderheidsaandeelhouders.

53. Het gaat hier met name om bevoegheden die door de wetgever aan het bestuur zijn toegekend om de crediteuren te beschermen, zoals inzake het bijeenhouden van het geplaatste kapitaal ( $\$ 43$ abs. 3 jo. $\S 30$ en $\S 33$ GmbHG) en de boekhoud- en jaarrekeningplicht ( $\$ 41 \mathrm{GmbHG}, \S 264$ abs. $1 \mathrm{HGB}$ ).

54. De instructiebevoegdheid vindt begrenzing in een aantal wettelijke voorschriften, inzake het bijeenhouden van het geplaatste kapitaal ( $\$ 43$ abs. 3 jo. 30, 33 GmbHG), de boekhoud- en jaarrekeningplicht ( $\$ 41 \mathrm{GmbHG}, \S 264$ abs. 1 HGB), het bijeenroepen van een 'verliesvergadering' ( $\$ 49$ abs. 3 GmbHG) en het aanvragen van een faillissement bij betalingsonmacht en Überschuldung van de vennootschap ( $\$ 64$ abs. 2 GmbHG). Zie o.m. M. Winter, Mitgliedschaftliche Treuebindungen im GmbH-Recht, 1988, p. 100 en U. Eisenhardt, Zum Weisungsrecht der Geselischafter in der nicht mitbestimmten GmbH in FS Gerd Pfeiffer, Kōln 1988, p. 840-846.

55. $\mathrm{Vgl}$. bijv. H. Konzen, Geschäftsführung, Weisungsrecht und Verantwortlichkeit in der GmbH \& Co KG, NJW 1989, p. 2979 en Lutter-Hommelhoff, GmbH-Gesetz $\$ 37$ p. 320.

56. Zie ook T. Raiser. Recht der Kapitalgesellschaften, 1992, p. 236.

57. $\mathrm{Vgl}$. ook H. Konzen, Geschäftsführung. Weisungsrecht und Verantwortlichkeit in der GmbH und GmbH \& Co KG, NJW 1989, p. 2979.

58. BGH 5-6-1975, BGHZ 65, 15. Zie voorts onder andere Die AG 1976, 16, GmbHR 1975, 269 en NJW 1976, 191. 
Het ITT-concern nam in 1968 de G-Gruppe, een internationale familieonderneming ovet. Aan de top van de G-Gruppe stond de G-GmbH waarin het ITT-concern (via een subhol. ding) een meerderheidsbelang had verworven van $85 \%$. Het overige aandelenpakket van is \% bleef in handen van een minderheidsaandeelhouder (lid van de 'oude' eigenaarsfamilie), De G-GmbH was onder andere beherend vennoot in twee Duitse commanditaire vernootschappen (GmbH \& Co. KG) met een participatie van $60 \%$ en $40 \%$ door de minderheidsaandeelhouder. Deze commanditaire vennootschappen hielden de aandelen in drie buitenlandse werkmaatschappijen.

De gang van zaken is vervolgens dat ITT, als meerderheidsaandeelhouder van de G-GmbH, ervoor zorgt dat de commanditaire vennootschappen, alsmede de buitenlandse werkman. schappijen, service-contracten afsluiten met een $100 \%$ dochtervennootschap van ITT, it weten ITTI (ITT Industries Inc). Op grond van deze dienstverieningscontracten konden de vennootschappen van de G-Gruppe gebruik maken van concernfaciliteiten. Echter, daartegenover bestond de plicht van die vennootschappen om aan ITTI een jaarlijkse vergoeding te betalen, bestaande uit $1 \%$ van hun omzet.

De minderheidsaandeelhouder meende dat - omdat zijns inziens slechts van 'fictieve' dienstverlening sprake was - het hier om een verkapte winstuitkering aan ITT ging, en vorderde terugbetaling van het betaalde bedrag van DM 1.777.000 aan de beide commandi. taire vennootschappen en de drie buitenlandse werkmaatschappijen. De minderheidsaandeel. houder boekt geen succes bij het Landesgericht en evenmin in hoger beroep bij het Oberlandesgericht.

Uiteindelijk wordt de minderheidsaandeelhouder echter in het gelijk gesteld door het BGH. Het BGH komt op grond van twee argumenten tot de conclusie dat de betaalde vergoedingen gekwalificeerd kunnen worden als een 'einseitig verdeckte Gewinnausschü. tung' aan ITT. Op de eerste plaats neemt het BGH aan dat tegenover de betalingen van de G-Gruppe geen danwel geen gelijkwaardige prestaties van ITT stonden. Op de tweede plats overweegt het BGH dat het bestuur van G-GmbH op aanwijzing van de meerderheidsaandeelhouder betalingen aan ITTI had gedaan, zonder de belangen van de minderheidsaandet. houder in acht te nemen.

\section{§ 6. Grenzen invloed ava op bestuur; eigen opvatting}

Waar liggen nu de grenzen van een instructiebevoegdheid in het Nederlandse recht? Wanneer is een instructie geoorloofd? Ik bepleit dat deze grenzen, naast de wet en statuten, worden bepaald door de redelijkheid en billijkheid. Vennootschapsorganen moeten zich immers redelijk en billijk jegens elkaar gedragen. Deze benadering impliceert in casu dat de ava die instructies geeft alle bij de onderneming c.q. vennootschap betrokken belangen in aanmerking moet nemen en eventueel ontzien, dan wel de 
belangen van alle betrokkenen moet waarborgen, ${ }^{59}$ en dat een instructie getoetst moet worden aan het belang van de vennootschap. Voorts zou ik menen dat een geïnstrueerde handeling nuttig moet zijn ter bereiking van dat belang en van het doel van de vennootschap. De ava is niet bevoegd opdrachten te geven tot handelingen welke niet dienstig zijn tot het verwezenlijken van het doel. ${ }^{\infty}$

Men denke aan het volgende geval: stel dat het bestuur bevoegd is om binnen de grenzen van het maatschappelijk kapitaal een emissie uit te schrijven (de ava heeft deze bevoegdheid gedelegeerd aan het bestuur zodat het bestuur snel en doelgericht kan optreden tegen eventuele vijandelijke overnamepogingen). De ava geeft vervolgens een instructie aan het bestuur om geen aandelen uit te geven, daar zij verwacht dat dit ten koste gat van de continuilteit van de vennootschap c.q onderneming. In zo'n geval is een instructie in het belang van de vennootschap en mijns inziens geoorloofd.

\section{§7. Aansprakelijkheid voor meerderheidsaandeelhouder?}

Aanvaardt men dat in bepaalde gevallen, zoals in $\S 3$ en 4 uiteengezet, een instructiebevoegdheid van de ava bestaat jegens het bestuur, dan rijst de vraag of dit consequenties heeft voor de aansprakelijkheid van aandeelhouders.

Kan men verdedigen dat een meerderheidsaandeelhouder die, door middel van het geven van instructies aan het bestuur, op het bestuursterrein opereert naast, of in plaats van, de bestuurder aansprakelijk wordt gesteld voor een instructie die bijvoorbeeld nadelige gevolgen teweegbrengt voor het vermogen van de vennootschap?

59. Uit de literatuur wordt als ratio van de bestuursautonomic aangenomen: de waarborgfunctie voor het ondernemings- c.q. vennootschapsbelang. De redelijkheid en billijkheid vervult mijns inziens dezelfde functie in dit geval. Het komt erop aan dat bij het uitvoeren van beleid de bij de vennootschap betrokken belangen worden afgewogen en dat uitsluitend beleid gevoerd wordt dat in het belang is van de venootschap.

60 . Het bestuur moet immers alles doen met het oog op het doel van de vennootschap, zie $\S 2$. 
In het Duitse recht wordt deze vraag bevestigend beantwoord in het bekende, reeds in $\S 5.2$. besproken ITT-arrest. ${ }^{61}$ Het BGH stelt in deze zaak vast dat de grondslag voor de aansprakelijkheid van de meerderheidsaandeelhouder wegens benadelende beleidsbeïnvloeding moet worden gezocht in een schending van de Treupflicht. De zorgvuldigheidsnorm die ingevolge \& $43 \mathrm{GmbHG}$ voor bestuurders geldt, speelt ook in dit kader een belangrijke rol voor het oordeel inzake de verwijtbaarheid (Verschu. Idensmaßstab). ${ }^{62}$

Het $\mathrm{BGH}$ is van mening dat een meerderheidsaandeelhouder die actief invloed uitoefent op het beleid, en dus functies vervult die krachtens wet en statuten toebedeeld zijn aan de bestuurder, de zorgvuldigheidsnorm van $\S 43$ (1) GmbHG in acht moet nemen ${ }^{63}$ en ook moet bewijzen dat hij 'die Sorgfalt eines ordentlichen Geschäftsmannes' betracht heeft.

Van groot belang in de ITT uitspraak is dat het BGH de tot dan toe gevolgde visie verwerpt, dat een GmbH-meerderheidsaandeelhouder die, alleen of in een groep, een overheersende invloed uitoefent slechts aansprakelijk en schadeplichtig kan zijn onder de strikte voorwarden van $\$ 826$ BGB (waaronder het vereiste van 'opzet'). ${ }^{64}$

Bovengenoemde opvatting van het BGH, volgens welke aansprakelijkheid berust op schending van de Treuepflicht, wordt door het merendeel van de gezaghebbende auteurs gedeeld. ${ }^{65}$ Slechts een enkeling ${ }^{66}$ verdedigt de opvatting dat de aansprakelijkheid van de meerderheidsaandeelhouder berust op een analoge toepassing van de bestuurdersaansprakelijkheid

61. Zie omtrent deze problematiek uitgebreid H.J. Mertens, Die Geschåftsführungshaftung in der GmbH und das ITT-Urteil in FS R. Serick 1992, p. 462 e.v., M. Lutter. Theorie der Mitgliedschaft, AcP 1980, p. 114 en H. Wiedemann, Die Bedeutung der ITT. Entscheidung, JZ 1976, p. 394.

62. Zie ook NJW 1976, 192 en M. Winter, Mitgliedschaftliche Treuebindungen im GmbH. Recht, München, p. 119.

63. Zie tevens H. Wiedemann, Die Bedeutung der ITT-Entscheidung, JZ 1976, p. 394, Immenga, Kapitalgesellschaft, p. 277 e.v. en 282 e.v.

64. $\mathrm{Vgl}$. onder meer Wiedemann, t.a.p., p. 393 en in NJW 1972, p. 409.

65. Zie onder andere Zöllner, Die Schranken mitgliedschaftlicher Stimmrechtsmacht bei den privatrechtlichen Personenverbånden, 1963 p. 337 en 350 , M. Winter, Mitgliedschaftliche Treuebindungen im GmbH-Recht, p.119 en Wiedemann, Gesellschaftsrecht, P. 455.

66. Zie bijvoorbeeld J. Wilhelm, Rechtsform und Haftung bei der juristischen Person 1981. p. 330 e.v. 
wegens niet in achtneming van de zorgvuldigheidsnorm van $\S 43$ $\mathrm{GmbHG}^{67}$

Ook naar Nederlands recht meen ik te kunnen verdedigen dat indien een meerderheidsaandeelhouder invloed uitoefent op het beleid van de vennootschap, en zich derhalve op het bestuursterrein begeeft, dit moet kunnen leiden tot aansprakelijkheid. Zo'n meerderheidsaandeelhouder zal, zoals ik hiervoor reeds aangaf, bij het geven van een instructie de belangen van alle bij de vennootschap en onderneming betrokkenen in acht moeten nemen. ${ }^{68}$ In het geval dat zo'n meerderheidsaandeelhouder deze belangen ernstig verwaarloost, is mijns inziens verdedigbaar dat een minderheidsaandeelhouder op eigen naam wegens schending van de redelijkheid en billijkheid van art. 2:8 BW schadevergoeding kan vorderen van de meerderheidsaandeelhouder in het kader van een onrechtmatige daadsactie. Weliswaar kunnen aandeelhouders, zoals blijkt uit de jurisprudentie, in beginsel niet een vordering tot schadevergoeding geldend maken als de schade geleden is door de vennootschap, maar dat betreft gevallen waarin de schade van een aandeelhouder louter valt aan te merken als een afgeleide van de schade die de vennootschap heeft geleden. ${ }^{69}$ Dat hoeft niet zo te zijn. De instructie kan de vennootschap zelf

67. In het Duitse recht wordt wat betreft de aansprakelijkheid van de bestuurder in geval van een instructie vooropgesteld dat, indien een bestuurder een niet-bindende instructie opvolgt, bijvoorbeeld een instructie die in strijd met de wet wordt gegeven, deze daarvoor aansprakelijk kan worden gesteld. In het geval dat een bestuurder een bindende instructie niet opvolgt, hangt de aansprakelijkheid van deze bestuurder af van de eventuele schadelijke gevolgen die de weigering voor de vennootschap meebrengt. Overigens mag een bestuurder soms afwijken van een instructie. Men denke aan de situatie waarin bepaalde omstandigheden zijn veranderd, waardoor redelijkerwijze te verwachten valt dat de meerderheidsaandeelhouder, indien hij kennis hiervan had, een andere instructie had gegeven. $\mathrm{Vgl}$. H. Gieseke, Interessenkonflikte der GmbH-Geschäftsführer bei Pflichtenkollissionen, GmbHR 1996, p. $489 / 490$.

68. $\mathrm{Vgl}$ een overweging van het BGH in de ITT-zaak: 'Zudem verlangt auch hier insbesondere die für eine Gesellschaftermehrheit bestehende Môglichkeit, durch Einflußnahme auf die Geschäftsführung die gesellschaftsbezogenen Interessen der Mitgesellschafter zu beeintrã̄chtigen, als gegengewichtige gesellschaftsrechtliche Pflicht, auf diese Interessen Rücksicht zu nehmen', BGH 65, p. $15,19$.

69. Vgl. HR 2 december 1994 (NJ 1995, 288/Poot/ABP), hierover M.J.G.C. Raaijmakers 'Omgekeerde doorbraak': Poot/ABP. AA 1995, p. 494-495. In navolging daarvan HR 29 november 1996, NJ 1997, 178 (Cri Cri) daarover L. Timmerman in TVVS 1997, p. 16-17. Zie tevens Rechtbank Arnhem 7 maart 1996 (JOR 1996, 43 nt. Van Hees), Hof 's-Hertogenbosch 20 augustus 1996, JOR 1996, 111, Rechtbank Amsterdam 26 februari 
ten goede komen, terwijl de minderheidsaandeelhouder schade lijdt. Indien een meerderheidsaandeelhouder bewust op een bepaalde wijze heeft gehandeld om die minderheidsaandeelhouder te treffen kan mijns inziens sprake zijn van schending van een specifieke zorgvuldigheidsnorm jegens de minderheidsaandeelhouder. Men denke bijvoorbeeld aan een situatie waarin de meerderheidsaandeelhouder aandringt op samenwerking met andere rechtspersonen, terwijl hij weet dat dit concurrentie oplevert met projecten van de minderheidsaandeelhouder, waardoor deze schade lijdt. Een dergelijke handelwijze kan mijns inziens strijd opleveren met art. 2:8 BW. ${ }^{70}$

\section{Slotbeschouwing}

In dit hoofdstuk is bezien hoe binnen kapitaalvennootschappen de bevoegdheden tussen de ava en het bestuur kunnen worden verdeeld. Dit doet de vraag rijzen of de ava een instructierecht heeft jegens het bestuur en wat de grenzen daarvan zijn.

Bij de bespreking van deze vraag stelde ik voorop dat krachtens de Nederlandse wet en statuten zowel de ava als het bestuur eigen bevoegdheden hebben met daaraan verbonden eigen verantwoordelijkheden. Deze zienswijze vindt steun in het Forumbank-arrest.

1997, JOR 1997, 78 en recentelijk Rechtbank Arnhem 15 januari 1998, JOR 1998, 90 en Rechtbank Rotterdam 26 februari 1998, JOR 1998, 103. Zie voorts onder meer L. Timmerman, Kan een aandeelhouder of vennootschapsschuldeiser afgeleide schade vorderen?, TVVS 1998, p. 97-101; M.J. Kroeze, Zelfstandige vorderingsrechten van de aandeelhouder voor schade, in: Beginselen van vennootschapsrecht in international perspectief, Antwerpen-Groningen, 1998, p. 217-234, E.C. du Perron, Schadevergoeding aandeelhouder bij onrechtmatig handelen jegens vennootschap, Bb 1995, p. 51.54 en P. van Schilfgaarde, Acties van aandeelhouders in verband met onrechtmatige gedragingen tegenover de vennootschap, in: Rechtspleging in het ondernemingsrecht. Deventer 1997, p. 1 e.v.

70. Losgekoppeld van de instructieproblematiek kan men bijvoorbeeld denken aan 'defamerende' gedragingen van de meerderheidsaandeelhouder jegens de minderheidsaandeethouder dat een schending van een specifieke zorgvuldigheidsnorm kan opleveren. Zir hieromtrent P. van Schilfgaarde, Acties van aandeelhouders in: Rechtspleging in thet ondernemingsrecht, Deventer 1996, p. 1 e.v. en de Conclusie van de AG. Hartkamp bi het Poot-arrest (NJ 1995, 288). 
De machts- en rechtsverhouding tussen de ava en het bestuur moet echter ook worden bezien in het licht van de redelijkheid en billijkheid. Dit heeft consequenties voor de invloed die de ava en het bestuur in de vennootschap kunnen uitoefenen. Zo kan de redelijkheid en billijkheid onder omstandigheden ertoe leiden dat bestuursbevoegdheden worden beperkt in die zin dat deze slechts mogen worden uitgeoefend met medewerking van de ava. Men denke aan ingrijpende besluiten als overdracht van een essentieel deel van de onderneming. Deze gedachte bestaat ook in het Duitse recht waar in de jurisprudentie uitdrukkelijk is aangenomen dat het redelijk en billijk is om, in het geval het bestuur besluiten neemt waarbij de rechten van aandeelhouders ernstig in het gedrang komen, de ava te raadplegen.

Anders dan schrijvers als Timmerman, Van Schilfgaarde, Westbroek, Maeijer, Van der Grinten, Van Solinge en Roelvink ben ik van mening dat een bevoegdheidsverdeling tussen de ava en het bestuur van een kapitaalvennootschap niet altijd behoeft te blijken uit een statutaire regeling. Dit standpunt verdedig ik ook in het kader van het aanvaarden van een instructierecht.

Wat betreft de vraag of er een instructierecht voor de ava bestaat, wordt in de Nederlandse doctrine in het algemeen slechts gedacht aan een instructierecht voor moedervennootschappen. De meerderheid ${ }^{71}$ van de rechtsgeleerde auteurs erkent een zekere instructiebevoegdheid in concernverhoudingen, waarbij sommige auteurs echter een statutaire grondslag daarvoor noodzakelijk achten.

Andere schrijvers, zoals Timmerman en Roelvink, hebben duidelijk gemaakt dat een bindend instructierecht niet noodzakelijk is voor de door de moedermaatschappij uit te oefenen concernleiding. Dit kan ook geschieden door gebruik van (machts)middelen als overleg en ontslag. ${ }^{72}$

Een instructierecht in een enkelvoudige vennootschap daarentegen wordt in het algemeen in de Nederlandse doctrine ontkend. Als argument wordt daarvoor enerzijds gewezen op de regel uit het Forumbank-arrest en $\S 9$ van de Departementale Richtlijnen (op grond waarvan alleen

71. Tot die meerderheid behoren onder meer Achterberg, Bartman, Huizink, Van Schilfgaarde, Slagter, Van Solinge en Uniken Venema.

72. L. Timmerman, Over multinationale ondernemingen en medezeggenschap van werknemers (diss.), Deventer 1988, p. 71 e.v. en H.L.J. Roelvink, Bestuurszelfstandigheid in concernverhoudingen, in: Piercing van Schilfgaarde, Deventer 1990, blz 48. 
statutaire aanwijzingen zijn toegestaan die de algemene lijnen van het te voeren financiële, sociale, economische en personeelsbeleid). Anderzijds wordt gewezen op het beginsel dat het bestuur zich bij de uitoefening van zijn taken moet richten naar het belang van de vennootschap, dat meer omvat dan de belangen van aandeelhouders. ${ }^{73}$

In mijn optiek echter komt de ava onder omstandigheden ook in enkelvoudige vennootschappen een instructierecht toe. In dit verband moet men denken aan vennootschappen waarin één of meerdere aandeelhouders een wezenlijke invloed kunnen uitoefenen op het bestuur. Dit zal in de praktijk met name het geval zijn in 'besloten' verhoudingen. Deze benadering wordt ook aangehangen door Schuit en met name Raaijmakers. ${ }^{74}$ Voor deze opvatting kan ook steun worden gevonden in de beslissing van de Hoge Raad inzake Meijers/Mast. Hierin oordeelt de Hoge Raad dat de weigering van een bestuurder om een door de ava gewenst beleid te voeren een redelijke grond voor ontslag kan zijn.

Ook in Duitsland en Engeland wordt aanvaard dat in 'besloten' vennootschappen, te weten de $\mathrm{GmbH}$ en de 'private company', de bevoegdhedenverdeling tussen de organen veel minder strikt is dan bij de 'publieke' vennootschappen als de AG en de 'public company', in die zin dat de ava veel invloed kan uitoefenen op het bestuur en de gang van zaken van de vennootschap. Met name in Duitsland wordt de invloed van de ava in de $\mathrm{GmbH}$ onderstreept doordat het instructierecht van de ava wettelijk is geregeld.

73. $\mathrm{Vgl}$. onder meer F.J. W. Lôwensteyn, Wezen en bevoegdheid van het bestuur van de vereniging en de naamloze vennootschap, Zwolle 1959, p. 58 e.v., M.P. Achterberg. De juridische definitie van het economische verschijnsel concern (diss.), Deventer 1989. p. 91/92 en H.L.J. Roelvink, Bestuurszelfstandigheid in concernverhoudingen, in: Piercing van Schilfgaarde, Deventer 1990, p. 47.

74. Vgl. M.J.G.C. Raaijmakers, Joint ventures (diss.) Deventer 1976, p. 85: 'Nuances (op de Forumbankregel, MK) zullen reeds moeten worden aangebracht indien men denkt aan kleinere vennootschappen, waarin de aandeelhoudersfunctie en bestuursfunctie veelal door dezelfde (groep van) personen wordt beheerst'. Zie ook in zijn noot bij Meijers Mast, AA 1993 p. 277 . Zie tevens S. R. Schuit, Instructiebevoegdheid in joint venture verhoudingen, De NV 1997, p. 246 e.v. Hij stelt de vraag ter discussie of de bestuurautonomie op een of andere wijze kan worden gedeeld met een ander orgaan. Hij meent dat art. 2:25 BW daaraan niet in de weg staat en vraagt zich af of niet op dezelfde wijzz de bestuurstaken kunnen worden vervuld door de ava en het bestuur (mits zij eef gelijkluidend belang nastreven). Hij komt mijns inziens terecht tot de conclusie dat 'de wet noch het wettelijk systeem in de weg lijken te staan aan de keuze van de ava om het vennootschappelijk belang te behartigen'. 
Wel meen ik dat er grenzen verbonden zijn aan zo'n instructierecht. Deze grenzen worden mijns inziens, naast de wet en statuten, bepaald door de redelijkheid en billijkheid. Die brengt, mijns inziens, in ieder geval mee dat de instructie moet worden getoetst aan het belang van de vennootschap.

Tenslotte heb ik verdedigd dat, aangenomen dat een instructierecht van de ava (meerderheidsaandeelhouder) bestaat, dit consequenties heeft voor de aansprakelijkheid van de meerderheidsaandeelhouder. De mate waarin de ava (meerderheidsaandeelhouder) invloed uitoefent op het beleid van een vennootschap dient, naar ik meen, gevolgen te hebben voor de daarbij behorende verantwoordelijkheid. 



\section{Beloeming van bestuurders}

\section{§1. Inleiding}

Opde verhouding tussen de ava en het bestuur wordt in belangrijke mate eenstempel gedrukt door de regeling van de wijze waarop de ava bestuurder benoemt. ${ }^{1}$ Dit is slechts anders indien de vennootschap verplicht of vrijvillig onder het volledige structuurregime valt. Dan ligt de benoemirgsbevoegdheid bij de raad van commissarissen (art. 2:162/272 BW). ${ }^{2}$

Je ava is in beginsel vrij om te bepalen welke (rechts)personen ${ }^{3} \mathrm{zul}^{\mathrm{z}}$ lenworden belast met het bestuur. Op dat beginsel kan door de statuten een uitzondering worden gemaakt. Zo kan statutair worden bepaald dat een ander orgaan dan de ava of een derde het recht krijgt om een bindenle voordracht op te maken voor de benoeming van een bestuurder (art 2:133/243 lid $1 \mathrm{BW}$ ). ${ }^{4}$ Deze voordracht dient voor iedere te vervullenvacature wel tenminste de namen van twee (rechts)personen te bevatten. De ava kan aan zo'n voordracht het bindend karakter ontnemen bij een besluit genomen met twee derden van de uitgebrachte stemmen, die meer dan de helft van het geplaatste kapitaal vertegenwoordigen. ${ }^{5}$

1. Aangenomen mag worden dat art. 2:132/242 BW van dwingend recht is. Dit impliceert dat deze bevoegdheid niet kan worden overgedragen aan een ander orgaan.

2. Tenzij de ava een aandeelhouderscommissie heeft ingesteld, aan wie de bevoegdheid met betrekking tot de benoeming van bestuurders wordt overgedragen. Zie hieromtrent H.M.L. Dings, De commissie van aandeelhouders bij structuurvennootschappen (diss. Nijmegen), Deventer 1998, p. 17 e.v.

3. Boek 2 BW bevat niet de regel dat alleen natuurlijke personen tot bestuurder kunnen worden benoemd. Met de bepaling van art. 2:5 BW gaat de wet met zoveel woorden uit van de mogelijkheid dat een rechtspersoon bestuurder kan zijn van een andere rechtspersoon. Zie ook Van Schilfgaarde, Van de BV en de NV, nr. 1, p. 18 en nr. 9, p. 32/33. Overigens stelt in het Franse recht de wet ten aanzien van gérants de eis dat het moet gaan om natuurlijke personen, zie art. 49 L. 1966.

4. Dit geldt niet indien de raad van commissarissen tot benoeming bevoegd is. Zie art. 2:133/243 lid 3 BW.

5. Ten aanzien van naamloze vennootschappen waarvan de statuten reeds voor 1 april 1929 de benoeming van een bestuurder aan een voordracht bonden, geldt de eerst sinds deze datum in de wet dwingendrechtelijk voorziene doorbraak van de voordracht niet, indien de statuten deze doorbraak niet mogelijk maken, vgl. art. XVIII van de overgangsbepalingen van de wet van 1928. 
Een beperking van de vrijheid van de ava kan ook bewerkstelligd worden door in de statuten bepaalde vereisten op te nemen waaraan een te benoemen bestuurder moet voldoen. ${ }^{6}$ Een statutaire regeling, volgens welke benoeming van bestuurders door de ava afhankelijk wordt gesteld van de goedkeuring van een ander orgaan of een derde wordt daarentegen in de literatuur, gezien het dwingende karakter van de benoemingsregeling, ongeldig geacht. ${ }^{7}$

Tenslotte kan de benoeming van bestuurders mede worden gereguleerd door buiten-statutaire regelingen. Op deze wijze kan een derde, aan wie geen recht van voordracht is toegekend, toch een zekere invloed uitoefenen op de benoemingsprocedure.

Als uitgangspunt voor mijn beschouwingen neem ik dat de vrijheid van de ava om een bestuurder te benoemen ook begrensd wordt door de redelijkheid en billijkheid. Bij de beoordeling van het benoemingsbesluit in het licht van de redelijkheid en billijkheid, zal de problematiek rond de bindende voordracht, kwaliteitseisen en buiten-statutaire regelingen worden bezien.

6. $\mathrm{Vgl}$. $\S 6$ van de Departementale Richtlijnen: 'De statuten mogen eisen stellen waaran bestuurders [...] moeten voldoen. De gestelde eisen mogen de kring van kandidaten niet te zeer beperken, tenzij de statuten bepalen dat de beperking kan worden doorbroken. De statuten mogen aan deze doorbreking geen strengere eisen stellen dan is toegestaan voor de besluitvorming tot het ontnemen van de bindende kracht aan een voordracht voor benoeming tot bestuurder of commissaris. Het Departement acht echter, wegens strijd met de anti-discriminatiebepalingen van het EEG-recht, niet toegelaten de statutaire bepaling dat slechts Nederlanders bestuurder mogen zijn. $\mathrm{Vgl}$. C.C.Th van Andel, De directeur; bestuurder en werknemer, Deventer 1992, p. 35, Van Schilfgaarde, Van de BV en NV, nr. 44 en Sanders-Westbroek, p. 145.

7. Zie Handboek, nr. 247 en Asser-Maeijer 2-III, nr, 313. 


\section{§2. Wie komt voor benoeming in aanmerking?}

Zoals hiervoor reeds is vermeld, is de ava in beginsel vrij het bestuur van de vennootschap samen te stellen. ${ }^{8}$ De wet stelt geen eisen aan het besturderschap en/of de samenstelling van het bestuur. 9

Dit is ook het geval in het Engelse recht. ${ }^{10}$ Het Franse recht is wat betreft de SA 'classique' anders. Hier wordt de eis gesteld dat een administrateur op de dag van zijn benoeming aandeelhouder moet zijn, of preciezer gezegd; 'ètre propriêtaire d'un nombre d'actions de la société déterminé par les statuts' (art. $95 \mathrm{~L} .1966$ ). De achterliggende gedachte is dat het de vennootschap ten goede komt wanneer bestuurders als aandeelhouders een persoonlijk belang hebben in de vennootschap. ${ }^{\text {I }}$

Een vraag die rijst is of, afgezien van statutaire kwaliteitseisen, iedere (rechts)persoon voor benoeming in aanmerking komt.

Aandeelhouders mogen in het kader van hun bevoegdheid om een bestuurder te benoemen, zich tot op zekere hoogte laten leiden door eigen belang. Een uitoefening van die bevoegdheid overeenkomstig de eisen van redelijkheid en billijkheid brengt echter naar mijn mening met zich dat een bestuurder wordt benoemd die geschikt en in staat is om zijn wette-

8. Een besluit van de ava is voor de benoeming van een bestuurder niet noodzakelijk. In een uitspraak van het Ktg Utrecht 29 september 1995 is bepaald dat een aangifte (van de te benoemen bestuurder) door aandeelhouders bij de Kamer van Koophandel hiermee gelijk te stellen is. Door deze aangifte te ondertekenen aanvaard de voorgedragen persoon, in casu een werknemer, de benoeming.

9. Zulks in tegenstelling tot de benoeming voor de functie van commissaris, vgl. art. 2: 142/160 BW. Zie hieromtrent J.M. Blanco Fernández, De Raad van Commissarissen bij NV en BV (diss. Maastricht), Deventer 1993, met name p. 126-147.

10. $\mathrm{Vgl}$. voor het Engelse recht bijv. Gower's principles of modern company law, London 1997. p. 180. Bestuurders van een AG of een GmbH moeten natuurlijke personen zijn (GmbHG \& 6 II 1 en AktG \& 14 II 2). Vgl. ook bijv. Karsten Schmidt, Gesellschaftsrecht, p. 678 en 894 .

11. In het Nederlandse recht kwam dit in vroegere tijden ook wel voor, zie Handboek 1992. nr. 246. In de huidige tijd speelt deze gedachte bij De Monchy, die ervoor pleit om bij joint-venture vennootschappen de dwingendrechtelijke benoemingsbevoegheid van aandeelhouders af te schaffen zodat houders van bepaalde pakketten aandelen hun 'eigen' bestuurder kunnen benoemen. $\mathrm{Vgl}$. C.W. de Monchy, Op weg naar een joint-venture regime? TVVS 1996, p. 4. 
lijke en statutaire bevoegdheden uit te oefenen in het belang van de vennootschap (curs. MK). ${ }^{12}$

Zo wordt bijvoorbeeld in de Engelse rechtspraak aangenomen dat de bevoegdheid van de meerderheidsaandeelhouder(s) om bestuurders te benoemen 'must be exercised for the benefin of the company as a whole and not to secure some ulterior advantage', aldus bijv. Jenkins $\mathrm{LJ}$ in Re Harmer Lid [1959] I WLR 62.

Voorts vindt men bovenstaande eisen min of meer terug in de Company Directors Disqualification Act 1986 (CDDA). Hier worden negatieve eisen gesteld aan de benoeming van een bestuurder. De CDDA 1986 bevat een aantal gronden waarop de rechtbank op verzoek van bijvoorbeeld een aandeelhouder, een crediteur of the Secretary of State, een bestuurder ongeschikt kan verklaren, waardoor deze zijn functie, gedurende een bepaalde periode niet meer mag uitoefenen. ${ }^{13}$

Deze gronden kunnen grofweg onderverdeeld worden in twee categorieën: ongeschikkheid wegens misconduct in relatie tot de vennootschap en wegens unfitness. ${ }^{14}$ De meest algemene grond om een persoon ongeschikt te verklaren als bestuurder is dat die persoon een bestuurder is of was van een vennootschap die in een insolvente positie geraakte.

Opgemerkt dient te worden dat indien de 'unfitness' van een bestuurder wordt bewezen, de rechtbank verplicht is om die persoon ongeschikt te verklaren. ${ }^{15}$ De invulling van het begrip 'unfitness' is derhalve van cruciaal belang in het Engelse recht. ${ }^{16}$ Verschillende richtlijnen worden daartoe gegeven in de CDDA (section 9 en Schedule 1). Daaronder valt onder meer: 'any misfeance or breach of any fiduciary or other duty by the director in relation to the company'.

Een voorbeeld van ongeschiktheid is mijns inziens dat een bestuurder een bepaalde nevenrol vervult of gaat vervullen, waardoor een tegenstrijdig

12. Vanuit deze benadering kan men redeneren dat door middel van een statutaire doelomschrijving indirect kwaliteitseisen kunnen worden gesteld aan de te benoemen besturders. $\mathrm{Zij}$ moeten zich bij hun taakuitoefening immers richten op de verwezenlijking van het vennootschappelijk doel.

13. Zie voor meer informatie hieromtrent bijv. A. Hicks, Disqualification of directors - 40 years on, JBL 1988, p. 27 e.v. en V. Finch, Disqualification of directors, a plea for competence, MLR 1990, p. 385 e.v.

14. Zie ook Gower's principles of modern company law, 1992, p. 144 en Sealy, Cases and materials, p. 344.

15. In de praktijk blijkt dat de ongeschiktheid van een bestuurder alleen niet voldoende is voor het oordeel van de rechter dat hij gediskwalificeerd dient te worden. Vaak moet die ongeschiktheid worden onderstreept door omstandigheden als het plegen van een strafbaar feit door de bestuurder of insolventie van de vennootschap en/of bestuurdet. Vgl. Hicks \& Goo, Cases \& Materials, p. 330.

16. $\mathrm{Vgl}$, ook R. Barham, International Liability of directors 1993, p. 1977. 
belng optreedt. ${ }^{17}$ Dit zou naar mijn mening het geval kunnen zijn indien de e benoemen (rechts)persoon tevens bestuurder is van een concurrerelle vennootschap. Een bestuurder is immers gehouden tot de verwezenlijkng van het doel van de vennootschap en een dergelijke nevenrol kan dacaan afbreuk doen. ${ }^{18}$ Een ander voorbeeld zou kunnen zijn dat een besuit tot benoeming van een bepaalde bestuurder de continuitteit van de onerneming bedreigt. ${ }^{19}$

Oneschiktheid van een kandidaat-bestuurder kan mijns inziens onder

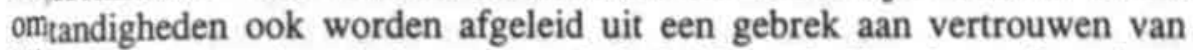
bijborbeeld het zittende bestuur, minderheidsaandeelhouders of werkne-

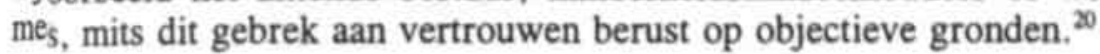

17. Ilustratief is een uitspraak in het Australische recht; Theseus Exploration NL v. Mining 4. Associated Industries Lid [1973] Qdr 81. In deze zaak legde de rechter een verbod op an aandeelhouders om bepaalde personen te benoemen, daar voldoende bewijs geleverd vas dat zij personen wilden benoemen, die van plan waren om het vermogen van de ennootschap alleen aan te wenden ten behoeve van de meerderheidsaandeelhouder. Jenoeming van zo'n bestuurder door de ava kan soms worden voorkomen indien in de statuten van de vennootschap de 'tegenstrijdig belang' bepaling (art. 2:12 BW) wordt opgenomen, waardoor een meerderheidsaandeelhouder en zijn familie niet mogen stemmen over een voorstel om hem te benoemen als bestuurder.

18. Dit geldt ook voor een vennoot die deelneemt in een v.o.f. Zie ook L. Timmerman over de relevantie van de uitspraak van HR 19 oktober 1990, NJ 1991, 21 (Koghee/Akkoca) voor het NV/BV recht in de bundel: De dubbelrol in het vennootschapsrecht, Deventer 1993, p. 8. In dit arrest besliste de Hoge Raad dat een vennoot die deelneemt in een v.o.f. zijn v.o.f. in de regel geen concurrentie mag aandoen.

19. Indien het ondernemingsbelang wordt aangetast door een vennootschappelijk besluit zoals benoeming of ontslag, bestaat de mogelijkheid dat werknemers dit besluit kunnen aantasten op grond van strijd met de redelijkheid en billijkheid. Vgl. Hof 's-Hertogenbosch 8 april 1992, NJ 1992, 701 (Gilissen c.S. - L. Beheer). In deze zaak vreesden werknemers (Gilissen c.s.) dat het ontslag van E. als bestuurder van $\mathbf{L}$. Beheer (en van de werkmaatschappij L.BV) desastreuze gevolgen zou hebben voor de onderneming. Het hof oordeelde dat Gilissen c.s. als belanghebbenden in de zin van art. 2:15 lid 3 sub a BW kunnen worden aangemerkt, omdat het ontslag van E. het hart van de onderneming raakt waaraan zij zijn verbonden. Wanneer het ontslagbesluit niet lijkt te sporen met de door de onderneming in acht te nemen goede trouw valt niet in te zien waarom Gilissen c.s. geen belang zouden hebben bij vernietiging van dat besluit, aldus het hof. Anderzijds kan de continuiteit van de vennootschap c.q. onderneming de benoeming van een bestuurder rechtvaardigen. Zie Hof 's-Heriogenbosch I april 1992, KG 1992, 347 ( Limbutex).

20. Vgl. Hof 's-Hertogenbosch 22 januari 1996, KG 1996, 92 (Van der Staak) waarin het hof bij de beoordeling van een schorsingsmaatregel ten aanzien van een bestuurder van een werkmaatschappij belang hecht aan het feit dat het personeel van die werkmaat- 
$\mathrm{Vgl}$. in dit verband de jurisprudentie met betrekking tot de beoordeling van een bezwar in het kader van art. 2:158 lid $6 \mathrm{BW}$, te weten de ongeschiktheid van een kandidaat voor benoeming tot commissaris. In de SER-beslissing inzake Lanser, Maandblad NV 56 (1976), p. 218 werd beslist dat gebrek aan vertrouwen alleen dan tot de conclusie kan voeren dat de voorgedragen persoon ongeschikt is, indien daarvoor gronden worden aangevoerd en bij tegenspraak aannemelijk gemaakt, van zulk een ernst, dat de kandidaat in redelijkheid niet in aanmerking behoort te komen voor benoeming tot commissaris. De SER bevestigt in de Amfas-zaak, Maandblad NV 62 (1984), p. 111: 'dat op ongeschiktheid van een kandidazt wegens het ontbreken van vertrouwen, slechts dan een beroep kan worden gedaan, indien en voorzover voor dit ontbreken van vertrouwen voldoende objectieve gronden moeten worden aangetoond'. Zie tenslotte ook OK 11 april 1991, NJ 1991, 533 ('Regev') waarin werd overwogen: 'dat voor het ontbreken van vertrouwen objectieve gronden moeten worden aangetoond'.

Is er sprake van de situatie dat de ava een bestuurder aanstelt, waarin het bestuur (op objectieve gronden) geen vertrouwen heeft, of doet zich het geval voor dat door de benoeming van een bestuurder een onwerkbare situatie binnen het bestuur zal ontstaan, dan geldt mijns inziens dat de ava zich jegens de vennootschap niet gedraagt overeenkomstig de eisen van redelijkheid en billijkheid. In zo'n geval kan de vennootschap krachtens bestuursbesluit een vordering tot vernietiging instellen. ${ }^{21}$

De oudere rechtspraak stelt zich echter terughoudend op. De Hoge Raad volstond in HR 13 februari 1942, NJ 1942, 360 (Baus - de Koedoe) met de overweging dat de benoeming van een bestuurder slechts strijd met de goede trouw oplevert, indien de benoeming geschiedt met 'opzet tot benadeling van de NV of van een derde dan wel bevoordeling van de meerderheid of een derde' (curs. MK). Mijns inziens schiet deze benadering tekort. Of een besluit geoorloofd is in het licht van de goede trouw moet niet aan de hand van subjectieve normen worden vastgesteld, zoals de Hoge Raad hier weergeeft, maar op grond van objectieve normen. ${ }^{2}$

schappij het vertrouwen in hem heeft opgezegd. In casu was sprake van een ernstig verstoorde relatie tussen de bestuurder en het personeel van de werkmaatschappij. Zie over deze zaak voorts hoofdstuk $9 \& 7$. Vgl. ook H.J. de Kluiver, Machtsstrijd en machtsovername in kapitaalvennootschappen. Opmerkingen over macht, recht en eti gegeven paard, Oratie Maastricht 1996, p. 10.

21. Zie ook Handboek, nr. 226.

22. Deze uitspraak kan wel illustratief zijn voor het geval dat een benoemingsbesluit gekwalificeerd kan worden als misbruik van bevoegdheid (art. 3:13 BW). 


\section{§. Bindende voordracht}

Het recht om personen voor benoeming tot bestuurder voor te dragen, kan an een ieder worden toegekend; houder(s) van prioriteitsaandelen, bestuurders, commissarissen en ook derden die buiten de vennootschap staan, bijvoorbeeld een instelling of een deskundige. ${ }^{23}$

Voorop staat mijns inziens dat een ieder, dus ook een derde, die dit recht van voordracht krachtens de statuten verkrijgt, betrokken is bij de organisatie en dat derhalve art. 2:8 BW van toepassing is. De voordragende instantie of persoon zal het recht om een bindende voordracht op te maken moeten uitoefenen overeenkomstig de eisen van redelijkheid en billijkheid. ${ }^{24}$ Dit impliceert mijns inziens onder meer dat de voordracht binnen een redelijke termijn opgesteld moet worden. Welke termijn als redelijk beschouwd kan worden, zal afhangen van alle concrete omstandigheden van het geval. Verstrijkt die 'redelijke' termijn zonder dat een voordracht plaatsvindt, dan kan de ava zonder voordracht tot benoeming besluiten. ${ }^{25}$ Het doen van een voordracht is namelijk geen constitutief vereiste voor benoeming.

In het Duitse GmbH-recht wordt het 'Vorschlagsrecht' onderverdeeld in het zgn. 'Benennungsrecht' en het 'Präsentationsrecht'. ${ }^{26}$ Dit laatstgenoemde recht kan alleen worden toegekend aan aandeelhouders en andere betrokkenen bij de vennootschap, en is in beginsel bindend voor de aandeelhouders. Slechts in geval er een goede grond ('wichtiger Grund') aanwezig is om de voorgedragen persoon, indien benoemd, te ontslaan, mogen aandeelhouders weigeren hun stem ten gunste van de kandidaat-bestuurder uit te brengen. Echter, voor derden/buitenstaanders ligt dit anders. Zij zijn aangewezen op het 'Benennungsrecht'.

23. Zie Van Schilfgaarde, Van de BV en NV, nr. 44, p. 142, Asser-Maeijer 2-III, nr. 313 en Handboek, nr. 250.

24. Zie reeds G.J. Boelens, Oligarchische clausules in statuten van naamloze vennootschappen, Kampen 1946, p. 117: 'Is een deelnemer of een groep deelnemers aan de vennootschapsovereenkomst of een vennootschappelijk orgaan met het maken der voordrachten belast, dan betekent hun voordracht een uitvoering van de vennootschapsovereenkomst, resp. van de overeenkomst, waaraan de personen, die als orgaan fungeren, hun aanstelling danken, op welke uitvoering de eisch van art. 1374 lid 3 BW van toepassing is'.

25. \$ 28 van de Departementale Richtlijnen bepalen expliciet dat de bindende voordracht binnen een in de statuten genoemde termijn moet plaatsvinden, waarna de algemene vergadering vrij is te benoemen wie men wil. Zie ook HR 19 maart 1976. NJ 1978, 52 (Van Rees) en Pres. Rb. Haarlem 9 november 1992, NJ 1993, 794.

26. $\mathrm{Vgl}$. Lutter-Hommelhoff, GmbH-Gesetz, p. 435. 
Deze voordracht is slechts bindend, indien dit in het belang is van de vennootschap. Hiervan is bijvoorbeeld sprake indien er onder de aandeelhouders geen geschikte kandidaten aanwezig zijn en ook niet elders gevonden worden.

Zoals gezegd (zie § 2) brengt de norm van redelijkheid en billijkheid mee dat niet iedereen mag worden voorgedragen voor de functie van bestuurder. De voorgedragen kandidaten zullen om voor benoeming in aanmerking te komen, 'geschikt en in staat' moeten zijn de bestuursfunctie te vervullen. Indien het voordrachtsrecht niet naar redelijkheid en billijkheid is uitgeoefend, kan de ava zo'n voordracht passeren en vrijelijk bestuurders benoemen. ${ }^{27}$

Het tot benoeming bevoegde orgaan, de ava, zal de geschiktheid van een kandidaat in de vergadering moeten kunnen beoordelen. In dit kader kan de vraag gesteld worden of de voordracht moet worden gemotiveerd door het voordragende orgaan. De wet bevat geen regeling hieromtrent, zulks in tegenstelling tot een aanbeveling of voordracht tot benoeming van een commissaris (art. 2:142/252 lid 3 BW). De wet schrijft in zo'n geval voor dat een aantal gegevens van de aanbevolene of voorgedragene moet worden meegedeeld, zoals het bedrag van door hem gehouden aandelen in het kapitaal van de vennootschap, en de overige functies die hij bekleedt. Bovendien moeten de aanbeveling en voordracht met redenen worden omkleed. Ik zou menen dat een motivering van een voordracht tot benoeming van een bestuurder aan de ava noodzakelijk is. Dit orgaan zal immers naar redelijkheid en billijkheid de geschiktheid van de bestuurder moeten kunnen beoordelen.

Het is denkbaar dat de ava op grond van een voordracht een bestuurder heeft benoemd en het besluit waarbij de bindende voordracht is vastgesteld achteraf vernietigd wordt wegens strijd met de redelijkheid en billijkheid. De vraag rijst dan of de ongeldigheid van die voordracht het benoemingsbesluit aantast. Ik zou deze vraag ontkennend willen beantwoorden. De bindende voordracht is immers, zoals ik reeds heb vermeld, geen vereiste voor een benoemingsbesluit.

27. Zie ook Handboek, nr. 250. 


\section{§4. Problematiek rond kwaliteitseisen}

Statutair kan worden bepaald dat slechts personen met bepaalde kwaliteiten mogen worden benoemd. Hiermee kan worden gepoogd de kring van benoembare personen te beperken. Niet duidelijk is welke kwaliteitseisen rechtsgeldig in de statuten kunnen worden opgenomen. ${ }^{28}$ Het Departement acht vergaande beperkingen mogelijk, mits de statuten bepalen dat de beperking kan worden doorbroken. De doorbreking van de kwaliteitseisen mag in de ogen van het Departement echter niet aan scherpere eisen worden onderworpen dan de wettelijk toegestane meerderheids- en quorumeisen voor de besluitvorming tot het ontnemen van het bindende karakter aan een voordracht tot benoeming (art. 2:133/243 lid 2). ${ }^{29}$

Ik meen echter dat de redelijkheid en billijkheid onder omstandigheden met zich mee kan brengen dat de ava een kwaliteitseis, waaromtrent statutair is bepaald dat deze slechts met tweederde kan worden verworpen, ook met een kleinere meerderheid naast zich neer kan leggen. Ook kan mijns inziens onder omstandigheden de kwaliteitseis achterwege worden gelaten.

Een goede illustratie hiervoor biedt $H R 19$ mei 1976, NJ 1978, 52 (Van Rees). Een NV Scheepsbouwwerf (voorheen C.M. van Rees, een familievennootschap), had in haar statuten de bepaling opgenomen dat het bestuur van de vennootschap bevoegd was om een bindende voordracht op te maken voor de benoeming van een bestuurder. Voorts was bepaald dat, om tot directeur te kunnen worden benoemd, men houder moest zijn van minstens 15 aandelen. Het bestuur, op dat moment bestaande uit één bestuurder, maakte geen bindende voordracht op. Daarop benoemde de ava in een buitengewone aandeelhoudersvergadering, op voorstel van aandeelhouder Lanser, Van der Weele tot bestuurder met een meerderheid van tweederde van de uitgebrachte stemmen vertegenwoordigende de helft van het geplaatste kapitaal.

Afstammelingen van C.M. van Rees, in het bezit van eenderde van het geplaatste aandelenkapitaal, vochten dit besluit aan aangezien C. van der Weele niet voldeed aan de statutaire benoembaarheidseis. De minderheid had echter met gebruikmaking van de statutaire blokkeringsregeling de overdracht van aandelen aan de te benoemen bestuurder belet.

28. Een voor de hand liggende clausule is, in het bijzonder wanneer het gaat om een kleine NV of BV, dat een bestuurder houder moet zijn van een zeker pakket aandelen of aandelen van een bepaalde soort. Vgl. de hierna te bespreken zaak HR 19 mei 1976, NJ 1978. 52 (Van Rees).

29. Dit geldt ook voor de besluitvorming met betrekking tot het ontslag van bestuurders en commissarissen (art. 2:134/244 lid 2 BW). 
De Hoge Raad overweegt: 'dat aan het statutaire vereiste met betrekking tot het aandelenbezit van de te benoemen bestuurder niet kan worden voldaan alléén tengevolge van het feil dat een minderheid van aandeelhouders met gebruikmaking van een blokkeringsbepaling in de statuten de overdracht van aandelen aan de te benoemen bestuurder kan beletten en in feite heeft belet; dat onder die omstandigheden [..] met het wettelijk stelsel van benoeming van bestuurders door de ava in ieder geval als onverenigbaar moet worden beschouwd da een zodanig statutair vereiste voor de benoembaarheid van een bestuurder een benoeming zou kunnen beletten waarvoor de algemene vergadering zich met tweederde van de uilgebrachte stemmen vertegenwoordigende meer dan de helft van het geplaatste kapitaal heeft uitgesproken.

Voorts oordeelt de Hoge Raad dat 'hieruit volgt dat in het onderhavige geval de statutaire bepaling, dat iemand om tot directeur van de NV te worden benoemd, houder moet zijn van 15 aandelen in de NV, niet in de weg staat aan de rechtsgeldigheid van de benoe. ming van $C$. van der Weele'.

In bovengenoemde uitspraak vormde voor de Hoge Raad het gedrag van de minderheidsaandeelhouders de doorslaggevende factor om de desbetreffende kwaliteitseis buiten beschouwing te laten (curs. MK). De minderheidsaandeelhouders maakten misbruik van hun aan de statutaire blokkeringsregeling ontleende bevoegdheid om de benoembaarheid van een kandidaat-bestuurder te frustreren. ${ }^{30}$

Een ander geval waarin het naar mijn mening voorstelbaar kan zijn om af te wijken van statutaire eisen dient zich aan indien zeer vergaande benoemingsvereisten de invloed van minderheidsaandeelhouders op de benoeming van bestuurders praktisch tot nul reduceren.

\section{$\S 5$. Invloed van afspraken omtrent benoeming}

Zoals eerder ter sprake is gekomen in hoofdstuk 4 , kunnen aandeelhouders de rechtsbetrekking die tussen hen bestaat nader vormgeven door het maken van afspraken jegens elkaar. Inzet van een afspraak kunnen de voor besluitvorming in acht te nemen procedures zijn alsmede de inhoud van de besluitvorming, mits dit niet strijdig is met de wet en de statuten. Ook ten aanzien van benoeming en ontslag van bestuurders worden in de praktijk aandeelhoudersovereenkomsten of, meer in het bijzonder, stemovereenkomsten gesloten. Men denke bijvoorbeeld aan de situatie dat de statuten geen regeling bevatten over de mogelijkheid een bindende

30. Zie ook Van Oven, WPNR 5571 (1981), p. 448 en B. Wachter in zijn noot bij HR 19 maart 1976, NJ 1978, 52. 
voordracht te doen voor de benoeming van bestuurders en de aandeelhouders door middel van een overeenkomst één of een aantal van hen die mogelijkheid geven. ${ }^{31}$

De jurisprudentie leert ons dat een aandeelhouder in beginsel vrij is om zich ten aanzien van de uitoefening van zijn stemrecht op de algemene vergadering contractueel jegens mede-aandeelhouders te binden. ${ }^{32}$ In de praktijk kan ook bij een derde/niet-aandeelhouder op grond van verschillende motieven behoefte bestaan om een zekere inspraak te krijgen in de benoeming van bestuurders. De vraag dient zich aan of het contractueel binden van aandeelhouders jegens die derden ten aanzien van de bevoegdheid om een bestuurder te benoemen (en te ontslaan) geoorloofd is.

In ieder geval moet als voorwaarde voor de geldigheid van zo'n overeenkomst worden aangenomen dat de wettelijke en statutaire organisatie van de vennootschap wordt geëerbiedigd. Dit geldt ook in het Engelse, Franse en Duitse recht..$^{33}$

Illustratief hiervoor is bijv. een uitspraak van de Cour de Cassation 19 december 1983. Rev.Soc. 1983, p. 105 e.v. In deze zaak werd een stemovereenkomst gesioten tussen twee groepen van aandeelhouders, waarbij de meerderheidsgroep (Verchere) zich verplichtte te stemmen voor de benoeming van een door de minderheid (Barnoin) aangewezen persoon tot directeur général. Met deze overeenkomst wilde men een evenwichtige samenstelling van het conseil d'administration bewerkstelligen. Enige tijd later, na de benoeming van de bestuurder, besiuit de meerderheidsaandeelhouder echter in een algemene vergadering deze bestuurder weer te ontslaan. Bij het Cour de Cassation komt vervolgens de stemovereenkomst ten toets. Het Cour de Cassation acht deze overeenkomst geldig, daar deze slechts een beperking van de keuzevrijheid van de ava impliceert en niet raakt aan de dwingendrechtelijke regel 'de la libre révocabilité' (het ontslag te allen tijde van de bestuurders van een SA classique). De Cour de Cassation overweegt vervolgens wel dat de meerderheidsaandeelhouder door gebruik te maken van zijn ontslagbevoegdheid in casu 'abus de droit' kan worden verweten. Anders is wel geoordeeld over de geldigheid van een stemovereenkomst indien hierdoor de vrijheid van een groep aandeelhouders inzake de benoeming van

31. Weliswaar kan dit door een statutenwijziging ook worden bewerkstelligd, maar hier zijn enkele nadelen aan verbonden, zoals het vereiste van een notariêle akte en een verklaring van geen bezwaar. Zie hierover B.C.M. Waaijer, Aandeelhoudersovereenkomsten, Deventer 1996, p. 22.

32. Vgl. HR 30 juni 1944, NJ 1944, 465, HR 13 november 1959, NJ 1960, 472 en HR 19 februari 1960, NJ 1960, 473. Overigens kunnen aandeelhouders aan een afspraak ook het karakter geven van een gentlemen's agreement.

33. Zie over stemovereenkomsten in Engeland, Duitsland en Frankrijk met name H.J. de Kluiver, Joint ventures en stemovereenkomsten. Een rechtsvergelijkend perspectief, AA 1995 p. 104-113. Tevens verwijs ik naar hoofdstuk 4 § 2.2 . 
bestuurders geheel wordt weggenomen, vgl. Cour d'appel Amiens 10 maart 1977, Rev.Soc. 1978, p. 258.

Men kan zich afvragen of het in dit verband verschil maakt of degene die partij is bij de stemovereenkomst een aandeelhouder is of een persoon instantie die buiten de rechtspersoon staat. In het het Aurora-arrest (HR 19 februari 1960, NJ 1960, 473) maakt de Hoge Raad geen onderscheid. ${ }^{34}$

In dit arrest oordeelde de Hoge Raad over de geoorloofdheid van een stemovereenkomst van aandeelhouders met een derde/buitenstaander. In deze zaak sloot een aantal aandeelhouders van de NV Levensverzekeringsmaatschappij Olva, tezamen de meerderheid vormend in de ava, een overeenkomst met de NV Levensverzekeringsmaatschappij Aurora. Deze overeen komst gaf Aurora het recht binnen zes maanden na ondertekening van de overeenkomst hun aandelen in Olva te verwerven tegen een koers van $150 \%$ van de nominale waarde. Voorts verplichtten de aandeelhouders/optiegevers zich om op aanwijzing van de 'overnemer' Aurora te stemmen vóór een voorstel tót ontslag van directie en/of commissarissen indien zij weigerden medewerking te verlenen aan een door Aurora gewenst boekhoudkundig onderzoek of aan de overdracht van de aandelen zelf.

Nog voor de afloop van de optietermijn die gold voor Aurora (zes maanden) droegen de

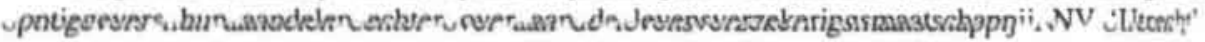
die een bod had uitgebracht dat de koers van de aandelen met $200 \%$ overtrof. Daarop vorderde Aurora schadevergoeding van de aandeelhouders wegens wanprestatie. Net als in het Melchers-arrest, HR 13 november 1959 (NJ 1960, 472) overwoog de Hoge Raad dat 'de enkele omstandigheid dat de overeenkomst waarbij de aandeelhouder zich daartoe verbonden heeft tot gevolg kan hebben dat zijn stem wordt uitgebracht in een andere zin dan waarin hij, niet gebonden zijnde, gestemd zou hebben op grond van zijn inzicht van dat ogenblik, al zou dit inzicht op zichzelf redelijk zijn, die overeenkomst niet onbetamelijk doet zijn.

De Hoge Raad oordeelde in casu dat de stemovereenkomst geoorloofd was door it overwegen dat de aandeelhouders/optiegevers zich niet in het algemeen jegens Auron hebben verbonden hun stemrecht uit te oefenen tot vervanging van commissarissen, mar uitsluitend tot vervanging in het geval dat het onderzoek dat aan de overdracht van aandelen vooraf moest gaan, en de overdracht zelf, bij de in functie zijnde commissarissen $p$ tegenstand mochten stuiten. Met andere woorden: het betrof hier een voorzienbare concrete situatie, zodat de aandeelhouders zelf de diverse in het geding zijnde belangen kunnen afwegen.

Ook in het Engelse recht, waar de vrijheid van aandeelhouders betreffende de uitoefening van het stemrecht hoog in het vaandel staat, wordt de

34. Zie ook A.M. Brenninkmeijer, Stemovereenkomsten van aandeelhouders, Deventet 1973. p. 115. Vgl. ook hoofdstuk $4 \$ 2.1$. 
aaneelhouders in beginsel toegestaan om stemovereenkomsten met deren te sluiten. ${ }^{35}$

nders wordt daarover gedacht in het Duitse en Franse recht. Weliswas wordt in de Duitse doctrine en rechtspraak het aangaan van stemoveenkomsten tussen aandeelhouders in het algemeen geldig geacht, mat indien het overeenkomsten met derden betreft, zijn de meningen vereeld. ${ }^{36}$

etreft het overeenkomsten waarbij andeelhouders zich verplichten te stermen overeenkomstig de instructies of voorstellen van het bestuur of de tad van commissarissen, dan is de heersende opvatting in de literatuur datieze niet toelaatbaar zijn. ${ }^{37}$ Als argument daarvoor wordt aangevoerd dat o'n overeenkomst in strijd is met het dualistisch systeem van ons venootschapsrecht. ${ }^{38}$ Een dergelijke overeenkomst zou het door de wet beogde evenwicht verstoren ${ }^{39}$ (zie ook hoofdstuk 4 § 2.1).

iit argument kan mij overigens niet volledig overtuigen. De opvatting dat let bestuur of de raad van commissarissen geen zeggenschap mogen uitofenen ten aanzien van de bevoegdheden die aan de algemene vergaderingijn toebedeeld, wordt afgeleid uit het Forumbank-arrest, dat ik reeds besprak in hoofdstuk 7 \& 3 . Daarin overwoog de Hoge Raad dat een vennootschapsorgaan geen zeggenschap toekomt buiten de door wet en statuten gegeven bevoegdheden. Mag hier echter zonder meer uit worden afgeleid dat de vennootschap een dualistisch karakter heeft? Zijn de grenzen tussen het bestuur en de ava wel zo scherp afgebakend? Zoals ik in hoofdstuk $7 \S 4$ reeds heb betoogd, kan een instructiebevoegheid van de ava in een enkelvoudige vennootschap geoorloofd zijn. Als illustratie daarvoor kan ook worden verwezen naar de uitspraak van de Hoge Raad inzake Meijers/Mast (zie hoofdstuk 7 §3).

35. Vgl, bijv. M.A. Pickering, Shareholders'voting rights, LQR 1965, p. 255/256.

36. Vgl. H.J. de Kluiver, Joint ventures en stemovereenkomsten. Een rechtsvergelijkend perspectief, AA 1995, p. 108. Zie voorts W. Zöliner, $\mathrm{Zu}$ schranken und Wirkung von Stimmbindungsverträgen, insbesondere bei der GmbH. ZHR 1991, p. 170 en 179.

37. Zie onder meer A.L. Mohr, Spijkers, rede Amsterdam 1993, p. 16; A.M. Brenninkmejer. Stemovereenkomsten van aandeelhouders, Deventer 1973, p. 149 (stemovereenkomsten met de eigen vennootschap) en J.M.M. Maeijer, De stemovereenkomst van aandeelhouders in Van der Ploeg bundel, p. 96/97.

38. Zie onder meer J.M.M. Maejjer. De stemovereenkomst van aandeelhouders in Van der Pioeg bundel, p. 103.

39. Zie ook an. 35 van de ontwerp 5e EG-Richtlijn, die met zoveel woorden deze regel bevat. 
Omgekeerd meen ik dat een overeenkomst inhoudende een toekenning van een recht van voordracht, een recht van advies aan het bestuur of de bevoegdheid van het bestuur tot het vastleggen van een wenselijk profiel van de te benoemen bestuurder, geen afbreuk hoeft te doen aan de wettelijke bevoegdheid van de ava inzake de benoeming van bestuurders. Het betreft hier een nadere invulling van de betrokken bevoegdheid. Wordt zo'n overeenkomst aangegaan voor een concrete overzienbare situatie, dan zou ik menen dat deze geldig is. Gaat het echter om een afspraak die in zijn algemeenheid zou gelden, dan is er mijns inziens sprake van strijd met de wettelijke regeling.

Overigens mogen naar mijn mening aandeelhouders niet met iedereen binnen de organisatie een stemovereenkomst aangaan. Te denken valt aan een minderheidsaandeelhouder/bestuurder die vanwege een tegenstrijdig belang uitgesloten is van de besluitvorming en langs deze weg probeert alsnog invloed uit te oefenen op de besluitvorming (vgl. hoofdstuk 4 § 2.3).

Zoals ik reeds in hoofdstuk $4 \S 2.4$ heb betoogd, zijn vermelde afspraken voor de beoordeling van het besluit in het licht van de redelijkheid en billijkheid mede van betekenis. Een besluit tot benoeming waarbij een afspraak, zonder dat daarvoor een goede grond bestaat, niet wordt nagekomen kan er mijns inziens toe leiden dat het benoemingsbesluit wegens strijd met de redelijkheid en billijkheid wordt vernietigd. ${ }^{* 0} \mathrm{De}$ redelijkheid en billijkheid binnen de rechtspersoon kan aldus mede inhoud krijgen door hetgeen betrokkenen bij overeenkomst/afspraak contractueel bindt. ${ }^{41}$

40. Als voorbeeld kan dienen Pres. Rb. Haarlem 19 februari 1988, KG 1988, 133. In deze zaak had de Raad van Toezicht van Stichting Ziekenhuis de Heel met de ondernemingr raad (or) afspraken gemaakt en een profiel geschetst van een te benoemen bestuurder. De Stichting benoemt vervolgens een persoon, waarbij hij naar de mening van de or in strijd heeft gehandeld met de gemaakte afspraken. De president is van oordeel dat nifl nakoming van de afspraken in casu strijd oplevert met de goede trouw en vernietigt het benoemingsbesluit.

41. In gelijke zin L. Timmerman in zijn bespreking van de twaalfde druk van het Handbeek. de NV 1994, p. 248. 
Ook in het Duitse recht wordt door sommige auteurs als Karsten Schmidt ${ }^{2}$ en HoffmannBecking" verdedigd dat de inhoud van de 'Treuepflicht' mede wordt beìnvloed door buitenstatutaire afspraken. Wat de Treuepflicht inhoudt wordt immers bepaald door het belang van de vennootschap (Gesellschaftsinteresse). Bij de concretisering van deze vage norm, moet ook de afspraken van aandeelhouders in acht worden genomen.

Indien, zoals vaak gebeur in familievennootschappen, aandeelhouders afspraken maken over bepaalde kwaliteiten die een bestuurder moet bezitten, dan dient het tot benoeming bevoegde orgaan met het $\infty \mathrm{og}$ op een evenwichtige bezetting van het bestuur hiermee rekening te houden.

Anderzijds zal juist geen betekenis worden toegekend aan een afspraak, indien daarvoor goede gronden aan te wijzen zijn. Men denke aan de situatie waarin een bestuurder wordt benoemd, waarin de mede-bestuurders (op objectieve gronden) geen vertrouwen hebben. Een goede illustratie hier biedt Pres. Rb. Den Haag 11 december 1992, Juridisch up to date 1993, nr. 2 m.nt. S.M. Bartman (HFD-Sijthoff).

De aandelen van het Financiële Dagblad BV (HFD) zijn gecertificeerd ter bescherming tegen een ongewenste overname en tot behoud van een zelfstandige redactievoering. De aandelen worden gehouden door een 'Beheerstichting'. De statuten van de Beheerstichting schrijven voor dat het bestuur uit drie leden bestaat. Een A-bestuurder die wordt benoemd door Hendrik Sijthoff Holding NV (de Holding), een B-bestuurder die wordt benoemd door de Personeelsstichting en een C-bestuurder die wordt benoemd door het A-lid en B-lid te zamen. Op deze wijze wordt getracht de zeggenschap gelijkelijk over de factoren arbeid en bapitaal te verdelen.

Ter completering van de verdeling van de zeggenschap binnen de HFD organisatie sloten de Beheerstichting, de Personeelstichting, de Holding en HFD in 1983 een overeenkomst waarin is opgenomen dat HFD evenveel commissarissen heeft als de Beheerstichting bestuurders en dat beide functies door dezelfde personen worden vervuld, terwijl het aantal bestuursleden/commissarissen bij de aanvang drie zal zijn. Op 15 oktober 1992 benoemt de Holding Sijthoff jr. tot A-bestuurder van de Beheerstichting. HFD en de andere bestuurders zijn het niet eens met deze benoeming. daar het dienstverband van Sijthoff jr. met HFD ruim een maand tevoren door de kantonrechter werd ontbonden wegens een ernstig verstoorde relatie tussen werkgever en werknemer. Zij vorderen derhalve in kort geding onder meer intrekking van het benoemingsbesluit alsmede een bevel aan Sijthoff zich te onthouden van gadragingen als ware hij bestuurslid van de Beheerstichting en/of lid van de Raad van Commissarissen.

De President stelt zich de vraag of de Holding in de gegeven omstandigheden in redelijkheid heeft kunnen beslissen om juist Sijthoff jr. te benoemen tot bestuurslid en darmee ook als commissaris van HFD. Gezien de eerdere problemen tussen HFD en

42. K. Schmidt, Jahrbuch der Fachanwălte für Steuerrecht 1988/89, p. 143, 146.

43. M. Hoffmann-Becking. Der Einfluß schuldrechtlicher Gesellschaftsvereinbarungen auf die Rechtsbeziehungen in der Kapitalgesellschaft, ZGR 1994, p. 459. 
Sijthoff jr oordeelt de President dat deze keuze 'allerminst voor de hand ligt' en kent het gevorderde toe.

Het vonnis kan zo gelezen worden dat de President de benoeming van Sijthoff jr. in strijd acht met de redelijkheid en billijkheid die betrokkenen bij de Beheerstichting in acht moeten nemen, vooral vanwege het gevolg van deze benoeming via de contractuele koppeling tussen bestuurderschap bij de beheerstichting en het commissariaat bij HFD. ${ }^{44}$

\section{§ 6. Slotbeschouwing}

In dit hoofdstuk werd de benoeming van bestuurders in het licht van de redelijkheid en billijkheid bezien. In dit kader is aandacht besteed aan statutaire en buiten-statutaire regelingen die de ava beperken in haar vrijheid om bestuurders te benoemen.

Anders dan in het Engelse en Franse recht, wordt in het Nederlandse recht geen enkele eis gesteld aan de benoeming van bestuurders. Wel kunnen in de statuten benoembaarheidseisen worden opgenomen. Tot nu toe is echter onduidelijk welke kwaliteitseisen rechtsgeldig statutair kunnen worden geregeld.

Als essentieel voor de redelijkheid en billijkheid van een benoemingsbesluit door de ava beschouw ik dat een bestuurder geschikt en in staat moet zijn om zijn wettelijke en statutaire bevoegdheden uit te oefenen in het belang van de vennootschap. De continuilteit van de vennootschap c.q. onderneming is hier in het geding.

Aandeelhouders mogen zich mijns inziens bij de benoeming van bestuurders derhalve slechts tot op zekere hoogte laten leiden door eigen belang. Dit geldt naar mijn mening ook voor een (rechts)persoon die het recht heeft een voordracht op te maken. Deze bevoegdheid zal immers ook naar redelijkheid en billijkheid moeten worden uitgeoefend. Dit betekent enerzijds dat de voorgedragen kandidaten, om voor benoeming in aanmerking te komen, 'geschikt en in staat' moeten zijn de bestuurs-

44. Het opmerkelijke in deze zaak is dat zowel de partijen als de President er kennelijk vanuit gaan dat de benoeming van Sijthoff jr. automatisch tot gevolg heeft dat hij tor commissaris wordt benoemd. Dit is niet het geval, de benoeming van een nieuwt commissaris bij HFD vereist een apart besluit van de ava van HFD. Blijkbaar namen alle betrokkenen echter aan dat de gemaakte afspraken tot besluitvorming in die th zouden dwingen. Zie ook S.M. Bartman, Juridisch up to date 28 januari 1993, nr. 2. 
functie te vervullen. Anderzijds dient de voordracht gemotiveerd te worden door het voordragende orgaan. Ook de mogelijkheid tot het stellen van statutaire kwaliteitseisen voor de benoeming van bestuurders wordt begrensd door de redelijkheid en billijkheid. Zo'n benoemingsvereiste kan zijn gelding verliezen indien de vrijheid van de ava inzake de benoeming van bestuurders op te vergaande wijze wordt beperkt. ${ }^{45}$ Een punt van discussie is in dit verband wat de consequenties zijn als de bestuurder de desbetreffende kwaliteit verliest. Deze vraag is niet in zijn algemeenheid te beantwoorden, zo schrijft Huizink. ${ }^{46}$ Maeijer is van mening dat de consequentie van het verlies van kwaliteit niet inhoudt dat de bestuurder ophoudt bestuurder te zijn. Maar hij meent dat dit wel een grond op kan leveren voor ontslag. ${ }^{47}$ Ook Huizink is die mening toegedaan. Hier sluit ik mij bij aan. Het gaat immers om het belang van een goed functionerende vennootschap, gericht op continuïteit. Deze benadering past ook bij mijn visie welke zal blijken in het volgende hoofdstuk over schorsing en ontslag. Daar verdedig ik dat, ook al bepaalt de wet dat schorsing en ontslag van bestuurders te allen tijde kan geschieden, de redelijkheid en billijkheid meebrengt dat hiervoor een goede grond vereist is.

Ten slotte meen ik dat voor de beoordeling van de redelijkheid en billijkheid van een benoemingsbesluit mede bepalend is of er afspraken (overeenkomsten) zijn gemaakt omtrent de benoeming. In dat verband heb ik verdedigd dat bij het aangaan van dergelijke overeenkomsten een aantal beperkingen zou moeten gelden, ter voorkoming van een onzuivere besluitvorming.

45. Zie HR 19 maart 1976 (NJ 1978, 52 (Van Rees).

46. J.B. Huizink, Losbladige rechtspersonen 1995, art. 132, p. 132-3.

47. Zie Asser-Maeijer 2-III. nr. 311, J.B. Huizink in Losbladige rechtspersonen, art 132. Anders Handboek, nr. 246. 



\section{Schorsing en ontslag van bestuurders}

\section{§1. Inleiding}

Schorsing en ontslag zijn rechtshandelingen van vennootschappelijke aard. In het kader van schorsing wordt de bestuurder tijdelijk onbevoegd verklaard om één of meer bestuurs- en vertegenwoordigingsbevoegdheden uit te oefenen. Ontslag is een verderstrekkende maatregel en heeft tot gevolg dat een bestuurder definitief ontheven wordt van zijn bestuurslidmaatschap met de daaraan verbonden bevoegdheden. In het oog moet worden gehouden dat niet zelden het ontheffen van een bestuurder uit zijn functie een teken is van een (bestuurs)crisis in de vennootschap. Met het ontslag van een bestuurder kan dan beoogd zijn de verhoudingen binnen de vennootschap te herstellen en/of het gedrag van de bestuurder aan een sanctie te onderwerpen.

Krachtens de wet komt de bevoegdheid tot schorsing en ontslag toe aan degene die bevoegd is tot benoeming (art. 2:134/244 lid $1 \mathrm{BW}$ ). In het gewone model is dat derhalve de ava. Voor zover de statuten niet anders bepalen, is ook de raad van commissarissen bevoegd om de bestuurders te schorsen. De ava kan echter wel te allen tijde die schorsing door de raad van commissarissen opheffen (art. 147/257 lid 1 BW), tenzij in het kader van het structuurregime de bevoegdheid tot benoeming van de bestuurders bij de raad van commissarissen berust.

In ons recht wordt voorop gesteld dat een bestuurder te allen tijde door de ava kan worden geschorst of ontslagen. Deze regel houdt volgens de heersende opvatting in dat ontslag van een bestuurder door het bevoegde orgaan op elk gewenst moment kan plaatsvinden, zonder dat het ontslag op een rechtvaardigingsgrond dient te berusten. ${ }^{1}$ De ava zal bij de uitoefening van haar bevoegdheid bestuurders te schorsen c.q. te ontslaan echter wel de eisen in acht moeten nemen die wet en statuten stellen voor een rechtsgeldig besluit.

Anders W.J. Slagter, TVVS 1978. p. 315, die stelt dat met 'te allen tijde' nog niet aangeduid is op welk moment het ontslag ingaat. Huizink geeft aan dat ontslag 'te allen tijde' betekent dat de bestuurder die voor bepaalde tijd is benoemd ook tussentijds kan worden ontslagen. Zie J.B. Huizink, Rechtspersonen losbladig 1997, art. 134, p. 134-13 en in Bestuurders van rechtspersonen (diss. Groningen), Deventer 1989, p. 65. 
In het algemeen geldt dat besluiten ook moeten voldoen aan de eisen van redelijkheid en billijkheid. Gaat het om een schorsings- of ontslagbesluit dan is dit echter een omstreden kwestie. Toetsing van een ontslagbesluit aan de redelijkheid en billijkheid stuit in de literatuur en rechtspraak op weerstand. Hieronder zal daaraan aandacht worden besteed. Tevens zal ik trachten te onderzoeken, mede in het licht van het buitenlandse recht, welke factoren van belang zijn bij de beantwoording van de vraag of een ontslag- of schorsingsbesluit redelijk en billijk is.

\section{$\S 2$. Ontslag; een betwiste kwestie}

Toetsing van een ontslagbesluit aan de redelijkheid en billijkheid verdraagt zich volgens vele schrijvers niet goed met art. 2:134/244 lid 1 BW waarin wordt bepaald dat iedere bestuurder te allen tijde kan worden ontslagen en geschorst door degene die bevoegd is tot benoeming. Bovendien wordt gesteld dat een toetsing aan de redelijkheid en billijkheid van zo'n besluit een conflict oproept met art. 2:134/244 lid 3 BW, dat in afwijking van art. 7:682 BW (voorheen art. 7A:1639t BW), bepaalt dat de rechter geen herstel van de dienstbetrekking kan bevelen. ${ }^{2}$ Door een toetsing aan redelijkheid en billijkheid zou via vernietiging van het ontslagbesluit toch herstel van de dienstbetrekking kunnen worden bewerkstelligd. $^{3}$

Allereerst zou ik hieromtrent willen opmerken dat de regel dat ontslag door de ava 'te allen tijde' mogelijk is, mijns inziens niet goed past bij de institutionele benadering van ons vennootschapsrecht. ${ }^{4}$ Deze regel is uitsluitend gebaseerd op het belang van een vertrouwensrelatie tussen

2. In art. 7:682 $\mathrm{BW}$ is de vordering tot 'herstel van de dienstbetrekking', zoals vermeld in art. 7A:1639 $\mathrm{BW}$, vervangen door de vordering tot 'herstel van de arbeidsverhouding'. De wetgever heeft hiervoor gekozen om misverstanden die onder de oude titel bestonden rond de term 'dienstbetrekking' te voorkomen. Vgl. G.J.J. Heerma van Voss, De arbeidsovereenkomst als Titel 7.10 BW, p. 20 in de serie: Actualiteiten sociaal recht.

3. Zie onder meer L. Timmerman, Het vennootschapsrecht en het ontslag van een bestuutder van een NV of BV, De NV 1985, p. 9 alsmede in: Over multinationale ondernemingen en medezeggenschap van werknemers (diss.), Deventer 1988, p. 81. H.J. Smit. Ontslag en schorsing van directeuren en de mogelijkheid van herstel der dienstbetrekking via kort geding, WPNR 5817 (1987), p. 89 e.v. en H.L.J. Roelvink, Rechtsbescherming van directeuren, NJB 1981, p. 75.

4. Zie over de institutionele benadering M.J.G.C. Raaijmakers, Rechtspersonen tusset contract en instituut, Deventer 1987. 
bestururders en aandeelhouders. Uitgaande van de ontwikkelingen in het vennootschapsrecht, moet mijns inziens het ontslag van bestuurders echter mede tegen de achtergrond van het vennootschappelijk belang worden bezien. Vanuit mijn visie betekent dit dat alle relevante belangen in aanmerking dienen te worden genomen.

Op de tweede plaats zou ik willen opmerken dat mijns inziens het bepaalde in art. 2:134/244 lid 3 BW sterk moet worden gerelativeerd. Eigenlijk hoort dit niet thuis in boek 2 BW en moet het worden bezien tegen de achtergrond van het arbeidsrecht. Daarvoor pleiten mijns inziens de volgende argumenten:

- Art. 2:134/244 lid $3 \mathrm{BW}$ is slechts van toepassing indien er tussen de bestuurder en de vennootschap een arbeidsverhouding bestaat.

- Die bepaling speelt slechts een rol in het kader van de vraag welke gevolgen het arbeidsrecht aan een vennootschapsrechtelijk gezien onaantastbaar besluit tot schorsing of ontslag verbindt. ${ }^{5}$

Art. $2: 134 / 244$ lid 3 BW schept verwarring. In welke situatie moet deze bepaling nu toegepast worden? En geldt deze zowel in geval van schorsing als van ontslag? Beide worden immers in lid 1 van art. $2: 134 / 244$ BW genoemd. ${ }^{6}$ En wat is de betekenis van deze bepaling in geval van een management-contract? ${ }^{7}$

In het licht van het bovenstaande zou ik willen verdedigen dat er een strikt onderscheid gemaakt moet worden tussen de vennootschapsrechtelijke toetsing van een ontslagbesluit en de beoordeling van zo'n besluit in het licht van het arbeidsrecht. Naar mijn mening staat niets een volledige toetsing van het ontslagbesluit aan de redelijkheid en billijkheid in de weg. ${ }^{8}$ Dit standpunt zal worden uitgewerkt in $\$ 9.3$ en volgende.

5. Vgl. HR 26 oktober 1984, NJ 1985, 375 (Sjardin/Sjartec). Zie ook Asser-Maeijer 2-III, nr. 308.

6. In de rechtspraak zien we echter dat een opheffing van een schorsing gehonoreerd wordt. Vgl. Pres. Rb. Amsterdam 28 december 1979, NJ 1980, 458 en Pres. Rb s-Hertogenbosch 7 november 1983, KG 1983, 353.

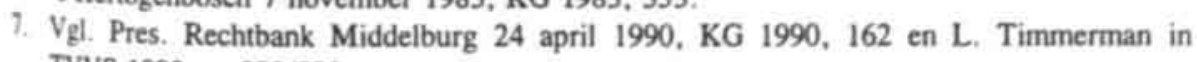
TVVS 1990 , p. 202/203.

8. Evenzo J.B. Huizink, Bestuurders van rechtspersonen, Deventer 1989, p. 72. Anders: L. Timmerman, Over multinationale ondernemingen en medezeggenschap van werknemers (diss.) Deventer 1988, p. 81 alsmede 'Het vennootschappelijk belang en het ontslag 


\section{3. Arbeidsrecht en vennootschapsrecht}

Zoals bekend bestaat er naast de organisatierechtelijke betrekking tussen de bestuurder en de vennootschap vaak een contractuele verhouding die kan berusten op een arbeidsovereenkomst dan wel een overeenkomst tot het verrichten van enkele diensten.

Van der Grinten, Timmerman en Schwarz zijn van mening dat de arbeidsprestatie en de taak waartoe de bestuurder krachtens de arbeidsovereenkomst gehouden is, niet anders zijn dan de vennootschappelijke taak van de bestuurder. $\mathrm{Zij}$ kwalificeren de relatie bestuurder - NV of BV als één (eventueel gemengde) rechtsbetrekking. ${ }^{10}$ Toegegeven zij, dat in de praktijk met de benoeming van een bestuurder de opgestelde overeenkomst veelal de condities regelt waaronder de bestuurder zijn bestuurstaak zal vervullen. Het vennootschapsrechtelijke ontslag van de bestuurder zal dan, volgens bovengenoemde auteurs, de beëindiging van de arbeidsverhouding inhouden, aangezien hij niet meer in staat zal zijn die werkzaamheden uit te oefenen.

Naar mijn mening moet er echter een onderscheid gemaakt worden tussen de organisatierechtelijke en de contractuele rechtsbetrekking. Als gevolg van de vennootschapsrechtelijke maatregel van ontslag, houdt de bestuurder op bestuurder te zijn van de vennootschap. De wet biedt naar mijn mening geen aanknopingspunt om meer daaruit af te leiden." Het ontslag van een bestuurder impliceert niet automatisch de beëindiging van de contractuele betrekking. Het besluit tot ontslag doet naar mijn mening

van een bestuurder van een nv of bv', De NV 1985, p, 9.

9. W.C.L. van der Grinten, Ontslag van een zieke bestuurder, de NV 1993, p. 48, L. Timmerman, De NV 1985, p. 6 en in TVVS 1991, p. 191 e.v. en C.A. Schwarz, Het ontslag van de op arbeidsovereenkomst werkzame bestuurder van een stichting of vereniging, S \& V 1993, p. 57 alsmede in NJB 1993, p. 1054 en meer genuanceerd in Dijk-Van der Ploeg. Van vereniging en stichting, coōperatie en onderlinge waarbork: maatschappij, Deventer 1997, p. 203/204.

10. In zekere zin ook T.J. van der Ploeg. De relatie tussen vennootschapsrecht en af beidsrecht bij het ontslag van bestuurders van vennootschappen, TVVS 1996, p. 281 et 285. Ook in zijn opvatting eindigen met het ontslag van de bestuurder zowel hef rechtspersonenrechtelijke als het arbeidsrechtelijke aspect van de rechtsbetrekking tegelijkertijd, tenzij blijkt dat het ontslaggevende orgaan dit anders bedoelt.

11. In gelijke zin H.L.J. Roelvink, Rechtsbescherming van directeuren, NJB 1981, p. 76. 
geen afbreuk aan de contractuele relatie tussen bestuurder en vennootschap, ${ }^{12}$ tenzij zulks uitdrukkelijk is bedongen.

Ook de jurisprudentie van de Hoge Raad hieromtrent tendeert mijns inziens in deze richting. In het Sjardin/Sjarnec-arrest (HR 26 oktober 1984, NJ 1985, 375) ${ }^{13}$ en in HR 13 november 1992, NJ 1993, 265 (Levinson-MAB Holding) wordt de nadruk gelegd op de gescheidenheid van de vennootschapsrechtelijke en arbeidsrechtelijke positie van de bestuurder. In Sjardin/Sjantec overweegt de Hoge Raad: 'Naast de toetsing van het ontslag zelf aan de regels berreffende de arbeidsovereenkomst, dient immers getoetst te worden of de op het ontslag gerichte wil van de BV, zoals deze in haar tot het ontslag strekkende wilsverklaring jegens de bestuurder tot uiting is gebracht, zich heeft gevormd overeenkomstig de daarvoor geldende regels van de wet en de statuten en de in dit verband tevens in acht te nemen eisen ven de goede trouw (curs. MK). Eerst indien het ontslagbesluit waarvan vernietiging is gevragd, onaantastbaar is geoordeeld, komt de vraag aan de orde welke gevolgen het arbeidsrecht aan het ontslag verbindt, waarbij art. 2: 244 lid 3 BW - dat bij de vernietiging van het ontsiagbesluit geen rol speelt - een beletsel vormt om herstel van de dienstbetrekking uit te spreken'.

In Levison/MAB Holding ${ }^{14}$ ging het om de vraag of de in het boek 7A BW (naar huidig recht boek 7, MK) opgenomen ontslagverboden ook van toepassing zijn op bestuurders van vennoosschappen. De Hoge Raad oordeelt dat 'voorop moet worden gesteld dat, wanneer een naturlijk persoon als bestuurder van een naamloze of besloten vennootschap is benoemd en - zoals veelal het geval is en hier door de rechtbank aangenomen - zijn werkzaamheden krachtens arbeidsovereenkomst verricht, een bij geldig besluit van het bevoegde orgaan van de vennootschap aan hem als bestuurder verleend ontslag wel ingevolge art. 2:134 lid 1/244 lid I BW meebrengt dat hij de hoedanigheid van bestuurder verliest en dus geen van de aan deze hoedanigheid verbonden bevoegdheden meer kan uitoefenen, maar niet tot gevolg behoeft te hebben dat ook de dienstbetrekking eindigt. Bovendien zo oordeelt de Hoge Raad. moet het antwoord op de vraag welke gevolgen het ontslagbesluit heeft voor de arbeidsverhouding tussen de bestuurder en de vennootschap worden gegeven aan de hand van het bepaalde in de arbeidsovereenkomst en in de op arbeidsovereenkomsten toepasselijke bepalingen, voor zover Boek 2 deze wetsbepalingen niet uitdrukkelijk terzijde stelt'.

$\mathrm{Vgl}$. ook HR 17 november 1995, NJ 1996, 142 (Atlantic Nominees), waarin overigens met name de procedurele bevoegdheidsvraag centraal staat. De uitspraak betreft de volgende situatie: De ava van Atlantic Nominees BV besluit de directeur, Van den Elshout, te ontslaan. Naar aanleiding hiervan ziet de BV geen reden meer om de arbeidsovereenkomst met Van den Elshout voort te zetten, temeer daar hij niet herplaatsbaar is in een andere functie binnen het bedrijf van de vennootschap. De BV verzoekt vervolgens de Rechtbank

12. Vgl. ook het Duitse recht, bijv. K-P. Martens, Die außenordentliche Beendigung von Organ- und Anstellungsverhăltnis in: FS Werner 1983, p. 495 e.v.

13. Zie hierover P. van Schilfgaarde. AA 1985, p. 141.

14. Zie hieromtrent M.G. Rood, TVVS 1993, p. 46, W.C.L. van der Grinten, Ontslag van een zieke bestuurder, De NV 1993, p. 48 e.v. en D. Christe, Hoge Raad dicht gat in rechtspositie van vennootschappelijk bestuurder, Sociaal recht 1993, p. 61-65. 
Haarlem om ontbinding van de arbeidsovereenkomst. De vraag is of het onderhavigt ontbindingsverzoek een overeenkomst betreft tussen de vennootschap en de bestuurder, zodat de rechtbank op grond van art. 2:241 BW, betrekking hebbende op vorderingen betreffende de overeenkomst tussen de vennootschap en de bestuurder, bevoegd is hierover te oordelen.

De Hoge Raad laat in het midden of een ontslagbesluit ook de beëindiging van de arbeidsovereenkomst impliceert maar overweegt: 'Indien [..] het door de algemene vergadering van aandeelhouders genomen ontslagbesluit de hoedanigheid van bestuurder, maar niet de arbeidsovereenkomst heeft doen eindigen, volgt hieruit niet dat een op deze overeenkomst betrekking hebbende rechtsvordering of ontbindingsverzoek niet meer zou gelden als een vordering of verzoek betreffende 'de overeenkomst tussen de vennootschap en de bestuurder' in de zin van art. 2:241 BW. Ook wanneer het ontslagbesluit van de algemene vergadering wel de beèindiging van de dienstbetrekking van de bestuurder meebrengt [..] dient een rechtsvordering die betrekking heeft op rechten of verplichtingen die voortvlocien uit de beëindigde overeenkomst, te worden aangemerkt als een rechtsvordering in art. 2:24! BW. Ik versta deze uitspraak aldus dat de HR er voor kiest om, met het oog op de grote financiële belangen die soms met geschillen tussen een vennootschap en haar bestuurder gemoeid zijn, niet een onderscheid te maken al naar gelang het geschil vóór dan wel ná de beëindiging van de vennootschappelijkè verhouding in rechte aanhangig wordt gemaakt.

\section{§ 4. Enige opmerkingen over het Engelse, Duitse en Franse recht}

Ook in het Engelse en Duitse recht wordt een onderscheid gemaakt tussen de organisatierechtelijke relatie van een bestuurder en de rechtspersoon en de relatie waarbij de bestuurder op grond van een arbeidsovereenkomst betrokken is bij de rechtspersoon. ${ }^{15}$

15. In het Engelse recht wordt een onderscheid gemaakt tussen directors, die alleen in etn organisatierechtelijke verhouding tot de vennootschap staan en 'managing' directors of 'executive' directors. Deze bestuurders zijn ook middels een arbeidsovereenkomst verbonden aan de vennootschap. Vgl. hieromtrent Gower's Principles of Modem Company Law, London 1997, p. 193/194. In de Duitse doctrine en rechtspraak gat men uit van het zgn. 'Trennungsprinzip'. Zie bijv. B. Eckhardt, Die Beendigung det Vorstands- und Geschäftsführerstellung in Kapitalgesellschaften, diss. Köln 1989, p. 6/7 en Ch. Munch. Amtsniederlegung. Abberufung und Geschäftsunfähigkeit des Geschäftsführers einer GmbH, DStR 1993, p. 916. Volgens dit principe wordt een strikt onderscheid gemaakt tussen de 'Organstellung', waarmee de organisatierechtelijke relatic wordt aangeduid en de 'Anstellungsverhältnis', waarmee de arbeidsrechtelijke relatic wordt bedoeld. De algemene opvatting is dat het bij een 'Anstellungsvertrag' gaat om een Geschäftsbesorgungsvertrag gericht op het verrichten van arbeid ( $\$ 611,675$ BGB). In de praktijk zijn beide relaties echter nauw met elkaar verbonden en dat levert ook hiet problemen op in het kader van de beëindiging van een van de relaties met de rechtspet. soon. Vaststaat echter dat het ontslag (Widerruf/Abberufung) van een bestuurder ats bestuurder niet automatisch leidt tot beèindiging van het Anstellungsvertrag. Vgl. bijv B. Eckhardt, t.a.p. p. 1 en Mertens in Kölner Kommentar zum Aktiengesetz 1988, § \&4. 
Ook volgens het Franse recht blijft een bestuurder, die tevens een arbeidsrechtelijke verhouding heeft met de vennootschap, middels een 'contrat de travail', na ontheffing van zijn functie als bestuurder werkzaam binnen het bedrijf van de vennootschap. Daarbij moet echter worden bedacht dat het in Frankrijk niet vanzelf spreekt dat een bestuurder ook een arbeidsovereenkomst aangaat. Met name een 'administrateur' van een SA ('classique') mag slechts onder strenge voorwaarden werkzaamheden verrichten in het kader van een arbeidsovereenkomst. ${ }^{10}$

Wat betreft de vennootschapsrechtelijke toetsing van ontslagbesluiten in de bovengenoemde landen kan opgemerkt worden dat deze met name in Engeland en in Frankrijk zeer beperkt is.

In het Engelse recht kan de ava van een public of private company met een gewone meerderheid de bestuurders te allen tijde ontslaan. Dit kan worden afgeieid uit s. 303 van de Companies Act, welke aangeeft dat ontslag van een bestuurder mogelijk is 'before the expination of his office, nothwithstanding anything in its Articles or in any agreement'. In Engeland wordt er vanuit gegaan dat een ontslagbesluit, dat in overeenstemming is met de wet en de statuten, in beginsel onaantastbaar is.

Echter, de uitoefening van de ontslagbevoegdheid van de algemene vergadering van andeelhouders kan wel worden onderworpen aan 'equitable considerations', voortvloeiend uit 'the principle of good faith'. Dit gebeurt echter slechts onder bepaalde omstandigheden. Deze kwestie komt aan de orde in $\$ 10$.

In tegenstelling tot het Engelse recht staat het ontslag van een bestuurder in het Duitse recht niet ter vrije discretie van het tot ontslag bevoegde orgaan. Wat betreft het ontslag van een bestuurder van een Aktiengesellschaft (AG), dat tot de bevoegdheid behoort van de Aufsichtsrat (vergelijkbaar met de rvc), stelt 'de wet een 'wichtiger Grund' (belangrijke grond/reden) als vereiste ( $\$ 84 \mathrm{AktG}) .{ }^{17}$ In het $\mathrm{GmbH}$-recht is de ava (Gesellschafterver-

nr. 93.

16. Zo moet de arbeidsovereenkomst tenminste twee jaar voor de benoeming tot administrateur zijn gesloten. Voorts mag de arbeidsovereenkomst slechts werkzaamheden betreffen die buiten de bestuurstaak liggen. Tenslotte stelt de wet als vereiste dat slechts een derde deel van het bestuur door middel van een arbeidsovereenkomst gelieerd mag zijn aan de vennootschap. Een arbeidsovereenkomst is nietig indien niet is voldaan aan deze voorwaarden (art. 93 L. 1966). De président is, daar hij ook administrateur is aan dezelfde regels onderworpen. Zie Cozian-Viandier-Deboissy, nr. 648, en Guyon, Droit des Affaires, nr. 321. Voor wat betreft de salariëring zijn de overige bestuurders aangewezen op 'jetons de presence' (presentiegeld) dat elk jaar door de ava wordt vastgesteld en verdeeld (art. 107/108 L. 1966).

17. Het gaat hier om ontslag voor de afloop van de ambtstermijn van een bestuurder, welke termijn in een AG maximaal vijf jaar kan zijn. Na afloop van deze termijn is de Aufsichtsrat volledig vrij om de desbetreffende bestuurder weer te benoemen. Zie bijv. T. Raiser, Recht der Kapitalgesellschaften, München 1982, p. 64. 
sammlung) op grond van $\$ 38 \mathrm{GmbHG}$ bevoegd te allen tijde, zonder termijn en gronden, een Geschäftsführer te ontslaan, tenzij statutair is bepaald dat een 'wichtiger Grund' wordt vereist.

In het Franse recht geldt voor wat betreft het ontslag van een dirigeant van een conseil d'administration van een klassieke SA ('forme classique') (zie hoofdstuk 2 \& 1) als uitgangs. punt dat de algemene vergadering van aandeelhouders de bevoegdheid heeft om ad nutum (te allen tijde) te ontslaan. " De 'révocation ad nutum' wordt van oudsher gerechtvaardigd door de visie dat aan de rechtsverhouding tussen de bestuurder en de vennootschap een 'contrat de mandat' (art. 2004 Code Civil) ten grondslag ligt. ${ }^{19}$ De bestuurder krijgt een opdracht om zijn bestuurstaak uit te oefenen en deze opdracht kan op elk moment worden herroepen (révocation). In de loop van de jaren zijn de schaduwzijden hiervan naar voren gekomen en is het in de jurisprudentic toegestaan om een ontslagbesluit te toetsen aan 'abus de droit'. Dit komt aan de orde in 89.

Wat betreft het ontslag van een membre du directoire van een nieuwe SA ('forme nouvelle') (zie hoofdstuk $2 \S 1$ ), dat op voorstel van de conseil de surveillance (vergelijkbaar met een rvc) geschiedt, en het ontslag van een gérant van een SARL is de situatie anders. Voor deze gevallen regelt de wet expliciet dat indien een bestuurder wordt ontslagen zonder de aanwezigheid van een rechtvaardigingsgrond ('un juste motif'), de betrokken bestuurder in aanmerking kan komen voor schadevergoeding op grond van het onrechtmatig karakter van zo'n ontslag. Bij deze vennootschappen geldt dus de regel 'révocabilité pour juste motif ${ }^{20}$ Schadevergoeding is echter het enige mogelijke rechtsgevolg.

\section{§ 5. Hoorrecht en stemrecht}

Wat betreft de vennootschapsrechtelijke toetsing van het ontslagbesluit aan de redelijkheid en billijkheid, lijkt de uitspraak van de Hoge Raad inzake het Sjardin/Sjartec arrest mee te brengen dat er in dit opzicht slechts ruimte is voor toetsing van de wijze van totstandkoming van het besluit (curs. MK).

In dit kader is een aantal vragen interessant. Allereerst de vraag of, indien het onderwerp van de besluitvorming het ontslag van een bestuurder is, de betrokken bestuurder door de ava moet worden gehoord. Voorts kan de vraag gesteld worden of er een motiveringsplicht bestaat van de ava betreffende het ontslagbesluit. Tenslotte rijst de vraag of een met ontslag bedreigde bestuurder, indien hij tevens aandeelhouder is, zijn stemrecht mag uitoefenen ten aanzien van zijn ontslag als bestuurder.

18. Vgl. art. 90 al. 2 Loi nr. 66-537 juillet 1966 betreffende de SA (classique).

19. Vgl. Didier, Droit Commercial, Paris 1997, p. 221.

20. $\mathrm{Vgl}$. bijvoorbeeld $\mathbf{R}$. Baillod, Le 'juste motif' de révocation des dirigeants sociaux, Rev.trim.dr.com. 1983. p. 395/396. Guyon, Droit des affaires, nr. 352 en p. 517/518 en Guyon, Traité des contrats, nr. 31. 


\section{\$ 5.1 Hoorrecht bestuurder?}

De wet verplicht alleen tot het horen van een bestuurder door het tot ontslag bevoegde orgaan, indien het structuurregime van toepassing is. Wel wordt aan bestuurders op grond van art. 2:117/227 lid 4 BW een raadgevende stem toegekend in de ava, hetgeen volgens de jurisprudentie en doctrine meebrengt dat zij in de gelegenheid moeten worden gesteld de ava bij te wonen. ${ }^{21}$ In de jurisprudentie tot nu toe wordt het raadplegingsrecht van de met ontslag bedreigde bestuurder steeds geëerbiedigd, $00 \mathrm{k}$ indien de besluitvorming van de ava buiten vergadering geschiedt. ${ }^{22}$

In het WTC-arrest was het Hof Amsterdam op 18 mei 1989, NJ 1990, 591 van mening dat de omstandigheid dat de ontslagen bestuurder, Van der Wiel, niet de gelegenheid was geboden om zijn mening te geven, strijd opleverde met de eisen van de goede trouw, die de vennootschap bij het nemen van het ontslagbesluit in acht dient te nemen. En in een recente uitsprak van de President van de Rechtbank 's-Gravenhage van 20 december 1995 (KG 1996, 33), wordt dit nog wat aangescherpt. De president overweegt hier: 'Ingevolge art. 2:227 lid 4 BW hebben bestuurders van een BV in de algemene vergadering van aandeelhouders een raadgevende stem. Een redelijke uitleg van deze wetsbepaling brengt met zich mee -bijzondere omstandigheden daargelaten- dat de directeur wiens ontslag op het spel staat tijdig in kennis wordt gesteld van dit voomemen, zodat hij in staat is zijn verdediging voor te bereiden'(curs. MK).

De Hoge Raad heeft zich over deze kwestie uitgesproken in HR 10 maart 1995 (NJ 1995, 595/Janssen Pers). ${ }^{23}$ In Janssen Pers is een machtsstrijd gaande. Ten gevolge van een financiële reorganisatie moet Paul Janssen, mede onder druk van de Bank, in het vervolg het bestuur van de Stichting Administratiekantoor, die enig aandeelhouder is van de moedermaatschappij Janssen Pers Beheer, delen met nog twee andere bestuurders. Op een gegeven moment, wordt hij geconfronteerd met een besluit tot aandelenemissie en een ten behoeve daarvan 'op handen zijnde' statutenwijziging, die zijn positie nog verder aantast. Voordat de emissie daadwerkelijk plaats heeft gevonden treden bij vergissing de twee mede-bestuurders

21. Vgl. F.J.P. van den Ingh, Het ongehoorde ontslag van een bestuurder, WPNR 1993, p. 457, P.J. Dortmond, De adviserende stem van bestuurders en commissarissen bij een besluit buiten vergadering, De NV 1996, p. 28 en Asser/Maeijer 2-III, nr. 268, p. 329. Zie tevens Pres. Rb Rotterdam 9 maart 1993, KG 1993, 137 (Zuiderster).

22. Bartman verdedigt de opvatting dat in geval van besluitvorming buiten vergadering het raadplegingsrecht des te zwaarder moet wegen, omdat daarbij per definitie wordt afgezien van formele totstandkomingsvereisten. Zie Onderneming in kort geding 1994/1995, Amhem 1996, p. 8.

23. Zie hieromtrent met name H.J. de Kluiver, S \& V 1995, p. 88/89 en dezelfde, Machtsstrijd en machtsovername, oratie Maastricht 1996, p. 5 e.v.. C.A. Schwarz, Goede raad is duur; motiveringsplicht, hoorrecht en raadgevende stem bij ontslag van bestuurders. WPNR 1995, p. 527-531 en M.J.G.C. Raaijmakers, AA 1995, p. 788-794. 
van het $\mathrm{AK}$ af. Janssen maakt van deze gelegenheid gebruik, dan wel misbruik, door met de stemmen van het AK enerzijds zichzelf te benoemen tot enig bestuurder van Janssen Pers Beheer en anderzijds de enig bestuurder van de vennootschap (Verheijen) te ontslaan. Deze 'ontslagen' bestuurder beroept zich erop dat hij niet is opgeroepen voor de vergadering waarin hij conform art. 2:227 lid $4 \mathrm{BW}$ had moeten worden geraadpleegd.

Het Hof wijst de stelling van Verheijen echter van de hand. 'Het beroep op art. 2:227 lid $4 \mathrm{BW}$, waarin aan bestuurders en commissarissen als zodanig in de ava een raadgevende stem is toegekend, is ongegrond, omdat Janssen terecht kon aannemen dat het horen van Verheijen alsnog zijnerzijds zou trachten de statutenwijziging en de emissie te effectueren, zelfs tegen het standpunt in van Janssen Beheer BV, zijnde op dat moment nog de enige aandeelhouder in Janssen Pers BV. De Hoge Raad daarentegen ziet hierin geen rechtvaardiging om het horen van een bestuurder achterwege te laten en honoreert het beroep op art. 2:227 lid 4 BW.

Slechts onder bijzondere omstandigheden mag de ava mijns inziens krachtens een statutaire regeling of op grond van art. 2:8 lid 2 BW aan de raadpleging van de met ontslag bedreigde bestuurder voorbijgaan. Men denke aan de situatie dat een dergelijke raadpleging niet in het belang van het functioneren van de vennootschap geschiedt. Daarvan is sprake in geval van tegenstrijdig belang situaties. De betreffende bestuurder is dan niet in staat om over het voorgenomen ontslag een visie te geven die strookt met het belang van de vennootschap. ${ }^{24}$

In dit verband moet echter wel worden onderscheiden tussen het uitoefenen van een raadgevende stem en het horen van een bestuurder. ${ }^{3}$ De raadgevende stem wordt aan de bestuurder in zijn hoedanigheid toegekend, waarbij in aanmerking moet worden genomen dat hij zijn taken moet vervullen in het belang van de vennootschap. Het horen van een bestuurder betreft daarentegen niet zijn hoedanigheid als bestuurder, maar zijn eigen (privé) belangen. Dit betekent mijns inziens dat indien een met ontslag bedreigde bestuurder zijn raadgevende stem niet mag uitoefe-

24. Zie ook F.J.P. van den Ingh, Het ongehoorde ontslag van een bestuurder, WPNR 1993 , p. 457. Het lijkt hem raadzaam 'ervan uitgaande dat art. 2:12 BW ook op dit bijzondere stemrecht ziet' om statutair te regelen dat een bestuurder wiens positie ter discussie stax zijn raadgevende stem te ontzeggen. Anders: C.A. Schwarz, Goede raad is duur. motiveringsplicht, hoorrecht en raadgevende stem bij ontslag van bestuurders. WPNR 1995, p. 530: 'Ik zou menen dat de raadgevende stem slechts dan verplicht gehoord dient te worden in die omstandigheden, waarin daarin ook een zeker objectief te verwachten nut in het kader van de besluitvorming verbonden kan zijn'.

25. $\mathrm{Vgl}$. ook Maeijer in zijn noot bij Janssen Pers en C.A. Schwarz, Goede raad is duur. motiveringsplicht, hoorrecht en raadgevende stem bij het ontslag van bestuurders. WPNR 1995, p. 528. 
neri 'als bestuurder', dit niet uitsluit dat deze naar redelijkheid en billijkheid het recht heeft om zich in de beslissende aandeelhoudersvergadering te verdedigen tegen het ontslagvoorstel (dus gehoord te worden).

In geval van schorsingsbesluiten wordt in de jurisprudentie veelal aangenomen dat een bestuurder voorafgaande aan het schorsingsbesluit gehoord moet worden. Zo'n hoorplicht wordt gebaseerd op de redelijkheid en billijkheid. Aangezien het ontslag van een bestuurder een zeer ingrijpend besluit is, zowel voor de betrokken bestuurder als voor de vennootschap, is het naar mijn mening redelijk en billijk dat ook een met ontslag bedreigde bestuurder in de gelegenheid wordt gesteld om zich daartegen te verdedigen. ${ }^{26}$

Een bestuurder zal zich overigens pas goed kunnen verweren indien hen de redenen van het ontslag worden medegedeeld. De verplichting tot het mededelen daarvan vloeit mijns inziens ook voort uit art. 2:8 BW. ${ }^{27}$ Dit kan anders liggen in het geval dat in een periode voorafgaand aan het ontslag, de betrokken bestuurder reeds is gewezen op zijn disfunctioneren en hem de gelegenheid is geboden daarop te reageren. ${ }^{28}$ Gesignaleerd kan worden dat in de jurisprudentie in geval van schorsing, anders dan in geval van ontslag, veelal een motiveringsplicht wordt aanvaard. Voor dit verschil in benadering van ontslag en schorsing bestaat mijns inziens geen rechtvaardiging.

Een motiveringsplicht in geval van schorsing wordt bijvoorbeeld aangenomen in Pres. $R b$. 'sHentogenbosch 7 november 1983, KG 1983, 353: 'De schorsing van een werknemer door zijn werkgever is een ernstige maatregel; een werkgever dient bij het toepassen van die maatregel dan ook grote zorgvuldigheid te betrachten. Die zorgvuldigheid brengt met zich, dat de werkgever direct bij het toepassen van die maatregel, of [..] binnen korte termijn, aan de betrokkene werknemer de redenen welke tot die maatregelen hebben geleid mededeelt. Ook dient de betrokken werknemer, zo mogelijk voorafgaand aan de schorsing, doch in ieder geval nadat hem de redenen, welke tot die maatregel hebben geleid, zijn medegedeeld, in staat te worden gesteld zijn visie op het hem verwetene te geven. Dit alles wordt niet anders wanneer het, zoals in het onderhavige geval, om een directeur/bestuurder van een

26. Zie ook F.J.P. van den Ingh, Het ongehoorde ontslag van een bestuurder, WPNR 1993. p. 457, Handboek, nr. 254 en Asser-Maeijer 2-III, nr. 316. Het niet-horen van een bestuurder in strijd met art. 2:8 BW kan leiden tot een kennelijk onredelijk ontslag, zie Rechtbank Zwolle 3 maart 1999, JAR 1999, 97.

27. Anders dan Schwarz (WPNR 1995, p. 528), meen ik dat een mededeling als 'verlies van vertrouwen' geen voldoende motivering oplevert voor het ontslag.

28. Of als de betreffende bestuurder weigert de aandeelhoudersvergadering bijeen te roepen, zie Hof 's-Gravenhage 23 september 1983. NJ 1985, 277 (Schipholtrans). 
besloten vennootschap gaat die door of namens de vergadering van aandeelhouders is geschorst'. Vgl. ook Pres. Rb. Assen 7 oktober 1992 (KG 1992, 365). 'De redelijkheid en billijkheid brengen mee dat een bestuurder in beginsel in de gelegenheid moet worden gesteld om zich tegen een voorgenomen schorsing te verweren'. Voorts dient de bestuurder, aldus de president, indien de schorsing geen uitstel kan dulden in ieder geval in de gelegenheid te worden gesteld zich te verdedigen alvorens tot schorsing wordt overgegaan. ${ }^{29}$

In het Engelse recht is het hoorrecht van de bestuurder verankerd in de wet. S. 304 van de Companies Act 1985 bepaalt dat 'a director is entitled to be heard on the resolution at the meeting'. Niet-inachtneming van dit recht leidt tot vernietiging van het besluit.

In de Duitse doctrine wordt aangenomen dat de geldigheid van een ontslagbesluit niet afhankelijk is van het al dan niet horen van een bestuurder. ${ }^{30}$ Echter, in de rechtspraak wordt dit aspect wel meegewogen bij de belangenafweging in het kader van beantwoording van de vraag of sprake is van een 'wichtiger Grund' voor het ontslag van een bestuurder. ${ }^{31}$

Wat het Franse recht betreft, heerst in de literatuur en jurisprudentie in het algemeen de opvatting dat het recht op verweer van de bestuurdet gerespecteerd dient te worden zij het dat de benadering van dit vraagstuk in de rechtspraak niet eenduidig is. Enerzijds vindt men in de jurisprudentie de opvatting dat het niet horen van een bestuurder misbruik van recht (abus de droit) oplevert. ${ }^{32}$ Anderzijds is het hoorrecht niet verenigbaar

29. Zie ook recentelijk Pres. Rb Zwolle 6 mei 1999, JOR 1999, 169 waarin sprake is van schorsing van een bestuurder door de raad van commissarissen. De president overweegt: 'Indien de Raad van Commissarissen van oordeel is dat het belang van de onderneming een schorsing noodzakelijk maakt, dan dient de Raad van Commissarissen zich bij deze bevoegdheid tot schorsen mede te richten naar de eisen van redelijkheid en billijkheid, gelet ook op de artikelen 2:8 BW eerste lid juncto 2:15 BW, eerste lid aanhef en sub b': Deze eisen brengen 'niet alleen met zich dat aan de motivering van een dergelijk besluit hoge eisen moeten worden gesteld', zo oordeelt de President, 'maar maken tevens dat op de Raad van Commissarissen de plicht rust om - voor zover mogelijk - de betrokkene omtrent dit voorgenomen besluit te horen'.

30. $\mathrm{Vgl}$. bijv. BGH GmbHR 60, 220.

31. Vgl. Mertens in Kölner Kommentar zum Aktiengesetz, 1988, par. 84, nr. 96.

32. Zie bijv. Guyon, Traité des contrats, nr. 31 en K. Adom, La révocation ses dirigeants de sociétés commerciales, Rev. Soc. 1998, p. 497. Vgl. bijv. Cass.com. 6 mei 1974, Rev, Soc. 1974, p. 524, m. nt P. Merle en Cour d'appel Paris 19 nov. 1987, Bull. Joly 1988, 76: 'Considérant [...] que cette décision apparaissant ainsi régulière en sa forme et justifiée par les circonstances de cette révocation qui porterait une atteinte injustifié aur droits des personnes et ayant un caractère dolosif, diffamatoire, intempestif ou que 
met constante jurisprudentie over het ontslag van administrateurs, directeurs généraux en de président-directeur bij de SA 'classique' waarin als uitgangspunt geldt dat, zoals ik reeds in $\$ 4$ heb aangegeven, zij te allen tijde (ad nutum) 'sans préavis, ni précision de motifs, ni indemnité 33 kunnen worden ontslagen. ${ }^{34}$ Bovendien staat art. 160 al. 3 L. 1966 de ava, bij wijze van uitzondering, zelfs toe om één of meer bestuurders of commissarissen te ontslaan indien dit onderwerp niet op de agenda staat vermeld. ${ }^{35}$

In de jurisprudentie wordt deze tegenstrijdigheid opgelost door te bepalen dat, op straffe van nietigheid van de ontslagbesluiten, deze bestuurders in de gelegenheid moeten worden gesteld om de vergadering, waarin hun ontslag aan de orde is, bij te wonen en daar hun visie te verkondigen. ${ }^{36}$ Met andere woorden, het hoorrecht van deze bestuurders wordt indirect gewaarborgd doordat bij niet-oproeping van de bestuurders sprake is van 'irregularité ' van de vergadering.

\section{\$ 5.2 Stemrecht bestuurder?}

De vraag of een bestuurder/aandeelhouder die met ontslag wordt bedreigd het stemrecht in zijn rol van aandeelhouder mag uitoefenen wordt in het buitenlandse recht op een andere wijze benaderd dan in Nederland.

In het Nederlandse recht biedt art. 2:12 BW $^{37}$ de mogelijkheid om in bepaalde gevallen van tegenstrijdig belang het stemrecht van een aandeel-

l'adminstrateur ait été mis dans l'impossibilité de se défendre, ou encore qu'une publicité abusive ait été donnée aux griefs invoqués contre lui;

33. Vgl. bijv. P. Reigne, Révocabilité ad nutum des mandataires sociaux et faute de la société, Rev. Soc. 1991, Guyon, Droit des Affaires, nr. 328, Cozian-Viandier-Deboissy, nrs. 684/685 en J-J. Caussain, La précarité de la fonction de mardataire social (révocation et modes de protection), Bull.Joly, p. 523 e.v.

34. Vgl. voor de administrateurs art. $90 \mathrm{~L}$. 1966, voor de directeurs généraux art. $116 \mathrm{~L}$. 1966 en voor de président art. 110 L. 1966.

35. Vgl. ook Y. Chartier, Rev.Soc. 1989, 51.

36. $\mathrm{Vgl}$. Mercadal-Jeanin, $\mathrm{nr}$. $1316 \mathrm{en} \mathrm{Ph}$. Reigne, Révocabilité ad nutum des mandataires sociaux, Rev.Soc. 1991, p. 505.

37. Art. 2:12 BW luidt: 'Het stemrecht over besluiten waarbij de rechtspersoon aan bepaalde personen, anders dan in hun hoedanigheid van lid, aandeelhouder of lid van en orgaan, rechten toekent of verplichtingen kwijtscheldt, kan door de statuten aan die personen en aan hun echtgenoot en bloedverwanten in de rechte lijn worden ontzegd'. 
houder/bestuurder statutair uit te sluiten (curs. MK). ${ }^{38}$ Onduidelijk is of dit ook mogelijk is in het kader van ontslag en schorsing van een bestuurder. ${ }^{39}$

Kritiek bestaat met name op de formule dat uitsluiting van het stemrecht kan platsvinden 'anders dan in hun hoedanigheid van lid, aandeelhouder of lid van een orgaan'. ${ }^{40}$ Dit kan meebrengen dat een aandeelhouder mag meestemmen over zijn eigen schorsing en ontslag omdat het besluit hem treft in zijn hoedanigheid van lid van een orgaan (namelijk het bestuur). ${ }^{41}$ Ontzegging van het stemrecht op grond van art. 2:12 BW is dus alleen mogelijk indien het gaat om toekenning van rechten of kwijtschelding van verplichtingen die los staat van de organisatierechtelijke hoeda. nigheid van de persoon in kwestie. ${ }^{42}$

Mohr stelt derhalve voor het woord 'een' te vervangen door het woord 'dat'. Mohr schrijft dat daarmee kan worden bereikt dat een lid van elk willekeurig orgaan het stemrecht daarin kan worden ontzegd, behoudens in het geval het besluiten van dat orgaan betreft die betrekking hebben op hem, juist uit hoofde van zijn lidmaatschap van dat orgaan. ${ }^{43}$

38. Evenals in het Nederlandse recht, kan in het Belgische recht een statutaire regeling worden getroffen die een stemverbod voor een aandeelhouder bevat in geval van tegenstrijjig belang situaties. Echter, een expliciete wettelijke bepaling daarvoor ontbreekt in het Belgische recht. $\mathrm{Vgl}$. Ph. Ernst, Belangenconflicten in naamloze vennootschappen (diss.), Antwerpen 1997, p. 769.

39. Deze vraag wordt ontkennend beantwoord door Van der Grinten in Asser-Van der Grinten-Maeijer 2-II, nr. 144. Handboek nr. 218 en L. Timmerman, Preadvies Vereeniging Handelsrecht 1991. Dorresteijn beantwoordt deze vraag echter bevestigend, vic Tegenstrijdig belang van bestuurders en commissarissen (diss.) Deventer 1989, p. 92.

40. Kritisch hierover is A.L. Mohr, De dubbelrol aandeelhouder-bestuurder, in de congresbundel de dubbelrol in het vennootschapsrecht 1993, p. 73 e.v. Deze mogelijkheid bestaat overigens ook in het Engelse recht, zie art. 94 Table A CA 1985: 'Save as otherwise provided by the articles, a director shall not vote a meeting of directors or of a committee of directors on any resolution concerning a matter in which he has, directly or indirectly, an interest or duty which is material and which conflicts or may confict with the interests of the company unless his interest or duty arises only because the case falls within one or more of the following paragraphs [...]'.

41. Vgl. A.L. Mohr, De dubbelrol aandeelhouder-bestuurder, in: De dubbelrol in be vennootschapsrecht, Deventer 1993, p. 77 en L. Timmerman, Preadvies vereeniging Handelsrecht 1991, p. 56.

42. Zie F.J.P. van den Ingh, Nietigheid van stem en besluit: vernietiging van besluiten, in: Nieuw vennootschaps- en rechtspersonenrecht, Serie praktijkhandleidingen, Zwolle 1992 , p. 86.

43. Zie A.L. Mohr, t.a.p. p. 78. 
Een probleem blijft wel natuurlijk dat een meerderheidsaandeelhouder/bestuurder op grond van zijn meerderheidspositie in staat is om opneming van een statutaire bepaling te verhinderen c.q. te schrappen. ${ }^{44}$ Dit heeft uiteraard tot gevolg dat het ontslag van een bestuurder/meerderheidsaandeelhouder onmogelijk wordt.

Aangezien zo'n bestuurder in een situatie verkeert waarin zijn persoonlijk belang conflicteert met dat van de vennootschap, ben ik van mening dat ook zonder een statutaire voorziening, voor zo'n bestuurder uit art. 2:8 BW de verplichting voortvloeit om zich van stemming te onthouden. $^{35}$

Evenals in het Nederlandse recht wordt in het buitenlandse recht in beginsel aangenomen dat een aandeelhouder mag deelnemen aan de stemming over zijn ontslag als bestuurder. Het Duitse recht bevat weliswaar specifieke verbodsbepalingen met betrekking tot de uitoefening van het stemrecht, maar deze hebben slechts betrekking op bepaalde gevallen waarin sprake is van tegenstrijdige vermogensrechtelijke belangen ${ }^{46}$ ( $\$ 47$ (4) GmbHG en $\S 136$ (1) AktG). ${ }^{47}$ Het ontslag van bestuurders valt hier niet onder.

Ook het Franse recht legt slechts in enkele specifieke gevallen aan aandeelhouders een stemverbod op. ${ }^{48}$ Dit verbod geldt niet in het kader van ontslag of schorsing van een bestuurder. Echter, het Franse recht biedt met betrekking tot een SARL een andere oplossing, namelijk de 'révocation judiciaire'.49 Op grond van art. 55 lid 2 L. 1966 kan iedere

4. In het Duitse recht is dit niet mogelijk. Een bestuurder heeft hier geen stemrecht ten aanzien van zijn ontslag. Zie bijv. Lutter-Hommelhoff, p. 330.

45. Evenzo Asser-Maeijer-Van der Grinten, nr. 144.

46. Zie Lutter-Hommelhoff, $\S 47$, p. 582 en Hüffer, $\S 136$ AktG, p. $585 / 586$.

47. In de Duitse literatuur wordt gesproken over 'Stimmverbote wegen Insichgeschäfts' en 'Stimmverbote wegen Richtens in eigener Sache'. Vgl. Schmidt, Gesellschaftsrecht, p. 500 , Lutter-Hommelhoff, $\$ 47$, p. 582 , Wiedemann, Gesellschaftsrecht, p. 422 en I. Siegmund, Stimmverbote im GmbH-Recht, BB 1981, p. 1674.

48. Zo voorziet de Franse wetgeving onder meer in een stemverbod bij de evaluatieprocedure voor een quasi-inbreng (art. 157-1 L. 1966) en in het kader van 'conventions réglementées' (art. 101 c.v. L. 1966). Vgl. Guyon, Droit des affaires, nr. 307 en Ph. Merle, Droit commercial, Sociétés commerciales, Parijs 1992, p. 186 en 273.

49. $\mathrm{Vgl}$ Cozian-Viandier-Deboissy, nr. 1305. 
aandeelhouder ('associé') de rechtbank verzoeken om bestuurders te ontslaan indien daarvoor een goede reden bestaat ('cause légitime'). ${ }^{50}$

In het Engelse recht daarentegen kan een bestuurder van een besloten vennootschap (private company) zich juist statutair beschermen tegen ontslag.

Zie hier met name de uitspraak inzake Bushell v. Faith. ${ }^{51}$ In deze zaak waren de aandelen in de private company verdeeld over drie bestuurders. In de Articles was een bepaling opgenomen dat in geval van ontslag van een bestuurder op elk aandeel van de met ontslag bedreigde bestuurder, drie stemrechten in plaats van én zou kunnen worden uitgebracht. Hierdoor kon de bestuurder (Faith), die met ontslag werd bedreigd zijn ontslag voorkomen.

De House of Lords achtte de statutaire clausule geldig; 'there is no fetter which compels the company to make voting rights or restrictions of general application and such rights of restrictions can be attached to special circumstances and to particular types of resolutions', .2

Ook in Engeland mag een aandeelhouder stemmen over zijn positie als bestuurder. Dit vloeit voort uit de gedachte dat de aandeelhouder een 'property-right' heeft met betrekking tot zijn aandelen. ${ }^{53}$

\section{§ 6. Toetsing ontslagbesluit aan materiële normen}

De hiervoor besproken gronden voor aantasting van ontslagbesluiten (hoorrecht, stemrecht) zijn met name 'formeel' van aard. Behalve de toetsing van de formele gronden van het ontslagbesluit aan de redelijkheid en billijkheid, acht ik verdedigbaar dat er ook ruimte bestaat voor toetsing

50. Overigens bestaat er geen verschil tussen een 'cause legitime' dat vereist wordt in het kader van een révocation judiciaire en een 'juste motif, vgl. onder meer Ripert-Roblo nr. 961 en D. Schmidt, Les conflits d'intérêts dans la société anonyme, Joly Parijs 1999. p. 286.

51. House of Lords [1970] AC 1099. Zie tevens LQR 1970, p. 155-157 en D. Prentict, MLR 1969, p. 693-696.

52. Voor een soortgelijke zaak in het Zuid-Afrikaanse recht, waar de CA een soortgelijke bepaling bevat als 303/184 oud CA, verwijs ik naar Stewart v. Schwab, LQR 1970, p. 156.

53. Vgl. Pender v. Lushington [1877] $6 \mathrm{Ch}$ D 70 en Northern Counties Ltd v Jackson \& Steeple Ld [1974] 1 WLR 1133. Zie tevens S. Goulding. Principles of company law, Londen 1996, p. 102/103 en Gower's principles of modern company law. Londen 1997. p. 707. 
van de materiële gronden van het ontslagbesluit aan de redelijkheid en billijkheid.

Bij de beoordeling van de vraag of een ontslagbesluit wel of niet gerechtvaardigd is in het licht van de redelijkheid en billijkheid, zou ik allereerst willen verdedigen dat getoetst kan worden of sprake is van een goede grond voor ontslag. Uiteraard komt dan de vraag op wat een 'goede grond' kan zijn. Deze vraag zal hieronder worden besproken.

Teneinde mijn standpunt te onderbouwen is het nodig om eerst enige opmerkingen te maken over het schorsingsbesluit. Ook meen ik dat het zinvol is om in dit kader aandacht te besteden aan enkele buitenlandse rechtsstelsels.

\section{\$ 7. IJkpunten voor toetsing schorsingsbesluit}

In de Nederlandse literatuur en jurisprudentie heerst in het algemeen de opvatting dat een schorsingsmaatregel slechts gerechtvaardigd is indien er sprake is van een goede grond daarvoor. ${ }^{54}$

Ontbreekt een goede grond voor het nemen van een schorsingsbesluit, dan is dit mijns inziens een doorslaggevende factor bij de beoordeling van de vraag of het besluit in strijd is met de eisen van redelijkheid en billijkheid. De vraag rijst vervolgens wat 'goede gronden' kunnen zijn. Dit wordt mede bepaald door het belang van de vennootschap.

Het bovenstaande kan geillustreerd worden aan de hand van een aantal uitspraken, die met name betrekking hebben op een vordering in kort geding om de schorsing van een bestuurder op te heffen of in te trekken. Zie bijvoorbeeld Pres. Rb. Roermond 4 april $1985^{5 s}$ inzake een diepgaand conflict tussen de algemeen directeur van een BV enerzijds en het bestuur van het administratiekantoor (als enig aandeelhouder) en de raad van commissarissen anderzijds.

54. Zie J.B. Huizink, Bestuurders van rechtspersonen, Deventer 1989, p. 85; Asser-Van der Grinten II, nr. 339 en F.J.W. Löwensteyn, Rechtspersonen art. 134 aant. 5. Zie ook Handboek, nr. 253; in de tiende druk van het Handboek (1984) werd echter de stelling verdedigd dat het bestaan van gronden tot schorsing niet vereist is en dat aanwijzingen en vermoedens voldoende zijn. Een lichtvaardige schorsing kan bovendien onrechtmatig zijn, zie Ariēns-Van Loo, HR 22 december 1961, NJ 1962, 43. De opvatting dat een goede grond vereist is voor schorsing, hangt naar mijn mening nauw samen met de opvatting die in de jurisprudentie wordt gehuldigd dat er voor het tot schorsing bevoegde orgaan de verplichting bestaat, voortvloeiend uit art. 2:8 lid $1 \mathrm{BW}$, de schorsing te motiveren. De redenen zullen moeten worden medegedeeld aan de betrokken bestuurder.

55. Zie De Naamloze Vennootschap 1985, p. 227/228. 
Een vruchtbare samenwerking lijkt uitgesloten (curs. MK). De president is van mening dat de ava terecht heeft mogen concluderen dat onder deze omstandigheden geen sprake metr kan zijn van een behoorlijke uitoefening door de bestuurder van zijn taak. De ava heef daarom niet in strijd gehandeld met de goede trouw door de bestuurder te schorsen teneinde een werkbaar klimaat te herstellen.

Het gebrek aan vertrouwen in een directeur, bijvoorbeeld in zijn bereidheid om het door de vennootschap voorgestane beleid te realiseren, wordt in de rechtspraak niet steeds als grond voor schorsing geaccepteerd. ${ }^{36}$

Een illustratie van een geval waarin een gebrek aan vertrouwen in een bestuurder als grond voor schorsing wordt geaccepteerd biedt Hof 's-Hertogenbosch 22 januari 1996, KG 1996, 92. In deze zaak ontstaan conflicten binnen het familiebedrijf Van der Staak over de bedrijfsvoering, die ertoe leiden dat Riny van der Staak wordt geschorst. Deze vecht vervolgens de schorsing aan. Het hof acht de schorsing allereerst op zijn plaats omdat thet een gezamenlijk belang van partijen is dat de bedrijfsactiviteiten van de vennootschap zoveel mogelijk ongestoord worden voortgeziet'. Tevens overweegt het hof dat 'daarbij niet kan worden voorbijgegaan aan het feitelijk gegeven dat het personeel van de werkmaatschappij zijn vertrouwen in Riny heeft opgezegd'.

Een andere factor welke bij de afweging van belangen rond de schorsing van betekenis kan zijn, is naar mijn mening welke gevolgen de schorsing meebrengt voor de betrokken bestuurder. Een goede grond voor schorsing kan bijvoorbeeld ontbreken indien er andere sanctiemogelijkheden bestaan voor de betrokkene die minder ingrijpend zijn.

Vgl. bijv. Pres. Rb. Rotterdam 11 augustus 1995, KG 1995, 355. In deze zaak hadden twet leden van de Raad van Bestuur van de structuur BV Wilton-Feijenoord na hun aantreden een reorganisatieplan opgesteld, waarin zij optimistische verwachtingen omtrent de resultaten van een reorganisatie presenteerden. Toen bleek dat dit plan binnen tien maanden na hun aantreden als bestuurders niet was geslaagd, vormde dit voor de Raad van Commissarissen een reden om het vertrouwen op te zeggen. Daarop besluit de RvC voorafgaande aan een vergadering waarin gesproken zou worden over de gesignaleerde problemen, om beide bestuurders met onmiddelijke ingang te schorsen. De vraag die in dit geding centraal staat is of het schorsingsbesluit strijd oplevert met de redelijkheid en billijkheid.

56. $\mathrm{Vgl}$. bijvoorbeeld $\mathrm{Rb}$. Zwolle 14 november 1979, NJ 1983, 75 waarin de ledenvergadering van een vereniging het vertrouwen in de bestuurder had verloren. $\mathrm{Vgl}$. ook $\mathrm{Rb}$. Rotterdam 19 maart 1985, NJ 1986, 504 en Pres.Rb. Rotterdam 11 augustus 1995, KG 1995, 355, hierna besproken. In deze zaak verliest de rvc in een structuurvennootschap het vertrouwen in twee bestuurders nadat zij een reorganisatieplan niet konden warmaken. De president oordeelt hierover dat dit niet zonder meer een schorsingsbesluit rechtvaardigt. 
Volgens de president kunnen de gegeven omstandigheden niet zonder meer een schorsingsbesluit rechtvaardigen, ook al zou de RvC hierdoor het vertrouwen in de bestuurders hebben verloren. 'Een schorsing met onmiddelijke ingang is immers zo ingrijpend en defamerend dat hiertoe niet had mogen worden overgegaan wanneer daar niet een hoogst dringende reden voor aanwezig was en niet alle andere mogelijkheden waren beproefd om in de ongewenst geoordeelde ontwikkelingen in te grijpen, aldus de president. Daaraan voegt de president nog toe dat 'zulks in versterikte mate geldt voor deze schorsing, die alleszins begrijpelijkerwijze door betrokkene werd opgevat als een ontslag op staande voet, immers geformuleerd was als een besluit tot beẽindiging van de functie en ook nog vergezeld ging van de anders onbegrijpelijke en bovendien volstrekt nodeloos krenkende sommatie op stel en sprong de biezen te pakken'.

Het voorgaande overziende kan men concluderen dat ondanks de discretionaire bevoegdheid van de ava, blijkende uit de bewoordingen van art. 134/244 BW dat de ava 'te allen tijde 'de bestuurders kan schorsen, de rechtspraak ruimte biedt om zowel de wijze van totstandkoming van het besluit als de materiële gronden daarvoor te toetsen aan de redelijkheid en billijkheid.

\section{\$ . Vergelijking met ontslagbesluit: discussie}

Zoals betoogd is er naar mijn mening geen reden een onderscheid te maken tussen toetsing aan redelijkheid en billijkheid van schorsing en ontslag. ${ }^{57}$ Ook het, bijvoorbeeld door Huizink benadrukte onderscheid van tijdelijkheid (van de schorsing) overtuigt mij niet. Schorsing is als tijdelijke maatregel, in tegenstelling tot ontslag, niet gericht op beëindiging van de rechtsbetrekking. Volgens Huizink moeten voor schorsing derhalve deugdelijke gronden voorliggen. Gezien de omstandigheid dat voor ontslag dezelfde wettelijke bepaling geldt, inhoudende dat de bevoegdheid 'te allen tijde' kan worden uitgeoefend en de omstandigheid dat een ontslagbesluit ingrijpender is en vergaander gevolgen meebrengt voor de betrokken bestuurder, ben ik van mening dat logischerwijze ook een ontslag slechts gerechtvaardigd kan worden door de aanwezigheid van een goede grond. $^{58}$

57. J.B. Huizink, Bestuurders van rechtspersonen, Deventer 1989, p. 86 en ook Asser-Van der Grinten-Maeijer, nr. 339.

58. Enigszins anders echter $R b$. Amsterdam, 26 februari 1997 (JOR 1997, 78). De statutair directeur Lustig van Robé Beheer BV wordt ontslagen door de ava. Het initiatief daartoe is afkornstig van de kredietverstrekker van de BV, de bank Pierson Heidring en Pierson. De bank meent dat Lustig niet goed functioneert en vraagt zich af of het verantwoord is 
Ook Maeijer neigt naar dit standpunt ${ }^{59}$ en is de mening toegedaan dat een ontslagbesluit moet voldoen aan de 'formele en materieel getinte normen die voortvloeien uit de vennootschapsrechtelijke goede trouw'. Zijns inziens kunnen ontslaggronden wel van belang zijn bij de beoordeling van het ontslagbesluit in het licht van de goede trouw, maar hij interpreteert de uitspraak Sjardin/Sjartec, door mij weergegeven in $\S 3$ in die zin dat strijd met de goede trouw niet uitsluitend gebaseerd kan worden op de ontslaggronden.

Van Schilfgaarde verdedigt dat een toetsing van het ontslagbesluit aan de goede trouw wat betreft de materiële normen slechts is toegestaan indien het gaat om andere materiële redenen dan de ontslaggronden, mits van vennootschapsrechtelijke aard. ${ }^{60}$

Zoals gezegd meen ik dat hier een stap verder kan worden gegaan. Men denke bijvoorbeeld aan het geval dat de ava een uitstekende besturder ontslaat, terwijl niemand anders klaar staat om de taak van de ontslagene over te nemen. ${ }^{61}$

Zie ook Hof 's-Hertogenbosch 19 november 1996, KG 1997, 19. In deze zaak willen twee aandeelhouders van Harry Weijts BV, te weten Johannes Weijts jr. en Johannes Weijts sr.,

om de kredietverlening voort te zetten. Als gevolmachtigde van een aandeelhouder met een belang van $24 \%$ in Robé Beheer stemt de bank in de ava voor het ontslag en dringt bij de mede-aandeelhouders van de BV erop aan hetzelfde te doen. Lustig stelt dat de bank hierdoor onrechtmatig heeft gehandeld jegens hem. De Rechtbank wijst dit echter van de hand en oordeelt onder meer 'dat het een kredietgever vrij staat aan andere aandeelhouders kenbaar te maken wat hij gewenste ontwikkelingen acht binnen de vennootschap'. Voorts overweegt de Rechtbank: 'blijkens art. 2:244 BW kan een bestuurder van een besloten vennootschap te allen tijde worden ontslagen door degene die tot benoeming bevoegd is. Voor de rechtsgeldigheid of rechtmatigheid daarvan is niet nodig dat de betreffende bestuurder onrechtmatig of anderszins verwijtbaar heeft gehandeld. "Voldoende is dat de ava meent dat het in het belang van de vennootschap is dat de bestuurder uit die functie wordt ontheven'. In deze uitspraak wordt weliswaar verondersteld dat het ontslag van een bestuurder in het belang van de vennootschap moet zijn. maar voldoende hiervoor is, naar het oordeel van de rechtbank, de opvatting van de ava. Mijns inziens moet wel sprake zijn van een objectieve benadering van het belang van de vennootschap.

59. J.M.M. Maeijer in zijn noot onder Sjardin/Sjartec, in NJ 1985, 375 en tevens in AsserMaeijer 2-III, nr.317.

60. Zie P. van Schilfgaarde in AA 1985, p. 143/144 en dezelfde in Van de NV en BV 1998, nr. 46.

61. Vgl. T.J. van der Ploeg. De relatie tussen vennootschapsrecht en arbeidsrecht bij het ontslag van bestuurders van vennootschappen. TVVS 1996, p. 285. 
Harry Weijts als bestuurder ontslaan dan wel schorsen. In een kort geding procedure wordt de twee aandeelhouders door de President van de Rechtbank te Breda geboden Harry Weijts in staat te stellen zijn directietaken ongestoord uit te voeren. 'Niet alleen was Harry Weijts immers statutair directeur doch bovendien functioneerde hij feitelijk sinds jaar en dag als enig directeur in het bedrijf, terwijl Johannes sr. gezien zijn leeftijd geen duidelijk voornemen had de feitelijke leiding van het bedrijf over te nemen en Johannes jr. daartoe voldoende bekwaamheid mist', aldus de President. Het hof steunt deze opvatting van de President weliswaar, maar voegt daaraan toe dat er een reden moet zijn om de rechten van andeelhouders (ontslaan c.q. schorsen/MK) te beknotten. Geen reden levert, aldus het hof, op thet enkele feit, dat ingeval van ontslag of schorsing van Harry Weijts de vennootschap aansprakelijk kan worden gesteld voor de dientengevolge aan hem opgekomen schade'.

Bovendien is het, zoals Timmerman terecht schrijft, 'kunstmatig om op grond van de gedachte, dat redelijkheid en billijkheid slechts het interne functioneren van de bestuurder beheersen, de redelijkheid en billijkheidstoetsing van een ontslag van een bestuurder alleen tot de wijze van totstandkoming van het ontslagbesluit te beperken en de ontslaggrond buiten beschouwing te laten bij de interne rechtspersoonlijke toetsing' ${ }^{62}$

\section{\$. Vergelijking met buitenlands recht}

Ook in het buitenland wordt wel bezien of 'goede gronden' voor het ontslag van bestuurders bestaan. Dit geldt met name voor Duitsland. Zoals eerder al beschreven is in het Duitse recht het bestaan van een 'wichtiger Grund' een belangrijk toetsingsmoment bij de beoordeling van het ontslag van een bestuurder van een AG ( $\$ 84$ AktG). Bij de $\mathrm{GmbH}$ kan statutair worden bepaald dat een 'wichtiger Grund' voorwaarde is voor het ontslag van een Geschäftsführer (en dit geschiedt veelvuldig in de praktijk). ${ }^{63}$

In de rechtspraak en literatuur wordt aangenomen dat er sprake is van een 'wichtiger Grund': wenn aufgrund bestimmter Umstände der Gesellschaft die Beibehaltung des Vorstandsmitglieds bis zum Ablauf seiner Amtszeit von Rechts wegen nicht mehr zugemutet werden kann' (curs.MK).

62. L. Timmerman in C.W de Monchy-L. Timmerman, De nieuwe algemene bepalingen van boek 2 BW (preadvies Vereeniging 'Handelsrecht' 1991) Tjeenk Willink-Zwolle 1991, p. 84.

63. Zie ook Ch. Mūnch. Amtsniederlegung, Abberufung und Geschăftsunfâhigkeit des Geschăftsfuhrers einer GmbH, DStR 1993, p. 917. 
Daarbij is het vennootschappelijk belang (Gesellschaftsinteresse) beslissend. ${ }^{64}$

De wet geeft in $\$ 84$ III AktG een drietal voorbeelden van gevallen waarin steeds sprake is van een 'wichtiger Grund', namelijk ingeval van:

- 'grobe Pflichtverletzung'door de bestuurder;

- 'Unfähigkeit zur ordnungsgemäßen Geschãftsführung'(onbekwaamheid van de bestuurder om de vennootschap behoorlijk te besturen).

- 'Mißtrauensvotum' van de Hauptversammlung (ava); een besluit van de ava waarin zi] het gebrek aan vertrouwen in de bestuurder uitspreekt en waardoor de rvc zich gedwongen ziet de betrokken bestuurder te ontslaan. Dit staat los van het functioneren van zo'n bestuurder.

In Frankrijk heeft een bestuurder van een SARL of van een SA 'nouvelle' (zie hierover hoofdstuk $2 \S 1$ ) die wordt ontslagen zonder een goede grond ('sans juste motif'), recht op schadevergoeding. ${ }^{65} \mathrm{Bij}$ de beoordeling wat een 'juste motif' is, worden blijkens jurisprudentie en literatuur twee opvattingen aangehangen. Volgens de eerste opvatting, die onder meer wordt verdedigd door Guyon, ${ }^{66}$ is slechts sprake van een "juste motif', indien een bestuurder niet goed functioneert, bijvoorbeeld zijn bestuurstaken ernstig verwaarloost. Vaak vindt men in de jurisprudentie de notie dat er sprake moet zijn van een 'faute'. De tweede opvatting daarentegen, beoordeelt een juste motif uitsluitend in het licht van het 'intérêt social' (het vennootschappelijk belang), losgekoppeld van het functioneren of het gedrag van de bestuurder. ${ }^{67}$

64. Zie Raiser, Recht der Kapitalgesellschaften 1992, p. 97 en Mertens in Kölner Kommentar zum AktG \$ $84 \mathrm{nr} .93 / 104$.

65. Vgl. art. 55 L. 1966 (SARL) en art. 121 L. 1966 (SA nieuwe stijl). Bij deze vennootschappen geldt de regel 'révocabilité pour juste motif. Zie R. Baillod, Le juste motif de révocation des dirigeants sociaux, Rev.trim.dr.com. 1993, p. Overigens is schadevergoeding de enige mogelijke sanctie van een ontslag sans juste motif. Volgens de Franse doctrine is in geval van vernietiging van het ontslagbesluit een herstel van de functie niel mogelijk.

66. Guyon, Traité des contrats, nr. 31, p. 62.

67. Zie P, Reigne t.a.p. p. 507. Vgl. ook het oordeel van de Cour d'Appel Paris in 1980 van oordeel:"la notion de juste motif se définit non pas seulement en fonction de l'activité ou du comportement du membre du directoire intéressé mais aussi en fonction de l'intérêt social réel et certain'. Zie tevens K. Adom, La révocation des dirigeants de sociétés commerciales, Rev. Soc. 1998, p. 510: 'La révocation est un droit essentiel que les associés exercent, ou devraient exercer, exclusivement dans l'intérêt de la socièté 
Volgens deze laatste opvatting, wordt een ontslag van een bestuurder al snel gerechtvaardigd, bijvoorbeeld indien de gewijzigde meerderheid van andeelhouders meent dat benoeming van een nieuwe bestuurder in het belang van de vennootschap is. Het criterium van het vennootschappelijk belang staat in de rechterlijke uitspraken echter minder op de voorgrond dan het gedrag van de bestuurder. ${ }^{68}$

Overigens rust de bewijslast dat een 'juste motif' voor het ontslag ontbreekt op de bestuurder. Aangezien de ava in beginsel niet gehouden is om het ontslag te motiveren, is dit bewijs zeer moeilijk. Dit verklaart waarom de bestuurders in de praktijk weinig succes hebben bij een verzoek tot schadevergoeding. ${ }^{69}$

Ten aanzien van het ontslag 'ad nutum' van een bestuurder van een 'Klassieke' SA, ${ }^{70}$ speelt daarentegen een 'juste motif' geen enkele rol. De rechtspositie van deze bestuurders is dan ook uiterst 'precair'. " $\mathrm{Zij}$ kunnen zich niet beroepen op arbeidsrechtelijke ontslagbescherming. Bovendien kan een bestuurder slechts dan aanspraak maken op schadevergoeding indien het ontslag kan worden aangemerkt als 'abus de droit'. Voorzover mij bekend, wordt een schadevergoeding in de praktijk nauwelijks toegekend. ${ }^{2}$ Deze situatie wordt in de literatuur sterk bekritiseerd. $^{73}$

68. Vgl. R. Baillod, Le 'juste motif de révocation des dirigeants sociaux, Rev.trim.dr.com 1993, p. 409.

69. Vgl. ook Rev.trim.dr.com. 1992, p. 395.

70. Een ontslag 'ad nutum' geldt ook ten aanzien van de président van het conseil d'administration van een SA classique (art. 110, al. 3 L. 1966) en đirecteurs généraux (art. 116 L. 1966).

71. Vgl. J.L. Caussain, La précarité de la fonction de mandataire social, Bull. Joly 1993, p. 523 e.v.

72. Zie Guyon, Droit des affaires, nr. 329 en Rev.Trim.Dr.Com. 1993, p. 522. Wel echter recentelijk in Cour d'appel de Paris, 28 januari 1999, Rev. Soc. 1999, p. $427 / 428$.

73. $V_{g l}$. Ripert-Roblot nr. 1287 'elle est mauvaise' en Guyon, Traité des contrats, nr. 31. Hij betreurt het dat er niet altijd logische redenen ten grondslag liggen aan het onderscheid tussen bestuurders die te allen tijde kunnen worden ontslagen en bestuurders die slechts op goede grond kunnen worden ontslagen. Guyon pleit voor een wettelijke regeling op grond waarvan de vennootschap kan kiezen voor een statutaire regeling 'révocation ad nutum' of 'révocation pour justes motifs' en voor een wettelijke mogelijkheid voor een rechterijik ontslag voorzover een cause légitime aanwezig is. Zie Y.Guyon in zijn noot onder Cass. com. 27 maart 1990 en in zijn noot onder Cass. com 4 juni 1996. JCP. éd E, 1996.II.849. 
Blijkens de Franse doctrine en rechtspraak mag in het kader van een toetsing van het ontslagbesluit aan 'abus de droit' slechts een onderzoek worden ingesteld naar de omstandigheden ('circonstances') waaronder het ontslagbesluit is genomen, en niet naar de gronden voor het ontslag zelf. ${ }^{74}$ Dit impliceert dat alleen een formele toetsing, een toetsing van de wijze waarop het ontslagbesluit tot stand is gekomen, geoorloofd is.

Uit de jurisprudentie kan worden afgeleid dat bij de toetsing van het ontslagbesluit gewicht moet worden toegekend aan factoren als:

- 'Ies circonstances injurieuses ou vexatoires'; Hieronder wordt onder meer begrepen bedreiging, misleidende publiciteit en beledigende gedragingen;

- procedurefouten, zoals het niet behoorlijk oproepen van bestuurders en niet-horen van bestuurders;

- ongerechtvaardigde inbreuk op de positie van de bestuurder; Zo zijn er uitspraken, die bepalen dat indien een bestuurder ontslagen wordt onder een misleidend voorwendsel (prétexte fallacieux) dat nadeel veroorzaakt bij de bestuurder, er sprake kan zijn van misbruik van recht.

Een goede illustratie biedt Cass. Com. 19 oktober 1981, Rev.Soc. 1982, 821 nt J.L. Sibon, p. 821 e.v. In deze zaak werd een voormalig kampioen wielrennen, Bobet, ontslagen uit zjn functie van president van het conseil d'administration van SA Thalasso International. De reden hiervoor was dat er verschil van inzicht bestond tussen Bobet en de meerderheidsaandeelhouder van Thalasso, de Sofitel Groep. Het ontslag van Bobet werd op een zeer indiscrete en voor hem krenkende wijze in de openbaarheid gebracht.

Zowel het Cour d'appel in Parijs als de Cour de Cassation waren van oordeel dat ef sprake was van 'abus de droit'. Twee belangrijke aspecten leverden in casu misbruik van recht op. Allereerst werd Bobet in aanwezigheid van klanten ontslagen en moest ter plekke zijn kantoor verlaten (brutalité). Bovendien werd het ontslag van Bobet op een ongelukkig moment bekend gemaakt aan het grote publiek. Zo oordeelde de Cour de Cassation: 'Attendu que la Cour d'appel, qui n'a pas àpprécier le motif de la révocation [..]. a constatét

Adom pleit voor een eenvormig ontslagsysteem voor bestuurders, in de vorm van 'révocation pour justes motifs', zodat er sprake is van een rechterlijke controle, zie Ls révocation des dirigeants de sociétés commerciales, Rev.Soc. 1998, p. 487-520. Sommige auteurs, waaronder Ripert-Roblot, dragen als oplossing aan dat het ontslag te allen tijde' moet worden beperkt dan wel dat niet afgeweken moet worden van de afspraken die partijen van te voren hebben gemaakt over een schadevergoeding in geval van ontslag. In de jurisprudentie wordt deze doctrine toegepast door te aanvaarden dat partijen van te voren afspraken maken over een bepaalde vergoeding in geval van ontslag. Zie Rev.trim.dr.com. 1993, p. 522. Zgn. 'golden parachute'-regelingen zijo geldig, zie art. 262-6 L. 1966, vgl. ook Guyon, Traité des contrats, nr. 275.

74. Vgl. R. Baillod, Le 'juste motif de révocation des dirigeants sociaux, Rev.trim.dr com. 1983, p. 421, P. Reigne, Révocabilité ad nutum des mandataires sociaux et faut de la société 1991, p. 506 en K. Adom, La révocation des dirigeants de sociéts commerciales, Rev. Soc. 1998, p. 507. 
que Bobet avait été contraint de quitter les lieux où il exercait ses fonctions dans les conditions de rapidité telles qu'elles tendaient à le discréditer auprès de la clientèle auprès de laquelle il gardait un contrat constant; qu'elle a relevé en outre [...] que le communiqué de presse par lequel la révocation de Bobet avait été divulguée aux yeux du grand public, était intervenu à une époque à laquelle il devait avoir la résonance la plus grande dans I'opinion'. Zie eveneens Cass. Com. 26 november 1996, Bull.Joly 1997, p. 141 (SA Econom Location). Volgens de Cour de Cassation is het ontslag van (in casu president) 'abusive si les inconstances dans lesquelles elle est intervenue ont porté atteinte à l'honneur du dirigeant ou si elle a été décidée brutalement sans respecter le principe de la contradiction."

In Engeland behoeft, zoals ik reeds eerder heb vermeld in $\$ 4$, aan een ontslagbesluit geen rechtvaardiging ten grondslag te liggen. ${ }^{76}$ Echter, een bestuurder die werkzaam is 'under a contract of service' (hetgeen dikwijls het geval is bij 'executive' directors), kan in aanmerking komen voor schadevergoeding indien er sprake is van een 'breach of contract', bijvoorbeeld indien ten tijde van het ontslag de tijdsduur van het contract nog niet is verstreken ${ }^{\pi}$ of de opzeggingstermijn niet in acht is genomen. ${ }^{78}$

\section{§10. 'Goede gronden' nader bezien}

Naar mijn mening kunnen (materiële) gronden, waaronder ontslaggronden, in het kader van de beoordeling van een ontslagbesluit getoetst worden aan de vennootschappelijke redelijkheid en billijkheid. De vraag of in een concrete situatie al of niet sprake is van een goede grond voor het ontslag van een bestuurder, is gelet op de rechtsontwikkeling in ons land, niet eenvoudig te beantwoorden. Gezien de beschouwingen in het

75. Dit staat echter op gespannen voet met de regel dat ontslag kan geschieden 'à tout moment sans indication des motifs et sans préavis'. Zie reeds $\$ 5.1$ en tevens P. le Cannu, Le principe de contradiction et la protection des dirigeants, Bull.Joly 1996, p. 11 e.v.

76. Het vereiste van een goede grond (a reasonable cause) speelde overigens wel een rol in oude cases, zoals Inderwick v. Snell [1850] 2 Mac. \& G. 216; 42 ER 83 en Dawkins v. Antrobus [1881] 17 Ch.D. 615. Zie J. F. O'Conner, Good faith in English Law 1990, p. 51.

7 . Echter, indien slechts statutair een bepaalde termijn is vastgelegd, kan dit anders zijn. $\mathrm{Vgl}$. Court of Appeal inzake Shuttleworth v. Cox Brothers \& Co. (Maidenhead) Ltd, 2 KB 9, zie Hicks \& Goo, Cases \& Materials, p. 196 e.v.

78. Zie Mayson, French \& Ryan on Company Law, p. 433, Gower's Principles of Modern Company Law, London 1997, p. 191 en Farrar's Company Law, p. 343. 
voorgaande kunnen echter wel enige opmerkingen hieromtrent worden gemaakt.

Bij de toetsing van het ontslag- (en schorsings) besluit aan de redelijk. heid en billijkheid staat, zoals gezegd, mijns inziens het belang van de vennootschap voorop. Bestuurders worden immers ook benoemd teneinde hun wettelijke en statutaire bevoegheden uit te oefenen in het belang van de vennootschap (zie hoofdstuk 8 \&2). Wat betekent dit nu concreet?

Een aanknopingspunt voor een rechtvaardiging van het ontslag kan het gedrag en/of functioneren van de bestuurder zijn. Bijvoorbeeld indien deze zijn bestuurstaak zodanig onbehoorlijk uitoefent dat dit strijdig is met het belang van de vennootschap, ${ }^{79}$ zoals in de situatie waarin een bestuurder zich geregeld een corporate opportunity toeëigent. Zie voor de behandeling van deze problematiek hoofdstuk 10 .

Ook kan, zoals ik reeds in het voorgaande heb verdedigd, het ontslag van een bestuurder redelijk en billijk zijn indien de bestuurder weigert om de aanwijzingen van de ava met betrekking tot het te voeren beleid op te volgen, terwijl dit beleid met het oog op bijvoorbeeld de financiële situatie van de vennootschap noodzakelijk is. ${ }^{80}$ In beginsel acht ik het ontslag van een bestuurder niet gerechtvaardigd indien een gewijzigde aandeelhoudersvergadering een nieuwe bestuurder wenst. ${ }^{81}$ Echter, verdedigbaar is dat wanneer een verschil in visie tussen het bestuur en de ava het functioneren van de vennootschap in gevaar brengt, een ontslag wel gerechtvaardigd is ${ }^{82}$

Voorts dient mijns inziens bij de beoordeling van het belang van de vennootschap rekening te worden gehouden met de verschillen die bestaan tussen bestuurders van besloten vennootschappen en publieke vennoot-

79. Vgl. CdC 4 mei 1993, Rev.Soc. 800, nt P. Didier en CA Paris 23 april 1992, RDA 1992, nr. 837.

80. Vgl, voor het Duitse recht bijv, OLG Hamburg BB 54, 978. Echter, in de spiegelbeeldige situatie waarin een bestuurder weigert een instructie op te volgen die de continuiteit van de vennootschap in gevaar brengt of leidt tot benadeling van betrokkenen, zaals minderheidsaandeelhouders, zal een ontslagbesluit strijdig zijn met de redelijkheid en billijkheid. Zie evenzo Mertens in Kölner Kommentar zum Aktiengesetz.

81. Vgl. bijv, in het Franse recht CdC. 29 mei 1972, Rev, soc. 1973, 487 : "le changement de majorité au sein d'une SARL et le désir des nouveaux associés de nommer un gérant de leur choix ne sont pas une cause légitime de révocation du gérant en exercicé: Zir voor het Duitse recht bijv. Mertens, t.a.p. nr. 109.

82. Vgl. bijv. CdC 17 juli 1984, Rev.Soc. 1984, 791, nt Guyénot. Zie ook R. Baillod. Le 'juste motif de révocation des dirigeants sociaux, Rev.trim.dr.com. 1983, p. 408. 
schappen. In (kleine) besloten vennootschappen, waarin op basis van 'intuitu personae' wordt samengewerkt, zullen bestuurders veelal worden benoemd met het oog op het vertrouwen dat de ava heeft in de persoon, terwijl in (grote) publieke vennootschappen de kwaliteiten van de bestuurders voorop zullen staan. Aldus kan het ontslag van een bestuurder in een besloten vennootschap redelijk en billijk zijn indien sprake is van verlies van vertrouwen van de ava in zijn persoon. ${ }^{83}$

Anderzijds echter moet in aanmerking worden genomen dat de positie van een bestuurder in een besloten vennootschap kwetsbaarder is dan in een grotere vennootschap. Vaak is zo'n bestuurder nauw betrokken bij de vennootschap doordat hij ook aandeelhouder is. Het rendement op zijn investering in de vennootschap gaat grotendeels verloren als hij de bestuurdersbeloningen verliest en tevens slechts aangewezen is op dividend waarvoor hij is 'overgeleverd' aan de overgebleven bestuurder(s)/ (meerderheids)aandeelhouder(s). In zo'n geval zou ik derhalve willen verdedigen dat, bij toetsing van het ontslagbesluit aan de redelijkheid en billijkheid, het belang van de vennootschap minder gewicht dient te krijgen. ${ }^{\text {s4 }}$

Deze zienswijze vindt men met name terug in het Engelse recht. Hier wordt in de jurisprudentie en literatuur aangenomen dat bestuurders van kleine besloten vennootschappen, waarin 'intuitu personae' wordt samengewerkt, in zekere zin 'beschermd' mogen worden vanuit de visie dat het niet onredelijk is dat elke partner recht heeft op participatie in het bestuur. $^{85}$

Onder omstandigheden kan het ontslag van zo'n bestuurder 'unfair prejudice' in de zin van section 459 CA 1985 opleveren op grond waarvan de rechter kan ingrijpen en zelfs de vennootschap kan ontbinden.

Een bekende illustratie is de beslissing van de House of Lords inzake Re Westbourne Galleries." Het betrof hier een in een Ltd. geincorporeerde 'partnership' waarin Ebrahimi

83. Anders C.A. Schwarz, die de mening is toegedaan dat het verlies van vertrouwen altijd het ontslag van een bestuurder rechtvaardigt. Zie C.A. Schwarz in Goede raad is duur; motiveringsplicht, hoorrecht en raadgevende stem bij ontslag van bestuurders. WPNR 1995 (nr. 6190), p. 528.

84. Dit kan mijns inziens anders zijn indien de bestuurder voor zijn 'nadeel' een 'passende' compensatie van de vennootschap verkrijgt.

85. Vgl. Gower's Principles of Modern Company Law, London 1997, p. 189 en B.J. Cartoon, The removal of company directors, JBL 1988, p. $21 / 22$.

86. [1973] AC 360, [1972] All ER 492 (House of Lords). 
als aandeelhouder-partner bij meerderheidsbesluit was ontslagen. Ebrahimi vorderde daarop ontbinding van het samenwerkingsverband op grond van het toenmalige art. 222 CA 1948 welke vordering kon worden toegewezen: 'if the court is of the opinion that it is just and equitable that the company should be wound up'.

The House of Lords overweegt dat de uitoefening van de ontslagbevoegdheid jegens een bestuurder slechts onder bepaalde omstandigheden door de rechter zal worden onderworpen aan 'equitable considerations' zoals: a) een samenwerkingsverband 'intuitu personae aangegaan, met het oog op bijvoorbeeld de betrouwbaarheid van de vennoten (members), b) waar beperkingen gelden ten aanzien van de overdracht van aandelen, en c) betrokkenen zijn overeengekomen dat alle of de meerderheid van de vennoten deelnemen in het bestuur van de vennootschap. In zo'n situatie kan een besluit tot het ontslag van een bestuurder er toe leiden dat ontbinding van de vennootschap 'just and equitable' is. Het geeft de bestuurder echter geen recht om de vennootschap te bevelen hem niet te ontslaan. ${ }^{87}$

Recentelijk heeft The Law Commission een wetswijziging van s. $459 \mathrm{CA}$ (inzake 'unfair prejudicial conduct') voorgesteld om tegemoet te komen aan de kwetsbare positie van bestuurders in dergelijke samenwerkingsverbanden.

Zo wordt op grond van dit voorstel in geval van ontslag van een bestuurder onder bepaalde omstandigheden vermoed dat sprake is van 'unfair prejudice'. ${ }^{8}$ Hierdoor ontsnapt zo'n bestuurder aan een langdurige en kostbare procedure in het kader van s. 459 CA. Voonts verkrijgt zo'n bestuurder het recht om uitgekocht te worden tegen 'pro rata' waarde, dat is de waarde van de aandelen in de marktwaarde van de vennootschap in haar geheel. Zit tevens hoofdstuk $2 \$ 5.1$.

87. Zie R. Hollington, Minority shareholders' rights, 1992, p. 36 en Farrar's Company Law, p. 444/445.

88. Zie The Law Commission consultation paper on 'shareholder remedies', London 1997, p. 24 e.v., m.n. p. 31. Op grond van dit voorstel wordt s. 459 A toegevoegd.

Deze ontwerpbepaling luidt onder meer als volgt:

1) This section applies if - a) a member of a private company limited by shares petitions under section 459 (1) for an order under this part, b) it is shown that the member has been removed as a director or has been prevented from carrying out all (or substantially all) his functions as a director, c) immediately before the removal or prevention mentioned in paragraph $b$ the member held at least 10 per cent of the voting rights in the company, and, d) immediately before the removal or prevention mentioned in paragraph b all (or substantially all) the members of the company fulfilled the director condition st out in subsection 3.

2) Uniess the contrary is shown, it must be presumed that because of the removal or prevention mentioned in subsection 1) b the company's affairs have been conducted in 2 manner which is unfairly prejudicial to the interests of the petitioner. 


\section{§11. Slotbeschouwing}

Net als ieder besluit moet ook het besluit tot schorsing of ontslag van een bestuurder voldoen aan de eisen die de wet, statuten en redelijkheid en billijkheid daarvoor stellen. Toetsing van een schorsings- of ontslagbesluit aan de redelijkheid en billijkheid is echter een omstreden kwestie. Onderzocht is in dit hoofdstuk of en in hoeverre een schorsings-en ontslagbesluit kan worden getoetst aan de redelijkheid en billijkheid.

Mijn betoog gaat uit van de veronderstelling dat de verhouding vennootschap - bestuurder een tweeledige is. Steeds moet mijns inziens een onderscheid gemaakt worden tussen de organisatierechtelijke en de contractuele rechtsbetrekking. Dit is ook de tendens in de jurisprudentie. Daar is ook alle reden toe daar de aanvechting van een besluit van de algemene vergadering van aandeelhouders door de wet anders is geregeld dan de aanvechting van de beëindiging van een dienstbetrekking. ${ }^{89}$

Een andere benadering van de verhouding van de bestuurder tot de rechtspersoon, uitgaande van een gemengde rechtsbetrekking, wordt aangehangen door Timmerman, Maeijer en Van der Grinten. Zij zijn de mening toegedaan dat de ontbinding van de arbeidsovereenkomst leidt tot beeindiging van de vennootschapsrechtelijke rechtsbetrekking. Iets genuanceerder is het standpunt van Van Schilfgaarde..$^{90}$ De opvatting die men huldigt over het rechtskarakter van de relatie van bestuurder tot de rechtspersoon lijkt echter niet samen te hangen met de visie over de toetsing van een ontslagbesluit aan de redelijkheid en billijkheid ex art. 2:15 lid 1 sub b BW.

Wat betreft die toetsing is de heersende opvatting in de literatuur en rechtspraak dat, met name wat betreft ontslagbesluiten, in ieder geval ruimte bestaat voor toetsing van 'formele' gronden daarvan, zoals het hoorrecht.

In navolging van Van den Ingh $^{\text {91 }}$ meen ik dat als uitgangspunt moet worden gehanteerd dat een bestuurder op grond van art. 2:8 BW in de gelegenheid moet worden gesteld om te worden gehoord. Ook in En-

89. Vgl. bijv. HR 13 november 1992, NJ 1993, 265 (Levison), HR 8 oktober 1993, NJ 1994, 211 (Mooij Verf), HR 17 november 1995, NJ 1996, 142 (Atlantic Nominees).

90. Zie Van Schilfgaarde, Van de NV en BV, nr. 46: 'Omgekeerd zal beēindiging van de arbeidsovereenkomst over het algemeen ook beēindiging van de bestuursfunctie meebrengen:

91. F.J.P. van den Ingh, Het ongehoorde ontslag van een bestuurder, WPNR 1993, p. 457. 
geland, Duitsland en Frankrijk wordt het hoorrecht direct dan wel indirect gewaarborgd.

Ik bepleit echter dat er ook ruimte bestaat om het ontslagbesluit te toetsen aan materiële normen. Een aantal auteurs voelt voor dit standpunt. Zo schrijft Van Schilfgaarde ${ }^{22}$ dat zijns inziens ook een beroep op materiële gronden mogelijk blijft. Timmerman ${ }^{93}$ meent zelfs dat het "kunstmatig is om op grond van de gedachte, dat redelijkheid en billijkheid slechts het interne functioneren van de bestuurder beheersen, alleen de wijze van totstandkoming van het ontslagbesluit te beperken en de ontslag. grond buiten beschouwing te laten bij de interne rechtspersoonlijke toetsing'.

Daarbij moet echter wel worden bedacht dat Timmerman een voorstander is van een zeer terughoudende toetsing van de grond voor een ontslagbesluit van een bestuurder aan de redelijkheid en billijkheid. Deze terughoudendheid baseert hij mede op de in het Nederlandse recht geldende regel dat een bestuurder te allen tijde door de ava kan worden geschorst of ontslagen (art. 2:134/244 BW). Timmerman beroept zich op het beginsel van discretionaire bevoegdheid van de algemene vergadering van aandeelhouders. Dit lijkt de heersende leer te zijn. Volgens Huizink ${ }^{4}$ volgt uit de (functionele) aard van de rechtsbetrekking niet snel dat een besluit tot ontslag in strijd is met de redelijkheid en billijkheid. Ook Schwarz ${ }^{95}$ meent dat het in hoge mate discretionaire karakter van de ontslagbevoegdheid maakt dat een ontslagbesluit slechts in uitzonderlijke gevallen aantastbaar zal zijn op grond van regels van redelijkheid en billijkheid.

Mijns inziens staat echter niets een volledige toetsing van het schorsings- en ontslagbesluit aan de redelijkheid en billijkheid in de weg. Hierin wijkt mijn opvatting af van de heersende leer. Art. 2:134/244 lid 1 BW doet mijns inziens ook niet af aan mijn visie. Met Huizink meen ik dat de term ontslag 'te allen tijde' slechts inhoudt dat een bestuurder die voor een bepaalde tijd is benoemd ook tussentijds kan worden ontslagen.

92. Van Schilfgaarde, Van de BV en NV, nr. 46.

93. Zie L. Timmerman in C.W de Monchy-L. Timmerman, De nieuwe algemene bepalingen van boek 2 BW (preadvies Vereeniging 'Handeisrecht' 1991) Tjeenk Willink- Zwolle 1991, p. 84.

94. Vgl. J.B. Huizink Rechtspersonen Losbladig (1997), Artikel 134, p. 14 alsmede in zijt dissertatie Bestuurders van rechtspersonen, Deventer 1989, p. 72.

95. Zie C.A. Schwarz in Dijk-Van der Ploeg, p. 197. 
In mijn optiek dient aan een ontslag een rechtvaardigingsgrond ten grondslag te liggen (een 'goede grond'). Met name een vergelijking met de rechterlijke beoordeling van schorsingsbesluiten geeft aanleiding voor de hier verdedigde opvatting. Voor het verschil in benadering van ontslag en schorsing bestaat mijns inziens in ieder geval geen rechtvaardiging.

Ook in het buitenland, met name in Duitsland, wordt bij de beoordeling van het ontslag van bestuurders betekenis toegekend aan het bestaan van een 'goede grond'. Daarbij staat het vennootschappelijk belang danwel het functioneren van de bestuurder voorop. In het Franse recht is de aanwezigheid van een 'goede grond' van belang voor de beantwoording van de vraag of ontslagen bestuurders van een SA 'nouvelle' of een SARL aanspraak hebben op schadevergoeding. Een bestuurder van een SA 'classique' komt slechts in aanmerking voor schadevergoeding indien het ontslag kan worden aangemerkt als 'abus de droit'.

Bij de toetsing van het ontslag- en schorsingsbesluit aan de redelijkheid en billijkheid meen ik dat in beginsel het belang van de vennootschap voorop staat. Bestuurders dienen immers hun wettelijke en statutaire bevoegdheden uit te oefenen in het belang van de vennootschap. Een goede grond voor ontslag kan mijns inziens gelegen zijn in het gedrag en/of het functioneren van een bestuurder. Bij de beoordeling van het ontslagbesluit acht ik het overigens passend mede in aanmerking te nemen het 'karakter' van een vennootschap dat immers mede bepalend is voor de positie van de betrokken bestuurder. Een bestuurder in een besloten vennootschap is veelal 'kwetsbaarder' dan een bestuurder van een (grote) naamloze vennootschap. Mijns inziens is dit een omstandigheid die bij de beoordeling van het ontslagbesluit in het licht van de redelijkheid en billijkheid betrokken dient te worden. 



\section{Bestuurders en Corporate Opportunities}

The law of corporate opportunities is among the least satisfactory limbs of corporate law ${ }^{2}$

\section{§1. Inleiding}

Een bestuurder van een vennootschap die een onderneming in stand houdt, kan in het kader van zijn functie-uitoefening een (winstgevende) 'corporate opportunity' ontdekken en vervolgens besluiten deze op eigen naam en voor eigen rekening te benutten. ${ }^{3}$ Juridische implicaties dienen zich aan, indien zo'n handelwijze van een bestuurder ertoe leidt dat er voor de betrokken onderneming een kans verloren gaat en aan deze onderneming voordelen worden onthouden. Te denken valt aan de situatie dat een bestuurder van een vennootschap deelnemingen verwerft ten behoeve van zijn privé holding en ze later tegen een veel hogere prijs doorverkoopt. ${ }^{4}$

In de Verenigde Staten wordt zulk gedrag van bestuurders reeds lang getoetst aan de zgn. 'corporate opportunities doctrine', een leer die is ontwikkeld met name op basis van het uitgangspunt dat een bestuurder

1. Hierbij zij opgemerkt dat de problematiek van corporate opportunities ook relevant is ten aanzien van commissarissen (vergelijkbaar met de Amerikaanse 'outside directors') en werknemers. Bij de laatste categorie moet het dan wel gaan om werknemers aan wie beleidsvrijheid is toegekend om een aantal bestuursbevoegdheden uit te oefenen. In deze paragraaf concentreer ik mij echter op de corporate opportunities problematiek ten aanzien van bestuurders.

2. V. Brudney en R.C. Clark, A new look at corporate opportunities, Harvard Law Review 1981, p. 998.

3. Dit benutten kan ook bestaan uit het 'buiten de deur van de vennootschap houden' van aanbiedingen, zoals bijvoorbeeld van grond, omdat de bestuurder zelf de vennootschap een aanbod wil doen.

4. Men denke aan de HCS-zaak, Pres. Rb. Amsterdam 15 juni 1988, KG 1988, 276 en Pres. Rb. Amsterdam 1 augustus 1988, KG 1988, 341. Kuyten, de directeur van HCS, kocht via zijn privé-vennootschap Reiss \& Co twee vennootschappen, die weliswaar aan HCS waren aangeboden, maar die HCS op dat moment niet kon betalen. Nauwelijks een jaar later verkocht Kuyten de beide vennootschappen door aan HCS met een aanzienlijke winst. Enkele aandeelhouders waren van mening dat Kuyten als directeur van HCS bij het verwerven van corporate opportunities geen voordeel ten koste van HCS mocht genieten en vorderden ongedaanmaking van de transactie. 
van een vennootschap te beschouwen is als een trustee en dat bepaalde regels van het trustrecht op bestuurders van toepassing zijn. ${ }^{5}$ Kern van deze - in de jurisprudentie ontwikkelde - leer is dat een bestuurder, uit hoofde van zijn functie, tot taak heeft corporate opportunities op te sporen en te benutten voor rekening van de onderneming, waarbij hij zijn persoonlijke belangen ten achter dient te stellen. Vanwege de trusteeachtige positie waarin de bestuurder zich bevindt, wordt van hem een hoge mate van loyaliteit en onbaatzuchtigheid verlangd. ${ }^{6}$

In het Nederlandse recht wordt de "corporate opportunities problematiek', bij gebrek aan een wettelijke regeling, mijns inziens beheerst door de norm van redelijkheid en billijkheid. ${ }^{7}$ Dit brengt mee dat een bestuurder in het kader van corporate opportunities rekening moet houden met alle betrokken belangen van de vennootschap en de daaraan verbonden onderneming. Veel aandacht kreeg deze kwestie in het Nederlandse recht tot voor kort echter niet. ${ }^{8}$

Opgemerkt dient te worden dat de problematiek van de corporate opportunities in verband kan worden gebracht met enkele andere onderwerpen in het Nederlandse vennootschapsrecht. Allereerst vertoont het gebruik maken van een corporate opportunity door een bestuurder verwantschap met het handelen met tegenstrijdig belang. In beide gevallen is er sprake van een verstrengeling van belangen. Echter, in het kader van handelen met tegenstrijdig belang, handelt de bestuurder niet alleen op eigen naam, maar tevens namens de vennootschap. In de tweede plaats zou ik willen opmerken dat er een zeker verband bestaat tussen het toeëigenen van een corporate opportunity door een bestuurder en een

5. C.AE. Uniken Venema, Corporate opportunities; aspecten van loyaliteit in het kader van een onderneming naar Amerikaans en Nederlands recht in: Jurist in bedrijf, Deventer 1980 , p. 173.

6. C.AE. Uniken Venema, t.a.p., p. 174.

7. Zie over de discussie met betrekking tot de grondslag van toetsing van de toeêigening van corporate opportunities door bestuurders $\$ 3$.

8. Gelukkig komt dit onderwerp steeds meer in de belangstelling te staan, zie mijn artikel 'Redelijkheid en billijkheid in het vennootschapsrecht, Gebruik van corporate opportunities: een (on)geoorloofde gedraging van bestuurders? in het themanummer van WPNR inzake Vermogensrecht; AlO-onderzoek en rechtsvergelijking. 1994, p. 714-719 alsmede de dissertatie van A.F. Verdam, Corporate opportunities, Tilburg 1995, welke zeker bijdraagt tot een verdere bewustwording van de problematiek rond corporate opportunities. Zie voor het Belgische recht met name $\mathrm{Ph}$. Emst, Belangenconflicten in naamloze vennootschappen (diss.), Antwerpen 1997, m.n. p. 369-383. 
lasthebber die in eigen naam een overeenkomst heeft gesloten en zijn verplichtingen jegens de lastgever niet nakomt (art. 7:420 BW). Aan de rechtsverhouding die bestaat tussen bestuurder en de vennootschap, ligt immers veelal ook een contractueel element ten grondslag.

Voorts kan een toeèigening van een corporate opportunity te beschouwen zijn als een concurrerende handeling en op grond van een concurrentiebeding niet zijn toegestaan ten opzichte van de vennootschap. De problematiek van de corporate opportunities omvat echter ook nietconcurrerende handelingen. ${ }^{10}$ Tenslotte bestaat er ook een zeker verband met het verschijnsel van misbruik van voorwetenschap. De situatie kan zich voordoen dat een bestuurder slechts in staat is (ongeoorloofd) gebruik te maken van een corporate opportunity omdat hij uit hoofde van zijn functie over belangrijke vertrouwelijke informatie beschikt. Noodzakelijk is dit echter niet.

Wat is een corporate opportunity? Wanneer en onder welke voorwaarden is het (on)geoorloofd dat een bestuurder gebruik maakt van een corporate opportunity? Waar kan de norm van redelijkheid en billijkheid toe leiden indien een bestuurder zich ongeoorloofd een corporate opportunity toeëigent? Deze vragen stel ik centraal in dit hoofdstuk.

Aangezien in de Nederlandse jurisprudentie bijna geen uitspraken voorkomen die specifiek op de corporate opportunities problematiek betrekking hebben, is het moeilijk om in het Nederlandse recht aanknopingspunten te vinden voor de toepassing van de norm van redelijkheid en billijkheid met betrekking tot bestuurders die zich een corporate opportunity toeëigenen ten nadele van de onderneming.

In de buitenlandse rechtspraak en literatuur, met name in de Verenigde Staten, heeft men meer nagedacht over de problematiek van corporate opportunities en heeft men geprobeerd criteria te formuleren die deze problematiek kunnen verhelderen. Onderzocht zal worden of het buitenlandse recht aanknopingspunten kan bieden voor de concretisering van de norm van redelijkheid en billijkheid in het Nederlandse recht met betrekking tot (opportunistische) gedragingen van bestuurders.

9. Een handelen van een bestuurder zou men kunnen zien als voortvloeiend uit een impliciete opdracht van een bestuur van een rechtspersoon als geheel aan de individuele leden daarvan om bepaalde zaken namens de rechtspersoon te behartigen', aldus H.J. de Kluiver, Nieuw Vennootschaps- en rechtspersonenrecht, Zwolle 1992, p. 30.

10. Men denke bijvoorbeeld aan winstgevende transacties die niet tot het terrein van (bestaande) activiteiten van de vennootschap c.q. onderneming behoren. 


\section{§ 2. Grondslag toetsing corporate opportunities in de Verenigde Staten, Duitsland en Engeland}

Het leerstuk 'corporate opportunity' is in het vennootschapsrecht van de Verenigde Staten tot ontwikkeling gekomen in de rechtspraak. Uit het algemene beginsel dat elke bestuurder zich loyaal dient te gedragen ten opzichte van de vennootschap, de 'fiduciary duty of loyalty', werd afgeleid dat een bestuurder zich geen corporate opportunity mocht toeeigenen."

Nog steeds kan de Verenigde Staten als toonaangevend worden beschouwd ten aanzien van de onderhavige problematiek. Allereerst is het onderwerp in een aantal staten wettelijk geregeld. Voorts is in ruime mate aandacht besteed aan dit onderwerp in de Revised Model Business Corporation Act $(\S 8)$. Ten slotte heeft het American Law Institute in zijn gezaghebbende 'Restatements' met betrekking tot 'principles of corporate governance' een aparte paragraaf gewijd aan corporate opportunities (§ 5.05). Ook moet gewezen worden op de niet aflatende stroom van jurisprudentie en literatuur over dit onderwerp. ${ }^{12}$

Ook in Engeland heeft het trustrecht, en de toepassingen daarvan op het vennootschapsrecht, een wezenlijk bijdrage geleverd aan de ontwikkelingen van de corporate opportunities doctrine. Evenals het Amerikaanse recht wordt in het Engelse recht het gebruik door bestuurders van corporate opportunities beoordeeld in het licht van fiduciary duties die op 'directors' als fiduciaries' berusten. ${ }^{13}$ Deze fiduciary duties brengen in de eerste plaats mee dat 'directors must exercise their substantial powers of management both bona fide for the benefit of the company and for their proper purpose'. ${ }^{14}$ In de tweede plaats moeten bestuurders zich niet plaatsen 'in a position in which their personal interest and duty to the

11. Vergelijk bijv. V. Brudney en R.C. Clark, A new look at corporate opportunities, Harvard Law Review 1981, p. 999.

12. Met name V. Brudney en R.C. Clark, t.a.p., p. 997-1063 en R.C. Clark, Corporate Law 1986, p. 234-238.

13. Zie voor een uitgebreide behandeling hieromtrent hoofdstuk 2 \$.1 en $\S 4.2$.

14. In vennootschapsrechtelijke context is dit het meest geciteerde dictum van Lord Greene in Re Smith and Facwett Ltd. [1942] Ch. 304 (C.A.), vgl. R. Grantham, The content of the Director's duty of loyalty, JBL 1988, p. 151. 
company may conflict'. ${ }^{15}$ Een consequentie van deze verplichting om het persoonlijke belang niet te laten botsen met het vennootschappelijke belang is dat het een bestuurder niet is toegestaan corporate opportunities voor eigen rekening te benutten.

Anders dan in de Verenigde Staten en Engeland is in Duitsland pas in de laatste jaren de 'Geschäftschancenlehre' tot ontwikkeling gekomen onder invloed van rechtsvergelijkende beschouwingen van enkele auteurs over de corporate opportunities doctrine. ${ }^{16} \mathrm{Er}$ bestaat geen specifieke wettelijke regeling omtrent de 'Geschäftschancenlehre'. In de rechtspraak werd aanvankelijk alleen vastgehouden aan het concurrentieverbod dat deels wettelijk is geregeld in $\S 88 \mathrm{AktG}$ en deels door de rechtspraak is ontwikkeld.

$\$ 88$ lid 1 AktG bepaalt dat bestuurders zonder toestemming van de raad van commissarissen 'weder ein Handelsgewerbe (handelsbedrijf) betreiben noch im Geschäftszweig (bedrijfstak) der Gesellschaft für eigene oder fremde Rechnung Geschäfte machen dürfen'. $\$ 88$ AktG legt niet alleen concurrerende activiteiten aan banden, maar bestuurders 'dürfen ohne Einwilligung auch nicht Mitglied des Vorstands oder Geschäftsführer oder persōnlich haftender Gesellschafter einer anderen Handelsgesellschaft sein'.17 Een vergelijkbare regeling ontbreekt in het GmbHG. Echter, ook zonder wettelijke regeling kan onder omstandigheden een concurrentieverbod voortvloeien uit de Treuepflicht. Hierbij zij opgemerkt dat het wettelijk geregelde concurrentieverbod in de Duitse literatuur in het algemeen wordt beschouwd als een geconcretiseerde Treuepflicht. ${ }^{18}$

Naar algemene opvatting zijn de concurrentieverboden echter maar een onderdeel van het omvangrijke verbod om zich corporate opportunities toe

15. Aldus ook bijv. G.K. Morse, Conflicts of interests in English company law in: De dubbelrol in het vennootschapsrecht, Deventer 1993, p. 42 en Gower's principles of company law 1997, p. 601.

16. Het is W. Timm geweest die in 1981 de term 'Geschăftschancenlehre' geintroduceerd heeft, zie zijn Wettbewerbsverbot und Geschäftschancenlehre im recht der $\mathrm{GmbH}$, GmbH-Rundschau 1981, p. 177. Zie voorts de beschouwingen van F. Kübler, Erwerbchancen und Organpflichten, FS Winfried Werner 1984, p. 437 e.v.

17. Desalniettemin bevat $\$ 88 \mathrm{AktG}$ toch een leemte. De heersende opvatting in de Duitse literatuur is dat afzonderlijke transacties (einzelne Geschäfte), die door bestuurders voor eigen rekening worden aangegaan, slechts in bedrijfstakken waarin de bestuurder wezenlijk actief is (tatsăchlicher Tätigkeitsbereich) zijn verboden. Dit zou meebrengen dat bestuurders business opportunities zouden kunnen toeèigenen welke niet passen in het kader van de huidige ondernemingsactiviteiten, \$ 93 AktG biedt echter een oplossing voor dit geval, vgl. Mertens, Kölner Kommentar zum Aktiengesetz, $\$ 88$ Rn. 8, p. 218.

18. Zie Karsten Schmidt, Gesellschaftsrecht, p. 489. 
te eigenen. Sinds enkele jaren wordt in de Duitse rechtspraak dan ook bij toetsing van het gedrag van bestuurders als aanknopingspunt de Treuepflicht genomen ${ }^{19}$ in samenhang met de zorgvuldigheidsverplichting die op bestuurders van GmbH's en AG's rust ( $\S 43$ GmbHG en $\S 93$ AktG). ${ }^{20}$

Bedoeld is dan de zogenaamde 'Organschaftliche Treuepflicht', die zijn grondslag vindt in de organisatierechtelijke betrekking van de bestuurder tot de vennootschap..$^{21}$ Deze Treuepflicht heeft, zoals ik reeds heb aangegeven in hoofdstuk $2 \& 3.1$, tweeërlei werking: aanvullend en corrigerend. Enerzijds heeft een bestuurder de verplichting zich in te zetten voor het doel van de vennootschap en datgene te doen wat in haar belang is. Anderzijds heeft een bestuurder loyaliteitsverplichtingen, op grond waarvan een bestuurder verplicht is gedrag, dat afbreuk kan doen aan zijn verplichting om het doel van de vennootschap te verwezenlijken, achterwege te laten. Uit deze loyaliteitsverplichting vloeit voort dat bestuurders 'Geschäftschancen' in beginsel slechts mogen benutten op naam en voor rekening van de onderneming. ${ }^{22}$

In tegenstelling tot de andere hierbovengenoemde landen, wordt in de Franse literatuur en rechtspraak aan de corporate opportunity problematiek als afzonderlijk leerstuk nauwelijks aandacht besteed. Men zou zelfs kunnen zeggen dat een afzonderlijke doctrine in Frankrijk niet bestaat. Opvallend is voorts dat in het Franse recht de situatie waarin bestuurders op eigen naam (voordelige) handelingen verrichten op een wijze die tegengesteld is aan het belang van de rechtspersoon met name beheerst

19. Zie voor een voorbeeld BGH 23 september 1985, NJW 1991, p. 584. Voorstanders voor de Treuepflicht als aanknopingspunt voor een oplossing van de corporate opportunities problematiek zijn onder meer J. Weisser in DB 1989, p. 2011 en in zijn dissertatic Corporate opportunities; zum Schutz des Geschäftschancen des Unternehmens im deutschen Recht, Bonn 1991, p. 127, W. Timm, GmbH-Rundschau 1981, p. 179 en M.Schiessl, GmbH-Rundschau 1988, p. 53.

20. $\$ 93 \mathrm{AktG}$ bevat de verplichting dat 'Die Vorstandsmitglieder bei ihrer Geschäftsführung die Sorgfalt eines ordentlichen und gewissenhaften Geschäftsleiters anzuwenden haben: Aan deze zorgvuldigheidsverplichting kan slechts worden voldaan, indien een bestuurder zijn belangen achter stelt ten opzichte van het belang van de vennootschap.

21. Vgl. H. Wiedemann, Zu den Treuepflicht im Gesellschaftsrecht, FS Th. Heinsius 1991 , p. $950 / 951$.

22. Zie ook W. Timm, t.a.p. p. 178. 
wordt door strafrechtelijke bepalingen die deels in de Code des Sociétés zijn opgenomen. ${ }^{23}$

Zo zou de toeèigening van een corporate opportunity kunnen worden gecorrigeerd door bepalingen die misbruik van goederen (of liever gezegd: het vermogen) van rechtspersonen strafbaar stellen ('abus de biens sociaux'). ${ }^{24}$ Daarnaast zou er in sommige gevallen sprake kunnen zijn van abus de pouvoirs. ${ }^{25}$ Het probleem is echter steeds dat een bepaalde corporate opportunity door de rechter gekwalificeerd moet worden als zo'n specifieke strafbare gedraging; steeds moet voldaan zijn aan de voorwaarden die de wet voor strafbaarstelling van de specifieke gedragingen stelt.

Een aardige illustratie hiervan biedt een uitspraak van de Cour d'appel van Limoges van 21 november 1963 (Gaz. Pal. 1963, 2, 154), waarin het gebruik van een corporate opportunity toelaatbaar wordt geacht. Het betreft in deze zaak drie bestuurders (administrateurs) en een president-directeur-général die van een bestuurscommissie de opdracht hebben gekregen om een bepaald casino te kopen. De bestuurders vervullen deze opdracht niet en kopen vervolgens op eigen naam en voor eigen rekening aandelen in de onderneming die dat casino exploiteert.

23. Vgl. J.P. Berdah, Fonctions et Responsabilités des Dirigeants de Sociétés par actions, Bibliotheque de droit commercial, T. 2, 1974, p. 249 en J.Y. Martin, Le détournement d'une chance economique par un dirigeant de société, thèse Paris I, 1981, p. 223. Naast de strafrechtelijke bepalingen bevat de Codę de Sociétés in de wet van 24 juli 1966 (artt. 101-105 en 143-147) en in het décret van 23 maart 1967 (artt. 91, 92 en 191) een uitgebreide 'tegenstrijdig belang' regeling. Deze is echter slechts van toepassing in geval van 'conventions entre les sociétés commerciales et leurs dirigeants'. Zie voor uitgebreide beschouwingen hieromtrent $\mathrm{A}$. Tunc, On the virtues of codification: The contracts in which a director is interested in FS für Kurt Lipstein, Heidelberg 1980.

24. Kern van dit strafbare feit is dat bestuurders te kwader trouw ('de mauvaise foi') goederen van de rechtspersoon gebruikt hebben (auront fait un usage) op een wijze tegengesteld aan het belang van de rechtspersoon (contraire aux intérêts de la société). Zie L. 1966 art. 437 sub 3 en 425 sub 4 . Overigens wordt in het Franse recht, anders dan in sommige gevallen in de Amerikaanse rechtspraak, niet aanvaard dat gebruik van informatie, welke de bestuurder heeft verworven uit hoofde van zijn functie, behoort tot het vermogen (property) van de vennootschap en onderdeel is van de corporate opportunities doctrine. Zie J.Y. Martin, t.a.p., p. 224.

25. Het gaat hier om een gebruik van bestuurders die 'de mauvaise foi, ont fait des pouvoirs qu'ils possédaient ou des voix dont ils disposaient, en cette qualité, un usage qu'ils savaient contraire aux interêts de la société à des fins personelles ou pour favoriser une autre société ou entreprise dans laquelle ils étaient intéresses directement ou indirectement' (art. L. 437 sub 4). Opgemerkt dient te worden dat een abus de pouvoirs vaak gepaard gaat met abus de biens sociaux. 
De Cour d'appel oordeelt dat de bestuurders geen misbruik van hun bevoegdheden hebben gemaakt, 'puisqu'ils avaient agi en vertu de leurs droits propres et non en vertu de pouvoirs émanés de la société dont ils étaient administrateurs. Ils n'avaient pas non plus détourné mission recue de la société car le comité direction qui les avait chargé de la mission n'avait que des attributions consultatives ou préparatoires aux décisions, qui ne pouvaient émaner que des organes sociaux. En outre, le comité n'avait pas donnéux adminstrateurs un mandat au sens juridique du terme, mais un simple mission d'information'.

Wellicht dat in het Franse recht in de komende jaren anders wordt geoordeeld over het gebruik van corporate opportunities door bestuurders. Immers, een nieuwe tendens in recente jurisprudentie is dat gedragingen van bestuurders direct getoetst worden aan de 'devoir de loyauté' (vgl. hoofdstuk $2 \S 3.1){ }^{26}$

\section{§ 3. Nederland: art. 2:8 of art. 2:9 BW?}

In het Nederlandse recht wordt hoofdzakelijk een tweetal opvattingen verdedigd met betrekking tot de grondslag van toetsing van toeëigening van corporate opportunities door bestuurders. Volgens de ene opvatting is de grondslag te vinden in de norm van redelijkheid en billijkheid van art. 2:8 BW. De andere opvatting is dat art. 2:9 BW, die de bestuurders verplicht tot een behoorlijke taakvervulling, van toepassing is op de corporate opportunities problematiek.

Deze laatste opvatting vindt, met name sinds het verschijnen van de dissertatie van Verdam ${ }^{27}$ inzake corporate opportunities in 1995, de meeste steun in de literatuur. ${ }^{28}$ Verdam betoogt dat het toeëigenen van een corporate opportunity door een bestuurder schending oplevert van de norm van art. 2:9 BW. Hij verdedigt dat art. 2:9 BW zich leent voor interpretatie in het licht van het loyaliteitsbeginsel. ${ }^{29}$ Art. 2:8 BW komt

26. Zie m.n. Cour de Cassation 24 februari 1998, JCP 1998, éd. E, nr. 17, p. 637.

27. A.F. Verdam, Corporate opportunities (diss. Tilburg), Zwolle 1995.

28. $\mathrm{Vgl}$. met name L. Timmerman. De dubbelrol in het (vennootschaps)recht, in: De dubbelrol van het vennootschapsrecht, Deventer 1993, p. 8-9 alsmede in Kroniek van het vennootschapsrecht, NJB 1996, p. 1320/1321 en M.J. Kroeze, Schadevergoedingsactie door aandeelhouders/corporate opportunities, Juridisch up to date, 1996, p. 4.

29. Zie A.F. Verdam, t.a.p., p. 156 alsmede in Behoorijike taakvervulling en trustetfunctic, in: Na twintig jaar Bock 2 BW, Deventer 1996, p. 166. 
naar zijn mening pas in aanmerking, indien andere regels geen uitkomst bieden. ${ }^{30}$

Ik meen echter dat de norm van art. 2:9 BW te beperkt is om als grondslag te dienen voor de corporate opportunities problematiek. Het gat bij de corporate opportunities problematiek om gedrag dat juist niet te maken heeft met het besturen van de vennootschap, maar deze, en alle betrokkenen wel schaadt. Het betreft niet alleen de verhouding tussen bestuurder en vennootschap, maar ook bijvoorbeeld de verhouding tussen bestuurders en aandeelhouders. ${ }^{31}$ Ik verdedig derhalve, in navolging van Uniken Venema $^{32}$ dat de problematiek beheerst wordt door de norm van redelijkheid en billijkheid.

\section{$\S 4$. Wat is een corporate opportunity?}

Bij het onderzoek van de vraag wanneer en onder welke voorwaarden een bestuurder (on) geoorloofd gebruik maakt van een corporate opportunity is het van belang vast te stellen wanneer een business opportunity 'toebehoort' aan de vennootschap en wat dat is.

Uniken Venema ${ }^{33}$ omschrijft een corporate (business) opportunity als een 'mogelijkheid tot zakendoen' die zich aan de onderneming 'presenteert' en die past in het kader van de huidige of de in de toekomst te verwachten ondernemingsactiviteiten. Deze definitie, welke ontleend is aan het 'corporate director's guidebook', ${ }^{34}$ dat is gepubliceerd door de Committee on Corporate Laws van de American Bar Association in de Verenigde Staten, laat echter ruimte open voor vragen.

30. A.F. Verdam, t.a.p. p. 151.

31. Ik heb derhalve ervoor gekozen om dit onderwerp in het deel betreffende de relatie avabestuur op te nemen.

32. C.AE. Uniken Venema, Corporate opportunities; aspecten van loyaliteit in het kader van een onderneming naar Amerikaans en Nederlands recht, in: Jurist in bedrijf, Deventer 1980, p. 167 e.v.

33. C. AE. Uniken Venema, t.a.p., p. 168.

34. Het Guidebook definieert een corporate opportunity als volgt: 'When an opportunity to acquire another business enterprise, to acquire property, to license patents or inventions, to market new products, or to seize any other business advantage, comes to the attention of the corporate director as a result of his relation to the corporation in a way that would permit its personal realization, and is relevant to the enterprise's present or prospective business activities, the director must first present it to his corporation'. 
Wat zijn 'in de toekomst te verwachten activiteiten? Dat wordt mede bepaald door de winstgevendheid van mogelijke activiteiten. Hoe winstgevender die zijn, hoe meer gezegd kan worden dat een onderneming verwacht die activiteiten te zullen ontplooien. Men denke aan overnames. En wanneer kan men zeggen dat een corporate opportunity zich 'presenteert' aan de onderneming? Een zo duidelijk mogelijke afbakening van het begrip corporate opportunities is vanuit het oogpunt van rechtszekerheid wenselijk.

Een betere afbakening van het begrip corporate opportunity biedt naar mijn mening de definitie van het American Law Institute. Deze luidt als volgt:

1) any opportunity to engage in a business activity of which a director or senior executive becomes aware, either:

A) in connection with the performance of functions as a director or senior executive, or under circumstances that could reasonably lead the director or senior executive to believe that the person offering the opportunity expects it to be offered to the corporation; or

B) through the use of corporate information or property, if the resulting opportunity is one that the director or senior executive should reasonably be expected to believe would be of interest to the corporation; or

2) any opportunity to engage in a business activity of which a senior executive becomes aware and knows is closely related to a business in which the corporation is engaged or expects to engage. ${ }^{35}$

Met deze definitie tracht het American Law Institute eenheid van benadering te bewerkstelligen met betrekking tot de vraag wanneer er sprake is van een corporate opportunity. ${ }^{36}$ In de Amerikaanse doctrine en rechtspraak zijn in de loop van de tijd namelijk een veelheid van criteria (tests) ontwikkeld teneinde vast te stellen wanneer een business opportunity 'toebehoort' aan de vennootschap. ${ }^{37}$ Weliswaar worden deze tests nog steeds gebruikt, erg verhelderend zijn ze niet.

35. The American Law Institute, Principles of corporate governance; analysis and recommendations, Volume 1, St. Paul, $1994 \$ 5.0 .5$ (b).

36. Positief over deze regeling is ook $\mathrm{Ph}$. Ernst, Belangenconflicten in naamloze vennootschappen (diss.), Antwerpen 1997, nr. 409 p. 379. Anders, A.F. Verdam, t.a.p., p. 66 67.

37. Materieelrechtelijk gezien kan de definitie beschouwd worden als een algemene weergave van de in de rechtspraak ontwikkelde regels. 
De oudste test die in de jurisprudentie rond 1900 werd ontwikkeld, biedt drie criteria aan de hand waarvan een business opportunity als een corporate opportunity kan worden beschouwd. Op de eerste plaats is elke business opportunity waarin de onderneming een belang (interest) heeft een corporate opportunity. Op de tweede plaats geldt dat voor elke business opportunity waarvan de onderneming redelijkerwijs mag verwachten dat het haar toebehoort (expectancy)." Men denke bijvoorbeeld aan de situatie dat er sprake is van ver gevorderde onderhandelingen van de onderneming met betrekking tot een transactie. Tenslotte worden volgens deze test ook als een corporate opportunity aangemerkt die business opportunities die van wezenlijk belang zijn (essential) voor de onderneming.

De 'interest or expectancy test' leidt tot een beperkt toepassingsgebied van de corporate opportunities doctrine. De kern van deze test is immers dat een bestuurder geen schade mag toebrengen aan zijn onderneming, deze geen concurrentie mag aandoen en geen eigen belang mag nastreven, dat strijdig is met het belang van de vennootschap. In Guth v. Loft Inc (5A 2d 503 Delaware 1939), een leading Delaware case, werd een corporate opportunity voor het eerst breder gedefinieerd. Tot een corporate opportunity werd gerekend: 'any business opportunity within the subject corporation's 'line of business'. 39

Rond de vijftiger jaren werd in sommige jurisdicties de 'faimess test' gehanteerd. Of een corporate opportunity bestond, hing in die benadering af van 'ethical standards of what is fair and equitable to particular sets of facts'. Factoren die bij deze test in beschouwing

38. Vgl. Lagarde v. Anniston Lime \& Stone Co. (126 Alabama 496, 28 So. 199) [1900]. In deze zaak verworven enkele bestuurders van een onderneming voor eigen rekening een meerderheidsdeelneming (tweederde van het uitstaand kapitaal) in een kalksteengroeve. De onderneming had zelf al een deelneming van eenderde in die groeve en had bovendien een optie verworven tot overneming van nog een derde deel van het kapitaal. Het hof maakte bezwaar tegen de koop van, de aandelen door de bestuurders waar de onderneming op grond van die optieovereenkomst recht op had. Het hof oordeelde dat de bestuurders eigendom moeten overdragen aan de onderneming voorzover het gaat om 'property wherein the corporation has an interest already existing or in which it has an expectancy growing out of an existing right [..]'

39. Guth v. Loft, Inc., 5 A.2d 503 Del. [1939], zie ook R.C. Clark, Corporate Law 1986, p. $227 / 228$. Guth verwierf als president van Loft, een bedrijf dat zich bezig hield met de fabricage en verkoop van alcoholvrije drank, een meerderheidsdeelneming in een andere fabriek van alcoholvrije dranken, de Pepsi Cola Company. Hij verbeterde vervolgens, met behulp van medewerkers en andere middelen van Loft, het produktieproces van Pepsi Cola en verkocht zelfs grote hoeveelheden van de verbeterde produkten aan Loft. De Supreme Court van Delaware oordeelde dat Guth zijn deelneming aan Loft Inc. moest overdragen. De Supreme Court gaf een goede omschrijving van opportunities die passen in de bestaande mogelijkheden van de onderneming: 'Where a corporation is engaged in a certain business, and an opportunity is presented to it embracing an activity as to which it has fundamental knowledge, practical experience and ability to pursue, which logically and naturally, is adapted to its business having regard for its finacial position, and is one that is consonant with its reasonable needs and aspirations for expansion, it may be properly said that the opportunity is in line of the corporation's business'. 
worden genomen zijn onder meer; het belang van de vennootschap om de opportunity zelf te benutten, de mate waarin de bestuurder de vennootschap heeft geinformeerd omtrent de opportunity en de goede trouw van de bestuurder.

Ook combinaties van bovenvermelde tests werden in de rechtspraak gebruikt, zoals de zgn. 'two step approach'. De eerste vraag die in dit kader beantwoord moet worden is of de business opportunity een corporate opportunity is. Deze vraag wordt beantwoord aan de hand van de 'line of business test'. Slechts indien het antwoord hierop bevestigend is, geldt vervolgens dat de toeēigening door de bestuurder van de corporate opportunity 'fair' moet zijn. ${ }^{40}$ Ten slotte werd in de jurisprudentie aangenomen dat het niet toegestaan was om goederen en informatie (zoals kennis opgedaan in functie) van de vennootschap voor privégebruik aan de vennootschap te onttrekken.

Een kritische kanttekening met betrekking tot de ALI-definitie zou ik hier wel willen maken. Bij lezing van de definitie valt op dat er sprake is van enige subjectivering. Vereist wordt immers dat de betrokken bestuurder 'redelijkerwijs moet verwachten' dat de opportunities werden aangeboden ten behoeve van de onderneming c.q. vennootschap. Deze subjectivering lijkt uit het oogpunt van rechtszekerheid niet wenselijk. Echter, op grond van een aantal redenen ontkomt men er mijns inziens niet aan. Zou men de elementen 'belang' en het 'redelijkerwijs verwachten' weglaten, dan zou een zeer ruime definitie ontstaan, op grond waarvan praktisch alle opportunities aan de vennootschap aangeboden zullen moeten worden en dit zou te ver gaan. Ook in andere rechtsstelsels vindt men steeds een zekere subjectivering terug.

\section{§ 5. Indeling in categorieën}

De definitie van het American Law Institute kan beschouwd worden als een richtlijn voor bestuurders, inhoudende dat in bepaalde gevallen de (fiduciary) duty of loyalty meebrengt dat zij een business opportunity dienen aan te bieden aan de vennootschap. Ook voor het Nederlandse recht kan naar mijn mening deze definitie als uitgangspunt worden genomen bij de beoordeling van het gedrag van bestuurders. De achterliggende gedachte van de corporate opportunities doctrine is immers het beschermen van de vennootschap en haar aandeelhouders tegen deloyaal

40. Zie Miller v. Miller, 222 N.W. 2d 71 Minn. [1974] 77 ALR 3d 941. 
gedrag van bestuurders. ${ }^{41}$ Ik zou willen verdedigen dat uit de norm van redelijkheid en billijkheid voortvloeit dat bestuurders in een aantal gevallen gehouden zijn om business opportunities aan te bieden aan de vennootschap.

Deze gevallen, zou ik willen indelen in drie categorieën, waarvan naar mijn mening gezegd kan worden dat deze ook grotendeels in lijn zijn met hetgeen in het Duitse en Engelse recht wordt aangenomen.

De eerste categorie bestaat uit de opportunities die aan de vennootschap c.q. aan de bestuurder in het kader van zijn functie-uitoefening worden aangeboden.

Ter illustratie kan dienen $R$ b. Haarlem 30 december 1941, NJ 1942, 798. Een bestuurder van een onroerend goed maatschappij had bij aankoop van onroerend goed door de vennootschap een provisie ontvangen. Centraal stond de vraag of de bestuurder bij die transactie als makelaar voor de verkoper was opgetreden of dat de verkoper rechtstreeks een aanbod had gedaan aan de betrokken onroerend goed maatschappij, waarbij de bestuurder zich als 'makelaar' had tussen geschoven. Zou dit laatste het geval zijn dan zou de bestuurder naar het oordeel van de rechtbank de ontvangen provisie moeten afstaan. Zou de bestuurder daadwerkelijk als makelaar zijn opgetreden, dan hangt het van de omstandigheden van het geval af of hij de provisie had mogen genieten. Gezien de omstandigheden van dit geval, namelijk dat de bestuursfunctie voor de betrokken bestuurder slechts een nevenbetrekking vormde en dat hij bovendien reeds jarenlang makelaar was, was de rechtbank van oordeel dat het niet onredelijk zou zijn dat de bestuurder de ontvangen provisie behield.

$\mathrm{Vgl}$. in het Engelse recht Regal Cinema's (Hastings) Lid v Gulliver [1942] 1 All ER 378, de leading case op dit gebied en in navolging hiervan Zwicker v Stanbury [1952] 3 DLR 273 en Peso Silver Mines Ltd. v Cropper [1966], 58 DLR 2d 1. In deze zaken werd zeer strikt als criterium voor een opportunity vereist dat de opportunity is opgespoord 'by reason and in course of their office of directors: 2 In de eerste uitspraak besloot een aantal bestuurders van de vennootschap Regal Hastings Ltd, welke een bioscoop exploiteerde, twee bioscopen erbij te verwerven met als doel al deze bioscopen onder te brengen in een op te richten dochtervennootschap, welke zij later weer zouden verkopen. Regal Hastings was echter niet in staat om het gehele benodigde kapitaal bijeen te brengen, waarop enkele bestuurders zelf het merendeel van de aandelen kochten. Toen deze aandelen voor een aanzienlijk hogere prijs werden verkocht, werd de winst van deze bestuurders met succes teruggevorderd. The

41. Het gedrag van bestuurders heeft rechtstreeks invloed op het functioneren van de vennootschap; daardoor worden aandeelhouders in hun vermogensbelang getroffen, bijv. in de zin dat zij minder dividend uitgekeerd krijgen, evenzo J. Weisser, Corporate Opportunities, Bonn 1991, p. 14.

42. Zie onder meer S.M. Beck, The quickening of fiduciary obligation: Canadian Aero Services v/. O'Malley. The Canadian bar review 1975, 772 en 776 en S.M. Beck. The saga of Peso Silver Mines: corporate opportunity reconsidered, The Canadian Bar Review 1971, p. 100. 
House of Lords stelden vast; 'that what the directors did was so related to the affairs of the company that it can be properly said to have been done in the course of their management and in utilisation of their opportunities and special knowledge as directors; and what they did resulted in a profit to themselves'.

In Peso Silver Mines kon de bestuurder, Cropper, vanwege de strikte toepassing van de doctrine juist ontsnappen aan aansprakelijkheid. In deze zaak kreeg de vennootschap Peso Silver Mines regelmatig mijnvelden aangeboden. Het bestuur van de vennootschap besioot deze kansen vanwege tekortschietende financiën niet te benutten. Zes weken later besloot Cropper samen met enkele andere bestuurders de corporate opportunities te benutten middels een daartoe in het leven geroepen vennootschap. Saillant detail was dat Cropper op het moment dat de vennootschap diezelfde opportunities 'vrijgaf' degene was die de financiên van de vennootschap beheerde. De Supreme Court van Canada oordeelde dat Cropper gebruik kon maken van de opportunities. De Supreme Court acht van belang dat nadat de vennootschap de opportunities had vrijgegeven de opportunities werden aangeboden aan Cropper als individu en niet in de hoedanigheid als bestuurder.

Tenslotte wijs ik op de Duitse rechtspraak, die met name betrekking heeft op GmbH's. Als voorbeeld in dit kader kan dienen BGH 10 april 1977, GmbHR 1977, 129. In deze zaak kreeg de bestuurder/aandeelhouder van een $\mathrm{GmbH}$ van een stad gesubsidieerd bouwterrein aangeboden ten behoeve van uitbreiding van het bedrijf. In plaats van dit terrein te verwerven ten behoeve van de vennootschap, verwierf deze bestuurder de grond ten behoeve van een vennootschap die hij met andere aandeelhouders had opgericht. Vervolgens verhuurde hij de grond aan de $\mathrm{GmbH}$, waardoor deze vennootschap de subsidie misliep.

Onder deze categorie vallen ook die opportunities waarvan de bestuurder redelijkerwijs kan verwachten dat deze hem worden aangeboden door een aanbieder/verkoper in de veronderstelling dat de bestuurder de opportunity zal aanwenden ten behoeve van de onderneming. Men denke bijvoorbeeld aan de situatie waarin de vennootschap zelf al belangstelling heeft getoond voor de betrokken transactie of de vennootschap al onderhandelingen heeft gevoerd over de transactie. ${ }^{43}$ In deze categorie hoort mijns inziens ook de eerder al besproken HCS-zaak thuis. ${ }^{44}$

De tweede categorie bestaat uit opportunities die zijn ontstaan ten gevolge van het gebruik van informatie (of vermogen) van de vennootschap, waarvan redelijkerwijs valt te verwachten dat de onderneming c.q. vennootschap hierbij een belang heeft.

43. $\mathrm{Vgl}$. voor het Duitse recht $\mathrm{M}$. Schiessl, Die Wahrnehmung von Geschäftschancen der $\mathrm{GmbH}$ durch ihren Geschäftsführer, GmbH-Rundschau 1988, p. 53/54, W. Timm. Wettbewerbsverbot und Geschăftschancenlehre im Recht der GmbH, GmbH-Rundschau 1981, p. 180/181 en H.J. Mertens, Kölner Kommentar zum Aktiengesetz § 93, p. 311.

44. Zie $\$ 1$. 
In de Engelse rechtspraak is de leading case op dit gebied Boardman v. Phipps [1967] 2 $A C^{\text {s }}$ In deze zaak handelden B en $\mathrm{P}$ als 'agents' van trustees in relatie tot een vennootschap waarin de trust een minderheidsdeelneming had. Aan de hand van informatie over de koers van aandelen van deze vennootschap, meenden B en P dat de vennootschap veel meer winst zou kunnen maken. Om dit te bewerkstelligen gebruikten zij, overigens zonder toestemming te vragen van de trustees, hun eigen geld om een bod te doen op de overige andelen, teneinde deze te verwerven. Inderdaad slaagden zij er in na de overname aanzienlijke winsten te genereren, die met name ten goede kwamen aan de agents zelf, die de meerderheid van de aandelen in hun bezit hadden. The House of Lords besliste dat de agents de winsten uit hun investeringen af moesten staan aan de trust.

Vgl. ook Industrial Development Consultants Ld v Cooley [1972] I WLR 443. In deze zak onderhandelde de managing director, Cooley, namens de vennootschap met de Eastern Gas Board over de bouw van vier nieuwe depots. Uiteindelijk werden de onderhandelingen in de loop van 1968 afgebroken. Een jaar later werd Cooley project manager van de Gas Board, alwaar hij soortgelijk werk ging verrichten als bij Industrial Development. Bij Industrial Development meldde hij zich ziek teneinde het werk bij de Gas Board te kunnen verrichten. Cooley zag weer kansen met betrekking tot het project dat hij voorheen niet ten behoeve van Industrial Development had kunnen veiligstellen, en trachtte de opdracht zelf te verwerven.

Industrial Development claimde van Cooley de beloningen die hij verkreeg in het kader va zijn werkzaamheden als project manager voor de Gas Board. Tevens claimde de vennootschap schadevergoeding op grond van 'breach of duty'. Cooley werd aansprakelijk gehouden door the House of Lords. Éen van de factoren die tot deze beslissing van the House of Lords leidde was dat het Cooley verplicht achtte de informatie die hij tijdens zijn bestuursfunctic had verkregen en die van belang was voor de onderneming, door te geven an de onderneming. Weliswaar werd Cooley als privépersoon benaderd door de Gas Board, maar hij was nog steeds managing director van de vennootschap, die al die tijd een 'active interest' had in de desbetreffende onderhandehingen. Zo oordeelde Roskill J: 'Information which came to Cooley while he was managing director and which was of concern to plaintiffs [the company of which he was managing director] and was relevant for the plaintiffs [company] to know, was information which it was his duty to pass on to the plaintiffs [company]'.

In dezelfde lijn ligt Canadian Aero Service v $O^{\prime}$ Malley [1973] 40 DLR 382. Daarin oordeelde het Canadian Supreme Court dat een 'conflict of interest and duty' een bestuurder angeschikt maakt om voor zich zelf of voor een andere onderneming waaraan hij is verbonden een corporate opportunity aan te wenden, "which his company is actively pursuing'.

De derde categorie tenslotte bestaat uit opportunities welke nauw verwant zijn (closely related) met de huidige of toekomstige activiteiten van de

45. Zie hieromtrent ook P.St.J. Smart, Misuse of confidential information; the company's and minority shareholder's remedies, JBL 1994, p. 464-470. 
vennootschap. Als voorbeeld van een 'related' transactie kan hier dienen het Duitse Druckmittelarrest. ${ }^{46}$

In deze zaak krijgt een bestuurder van een $\mathrm{GmbH}$, die zich bezig houdt met de produktie van Druckmittelzylinder een octrooirecht aangeboden ten behoeve van een voordelige produktie van deze cilinders. De bestuurder zegt vervolgens zijn baan op en richt een eigen bedrijf op teneinde dit octrooirecht te kunnen benutten. Het BGH oordeelde dat de bestuurder door zijn gedrag de '\& 43 I obliegende Sorgfalt eines ordentlichen Geschäftsleiters verletzt hat und sich deshalb der GmbH gegenüber schadenersatzpflichtig gemacht habe'. Of de opportunity aan de bestuurder prive of in functie werd aangeboden speelt hier, evenals in het Amerikaan. se recht, geen rol.

Het is zinvol om bij deze laatste categorie een onderscheid te maken tussen beurstransacties en niet-beurstransacties. Bij transacties met ter beurze genoteerde aandelen gaat er voor de onderneming geen kans verloren, aangezien een soortgelijke aankoop voor de vennootschap mogelijk is. Wat betreft de niet-beurstransacties ligt dit anders. Het gaat hierbij vaak om onvervangbare goederen en/of met eenmalige kansen. ${ }^{47}$

\section{§. Beoordeling gedrag bestuurders; structuur van de vennootschap}

Kan nu gezegd worden dat, indien er op grond van één van bovenvermelde categorieën sprake is van een corporate opportunity, toeëigening daarvan door een bestuurder ongeoorloofd is en in strijd met de eisen van redelijkheid en billijkheid? Deze vraag kan niet zonder meer bevestigend worden beantwoord. Naar mijn mening dient hier met name rekening te worden gehouden met de structuur van de vennootschap. Ik sluit mij hier aan bij Brudney en Clark, ${ }^{48}$ die naar ik meen, waardevolle kritiek hebben geleverd op de huidige Amerikaanse corporate opportunities doctrine.

Hun voornaamste kritiek is dat de doctrine geen onderscheid maakt tussen close corporations en public corporations, terwijl er toch grote structurele verschillen bestaan tussen de twee typen kapitaalvennootschappen. Het gedrag van bestuurders van public corporations onderwerpen zij aan strengere maatstaven. $\mathrm{Zij}$ achten het, mede uit economisch oogpunt,

46. BGH 23 september 1985, NJW 1986, 585, ZIP 1985, 1484.

47. $\mathrm{Vgl}$. ook Uniken Venema, t.a.p. p. 173.

48. V. Brudney en R.C. Clark, A new look at corporate opportunities, Harvard Law Review 1981, p. 1001-1061 en R.C. Clark, Corporate Law 1986, p. 223-262, met name p. 234 238. 
gerechtvaardigd dat het voor deze bestuurders in beginsel verboden is om gebruik te maken van zgn. 'active's9 business opportunities. Daartoe voeren zij onder meer als gronden aan:

- 'dat aandeelhouders in een public corporation niet in staat zijn om bestuurders te controleren;

- dat van fulltime bestuurders in een public corporation, verwacht mag worden dat zij al hun tijd aanwenden ten behoeve van de onderneming; - dat de kans, dat een bestuurder de onderneming schade toebrengt ingeval hij zich een business opportunity toeëigent, groot is daar voor veel public corporations elke business opportunity een (financierbaar) potentieel project vormt'. ${ }^{\text {so }}$

Met betrekking tot de beoordeling van het gedrag van bestuurders van close corporations zijn zij van mening dat, gezien het 'contractuele karakter' van een close corporation, een meer selectieve benadering is toegestaan, waarbij rekening mag worden gehouden met de behoeften en verwachtingen van de onderneming en de aandeelhouders en de omstandigheden van het geval. De gronden die Brudney en Clark aanvoeren voor een differentiatie tussen de close corporation en public corporation, die met name voortvloeien uit de verschillen in structuur tussen deze kapitaalvennootschappen, zijn ook voor het Nederlandse recht steekhoudend.

Echter, niet eens ben ik het met Brudney en Clark voorzover zij betekenis toekennen aan de omstandigheid dat bestuurders van public corporations veelal full-time werkzaam zullen zijn in de door de vennootschap in stand gehouden onderneming en daardoor een grotere aanspraak hebben op remuneratie. Volgens hen wordt van zo'n bestuurder, in tegenstelling tot een part-time bestuurder, verwacht dat hij al zijn kennis, talenten en tijd zal aanwenden ten behoeve van de onderneming. ${ }^{31}$

49. Hieronder verstaan zij die opportunities, waarbij de 'belegger' op grond van zijn deeiname, participeert of het recht heeft te participeren in de besluitvorming van de onderneming. Zie Brudney en Clark, t.a.p. p. 1002.

50. Zie voor uitgebreide beschouwingen daaromtrent R.C. Clark, Corporate Law 1986, p. 244-246.

51. R.C. Clark, Corporate Law, t.a.p., p. 244, Brudney en Clark, t.a.p., p. 1003 en 1023. 
Dit argument acht ik niet juist. Op elke bestuurder, parttime of full-time, rust de verplichting om zich redelijk en billijk te gedragen jegens de vennootschap. ${ }^{52}$ Het zou niet zo mogen zijn dat een vennootschap blootgesteld zou worden aan een groter risico om een opportunity te 'verliezen', door de enkele omstandigheid dat de 'gebruiker' van de corporate opportunity een parttime-bestuurder is.

Deze 'structuurverschillen's3 rechtvaardigen mijns inziens dat het gedrag van bestuurders die gebruik maken van corporate opportunities aan verschillende 'regels' dient te worden onderworpen. Wel dient hierbij in het oog te worden gehouden dat een BV en een NV niet zo scherp van elkaar zijn te onderscheiden als een close en public corporation. ${ }^{54}$

Niet alleen in de Verenigde Staten, maar ook in Duitsland worden de criteria van de huidige 'Geschäftschancenlehre' bestreden en wordt een 'ruimere' opvatting verdedigd. Men zie Timm (GmbHR 1981, blz 178) die van mening is dat alle 'Geschäftschancen' die de vennootschap zelf had kunnen benutten, aan de vennootschap toegerekend behoren te worden. Nog verder gaat Schneider (GmbHG 1983, \& 43 aant. 145). Hij pleit voor het hanteren van één criterium, namelijk 'abstrakte Gefährdung der Interessen der Gesellschaft' en is van mening dat dit criterium voldoende is om de transactie in de sfeer van de vennootschap te plaatsen. Kübler" is ook van mening dat de door Brudney en Clark voorgestelde regels van belang zijn voor de ontwikkeling van de 'Geschäftschancenlehre'.

\section{§ 7. Geoorloofd gebruik: 'toestemming' of 'goedkeuring'}

Soms zal een onderneming een corporate opportunity niet willen c.q. niet kunnen benutten. Wat betreft het niet willen, denke men aan de situatie dat de onderneming besluit geen gebruik te maken van een corporate opportunity omdat zij daarin niet geinteresseerd is. Denkbaar is dat de onderneming een bepaalde bedrijfspolitiek voert, bijvoorbeeld in die zin dat geen minderheidsdeelnemingen zullen worden verworven.

52. $\mathrm{Vgl}$. ook M. Schiessl, Die Wahrnehmung von Geschãftschancen der Gmbh durch ihren Geschäftuhurer, GmbhR 1988, p. 55, waar hij schrijft: 'Solange er zum Geschāftsfüret bestellt ist, ist seine Sorgfalts- und Treuepflicht gegenūber der Gesellschaft unteilbar'

53. In algemene zin, dus niet op te vatten in de strikte betekenis van art. 2:153/263 BW.

54. Zowel BV's als NV's kunnen tal van verschijningsvormen hebben. Zo kan een BV verwantschap vertonen met een personenvennootschap en een NV een besloten karakter hebben. Vgl. hieromtrent ook J.J.A. Hamers, Verpanding van aandelen en de beslotenheid van kapitaalvennootschappen, diss. Deventer 1996, p. 139-141.

55. F. Kübler, Erwerbchancen und Organpflichten (Ueberlegungen zur Entwicklung der Lehre von der 'corporate opportunities') in FS Winfried Werner 1984, p. 437-448. 
Wat betreft het niet kunnen, denke men bijvoorbeeld aan tekortschietende financiële middelen van de vennootschap of aan juridische problemen, die zich bijvoorbeeld voordoen in het geval dat statutaire of wettelijke bepalingen van de vennootschap aan het verwerven van een opportunity in de weg staan. Het kan ook zijn dat zich een opportunity voordoet, maar dat een derde niet bereid is om met de onderneming c.q. vennootschap zaken te doen. ${ }^{56}$

Men zou kunnen verdedigen dat door aanwezigheid van bovenstaande factoren een business opportunity niet meer kan worden gekwalificeerd als corporate opportunity. Deze visie vindt men regelmatig in de Amerikaanse rechtspraktijk terug." Dit zou ik echter willen bestrijden." De vraag van kwalificatie van een opportunity behoort mijns inziens los te staan van bijvoorbeeld de financiële positie van de vennootschap. Zo'n visie leidt er als het ware toe dat de bestuurder zelf beslist over de business opportunities, die hij echter uit hoofde van zijn functie behoort aan te bieden aan de vennootschap. Bovendien is een bestuurder ook in staat te proberen financiering voor de vennootschap te regelen (hierop kom ik terug aan het eind van deze paragraaf). Het is aan de vennootschap om te beslissen of al dan niet cen opportunity benut zal worden en op welke wijze.

De vraag rijst of een bestuurder in bovengenoemde gevallen wel gebruik mag maken van een corporate opportunity. Bij beantwoording van deze vraag stel ik voorop dat een bestuurder daar niet 'zonder meer' vanuit mag gaan. Daarbij zij bedacht dat een bestuurder die gebruik maakt van een corporate opportunity, in een situatie terecht komt waarin zijn persoonlijk belang conflicteert met dat van zijn vennootschap. Deze conflictsituatie moet nu juist worden voorkomen. Mijns inziens is daarom een verstandig uitgangspunt dat een bestuurder toestemming van de vennootschap verwerft. Dit wordt ook aangenomen in het Engelse, Duitse en het Amerikaanse recht. ${ }^{59} \mathrm{Om}$ te voorkomen dat het persoonlijk belang van de bestuurder en de belangen van de vennootschap verstrengeld raken, gelden in die stelsels, een tweetal voorwaarden:

56. $\mathrm{V}_{\mathrm{gl}}$. bijv. voor het Engelse recht Abbey Glen Property Corp. v. Stumborg. DLR [1978] 85 (Alt S.C).

57. $\mathrm{Vgl}$. bijv. J. Weisser, Corporate opportunities, 1991, p. 76.

58. Ook Verdam staat terughoudend ten opzichte van deze visie, t.a.p. p. 112, 115 en 117.

59. Zie voor het Duitse recht bijvoorbeeld, voor het Engelse recht bijvoorbeeld, G.M.D. Bean, Corporate Governance and corporate opportunities. The Company lawyer 1994, p. 266-272. 
1) openbaarmaking door de bestuurder van de aard en de omvang van zijn betrokkenheid bij een transactie;

2) toestemming of goedkeuring door een van de bestuurder onafhankelijk vennootschappelijk orgaan.

Ten opzichte van welk vennootschapsorgaan dient nu die openheid te worden betracht en aan welk orgaan moet de bevoegdheid worden toegekend toestemming te verlenen?

Het zal duidelijk zijn dat in ieder geval het tot toestemming bevoegde orgaan tijdig alle informatie zal moeten verkrijgen, die het redelijkerwijs nodig heeft voor het vormen van een verantwoord oordeel over een bepaalde opportunity. Het bestuur lijkt het meest aangewezen orgaan om te beslissen over toestemming. Een corporate opportunity is per definitie een aangelegenheid die het bestuur aangaat. Het probleem hierbij is echter, dat zich binnen het bestuur al snel een belangenconflict kan gaan aftekenen, omdat de bestuurder die de corporate opportunity inbrengt, een tegenstrijdig belang heeft bij de besluitvorming omtrent het al dan niet benutten daarvan. Ook bij zijn mede-bestuurders kan sprake zijn van een tegenstrijdig belang. Een aantal van de voor tegenstrijdige belangen ontwikkelde gedragsregels, die voortvloeien uit de redelijkheid en billijkheid, lijken mij in casu van toepassing.

Een belangrijke regel, die afgeleid kan worden uit het Linders-Hofstee arrest OK 26 mei 1983, NJ 1984, 481 met nt. Maeijer ${ }^{50}$, is dat de te onderscheiden belangen gescheiden moeten worden gehouden. Het betrachten van een zo groot mogelijke openheid is een belangrijke voorwaarde voor het op zorgvuldige wijze gescheiden houden van de te onderscheiden belangen. Die openheid houdt in dat de vennootschap op de hoogte moet worden gebracht van het motief en de voorwaarden van de transactie en de aard en omvang van de betrokkenheid van de geïnteresseerde bestuurder. ${ }^{61}$

Dit kan ertoe leiden dat de bestuurders met een tegenstrijdig belang zich onthouden van het bijwonen van en het deelnemen aan de besluitvor-

60. Besproken door A.F.M. Dorresteijn in zijn dissertatie op p. 62-65.

61. $\mathrm{Vgl}$. B.H.A. van Leeuwen, Verstrengeling van belangen en het vennootschapsrecht. TVVS 1987, p. 34. 
ming over een transactie waarbij hun persoonlijk belang is betrokken. ${ }^{62}$ Ik zou echter nog een stap verder willen gaan en willen verdedigen dat ook in die situaties waarin het 'tegenstrijdig belang' slechts één van een veelheid van bestuurders betreft, het besluit om al dan niet een opportunity binnen de sfeer van de vennootschap te brengen, steeds aan de raad van commissarissen wordt voorgelegd. Bij het ontbreken van een raad van commissarissen, dient mijns inziens zodanig besluit steeds te worden voorgelegd aan en verantwoord jegens de algemene vergadering van aandeelhouders. ${ }^{63}$

In het Duitse recht bestaat met betrekking tot GmbH's in het algemeen de opvatting dat uitsluitend de Gesellschafterversammlung bevoegd is tot 'Freigabe' van Geschäftschancen. ${ }^{64}$ In een AG wordt die bevoegdheid toegekend aan de Aufsichtsrat. Als aanknopingspunt hiervoor wordt onder meer verwezen naar $\S 88$ AktG, dat uitdrukkelijk bepaalt dat de Aufsichtsrat bevoegd is om bestuurders te ontheffen van het Wettbewerbsverbot. ${ }^{65}$ De Sorgfalts- en Treuepflicht brengt mee dat de bestuurder de raad van toezicht c.q. de Gesellschafterversammlung informeert.

Onder het Engelse recht dient het besluit om af te zien van een corporate opportunity in beginsel door aandeelhouders te worden genomen. De statuten kunnen deze beslissing ook in handen leggen van een ander orgaan, zoals het bestuur, maar dan moet het besluit worden genomen door niet-belanghebbende (disinterested) bestuurders. S. 317 van

62. De wettelijke regeling inzake tegenstrijdig belang $(2: 146 / 2: 256 \mathrm{BW})$ is mijns inziens niet van toepassing. Deze regeling ziet op rechtshandelingen van de vennootschap die vertegenwoordiging behoeven. Evenals een toeëigening van een corporate opportunity niet plaatsvindt door middel van een handeling waarbij de onderneming is vertegenwoordigd, is ook het verlenen van toestemming geen rechtshandeling van de vennootschap die vertegenwoordiging behoeft.

63. De HCS-zaak was een duidelijk geval van tegenstrijdig belang. Kuyten had als presidentdirecteur van HCS, en als bestuurder van zijn Holding Reiss \& Co., bij de (voorbereiding van de) transactie bestaande uit de verkoop van zijn twee vennootschappen aan HCS, een belangrijke rol gespeeld. In dit geval had mijns inziens het besluit omtrent de transactie moeten worden voorgelegd aan de algemene vergadering van aandeelhouders. Dit moet mijns inziens ook geschieden indien een of meer commissarissen een tegenstrijdig belang hebben.

64. $\mathrm{V}_{\mathrm{gl}}$. bijv. M. Schiessl, t.a.p. p. 55, W. Timm, t.a.p. p. 53/54 en J. Weisser, t.a.p. p. 209.

65. $\mathrm{V}_{\mathrm{gl}}$. F. Kübler, Erwerbchancen und Organpflichten, Festschrift Werner 1984, p. 447 en H.J. Mertens, Kōiner Kommentar zum Aktiengesetz, Kōln 1988, p. 311. 
de Companies Act 1985 schrijft voor dat de desbetreffende bestuurder aan zijn mede-bestuursleden in de bestuursvergadering de aard en omvang van zijn belang meedeelt. In de Amerikaanse rechtspraak wordt er in het algemeen vanuit gegegaan dat primair het bestuur bevoegd is. Daarbij wordt wel als vereiste gesteld dat de beslissing om al dan niet gebruik te maken van een corporate opportunity dient te geschieden door 'disinterested' directors teneinde een objectieve besluitvorming te waarborgen. ${ }^{66}$

Zo leest men in \$ 5.0.5, van de Principles of Corporate Governance, die zijn opgesteld door het American Law Institute dat een bestuurder zich geen corporate opportunity mag toeêigenen, tenzij:

1) the director or senior executive first offers the corporate opportunity to the corporation and makes disclosure concerning the conflict of interest and the corporate opportunity;

2) the corporate opportunity is rejected by the corporation; and

3) A) the rejection of the corporate opportunity is fair to the corporation; or

B) the rejection is authorized in advance, following such disclosure, by disinterested directors, or in the case of a senior executive who is not a director, authorized in advance by a disinterested superior, in a manner that satisfies the standards of the business judgement rule; or

C) the rejection is authorized in advance or ratified following such disclosure, by disinterested shareholders, and the rejection is not equivalent to a waste of corporate assets.

Brudney en Clark zijn van mening dat toestemming voor bestuurders in een close corporation zowel bij aanvang van de dienstbetrekking als per geval verleend kan worden. Speciale en uitdrukkelijke toestemming eisen zij indien het gaat om opportunities die 'functionally related' zijn en waarvan de toeèigening de vennootschap financieel beinvloedt. ${ }^{67}$ Toestemming voor een bestuurder van een public corporation willen zij aan strengere voorwaarden onderwerpen. Nodig achten zij toestemming van zowel de board of directors als de aandeelhouders. Bovendien zal toestemming slechts per geval kunnen worden verleend. Dit hangt onder meer af van de waarde van de opportunity en de reden waarom de vennootschap er afstand van doet. ${ }^{\text {ts }}$

66. Men moet zich realiseren dat in het Anglo-saxische recht een apart toezichthoudend orgaan, zoals de raad van commissarissen, zeer ongebruikelijk is. Wel worden in het bestuur veelal buitenstaanders opgenomen (de zgn. non-executive directors). Door de beslissing op te dragen aan deze non-executive directors wordt de facto dus hetzelfde bereikt als goedkeuring door de raad van commissarissen in het Nederlandse en Duitse recht.

67. $\mathrm{Vgl}$. V. Brudney en R.C. Clark, A new look at corporate opportunities, Harvard Law Review 1981, p. 1011.

68. Idem, p. 1032. 
Indien voldaan is aan bovenstaande voorwaarden, te weten verstrekking van alle relevante informatie en toestemming of goedkeuring, dan kan deze toestemming overigens toch nog onredelijk en onbillijk zijn jegens bijvoorbeeld minderheidsaandeelhouders. ${ }^{\omega}$ Bij de beantwoording van de vraag wanneer het verlenen van toestemming (on)redelijk en (on)billijk is, zullen de argumenten, genoemd aan het begin van deze paragraaf in beschouwing moeten worden genomen.

Vaak zal zich de situatie voordoen dat de vennootschap niet genoeg financiēle middelen heeft, en dat de bestuurder daarin een rechtvaardiging ziet om de opportunity zelf te benutten. Hier is echter voorzichtigheid geboden. Het aanvaarden van dit argument kan er immers toe leiden dat bestuurders geen inspanningen meer zullen verrichten om fondsen te genereren voor de vennootschap. Dit werd onder meer verdedigd in Klinicki v. Lundgren, Irving Trust Co. v. Deutsch (de leading case op dit gebied) en Electronic Development Corporation v. Robson. ${ }^{70}$ De verplichting tot loyaliteit van bestuurders jegens de vennootschap, brengt mee dat indien een opportunity zich voordoet, zij hun best moeten doen om de financiering rond te krijgen.

Deze benadering vindt men ook terug in het Duitse en Engelse recht. $\mathrm{Vgl}$. voor het Duitse recht bijv. het Betriebsgrundstückfall, BGH 8 mei 1967, GmbHR 68, 141. In deze zaak liet een beherend vennoot van een offene Handels Gesellschaft (oHG, vergelijkbaar met de Nederlandse vennootschap onder firma) een bedrijfsterrein, dat hij op eigen naam voor de vennootschap huurde, door zijn echtgenote verwerven. Hij betaalde de koopprijs. Daarop zegde de echtgenote het huurcontract met de OHG op, om vervolgens opnieuw aan de OHG te verhuren maar nu voor een veel hogere huurprijs. Later stapte hij uit de vennootschap, zegde samen met zijn echtgenote het huurcontract op en begon met zijn familie een concurrerend bedrijf op dit terrein. De voormalige mede-vennoot van de oHG eiste schadevergoeding van de vroegere beherend vennoot wegens 'Verietzung gesellschaftsvertraglicher Pflichten'. De bestuurder stelde dat hij door deze handelwijze slechts had willen bewerkstelligen dat de vennootschap het terrein kon blijven huren. Het BGH dacht er anders

69. Vgl. ook Klaus J. Hopt, Self-Dealing and Use of Corporate Opportunity and Information: Regulating Directors' Conflicts of Interest in: Corporate Governance and Directors' Liabilities 1985, p. 291, die verwijst naar de Remillard-uitspraak (109 CAl. App. 2d 405, 241 P 2d 66) [1952]: 'It would be a shocking concept of corporate morality to hold that because the majority directors or stockholders disclose their purpose and interest. they may strip a corporation of its assets to their own financial advantage, and that the minority is without legal adress'. Zie ook $\$ 5.0 .5$. onder a van de Principles of Corporate Governance van het American law Institute.

70. Zie Cary-Eisenberg, t.a.p., p. 443-447. 
over. Om onzekerheid met betrekking tot het huren van het terrein te voorkomen had de bestuurder zich moeten inspannen om het terrein voor de vennootschap te verwerven. Zelfs in het geval dat de financiële middelen van de vennootschap niet toereikend zouden zijn geweest. De Treuepflicht kan in zo'n geval meebrengen dat een kapitaalkrachtige partner moet worden gezocht. ${ }^{\text {" }}$

In het Engelse recht vormde zowel in Regal als in Boardman v. Phipps (besproken in 89) de financiële positie van de vennootschap geen belemmering voor de aansprakelijkheid van resp. de bestuurders en agents van een trust. ${ }^{n}$ Dit was ook het geval in de Canadese uitspraak inzake Abbey Glen Property Corp. v. Stumborg. [1976] 65 D.L.R. (3d) 355 (Alt. H.C.) . De Stumborgs waren bestuurders en aandeelhouders van T. Ltd. vanaf het moment van oprichting tot 1969 toen zij hun aandelen verkochten. T. Ltd was een investeringsmaatschappij die zich met name bezig hield met investeringen in onroerend goed in de omgeving van de stad Edmonton. In 1964 benaderden de Stumborgs, namens T.Ltd, F. Ltd teneinde een joint venture aan te gaan met het doel samen land te verwerven. $\mathrm{Na}$ onderhandelingen bleek dat F. Ltd slechts geinteresseerd was om zaken te doen met de Stumborgs persoonlijk en niet met T.Ltd. Uiteindelijk besluiten de Stumborgs om samen met F. Ltd. een bedrijf op te richten en land te verwerven. Dit leverde volgens T. Ltd een "breach of their (de Stumborgs/MK) fiduciary duty' òp. De Stumborgs verweerden zich onder meer met het argument dat $\mathrm{T}$. Ltd niet voldoende middelen had om de opportunity te benutten. De rechters sprongen voorzichtig om met dit argument. 'The desirability of permitting such a defence is problematical as it could chill a director's enthusiasm to use his best efforts for the company'.

De situatie is anders indien de belemmering voor de vennootschap om een corporate opportunity te benutten, ondanks de inspanningen van de bestuurder niet ongedaan gemaakt kan worden. Men denke bijvoorbeeld aan belemmeringen op het gebied van het mededingingsrecht.

\section{§ 8. Rechtsgevolgen ingeval van ongeoorloofd gebruik corporate opportunities}

Het ongeoorloofd gebruik maken van een corporate opportunity door een bestuurder levert strijd op met de redelijkheid en billijkheid jegens de vennootschap. De volgende vraag die dan beantwoord moet worden is: tot welke rechtsgevolgen kan zo'n schending van de norm van redelijkheid en billijkheid leiden?

71. Vgl. ook H. Merkt, Unternehmensleitung und Interessenkollision, ZHR 1995. P. 426/427.

72. Zie eveneens H. Rajak, Fiduciairy duty of a managing director, MLR 1972, p. 657 en G. R. Sullivan, Going it alone-Queensland Mines v. Hudson, MLR 1979, p. 714. 
Naar mijn mening moet onderscheid worden gemaakt tussen twee situaties. Enerzijds de situatie dat een 'transactie' nog niet is afgerond of een bepaald recht nog niet is verworven, men denke bijvoorbeeld aan het geval dat een bestuurder nog aan het onderhandelen is over een exclusief contract voor eigen rekening en anderzijds de situatie dat er sprake is van een reeds voltooide handeling.

In het geval dat de transactie nog niet is afgerond, ben ik van mening dat op grond van de redelijkheid en billijkheid van de bestuurder kan worden gevorderd dat hij zijn gedrag herziet en de transactie alsnog anbiedt aan de vennootschap. De bestuurder behoort immers overeenkomstig de eisen van redelijkheid en billijkheid de corporate opportunities ten behoeve van de onderneming te benutten.

In het geval dat de bestuurder de transactie reeds heeft afgerond en zich de voordelen ervan toegeëigend, ligt dat anders. Aangezien Verdam ${ }^{73}$ in zijn dissertatie uitgebreid op de dan mogelijke rechtsgevolgen ingaat, zal ik mij beperken in de behandeling hiervan.

Interessant is in dit kader allereerst de vraag of het mogelijk is de transactie in de sfeer van de vennootschap te brengen.

In het Engelse en Amerikaanse recht leidt een schending van 'fiduciary duties' als regel tot een verplichting tot afdracht van het ten onrechte genoten voordeel. In het Amerikaanse recht is de meest gangbare sanctie die leidt tot vergoeding van schade de 'constructive trust'. Een bestuurder, die een corporate opportunity heeft benut, wordt van rechtswege beschouwd als een 'constructive trustee' van bepaalde hem toebehorende goederen, zulks omdat hij de betrokken goederen naar de maatstaf van

73. A.F. Verdam, Corporate opportunities, Zwolle 1995, p. 257-288. 
'equity' niet te eigen bate behoort te houden. ${ }^{74}$ De trustee wordt verplicht om alle aanspraken en winst af te dragen aan de vennootschap.

In Duitsland heeft zowel een AG op grond van $\S 88$ abs. 2 AktG als een $\mathrm{GmbH}$ op grond van $\S 113 \mathrm{HGB}$ een zgn. 'Eintrittsrecht'. ${ }^{75} \mathrm{Dit}$ recht houdt in dat de vennootschap kan vorderen dat de transactie voor haar rekening wordt afgewikkeld of dat het behaalde voordeel wordt afgedragen. Het bijzondere van deze sanctie is dat deze ook kan worden toegepast in het geval dat geen schade is geleden.

'Afdracht' van de met een corporate opportunity verbonden voordelen kan in het Duitse recht ook min of meer worden verkregen via een aanspraak die bestaat op grond van 'unechte Geschäftsführung ohne Auftrag"76 omdat het benutten van een corporate opportunity door een bestuurder te beschouwen is als een 'vreemde transactie' (fremdes Geschäft) in de zin van $\S 687$ BGB. $^{n}$

Voor het Nederlandse recht draagt De Kluiver ${ }^{78}$ een interessante mogelijke oplossing aan. Door overeenkomstige toepassing van art. 7:420 BW zou de handelwijze van een bestuurder voor rekening van de rechtspersoon kunnen worden gebracht. Art. 7:420 BW bepaalt namelijk dat in

74. Vgl. A.F. Verdam, t.a.p., p. 265, waar hij verwijst naar de omschrijving van het begrip constructive trust door Uniken Venema in Law en Equity, p. 170: 'Van een constructive trust is sprake, indien iemand van rechtswege wordt aangemerkt als een trustee van bepaalde hem toebehorende goederen, zulks omdat hij de betrokken goederen - hoewel zij hem toebehoren in legal ownership - naar de maatstaf van het Equity-recht niet te eigen bate behóort te kunnen behouden. Krachtens het Equity-recht wordt de betrokkene dan beschouwd als een trustee, die met behulp van de dwangmiddelen van het Equityrecht [..] zal worden gedwongen de betrokken goederen af te geven of anderzins te doen strekken ten bate van een of meer anderen - die dan van rechtswege worden beschouwd als de beneficiaries van de constructive trust aan wie, een equitable interest toekomt Globaal gezegd is de figuur van de constructive trust te bschouwen als een middel tot correctie van - in ruime zin - ongerechtvaardigde verrijking.

75. $\S 88$ sub 2 AktG bepaalt: 'VerstöBt ein Vorstandsmitglied gegen dieses Verbot, so kann die Gesellschaft Schadenersatz fordern. Sie kann statt dessen von dem Mitglied veriangen, daß es die für eigene Rechnung gemachten Geschäfte als für Rechnung der Gesellschaft eingegangen gelten läßt und die aus Geschäften für fremde Rechnung bezogene Vergũtung herausgibt oder seinen Auspruch auf die Vergũtung abtritt'.

76. Vgl. J. Weisser, Corporate opportunities, Köln, p. 245 en H. Merkt, Unternehmensleitung und Interessenkollision. ZHR 1995, p. 450/451.

77. In dat geval is $\S 667$ BGB van toepassing welke bepaalt dat: 'Der Beauftragte ist verpflichtet, dem Auftraggeber alles, was er zur Ausführung des Auftrags erhălt und was er aus der Geschäftsbesorgung erlangt, herauszugeben".

78. H.J. de Kluiver, in: Nieuw vennootschaps-en rechtspersonenrecht, Zwolle 1992, p. 30. 
het geval een lasthebber in eigen naam een overeenkomst heeft gesloten met een derde en zijn verplichtingen jegens de lastgever niet nakomt, de lastgever de voor overgang vatbare rechten van de lasthebber jegens de derde door een schriftelijke verklaring aan hen beiden op zich kan doen overgaan. Ingevolge de schakelbepaling art. 7:424 BW zou deze bepaling van toepassing kunnen zijn. Probleem is wel dat deze bepaling zich beperkt tot het geval dat een persoon krachtens een overeenkomst voor rekening van een ander kan handelen. Dit probleem zou wellicht worden 'opgelost' indien men het handelen van een bestuurder zou zien als voortvloeiend uit een impliciete opdracht van het bestuur van een rechtspersoon aan de individuele leden daarvan om bepaalde zaken namens de rechtspersoon te behartigen.

Aanvaardt men het voorgaande dan betekent dit overigens dat niet alleen de voordelen van een transactie aan de vennootschap toegerekend worden, maar ook de schade ontstaan door het handelen van een bestuurder (vgl. art. 7:421 BW).

Een andere sanctie voor het geval dat een bestuurder zich ongeoorloofd een corporate opportunity toeêigent, is het ontslag van de desbetreffende bestuurder. Komt het tot ontslag dan kan de redelijkheid en billijkheid ook van betekenis zijn in het tijdvak na beëindiging van de functionele rechtsbetrekking. Denk aan de situatie dat een bestuurder een exclusief contract heeft afgesloten met een derde en na zijn ontslag dat contract gaat uitbaten. De redelijkheid en billijkheid brengt naar mijn mening mee dat hij zich de voordelen van dat contract niet mag toeëigenen.

In Duitsland spreekt men over de nachwirkende Treuepflicht. ${ }^{7}$ In Engeland wordt in de rechtspraak aangenomen dat onder omstandigheden een bestuurder die ontslag heeft genomen geen gebruik mag maken van een corporate opportunity, die hem ter kennis is gekomen terwijl hij nog bestuurder was van de vennootschap. Zie bijv. Boardman v Phipps (1967) 2 AC 63.

Een vergelijking kan worden gemaakt met concurrentieverboden. Concurrentiebeperkingen strekken zich veelal juist uit over een tijdvak dat gelegen is na de beëindiging van de rechtsbetrekking. De verplichtingen van voormalige bestuurders die betrekking hebben op een verbod tot het

79. $\mathrm{Vgl}$. H.J. Mertens, Kölner Kommentar zum Aktiengesetz, Köln 1988, p. 313. 
aandoen van concurrentie kunnen voortvloeien uit de redelijkheid en billijkheid. ${ }^{80}$

\section{\$ 8.1 Schade, schadevergoeding en acties door aandeelhouders}

Kan de redelijkheid en billijkheid als grondslag dienen voor schadevergoeding? Uniken Venema ${ }^{81}$ is - mijns inziens terecht - van mening dat indien een bestuurder de norm van redelijkheid en billijkheid overtreedt door zich op een ongeoorloofde wijze een corporate opportunity toe te eigenen, deze verplicht is tot schadevergoeding jegens de vennootschap. $^{82}$ De schadevergoeding bestaat dan uit het voordeel dat aan de vennootschap door het gedrag van de bestuurder is onthouden. Voorts kan naar mijn mening een bestuurder aansprakelijk zijn jegens aandeelhouders op grond van het feit dat hij zich niet overeenkomstig de eisen van redelijkheid en billijkheid heeft gedragen. ${ }^{83}$

Een andere vraag die zich aandient is of een aansprakelijkheid gebaseerd op 2:8 BW ook betekent dat aandeelhouders elk, of gezamenlijk, een aanspraak jegens de bestuurder, die een corporate opportunity heeft toegeëigend, geldend kunnen maken. Gelet op de jurisprudentie van de HR in de arresten Poot/ABP en Cri/Cri, ${ }^{84}$ en met name gelet op het daarin ontwikkelde criterium van 'afgeleide schade', moet naar huidig recht in beginsel worden aangenomen dat dit niet mogelijk is. Geconstateerd kan worden dat de schade die aandeelhouders leiden door de

80. Zie ook J.B. Huizink, Bestuurders van rechtspersonen 1989, p. 116/117.

81. C.AE.Venema, Corporate opportunities, aspecten van loyaliteit in het kader van een onderneming naa Amerikaans en Nederlands recht in: Jurist en bedrijf, Deventer 1980, p. 181.

82. Schadevergoeding anders dan in geld, bijvoorbeeld in de vorm van overdracht van de opportunity is een mogelijkheid (art. 6:103 BW). Zie hieromtrent A.F. Verdam, Corporate opportunities, diss. 1995, Zwolle, p. 280/281.

83. Dit kan men naar mijn mening ook impliciet afleiden uit de HCS-zaak. De president oordeelde dat de ongeldigheid van de transactie niet kon worden vastgesteld op grond van het persoonlijk voordeel dat de bestuurder daarbij had behaald. Wel zou, aldus de president zulks kunnen leiden tot schadeplichtigheid van de desbetreffende bestuurder wegens wanprestatie ten opzichte van de NV dan wel jegens onrechtmatig handelen jegens de overige aandeelhouders.

84. HR 2 december 1994, NJ 1995, 288 (Poot/ABP) en HR 29 november 1997, NJ 1997, 178 (Cri/Cri). Zie tevens M.J.G.C. Raaijmakers, 'Omgekeerde doorbraak': Poot/ABP. AA 1995, p. 491. Zie ook L. Timmerman. TVVS 1997, p. 16 e.v. 
ongeoorloofde toeëigening van een corporate oppportunity door een bestuurder afgeleide schade betreft. De aandeelhouders lijden immers indirecte schade omdat door de vermogensschade van de vennootschap de aandelen in waarde dalen.

In het Poot/ABP-arrest is bepaald dat bij wanprestatie of onrechtmatig handelen jegens de vennootschap alleen de vennootschap het recht heeft uit dien hoofde van de schadetoebrenger vergoeding van de aan haar toegebrachte schade te vorderen. De Hoge Raad overweegt dat aandeelhouders in beginsel geen eigen vordering tot schadevergoeding geldend kunnen maken. In het $\mathrm{Cri} / \mathrm{Cri}$ arrest wordt dit bevestigd door de Hoge Raad. De Hoge Raad overweegt dan voor het eerst dat voorzover aandeelhouders in privé schade hebben geleden, deze slechts voor vergoeding in aanmerking kan komen indien zij geen afgeleide schade van de vennootschap is. Met andere woorden: aandeelhouders kunnen slechts de schade verhalen die niet samenvalt met de schade van de vennootschap zelf. ${ }^{\text {s5 }}$

Naar aanleiding van bovengenoemde uitspraken menen Van Schilfgaarde, Timmerman en Kroeze dat slechts dan een zelfstandig vorderingsrecht aan een aandeelhouder kan toekomen indien sprake is van schending van een specifieke zorgvuldigheidsnorm jegens de aandeelhouder in privé en als zijn afgeleide schade definitief is geworden. ${ }^{86}$ Dit is het geval indien de vennootschap geen vordering meer kan of mag instellen.

Er wordt wel betoogd dat het Nederlandse rechtsstelsel voldoende mogelijkheden biedt voor (minderheids)aandeelhouders om het bestuur tot het instellen van een schadevergoedingsactie te nopen. ${ }^{87}$ Daarmee ben ik het niet eens. Het probleem hierbij is dat het bestuur veelal de hand boven het hoofd zal houden van de bestuurder die zich een corporate opportunity

85. Zie J.B. Wezeman, Aansprakelijkheid van bestuurders, Kluwer 1998, p. 123 en M. Kroeze, Zelfstandige vorderingsrechten van de aandeelhouder voor schade aan het vennootschapsvermogen, in: Beginselen van vennootschapsrecht in binationaal perspectief, Antwerpen-Groningen 1998, p. 228.

86. P. van Schilfgaarde, Acties van aandeelhouders in verband met onrechtmatige gedragingen tegenover de vennootschap, in: Rechtspleging in het vennootschapsrecht, Deventer 1997. p. 5/6, L. Timmerman, Kan een aandeelhouder of vennootschapsschuldeiser afgeleide schade vorderen? TVVS 1998, p. 98 en M. Kroeze, Zelfstandige vorderingsrechten van de aandeelhouder voor schade aan het vennootschapsvermogen, in: Beginselen van vennootschapsrecht in binationaal perspectief. Antwerpen-Groningen 1998, p. 222.

87. Zie J.M.M. Maeijer in zijn noot onder ABP/Poot, NJ 1995, 288, p. 1346. 
heeft toegeëigend (vgl. § 7). Ik zou derhalve willen verdedigen dat niet het bestuur maar, indien aanwezig, de raad van commissarissen dient te beslissen over het instellen van een schadevergoedingsactie. Bij het ontbreken van een raad van commissarissen dient mijns inziens de ava te beslissen over het instellen van een schadevordering namens de vennootschap. Mijns inziens is er reden genoeg om, in navolging van het Franse en Amerikaanse recht, te denken aan de ontwikkeling van een 'derivative suit'. 88

\section{§ 9. Winstclaim bestuurder?}

Een andere kwestie die hier aandacht verdient is of een bestuurder die zich op ongeoorloofde wijze een corporate opportunity heeft toegeëigend toch een gedeelte van de winst kan claimen.

Zou men een dergelijke aanspraak van een bestuurder aannemen, dan berust dit op de gedachte dat de kwaliteit van de prestatie van de bestuurder, die noodzakelijk was om de winst te realiseren, beloond dient te worden. Mijns inziens past hier echter terughoudendheid. Een belangrijke reden voor die terughoudendheid lijkt mij dat een bestuurder dan wellicht juist een groot gedeelte van zijn tijd en aandacht zal besteden aan het verwerven van lucratieve opportunities, met het oog op de behartiging van zijn eigen belang.

Ook in het buitenlandse recht valt een zekere terughoudendheid te bespeuren. In de Amerikaanse rechtspraak beperkt een eventuele vergoeding in het kader van het opleggen van een zgn. constructive trust aan de bestuurder, zich slechts tot een vergoeding voor de kosten die de bestuurder heeft gemaakt ten behoeve van het aanwenden van de opportunity. ${ }^{89}$ Dit is ook het geval in het Duitse recht. Een zgn. 'Aufwendungsersatzanspruch' komt in de rechtspraktijk vaak hierop neer dat de door de bestuurder gemaakte kosten worden vergoed en dat de zuivere winst ('Reingewinn') aan de vennootschap moet worden afgedragen. ${ }^{90}$

88. Zie hieromtrent J. Sperling. Derivative suits in Nederland?, De NV 1998, p. 62-67.

89. Zelfs al zijn de opbrengsten van de corporate opportunity in belangrijke mate te danken aan de kwaliteiten van de bestuurder en heeft hij het volledige verliesrisico gedragen. Vgl. bijv. Electronic Development. Co. v. Robson, 148 Neb. 526, 28 N.W. $2 d 130$ (1947), p. 140. Zie tevens J. Weisser, Corporate opportunities, diss, Köln 1991, p. 105 en Note: Corporate opportunity, Harvard Law Review 1961, p. 766.

90. $\mathrm{Vgl}$. J. Weisser, t.a.p., p. 250/251. 
In het Engelse recht wordt soms, zij het onder zeer bijzondere omstandigheden, wel aangenomen dat een aanspraak van de bestuurder op een gedeelte van de winst kan bestaan. Een omstandigheid waaraan dan belang kan worden toegekend, is bijvoorbeeld de mate waarin een bestuurder bij het exploiteren van de opportunity financieel risico heeft gelopen.

Men zie hier bijvoorbeeld Boardmann v. Phipps [1964] I WLR, reeds weergegeven in $\S 4$. In deze zaak oordeelde de House of Lords enerzijds, evenals in Regal, dat de winst die de bestuurders $\mathbf{B}$ en $\mathbf{P}$ uit eigen investering hadden verworven, moesten afdragen aan de trust. Anderzijds echter, en dat is het interessante aan deze uitspraak, oordeelde de House of Lords dat de bestuurders B en P recht hadden op een vergoeding van de gemaakte kosten en op een royale vergoeding voor het werk en de bekwaamheid die zij hadden aangewend, zonder welke de winst niet zou zijn gemaakt. 'It would be inequitable [..] for the beneficiaries to step in and take the profit without paying for it', aldus Lords Cohen en Guest. De vergoeding wordt, volgens Lord Templeman, gerechtvaardigd door het risico dat op de beide fiduciaries lag. De aankoop van het meerderheidsbelang in de andere vennootschap had ook slecht kunnen uitpakken en in dat geval zouden B en P persoonlijk een aanzienlijk verlies lijden."

In Guinness v. Saunders [1990] 2 WLR 333, ${ }^{n}$ werd daarentegen een zgn. "quantum meruit claim' van een bestuurder niet aangenomen. Ward, een non-executive director van Guinness, maakte deel uit van een bestuurscommissie die de takeover door Guinness van Distillers begeleidde. Na de geslaagde takeover betaalde de vennootschap maar liefst een bedrag van 5.2. miljoen pond uit aan Ward. De uitbetaling was gebaseerd op een afspraak van de commissie met de vennootschap (een beloning van $0.2 \%$ gerelateerd aan de waarde van het door Guinness uitgebrachte bod). Echter, deze uitbetaling was niet, zoals vereist in de statuten van de vennootschap, goedgekeurd door het volledige bestuur.

Als deze praktijk in de openbaarheid komt'vordert Guinness het bedrag terug van Ward en stelt dat er sprake is van breach of fiduciary duty. Ward echter meent dat hij recht heeft op een redelijke vergoeding (equitable allowance). The House of Lords weigert dit. Lord Goff oordeelt: As to be reconciled with the fundamental principle that a trustee is not entitled to remuneration for services rendered by him to the trust except as expressiy provided in the trust deed. Strictly speaking, it is irreconcilable with the rule so stated [..] it can only be reconciled with the extent that the exercise of the equitable jurisdiction does not conflict with the policy underlying the rule. And, as I see it, such a conflict will only be avoided if the exercise of the jurisdiction is restricted to those cases where it cannot have the effect of encouraging trustees in any way to put themselves in a position where their interests in any way conflict with their duties as trustees'.

91. Zie WLR. 1993 , p. 1018 en ook J. Gardner, Restitutionary claims by company directors, LQR 1990, p. 366 en J. Hopkins, Fiduciary duty-receipt of company's property by director-equitable allowance to fiduciary, CLJ 1990, p. 222.

92. $\mathrm{Vgl}$. ook Hicks \& Goo, Cases \& Materials, p. 310 e.v. 
Een reden die in de literatuur wel wordt aangevoerd om het verschil in uitkomst tussen deze twee uitspraken te verkiaren, is dat in Guinness sprake was van een 'direct taking of company's property' en in Boardman v. Phipps niet.

Ook in het geval een bestuurder vanwege uitzonderlijke bekwaamheden voor een belangrijke (significant) winst heeft gezorgd, kan er volgens de Engelse rechtspraak een recht bestaan voor de bestuurder op een hoger salaris. ${ }^{93}$ Echter, de vraag wanneer en in hoeverre de rechter een recht op vergoeding van een bestuurder aanneemt, is in het Engelse recht niet duidelijk. ${ }^{94}$

Voor wat het Nederlandse recht betreft, meen ik dat ook voor de vraag of een aanspraak bestaat van de bestuurder op een extra vergoeding, als uitgangspunt geldt de loyaliteit van de bestuurder jegens de vennootschap. Zijn persoonlijke inzet en prestaties zijn aspecten daarvan. Dat neemt niet weg dat een vennootschap een beleid kan voeren op grond waarvan een bestuurder die bijvoorbeeld een aanzienlijk financieel risico heeft gelopen toch aanspraak kan maken op een extra vergoeding.

\section{§ 10. Slotbeschouwing}

In dit hoofdstuk staat de problematiek van corporate opportunities van bestuurders van NV's en BV's centraal. Aanvankelijk werd deze problematiek alleen in het Anglo-Amerikaanse recht onder ogen gezien. In navolging daarvan is echter ook het Duitse en Nederlandse recht doordrongen geraakt van het belang om de toeëigening van corporate opportunities door bestuurders aan banden te leggen. ${ }^{95}$ De algemene gedachte

93. Vgl. bijv. Re Keeler's S.T. [1981], Ch. 156.

94. Zie J. Hopkins, Fiduciary duty-receipt of company's property by director-equitable allowance to fiduciary, CLJ 1990, p. 222.

95. Zie C.AE. Uniken Venema, Corporate Opportunities; aspecten van loyaliteit in het kader van een onderneming naar Amerikaans en Nederlands recht, in Jurist en bedrijf (NGB-Bundel), Deventer 1980, p. 167 e.v., A.F.M. Dorresteijn, Tegenstrijdig belang van bestuurders en commissarissen (diss.), Deventer 1989, p. 15, B.H.A. van Leeuwen, Beginselen van behoorlijk ondernemingsbestuur, Deventer 1990, p. 74/75, M.J.G.C. Raaijmakers, Enkele rechtsvergelijkende beschouwingen over joint ventures, Preadvies Nederlandse Vereniging voor Rechtsvergelijking, Deventer 1992, p. 60/61, L. Timmerman, De dubbelrol in het (vennootschaps)recht, in: De dubbeirol in het vennootschapsrecht, Deventer, 1993, p. 9. M. Koelemeijer, Redelijkheid en billijkheid in het vennootschapsrecht. WPNR 1994, p. 714 e.v., A.F. Verdam, Corporate Opportunities (diss.). Tjeenk Willink 1995 alsmede 'De norm van behoorlijke taakvervulling en de 
is dat van de bestuurder, vanwege de trustee-achtige positie waarin hij zich bevindt, een hoge mate van loyaliteit en onbaatzuchtigheid mag worden verwacht.

Bij deze overeenstemming staat in het Nederlandse recht wel ter discussie wat de grondslag voor de toetsing van dergelijk gedrag zou moeten zijn. Een tweetal visies worden onderscheiden. Allereerst bestaat de visie dat de corporate opportunities problematiek wordt beheerst door de norm van de redelijkheid en billijkheid van art. 2:8 BW. De tweede visie baseert zich op de norm van art. 2:9 BW, die de bestuurder verplicht tot een behoorlijke vervulling van de hem opgedragen taken. Deze laatste visie vindt, sinds het verschijnen van de dissertatie van Verdam inzake corporate opportunities ${ }^{\%}$ in 1995 , de meeste steun in de literamur. ${ }^{97}$

Ik verdedig echter, in navolging van Uniken Venema, ${ }^{98}$ dat de problematiek wordt beheerst door de norm van redelijkheid en billijkheid. ${ }^{99} \mathrm{De}$ redelijkheid en billijkheid is mijns inziens de norm bij uitstek om toeẽigening van corporate opportunities door bestuurders te reguleren. Het gaat bij de corporate opportunities problematiek immers om gedrag dat juist niet te maken heeft met het besturen van de vennootschap, maar deze wel schaadt. De verplichting tot loyaliteit welke van bestuurders mag worden verwacht, bestaat mijns inziens niet alleen ten opzichte van de vennootschap, maar ook jegens aandeelhouders. De achterliggende gedachte van de 'corporate opportunities doctrine' in de Anglo-Saksische rechtsstelsels is ook gelegen in de bescherming van aandeelhouders. De norm van art. 2:9 BW acht ik derhalve te beperkt als grondslag voor toetsing van de corporate opportunities problematiek.

lets anders is of een aansprakelijkheid gebaseerd op art. 2:8 BW ook betekent dat aandeelhouders elk, of gezamenlijk, een aanspraak jegens de bestuurder geldend kunnen maken. Gelet op de jurisprudentie van de HR

trustee-functie van het bestuur, in: Na twintig jaar boek 2 BW, Deventer 1996, p. 149 c.v. en M. Kroeze, Juridisch up to date 1996, p. 2-4.

96. A.F. Verdam, Corporate Opportunities, Zwolle 1995.

97. Zie onder meer M. Kroeze, Juridisch up to date 1996, p. 2-4 en L. Timmerman, Kroniek van het vennootschapsrecht, NJB 1996, 1320/1321.

98. C.AE. Uniken Venema, Corporate opportunities, in: Jurist in bedrijf, Deventer 1980, p. 179.

99. Zie tevens M.A.J.G. Janssen, Corporate business opportunities en besloten verhoudingen, $\mathrm{Bb} 1997$, p. 10. 
in zijn arresten Poot/ABP (NJ 1995, 288) en Cri/Cri (NJ 1997, 198) en met name gelet op het daarin ontwikkelde criterium van 'afgeleide schade' moet naar huidig recht in beginsel worden aangenomen dat dit niet mogelijk is. Dit lijkt mij een reden om de ontwikkeling van een 'action sociale' c.q. derivative suit ter hand te nemen.

Aan de hand van een aantal aanknopingspunten in buitenlandse rechtsstelsels, die meer ontwikkeld zijn op het gebied van de corporate opportunities problematiek, heb ik getracht de norm van redelijkheid en billijkheid te concretiseren. Zo heb ik verdedigd dat uit de norm van redelijkheid en billijkheid voortvloeit dat bestuurders in een aantal gevallen gehouden zijn om business opportunities aan te bieden aan de vennootschap.

Voorts heb ik gepoogd een procedure aan te geven op grond waarvan meer inzicht kan worden verkregen in de vraag wanneer een bestuurder een corporate opportunity mag benutten. Deze procedure bestaat uit een tweetal stappen; openbaarmaking door de bestuurder van de aard en de omvang van zijn betrokkenheid bij een transactie en toestemming of goedkeuring door een van de bestuurder onafhankelijk, vennootschappelijk orgaan.

Daarenboven heb ik verdedigd dat in tegenstrijdig belang situaties de betrokken bestuurder dient te worden uitgesloten van het bijwonen van en het deelnemen aan de besluitvorming en dat vervolgens het bestuursbesluit om al dan niet een opportunity binnen de sfeer van de vennootschap te brengen, steeds aan de raad van commissarissen dient te worden voorgelegd. Het besluit tot 'vrijgave' van een 'opportunity' dient overigens ook inhoudelijk te voldoen aan de eisen van redelijkheid en billijkheid. Hierbij dient mijns inziens in beschouwing te worden genomen of het een bestuurder betreft van een 'publieke' vennootschap met een groot activiteitengebied, of een bestuurder van een besloten vennootschap. ${ }^{100}$

Bij het 'vrijgeven' van de corporate opportunity aan de 'betrokken' bestuurder is echter, met name bij tekortschietende financiële middelen van de vennootschap, voorzichtigheid geboden. De loyaliteit van bestuur-

100. Anders A.F. Verdam, Corporate Opportunities, Zwolle 1995, p.61. Hij geeft als kritiek op de voorstellen van Brudney en Clark onder meer dat public corporations niet altijd een groter activiteitengebied en meer financiële middelen zullen hebben dan close corporations. Hij pleit voor hantering van een flexibel criterium waarin voor invulling al naar gelang de omstandigheden ruimte is. Naar mijn mening biedt de redelijkheid en billijkheid die flexibiliteit. 
ders is dan in het geding. Terughoudendheid is ook op zijn plaats inzake het toekennen van een vergoeding aan de bestuurder die, na succesvolle verwerving van corporate opportunities, deze moet afstaan aan de vennootschap. 



\section{DEEL III:}

VERHOUDING TUSSEN BESTUURDERS 



\section{Besluitvorming en gedrag binnen het bestuur}

\section{§1. Inleiding}

De verhouding tussen bestuurders onderling is in de voorgaande hoofdstukken impliciet herhaaldelijk belicht. Het ging dan met name om conflictsituaties waarin een bestuurder, doordat hij tevens meerderheidsaandeelhouder is, de mogelijkheid heeft om de macht binnen de vennootschap naar zich toe te trekken. Daarop voortbouwend, tracht ik in dit hoofdstuk de interne verhoudingen binnen het vennootschapsbestuur aan een nadere analyse te onderwerpen.

In tegenstelling tot de algemene vergadering, is de organisatie en besluitvorming van het bestuur in de wet niet geregeld. ${ }^{1}$ Wat betreft de concretisering van de interne verhoudingen, geldt in ons recht als uitgangspunt het beginsel van collegiaal of, zo men wil, collectief bestuur. ${ }^{2}$ Uit het collegialiteitsbeginsel vloeit de regel voort dat het algemene en financiële beleid tot de gezamenlijke verantwoordelijkheid behoort van de leden van het bestuur.

In de praktijk wordt een consequente uitwerking van dit beginsel van collegiaal bestuur niet steeds wenselijk geacht. Dat roept de vraag op in hoeverre het mogelijk is om bij het besturen van Nederlandse BV's en NV's af te wijken van het uitgangspunt van 'collegiaal' bestuur. Enerzijds kan men hierbij denken aan een meer 'informeel' besturen van de vennootschap. Anderzijds valt juist te denken aan een formelere bestuursstructuur, die in de richting gaat van een hiërarchische ordening. Een vergelijking met de hiërarchisch getinte bestuursstructuur binnen een Franse SA 'classique' ligt dan voor de hand. Een en ander heeft conse-

1. Vgl. bijv. Asser-Maeijer, 2-III 1994, nr. 303 en Pitlo-Lôwensteyn, p. 278. Dit is eveneens het geval in het Duitse en Engelse recht. Vgl. Karsten Schmidt, Gesellschaftsrecht, 1994, p. 681 e.v. en Henn, Handbuch des Aktienrechts, p. 573 e.v. en S. Goulding, Principles of company law, Londen 1996, p. 109. Anders is dit voor wat betreft het Franse recht. Zie Guyon, Droit des affaires, nrs. 330 e.v.

2. Vgl. Asser-Maeijer, 2-III, nr. 302, Handboek, nr. 233, Van Schilfgaarde, Van de BV en NV 1998, nr. 42 en J.B. Huizink, Rechtspersonen losbladig art. 2:9 (1998), p. 9-5. Evenzo in het Duitse recht, zie Henn, Handbuch des Aktienrechts, p. $257 / 258$ en K. Schmidt, Gesellschaftsrecht, p. 681. Het beginsel van collegialiteit geldt ook voor de Conseil d'administration in een SA 'classique'. Vgl. Hémard, Terré et Mabilat, Sociétés commerciale, tome 1, Parijs 1972, nr. 924 en Cozian-Viandier-Deboissy, nr. 637. 
quenties voor het interne functioneren van het bestuur en voor de verschillende aspecten die daarmee samenhangen, zoals overlegverplichtingen, informatieverschaffing en besluitvorming.

Bij het onderzoeken van deze kwestie vormt art. 2:8 BW, dat de interne verhoudingen binnen het bestuur kleurt, de leidraad. Op basis van dit artikel rust immers op bestuurders niet alleen de verplichting tot loyaliteit jegens de vennootschap (en de overige krachtens wet of statuten bij de organisatie betrokkenen), maar ook jegens de mede-bestuurders.

\section{§ 2. Uitoefening van bevoegdheden binnen bestuur: delegatie, man- daat en instructie}

In het Nederlandse recht wordt, zoals reeds vermeld, uitgegaan van het beginsel van collegiaal bestuur. Het collegiale karakter van het bestuur brengt mee dat taken en bevoegdheden die zijn toebedeeld aan het bestuur moeten worden uitgeoefend door het bestuur als college. Voorts impliceert dit dat de individuele leden van het bestuur gelijk dienen te worden behandeld. ${ }^{3}$

Echter, in de praktijk bestaat, afhankelijk van het type organisatie en de organisatiestructuur, ${ }^{4}$ in meer of mindere mate behoefte aan een verdeling van taken en bevoegdheden binnen het bestuur. Daarvoor zijn ook bedrijfskundige argumenten aan te voeren.

De grondvorm van elke organisatie heeft de gedaante van de zogenaamde lijnorganisatie. De klassieke vorm van zo'n organisatie wordt gekenmerkt door een hiêrarchische structuur. In de praktijk echter vindt coördinatie van activiteiten en mensen niet alleen plaats via hiërarchische relaties. Veelal is er ook sprake van een bepaalde horizontale en verticale verdeling van taken, bevoegdheden en verantwoordelijkheden in het bedrijf. De horizontale taakverdeling betreft het opsplitsen van taken, bevoegdheden en verantwoordelijkheden op een zelfde hiêrarchisch niveau. De verticale taakverdeling betreft het verdelen van taken, bevoegdheden en verantwoordelijkheden over de verschillende hiērarchische niveaus. Het gaat hier met name om delegatie van bevoegdheden. De mate van delegatie wordt onder

3. $\mathrm{Vgl}$, B.H.A. van Leeuwen, Beginselen van behoorlijk ondememingsbestuur 1990, p. 168.

4. Een organisatiestructuur is de wijze waarop taken, bevoegdheden en verantwoordelijkheden zijn verdeeld over personen en afdelingen van het bedrijf en de wijze waarop personen en afdelingen met elkaar in relatie staan. $\mathrm{V}_{\mathrm{gl}}$. bijv. J. Heijnsdijk. Besturen van het bedrijf, Groningen 1992, p. 102. 
meer bepaald door het type organisatie.' Daarnaast komen in vrijwel elke lijnorganisatie ook (ettn of meer) staforganen voor. In zo'n lijn- en staforganisatie spelen in de praktijk functionele relaties een belangrijke rol. Hierbij kan de ene functionaris dwingende aanwijzingen geven aan een andere functionaris op een bepaald gebied zonder dat er sprake is van een hięrarchische relatie.

De praktijk van het management geeft aanleiding tot de vraag in hoeverre nu juridisch een verdeling van bevoegdheden binnen het bestuur van een Nederlandse kapitaalvennootschap mogelijk is en welke vormen van bevoegdheidsuitoefening toelaatbaar zijn. Men zou hierbij een onderscheid kunnen maken tussen delegatie, mandaat en instructie. ${ }^{6}$ Dan rijst ook de vraag wie de bevoegheid heeft om te delegeren, te mandateren of te instrueren en aan wie.

Van delegatie spreek ik wanneer één of meer bevoegdheden van het bestuur worden overgedragen aan bijvoorbeeld één bestuurder, die deze bevoegheden gaat uitoefenen in plaats van het (oorspronkelijk bevoegde) bestuur als college. Bij mandaat is er, anders dan bij delegatie, geen sprake van een bevoegdheidsverschuiving. Eén of meer bestuurders handelen in dat geval namens het bestuur. ${ }^{7}$ Delegatie of mandatering van

5. Vanuit een bedrijfskundige invalshoek wordt veelal een onderscheid gemaakt tussen vier organisatietypen; de lenige organisatie, de appendix-organisatie, de corporatie en de institutie. Uit bedrijfskundig onderzoek kan worden afgeleid dat in een lenige organisatie, een organisatie die zich steeds weet aan te passen aan de omgeving, het machtscentrum ligt bij de ondernemer of eigenaar en hij in geringe mate bevoegdheden delegeert. Een appendix-organisatie, bijvoorbeeld een 'business unit', wordt sterk beinvloed door de omgeving en de 'moeder'organisatie. Een afstemming van de bevoegdheden tussen de leiding van de appendix-organisatie en de moederorganisatic is noodzakelijk. Binnen corporaties, bijvoorbeeld holding-organisaties, kan een delegatie van bevoegdheden in hoge mate plaatsvinden. De machtscentra van deze organisaties ligt steeds meer bij leidinggevenden van de eenheden (bijvoorbeeld produktdivisies). Bij een institutie liggen de centra van macht niet alleen in de organisatie, maar ook bij strategisch belanghebbenden buiten de organisatie, zoals de overheid ten aanzien van ziekenhuizen. In dit type organisatie blijkt de feitelijke organisatie soms behoorlijk te verschillen van de formele. Zie hieromtrent C.T.B. Ahaus, Bevoegdheidsverdeling en organisatie, Evaluatie van een bedrijfskundige methode, diss. Groningen 1994, p. 91-99.

6. Voor delegatie en mandaat in stichtingen verwijs ik naar C.H.C. Overes, Delegatie en mandaat in het stichtingenrecht, S \& V 1995, p. 148-152.

7. $\mathrm{Vgl}$, voor de begrippen delegatie en mandaat in het administratief recht H.D van Wijk, Hoofdstukken van administratief recht, bewerkt door W. Konijnenbelt en R.M. van Male, Lemma Utrecht 1994 , p. 135 en 143 en P. de Haan e.a., Bestuursrecht in de sociale rechtsstaat, Deel I Ontwikkeling. Organisatie, Instrumentarium, Deventer 1996, 
één of meer bestuursbevoegdheden aan één of meer individuele bestuurders, zou kunnen geschieden door het bestuur op grond van een reglement, de statuten of een bestuursbesluit. ${ }^{8}$ Bij een instructie moet men tenslotte denken aan de situatie waarin een bestuurvoorzitter juridisch bindende opdrachten geeft aan zijn mede-bestuurders.

Het oordeel over de toelaatbaarheid van een en ander, hangt samen met de uitleg en betekenis die men geeft aan het beginsel van de collectieve verantwoordelijkheid, welke gekoppeld is aan de taakvervulling door het bestuur. ${ }^{9}$ In het navolgende zal een poging worden ondernomen om, met inachtneming van wet en statuten, te onderzoeken waar de grenzen liggen van een taakverdeling binnen het bestuur.

\section{§ 2.1 Taakverdeling en verantwoordelijkheid}

Vast staat dat in ons recht op grond van de statuten een zekere taakverdeling kan worden gerealiseerd binnen het bestuur. Zo wordt ingevolge $\S 8$ van de Departementale Richtlijnen bijvoorbeeld toegestaan dat bij de statuten wordt bepaald dat een bestuurder speciaal belast is met bepaalde bestuurswerkzaamheden. Het gaat hier om een zgn. 'horizontale' taakverdeling. Ook art. 2:9 BW houdt daarmee kennelijk rekening. In art. 2:9 BW wordt immers gesproken over de situatie waarin een aangelegenheid tot de werkkring van twee of meer bestuurders behoort. Is een taak impliciet of expliciet toebedeeld aan bepaalde bestuurders, dan hoort deze niet tot de werkkring van andere bestuurders. ${ }^{10}$ Dit is relevant voor de vaststelling van de individuele aansprakelijkheid van de bestuurders."

p. 210 en 213 . Weliswaar ontleen ik daaraan inspiratie voor het navolgende, maar ik neem daarbij het administratiefrechtelijk begrippenkader niet zonder meer over.

8. Vgl. Asser-Maeijer 2-III 1994, nr. 302.

9. Dit is naar mijn mening anders indien de ava een bevoegheid zou willen delegeren. Dit orgaan is in beginsel 'vrij' om te beschikken over die bevoegdheid. De ava kan immers bevoegdheden en verplichtingen overdragen aan een commissie van aandeelhouders (zie art. 2:158/268 lid 11 BW). Vgl. hieromtrent, H.M.L. Dings. De commissie van aandeelhouders bij structuurvennootschappen (diss. Nijmegen), Deventer 1998 en F.J.P. van den Ingh, Naar een uitbreiding van de aandeelhouderscommissie, WPNR 1992, p. 805-807.

10. Zie ook P, van Schilfgaarde, Misbruik van rechtspersonen, Arnhem 1986, p. 13.

11. Evenzo L. Timmerman, Aansprakelijkheid van bestuurders van nv's en bv's: een overzicht van enige recente rechtspraak, TVVS 1991, p. 199-200, J.B. Wezeman. Aansprakelijkheid van bestuurders (diss. Utrecht), Deventer 1998, p. 72 en P. van 
Daarnaast blijft echter voor elke bestuurder de collectieve verantwoordelijkheid voor het besturen van de kapitaalvennootschap bestaan. ${ }^{12}$ Deze collectieve verantwoordelijkheid is mijns inziens gekoppeld aan het belang van de vennootschap. Een behoorlijke taakvervulling is in het belang van de vennootschap en brengt onder meer voor iedere bestuurder mee dat hij maatregelen moet treffen om de gevolgen van wanbeheer af te wenden.

Op dit punt is het Duitse AG-recht vergelijkbaar met het Nederlandse. Alle bestuurders van cen AG zijn onderworpen aan $\$ 93$ AktG dat vereist dat zij handelen met 'die Sorgfalt eines ordentlichen und gewissenhaften Geschăftsleiters'. "B Bestuurders die hun zorgvuldigheidsplicht verwijtbaar ('schuldhaft') schenden, zijn aansprakelijk ten opzichte van de vennootschap. Ook hier moet een bestuurder, om aan aansprakelijkheid te ontkomen, zelf

Schilfgaarde, Misbruik van rechtspersonen, p. 18/19.: een bestuurder, die kan aantonen dat een aangelegenheid niet tot zijn werkkring behoort en hij daar evenmin krachtens wet, statuten of ongeschreven recht in had moeten worden betrokken, is niet aansprakelijk. Aan de disculpatievraag zou men dan volgens Van Schilfgaarde niet toe komen. Anders: P.J. Dortmond, Misbruik van rechtspersonen in de bundel Piercing van Schilfgaarde, 1990 p. 17. Hij is van mening dat bij de NV en BV een aangelegenheid altijd tot de werkkring van alle bestuurders behoort en dat er derhalve steeds van een hoofdelijke aansprakelijkheid moet worden uitgegaan. Evenals Dortmond: F.J.P. van den Ingh, Interne aansprakelijkheid bij vereniging en stichting, S \& V 1990, p. 161. C.A. Schwarz, Décharge van bestuurders van vereniging en stichting, S \& V 1993, p. 42. Asser-Maeijer nr. 413 en J.B. Huizink, Vraagtekens bij art. 2:9 BW, De NV 1997. p. 334 en in Rechtspersonen losbladig art. 9, p. 9-7 die daarmee afwijkt van zijn oorspronkelijke opvatting in zijn dissertatie Bestuurders van rechtspersonen, Deventer 1989, p. 104. Zie over de vraag wanneer er sprake is van onbehoorlijke taakvervulling van bestuurders in de zin van art. 2:9 BW met name H.J. de Kluiver, Aansprakelijkheid en décharge; 'een paar apart', WPNR 1997, p. 373 e.v., J.B. Huizink, Rechtspersonen losbladig art. 9, p. 9-4 en J.B. Wezeman, Aansprakelijkheid van bestuurders (diss.). Deventer 1998, m.n. p. 68-70.

12. Vgl, ook J.R. Glasz, H. Beckman en J. Bos, Bestuur en toezicht, Deventer 1994, p. 60. Voorstelbaar is dat de financiên en de organisatie van de informatievoorziening binnen een organisatie behoren tot het aandachtsveld van een bestuurder. Volgens Bos is dit aandachtsveld binnen het bestuur dan de bijzondere verantwoordelijkheid van die bestuurder. De overige bestuurders dragen echter de bijzondere verantwoordelijkheid voor een adequate bestuurlijke organisatie. Zij moeten ervoor zorgen dat het aandachtsveid niet ontspoort tot een 'one man' activiteit.

13. Dit brengt mee dat iedere bestuurder verplicht is 'nach besten Kralften für alle Zweige der Geschäftsführung zu sorgen, unberührt und gestaltet sich, soweit es sich nicht um die ihm besonders zugewiesenen Aufgaben handelt, zu einer Pflicht zur Überwachung des Mitgeschäftsführers', zie $\mathrm{M}$. Dreher, Die persônliche Verantwortlichkeit von Geschäftsleitern nach außen und die innergesellschaftliche Aufgabenteilung. ZGR 1992. p. 51 . 
aantonen dat hem geen verwijt treft terzake van het handelen of nalaten. ${ }^{14}$ In het Franse recht wordt de civielrechtelijke aansprakelijkheid van bestuurders ten opzichte van de vennootschap en ten opzichte van derden in één artikel neergelegd. Art. 244 L. 1966 bepaalt; 'les administrateurs sont responsables, individuellement ou solidairement, selon le cas, envers la société ou envers les tiers, soit des infractions aux dispositions législatives ou réglementairs applicables aux sociétés anonymes, soit des violations des statuts, soit des fautes commises dans leur gestion'.'Si plusieurs administrateurs ont coopéré aux mèmes faits, le tribunal détermine la part contributive de chacun dans la réparation du dommage'. Uit de laatste zin van dit artikel blijkt dat kennelijk rekening wordt gehouden met zekere werkverdeling. Echter, ook in het Franse recht lijkt te gelden dat een bestuurder aansprakelijk kan worden gehouden voor een handeling buiten zijn werkkring, ten aanzien waarvan hem een persoonlijk verwijt te maken valt. ${ }^{15}$ In het Engelse recht rust op elke bestuurder een 'duty of care (and skill)'. Deze wordt bepaald door 'the general knowledge, skill and experience that may reasonably be expected of a person carrying out the same functions as are carried out by that director'. ${ }^{16}$

\section{§ 2.2 Instructie en collectieve verantwoordelijkheid}

Een behoorlijke taakvervulling in de zin van art. 2:9 BW kan naar mijn mening onder omstandigheden ook meebrengen dat de aanwijzingen van de bestuursvoorzitter moeten worden gevolgd door de overige bestuursleden. Het bestaan van zo'n instructierecht vloeit echter niet rechtstreeks voort uit art. 2:9 BW, daar dit strijdig is met het collegialiteitsbeginsel.

Verdedigbaar is echter mijns inziens dat onder omstandigheden een instructierecht kan worden gebaseerd op de redelijkheid en billijkheid. De bestuursvoorzitter verkeert namelijk in een positie waarin hij het overzicht heeft over de gang van zaken in de onderneming en een zekere mate van toezicht kan uitoefenen op het beleid van de bestuurders. Daardoor is hij ook in staat om de betrokken belangen, en met name het belang van de vennootschap c.q. de onderneming, te behartigen.

Met andere woorden, ik meen dat de redelijkheid en billijkheid kan meebrengen dat onder omstandigheden afgeweken kan worden van het collegialiteitsbeginsel. Een instructierecht van de bestuursvoorzitter doet

14. Zie o.m. Henn, Handbuch des Aktienrechts, nr. 596. Zie voor wat betreft de GmbH $\S$ $43 \mathrm{GmbHG}$ en Lutter-Hommelhoff, Köln 1995, $\S 43$ GmbHG.

15. $\mathrm{Vgl}$. Cass. com. 22 janv. 1991. RDA 1992, nr. 152.

16. Vgl. Re D' Jan of London [1994] 1 BCLC 561, geciteerd uit Sealy, Cases and materials, nr. 143 en S. Goulding, Principles of company law, London 1996, p. 250. Zie ook H.J. de Kluiver, Aansprakelijkheid en décharge; 'een paar apart!' WPNR 1997, p. 374. 
naar mijn mening ook niet af aan de collectieve verantwoordelijkheid van het bestuur.

\section{\$ 2.3 Delegatie en collectieve verantwoordelijkheid}

Delegatie middels bestuursbesluit is ingevolge de Departementale Richtlijnen $^{17}$ weliswaar toegestaan, ${ }^{18}$ maar ik zou juist in verband met het beginsel van collectieve verantwoordelijkheid, wel enige terughoudendheid willen betrachten. In geval van delegatie worden immers bevoegheden (en daaraan gekoppeld verantwoordelijkheid) overgedragen aan een individuele bestuurder met als gevolg dat het bestuur (als college) geen zeggenschap meer over die bevoegdheden kan uitoefenen. Het lijkt er dus op dat beslissingen over bepaalde onderwerpen aan het bestuur worden onttrokken. Het probleem schuilt mijns inziens met name in de controle van het bestuur op de uitoefening van de gedelegeerde bevoegdheden door die bestuurder. Zolang het bestuur controle kan uitoefenen op de vervulling van de gedelegeerde bevoegdheden en taken, komt de collectieve verantwoordelijkheid niet in het gedrang. In dit kader lijkt gewenst dat bepaalde strikte voorwaarden worden verbonden aan de delegatie. Een regelmatige informatieverschaffing lijkt mij in ieder geval onontbeerlijk. ${ }^{19}$ Daarnaast kan men denken aan het geregeld rapporteren van de werkzaamheden.

$\mathrm{Vgl}$. ook Raiser die, in afwijking van de algemene opvatting in Duitsland op dit punt, ${ }^{20}$ delegatie wel toestaat, maar hierbij wel als eis stelt 'prâzise Vorgaben und Zustândig-

17. Zie Departementale Richtlijnen $\$ 8$, aant. 2.

18. Evenals in Nederland worden in Duitsland met name in grote organisaties de bestuurstaken verdeeld over de verschillende divisies (bijv. productdivisies) dan wel over de verschillende bestuursfuncties (bijv. financiële, economische juridische, technische aangelegenheden). Zie hieromtrent bijv. Eisenführ, Zur entscheidung zwischen funktionaler und divisionaler Organisation in: Grochla, Unternehmungsordnung 1972, p. 256 e.v.

19. Zie hieromtrent ook $\$ 4$.

20. In de Duitse doctrine geldt in het algemeen op dit punt eveneens een zeer restrictieve opvatting. Weliswaar kan het zo zijn dat de statuten een zekere taakverdeling toelaten, maar dit mag niet zover gaan dat het bestuur als college zijn taken delegeert aan een of meer bestuurders. Vgl. bijv. K-P. Martens, Der Grundsatz gemeinsamer Vorstandsverantwortung. FS Fleck 1988, p. 205, Mertens in Kölner Kommentar \$ 77 AktG Rdn. 9. 12 en Meyer-Landrut, $\$ 77$ Rdn 3. 
keitsregein aufzustellen und eine zuverlāssige Rückkoppelung und Kontrolle einzurichten'. In het Engelse vennootschapsrecht daarentegen wordt delegatie van bevoegdheden algemeen aanvaard. Het gaat hier met name om delegatie aan een of meer 'managing directors'. Echter, ook hier kunnen bestuurders allerlei voorwaarden aan delegatie verbinden. $\mathrm{Vgl}$. art. 72 Table A: "The directors may [..] delegate to any managing director[..]such of their powers as they consider desirable to be exercised by him. Any such delegation may be subject to any conditions the directors may impose, and either collaterally with or to the exclusion of their own powers and may be revoked or altered'.

\section{\$ 2.4 Mandaat en collectieve verantwoordelijkheid}

Het mandateren van bevoegdheden levert naar mijn mening minder problemen op. Mandaat lijkt sterk op de rechtsfiguur volmacht. ${ }^{22}$ Evenals bij volmacht gaat het bij mandaat om een bevoegdheid om in naam van een ander (volmachtgever, mandaatgever) rechtshandelingen te verrichten die aan de volmachtgever of de mandaatgever worden toegerekend. De verantwoordelijkheid blijft dan bij de mandaatgever (het bestuur). Mandatering leidt, in tegenstelling tot delegatie, niet tot 'uitholling' van het bestuur.

\section{§3. De rol van de bestuursvoorzitter nader bezien}

In het Nederlandse en Duitse recht is de leiding van de vennootschap in handen van een bestuur, waarop eventueel toezicht wordt uitgeoefend door een toezichthoudend orgaan zoals een raad van commissarissen. In het Franse recht, althans wat betreft de SA 'classique', is het de voorzitter, de président, die primair verantwoordelijk is voor het algemene, dagelijkse bestuur van de SA. Tevens roept hij de vergaderingen van het bestuur (conseil d'administration) bijeen en stelt de agenda daarvoor op. Bovendien kan de voorzitter in het geval dat de stemmen staken een doorslaggevende stem uitbrengen. ${ }^{23}$ De president oefent zijn bevoegdheden uit onder eigen verantwoordelijkheid en is daarvoor zelf aansprakelijk (art. 113 L. 1966).

21. T. Raiser. Recht der Kapitalgesellschaften, 1992 § 14, Rdn 63.

22. Zie voor overeenkomsten en verschillen tussen mandaat en volmacht. G.R.J. de Groot en A.A. van Rossum, Mandaat en volmacht, RM Themis 1993, p. 127 e.v.

23. Tenzij de statuten anders bepalen. $\mathrm{Vgl}$, art. 100 L. 1966 en Guyon, Droit des Affaires, nr. 342 . 
Hoe moet de positie van de bestuursvoorzitter in ons recht worden bezien? In de vorige paragraaf heb ik reeds aangegeven dat een wettelijke grondslag voor een speciale positie van de bestuursvoorzitter ontbreekt. Toch meen ik dat, hoewel er sprake is van een 'gelijke' positie van bestuurders, de voorzitter ook in het Nederlandse recht in zekere zin een andere plaats inneemt in het bestuur. Die brengt ook mee dat hij, tot op zekere hoogte, 'instructies' kan geven aan bestuurders. Voor mijn stelling zijn een tweetal argumenten aan te voeren.

In de eerste plaats kan aangevoerd worden dat een zeker 'overwicht' van de voorzitter in het bestuur, voortvloeit uit de coördinerende rol van de bestuurswerkzaamheden die de voorzitter veelal krijgt toebedeeld. Een afwijking van het collegialiteitsbeginsel kan daarom op grond van redelijkheid en billijkheid geoorloofd zijn.

In de tweede plaats zou ik willen wijzen op de rol die de bestuursvoorzitter speelt in het besluitvormingsproces. Alleen al het feit dat de voorzitter de vergaderingen leidt, geeft hem de mogelijkheid om meer invloed uit te oefenen op het besluitvormingsproces dan de overige bestuurders. Bovendien geldt in ons recht weliswaar als hoofdregel voor de besluitvorming in het bestuur dat aan iedere bestuurder één stem toekomt, ${ }^{24}$ maar statutair kan hiervan worden afgeweken. Het Departement laat toe dat een bestuurder meer dan één stem wordt toegekend, mits deze bestuurder alleen niet meer stemmen kan uitbrengen dan de andere bestuurders tezamen. ${ }^{25}$

Zie in gelijke zin het Duitse recht, zoals neergelegd in $\S 77$ Abs. 1 AktG, op grond waarvan het niet is toegestaan om in de statuten de bepaling op te nemen 'daß ein oder mehrere Vorstandsmitglieder Meinungsverschiedenheiten im Vorstand gegen die Mehrheit seiner Mitglieder entscheiden'.

24. Zie voor het Amerikaanse recht O'Neal \& Thompson, $\$ 4.12$.

25. Zie hieromtrent ook Asser-Maeijer 2-III, nr. 303 en Van Solinge, in: Van vennootschappelijk belang, 1988, p. 312 . Wetsontwerp 26.277 voorziet er in deze regel in de artikelen 2:129 en 2:239 in Boek 2 BW te verankeren. Zie M.J.A. van Mourik. Herziening van het preventief toezicht, WPNR 1999, p. 103. 
In de praktijk komt deze regel natuurlijk wel heel dicht bij de situatie waarin een bestuursvoorzitter de besluitvorming kan overheersen. ${ }^{26}$

In het Duitse, Anglo-Amerikaanse en Franse recht is de heersende opvatting dat een doorslaggevende stem van de voorzitter (of de presidentdirecteur), in geval van een impasse in de besluitvorming, toelaatbaar wordt geacht. ${ }^{27}$ Ook voor het Nederlandse recht kan dit worden aangenomen. De Departementale Richtlijnen staan in $\S 8$ toe dat bij staking van stemmen de beslissing aan een ander vennootschapsorgaan kan worden opgedragen.

Een andere vraag die in dit kader opkomt is of een bestuursvoorzitter de beschikking heeft over een vetorecht om een meerderheidsbesluit te blokkeren. Dit gaat verder dan de situatie waarin een bestuursvoorzitter evenveel stemmen heeft als de andere bestuurders gezamenlijk. In beginsel meen ik dat een vetorecht niet toekomt aan een bestuursvoorzitter. ${ }^{28}$ Indien er sprake is van een zwaarwichtig belang van de vennootschap, is het wel denkbaar dat de redelijkheid en billijkheid met zich kan brengen dat een bestuursvoorzitter de vergadering verdaagt.

Het voorgaande overziende kan de vraag gesteld worden of de enigszins 'bijzondere' plaats die de bestuursvoorzitter in feite inneemt in het bestuur consequenties heeft voor de verantwoordelijkheid en aansprakelijkheid van de bestuursvoorzitter. Ik zou menen dat een bestuursvoorzitter, vanwege de coördinerende rol, moeilijk zal kunnen aantonen dat een bepaalde aangelegenheid niet tot zijn werkkring behoort. En voorzover dat wel kan worden aangetoond kan dat op zichzelf al weer voldoende reden zijn om aan te nemen dat hij als voorzitter zijn taak onzorgvuldig heeft vervuld omdat voor een adequate coördinatie vereist is dat de voorzitter inzicht heeft in alle relevante aangelegenheden van de vennootschap. Voorts zal het feit dat de voorzitter op de hoogte moet zijn van alle

26. Zoals Van Schilfgaarde in zijn artikel 'Contractuele structurering van bestuur en toezicht', in de bundel Ondernemingsrechtelijke contracten, Deventer 1991, p. 11 e.v. terecht stelt kan een president-directeur 'het onderste uit de kan halen' indien een stichting waarvan de president-directeur de enige directeur is tot mede-bestuurder van de vennootschap wordt benoemd.

27. $\mathrm{Vgl}$. voor het Duitse recht T. Bezzenberger, Der Vorstandsvorsitzende, ZGR 1996, $\mathrm{p}$ $669 / 670$ en H.J. Priester, Stichentscheid bei Zweiköpfigem Vorstand, Die AG 1984, p. 253 e. v. Zie voor het Amerikaanse recht O'Neal \& Thompson, $\$ 4.12$.

28. Evenzo in het Duitse recht. Zie B. Erle, Das Vetorecht des Vorstandsvorsitzenden in der AG. Die AG 1987, p. 7-12. 
aangelegenheden naar mijn mening een eventueel beroep op disculpatie van art. 2:9 BW bemoeilijken.

\section{\$4. Informatie en overleg}

Het collegiale karakter van het bestuursorgaan brengt mee dat beslissingen worden genomen door het orgaan als zodanig. Gezien de aard van de taken van het bestuur, die met name bestaan uit het voorbereiden, vaststellen en uitvoeren van beleid met de strekking om de doelstellingen van de organisatie te realiseren, is volledige en juiste informatie onontbeerlijk. Ook zal een effectieve vervulling van de bestuurstaken, veelal samenwerking en overleg tussen bestuurders vergen. In hoeverre hebben bestuurders een aanspraak op informatie c.q. overleg?

Voor het beantwoorden van deze vraag is het mijns inziens zinvol om een onderscheid te maken tussen functies, taken en bevoegdheden van bestuurders. Een bestuurder maakt in het kader van zijn functie deel uit van het bestuursorgaan. Het bestuur speelt een bepaalde rol in de organisatie van de rechtspersoon. Daaruit worden bepaalde bestuurstaken afgeleid. Ter uitvoering van die taken zijn bevoegdheden toebedeeld aan het bestuur c.q. bestuurders. ${ }^{29}$ Een bestuurder draagt uit hoofde van zijn functie naast zijn verantwoordelijkheid voor de 'eigen' werkkring ook verantwoordelijkheid voor wat betreft de collectieve taakvervulling door het orgaan. Een bestuurder heeft derhalve niet alleen informatie nodig om een juiste uitoefening van zijn taken en bevoegheden te bewerkstelligen, maar hij dient ook op de hoogte te zijn van de hoofdlijnen van het beleid van de andere orgaanleden.

Kortom, een bestuurder heeft naar mijn mening recht op informatie van zijn mede-bestuurders, ook indien die informatie ziet op taken die niet tot zijn takenpakket behoren. Informatierechten en -plichten zijn naar mijn mening gerelateerd aan de functie van bestuurder (curs. MK). ${ }^{30}$ Zo

29. $\mathrm{Vgl}$. hieromtrent ook J.B. Huizink, Bestuurders van rechtspersonen, Kluwer 1989, p. 16.

30. Een andere kwestie betreft het gebruiken van informatie. Onder bepaalde omstandigheden mag een bestuurder geen gebruik maken van informatie van de vennootschap. $\mathrm{Te}$ denken valt aan de situatie waarin een bestuurder zijn persoonlijke belangen boven het belang van de vennootschap stelt. We komen hier op het terrein van de corporate opportunities problematiek, vgl. hieromtrent H 10. Zie hieromtrent ook K.J. Hopt, SelfDealing and Use of Corporate opportunity and Information: Regulating Directors' 
hebben individuele bestuurders uit hoofde van hun functie tot taak om te participeren in de besluitvorming, hetgeen impliceert dat bestuurders in ieder geval een recht op informatie hebben ter vergadering. ${ }^{31}$ Echter, ook buiten de vergadering kan behoefte bestaan aan informatie. Voorafgaande aan de vergadering hebben bestuurders informatie nodig teneinde zich voor te bereiden op onderwerpen die ter vergadering aan de orde zullen komen. Informatie die niet gerelateerd is aan de uitoefening van de functie van een bestuurder, ${ }^{32}$ kan achterwege blijven.

Het informatierecht van bestuurders vloeit mijns inziens voort uit de redelijkheid en billijkheid. Ook in het Engelse, Duitse en Franse recht wordt het recht van bestuurders op informatie zonder meer erkend.

In het Franse recht is deze kwestie lange tijd een discussiepunt geweest. Een tweetal uitspraken van de Cour de Cassation heeft daaraan echter een einde gemaakt. In 1985 velt de Cour de Cassation zijn oordeel in de zgn. Cointreau-zaak." De leden van de conseil d'administration van Rémy-Martin S.A. worden opgeroepen voor een vergadering met de volgende agendapunten; een verslag van de président over de ontwikkeling van het vermogen van de vennootschap, over het beleid van de dochters en over het oprichten van dochterondernemingen voor distributie en produktie. Eén bestuurder, Mme G. Cointreau is van oordeel dat het belang van de onderwerpen die op de agenda staan, vereist dat vóór de vergadering informatic wordt verschaft. $Z_{i j}$ verzoekt de rechter om verdaging van de vergadering en inzage in diverse documenten met betrekking tot de agenda.

De Président van het Tribunal de commerce de Cognac wijst haar verzoek af. In hoget beroep wordt bevestigd door het Cour d'appel van Bordeaux. De afwijzing wordt gemotiveerd op de grond dat de wet niets bepaalt omtrent een informatierecht ('qu'aucune disposition légale n'impose au président du conseil d'administration de joindre à la convoca-

Conflicts of Interest, in: Corporate Governance and Directors' Liabilities, Berlijn 1985. p. 302.

31. In zekere zin is hier sprake van een parallel met een individuele aandeelhouder die aan zijn participatie in de besluitvorming een afgeleid recht op informatie kan ontlenen en zijn recht op informatie in beginsel alleen kan uitoefenen op de vergadering van andeelhouders. Vgl. Rechtspersonen (losbladig) ant. 107, aant. 5, Pres. Rb. Amsterdam, KG 1988, 276 en Handboek nr. 203.1.

32. Zie voor het Franse recht bijv. Lamy Droit des Sociétés 1996, p. 1345. Zie met betrekking tot het Amerikaanse recht de Principles of Corporate Governance $\$ 3.03$. $b(1):$ a judicial order to enforce such right (informatierecht) should be granted unless the corporation establishes that the information to be obtained by the exercise of the right is not reasonably related to the performance of the directorial functions and duties, or that the director or the director's agent is likely to use the information in a manner that would violate the director's fiduciary obligation to the corporation'.

33. Cass. com. 2 juillet 1985. D. 1986, p. 351, Rev. Soc. 1986, p. 231 met noot van P. Le Cannu en Bull.Joly 1985, p. 919. 
tion qu'il adresse aux membres de celui-ci, son projet de rapport ou des documents iconomiques et financiers se rapportant à l'ordre du jour'). Uiteindelijk stelt de Cour de Cassation haar wel in het gelijk. De Cour de Cassation is van oordeel dat de président van het conseil 'doit mettre les administrateurs en mesure de remplir leur mission en toute connaissance de cause'. Met andere woorden, de président moet er voor zorgdragen dat de bestuurders met volledige kennis van zaken hun taken kunnen vervullen. Bovendien verwijt de Cour de Cassation het Cour d'appel niet onderzocht te hebben 'si Mme. Cointreau avait recu au préalable et dans un délai suffisant l'information à la quelle elle avait droit'.

Voorts vermeld ik de uitspraak inzake de Dennery-affaire." In deze zaak stond de vrag centraal of een bestuurder die niet aanwezig was geweest in een bestuursvergadering. waarin het salaris van de président werd vastgesteld, recht heeft op een kopie van de notulen van de vergadering. Het Cour d'appel weigert de vennootschap te veroordelen om een kopie van de gevraagde notulen te verschaffen aan de bestuurder Dennery, met het argument dat er geen wettelijke of statutaire bepaling is op grond waarvan de vennootschap gehouden is een kopie van de beraadslaging te verschaffen. Ook in deze zaak wijst de Cour de Cassation de vordering toe: 'le président du conseil d'administration doit mettre les membres de celui-ci en mesure de recevoir les informations qui leur sont nécessaires'.

Wat betreft de overlegplichten binnen het bestuur, biedt de door de Hoge Raad in het Wijsmuller-arrest ${ }^{35}$ geformuleerde regel een belangrijk aanknopingspunt: besluiten van een meerhoofdig orgaan dienen tot stand te komen als vrucht van onderling overleg van alle leden van het betrokken orgaan die na daartoe in de gelegenheid te zijn gesteld, aan dat overleg wensen deel te nemen. Onduidelijk blijft echter hoe deze regel in de praktijk moet worden toegepast.

Bij het beantwoorden van de vraag in hoeverre een overlegverplichting op zijn plaats is zal, veel meer dan bij informatierechten en -plichten, de taakverdeling tussen de leden van een orgaan meewegen. De redelijkheid en billijkheid brengt mijns inziens mee dat een lid van een bestuur in beginsel aanspraak heeft op overleg indien er beslissingen worden genomen die tot zijn takenpakket behoren. Gaat het daarentegen om beslissingen die betrekking hebben op andere taken, dan kan verdedigd worden dat overleg niet hoeft plaats te vinden. De verplichting tot overleg is derhalve naar mijn mening gerelateerd aan de taken van bestuurders.

34. Cour de Cassation 1 december 1987, Rev. Soc. 1988, 237 (nt. P. le Cannu).

35. HR 15 juli 1968, NJ 1969, 101. Zie omtrent het oude artikel 47 a Koophandel Ktg Amsterdam 17 mei 1935 (NJ 1937, 720): '[..] dat bij meerhoofdige directie het optreden naar buiten steeds moet kunnen worden geschraagd door de mogelijkheid van gemeenschappelijk overleg tussen de leden der directie onderling...' 
Een andere factor die de mate van overleg kan beïnvloeden is of de besluitvorming in of buiten vergadering geschiedt. Wat betreft de besluitvorming buiten vergadering, geeft het Departement als richtlijn dat de statuten moeten bepalen dat algemene stemmen zijn vereist of dat aan alle bestuurders moet zijn bericht dat zij de gelegenheid hebben zich uit te spreken omtrent een bepaald voorstel. Uit deze mijns inziens summiere eis voor besluitvorming buiten vergadering ${ }^{36}$ kan worden afgeleid dat overleg maar zeer beperkt mogelijk is.

Ten slotte meen ik dat een tegenstrijdig belang van een bestuurder met betrekking tot een bepaalde kwestie, gevolgen kan hebben voor de aanspraak op c.q plicht tot overleg. Naar mijn mening kan worden verdedigd dat de redelijkheid en billijkheid meebrengt dat de bestuurder in zo'n geval wordt uitgesloten van de beraadslaging omtrent die kwestie. Dit impliceert dat een bestuurder dan ook geen aanspraak kan maken op overleg. Het is immers van belang dat de besluitvorming niet op ongeoorloofde wijze wordt beïnvloed. ${ }^{37}$

\section{§ 5. Gedrag van bestuurders: afwezigheid ter vergadering}

Het bestuurdersschap bestaat mede uit de participatie in de besluitvorming van het bestuur. Het bestuur functioneert doordat bestuurders de bestuursvergadering bijwonen, deelnemen aan de beraadslaging en vervolgens de hun toekomende stemrechten ter vergadering uitoefenen. In de praktijk wordt overigens in bestuursvergaderingen niet vaak gestemd.

In de literatuur en rechtspraak bestaat er geen twijfel over dat elke bestuurder moet worden opgeroepen voor de bestuursvergadering. Iedere bestuurder moet immers in staat worden gesteld om zijn standpunt naar voren te brengen en argumenten aan te voeren om zijn mede-bestuurders ter vergadering te overtuigen van zijn visie.

Het komt echter regelmatig voor dat een bestuurder niet in staat is een bestuursvergadering bij te wonen, omdat hij voor enige tijd in het buitenland vertoeft of ziek is. Bij afwezigheid van een bestuurder ter bestuursvergadering komt de vraag op naar eventuele juridische consequenties

36. Evenzo Dortmond, De NV 1986, p. 175.

37. Vgl, B.H.A. van Leeuwen. TVVS 1987, p. 30/31. 
daarvan. ${ }^{38}$ Bovendien rijst de vraag of er juridische mogelijkheden zijn om de afwezigheid van een bestuurder te compenseren. Als mogelijkheid kan hier met name worden gedacht aan het verlenen van een volmacht. Aangezien een wettelijke basis voor zo'n volmacht ontbreekt en dikwijls ook de statuten hierin niet voorzien, wordt een en ander beheerst door de norm van redelijkheid en billijkheid.

\section{\$ 5.1 Is een 'bestuurdersvolmacht' zinvol?}

Volmacht is één van de machtigste instrumenten voor aandeelhouders om hun krachten te bundelen en gezamenlijk macht uit te oefenen in de ava. Indien een aandeelhouder niet in staat is om, vanwege gebrek aan tijd of bekwaamheid, in de ava voor zijn belangen op te komen, kan deze een volmacht geven aan iemand die wel over de tijd c.q. capaciteiten beschikt om die belangen te behartigen (art. 2:117/227 lid 1 BW). ${ }^{39}$ Voor bestuurders daarentegen geldt, dat er binnen de organisatie geen ruimte is om eigen belangen te kunnen en mogen na te streven. Wat kan volmacht nu voor bestuurders betekenen?

Uit de rechtspraak blijkt dat de geldigheid van besluitvorming niet afhankelijk is van de voltalligheid van het bestuur. ${ }^{40}$ Deze visie onderschrijf ik, aangezien dit de continuilteit in de besluitvorming van het bestuur bevordert. Een vennootschap kan immers slechts functioneren indien er sprake is van continuitteit in de besluitvorming. Een afwezige bestuurder kan overigens wel zijn standpunt kenbaar maken. Door de technologische ontwikkelingen behoren bijvoorbeeld 'conference-calls' tot de mogelijkheden. Een interessante vraag is of bestuurders die telefonisch meevergaderen, tot het quorum kunnen worden meegerekend. Ik zou deze vraag bevestigend willen beantwoorden. De bestuurder is wel aanwezig, doch niet in persoon. De redelijkheid en billijkheid brengt naar mijn mening mee dat zo'n standpunt tijdens de vergadering in aanmerking moet worden genomen.

38. Het bijwonen van bestuursvergaderingen behoort immers tot hun bestuurstaak. Regelmatige afwezigheid van een bestuurder zou mijns inziens onbehoorlijke taakvervulling kunnen opleveren.

39. Vgl. ook W. J. Slagter, Gebundelde actièn in de bundel Goed \& Trouw 1984, p. 237.

40. Vgl. HR 17 september 1993, NJ 1994, 548 m.nt. Maeijer en M.J.G.C. Raaijmakers, AA 1994. p. 765-771. Zie ook H.J. de Kluiver in S \& V 1993. p. 168 en PitloLôwensteyn, p. 155. 
In het geval een bestuurder niet in de gelegenheid is om mee te vergaderen, moet de vergadering wat betreft niet-dringende agendapunten mijns inziens worden verdaagd. Dit is anders indien het gaat om dringende kwesties waarover niet kan worden besloten doordat een bepaald quorum niet wordt gehaald. Bij het bepalen van de dringendheid van een kwestie is naar mijn mening in ieder geval van belang de termijn waarbinnen een besluit daaromtrent moet worden genomen. Voorts moet het belang van de vennootschap en/of het belang van de onderneming zo'n besluit van het bestuur vergen. Te denken valt aan zwaarwegende bedrijfseconomische of bedrijfsorganisatorische kwesties. In zo'n geval acht ik volmacht een nuttig instrument voor bestuurders, die niet in de gelegenheid zijn om zelf ter vergadering te verschijnen en aldaar het stemrecht uit te oefenen. Anderzijds is het denkbaar dat (de corrigerende werking van) de redelijkheid en billijkheid met zich meebrengt dat het bestưur ook zonder het quorum het besluit kan nemen.

\section{§ 5.2 Toelaatbaarheid volmacht}

Ik zou willen aannemen dat een bestuurder aan wie de hoogst persoonlijke en functioneel bepaalde bevoegdheid ${ }^{41}$ toekomt om binnen het bestuur stem uit te brengen, slechts een volmacht tot het uitoefenen van stem mag verstrekken, indien hij een goede reden heeft om de vergadering waarin het stemrecht moet worden uitgeoefend niet zelf bij te wonen. ${ }^{42}$ Een goede reden voor de afwezigheid van een bestuurder acht ik bijvoorbeeld ziekte of een verblijf in het buitenland uit hoofde van zijn taak. Voorts ben ik van mening dat het, zoals ik hierboven reeds heb aangegeven, moet gaan om dringende kwesties.

Het hoogst persoonlijke karakter van de bevoegdheid om stemrecht uit te oefenen, brengt mijns inziens voorts mee dat slechts een volmacht mag

41. Zie voor het Belgische recht K. Geens, die de mening verkondigt dat het 'buiten kijf staat dat het stemrecht van bestuurders, zoals de bestuursbevoegdheid in het algemeen. een functionele bevoegdheid is. Het functioneel karakter van de bestuursbevoegdheid impliceert dat zij uitsluitend in het belang van de vennootschap mag worden uitgeocfend'. Zie De jurisprudentiēle bescherming van de minderheidsaandeelhouder tegen door de meerderheid opgezette beschermingsconstructies, TPR 1990, p. 42.

42. In het Handboek, nr. 233 wordt de opvatting verdedigd dat het verlenen van een volmacht toelaatbaar is indien een bestuurder redelijkerwijs niet in de gelegenheid is de bestuursvergadering bij te wonen. 
worden verleend aan een ander lid van het orgaan waarvan een bestuurder deel uitmaakt. Volmacht is een zodanig direct met het functioneren van het bestuur (en de vennootschap) verbonden instrument, dat het onwenselijk is om het stemrecht te laten uitoefenen door anderen dan bestuurders. $^{43}$

Ook in het Franse recht wordt (in Décret 1967 art. 83-1) de opvatting gedeeld dat volmacht slechts verleend kan worden aan een andere bestuurder en schriftelijk, per brief of telegram, moet worden gegeven. Toegevoegd wordt bovendien de bepaling dat een bestuurder niet meer dan één andere bestuurder mag vertegenwoordigen op een bestuursvergadering. De achterliggende gedachte van deze beperking is dat een bestuurder die over verschillende volmachten beschikt de beraadslaging zou kunnen overheersen."

Niet iedere bestuurder mag naar mijn mening een volmacht verlenen. Een bestuurder die geen stem mag uitbrengen wegens een tegenstrijdig belang. mag mijns inziens ook geen stem laten uitbrengen middels een gevolmachtigde.

Een in de tijd onbeperkte volmacht en ook een onherroepelijke volmacht acht ik in beginsel niet toelaatbaar. $\mathrm{Z}_{\mathrm{ij}}$ verdragen zich niet met het feit dat het stemrecht aan de bestuurder of commissaris niet in zijn eigen belang is toegekend. Voor wat betreft de onherroepelijke volmacht is dit naar mijn mening slechts anders indien deze wordt gebruikt ter nakoming van een stemovereenkomst tussen bestuurders in de bijzondere gevallen dat deze geoorloofd is. Dit is het geval indien de stemovereenkomst in het belang van de vennootschap wordt aangegaan.

\section{§5.3 Gedrag gevolmachtigde}

Aangezien in mijn optiek de gevolmachtigde van een bestuurder slechts een andere bestuurder van de vennootschap kan zijn, wordt de verhouding tussen deze bestuurders beheerst door de redelijkheid en billijkheid van art. 2:8 BW. Op de gevolmachtigde rust de verplichting om het stemrecht zodanig uit te oefenen dat dit strookt met het belang van de vennootschap en de met haar verbonden onderneming. De gevolmachtigde mag in geen

43. Zo schrijft Van der Grinten over het bestuur in de NV nr. 39, p. 119 dat: "het essentièle van de bestuursmacht niet zozeer is de vertegenwoordigingsbevoegdheid als wel het bezit van de hoogste zeggensmacht in bestuursaangelegenheden'.

44. $\mathrm{Vgl}$. Guyon, Droit des affaires, nr. 336. 
geval door zijn handelen de vennootschap en de bij haar betrokkenen schaden. Dit betekent bijvoorbeeld dat indien de gevolmachtigde ontdekt dat de volmachtgever een belang heeft, dat onverenigbaar is met het belang van de vennootschap hij dat zal moeten melden op de bestuursvergadering.

De redelijkheid en billijkheid brengt met zich dat een gevolmachtigde zijn standpunt en de wijze waarop hij van een volmacht gebruik maakt, (mede) mag laten bepalen door het overleg binnen het bestuur. Het probleem dat zich immers vaak voordoet is dat pas na het geven van de volmacht over een bepaalde kwestie, omstandigheden bekend worden die een andere beoordeling van de zaak vergen. Ook zal de gedachtenwisseling tijdens de vergadering een zodanig ander licht op een bepaalde kwestie kunnen werpen, dat een wijziging in de beoordeling van de kwestie noodzakelijk is.

\section{§ 6. Schriftelijke besluitvorming}

Als uitgangspunt van de collegiale besluitvorming geldt dat alle bestuurders moeten worden uitgenodigd om aan de beraadslaging deel te nemen. Betekent dit nu dat aan elk besluit van het bestuur een beraadslaging in het college vooraf dient te gaan? De vraag rijst hier of en onder welke omstandigheden het bestuur ook zonder beraadslaging een schriftelijk besluit kan nemen en welke eisen aan schriftelijke besluitvorming moeten worden gesteld. ${ }^{45}$

Aan deze wijze van besluitvorming bestaat in de praktijk steeds meer behoefte vanwege de sterke internationalisering van het bedrijfsleven.

België kan met betrekking tot deze kwestie als een voorloper worden beschouwd. De wetgever heeft hier, middels de wetswijzigiging van 13 april 1995, de mogelijkheid van schriftelijke besluitvorming uitdrukkelijk vastgelegd in art. 67 van de Vennootschapswet, zij het dat strenge eisen hieraan verbonden zijn. ${ }^{46}$ Zo geldt allereerst de eis dat de statuten schriftelijke besluitvorming van het bestuur moeten toelaten. Voorts bepaalt art. 67 lid 3 dat schriftelijke besluitvorming moet worden aangewend indien

45. Zie hieromtrent ook H. Laga, Kan de raad van bestuur geldig besluiten zonder effectief bijeen te komen, TRV 1992, p. 340-342.

46. Zie E. Wymeersch, Nieuwe regelen inzake bestuur, in: Het gewijzigde vennootschaps: recht, Antwerpen 1986 p. 114 e.v. 
zich een dringende noodzaak voordoet en het belang van de vennootschap dit vereist. Daarenboven verbiedt de wet schriftelijke besluitvorming inzake een aantal onderwerpen, zoals besluiten over het vergroten van het vennootschappelijk kapitaal. ${ }^{47}$

Ook voor het Nederlandse recht moet een schriftelijke besluitvorming voor het bestuur worden aanvaard. En dan niet alleen, zoals voor de ava is bepaald in art. 2:128/238 BW, in de situatie waarin de statuten hierin voorzien.

Wel zou ik menen dat niet onder elke omstandigheid schriftelijke besluitvorming toelaatbaar is. Vooropgesteld dient mijns inziens te worden dat bestuurders de vergaderingen bij dienen te wonen en dat schriftelijke besluitvorming slechts dan geoorloofd is indien er sprake is van omstandigheden die een goede reden daarvoor opleveren. De omstandigheid dat een bestuurder verhinderd is om op een bepaalde vergadering aanwezig te zijn, levert geen goede reden op. In zijn afwezigheid kan dan immers gebruik worden gemaakt van volmacht.

Het belang van de vennootschap, dat als criterium wordt gehanteerd in het Belgische recht komt mij ook voor het Nederlandse recht als een aannemelijk criterium voor. Zo is het in het belang van de vennootschap indien snel beslist kan worden over de vraag of een bepaalde 'corporate opportunity' al dan niet wordt benut. De eis van 'dringende noodzaak' is naar mijn mening overigens al vervat in het criterium 'belang van de vennootschap'. Indien de vennootschap schade kan ondervinden doordat niet op korte termijn een besluit kan worden genomen, ligt de noodzaak van een schriftelijke besluitvorming voor de hand.

\section{\$7. Slotbeschouwing}

In dit slothoofdstuk bezag ik de organisatie en de besluitvorming van het vennootschapsbestuur. De praktijk van het management geeft aanleiding tot de juridische vraag of en in hoeverre delegatie, mandaat en instructie binnen het bestuur van een kapitaalvennootschap toelaatbaar is. Deze vraag moet worden beschouwd in het licht van het in ons recht geldende collegialiteitsbeginsel en, daaruit voortvloeiend, de collectieve verantwoordelijkheid voor de taakvervulling door het bestuur. Deze collectieve verantwoordelijkheid is mijns inziens in het belang van de vennootschap.

47. Zie E. Wymeersch, t.a.p. p. 117. 
Maar ook de redelijkheid en billijkheid die de verhouding tussen bestuurders mede beheerst, levert een bijdrage aan bovengenoemde vraag.

Een zekere werkverdeling tussen bestuurders onderling wordt in het Nederlandse recht in het algemeen aanvaard, daar dit de collectieve verantwoordelijkheid voor een behoorlijke uitvoering van de bestuurstaken onverlet laat. ${ }^{48}$ Een behoorlijke taakvervulling in het belang van de vennootschap impliceert dat iedere bestuurder zich zal moeten inspannen om, voorzover mogelijk, de onbehoorlijke taakuitoefening van een andere bestuurder te beëindigen en de schadelijke gevolgen daarvan te beperken. ${ }^{49}$

In mijn optiek bestaat er in het Nederlandse vennootschapsrecht ook ruimte voor mandaat en delegatie. Mandatering van bevoegdheden levert in het kader van de collectieve verantwoordelijkheid geen problemen op. De gemandateerde bevoegdheden blijven immers ter beschikking van het bestuur als college, dat op elk moment de bevoegdheden weer aan zich kan trekken.

Enige terughoudendheid is echter geboden ten opzichte van delegatie van bevoegdheden. Kernpunt is mijns inziens dat een delegatie 'controleerbaar' moet zijn. Alleen in dat geval kan het bestuur zijn collectieve verantwoordelijkheid 'waarmaken'. ${ }^{30}$ Ik verdedig derhalve dat delegatie slechts kan plaatsvinden onder een aantal strikte voorwaarden, zoals een regelmatige en juiste informatieverschaffing.

Ook de situatie waarin een bestuursvoorzitter instructies geeft aan zijn mede-bestuurders kan mijns inziens een redelijke en billijke 'afwijking' van het collegialiteitsbeginsel zijn. Als essentieel hierbij beschouw ik de bijzondere positie die een bestuursvoorzitter inneemt in het bestuur. Wel meen ik dat die positie van invloed kan zijn op de zwaarte van de verantwoordelijkheid (en eventueel aansprakelijkheid) van de bestuursvoorzitter.

48. Dit blijkt ook recentelijk uit HR 10 januari 1997, NJ 1997, 360 (Staleman/Van der Ven), waarin de Hoge Raad bij de beoordeling van het bestuursgedrag met zoveel woorden de taakverdeling binnen het bestuur als omstandigheid meeweegt.

49. Zie in deze zin ook P. van Schilfgaarde, Misbruik van rechtspersonen, Deventer 1986. p. 18 en Van de BV en NV. nr. 47, L. Timmerman, Aansprakelijkheid van bestuurders van nv's en bv's; een overzicht van enige recente rechtspraak. TVVS 1991, p. 200 en J.B. Wezeman, Aansprakelijkheid van bestuurders, Deventer 1998, p. 72.

50. $\mathrm{Vgl}$, in die zin ook Dijk-Van der Ploeg, p. 185: 'Ook voor de gedelegeerde bevoegdheden blijft het bestuur als geheel in principe verantwoordelijk: 
Wat betreft de besluitvorming in een vennootschapsbestuur, heb ik aandacht besteed aan de vraag in hoeverre er overleg- en informatieplichten c.q. overleg - en informatierechten bestaan voor bestuurders. Bij het beantwoorden van deze vraag, verdedig ik dat informatierechten en -plichten inherent zijn aan de functie van bestuurder en dat bij de overlegplichten de takkverdeling binnen het bestuur een belangrijke rol speelt. Hiermee heb ik getracht de uitspraak van de Hoge Raad inzake Wijsmuller uit te werken voor de bestuurspraktijk.

Ten slotte ga ik in op twee 'instrumenten' die de besluitvorming en het functioneren van het bestuur ten goede kunnen komen in geval van 'absenteïsme' van één of meer bestuurders. Het gaat hier om de mogelijkheden tot het verlenen van volmacht en schriftelijke besluitvorming. Vanwege het functionele karakter van de bestuursbevoegdheid ben ik terughoudend waar het betreft de toelaatbaarheid van een "bestuurdersvolmacht'. Zo meen ik dat een volmacht slechts mag worden verleend aan een andere bestuurder. ${ }^{51}$ Een schriftelijke besluitvorming kan noodzakelijk zijn in het kader van een goed functioneren van de vennootschapsbestuur. Ik pleit derhalve voor het uitdrukkelijk regelen van deze mogelijkheid in het Nederlandse recht.

51. Hierin sta ik niet alleen. Zie bijvoorbeeid ook Asser-Maeijer 2-III, nr. 306. 



\section{Afsluitende beschouwing}

\section{§1. Inleiding}

In dit boek staat centraal de betekenis en functie van de redelijkheid en billijkheid in kapitaalvennootschappen in het bijzonder in de verhouding tussen meerderheids- en minderheidsaandeelhouders, in de verhouding tussen de algemene vergadering van aandeelhouders en het bestuur, en in de verhouding tussen bestuurders. Die functie en betekenis is bezien aan de hand van beschouwingen over gedragingen en besluiten die bovengenoemde verhoudingen beïnvloeden.

In Nederland bestaat tot nu toe geen duidelijk beeld van het 'functioneren' van de redelijkheid en billijkheid in de verhoudingen binnen de rechtspersoon. In dit boek heb ik getracht een bijdrage te leveren aan de ontwikkeling van duidelijker regels van redelijkheid en billijkheid in de voornoemde verhoudingen binnen kapitaalvennootschappen. Nu het eigen (Nederlandse) recht en de rechtsliteratuur nog vele vragen open laten met betrekking tot de vraag naar de functie en betekenis van redelijkheid en billijkheid in het rechtspersonenrecht heb ik veel aandacht besteed aan rechtsvergelijking. Bij de analyse van conflicten die zich voor (kunnen) doen in kapitaalvennootschappen zijn derhalve mede betrokken het recht van twee continentale landen, Duitsland en Frankrijk, alsmede Engeland als representant van de common law traditie.

Doel van dit afsluitende hoofdstuk is enerzijds aan te geven hoe de redelijkheid en billijkheid in de door mij onderzochte verhoudingen binnen een kapitaalvennootschap functioneert. Anderzijds tracht ik enkele richtlijnen te geven aangaande de concretisering van de redelijkheid en billijkheid in die verhoudingen. In dit kader zal ik tevens de overeenkomsten en verschillen met het buitenlandse recht aankaarten.

\section{\$2. Redelijkheid en billijkheid in rechtsvergelijkend perspectief}

\section{\$2.1 Functioneel vergelijkbare rechtsfiguren}

In mijn onderzoek staat centraal hoe en in welke mate in het Nederlandse en buitenlandse recht met betrekking tot kapitaalvennootschappen wordt omgegaan met het 'goede trouw' beginsel. In dit kader heb ik bewust 
gekozen voor een functionele benadering, waarin een analyse van problemen voorop staat. Vastgesteld kan worden dat in het buitenlandse recht met redelijkheid en billijkheid vergelijkbare beoordelingsnormen voor het gedrag van betrokkenen aanwezig zijn, zij het dat de terminologie, de betekenis en de reikwijdte daarvan verschillen. In het Engelse vennootschapsrecht biedt het stelsel van 'fiduciary duties' vergelijkingsmateriaal. Als essentieel daarbij wordt beschouwd dat er sprake is van een 'fiduciary relationship'. Daarnaast wordt, voorzover het gedragingen van (meerderheids)aandeelhouders betreft, door de jurisprudentie rond section $459 \mathrm{CA}$ 1985 , invulling gegeven aan de 'goede trouw'. In het Duitse recht normeert de 'Treuepflicht' de gedragingen van aandeelhouders en bestuurders. Zoals in het Nederlandse recht de notie van misbruik van recht en misbruik van (meerderheids)macht wordt geabsorbeerd door de redelijkheid en billijkheid (zie hoofdstuk 1), wordt in het Duitse recht het leerstuk van misbruik van recht geabsorbeerd door de Treupflicht. In Frankrijk daarentegen wordt de rol van de 'goede trouw' in het vennootschapsrecht juist geplaatst in het teken van misbruik van recht, misbruik van meerderheids- of minderheidsmacht ('abus de majorité/'abus de minorité) en misbruik van bevoegdheid ('abus de pouvoirs'). Daarnaast gaat echter in recente jurisprudentie van de Cour de Cassation de verplichting tot loyaliteit voor bestuurders ook zelfstandig betekenis krijgen (vgl. hoofdstuk $2 \S 3.1$ en $\S 4.3$ ).

\section{\$ 3 Verhouding tussen meerderheids- en minderheidsaandeelhou- der(s)}

In het eerste deel van mijn onderzoek heb ik getracht te inventariseren welke soorten van conflicten kunnen ontstaan in de verhouding tussen meerderheids- en minderheidsaandeelhouder(s). In dat kader heb ik een onderscheid gemaakt tussen conflicten met betrekking tot het besluitvormingsproces rond - en in - de algemene vergadering van aandeelhouders, en conflicten met betrekking tot de inhoud van de te nemen besluiten. In hoofdstuk 2 werd belicht dat in alle onderzochte rechtsstelsels geldt dat de macht van de meerderheidsaandeelhouder niet onbeperkt is. De uitwerking van die gedachte verschilt echter. Om tot een zinvolle analyse en vergelijking te (kunnen) komen heb ik allereerst een onderscheid gemaakt tussen de toetsing van de besluitvormingsprocedure en de toetsing van de inhoud van besluiten. 


\section{\$3.1 Toetsing van (behoorlijkheid van) besluitvorming}

In hoofdstuk 3 heb ik de rol van redelijkheid en billijkheid (en daarmee vergelijkbare rechtsfiguren) onderzocht in de verschillende fasen van het besluitvormingsproces. Oproeping, agendering en de gang van zaken in de algemene vergadering van aandeelhouders werden bezien. Centraal stond de notie van een 'behoorlijke' besluitvorming, in het bijzonder vanuit het perspectief van de minderheidsaandeelhouder.

Een behoorlijke besluitvorming brengt allereerst mee dat ook de belangen van minderheidsaandeelhouders tot uitdrukking (kunnen) worden gebracht en in het besluitvormingsproces een rol (kunnen) spelen. Op basis van dat uitgangspunt bepaalt de redelijkheid en billijkheid mede in hoeverre minderheidsaandeelhouders de agenda kunnen bepalen en in hoeverre hun spreekrecht in de algemene vergadering al of niet kan worden beperkt. Ook verdedig ik dat de redelijkheid en billijkheid kan meebrengen dat een minderheidsaandeelhouder, voorafgaande aan de besluitvorming, openheid van zaken kan eisen van het bestuur of een (meerderheids)aandeelhouder.

Dat laatste geldt in het bijzonder waar de belangen van een (meerderheids)aandeelhouder strijdig zijn met die van de vennootschap. Ik verdedig dat redelijkheid en billijkheid juist in dergelijke situaties van tegenstrijdig belang een belangrijke normerende functie heeft. Die kan meebrengen dat een aandeelhouder het stemrecht, en meer algemeen het recht om aan de beraadslaging deel te nemen, wordt ontzegd. In Nederland geeft art. 2:12 BW weliswaar een (mogelijkheid tot statutaire) regeling van deze materie, maar mijns inziens schiet deze wettelijke bepaling op zich tekort in het waarborgen van een behoorlijke besluitvorming.

Wanneer een (meerderheids)aandeelhouder onvoldoende rekening houdt met het voorgaande dient een rechter in te (kunnen) grijpen. In het Nederlandse recht biedt de algemene norm van redelijkheid en billijkheid (zoals die is vastgelegd in art. 2:8 BW) daartoe de mogelijkheid. In bepaalde conflicten biedt het enquêterecht (art. 2:344-359 BW) of de geschillenregeling (art. 2:335-343 BW) uitkomst. In het Franse recht vormt met name de figuur van de 'mandataire de justice' (in diverse gedaanten) een waarborg voor een behoorlijke besluitvorming (vgl. hoofdstuk 2 \& 5.2.II).

In hoofdstuk 4 heb ik in het verlengde van het voorgaande aandacht besteed aan de vraag in hoeverre besluitvorming kan worden 'overgelaten' 
aan anderen. Mijns inziens geldt dat niet slechts de uitoefening van het vergader- en stemrecht is onderworpen aan de redelijkheid en billijkheid, maar ook het 'overdragen' daarvan door middel van een stemovereenkomst of een volmacht. Zo meen ik dat de keuze van een gevolmachtigde onderworpen is aan de redelijkheid en billijkheid. Hetzelfde geldt in mijn benadering voor degene(n) met wie men een stemovereenkomst sluit en met betrekking tot de inhoud van zo'n overeenkomst (hoofdstuk $4 \S 1.1$ en $\S 2.3$ ).

Voorts betoog ik in hoofdstuk 4 dat de redelijkheid en billijkheid richting geeft aan de normering van het gedrag van aandeelhouders die door middel van een 'stemmenbundeling' meer invloed kunnen uitoefenen dan de omvang van hun aandelenbezit rechtvaardigt. Het belang van deze kwestie wordt onderstreept door de op komst zijnde regulering en facilitering van proxy solicitation bij Nederlandse beursvennootschappen. Bij de vraag hoe het gedrag van een gevolmachtigde moet worden beoordeeld met name als deze zelf volmachten verwerft - biedt vooral het Duitse recht aanknopingspunten. Dit valt te verklaren door de lange bestaansgeschiedenis van het zogenaamde 'Depotstimmrecht' (vgl. hoofdstuk 4 $\S 1.4)$.

Wat betreft de omvang van de verplichtingen die krachtens redelijkheid en billijkheid op een aandeelhouder of een gevolmachtigde rusten, verdedig ik dat deze varieert. De kerngedachte is hier dat de mate van invloed die een aandeelhouder dient te corresponderen met de mate van verantwoordelijkheid (vgl. hoofdstuk $4 \S 1.2$ als ook hoofdstuk $12 \S 6.2$ ).

\section{$\S 3.2$ Toetsing van de inhoud van besluiten}

De verhouding tussen aandeelhouders, en het verschil in zeggenschap tussen meerderheids- en minderheidsaandeelhouders, doet zich uiteraard niet alleen gevoelen in de besluitvormingsprocedure, maar ook met name bij de uiteindelijke bepaling van de inhoud van een besluit. Als op de totstandkoming van het besluit niets is aan te merken, kan toch het uiteindelijke besluit zodanig in strijd zijn met de belangen van minderheidsaandeelhouders dat ingrijpen gerechtvaardigd is.

Ook met betrekking tot de inhoud van een besluit moet de redelijkheid en billijkheid, en daarmee vergelijkbare rechtsfiguren, daarom een controlefunctie worden toegekend ter bescherming van vennootschap en (minderheids)aandeelhouders. De vraag is natuurlijk wel hoever deze controle gaan mag en gaan moet. In het bijzonder moet daarbij in het oog 
worden gehouden dat een belangrijk uitgangspunt van besluitvorming in een kapitaalvennootschap is dat een meerderheid van aandeelhouders beslist, zij het dat dit geen vrijbrief is voor onredelijke en onbillijke beslissingen (zie reeds hoofdstuk $1 \S 9.2$ in fine).

In de hoofdstukken 5 en 6 heb ik ter concretisering en verdieping van het voorgaande getracht vanuit het perspectief van redelijkheid en billijkheid conflicten te analyseren die kunnen ontstaan naar aanleiding van typen van besluiten waarvan de inhoud minderheidsaandeelhouders in het bijzonder raken kan. Het gaat dan om besluiten tot wijziging van de structuur - en dus veelal tot wijziging van de statuten - en besluiten die direkt de financiële positie van aandeelhouders betreffen omdat zij betrekking hebben op (reservering of uitkering van) de winst.

Wat betreft de wijziging van de structuur en de statuten van de vennootschap, blijkt uit het in hoofdstuk 5 weergegeven onderzoek dat in de jurisprudentie door rechters met name als criterium wordt gehanteerd of en in hoeverre het belang van de vennootschap wordt geschaad, en niet zozeer of minderheidsaandeelhouders worden benadeeld. Hoewel die benadering mij op zich wel aanspreekt, heb ik verdedigd dat onder omstandigheden voor de geldigheid van een besluit tot statutenwijziging wel moet worden voorzien in een compensatie van minderheidsaandeelhouders die daardoor in hun belangen worden geschaad. Mijns inziens zou anders een discriminerend effect kunnen optreden dat naar redelijkheid en billijkheid niet aanvaardbaar is (vgl. hoofdstuk 5 \& $3, \& 4.2$ en $\S 5$ ).

Met betrekking tot de problematiek van 'winstbesluiten' blijkt in hoofdstuk 6 dat in alle onderzochte rechtsstelsels het zogenaamde 'uithongeren' van minderheidsaandeelhouders wordt ondervangen, maar dat de wijze waarop dat geschiedt - en het resultaat dat kan worden bereikt verschilt. De Nederlandse jurisprudentie leert dat redelijkheid en billijkheid aanleiding kan zijn voor een rechterlijk bevel aan de vennootschap om aandeelhouders een 'redelijk' dividend uit te keren (hoofdstuk 6 § 6.1). In het Engelse recht wordt dit niet mogelijk geacht. Wel kan een minderheidsaandeelhouder op basis van s. 459 e.v. CA een aantal andere maatregelen uitlokken (bijvoorbeeld een bevel om hem tegen een passende prijs uit te kopen). In Duitsland eist de wet op de 'Aktiengesellschaft', uitkering van een minimum dividend. In het Franse recht bestaan niet dergelijk specifieke regels maar kan onder omstan- 
digheden een met het Nederlands recht vergelijkbaar resultaat worden behaald indien op verzoek van aandeelhouders een zogenaamde 'mandataire ad hoc' wordt benoemd, die in plaats van een meerderheid of minderheid van aandeelhouders kan stemmen voor een dividendbesluit. In hoofdstuk $6 \S 6.3$ gaf ik aan dat een dergelijke methodiek mij op zich wel aanspreekt.

\section{$\S 4$ Verhouding ava en bestuur}

In deel II van mijn onderzoek heb ik aandacht besteed aan de machts- en rechtsverhouding tussen ava (aandeelhouders) en bestuur (bestuurders). Ook deze verhouding wordt gekleurd door de redelijkheid en billijkheid. Aan de hand van kwesties als het instructierecht, benoeming en ontslag van bestuurders alsmede de problematiek rond corporate opportunities heb ik getracht de 'machtsverhouding' en 'machtsstrijd' tussen de ava en het bestuur te belichten. Bij de beoordeling van die belangenconflicten moet steeds voor ogen worden gehouden dat in ieder geval het bestuur zich bij de vervulling van zijn taak uitsluitend moet richten naar het belang van de vennootschap en de daarmee verbonden onderneming.

In hoofdstuk 7 is bezien hoe de bevoegdheden tussen de ava en het bestuur kunnen worden verdeeld. Wat opvalt is dat in het Duitse recht, anders dan in het Engelse en Franse recht, de Treupflicht een functie kan vervullen bij vragen van bevoegdheidsverdeling tussen de ava en het bestuur. Zo blijkt uit de rechtspraak dat op grond van ongeschreven recht nog andere dan de wettelijke bevoegdheden aan de ava kunnen toekomen. In jurisprudentie van het BGH (zie hoofdstuk $7 \S 2.1$ ) is uitdrukkelijk aangenomen dat in geval het bestuur besluiten neemt waarbij de rechten van aandeelhouders ernstig in het gedrang komen, het redelijk en billijk is om de ava te raadplegen. Ik verdedig dat ook in Nederland de redelijkheid en billijkheid een functie vervult bij de bevoegdhedenverdeling tussen ava en bestuur en ertoe kan leiden dat medewerking van de ava bij voor aandeelhouders ingrijpende bestuursbesluiten vereist is (zie hoofdstuk 7 $\S 2)$.

In hoofdstuk 8 heb ik verdedigd dat, ondanks dat de Nederlandse wet geen eisen stelt aan het bestuurderschap, de redelijkheid en billijkheid meebrengt dat een bestuurder geschikt en in staat moet zijn om zijn bestuurstaak te vervullen. De continuilteit van de vennootschap c.q. onderneming 
is hiermee in het geding. Aandeelhouders mogen zich mijns inziens derhalve bij de benoeming van bestuurders slechts tot op zekere hoogte laten leiden door eigen belang.

De machtstrijd tussen ava en bestuur komt duidelijk naar voren bij ontslag en schorsing van bestuurders door de ava. Een bestuurder dient het vennootschappelijk belang te behartigen, terwijl de ava haar ontslagbevoegdheid kan uitoefenen, geleid door eigen belang. In hoofdstuk 9 heb ik betoogd dat de redelijkheid en billijkheid ook een een functie vervult inzake schorsings- en ontslagbesluiten. Ik meen dat niet alleen ruimte bestaat om zo'n besluit te toetsen aan formele, maar ook aan materiële gronden. Daarmee wijk ik af van de heersende leer waarin op basis van art. 2:134/244 BW wordt aangenomen dat bestuurders te allen tijde kunnen worden geschorst en ontslagen. Deze gedachte vloeit voort uit een oude traditie waarin bestuurders werden gezien als lasthebbers van de aandeelhouders aan wie zij hun mandaat ontlenen.

Deze opvatting acht ik verouderd. Een vergelijking met de rechterlijke beoordeling van schorsingsbesluiten geeft aanleiding voor de opvatting dat ook aan een ontslag van een bestuurder een rechtvaardiging (goede grond) ten grondslag dient te liggen. Mijns inziens impliceert dit dat bestuurders die handelen in het belang van de vennootschap, niet zonder meer kunnen worden ontslagen. Dit komt de continuïteit van de vennootschap ten goede.

De regel van ontslag te allen tijde (ad nutum) vindt men terug in het Engelse en Franse recht. Echter, in het Engelse recht wordt de spanning tussen de ava en de bestuurders grotendeels weggenomen door de sterke arbeidsrechtelijke bescherming van bestuurders (hoofdstuk 9 \& 9). In het Franse recht is de positie van een bestuurder tamelijk wankel. Weliswaar hebben bestuurders van een SA 'nieuwe stijl' en een SARL recht op schadevergoeding indien zij 'sans juste motif' zijn ontslagen, maar in de praktijk hebben zij weinig succes bij een verzoek tot schadevergoeding. Een bestuurder van een SA 'classique' heeft in het geheel geen recht op schadevergoeding, tenzij contractueel overeengekomen.

Een andere kwestie waarin zich een belangenconflict tussen ava en bestuur voordoet is de corporate opportunities problematiek. In hoofdstuk 10 heb ik betoogd dat de redelijkheid en billijkheid het gedrag normeert van bestuurders die zich corporate opportunities toeëigenen. De verplichting 
tot loyaliteit, welke in elk onderzocht rechtsstelsel van bestuurders wordt verwacht, bestaat mijns inziens niet alleen ten opzichte van de vennootschap, maar ook jegens aandeelhouders. De norm van art. 2:9 BW, die door de meerderheid van de auteurs als passend wordt beschouwd, acht ik als grondslag voor toetsing van de corporate opportunities problematiek daarom te beperkt.

\section{$\S 5$. Verhouding tussen bestuurders}

In het derde, en tevens laatste, deel van dit onderzoek wordt de verhouding tussen bestuurders bezien. Ook deze verhouding wordt mede beheerst door de redelijkheid en billijkheid zoals bedoeld in art. 2:8 BW.

In hoofdstuk 11 heb ik de organisatie en de besluitvorming van het vennootschapsbestuur bezien. Wat betreft de organisatie van het bestuur is de vraag onderzocht of en in hoeverre delegatie, mandaat en instructie binnen het bestuur van een kapitaalvennootschap toelaatbaar is. Met betrekking tot de besluitvorming heb ik aandacht besteed aan de vraag in hoeverre er overleg- en informatieplichten c.q. overleg - en informatierechten bestaan voor bestuurders. Ook ben ik ingegaan op twee instrumenten die de besluitvorming en het functioneren van het bestuur ten goede kunnen komen in geval van 'absenteïsme' van één of meer bestuurders. Het betreft hier de mogelijkheden tot het verlenen van volmacht en schriftelijke besluitvorming.

\section{$\S 5.1$ Betekenis en functie}

De redelijkheid en billijkheid levert een bijdrage aan de concretisering van de verhouding tussen bestuurders. Dit is in de eerste plaats het geval bij de vraag in hoeverre een verdeling van bevoegdheden binnen het bestuur van een kapitaalvennootschap toelaatbaar is. In dit kader bepleit ik dat de redelijkheid en billijkheid kan meebrengen dat onder omstandigheden afgeweken kan worden van het collegialiteitsbeginsel. Zo kan mijns inziens een bestuursvoorzitter, gelet op zijn bijzondere positie in het bestuur, onder omstandigheden een 'instructierecht' toekomen ( $\mathrm{vgl}$. hoofdstuk $11 \S 3$ ).

In de tweede plaats vormt de redelijkheid en billijkheid een waarborg voor een behoorlijke besluitvorming in het bestuur. In tegenstelling tot de algemene vergadering ontbreekt een wettelijke regeling daaromtrent. Ik heb verdedigd dat informatierechten en -plichten van bestuurders voort- 
vloeien uit de redelijkheid en billijkheid. Tevens meen ik dat de redelijkheid en billijkheid overlegplichten binnen het bestuur reguleert. Mijns inziens heeft een bestuurder in beginsel aanspraak op overleg indien er beslissingen worden genomen die tot zijn takenpakket behoren. In het kader van een behoorlijke besluitvorming kan de redelijkheid en billijkheid, evenals in de verhouding tussen aandeelhouders, er aan bijdragen dat de besluitvorming niet op ongeoorloofde wijze door tegenstrijdige belangen van een bestuurder wordt beïnvloed (vgl. hoofdstuk $11 \S 4)$ ). De bestuurder zal in geval van (potentiële) belangenverstrengeling openheid van zaken dienen te verschaffen en deze belangen gescheiden dienen te houden.

\section{§ 6. Toetsing aan de redelijkheid en billijkheid; relevante factoren}

In dit boek heb ik telkens getracht (potentiële) belangenconflicten te analyseren vanuit het perspectief van de redelijkheid en billijkheid. Het moment is nu aangebroken om te bezien waardoor de uitkomst van die analyse wordt bepaald.

De beschouwingen uit de voorafgaande hoofdstukken overziende, meen ik in ieder geval een achttal factoren te kunnen signaleren die in min of meerdere mate van invloed kunnen zijn op de belangenafweging door de rechter en die een rol spelen bij het bepalen van de eisen van redelijkheid en billijkheid in een concreet geval:

1. Hoedanigheid betrokkene(n) bij een belangenconflict;

2. Invloed van betrokkene(n) bij een belangenconflict;

3. Dubbelrollen/tegenstrijdig belang van de betrokkene(n) bij een belangenconflict;

4. Aard en inhoud van het besluit;

5. Gevolgen van het besluit c.q. een gedraging voor betrokkene(n);

6. Compensatie van de gevolgen van een besluit voor betrokkene(n);

7. Karakter van de vennootschap;

8. Overeenkomsten tussen betrokkenen.

Het gewicht van deze factoren en de uiteindelijke beslissing van een conflict hangt af van de waardering door de rechter van alle relevante omstandigheden, welke waardering mede bepaald wordt door het rechtssysteem waaraan de rechter op zijn beurt gebonden is. Opgemerkt kan 
worden dat Franse rechters, in vergelijking met hun collega's in Nederland, Duitsland en Engeland terughoudender zijn ten opzichte van een inhoudelijke toetsing van besluiten. Pas indien daadwerkelijk sprake is van misbruik van recht, misbruik van (meerderheids- of minderheids) macht of misbruik van bevoegdheid zal de rechter sancties opleggen, zoals de vernietiging van een besluit. Dit wordt echter enigszins gecompenseerd door het scala aan preventieve maatregelen dat de Franse wet biedt aan met name (minderheids)aandeelhouders, zoals de mogelijkheid de rechter te verzoeken een 'mandataire de justice' te benoemen (vgl. hoofdstuk 2 § 5.2.II).

\section{§ 6.1 Hoedanigheid van betrokkenen bij een belangenconflict}

Een factor van belang voor de belangenafweging is in welke hoedanigheid personen betrokken zijn bij een belangenconflict (zie III). Zo dient een bestuurder zich bij zijn taakuitoefening steeds te richten naar het vennootschappelijk belang. In ieder van de onderzochte landen geldt de norm van het vennootschappelijk belang als leidraad voor bestuurlijk handelen. Wat betreft het handelen van een aandeelhouder zijn de opvattingen genuanceerder.

In Nederland is de heersende mening dat de redelijkheid en billijkheid die de verhouding tussen aandeelhouders beheerst, meebrengt dat aandeelhouders hun gedrag en handelen mede moeten laten bepalen door de gerechtvaardigde belangen van hun mede-aandeelhouders.

In Duitsland wordt in dit verband tot op zekere hoogte onderscheid gemaakt tussen 'Kleinaktionäre' en 'Minderheitsaktionäre' aan de ene kant en 'Mehrheitsaktionäre (of 'Großaktionäre') aan de andere kant. Deze laatsten dienen ingevolge hun machtspositie rekening te houden met de belangen van de overige aandeelhouders en de vennootschap, terwijl een 'Kleinaktionär' in beginsel het eigen belang voor ogen mag houden. Dit is slechts anders indien de 'Kleinaktionäre' de mogelijkheid verkrijgen om daadwerkelijk invloed en macht uit te oefenen op de besluitvorming van de vennootschap (vgl. de baanbrekende Girmes zaak waarover hoofdstuk 
$4 \S 1.5)$. Door middel van bundeling van stemrechten kunnen 'Kleinaktionäre' toch de besluitvorming van de vennootschap blokkeren.'

Uitgangspunt in het Engelse recht is dat het stemrecht een aandeelhouder toebehoort ('property right') en deze zelf mag bepalen hoe hij zijn stemrecht uitoefent. Echter, ook hier legt de rechtspraak beperkingen op aan de uitoefening van het stemrecht door aandeelhouders. Dit is met name het geval bij tegenstrijdig belang kwesties, misbruik van macht ('oppression') en statutenwijzigingen (vgl. hoofdstuk 5 § 4,2) waartoe moet worden besloten 'bona fide for the benefit of the company as a whole'.

\section{\$ 6.2 Invloed van betrokkene(n)}

In samenhang met het voorgaande geldt mijns inziens in het algemeen dat de mate van invloed die een betrokkene op de besluitvorming in een kapitaalvennootschap kan uitoefenen relevant is voor de belangenafweging door de rechter en mede de eisen van redelijkheid en billijkheid in een concreet geval bepaalt. Zowel in het Franse, als in het Engelse en Duitse recht heerst de gedachte dat invloed dient te corresponderen met verantwoordelijkheid. ${ }^{2}$ Op verschillende plaatsen in dit onderzoek verdedig ik dat ook in het Nederlandse recht de mate van verantwoordelijkheid van een betrokkene, en daaraan gekoppeld de omvang van de verplichtingen krachtens redelijkheid en billijkheid, ,afhangt van de mate van (feitelijke) invloed die een betrokkene kan uitoefenen op de gang van zaken in de kapitaalvennootschap. Zo meen ik dat de mate van invloed die een meerderheidsaandeelhouder uitoefent op het beleid van de vennootschap consequenties heeft voor zijn verantwoordelijkheid en aansprakelijkheid (vgl. hoofdstuk 7 \& 7). Dit geldt mijns inziens evenzeer voor een gevol-

1. Een ' Minderheitsaktionär' is derhalve niet hetzelfde als een 'Kleinaktionăr'. Vgl. ook recentelijk H. Henze, Treupflichten der Gesellschafter im Kapitalgesellschaftsrecht, ZHR 1998. p. 187.

2. $\mathrm{V}_{\mathrm{gl}}$. voor het Duitse recht bijv. H. Wiedemann, $\mathrm{Zu}$ den Treupflichten im Gesellschaftsrecht, in: FS Heinsius, Berlin - New York, 1991, p. 960 en in Geselischaftsrecht I. München 1980, p. 432. Voor het Engelse recht, L.S. Sealy. Cases and Materials in Company Law, London, p. 453 en Farrar's Company law, p. 584. Ten slotte voor het Franse recht, D. Schmidt, Les droits de la minorité dans la société anonyme, Paris 1970 , nr. 186. 
machtigde (hoofdstuk $4 \S 1.2$ ) en een bestuurder, in het bijzonder een bestuursvoorzitter (hoofdstuk $11 \S 3$ ).

\section{§ 6.3 Dubbelrollen/tegenstrijdig belang}

Conflictsituaties waarin een bestuurder, doordat hij tevens meerderheidsaandeelhouder is, de mogelijkheid heeft om de macht binnen de vennootschap naar zich toe te trekken, komen veelvuldig aan de orde in mijn onderzoek. Problemen ontstaan veelal indien de persoon (of rechtspersoon) die een dubbelrol vervult zich laat leiden door een tegenstrijdig belang. ${ }^{3}$ Gesteld kan worden dat in zo'n geval in alle rechtsstelsels de belangenafweging een andere kleur krijgt (zie hoofdstuk $3 \& 7.1$, hoofdstuk $6 \S 5.3$, hoofdstuk $9 \S 5$ en hoofdstuk $10 \S 7$ ).

\section{§ 6.4 Aard/inhoud van het besluit}

Ik verdedig dat in het Nederlandse recht een verschil moet worden gemaakt tussen besluiten van de algemene vergadering van aandeelhouders die aandeelhoudersbelangen aantasten, en besluiten die veeleer het bestuur en het beleid van de rechtspersoon betreffen. Bij de eerste categorie van besluiten is een oordeel over de redelijkheid en billijkheid eerder mogelijk (en geïndiceerd) dan bij een besluit uit de tweede categorie.

Binnen de eerste categorie kan vervolgens weer een onderscheid worden gemaakt tussen de zogenaamde 'structuurbesluiten' die betrekking hebben op de structuur van de vennootschap en de besluiten met betrekking tot concrete rechten en verplichtingen van betrokkenen. Tot de structuurbesluiten kunnen bijvoorbeeld worden gerekend besluiten tot statutenwijziging, omzetting en ontbinding. Dit onderscheid vormt in de Duitse doctrine en jurisprudentie een belangrijk aanknopingspunt bij de inhoudelijke toetsing van besluiten in het licht van de Treupflicht ('materielle Beschlußkontrolle'). De Duitse jurisprudentie leert dat aan structuurbesluiten, die ingrijpen in de rechtspositie van aandeelhouders zeer strenge eisen worden gesteld. Allereerst moeten zulke besluiten in het belang zijn van de vennootschap en tevens 'geschikt' voor het nagestreef-

3. Timmerman spreekt over het probleem van het rolconflict; L. Timmerman, De dubbelrol in het (vennootschaps)recht, in: De dubbelrol in het vennootschapsrecht, Deventer 1993. p. 1 . 
de doel. Vanuit dat perspectief formuleert het BGH de eis dat structuurbesluiten moeten worden getoetst aan maatstaven van 'erforderlichkeit' en 'verhältnismäßigkeit' (vgl. hoofdstuk 5 § 4.1).

Ook in het Engelse en Nederlandse recht kan gesignaleerd worden dat bij structuurbesluiten, het belang van de vennootschap voorop staat (hoofdstuk 5 \$ 4.2). Mijns inziens wordt echter in deze rechtsstelsels wat betreft de inhoudelijke toetsing van besluiten niet zo'n scherp onderscheid gemaakt tussen structuurbesluiten en andere besluiten.

\section{§ 6.5 Gevolgen van een besluit c.q. gedraging voor betrokkene(n)}

Bij de beantwoording van de vraag of een besluit of een gedraging redelijk en billijk is, wordt in elk onderzocht rechtsstelsel mede in aanmerking genomen wat de gevolgen daarvan zijn voor de vennootschap en de bij zijn organisatie betrokken personen (zie bijv. hoofdstuk $3 \S 3.3$, hoofdstuk $5 \S 2$ en $\S 3$, hoofdstuk $9 \S 10$ en hoofdstuk $10 \S 4$ ).

In het Duitse recht worden de gevolgen voor betrokkenen grotendeels meegewogen in de zgn. 'materielle Beschlußkontrolle', die hiervoor in $\$ 6.4$ reeds ter sprake kwam. In het Franse recht blijkt uit de criteria die in de rechtspraak zijn ontwikkeld inzake 'abus de majorité' en 'abus de minorité', dat rekening gehouden wordt met zowel het belang van de vennootschap als met de belangen van (minderheids- of meerderheids) aandeelhouders (vgl. bijv. hoofdstuk 5 \& 4.3 en hoofdstuk 6 § 3.1).

In het Engelse recht komt uit de jurisprudentie rond de procedure van section $459 \mathrm{CA}$, waarin het criterium van 'unfairly prejudicial conduct' bepalend is, duidelijk naar voren dat rekening wordt gehouden met de gevolgen van een besluit c.q. van een gedraging voor een aandeelhouder (vgl. bijv. hoofdstuk $5 \S 4.2$ ).

\section{§ 6.6 Compensatie van de gevolgen van een besluit}

In samenhang met het voorgaande speelt in de belangenafweging een rol of en in hoeverre aandeelhouders of bestuurders die in hun belangen worden geschaad door besluiten/gedragingen, gecompenseerd worden. Een en ander hangt samen met de mate waarin aandeelhouders of bestuurders in hun belangen worden aangetast en of het financiële en/of zeggenschapsbelangen betreft. 
Met name in het Duitse recht, maar ook in het Franse en Engelse recht wordt hieraan aandacht besteed. Zo biedt in Engeland de procedure van section $459 \mathrm{CA}$ aandeelhouders de mogelijkheid om tegen een goede prijs te worden 'uitgekocht'. Ook het Nederlandse (vennootschaps)recht geeft blijk compensatie van betekenis te achten voor de (uitkomst van een) belangenafweging. Ik wijs in dit verband op het recente ontwerp beschermingsconstructies en met name op het daarin vervatte art. $359 \mathrm{~h}$ lid $2 \mathrm{BW}$ (hoofdstuk 5 \& 3).

Mijns inziens mag gesteld worden dat bij toetsing van de redelijkheid en billijkheid van een bepaald besluit minder rekening behoeft te worden gehouden met de nadelige gevolgen voor een aandeelhouder indien deze 'passende' compensatie verkijgt.

\section{\$ 6.7 Karakter van de vennootschap}

Hoe zwaar de redelijkheid en billijkheid weegt in een bepaald geval zal mede worden bepaald door het karakter, of zo men wil de structuur van de vennootschap. ${ }^{4}$ Hiermee wordt gedoeld op het karakter van de verhoudingen in een kapitaalvennootschap. Deze factor is, blijkens mijn onderzoek, niet alleen medebepalend voor de redelijkheid en billijkheid die geldt in de rechtsbetrekkingen tussen aandeelhouders, maar ook relevant voor de verhouding tussen de algemene vergadering van aandeelhouders en het bestuur (c.q. de bestuurders).

Ik bespreek deze beide aspecten hierna.

\section{Verhouding tussen aandeelhouders}

Beantwoording van de vraag naar de gerechtvaardigde belangen van een of meer aandeelhouders in een belangenconflict, hangt mede af van het karakter van hun onderlinge verhouding. In het bijzonder het besloten karakter van een vennootschap, in beginsel in de vorm van een BV, heeft zijn uitwerking op de concretisering van de redelijkheid en billijkheid. De algemene gedachte is dat besloten verhoudingen, waarin slechts enkele personen een onderneming drijven, worden gekenmerkt door een onder-

4. Hier niet bedoeld in de zin van een structuurvennootschap. 
linge 'vertrouwensrelatie' op grond waarvan aandeelhouders meer loyaliteit van elkaar mogen verwachten. ${ }^{5}$

In de Duitse en Engelse rechtspraak en doctrine vormt het karakter van de vennootschappelijke organisaties bij de vaststelling van de redelijkheid en billijkheid in een concreet geval, en bij de in acht te nemen mate van loyaliteit, een onmiskenbare factor.

In Duitsland wordt algemeen erkend dat de intensiteit van de Treupflicht afhankelijk is van de zgn. 'Realstruktur'. In Engeland kan dit goed worden geill lustreerd aan de hand van de rechtspraak ter bescherming van minderheidsaandeelhouders tegen 'unfairly prejudicial conduct' van bestuurders of meerderheidsaandeelhouders op grond van s. 459 CA. Deze procedure is weliswaar van toepassing op zowel de private company als de public company, maar tot nu toe eigenlijk slechts succesvol gebleken met betrekking tot private companies. De achterliggende gedachte is dat bescherming geboden is voor aandeelhouders in kleine besloten vennootschappen juist gelet op de veelal nauwe persoonlijke banden en de omstandigheid dat er geen markt is voor hun aandelen ( $\mathrm{vgl}$. hoofdstuk 2 $\S 4.2$ en $\S 5.1$ alsmede hoofdstuk $6 \$ 3.3){ }^{6}$ Deze gedachte vinden we soms ook terug in het Franse recht (zie hoofdstuk 6 \$ 5.2).

De betekenis van 'besloten verhoudingen' voor de invulling van wat redelijkheid en billijkheid van aandeelhouders vergen moet in het Nederlandse recht mijns inziens overigens niet worden overtrokken. Uit mijn onderzoek blijkt dat, met name indien de inhoud van besluiten wordt getoetst aan de redelijkheid en billijkheid, in de belangenafweging vooral veel gewicht wordt toegekend aan het belang van de vennootschap, vanuit het perspectief van de continuilteit van de vennootschap (vgl. hoofdstukken 5 en 6). Van groter gewicht dan het enkele bestaan van besloten verhoudingen acht ik de constatering dat bij aanwezigheid van die verhoudingen veelal sprake is van dubbelrollen die kunnen leiden tot tegenstrijdig belang situaties (zie hiervoor $\S 6.3$ ).

5. Met name Raaijmakers is een belangrijke boodschapper van deze gedachte. Zie bijv. 'Besloten vennootschappen: quasi-NV of quasi-v.o.f.?', AA 1994, p. 76 e.v. alsmede in 'Over rechtsbetrekkingen tussen aandeelhouders in een 'quasi-Vof', in: In het nu, wat het worden zal (Schoordijk-bundel), Deventer 1991, p. 203 e.v.

6. $\mathrm{Vgl}$. Ebrahimi $v$ Westbourne Galleries [1973] AC 360 en Re Saul D Harrison \& Sons [1995] I BCLC 14. Zie ook Ringtower, [1989] BCLC en Re Kenyon Swansea Ltd [1987] BCLC , p. 514 e.v. 


\section{Verhouding tussen ava en bestuur/bestuurders}

Het karakter van de vennootschap, en het bestaan van 'besloten' verhoudingen, beïnvloedt ook de bevoegdheidsverdeling tussen de ava en het bestuur. Het uitgangspunt van een strikte scheiding tussen bevoegdheden van de ava en het bestuur kan, zo heb ik betoogd in hoofdstuk 7, niet altijd meer gelden. Ik heb bepleit dat onder omstandigheden de ava in enkelvoudige vennootschappen een instructierecht kan toekomen, zij het niet onbegrensd. In dit verband moet men denken aan vennootschappen waarin één of meerdere aandeelhouders wezenlijke invloed kunnen uitoefenen op het bestuur (vgl. hoofdstuk 7 § 4 en $\S 8$ ).

Ook in Duitsland en Engeland wordt aanvaard dat in 'besloten' vennootschappen, te weten de $\mathrm{GmbH}$ en de 'private company', de bevoegdhedenverdeling veel minder strikt is dan bij de 'publieke' vennootschappen als de AG en de 'public company', in die zin dat de ava veel invloed kan uitoefenen op het bestuur en de gang van zaken in de vennootschap. Met name in Duitsland wordt de invloed van de 'Gesellschafterversammlung' in de $\mathrm{GmbH}$ onderstreept doordat het instructierecht daarvan wettelijk is geregeld.

Behalve dat 'besloten' verhoudingen een rol kunnen spelen bij de aanvaarding van een instructierecht van de ava ten opzichte van het bestuur, heb ik in hoofdstuk 9 verdedigd dat deze ook van betekenis zijn voor de positie van een bestuurder. Indien een bestuurder in een besloten vennootschap wordt ontslagen verliest hij veelal niet alleen zijn functie, maar kan hij tevens zijn eventuele aandelen niet te gelde maken. Dit heeft mijns inziens gevolgen voor de beoordeling van een ontslagbesluit in het licht van de redelijkheid en billijkheid (vgl. hoofdstuk $9 \& 10)$.

\section{§ 6.8 Aandeelhoudersovereenkomsten}

De concrete organisatie van een kapitaalvennootschap wordt, behalve door wet en statuten, mede bepaald door aandeelhoudersovereenkomsten. Uit de Nederlandse jurisprudentie en doctrine kan worden afgeleid dat (geldige) overeenkomsten tussen aandeelhouders van betekenis zijn voor hun onderlinge rechtsbetrekking en aldus voor de wijze waarop zij zich naar redelijkheid en billijkheid jegens elkaar moeten gedragen. Dit geldt niet alleen voor stemovereenkomsten (zie hoofdstuk 4 \& 2.4 en hoofdstuk 8 \$ ). Ook blijkens Duitse jurisprudentie kunnen overeenkomsten de reikwijdte van de Treupflicht medebepalen en een grond opleveren voor 
de aantasting van een besluit van de ava zij het dat in de Duitse doctrine verdeeldheid bestaat over het hoe en wanneer (hoofdstuk $8 \S 5$ ).

In het Engelse recht spelen (stem)overeenkomsten tussen aandeelhouders een prominente rol. Dit hangt samen met de visie dat aandeelhouders hun stemrechten in beginsel mogen uitoefenen in hun eigen belang en deze veelal nog worden beschouwd als hen toekomende 'property rights'. Recente rechtspraak in het Engelse recht laat zien dat contractuele regelingen ertoe kunnen leiden dat een 'fiduciary duty' wordt aangenomen tussen aandeelhouders onderling en/of tussen bestuurders en aandeelhouders (zie hoofdstuk $2 \S 4.2$ ).?

\section{§7. Afronding}

De redelijkheid en billijkheid is een fascinerend rechtsinstituut. Dat geldt van oudsher in het contractenrecht. Ik hoop in dit boek te hebben geillustreerd dat dit ook geldt voor het vennootschapsrecht. Tevens hoop ik dat mijn (rechtsvergelijkende) beschouwingen het perspectief op de betekenis en de functie van redelijkheid en billijkheid in het vennootschapsrecht verbreden en een bijdrage mogen leveren aan het verder doordenken en ontwikkelen van de rechtsopvattingen terzake. Want één ding staat vast; ook na de afronding van dit boek is het laatste woord over deze materie nog lang niet gezegd.

7. Vgl. \$ 2.6.2. alsmede Elliott v Wheeldon [1993] BCLC 53. 



\section{Summary}

\section{Introduction}

The central theme of this dissertation is the content and operation of the Dutch concept of reasonableness and fairness (redelijkheid en billijkheid) related to companies limited by shares, in particular with regard to the relationships between majority and minority shareholders, between the general shareholders' meeting and the board of directors, and between the directors themselves. Its operation and content are examined on the basis of reflections on the acts and decisions influencing these relationships.

In the Netherlands, no clear picture exists as yet of the operation of 'reasonableness and fairness' with regard to the relationships within companies. This study intends to contribute towards the development of clearer rules of reasonableness and fairness in these relationships within companies limited by shares. Dutch law and legal literature leave many questions unanswered on the operation and content of reasonableness and fairness in company law. In consequence, the author has paid much attention to comparative law. In her analysis of possible conflicts which may arise in companies limited by shares, she has included the laws of two other continental countries, Germany and France, as well as the law of England and Wales as an exponent of the Common Law tradition.

\section{'Reasonableness and Fairness' from a Comparative Perspective}

The author examines how and to what extent the principle of 'good faith' is applied in connection with companies limited by shares under Dutch and foreign law. For this purpose, a conscious choice has been made for a functional approach, in which problem analysis prevails. It may be concluded that in the foreign systems under study corresponding norms exist for assessing the acts of the parties involved, although their terminology, content and scope differ. English company law offers comparative material in the form of 'fiduciary duties'. Under English law, the 'fiduciary relationship' is essential. Furthermore, case law relating to s. 459 Companies Act 1985, governing the acts of (majority) shareholders. has further defined the concept of 'good faith'. Under German law, the 'Treupflicht' regulates the acts of shareholders and directors. Where under Dutch law the notion of abuse of law and abuse of (majority) power is 
absorbed by reasonableness and fairness (see Chapter 1), in Germany, similarly, the doctrine of abuse of law is for the most part absorbed by the Treupflicht. In France, on the other hand, 'good faith' in company law is placed within the context of abuse of law, abuse of majority or minority power ('abus de majorité/'abus de minorité) and abuse of powers ('abus de pouvoirs'). Furthermore, in recent case law the Cour de Cassation has held the duty of loyalty to be a separate and independent ground for testing the acts of directors.

\section{The Relationship between Majority and Minority Shareholders}

In Part I of the study, the author has attempted to make an inventory of the types of conflict which may arise in the relationship majority/minority shareholders. A distinction was made for this purpose between conflicts relating to the decision-making process at and around shareholders' meetings and conflicts in relation to the content of resolutions to be passed. In Chapter 2 it is made clear that in all legal systems under study the powers of majority shareholders are not limitless. The way in which this idea has been given shape differs from system to system. In order to make a meaningful analysis, the author distinguishes between testing the decision-making process and testing the content of decisions.

In Chapter 3 the role of 'reasonableness and fairness' -and of comparable principles abroad- is examined in the various stages of the decision-making process. Notification, agenda setting and the course of affairs during the general shareholders' meeting are studied. The core notion is "proper" decision making, especially from the perspective of the minority shareholder.

This theme is continued in Chapter 4, where attention is paid to the possible extent of leaving the decision making to others. In the author's view, the requirement of 'reasonableness and fairness' does not only apply to the exercise of the rights to attend meetings and to vote at meetings, but also to the transfer of these rights through voting agreements or proxies (Chapter 4 at 1.1 and 2.3).

It is furthermore argued that the requirement of reasonableness and fairness gives direction to regulating the acts of those shareholders who through "vote clustering" can exercise more influence than warranted by the size of their participation. The importance of this issue is underscored by the impending regulation and facilitation of proxy soliciting in Dutch listed companies. 
It is contended that the extent of obligations imposed on shareholders and their proxies by the requirement of reasonableness and fairness varies. The principal assumption is that the degree of influence a shareholder exercises should be commensurate with the degree of responsibility carried ( $c f$. Chapter 4 at 1.2 and Chapter 12 at 6.2).

The relationship between shareholders and the difference in control between majority and minority shareholders are not only felt during the decision-making process, but in particular when a final decision is made as to the content of a resolution. Even where the procedure by which the resolution was taken was flawless, the resolution may still turn out to be contrary to the interests of the minority shareholders to the degree that interference is justified.

'Reasonableness and fairness', and similar concepts abroad, must therefore also have a control function with regard to the content of resolutions in order to protect the company and the (minority) shareholders. This, however, raises the question of the extent of such control. It should be particularly borne in mind that it is a major premise of decision making in a company limited by shares that resolutions are passed by majority vote. On the other hand, this is not a license for passing unreasonable and unfair resolutions (see before Chapter 1 at 9.2).

In Chapters 5 and 6 an attempt is made to specify and examine more thoroughly from the perspective of reasonableness and fairness conflicts which may arise as a result of types of resolutions, whose content may in particular affect minority shareholders. Examples of such resolutions are those to change the organisation of the company -and consequently to amend the articles of association- and resolutions directly involving the position of the shareholders, since they relate to (the reservation or distribution of) dividends.

With regard to changes to the organisation of the company and the articles of association, the study in Chapter 5 shows that the courts employ the criterion of whether and, if so, to what extent the company's interest has been prejudiced, rather than whether minority shareholders have been negatively affected.

In connection with dividend resolutions, Chapter 6 reveals that in all systems under investigation so-called "starving" of minority shareholders is pre-empted, but the way in which this is done and the result which may be achieved vary from country to country. 


\section{The Relationship between the General Shareholders' Meeting and the Board of Directors}

In Part II of the study attention is paid to the power and the legal relationships between the general shareholders' meeting and the board of directors. Those relations are also coloured by the rule of reasonableness and fairness. By discussing such subjects as the right to give instructions, the appointment and removal of directors, as well as the problem of corporate opportunities, the author has made an attempt to show the power relationship and the power struggle between the general shareholders' meeting and the directors. When assessing conflicts of interest, it should be borne in mind that directors must act in the interest of the company and its business when exercising their duties.

Chapter 7 deals with the distribution of powers between the general shareholders' meeting and the directors. Worth noticing is that in German law, unlike English and French law, the Treupflicht may play a role in issues of distribution of powers between the general shareholders' meeting and the directors. German case law shows that by virtue of unwritten law the shareholders meeting may possess powers other than statutory ones. In case law relating to the German Civil Code (see Chapter 7 at 2.1) there is an express assumption that if directors take decisions by which the rights of shareholders are seriously jeopardised, 'reasonableness and fairness' requires that the general shareholders' meeting be consulted. The author contends that in the Netherlands 'reasonableness and fairness' also plays a role in the distribution of powers between the general shareholders' meeting and the directors. This may result in the mandatory co-operation of the general shareholders' meeting in decisions likely to seriously affect the shareholders (see Chapter 7 at 2.3).

In Chapter 8 the proposition is defended that, in spite of the fact that under Dutch law there are no rules governing directorship, the requirement of reasonableness and fairness entails that directors must be fit and capable to fulfil their duties. The continuity of the company and/or the company's business is at stake here.

The power struggle between the general shareholders' meeting and the directors manifests itself most clearly in procedures by which the general shareholders' meeting removes or suspends directors. In Chapter 9 it is argued that the requirement of reasonableness and fairness also plays a role in decisions regarding suspension or removal. The author contends that there is not only room to test such decisions against procedural 
grounds, but also against substantive grounds. This represents a departure from the prevailing theory by which it is assumed, on the basis of Articles 134 and 244 Book 2 Dutch Civil Code that directors may be suspended or removed at all times.

A second issue, in which the conflict of interest between the general shareholders' meeting and the directors arises, is the problem of corporate opportunities. In Chapter 10 the author submits that the requirement of reasonableness and fairness regulates the acts of those directors who use corporate opportunities to their personal advantage. The duty of loyalty, which in each of the systems under study is expected of directors, is not only owed, she argues, to the company, but also to the shareholders. In consequence, she considers the norm of Article 9 Book 2 Dutch Civil Code, deemed appropriate by most scholarly writers, as too limited a ground for testing issues of corporate opportunities.

\section{The Relationship between Directors}

In the Part III, the final part of the study, the relationship between directors is examined. This relationship is also governed in part by the requirement of reasonableness and fairness as specified in Article 8 Book 2 Dutch Civil Code.

The organisation and the decision making of company directors are the subject of Chapter 11. As regards the organisation of the board of directors, the author investigates whether and, if so, to what extent, delegation, mandate and instruction are allowed within the board of a company limited by shares. Where decision-making is concerned, she pays attention to the question of the extent to which there is a duty to consult and a duty to inform, or conversely, a right to be consulted and a right to be informed. Two instruments are discussed which could enhance the decision-making process and the functioning of the board of directors in the event of absenteeism of one or more directors, namely the possibility to confer a power of attorney and decision-making in writing.

\section{The Reasonableness and Fairness-Test; Relevant Factors}

An attempt has been made to analyze (potential) conflicts of interest from the perspective of reasonableness and fairness. The question of what determines the outcome of the analysis is dealt with in Chapter 12. 
Reviewing the preceding chapters, the author distinguishes at least eight factors which play a role of sorts in determining 'reasonableness and fairness' in concrete cases:

1. the capacity of the person(s) involved in the conflict;

2. the influence the person(s) involved is/are capable of exercising;

3. the dual role/conflicting interests of the person(s) involved;

4. the nature and content of the decision;

5. the consequence of the decision or act for the person(s) involved;

6. the compensation for the person(s) involved as a result of the decision;

7. the character of the company;

8. the agreements between the parties involved.

The degree of importance of these factors and the ultimate resolution of a conflict depend on the court's assessment of all relevant circumstances. The assessment is also determined in part by the legal system which the court is bound to apply. For example, compared to their Dutch, German and English counterparts, French judges exercise more restraint with regard to substantive testing of decisions. Only in clear cases of abuse of law, abuse of (majority or minority) power, or abuse of powers will the judge impose such sanctions as annulment of the decision. This is somewhat compensated, however, by the range of preventative measures offered in French law to minority shareholders in particular, such as the possibility to request the court to appoint a 'mandataire de justice' ( $c f$ Chapter 2 at 5.2).

\section{In Conclusion}

Traditionally, 'reasonableness and fairness' has been a fascinating concept of Dutch contract law. With this book the author hopes to have demonstrated that this also holds true for company law. Furthermore, it is hoped that her observations have broadened the outlook on the meaning and operation of 'reasonableness and fairness' in company law. May they have contributed to a further analysis and development of legal views on this subject.

Translated by Louise Rayar 


\section{Lijst van aangehaalde en geraadpleegde literatuur}

\section{Nederland en België}

Abas, P.:

Abas, P.:

Achterberg, M.P. van:

Ahaus, C.T.B.:

Bartman, S.M.:

Bartman, S.M.:

Belinfante

Blaisse, $\mathrm{H}$.

en Moes, E.A.:

Blanco Fernández, J.M.:

Blanco Fernandéz, J.M.:

Blom, W.F.C.:

Bock, E.S. de:

Boelens, G.J.:

Boogert, M.W. den:

Bosse, W.:

Boukema, C.A., e.a. (ed):

Brenninkmeijer, A.M.:

Buijs, D.C.:
Beperkende werking van de goede trouw (diss.), Deventer 1972.

Beperkende werking van de goede trouw, toen (1972), nu en in de toekomst, in: Non sine causa. Opstellen aangeboden aan prof.Mr. G.J. Scholten, Zwolle 1979, p. 1 e.v.

De juridische definitie van het economische verschijnsel concern (diss.), Deventer 1989.

Bevoegdheidsverdeling en organisatic, Evaluatic van een bedrijfskundige methode (diss.) Groningen 1994 .

De onderneming in (kort) geding 1994/1995, Arnhem 1996.

De rol van de ondernemingskamer bij overnamegeschillen, Ondernemingsrecht 1999, p. 138 e.v. en p. 247 e.v.

Ontwerpen van wetten op de vennootschappen en andere. Wijziging en aanvulling van de bepalingen omtrent de naamloze vennootschap en de regeling van de aansprakelijkheid voor het prospectus. 1929.

Statuten en statutenwijziging, WPNR 1943, p. 137 e.v en p. 145 e.v.

De Raad van Commissarssen bij de NV en BV (diss. Maastricht), Deventer 1993.

De vennootschappelijke werking van stemovereenkomsten, Ondernemingsrecht 1999 , p. 148 e.v.

Blokkering van BV-aandelen: tegen welke blokkeringsprijs? De NV 1992, p. 140 e.v.

De vennootschapsrechtelijke aantasting van ontslagbesluiten, TVVS 1998, p. 349 e.v.

Oligarchische clausules in statuten van naamloze vennootschappen (diss.), Kampen 1946.

De orde van de algemene vergadering, De NV 1997, p. 216 e.v.

$1 \%$-regelingen, TVVS 1991, p. 141 e.v.

Rechtspersonen, Deventer, losbladig.

Stemovereenkomsten van aandeelhouders. De gebondenheid van stemovereenkomsten, tegen de achtergrond van het Franse en Duitse vennootschapsrecht (diss.), deel 8 in de Serie Vennootschaps-en Rechtspersonenrecht van het Van Der Heijden Instituut te Nijmegen, Deventer 1973.

Proxy Solicitation uitgesteld, TVVS 1998, p. 82 e.v. 
Cahen, J.L.P.:

Christe, D.

Commissie Corporate

Governance:

Dijk, P.L.:

Dorhout Mees, T.J.:

Dorresteijn, A.F.M.:

Dorresteijn, A.F.M.:

Dortmond, P.J.:

Dortmond, P.J.:

Dortmond, P.J.:

Drion, H.:

Drost, J.:

Dubbink, C.W.:

Dumoulin, S.H.M.A.:

Eggens, J.:

Eggens, J.:

Eisma, S.E.:

Eisma, S.E.:

Eisma, S.E.:

Ernst, $\mathrm{Ph}$ :

Esch, B, van der:

Frielink, $\mathrm{K}$.:
De invloed van de belangenverbreding op het handelen van de aandeelhouder, in: Honderd jaar rechtsleven, Zwolle 1971, p. 71 e.v.

Hoge Raad dicht gat in rechtspositie van vennootschappelijk bestuurder, Sociaal Recht 1993, p. 61 e.v.

'De veertig aanbevelingen', 1997.

Art. 8 en de identiteit van de rechtspersoon, WPNR 1983, p. 549 e.v.

Kort begrip van het Nederlands handelsrecht, 2e druk 1956.

Tegenstrijdig belang van bestuurders en commissarissen (diss.), Deventer 1989.

Dubbeirollen in het vennootschapsrecht, TVVS 1993, p. 5 e.v.

De adviserende stem van bestuurders en commissarissen bij een besluit buiten vergadering, De NV 1996, p. 27 e.v.

Misbruik van rechtspersonen, in: Piercing van Schilfgaarde, Deventer 1990, p. 13 e.v.

Luctor et Emergo, Geworstel met agendapunten, De NV 1997, p. 219 e.v.

Functies van rechtsregels in het privaatrecht, in: Speculum Langemeijer, Zwolle 1973, p. 49 e.v.

Rechten van aandeelhouders in Naamloze Vennootschappen, diss. Utrecht 1903.

De redelijkheid en billijkeid volgens art. 3:12 NBW, WPNR 1990. p. 359 e.v. (I) en p. 375 e.v. (II).

Besluitvorming in rechtspersonen (diss. Groningen), Deventer 1999.

Het 'misbruik van recht' en de vrijheid (rede). Wolters, Groningen, Batavia 1946.

Over het wezen van het misbruik van recht, WPNR 1947, p. 221 e.v.; p. 229 e.v. en p. 237 e.v.

Bij, of bij of krachtens, bij Van Solinge, De NV 1997, p. 221 e.v.

Wetsontwerp beschermingsconstructies (I en II), WPNR 1998, p. 83 e.v. (I) en p. 97 e.v. (II).

Record dates, WPNR 1998, p. 551 e.v.

Belangenconflicten in naamloze vennootschappen (diss. Antwerpen), Antwerpen-Groningen 1997.

Vergelijkend vennootschapsrecht. De N.V. naar Engels, Amerikaans, Frans en Belgisch recht tegen de achtergrond van de Nederlandse voorschriften, Tjeenk Willink Zwolle 1953.

Rechten van beknelde minderheids-aandeelhouders, V \& 0 1997, p. 31 e.v. 
Geens, K. en Ronse, J.:

Geens, K:

Gerven, W. van:

Ginneken, M.J.:

Glasz, J.R., Beckman, H. en Bos, J.:

Grinten, W.C.L. van der:

Grinten, W.C.L. van der:

Grinten, W.C.L. van der:

Grinten, W.C.L. van der:

Grinten, W.C.L. van der:

Grinten, W.C.L. van der: Grinten, W.C.L. van der: Grinten, W.C.L. van der: Grinten, J.W.M. van der:

Groot, G.R.J. de, Rossem, A.A. van:

Haan, P.:

Grooth, G. de:

Hamers, J.J.A.:

Heerma van Voss, G.J.J.:

Heijden, E.J.J. van der:

Heijden, E.J.J. van der:

Heijden, E.J.J. van der:

Heijden, E.J.J. van der:

Heijden, E.J.J. van der:
Misbruik van minderheidspositie, in: Van vennootschappelijk belang 1988, p. 227 e.v.

De jurisprudentiele bescherming van de minderheidsaandeelhouder tegen de door de meerderheid opgezette beschermingsconstructies, TPR 1990, p. 35 e.v.

Variaties op het thema misbruik, RW 1979-1980, nr. 2476.

Proxy solicitation voor en door aandeelhouders, De NV 1998. p. 134 e.v.

Bestuur en toezicht, Deventer 1994.

Nietigheid van besluiten wegens strijd met het ongeschreven recht, De NV 1942, p. 224 e.v.

Uitgifte van nieuwe aandelen en voorkeursrecht, de NV 1949. p. 121 e.v.

Handelen te goeder trouw, in: Opstellen aangeboden aan Prof. mr. B.H.D. Hermesdorf 1965, p. 155 e.v.

Preadvies over nietigheid van besluiten van organen van de NV, Zwolle 1966.

De aandeelhoudersvergadering en de NV, in: Uit het Recht, Rechtsgeleerde opstellen aangeboden aan P.J. Verdam, Deventer 1971, p. 295 e.v.

Aantasting van besluiten, WPNR 1983, p. 137 e.v.

Minderheidsrechten, De NV 1992, p. 271 e.v.

Ontslag van een zieke bestuurder. De NV 1993, p. 48 e.v.

Misbruik van Recht in het nieuw BW, in: Goed en Trouw, Zwolle 1984, p. 367 e.v.

Mandaat en volmacht, RM Themis 1993, p. 127 e.v.

Bestuursrecht in de sociale rechtsstaat, Deel 1 Ontwikkeling, Organisatie, Instrumentarium, Deventer 1996.

De Naamloze Vennootschap, Rotterdam 1905.

Verpanding van aandelen en de beslotenheid van kapitaalvennootschappen (diss. Maastricht), Deventer 1996.

De arbeidsovereenkomst als titel 7.10 BW (serie actualiteiten sociaal recht), Deventer 1997.

Handboek voor de naamloze en besloten vennootschap, Zwolle, le druk, 1929.

Handboek voor de naamloze en besloten vennootschap, Zwolle, 2e druk 1931.

Handboek voor de naamloze en besloten vennootschap, Zwolle, 3e druk, 1936.

Handboek voor de naamloze en besloten vennootschap. Zwolle, 4e druk, 1946.

Handboek voor de naamloze en besloten vennootschap. Zwolle 6e druk, 1955. 
Heijden, E.J.J. van der:

Heijden, E.J.J. van der:

Heijnsdijk, J.:

Hellemans, F:

Hesselink, M.W.:

Honée, H.J.M.N.:

Honée, H.J.M.N.:

Huizink, J.B.:

Huizink, J.B.:

Huizink, J.B.:

Huizink, J.B.:

Huizink, J.B.:

Hülsmann, J.H.H.:

Ingh, F.J.P. van den:

Ingh, F.J.P. van den:

Ingh, F.J.P. van den:

Ingh, F.J.P. van den:

Ingh, F.J.P. van den:

Ingh, F.J.P. van den:

Jansen, H.C.J.C.:

Jongsma, $\mathrm{K}$.:
De ontwikkeling van de Naamloze Vennootschap in Nederland vóór de codificatie, diss. Utrecht 1908.

Natuurlijke normen in het recht, rede Nijmegen 1933.

Besturen van het bedrijf, Groningen 1992.

Stemovereenkomsten naar Belgisch recht, in: Beginselen van vennootschapsrecht in binationaal perspectief. Vergelijkende beschouwingen naar Belgisch en Nederlands recht, Antwerpen 1998, p. 185 e.v.

De redelijkheid en billijkheid in het Europese privaatrecht, (diss. Utrecht), Deventer 1999.

De ontwikkeling van het vennootschapsrecht, in: 150 jaar Wetboek van Koophandel; Het verleden en de toekomst, Deventer 1989, p. 35 e.v.

Het ontslag van de bestuurder in wetshistorisch perspectief, De NV 1998, p. 280 e.v.

Bestuurders van rechtspersonen (diss. Groningen), Deventer 1989.

lets over dividend, De NV 1992, p. 135 e.v.

Perikelen rond de besluitvorming van aandeelhouders, WPNR 1995, p. 837 e.v.

Vraagtekens bij art. 2:9 BW, De NV 1997, p. 333 e.v.

Het voldongen feit in ondernemingsrechtelijke procedures, in: Rechtspleging in het ondernemingsrecht, Kluwer 1997, p. 75 e.v.

De ongeldigverklaring van meerderheidsbesluiten op grond van wilsgebreken en haar gezagde van gewijsde, Amsterdam 1935.

Interne aansprakelijkheid bij vereniging en stichting, S \& V 1990, p. 159 e.v.

Certificering en certificaat van aandeel bij de besloten vennootschap (diss.), Deventer 1991.

Nietigheid van stem en besluit; vernietiging van besluiten, in: Nieuw vennootschaps- en rechtspersonenrecht, Serie praktijkhandelingen, Zwolle 1992, p. 85 e.v.

Naar een uitbreiding van de bevoegdheden van de aandeel. houderscommissie? WPNR 1992, p. 805 e.v.

Het ongehoorde ontslag van een bestuurder, WPNR 1993, p. 457 e.v.

Vergaderrechten bij tegenstrijdig belang, WPNR 1998, p. 269 e.v.

Meerderheids-aandeelhouders-bestuurders, prioriteitsaandeelhouders en fusie, De NV 1973, p. 4 e.v.

Stichting Communicatiekanaal Aandeelhouders opgericht, Corporate Governance Nieuwsbrief 1998, p. 6 e.v. 
Kist-Visser:

\section{Kist-Visser:}

Kluiver, H.J. de:

Kluiver, H.J. de:

Kluiver, H.J. de:

Kluiver, H.J. de:

Kluiver, H.J. de, Gerven, W, van (ed.): Kluiver, H.J. de: Kluiver, H.J. de:

Kluiver, H.J. de:

Koelemeijer, M.

Koelemeijer, M.:

Kortmann, S.C.J.J. en Faber, N.E.D.:

Kottenhagen, R.J.P.:

Kreijen, G.P.H.:

Kroeze, M.J.:

Kroeze, M.J.:

Kuile, H.J.C., ter:

Laga, H.:
Beginselen van Handelsrecht volgens de Nederlandse wet, Belinfante 's Gravenhage, 1914.

Beginselen van Handelsrecht volgens de Nederlandsche wet, Belinfante 's-Gravenhage, 1929.

De betekenis van het nieuwe BW voor vennootschappen en rechtspersonen(recht), in: T.J. van der Ploeg e.a., Nieuw vennootschaps-en rechtspersonenrecht, Zwolle 1992, p. 1 e.v.

Onderhandelen en privaatrecht (diss. VU Amsterdam), Deventer 1992.

Het vennootschapsrecht dient te worden versoepeld...en verscherpt, TVVS 1994, p. 174 e.v.

Joint ventures en stemovereenkomsten. Een rechtsvergelijkend perspectief, AA 1995, p. 104 e.v.

The European Private Company? Antwerpen-Apeldoorn 1995. Mag het nog ietsje meer zijn?, NJB 1996, p. 1439 e.v.

Machtsstrijd en machtsovername (oratie Maastricht), Deventer 1996.

'Aansprakelijkheid en décharge. Een paar apart', WPNR 1997, p. 373 e.v.

Redelijkheid en billijkheid in het vennootschapsrecht. Gebruik van corporate opportunities: een (on)geoorloofde gedraging van bestuurders? in: het themanummer van WPNR inzake Vermogensrecht; AIO-onderzoek en rechtsvergelijking, 1994, p. 714 e.v.

Volmacht en aandeelhouders, in: Onderneming en 5 jaar nieuw burgerlijk recht, serie onderneming en recht, Deventer 1997, p. 21 e.v.

Reactie op 'Kan een aandeelhouder of vennootschapsschuldeiser afgeleide schade vorderen? van L. Timmerman TVVS 1997, p. 16 e.v., in TVVS 1998, p. 186 e.v.

Van precedent tot precedent. Over de plaats en functie van het rechtersrecht in een gecodificeerd rechtsstelsel, Arnhem 1996.

Proxy solicitation, V \& O 1998, p. 76 e.v.

Schadevergoedingsactie door aandeelhouders/corporate opportunities, Juridisch up to date 1996, p. 2 e.v.

Zelfstandige vorderingsrechten van de aandeelhouder voor schade aan het vennootschapsvermogen, in: Beginselen van vennootschapsrecht in internationaal perspectief, AntwerpenGroningen 1998, p. 217 e.v.

Gelijkheid van aandeelhouders, in: Quid Iuris, Deventer 1977, p. 49 e.v.

Kan de raad van bestuur geldig besluiten zonder effectief bijeen te komen, TRV 1992, p. 340 e.v. 
Langemeijer, G.E.:

Leeuwen, B.H.A. van:

Leeuwen, B.H.A., van:

Löwensteyn, F.J.W.:

Löwensteyn, F.J.W.:

Maeijer, J.M.M.:

Maeijer, J.M.M.:

Maeijer, J.M.M.:

Maeijer, J.M.M.:

Maeijer, J.M.M.:

Maeijer, J.M.M.:

Maeijer, J.M.M.:

Maeijer, J.M.M.:

Maeijer, J.M.M.:

Mak, S.N.S.M.:

Meijers, E.M.:

Meijers, E.M.:

Mendel, M.M.

Molengraaff:

Mohr, A.L.:

Mohr, A.L:
De gerechtigdheid in ons burgerlijk vermogensrecht, Zwolle 1985.

Beginselen van behoorlijk ondernemingsbestuur (diss.), Deventer 1990.

Verstrengeling van belangen en het vennootschapsrecht, TVVS 1987, p. 49 e.v.

Wezen en bevoegdheid van het bestuur van de vereniging en de naamloze vennootschap (diss.), Zwolle 1959.

Rechterlijke toetsing van besluiten nu en in de toekomst, in: Goed en Trouw, Zwolle 1984, p. 127 e.v.

Matiging van schadevergoeding, diss. Nijmegen, Zwolle 1962.

Aandeelhouders in een n.v. en de eisen van de goede trouw, de NV 1965, p. 153 e.v. en p. 169 e.v.

De stemovereenkomst van aandeelhouders, in: Recht die zo gaat, Zwolle 1979, p. 95 e.v.

De corrigerende werking van goede trouw, in: Goed en Trouw, Zwolle 1984, p. 31 e.v.

25 jaren belangenconflict in de Naamloze Vennootschap, Zwolle 1989 alsmede in de NV 1989, p. 1 e.v.

Beslechting van geschillen, in: Met hoofd en hart, Zwolle 1991, p. 328 e.v.

De goede trouw of redelijkheid en billijkheid, TPR 1991, p. 5 e.v.

Vertegenwoordiging en voimacht, in: Problemen rond de algemene vergadering. Deventer 1994, p. 63 e.v.

Proxy Solicitation; beschermingsconstructies, in: Ontwikkelingen in het effectenverkeersrecht, Deventer 1995, p. 119 e.v.

Doorbraak in omgekeerde doorbraak? in, de Cahen Bundel 1997, p. 195 e.v.

Individuele en vennootschappelijke rechtsvorderingen, toekomende aan aandeelhouders van Naamloze Vennootschappen, NJB 1927, p. 445 e.v.

Ontwerp voor een nieuw burgerlijk wetboek, Toelichting eerste gedeelte, 's-Gravenhage 1954.

Stemrecht, minderheidsaandeelhouders en ongelijkheidscompensatic, in: Ongelijkheidscompensatie als roode draad in 't recht, Deventer 1997, p. 207 e,v.

'Eene terugblik' (18 juni 1917), Molengraaff Bundel, Zwolle 1978, p. 77 e.v.

Spijkers. Ondernemingsrecht op de breuklijn van praktijk en wetenschap, Arnhem 1993.

De aandeelhouder en zijn stemmen, WPNR 1994, p. 237 e.v. 
Mohr, A.L.:

Mourik, M.J.A. van:

Nieuwenhuis, J.H.:

Noldus, W.J.M.:

Okma, N.:

Olffen, M. van:

Ommeslaghe, P. van

Oven, J.C. van:

Overes, C.H.C.:

Petit, Ch.J.J.M.:

Perron, E. C. du:

Ploeg, T.J. van der:

Ploeg, T.J. van der:

Ploeg, T.J van der:

Polak, M.:

Polak, M.

Posch, L.J.:

Raaijmakers, M.J.G.C.:

Raaijmakers, M.J.G.C.:

Raaijmakers, M.J.G.C.:

Raaijmakers, M.J.G.C.:

Raaijmakers, M.J.G.C.:
De dubbelrol aandeelhouderbestuurder, in: De dubbelrol in het vennootschapsrecht 1993, p. 73 c.v.

Herziening van het preventief toezicht, WPNR 1999, p. 99 e.v.

$\mathrm{Zij}$ moeten te goeder trouw worden ten uitvoer gebragt, in: Recht Vooruit, Deventer 1988, p. 111 e.v.

Ongeldigheid van besluiten in de naamloze vennootschap (diss.), Deventer 1969.

Misbruik van recht, uitg. N.V. Gebrs. Zomer en Keuning, Wageningen 1945.

Vennootschaps- en rechtspersonenrecht en invoering van de boeken 3, 5, en 6 Nieuw BW, Deventer 1991.

Abus de droit, fraude aux droits des tiers et fraude a la loi, RCJB 1976, p. 1318.

De Hooge Raad en de art. 1374 en 1375 BW, NJB 1931, p. 568 e.v.

Delegatie en mandaat in het stichtingenrecht, S \& V 1995, p. 148 e.v.

Overeenkomsten in strijd met de goede zeden, diss. Leiden 1920.

Schadevergoeding aandeelhouder bij onrechtmatig handelen jegens vennootschap, Bb 1995, p. 51 e.v.

De verbintenis in het rechtspersonenrecht, in: Met recht verenigd, Arnhem, p. 185 e.v.

De regels die de betrekkingen 'binnen' de rechtspersoon beheersen, in: Nieuw vennootschaps- en rechtspersonenrecht, Zwolle 1992, p. 70 e.v.

De relatie tussén vennootschapsrecht en arbeidsrecht bij het ontslag van bestuurders van vennootschappen, TVVS 1996, p. 281 e.v.

Handboek voor het Nederlandsche Faillissementsrecht, Groningen 1935.

Handboek voor het Nederlandsch handels- en faillissementsrecht, I, Se druk 1969.

Proxy solicitation, De NV 1997, p. 264 e.v.

Joint ventures (diss.), Deventer 1976.

Rechtspersonen tussen contract en instituut (rede Tilburg). Deventer 1987.

Geschillen in 50/50-verhoudingen, in: Tot vermaak van Slagter, 1988 p. 96 e.v.

Over de rechtsbetrekkingen tussen aandeelhouders in een 'quasi-vof, in: In het nu, wat het worden zal, Deventer 1991, p. 203 e.v.

Besluit van aandeelhouders tot statutenwijziging in strijd met de redelijkheid en billijkheid, AA 1991, p. 1009 e.v. 
Raaijmakers, M.J.G.C.:

Raaijmakers, M.J.G.C.: Raaijmakers, M.J.G.C.:

Rijken, G.J.:

Rijken, G.J.:

Rodenburg, P.:

Roelvink, H.L.J.:

Roelvink, H.L.J.:

Rozendaal, J.:

Sande Bakhuijzen, N.J.:

Schilfgaarde, P. van:

Schilfgaarde, P. van:

Schilfgaarde, P, van:

Schilfgaarde, P, van:

Schilfgaarde, P, van:

Schilfgaarde, $P$, van:

Scholten, P.:

Schoordijk, H.C.F.:

Schoordijk, H.C.F.:

Schuit, S.R.:

Schut, G.H.A.:

Schwarz, C.A.:

Schwarz, C.A.:
Enkele rechtsvergelijkende beschouwingen over joint ventures, Preadvies Nederlandse Vereniging voor Rechtsvergelijking, Deventer 1992.

'Omgekeerde doorbraak': Poot/ ABP, AA 1995, p. 491 e.v.

Een halve eeuw Nederlands rechtspersonen- en vennootschapsrecht en twintig jaar Boek 2 BW, in: Na twintig jaar Boek 2 BW, Deventer 1996, p. 1 e.v.

Exoneratieclausules; Een analyse van de omstandigheden van welker waardering het afhangt of een beroep op een exoneratieclausule vrijstaat, diss. Utrecht, Deventer 1983.

Redelijkheid en billijkheid, Monografieên Nieuw BW, Deventer 1994.

Misbruik van bevoegdheid, Serie Monografieên NBW, deel 4A, Deventer 1985.

Bestuurszelfstandigheid in concernverhoudingen, in: Piercing van Schilfgaarde, Deventer 1990, p. 45 e.v.

Rechtsbescherming van directeuren, NJB 1981, p. 75 e.v.

Rechten van derden ten aanzien van ongeldige besluiten en antistatutaire handelingen bij de naamloze vennootschap, diss. Rotterdam 1931.

Artikel 6.5.3.1. NBW en goede trouw, WPNR 1977, p. 247 e.v.

Misbruik van rechtspersonen, Arnhem 1986.

Contractuele structurering van bestuur en toezicht, in: Ondernemingsrechtelijke contracten, Deventer 1991, p. 11 c.v.

Repliek, in: Piercing van Schilfgaarde, Deventer 1991, p. 69 e.v.

Tegenstrijdig belang in het vennootschapsrecht, in: De dubbelrol in het vennootschapsrecht, Deventer 1993, p. 30 e.v.

Acties van aandeelhouders, in: Rechtspleging in het ondernemingsrecht, Deventer 1996, p. 1 e.v.

Van de BV en NV, elfde druk Deventer 1998.

Rechtsbeginselen, in: de serie mededeelingen der Koninklijke Akademie van Wetenschappen, 1934.

De aandeelhouder en zijn stem, Studiekring Prof.Mr. J. Offerhaus, reeks Handelsrecht, nr. 7. Amsterdam, Scheltema \& Holkema 1969.

Redelijkheid en billijkheid aan de vooravond van een nieuw millenium (rede), Zwolle 1996.

Instructiebevoegdheid in joint venture-verhoudingen, De NV 1997 , p. 246 e.v.

Rechtshandeling, overeenkomst en verbintenis, Zwolle 1987.

Blokkering van aandelen (diss.), Deventer 1986.

Décharge van bestuurders van vereniging en stichting, S \& V 1993, p. 42 e.v. 
Schwarz, C.A.:

Schwar, C.A.:

Schwarz, C.A.:

Schwarz, C.A.:

Slagter, W.J.:

Slagter, W.J.:

Slagter, W.J.:

Slagter, W.J.:

Slijkhuis, L.H.:

Smit, H.J.:

Smits, J.;

Solinge, A.G. van:

Solinge, A.G. van:

Sperling, J.:

Suetens-Bourgeois:

Tekenbroek, E.:

Timmerman, L.:

Timmerman, L.:

Timmerman, L.:

Timmerman, L.:
Het ontslag van de op arbeidsovereenkomst werkzame bestuurder van een stichting of vereniging. S \& V 1993, p. 57 e.v.

Ziek zijn en ontslagen worden. Dubbele rechtsbetrekking of gemengde overeenkomst? NJB 1993, p. 1054 e.v.

De invloed van vergadergerechtigden zonder stemrecht op besluitvorming in de aandeelhoudersvergadering, in: Heden verschenen voor mij, Liber Amicorum aangeboden aan prof. mr. A.L.M. Soons, Amhem 1995, p. 201 e.v.

Goede raad is duur; motiveringsplicht, hoorrecht en raadgevende stem bij ontslag van bestuurders, WPNR 1995, p. 525 e.v.

Degradatie van aandeelhouders of wijziging van hun rechten? TVVS 1965, p. 130 e.v.

Gebundelde actiên, in: Goed en Trouw, Opstellen voor W.C.L. van der Grinten, Zwolle 1984, p. 235 e.v.

Macht en onmacht van de aandeelhouder (rede), Deventer 1988.

Besluitvormingsprocessen in: Miscellanea, Juris consulto vero Delicata, Van Dunné-bundel, Deventer 1997, p. 381 e.v.

De bank als kredietverschaffer/aandeelhouder, in: De dubbelrol in het vennootschapsrecht, Deventer 1993, p. 61 e.v.

Ontslag en schorsing van directeuren en de mogelijkheid van herstel der dienstbetrekking via kort geding. WPNR 1987, p. 89 e.v.

Het vertrouwensbeginsel en de contractuele gebondenheid (diss. Leiden), Arnhem 1995.

Instructiebevoegdheid in concernverhoudingen, in: Goed en Trouw, Zwolle 1984, p. 255 e.v.

Vergaderorde, in: Problemen rondom de algemene vergadering, Deventer 1994, p. 41 e.v.

Derivative suits in Nederiand?, De NV 1998, p. 62 e.v.

De verhouding meerderheid minderheid in de naamloze vennootschap (diss.), Gent-Leuven 1970.

De verhouding tusschen de aandeelhouders en de bestuurders bij de publieke naamloze vennootschap in Nederland, Universiteits-boekencentrale Delft 1923.

Het vennootschapsrecht en het ontslag van een bestuurder van een NV of BV, De NV 1985, p. 6 e.v.

Over multinationale ondernemingen en medezeggenschap van werknemers (diss. Groningen), Deventer 1988.

Concretisering van vage normen in het ondernemingsrecht, in: Van vennootschappelijk belang, Zwolle 1988, p. 337 e.v.

Het aan ondernemingen toekomende recht op geheimhouding. in: Tot vermaak van Slagter, 1988, p. 337 e.v. 
Timmerman, L.:

Timmerman, L.:

Timmerman, L.:

Timmerman, L.:

Timmerman, L.:

Timmerman, L.:

Timmerman, L.:

Timmerman, L.:

Timmerman, L.:

Timmerman, L.:

Timmerman, L.:

Timmerman, L.:

Timmerman, L.:

Timmerman, L.:

Uniken Venema, C.AE.:

Uniken Venema, C.AE.:

Verdam, A.F.:

Verdam, A.F.:

Verdam, A.F.:

Verdam, P.J.:

Vletter-van Dort, H.M.:

Vlug, G.:

Völlmar, H.F.A.:

Voogd, R.P.:
De stand van het vennootschapsrecht (rede Groningen), Deventer 1990.

Aansprakelijkheid van bestuurders van nv's en bv's; een overzicht van enige recente rechtspraak, TVVS 1991, p. 197 e.v.

Bespreking van het Tonnema-arrest, TVVS 1991, p. 189 e.v. Waarom hebben wij dwingend vennootschapsrecht?,in: Ondernemingsrechtelijke contracten, uitgave vanwege het instituut voor Ondernemingsrecht, Deventer 1991, p. 1 e.v.

Nietigheden in het nv- en bv-recht, RM Themis 1992, p. 148 e.v.

Enkele opmerkingen over normering van het handelen van bestuurders van NV's en BV's, TVVS 1992, p. 31 e.v.

Is versoepeling van het Nederlandse n.v/b.v.-recht wenselijk?, TVVS 1992, p. 163 e.v.

Dient de rechter voor een rechtspersoon besluiten te kunnen vaststellen? in: Knelpunten in de vennootschapswetgeving, Deventer 1995, p. 23 e.v.

Het krakende gebouw van het vennootschapsrecht, TVVS 1995 , p. 178 e.v.

Kroniek van het vennootschapsrecht, NJB 1996, p. 1318 e.v.

Kunnen aandeelhouders in privé vergoeding vorderen van schade die de vennootschap heeft geleden?. TVVS 1997, p. 16 e.v.

Kroniek van het vennootschapsrecht, NJB 1997, p. 1457 e.v.

Kan een aandeelhouder of vennootschapsschuldeiser afgeleide schade vorderen? TVVS 1998, p. 97.

Kroniek van het vennootschapsrecht, NJB 1998, p. 1456 e.v. Corporate opportunities; aspecten van loyaliteit in het kader van een onderneming naar Amerikaans en Nederlands recht, in: Jurist in bedrijf, Deventer 1980, p. 167 e.v.

Law en Equity in het Anglo-Amerikaanse privaatrecht, Zwolle 1990

Corporate opportunities (diss.), Zwolle 1995.

Corporate opportunities, De NV 1996, p. 284 e.v.

Behoorlijke taakvervulling en trustee-functic, in: $\mathrm{Na}$ twintig jaar Boek 2 BW. Deventer 1996, p. 149 e.v.

Nietigheid van besluiten (diss.), Zwolle 1940.

Meldingsplicht voor beursvennootschappen, Deventer 1994.

Naamloze Vennootschappen, Wet tot wijziging en aanvulling van de bepalingen omtrent de naamloze vennootschap en regeling van de aansprakelijkheid voor het prospectus, Rotterdam 1928.

Nederlands Burgerlijk Recht, Zwolle 1952.

Statutaire beschermingsmiddelen bij beursvennootschappen (diss.) 1989. 
Voûte, A.:

Vijver, J.J. van de:

Vijver, R. van den:

Vranken, J.B.M.:

Waaijer, B.C.M.:

Waaijer, B.C.M.:

Wezeman, J.B.:

Wiarda, G.J.:

Winter, J.W:

Winter, J.W.:

Witt Wijnen, O.L.O. de:

Wymeersch, E.:

Zaman, D.F.M.M.:

Zeben, C.J.:

Zeylemaker, JB:

Zeylemaker, JB,:

Zevenbergen, Chr:

\section{Duitsland}

Baumann, H.-Reiß, W.:

Baums, Th.-Randow von, $\mathrm{Ph}$.:

Bischoff, Th.:
Prijs van de derde kan blokkeringsprijs van BV-aandelen zijn. NV 1992, p. 167 e.v.

Proxy Solicitation, in: Jurist in bedrijf. Nederlands Genootschap van Bedrijfsjuristen 1930-1980, p. 213 e.v.

Besluitvorming in besturen van vennootschappen, in: Recht zo die gaat, Zwolle 1976, p. 167 e.v.

Le bon juge en onbillijke rechtspraak, in: Met hoofd en hart, Zwolle 1991, p. 51 e.v.

Statuten en statutenwijziging (diss. Nijmegen), Deventer 1993.

Aandeelhoudersovereenkomsten, Deventer 1996.

Aansprakelijkheid van bestuurders (diss.), Deventer 1998.

Drie typen van rechtsvinding. Zwolle 1988.

Recht op dividend, WPNR 1991, p. 246 e.v.

Stemmen op afstand via het Communicatiekanaal Aandeelhouders, in: Corporate Governance voor Juristen, Uitgave vanwege het Instituut voor Ondernemingsrecht Rijksuniversiteit Groningen, Deventer 1998, p. 81 e.v.

Toegang vergader- en stemgerechtigden, in: Problemen rond de algemene vergadering. Deventer 1994, p. 15 e.v.

Nieuwe regelen inzake bestuur, in: Het gewijzigde vennootschapsrecht 1995. Antwerpen 1996.

Verdeling, beperking en opschorting van aan aandelen verbonden rechten en besluitvorming door de algemene vergadering, TVVS 1982, p. 78 e.v.

Parlementaire geschiedenis van het nieuw burgerlijk wetboek, boek 2 rechtspersonen.

Het keeren van misbruiken in de onderlinge verhouding van naamloze vennootschappen, Indisch Tijdschrift voor het Recht 1932, p. 25 e.v.

Verleden, heden en toekomst van de naamloze vennootschap, Tjeenk Willink, Zwolle 1947.

Aard en werking der goede trouw in het Romeinsche verbintenissenrecht, Utrecht 1942.

Satzungsergãnzende Vereinbarun-gen-Nebenvertrăge im Gesellschaftsrecht. Eine rechtstatsấchliche und rechtsdogmatische Untersuchung, ZGR 1989, p. 157 e.v.

Der Markt für Stimmrechtsvertreter, Die AG 1995, p. 145 e.v.

Sachliche Voraussetzungen von Mehrheitsbeschlussen in Kapitalgesellschaften, BB 1987, p. 1055 e.v. 
Bungert, $\mathrm{H}$.:

Dreher, M.:

Dreher, M.:

Dreher, M.:

Dreher, M.:

Ebenroth, C.T. en Lange, K.W.:

Eckhardt, B.:

Eisenhardt, U.:

Flume, W:

Freiherr von

Rechenberg, W-G.:

Gieseke, H.:

GroB, W.:

Hammen, H.:

Heermann, P.W.:

Henssler, M:

Henze, $\mathrm{H}$ :

Henze, $\mathrm{H}$.:

Henze, $\mathrm{H}$ :

Hommelhoff, P.:
Die Treupflicht des Minderheitsaktionärs, DB 1995, p. 1749 e.v.

Die persōnliche Verantwortlichkeit von Geschäftsleitern nach außen und die innergesellschaftliche Aufgabenteilung, ZGR 1992, p. 22 e.v.

Die Schadenersatzhaftung bei Verletzung der aktienrechtlichen Treupflicht durch Stimmrechtausübung, ZIP 1993, p. 330 e.v.

Treuepflichten zwischen aktionären und Verhaltenspflichten bei der Stimmrechtsbündelung, ZHR 1993 p. 160 e.v.

Die gesellschaftsrechtliche Treuepflicht bei der GmbH, DStR 1993, p. 1632 e.v.

Sorgfaltspflichten und Haftung des Geschäftsführers einer GmbH nach $\$ 43 \mathrm{GmbhG}, \mathrm{GmbHR} 1992$, p. 69 e.v.

Die Beendigung der Vorstands- und Geschäftsführerstellung in Kapitalgesellschaften (diss.), Köln 1989.

Zum Weisungsrecht der Gesellschafter in der nicht mitbestimmten GmbH, in: Festschrift für Gerd Pfeiffer, Köln 1988, p. 839 e.v.

Die Rechtsprechung des II. Zivilsenats des BGH zur Treupflicht des GmbH-Gesellschafters und des Aktionärs, ZIP 1995 , p. 160 e.v.

Die Hauptversammlung als oberstes Organ der Aktiengesellschaft, Heidelberg 1986.

Interessenkonflikte der GmbH-Geschãftsführer bei Pflichtenkollissionen, GmbHR 1996, p. 486 e.v.

Vorbereitung und Durchführung von Hauptversammlungsbeschlüssen zu Erwerb oder Verăußerung von Unternehmensbeteiligungen, Die AG 1996, p. 230 e.v.

Zur geplanten Neuregelung des Depotstimmrechts, ZIP 1995. p. 1301 e.v.

Stimmrechtsvertretung in der Hauptversammlung und Schadenersatzhaftung, ZIP 1994, p. 1243 e.v.

Aktienrechtliche Verhaltenspflichten bei Stimmrechtsausubung. ZHR 1993, p. 91 e,v.

Materiellrechtliche Grenzen für Mehrheitsentscheidungen im Aktienrecht (Teil D), DstR 1993, p. 1823 e.v.; (Teil II), DstR 1993, p. 1863 e.v.

Die Treupflicht im Aktienrecht, BB 1996, p. 489 e.v.

Treupflichten der Gesellschafter im Kapitalgesellschaftsrecht. ZHR 1998, p. 185 e.v.

Ergebnisverwendung in der GmbH, ZGR 1986, p. 419 e.v. 
Hüffer, U.:

Hüffer, U.:

Hûffer, U.:

Immenga, U.:

Immenga, U.:

Joost, D.:

Joost, D.:

Kallmeyer, H.:

Kallmeyer, H.:

Konzen, H.

Krieger, G.:

Kübler, F.:

Kübler, F.:

Lutter, M:

Lutter, M.:

Lutter, M.:

Lutter, M.:

Lutter,M:

Martens, K-P.:

Martens, K-P.:
Zur gesellschaftsrechtlichen treupflicht als richterrechtlicher Generalklausel, in: Festschrift für Ernst Steindorff, BerlinNew York 1990, p. 59 e.v.

Zur gesellschaftsrechtlichen Treuplicht als richterrechtlicher Generalklausel, in: Festschrift für Emst Steindorff zum 70. Geburtstag am 13. Mărz 1990, Berlin-New York 1990, p. 59 e.v.

Aktiengesetz mit Erlâuterungen, 2. Auflage, München, 1995.

Die personalistische Kapitalgesellschaft, Bad Homburg. Athenăum Verlag 1970.

Bindung von Rechtsmacht durch Treueplichten, in: Festschrift 100 Jahre GmbH-Gesetz, Köln 1992, p. 189 e.v.

Bestândigkeit und Wandel im Recht der Gewinnverwendung in: Festschrift 100 Jahre GmbH Gesetz, Köln 1992, p. 289 e.v.

'Holzmüller 2000' vor dem Hintergrund des Umwandlungsgesetzes, ZHR 1999, p. 164 e.v.

Recht der Gewinnverwendung in der GmbH, GmbHR 1992 , p. 788 e.v.

Die Ausübung von Aktionärsrechten in der Hauptversammlung durch 'Form-Aktionăre', die AG 1998, p. 123 e.v.

Geschāftsführung, Weisungsrecht und Verantwortlichkeit in der GmbH \& Co KG, NJW 1989, p. 2979 e.v.

Fehlerhafte Satzungsänderungen: Fallgruppen und Bestandskraft, ZHR 1994, p. 35 e.v.

Erwerbchancen und Organpflichten - Uberlegungen zur Entwicklung der Lehre von den 'corporate opportunities', in: Festschrift Winfried Werner, Berlin 1984, p. 437 e.v.

Geschäftschancen der Kommanditgesellschaft, ZGR 1991, p. 162 e.v.

Zur Treupflicht des Großaktionărs, JZ 1976, p. 225 e.v.

Theorie der Mitgliedschaft, AcP 1980, p. 84 e.v.

Zur inhaltlichen Begründung von Mehrheitsentscheidungen Besprechung der Entscheidung BGH WM 1980, 378, ZGR 1981, p. 171 e.v.

Zur Vorbereitung und Durchführung von Grundlagenbeschlüssen in Aktiengesellschaften, in: FS Fleck, 1988, p. 169 e.v.

Die Treupflicht des Aktionärs. Bemerkungen zur LinotypeEntscheidung des BGH, ZHR 1989, p. 464 e.v.

Grundlagen und Entwicklung des Minderheitsschutzes in der GmbH, in: Festschrift 100 Jahre GmbH Gesetz, Köln 1992. p. 607 e.v.

Zum Interesse an wirtschaftlicher Selbständigkeit, FS Fischer, 1979, p. 442 e.v. 
Martens, K-P.:

Martens, K-P.:

Marsch-Barner, R.:

Marsch-Barner, R.:

Mayer, D.:

Merkt, H.:

Meilicke, H.:

Mertens, H.J.:

Mertens, H-J.:

Meyer, F.:

Michalsky, U.:

Munch, Ch.:

Paschke, M. von:

Paefgen, T.C.:

Piepenburg, M.:

Raiser, Th.:

Raiser, T.:

Raiser, T.:

Raiser, T.:

Reichert, J.:

Saenger, I.:

Schiessl, M.

Schmidt, K:
Zum außenordentliche Beendigung von Organ- und Anstellungsverhältnis, in: FS Werner 1983, p. 495 e.v.

Der Einfluß von Vorstand und Aufsichtsrat auf Kompetenzen und Struktur der Aktionäre - Unternehmensverantwortung contra Neutralitätspflicht, in: FS Karl Beusch 1993, p. 529 e.v.

Treuepflichten zwischen Aktionären bei Stimmrechtsbündelung, ZHR 1993, p. 179 e.v.

Treupflicht und Sanierung, ZIP 1996, p. 853 e.v.

Die Zulässigkeit von Stimmrechtsvereinbarungen im $\mathrm{GmbH}$ Recht, GmbHR 1990, p. 61 e.v.

Unternehmungsleitung und Interessenkollision, ZHR 1995, p. 423 e.v.

Das Auskunftsrecht des Aktionärs in der Hauptversammlung, DStR 1992, p. 72 e.v.

Die Geschäftsführungshaftung in der $\mathrm{GmbH}$ und das ITTUrteil, in: FS Robert Fischer, Berlin-New York 1979, p. 461 e. $\dot{v}$.

Das Minderheitsrecht nach $\S 122$ Abs. 2 AktG und seine Grenzen, die AG 1997, p. 481 e.v.

Das 'Eintrittsrecht' der Aktiengesellschaft gemäß 88 Abs. 2 S. 2 Aktiengesetz, AG 1988, p. 259 e.v.

Vergleichender Überblick über das Recht der Kapitalgesellschaften in Frankreich, DStR 1991, p. 1563 e.v.

Amtsniederlegung. Abberufung und Geschãftsunfähigkeit des Geschäftsfūhrers einer GmbH, DStr 1993, p. 912 e.v.

Treuepflichten im Recht der juristischen Person, FS Rolf Serick 1992, p. 313 e.v.

Die Geschäftschancenlehre: Ein notwendiger Rechtsimport?, AG, 1993, p. 457 e.v.

Mitgliedschaftliche Treupflichten der Aktionäre (diss.), Hamburg 1996.

Das Unternehmensinteresse, in: Festschrift für Reiner Schmidt, Karlsruhe 1976, p. 101 e.v.

Recht der Kapitalgesellschaften, München 1992.

Nichtigkeits- und Anfechtungsklagen, in: 100 Jahre GmbHGesetz 1992, p. 53 e.v.

Das Recht der Gesellschafterklagen, ZHR 1989, p. 1 e.v.

Vinkulierungsklausein und gesellschaftsrechtliche Treupflicht, in: FS 100 Jahre GmbH-Gesetz, Kōln 1992, p. 209 e.v.

Minderheitenschutz und innergesellschaftliche Klagen, GmbHR 1997, p. 112 e.v.

Die Wahrnehmung von Geschäftschancen der $\mathrm{GmbH}$ durch ihren Geschäftsfuhrer, GmbHR 1988, p. 53 e.v.

Die Information des Gesellschafters, in: FS 100 Jahre GmbH-

Gesetz 1992, p. 559 e.v. 
Schneider, U.H.:

Semler, J.:

Siegmund, I.:

Siepelt, S.:

Siepelt, S.:

Sonnenberg, $\mathrm{T}$.

Sünner, E.:

Teubner, G.:

Than, J.:

Timm, W.:

Timm, W.:

Timm, W.:

Timm, W.:

Ulmer, P.:

Ulmer, P.:

Volhard, R :

Weisser, J.:

Weisser, J.:

Wenger, E.:

Westermann, H-P:

Wiedemann, H.:

Wiedemann, $\mathrm{H}$.:

Winter, M.

Winter, M.

Zöllner, W.:

Zöllner, W.:
Gesetzliches Verbot für Stimmrechtsbeschrănkungen bei der Aktiengesellschaft? Die AG 1990 , p. 56 e.v.

Leitung und Überwachung der Aktiengesellschaft: die Leitungsaufgabe des Vorstands und die Uberwachungsaufgabe des Aufsichtsrats, Kōln 1996.

Stimmverbote im GmbH-Recht, BB 1981, p. 1674 e.v.

Das Rederecht in der Hauptversammlung (diss), Köln 1992.

Das Rederecht des Aktionărs und dessen Beschränkung, Die AG 1995, p. 254 e.v.

Die Änderung des Gesellschaftszwecks, Frankfurt am Main 1990.

Aktionărsschutz und Aktienrecht, Die AG 1983, p. 169 e.v.

Unternehmensinteresse - das gesellschaftliche Interesse des Unternehmens 'an sich"?, ZHR 1985, p. 470 e.v.

Aktienrechtliche Verhaltenspflichten bei Stimmrechtsausübung. ZHR 1993, p. 124 e.v.

Der Mißbrauch des Auflósungsbeschlüsse durch den Mehrheitsgesellschafter, JZ 1980, p. 138 e.v.

Wettbewerbsverbot und Geschăftschancenlehre im recht der GmbH, GmbHR 1981, p. 177 e.v.

Zur Sachkontrolle von Mehrheits-entscheidungen im Kapitalgesellschaftsrecht, ZGR 1987, p. 403 e.v.

Treuepflichten im Aktienrecht, WM 1991, p. 481 e.v.

Verletzung schuldrechtlicher Nebenabreden als Anfechtungsgrund im GmbH-Recht?, NJW 1987, p. 1849 e.v.

Aktionårsklage zur Kontrolle von Vorstand und Aufsichtsrat, die AG 1999, p. 290 e.v.

'Siemens/Nold': Die Quittung, die AG 1998, p. 397 e.v.

Gesellschafterliohe Treuepflicht bei Wahrnehmung von Geschäftschancen der Gesellschaft durch de facto geschäftsführenden Gesellschafter, DB 1989, p. 2010 e.v.

Corporate Opportunities (diss.), Köln-Berlin-Bonn-München 1991.

Der Fall Girmes - ein Stūck aus dem Tollhaus, ZIP 1993, p. 321 e.v.

Das Verhältnis von Satzung und Nebenordnungen in der Kapitalgesellschaft, Heidelberg 1994.

Die Bedeutung der ITT-Entscheidung, JZ 1976, p. 110 e.v.

$\mathrm{Zu}$ den Treuepflichten im Gesellschaftsrecht, in: Festschrift für Theodor Heinsius, Berlin-New York 1991, p. 949 e.v.

Mitgliedschaftliche Treuebindungen im GmbH-Recht (diss.), München 1988.

Vinkulierungsklauseln und gesellschafterliche Treuepflicht, in 100 Jahre GmbH-Gesetz 1992, p. 209 e.v.

Die Schranken mitgliedschaftlicher Stimmrechtsmacht bei den privatlichen Personenverbănden, München-Berlin 1963.

$\mathrm{Zu}$ Schranken und Wirkung von Stimmbindungsverträgen, insbesondere bei der GmbH, ZHR 1991, p. 168 e.v. 


\section{Engeland, Canada, Australië en de Verenigde Staten}

American Law Institute: Principles of Corporate Governance: Analysis and Recommendations, St. Paul, ALI Publishers, 1994, vol I, 432 p.; vol II, $477 \mathrm{p}$.

André, Th.J.:

The Corporate Governance Reform Act of 1995, The Journal of Corporation Law 1995, p. 89 e.v.

Beck, S.M.:

Beck, S.M.:

Boyle, A.J.: The saga of Peso Silver Mines: corporate opportunity reconsidered, The Canadian Bar Review 1971, p. 80 e.v.

The quickening of fiduciary obligation: Canadian Aero Services v. O' Malley, The Canadian Bar Review 1975, p. 55 e.v.

Directors' Fiduciary Duties: The Continuing Problem Of Effective Enforcement, in: Forum Internationale, 1987, p. 3 e.v.

Brudney, V.

en Clark, R.C:

A new look at corporate opportunities, Harvard Law Review 1981, p. 997 e.v.

Cary, W.L.I

Eisenberg, M.A.:

Cases and Materials on corporations, 1980.

Cheffins, B.R.:

Clark, R.C.:

Davenport, B.J.:

Davies, P.L.:

Dawson, I.J.

en Stephenson, I.S:

Ellis, M.V.:

Company Law; Theory, structure and operation, Oxford 1997.

Corporate Law, Boston 1986.

What did Russell v. Northern Bank Development Lid. decide? LQR 1993, p. 553 e.v.

Directors' fiduciary duties and individual shareholders in 'Commercial aspects of trusts and fiduciary obligations. Oxford 1992, p. 83 e.v.

Minority shareholders, London 1993.

Fiduciary duty and joint business relations, in: Special lectures of the Law society of upper Canada 'Fiduciary Duties' 1990.

Ferran, E.:

The decision of the House of Lords in Russell v. Northern Bank Development Corporation Limited, CLJ 1994, p. 343 e.v.

Finch, $V_{\text {: }}$

Disqualification of directors, a plea for competence, MLR 1990, p. 385 e.v.

Finn, P.D.:

Finn, P.D.:

The Fiduciary Principle, in: Equity, Fiduciaries \& Trusts, 1989.

Fiduciary law and the Modern Commercial World, in: E. McKendrick (ed.), Commercial Aspects of Trusts and Fiduciary obligations, Oxford 1992, p. 7 e.v.

Flannigan, R.:

The Fiduciary Obligation, Oxford Journal of Legal Studies 1989 , p. 285 e.v. 
Gardner, J.:

Gautreau, J.R.M.:

Giora, S.;

Goldberg, G.D.:

Goulding. S.:

Goulding, S.:

Gower, L.C.B.:

Grantham, R.

Grantham, R.

Grantham, R.

Hawke, N.:

Hicks, A.:

Hill, J.:

Hollington, R.:

Hopkins, J.:

Hopt, K.J.:

Hopt, K.J.,

Teubner, G.:

Kast, F.E.,

Rosenzweig, J.E.:

Law Commission, the:

Law Commission, the:

Lower, M:

Macintosh, J.G.:
Restitutionary claims by company directors, LQR 1990, p. 366 e.v.

Demystifying the fiduciary mystique, The Canadian Bar Review 1989, p. 1 e.v.

Voting agreements and corporate statutory powers, LQR 1993, p. 210 e.v.

Article 80 of Table 80 of the Companies Act 1948, MLR 1970 , p. 177 e.v.

The private company in the United Kingdom, in: The European Private Company? Antwerpen/Apeldoom 1995, p. 55 e.v.

Principles of Company Law, London 1996.

Gower's principles of modern company law, London 1997.

The content of the director's duty of loyalty, JBL 1993, p. 149 e.v.

The unanimous consent rule in company law, CLJ 1993, 245 e.v.

The Doctrinal Basis of the Rights of Company Shareholders, CLJ 1998, p. 554 e.v.

Legal control of directors' dividend discretion, Business Law Review 1989, p. 3 e.v.

Disqualification of directors -40 years on, JBL 1988, p. 27 e.v.

Protecting minority shareholders and reasonable expectations, Company and Securities Law Journal 1982, p. 87 e.v.

Minority shareholders'rights, London 1992.

Fiduciary duty - receipt of company's property by director equitable allowance to fiduciary, CL 1990, p. 220 e.v.

Self-Dealing and Use of Corporate Opportunity and Information: Regulating Directors' Conflicts of interest, in: Corporate Governance and Directors' Liabilities, Berlin-New York 1985, p. 285 e.v.

Corporate Governance and directors' liabilities, Berlin-New York 1985.

Organization and Management. A systems and contingency approach, New York 1979.

Fiduciary duties and regulatory rules: report on a reference under s. 3 (1) (e) of the Law Commissions Act 1965, London 1995.

Shareholder Remedies, (no, 246) London 1997.

Towards an emerging law of joint ventures: Elliot v. Wheeldon, JBL 1994, p. 507 e.v.

Corporations, in: Special Lectures of the Law Society of upper Canada 'Fiduciary duties' 1990, p. 88 e.v. 
Maddaugh, P.D.:

Magner, E.S.:

Marsden, A.:

Maurice

Gautreau, J.R.:

McKendrick, E.(ed.):

McGlynn, C.:

Minow, N.:

Morse, G.K.:

Parkinson, J.E.:

Pennington, R.R.:

Pennington, R.R.:

Pickering, M.:

Poole, P./Roberts, J.:

Poole, P./Roberts, J.:

Prentice, D.D.

Prentice, D.D.

Prentice, D.D.

Prentice, D.D.

Rajak, H.:

Riley, C.A.:

Riley, C.A.:
Definition of fiduciary duty, in: Fiduciary Duties, Special lectures of the Law Society of upper Canada, 1990, p. 15 e.v.

Convocation of general meetings in company, reflections on Totex-Adon pty.Itd and the Companies Act, ABLR 1981, p. 96 e.v.

Does a shareholders'agreement require filling with the Registrar of Companies. The Company Lawyer 1994, p. 19 e.v.

Demystifying the fiduciary mystique, The Canadian Bar Review 1989, p. 3 e.v.

Commercial Aspects of Trusts and Fiduciary Obligations, Oxford 1992.

Re-writing the Corporate Constitution, JBL 1995, p. 585 e.v.

Proxy Reform: The case for increased shareholder communication, The Journal of Corporation Law 1991, p. 149 e.v.

Conflicts of interests in English company law, in: De dubbelrol in het vennootschapsrecht, Deventer 1993, p. 41 e.v.

Corporate Power and Responsability. Issues in the Theory of Company Law, Oxford, Clarendon Press 1993.

Management structures and functions in English law, in: Quo vauis ius socieiatum 1912 , p. 131 e.v.

Directors' personal liability, London 1987.

Shareholders' voting rights and company control, LQR 1965 , p. 248 e.v.

Shareholder Remedies-Efficient Litigation and the Unfair Prejudice Remedy, JBL 1999, p. 38 e.v.

Remedies-Corporate Wrongs and the Derivative Action, JBL 1999, p. 99 e.v.

The Corporate Opportunity Doctrine, MLR 1974, p. 464 e.v.

The theory of the firm: minority shareholder oppression: section 459-461 of the Companies Act 1985, OJLS 1988, p. 55 e.v.

Corporate Opportunity - Windfall Profits, MLR 1979, p. 215 e.v.

Restraints of the exercise of majority shareholder power. LQR 1976, p. 502 e.v.

Fiduciary duty of a managing director, MLR 1972, p. 657.

Contracting out of Company Law: section 459 of the Companies Act and the Role of the Courts, MLR 1992, p. 782 e.v.

Vetoes and voting agreements, Northern Ireland Legal Quarterly 1993, p. 34 e.v. 
Sealy, L.S.:

Sesiy, L.S.:

Sealy, L.S.:

Sealy, L.S.:

Shahara, N.M./ HokeWitherspoon, A.E:

Smart, P.St.J.:

Sugarman, D.:

Sullivan, G.R.:

Sullivan, G.R.:

Tufnell, K.D.:

Tunc, A.:

Wedderburn, W.:

Wedderburn, W.:

Xuereb, P.:

Xuereb, P.

Xuereb, P.:

Xuereb, P:

Youdan, T.G. (ed):
Rixon, F.G.:

Competing interests and conflicting principles: an examination of the power of articles of association, MLR 1986, p. 415 e.v.

Fiduciary relationships, CLJ 1962, p. 69 e.v.

Some principles of fiduciary obligation, CLJ 1963, p. 119 e.v.

Company-directors duties and exempting articles, CLJ 1987. p. 217 e.v.

Power of the general meeting to intervene, CLJ 1989, p. 26 e.v.

The Evolution of the 1992 Shareholder Communication Proxy Rules and their impact on Corporate Governance, The Business Lawyer 1993, p. 327 e.v.

Misuse of confidential information; the company's and minority shareholder's remedies, JBL 1994, p. 464 e.v.

Reconceptualising company law: reflections on the Law Commission's consultation paper on shareholder remedies (part I), The Company Lawyer 1997, p. 226 e.v.

The relationship between the board of directors and the general meeting in limited companies, LQR 1977, p. 569 e.v.

Going it Alone - Queensland Mines v. Hudson, MLR 1979. p. 711 e.v.

Restrictions on shareholders' voting rights, The Company Lawyer 1993, p. 90 e.v.

The judge and the businessman, LQR 1986, p. 552 e.v.

Shareholders' rights and the rule in Foss v. Harbottle, CLJ 1957, p. 194 e.v.

Control of corporate actions, MLR 1989, p. 401 e.v.

The limitation on the exercise of majority power, The Company Lawyer 1985, p. 199 e.v.

The 'interests of the company' and directors' in English, Italian and French company law, in: Current issues in International Business Law, ed: D.L. Perrot/l. Pogany, 1988, p. 215 e.v.

The Rights of Shareholders, Oxford 1989.

Voting rights: A Comparative Review, The Company Lawyer 1994, p. 16 e.v.

Equity, Fiduciaries and Trusts, Toronto 1989.

\section{Frankrijk}

Adom, $\mathrm{K}$ :
La révocation des dirigeants de sociétés commerciales, Rev.

Soc. 1998, p. 487 e.v. 
Aubert, J-L:

Baillod, R.:

Baillod, V.R.:

Beaufort, J-L.:

Berdah, J.P.:

Bissara, Ph.:

Bissara, Ph.:

Boizard, M.:

Bolard, G.:

Bosquet-Denis, J-B.:

Bras, W. le:

Cabrillac, M.:

Calais-Auloy, J.:

Cannu, P. le:

Cannu. P. le:

Cannu, P. le:

Cannu, P. le:

Cannu, P. le:

Cannu, P. le:

Caussain, J.L.:

Chartier, Y/ Mestre, J.:

Couret, A:

Dabin, J.:

Daigre, J-J:
La révocation des organes d'administration des sociétés commerciales, Rev.trim.dr.com. 1968, p. 977 e.v.

Le 'juste motif de révocation des dirigeants sociaux, Rev. trim.dr.com. 1983, p. 395 e.v.

L'information des administrateurs de sociétés anonymes, Rev. trim.dr.com. 1990, p. 1 e.v.

Le droit d'agrément dans la sociétés de presse, Rev.Soc. 1994, p. 430 e.v.

Fonctions et Responsabilités des Dirigeants de Sociétés par actions, Bibliotheque de droit commercial, T. 2, 1974.

L'Inadaptation du droit francais des sociétés aux besoins des entreprises et les aléas des solutions, Rev.Soc. 1990, p. 553 e.v.

L'intérêt social, Rev.Soc. 1999, p. 5 e.v.

L'abus de minorité, Rev.Soc. 1988, p. 365 e.v.

Administrateur provisoire et mandat ad hoc, JCP 1995, éd E. p. 509 e.v.

La protection de l'associé contre le gérant statutaire et égalitaire d'une société à responsabilité limitée, Rev.Soc. 1993, p. 751 e.v.

La validité des clauses de préemption dans les conventions extra-statutaires, Bull.Joly 1986, p. 665 e.v.

$\mathrm{De}$ quelques handicaps dans la construction de la theoric de I'abus de minorité, Mélanges Colomer 1993, p. 109 e.v.

L'abus de pouvoirs ou de fonctions en droit commercial francais, in L'abus de pouvoirs ou de fonctions, Travaux de L'Association Henri Capitant des amis de la culture juridique francais, Tome XXVIII, Paris 1980, p. 221 e.v.

L'abus de minorité, Bull.Joly 1986, p. 429 e.v.

Eléments de réflexion sur la nature de l'expertise judiciaire de gestion: Bull.Joly 1988, p. 553 e.v.

La protection des administrateurs minoritaires, Bull.Joly 1990, p. 511 e.v.

L'absence de majorité, Rev.Jur. Com. 1991, p. 96 e.v.

L'action de concert, Rev.Soc. 1991, p. 675 e.v.

La minorité inerte (observations sous l'arrêt Flandin), Bull. Joly 1993 , p. 540 e.v.

La précarité de la fonction de mandataire social, Bull.Joly 1993, p. 520 e.v.

Les grandes décisions de la jurisprudence. Les sociétés, Parijs 1988.

Le harcèlement des majoritaires, Bull.Joly 1996, p. 112 e.v.

Le droit subjectif, Parijs 1952.

Réflexions sur le statut individuel des dirigeants de sociétés anonymes, Rev.Soc. 1981, p. 497 e.v. 
Daille-Duclos, B.:

\section{Didier:}

Dubout, $\mathrm{H}$ :

Engel, Ph./Trossière, P.;

Godon, L:

Gourlay, G.:

Goyet, C.:

Grillet-Ponton, D.:

Guengant, A. e.a.:

Hémard, Terré et

Mabilat:

Jauffret-Spinosi, C.:

Jeantin, $\mathbf{M}$ :

Legros, J.P.:

Lepoutre, E.:

Lyonnet, B:

Marin, J-C.:

Martin, D.,

Faugerolas, L.:

Martin, J.Y.:

Maze, S.:

Mazet, G.:

Merle, $\mathrm{Ph}$ :

Merie, $\mathrm{Ph}$.

Mestre, J.:
Le devoir de loyauté du dirigeant, JCP 1998 ed. E. p. 1486 e.v.

Droit Commercial, Paris 1997.

Les clauses de durée dans les pactes extrastatutaires entre actionnaires, Bull.Joly 1997, p. 5 e.v.

La prime de fidélité aux actionnaires par distribution d'une majoration de dividende, JCP ed.E 1994, p. 55 e.v.

Les obligations des associés, thèse Parijs, Economica Parijs 1999.

Le conseil d'administration de la société anonyme, Parijs 1971.

Les limites du pouvoir majoritaire dans les sociétés, in: La loi de la majorité, Rev.Jur.Com. numéro spécial nov. 1991. p. 58 e.v.

La méconnaissance d'une règle impérative de la loi, cause des nullité des actes et délibérations des organes de la société, Rev. Soc. 1984, p. 259 e.v.

Le rôle des juges dans la vie des sociétés, Paris 1993.

Sociétés commerciales, Dalloz Parijs 1972.

Les assemblées générales d'actionnaires dans les sociétés anonymes, réalité ou fiction, in: Études Rodière, Parijs 1982, p. 125 e.v.

Les conventions de vote, Rev.Jur. Com. 1990, p. 124 e.v.

La nullité des décisions de sociétés, Rev.Soc. 1991, p. 275 e.v.

Autofinancement des entreprises et abus de majorité, Bull. Joly 1996, p. 189 e.v.

L'administrateur judiciaire, Rev. Jur.Com 1991, p. 241 e.v.

La mission du juge dans la prévention des abus, in: La loi de la majorité, Rev.Jur.Com. spécial novembre 1991, p. 65 e.v.

Les pactes d'actionnaires, JCP 1989 éd. E 15526.

Le détournement d'une chance economique par un société, these Paris I, 1981.

Les devoirs des actionnaires prépondérants en droit comparé (diss.), Parijs 1987.

Les clauses statutaires d'agrément, in: 'La stabilité du pouvoir et du capital dans les sociétés' Rev.Jur. Com. spécial 1990, p. 66 e.v.

L'abus de minorite, in: La loi de la majorité, Rev.Jur.Com. spécial novembre 1991, p. 81 e.v.

Droit Commercial, Sociétés commerciales, Parijs 1992.

Réflexions sur les pouvoirs du juge dans la vie des sociétés. Rev.Jur.Com. 1985, p. 81 e.v. 
Michelin-Finielz, S.:

Moury, J.:

Nabasque, H. Le:

Parleani, G.:

Peltier, F.:

Prat, S:

Reigne, P.:

Reinhard, Y:

Ripert, G.:

Rives-Lange, J.L.:

Saintourens, B.:

Schapira, J.:

Schmidt, D.

Schmidt, D.:

Storck, M.:

Tricot, D.:

Tunc, A.:

Tunc, A :

Viandier, A.:

Viandier, A.:

Viandier, A:

Vidal, D.:
L'expertise de l'article L. 226 et l'expertise preventive dans la société anonyme, Rev.Soc. 1982, p. 33 e.v.

Des clauses restrictives à la libre négociation des actions, Rev.trim.dr.com. 1989, p. 187 e.v.

Le développement du devoir de loyauté en droit des sociétés, Rev.trim.dr.com. 1999, p. 273 e.v.

Les pactes des actionnaires, 1991, p. 1 e.v.

L'attribution d'une dividende majoré à l'actionnaire stable, Bull.Joly 1995, p. 38 e.v.

Les pactes d'actionnaires relatifs au transfert de valeurs mobilières, thèse Parijs 1992.

Révocabilité ad nutum des mandataires sociaux et faute de la société, Rev.Soc. 1991 , p. 499 e.v.

Les clauses de préférence et préemption en cas de cession entre actionnaires, Rev.Jur.Com 1990, p. 88 e.v.

La loi de la majorité dans les sociétés par actions, Rev.Jur. Com. numéro spécial nov. 1991.

L'abus de majorité, in: La loi de la majorité, Rev.Jur.Com. spécial novembre 1991 , p. 65 e.v.

La flexibilité du droit des sociétés, Rev.trim.dr.com. 1987, p. 467 e.v.

L'intérêt social et le fonctionnement de la société anonyme, Rev.trim.dr.com. 1971, p. 957 e.v.

Les droits de la minorité dans la société anonyme, thèse, Strasbourg 1970.

Les conflits d'intérêts dans la société anonyme, Parijs, Joly, 1999.

La réglementation des conventions de vote, Rev.Jur.Com. 1991, p. 97 c.v.

Abus de droits dans les sociétés/ abus de majorité et abus de minorité, Rev.trim.dr.com. 1994, p. 617 e.v.

On the virtues of codification: the contracts in which a director is interested, Festschrift Kurt Lipstein, Heidelberg 1980. p. 343 e.v.

The judicial settlement of intra-corporate conflicts, in: The Cambridge Lectures, 1981 , p. 70 e.v.

La notion d'associé, Parijs 1978.

Observations sur les conventions de vote: JCP 1986, éd.E. 15405.

Chronique droit des sociétés, JCP éd.G. 1999, p. 1568 e.v.

Grand arrêts du droit des affaires, Parijs 1992. 


\section{Zakenregister}

(Verwezen wordt naar paragrafen, het cerste cijfer staat voor het hoofdstuk)

Abus de droit 2.5. 8.5, 9.4, 9.9, 12.2.1

Abus de majorité $\quad 2.3 .1,2.4 .3,2.5 .2$,

$2.6,5.4 .3,6.3 .1,12.2 .1$

Abus de minorité $\quad 2.3 .1,2.4 .3,2.5 .2$,

$2.6,5.4 .3,12.2 .1$

Abus de pouvoirs $\quad 2.3 .1,10.2,12.2 .1$

Aandeelhouder(s)

acties van-

als volmachtgever

$7.7,10.8 .1,10.10$

en stemovereenkomst

4.1.1 e.v.

4.2 e.v.

4.1 e.v.

en volmacht

4.2 e.v., 12.6 .8

overeenkomst

3.7 .1

spreekrecht van-

stemrecht van-

$3.7 .1,3.7 .2,4.1 .1$

Aansprakelijkheid

bestuursvoorzitter

11.3

gevolmachtigde

$4.1 .6,4.3$

meerderheidsaandeelhouder

7.7

Aktiengesellschaft

karakter

$2.1,12.6 .7$

organisatiestructuur

Algemene vergadering van

aandeelhouders

agendering

bijeenroeping

$3.3,3.3 .1,6.6 .1$

deelname aan-

3.7 .1

invloed-

oproeping

7.1 e.v.

overleg

$3.3,3.3 .3$

raadpleging van-

7.2 e.v.

redelijk belang bij houden- $3.3 .1,3.3 .2$

tegenvoorstellen

3.5

verdaging

3.6

American Law Institute 10.4, 10.5, 10.7

Benoeming bestuurder

8.1 e.v.

bindende voordracht-

8.1, 8.3, 8.6

invloed afspraken op-

8.5

kwaliteitseisen-

$8.1,8.2,8.6$

motivering-

8.3

Besloten vennootschap

karakter

2.1, 12.6.7

organisatiestructuur
Besluit

heroverweging van-

3.8 .2

intrekking van-

3.8 .2

nietigheid- $\quad 1.3 .1,2.5 .2 \mathrm{e} . \mathrm{v} ., 9.5 .1$

Besluitvorming $1.3,3.7 \mathrm{e.v}, 11.1 \mathrm{e.v}$

behoorlijke- $\quad 2.5 .2,3.9,12.3 .1$

buiten vergadering $\quad 3.1,9.5 .1$

$\begin{array}{ll}\text { blokkeren van- } & 3.8\end{array}$

fasen in de- $\quad 3.1$

schriftelijke- $\quad 11.6,12.5$

in geval van corporate

opportunities

10.7

Bestuur

collectieve verantwoorde-

lijkheid van- $11.1,11.2,1$ e.v., 11.7

collegiaal-

$11.1,11.2,11.2 .2$

delegatie binnen- $\quad 11.2,11.2 .3,11.7$

instructie binnen- $\quad 11.2,11.2 .2$

mandaat binnen- $\quad 11.2,11.2 .4$

taakverdeling binnen- $\quad 11.2 .1,11.4$

zelfstandigheid- $\quad 1.4 .2,7.2 .1,7.5$

Bestuurder

als fiduciary $10.2 \mathrm{e.v}$.

(behoorlijke) taakvervulling- $\quad 7.2$.

9.7, 10.3, 11.2.1,

$11.4,11.7$

contractuele rechtsbetrekking- $\quad 9.3$

en volmacht $\quad 11.5 .1,11.5 .2$

hoorrecht- $\quad 9.5,9.5 .1$

loyaliteit- $\quad 10.2$ e.v., 12.4

(on)geschiktheid -

organisatierechtelijke

rechtsbetrekking-

recht op informatie $11.4,11.7,12.5 .1$

recht op overleg $\quad 11.4,11.7,12.5 .1$

stemrecht- $\quad 9.5,9.5 .2,11.5 .2$

van besloten vennootschap $9.10,10.6$

van publieke vennootschap $9.10,10.6$

winstclaim van-

11.9

Bestuursvoorzitter

aansprakelijkheid (zie aansprake-

lijkheid) positie

11.3 


$\begin{array}{lr}\text { Bevoegdhedenverdeling } & \begin{array}{r}4.2 .1, \\ \text { Blokkeringsregeling }\end{array} \\ \begin{array}{lr}\text { wijziging- } \\ \text { Compensatie }\end{array} & 5.5 \\ \quad \text { voor aandeelhouders } & 5.3,5.7,12.6 .6 \\ \text { voor bestuurders } & 9.10,12.6 .6 \\ \text { Contractleer } & 1.2 .1,2.3 \\ \text { Corporate opportunities } & 10.1 \text { e.v. } \\ \text { categorieên van- } & 10.5 \\ \text { constructive trust } & 10.8,10.9 \\ \text { en concurrentie } & 10.1 \\ \text { en misbruik van voorwetenschap } & 10.1 \\ \text { en tegenstrijdig belang } & 10.1,10.7 \\ \text { en structuur vennootschap } & 10.6 \\ \text { gedragsregels } & 10.7 \\ \text { financiering- } & 10.7 \\ \text { grondslag toetsing- } & 10.2,10.3 \\ \text { rechtsgevolgen gebruik- } & 10.8 \\ \text { toestemming gebruik- } & 10.7\end{array}$

vrijgave van-

$10.7,10.10$

Dividend 6.2 e.v., 6.6 e.v.

en bestuurdersbeloningen

6.5 .3

en winst

6.5 .2

Derivative suit

$10.8,10.10$

Dubbelrol

3.7.1, 4.1.5.

$6.5 .3,9.10,12.6 .3$

Enquêterecht

1.2 .1 e.v., 2.5.2,

$2.5 .3,3.8 .1,6.6 .2$

Fiduciary duties

2.3 e.v., 2.6 , $10.2,12.2 .1$

begrip

2.3.1

duty of loyalty

$2.4 .1,10.5$

reikwijdte-

2.4 .2

Fiduciary relationships $\quad 2.3,2.4 .2,2.6$

Gesellschaft mit beschränkter Haftung

\begin{tabular}{lr}
$\begin{array}{l}\text { karakter } \\
\text { organisatiestructuur } \\
\text { Gevolmachtigde }\end{array}$ & $2.1,12.6 .7$ \\
gedrag- & 2.2 \\
gedragsregels & $2.3,4.1 .2 \mathrm{e.v}$. \\
$\begin{array}{l}\text { stemgedrag- } \\
\text { Goede trouw } \\
\text { begrippen }\end{array}$ & $4.1 .2,11.5 .3$ \\
betekenis- & 4.1 .3 \\
functies- & $4.1 .5 \mathrm{e.v}$. \\
\hline
\end{tabular}

ontwikkeling-

1.2 e.v

ontwikkeling- 1838-1928

1.2.1

ontwikkeling- 1900-1945 $\quad 1.3$

ontwikkeling- na 1945

ontwikkeling- 1976-1992 1.5

verhouding- en goede zeden 1.3.1. 2.3

verhouding- misbruik van

(meerderheids)macht

$1.3 .1,2.3$

Instructierecht $\quad 7.1$ e.v., 11.2, 11.2.2

Law Commission

2.5.1

Mandataire de justice $\quad 2.5 .2 \mathrm{II}, 3.3 .1$, $3.9,6.6 .2,6.7,12.3 .1$

Meerderheidsaandeelhouder(s) 1.3 e.v., 2.3 e.v., 3.1 e.v., 4.1 e.v., 5.1 e.v., 6.1 e.v.

belang van-

5.1 e.v., 6.1 e.v

invloed van-

$7.4,7.8,12.6 .2$

Minderheidsaandeelhouder(s) 1.3 e.v., 2.3 e.v., 3.1 e.v., 4.1. e.v., 5.1 e.v., 6.1 e.v

belang van- $\quad 3.1$ e.v., 5.2 e.v., $6.2 .1,7.5$

bescherming van-

1.2.2, 5.4

benadeling van-

5.2 e.v., 6.1 e.v.,

7.5, 7.7, 12.6 .5

Misbruik van bevoegdheid

1.3.2.

Misbruik van recht

$1.9 .1,1.10 .1$

Naamloze vennootschap

karakter

$2.1,12.6 .7$

organisatiestructuur

2.2

Ontslag bestuurder

9.1 e.v.

goede grond -

9.6, 9.8 e.v.

verhouding - en schorsing

9.8

\section{Ontslagbesluit}

(zie redelijkheid en billijkheid)

\section{Proxy solicitation}

4.1 e.v., 12.3 .1

Private company

karakter

2.1, 12.6.7

organisatiestructuur

Public company

karakter

$2.1,12.6 .7$

organisatiestructuur

2.2

Rechtsvergelijking

BV en NV

2.1 e.v.

functionele-

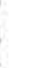

5

3


Redelijkheid en billijkheid

als beslissingsnorm

als gedragsnorm

betekenis-

en agendering

en benoeming

en beraadslaging

en corporate opportunities $10.1,10.3$. $10.5,10.6,10.7,10.8$

en gevolmachtigde

11.5 .3

en informatic

11.4

en kwaliteitseisen

en ontslag

en oproeping

$9.1,9.2,9.8,9.10$

3.3 e.v.

en overleg

11.4

en quorumeisen

11.5 .1

en stemovereenkomst

4.2

en voordracht benoeming bestuurder

functies-

reikwijdte-

$3.1 \mathrm{e.v}$

toetsing ontslagbesluit aan- $\quad 9.6,9.11$

toetsing schorsingsbesluit aan-9.7, 9.11

toetsing statutenwijziging aan- 5.1 e.v.

toetsing winstreserveringsbesluit aan-

verhouding-en misbruik van recht

$1.9 .1,1.9 .2,1.10 .2$

verhouding-en misbruik van bevoegdheid

Schorsing bestuurder

goede grond -

gevolgen -

9.7

Schorsingsbesluit

(zie redelijkheid en billijkheid)

Sociéte Anonyme

karakter-

structuur-

Statuten

$3.1 .3,5.1$

Société à Responsabilité Limité

karakter

organisatiestructuur

2.2

Statutenwijziging goede grond voor-

Stemgedrag

1.2.2, 5.1 e.v.

herziening van

$2.4,4.1 .5$. e.v.

3.8.1
Steminstructie

4.1 .3 e.v.

Stemovereenkomsten

4.2 e.v.

$8.5,12.6 .8$

categorieên van-

criteria geldigheid-

$4.2 .1,8.5$

4.2 .2

toelaatbaarheid-

\section{Stemrecht}

(zie aandeelhouders en bestuurders)

functioneel-

$3.7 .2,11.5 .2$

verlies van-

5.6

Tegenstrijdig belang $3.7 .1,6.5 .3,9.5$, $10.7,12.6 .3$

stemrecht bij-

3.7 .1

vergaderrecht bij-

3.7 .1

\section{Toetsing}

inhoud besluit

1.3.1, 5.1 c.v., 6.1 e.v., 12.3.2, 12.6 .4

marginale-

$1.9 .2,1.10 .2$

totstandkoming besluit

1.3.1.

3.3 e.v., 9.5 e.v.

van structuurbesluiten $\quad 5.4 .1,12.6 .4$

volledige-

$1.9 .2,9.2,9.11$

Treupflicht $\quad 2.4 .1,3.5 .3,4.1 .5,5.4 .1$, $6.3 .2,7.5 .2,7.7,10.2,10.7,10.8$ begrip

functies-

mitgliedschaftliche-

2.4 .1

organschaftliche-

2.4 .1

reikwijdte-

2.4 .1

Unfair prejudicial conduct $\quad 2.3,2.4 .2$.

$5.4,6.3 .3,6.4 .2$,

$6.5,9.10,12.2 .1$

\section{Vennootschap}

belang van-

4.2.2, 4.2.3. 5.3, $5.5,6.2 .2,6.3 .7 .3$ e.v, $9.5 .1,9.7,9.9,10.2,11.3$

karakter van-

2.1 e.v., 12.6.7

Vennootschapsrecht

dualistisch systeem

$4.2 .1,8.5$

institutioneie benadering

1.4 .2 ,

$1.11,9.2$

relatie- en arbeidsrecht

8.3

Volmacht

4.1 e.v., 11.5 .1 e.v.

Winstreservering

6.1 e.v.

verhouding - dividend-verieden 6.5 .1

verhouding - dividend

6.5 .2 



\section{Rechtspraakregister}

Verwezen wordt naar de paragrafen: het eerste cijfer staat voor het hoofdstuk

\section{Nederland}

\section{Hoge Raad}

10 januari 1988, W. 5518

1.2.1, 1.7.2.

27 mei 1898 , W. 7128

18 april 1913, W. 9500, NJ 1913, p. 723 (Van Roessel/De Posthoorn)

$1.2 .1,1.3 .1$

29 november 1923, W. 11147, NJ 1924, p. 129

17 juni 1921, W. 10740 (Deen Perlak)

$1.2 .1,1.3 .1,5.1$

4 april 1924, NJ 1924, p. 564

1.7 .2

20 juni 1924 , W. 11259 , NJ 1924 p. 1107

$1.2 .1,1.7 .2$

1.7 .2

1.7 .2

8 januari 1926, NJ 1926, 203 (Sarong)

3 november 1927, NJ 1928, p. 397

1.3 .1

15 juni 1928 , NJ 1928 , p. 1626

1.3 .1

1.3 .1

6 december 1929, NJ 1930, p. 109

2.7 .2

9 januari 1941, NJ 1941, 528 (Willink/Ter Kuile)

$1.3 .1,2.7 .2$

13 februari 1942, NJ 1942, 360 (eerste Baus/De Koedoe)

21 mei 1943, NJ 1943, 484 (Tweede Baus/De Koedoe)

$1.3 .1,1.7 .2,8.2$

$1.9 .2,6.5 .2$

30 juni 1944, NJ 1944, 465 (Wennex)

8.5

23 juli 1946, NJ 1947, 1

I april 1949, NJ 1949, 465 (Doetinchemse ijzergieterij)

$1.4 .2,1.10 .2$

21 januari 1955, NJ 1959, 43 (Forumbank)

$1.4 .2,1.7 .2,7.2 .3$

27 januari 1956, NJ 1956, 48 (Unipart-RDM)

1.4

13 november 1959, NJ 1960, 472 (Distilleerderij Melchers)

19 februari 1960, NJ 1960, 473 (Aurora)

22 december 1961, NJ 1962, 43 (Ariềns-Van Loo)

$3.7 .2,4.2 .1,8.5$

$3.7 .2,8.5$

9.7

4 januari 1963, NJ 1964, 434 (Scholten's Aardappelmeelfabrieken)

1.10 .1

30 oktober 1964, NJ 1965, 107 (Mante)

14 mei 1965, NJ 1965, 259

19 mei 1967, NJ 1967, 261 (Saladin-HBU)

15 juli 1968, NJ 1969, 101 (Wijsmuller)

19 maart 1976, NJ 1978, 52 (Van Rees)

24 september 1976, NJ 1978, 135 (Erdal)

5 januari 1979, NJ 1979, 317 (Slijkerman-Öldorp)

$3.3,3.9$

1.10 .2

1.7 .2

$1.10 .2,3.3 .1,3.7 .1$

$8.2,8.3,8.4,8.6$

1.10 .2

1.10 .1

18 juni 1982, NJ 1983, 200 (De Vries/ Biologische Tuinbouwvereniging Elderveld)

1.10 .2

26 oktober 1984, NJ 1985, 375 (Sjardin/Sjartec)

$1.10 .2,9.2,9.3,9.8$

1.10 .2

9.5

18 mei 1989, NJ 1990, 591 (WTC)

1.10 .2

19 mei 1989, NJ 1989, 652

1.10 .2

20 oktober 1989, NJ 1990, 308

9 juli 1990, RvdW 1990. 147, NJ 1991, 51 (Sluis BV) 
19 oktober 1990, NJ 1991, 21, TVVS 1991, p. 18 nt. Timmerman (Koghee/Akkoca)

17 mei 1991, NJ 1991, 645 (Lampe-Tonnema)

13 november 1992, NJ 1993, 265 (Levinson-MAB Holding)

4 december 1992, NJ 1993, 271, AA 1993, p. 275 nt. Raaijmakers, TVVS 1993, p. 45 nt. Timmerman (Meijers/Mast)

19 maart 1993, NJ 1994, 92

17 september 1993, NJ 1994, 548 (Meier/Mattern)

6 oktober 1993, NJ 1994, 300 (Bobel/VEB)

8 december 1993, NJ 1994, 273

2 december 1994, NJ 1995, 288, TVVS 1995, p. 16 nt. Timmerman (Poot/ABP)

10 maart 1995, NJ 1995, 595, AA 1995, p. 788 nt. Raaijmakers, TVVS 1995, p. 163 nt. Timmerman (Janssen Pers)

I, $1.10 .2,3.8 .2,9.5 .1$

9 juni 1995, NJ 1996, 213 (Citco-Krijger)

17 november 1995, NJ 1996, 142 (Atlantic Nominees)

29 november 1996, JOR 1996, 26, NJ 1997, 178 (Cri Cri)

10 januari 1997, JOR 1997, 29, NJ 1997, 360 (Van de Ven)

\section{Ondernemingskamer}

18 maart 1976, NJ 1978, 317 (Batco)

26 mei 1983, NJ 1984, 481 (Linders-Hofstee)

26 november 1987, NJ 1989, 271 (IKON)

11 april 1991, NJ 1991, 533 (Regev)

24 januari 1991, NJ 1991, 224 (Sluis BV)

16 maart 1995, JOR 1996, 54

15 mei 1997, NJ 1998, 517

5 februari 1998, NJ 1998, 560

3 maart 1999, JOR 1999, 87, NJ 1999, 350 (Gucci I),

22 maart 1999, JOR 1999, 88 (Gucci II)

27 april 1999, JOR 1999, 105 (Gucci III)

27 mei 1999, JOR 1999, 121, NJ 1999, 487 (Gucci IV),

\section{SER- beslissing}

22 september 1978, NV 1978, 218 (Lanser) 


\section{Gerechtshoven}

\section{Gerechtshof Amsterdam}

18 mei 1989, NJ 1990, 591 (WTC)

\section{Gerechtshof Amhem}

24 april 1917, NJ 1917, p. 634

9 oktober 1974, NJ 1976, 42 (Makelaarskantoor Van E.)

26 mei 1992, NJ 1993, 182 nt. Maeijer, TVVS 1993.

p. $105 \mathrm{nt}$. Timmerman (Uniwest)

10 september 1996, JOR 1996, 130

\section{Gerechtshof 's-Gravenhage}

15 april 1971, NJ 1971, 301 (Goodrich)

1 oktober 1982, NJ 1983, 393

17 maart 1983, NJ 1984, 81 (Reijnders/McKinney)

23 september 1983, NJ 1985, 277 (Schipholtrans)

14 juni 1985, NJ 1987, 574

9 oktober 1987, KG 1987, 454 (Nevesbu)

Gerechtshof 's-Hertogenbosch

1 april 1992, KG 1992, 347 (Limbutex)

8 april 1992, NJ 1992, 701 (Gilissen c.s-L. Beheer)

22 januari 1996, KG 1996, 92 (Van der Staak)

19 maart 1996, NJ 1997, 462 (Van Beuningen/Drukkerij Skyline BV)

15 mei 1996, JOR 1996, 70 (Philips/VEB)

20 augustus 1996, JOR 1996, 111

7.7

19 november 1996, KG 1997, 19 (Weijts)

10.8

\section{Arrondissementsrechtbanken}

Alkmaar

Pres. Rb. Alkmaar 15 december 1976, NJ 1977, 319

\section{Amsterdam}

$\mathrm{Rb}$. Amsterdam 20 oktober 1936. NJ 1938, 213 (Dominium Patriae) 
Rb. Amsterdam 28 september 1979, NJ 1980, 458

Pres. Rb. Amsterdam 15 juni 1988, KG 1988, 276 (HCS)

$10.1,10.7$

Pres. Rb. Amsterdam 1 augustus 1988, KG 1988, 341 (HCS)

$10.1,10.7$

Rb. Amsterdam 26 februari 1997, JOR 1997, 78 (MeesPierson/Lustig)

\section{Arnhem}

Rb. Arnhem 12 november 1942, NJ 1943, 846

$1.3 .1,3.9$

Rb. Amhem 17 januari 1946, NJ 1947, 280

Rb. Arnhem 22 september 1967, NV 45, 125 (Veenendaalsche Stoomspinnerij en Weverij NV)

Pres. Rb. Amhem 28 december 1987, NJ 1988, 699 (Amstelland)

Rb. Arnhem 7 maart 1996, JOR 1996, 43

Assen

Pres. Rb. Assen 7 oktober 1992, KG 1992, 365

Pres. Rb. Assen 17 december 1993, KG 1994, 90 (Cemex-Zeidenrust)

\section{Breda}

Rb. Breda 17 november 1942, NJ 1943, 463 (Astarte)

Rb. Breda 12 juni 1979, NJ 1981, 219 (Tilburgse Waterleidingmaatschappij)

\section{'s-Gravenhage}

Rb. 's-Gravenhage 29 oktober 1927, W. 11756, NJ 1929, 47

Rb. 's-Gravenhage 26 november 1928, NJ 1929, 1026 (De Econoom)

Rb. 's-Gravenhage 22 mei 1970, NV 48, 51 (Vredestein)

Rb. 's-Gravenhage 19 februari 1982, NJ 1983, 522

Pres. Rb. 11 december 1992, Juridisch up to date 1993, nr. 2 (HFD-Sijthoff)

Pres. Rb. 20 december 1995, KG 1996, 33.

\section{Haarlem}

Rb. Haarlem 30 december 1941, NJ 1942, 798

Pres. Rb. Haarlem 19 februari 1988, KG 1988, 133

Pres. Rb. Haarlem 8 mei 1990, KG 1990, 247 (Keijzer Papier)

\section{'s-Hertogenbosch}

Rb. 's-Hertogenbosch 20 januari 1959, NJ 1959, 487 


\section{Leeuwarden}

Pres. Rb. Leeuwarden 3 februari 1988, KG 1988, 200 (Lampe/Tonnema)

\section{Maastricht}

Rb. Maastricht 6 oktober 1932, NJ 1933, p. 420

\section{Middelburg}

Pres. Rb. Middelburg 24 april 1990, KG 1990, 162

\section{Roermond}

Rb. Roermond 17 mei 1973, NJ 1974, 57

Rb. Roermond 4 april 1985, NV 1985, p. 227

\section{Rotterdam}

Rb. Rotterdam 20 februari 1911, W. 9183

Rb. Rotterdam 19 maart 1985, NJ 1986, 504

Pres. Rb. Rotterdam 11 augustus 1995, KG 1995, 355 (Wilton/Feyenoord)

\section{Utrecht}

Rb. Utrecht 30 juni 1920 , NJ 1920, p. 1139

Rb. Utrecht 15 mei 1953, NJ 1954, 337

Pres. Rb. Utrecht 16 februari 1989, KG 1989, 156 (Cobu)

Zutphen

17 januari 1991, WPNR (6001) 1991, p. 246 (Uniwest)

\section{Zwolle}

Rb. Zwolle 14 november 1979, NJ 1983, 75

Rb. Zwolle 3 maart 1999, JAR 1999, 97 
Rechtspraakregister

\section{Duitsland}

\section{Reichsgericht}

31 maart 1931, RGZ 132, p. 149 (Victoria)

\section{BundesGerichtshof}

8 mei 1967, GmbHR 68, p. 141 (Betriebsgrundstück)

5 juni 1975, BGHZ 65, p. 15, die AG 1976, 16, NJW 1976, 191 (ITT)

3 maart 1980, BGHZ 76, 191, Die AG 1980, p. 187

10 april 1977, GmbHR 1977, p. 129

13 maart 1978, BGHZ 71, p. 40 (Kali \& Salz)

1 februari 1988, BGHZ 103, p. 184, NJW 1988, p. 1579 (Linotype),

20 maart 1995, ZIP 1995, 819.

\section{Oberlandesgericht}

\section{Oberlandesgericht Düsseldorf}

20 november 1992, ZIP 1993, 347

17 mei 1994, ZIP 1994, 878

14 juni 1996, ZIP 1996, 1211

Oberlandesgericht Hamm

3 juli 1991. GmbHR 1992, p. 458, BB 1992, p. 33

Oberlandesgericht München

24 maart 1993, die AG 1993, 283 (Siemens)

Landgericht

Landgericht Dïsseldorf

4 juni 1991, ZIP 1991, 932 


\section{Landgericht München}

19 januari 1993, GmbHR 1993, p. 664

\section{Frankrijk}

\section{Cour de Cassation, Chambre civile Section commerciale}

4 juni 1946, JCP 1947.II.3518 (Sté anonyme de Teinture et d'impressions c. Motte et autres)

18 april 1961, D. 1961, p. 661, JCP 1961.II.69087

(Anciens Etablissement Piquard)

29 mei 1972, Rev. Soc. 1973, p. 487

$2.4 .3,6.3 .1$

10.10

21 maart 1974, Rev. Soc. 1974, 471

6 mei 1974 , Rev. Soc. 1974 , p. 524

22 april 1976, Rev. Soc. 1976, p. 479 (SARL Etablissement Langlois et Peter c. Roizot)

19 oktober 1981, Rev. Soc. 1982, p. 821

$5.5,7.2 .1$

18 mei 1982, Rev. Soc. 1983, p. 71

17 juli 1984, Rev. Soc. 1984, 791

2 juli 1985, D. 1986, p. 351, Rev. Soc. 1986, p. 231 (Cointreau)

6.3 .1

23 juni 1987 , BRDA 1987 , nr. 14, p. 17

17 oktober 1989. Bull. 1989 IV, no. 250

19 december 1983, Rev. Soc 1983, p. 105

6 juni 1990 , Rev. Soc. 1990 , p. 606, D. 1990 , p. 56 (SARL Huber)

19 juni 1990, Rev. Soc. 1990, 621 (Consorts Radoux c. Consort Mercier et autres)

14 januari 1992, Bull. Joly 1992, p. 273 (Vitama) 
Rechtspraakregister

\section{Cour d'appel}

Cour d'appel Amiens

10 maart 1977, Rev. Soc. 1978, 258

\section{Cour d'appel Aix en Provence}

21 november 1963, Gaz. Pal. 1963, 2, 154

28 september 1982, Rev. Soc. 1983, p. 773

29 juni 1995, Juris Data nr. 95- 45922

Cour d'appel Limoges

21 november, Gaz.Pal. 1963, 2, 154

10.2

Cour d'appel Limoges 26 juni 1995, Juris Data nr. 95-43884

\section{Cour d'appel Paris}

22 februari 1933, D. p. 528 (Carelles et Hirsch v. Compagnie Francaise des tramways du Douai et la Bienhoa)

22 mei 1965, Rev.trim.dr.com. 1965, p. 619 (Freuhauf)

1 december 1987, Rev.Soc. 1987, p. 237 (Dennery)

24 januari 1997, Bull. Joly 1997, p. 405

23 april 1992, RDDA 1992, nr. 837

28 januari 1999, Rev. Soc 1999, p. 427

Cour d'appel Pau

21 januari 1991, Rev. Soc. 1992, p. 46. Bull. Joly 1993, p. 547 (Flandin c. SARL Alarme Service)

Cour d'appel Versailles

7 december 1995, Bull. Joly 1996, p. 197

\section{Tribunal Commercial}

Paris

20 februari 1970, Gaz. Pal. 1970-2-J-94 


\section{Cases}

\section{Engeland}

Allen v Gold Reefs of West Africa Ltd [1900] 1 Ch. 656

Automatic Self-Cleansing Filter Syndicate Co. Ltd. v. Cunninghame [1906] 2 Ch. 34

Boardman v Phipps [1967] 2 AC

Breckland Group Holdings Ltd. v London \& Suffolk Properties Ltd.

[1988] Ch div. 4 BCC 542

British Union for the abolition of Vivisection, Re [1995] 2 BCLC 1 (Ch D)

Burland v Earle [1902] AC 83

Bushell v. Faith [1970] AC 1099

Byng v London Life Association Lud [1989] 1 All ER 560

Company, a, Re, no. 00477 [1986] BCLC 1986, 376

Company, a, Re no. 005685 [1988] Ringtower [1989] BCLC, 427

Company, a, $\operatorname{Re}$ [1986] 2 BCC 99, 453 en 2 BCC 99, 495 (Appeal)

Company, a, Re [1988] 4 BCC 506

Curnana Ltd, Re [1986] BCLC 430 CA

D' Jan of London, Re [1994] 1 BCLC

Dawkins v. Antrobus [1881] 17 Ch.D. 615

10.9

Ebrahimi v. Westbourne Galleries [1972] 2 All ER 492

Edwards v. Haliwell [1950] 2 All. ER 1064

Elliot v. Wheeldon [1993] BCLC 53

El Sombrero Ltd., Re [1958] Ch 900

Foss v. Harbottle [1843] 2 Hare $461 \mathrm{Ch}$.

Greenhalgh v. Aderne Cinema's Ltd [1951] 1 Ch 286, [1950] 2 All ER 1120 (CA) 5.4 .2

Guinness v. Saunders [1990] 2 WLR 333.

Harman v. BML Group Limited [1994] 2 BCLC 674, [1994] 1 WLR 893, (CA)

Howard Smith Ltd v. Ampel Petroleum Ltd. [1974] AC 821

Inderwick v. Snell [1850] 2 Mac. \& G. 21642 ER 83

Industrial Development Consultants Ltd v. Cooley [1972] 1 WLR 443

Isle of Wight Rly Co v. Tahourdin [1883] 25 Ch D 320

Kenyon Swansea Ltd, Re, [1987] BCLC, 514

Lundie Brothers, Re [1965] 1 WLR 1051

Marshall's Valve Gear Lid. v. Manning Wardle Lid [1909] 1 Ch 267

Northern Counties Securities Ltd. v. Jackson and Steeple Ltd [1974] 1 WLR 1133, [1974] 2 All ER 625

North-West Transportation Co. Ltd. v. Beatty [1887] 12 App Cas 589

Regal Cinema's Hastings Ltd v. Gulliver [1967] 2 AC

Pender v. Lushington [1877] 6 Ch D 70

Salomon v. Salomon \& Co. Lid [1897] AC 2

Sam Weller \& Sons Led, Re, [1986] BCLC 430 CA

Saul D. Harrison \& Sons, Re, [1995] 1 BCLC 14

Scott v. Scott [ 1943] CA All ER 582 
Shuttleworth v Cox Brothers \& Co. [1927] 2 KB 9 CA

\section{Australië}

Club Flotilla Ltd. v. Isherwood [1987] 12 ACLR 387

Peter's American Delicacy Co v. Health [1939] 61 CLR 457 High Court of Australia

Gambotto v. WCP Ltd [1995] 127 ALR (High Court of Australia), [1992] 8 ALSR 141 (Court of Appeal)

Roberts v. Walter Developments Pty Ltd [1992] 10 ACLC 804

Sanford v. Sanford Courier Services Pty Ltd [1987] 5 ACLC 394

(Supreme Court of New South Wales)

Theseus Exploration NL v. Mining \& Associated Ltd [1973] Qdr 81

\section{Canada}

Abbey Glen property Corp. v. Stumborg, DLR 197885 (Alt S.C),

\section{Ierland}

Russell v. Northern Bank Development Corporation Limited, Northern Ireland Court of Appeal, 16 april 1991, BBC 1991, 517, House of Lords 8 april en 11 juni 1992, WLR 1992, 588

\section{Verenigde Staten}

Guth v. Loft, 5 A.2d 503 Del. [1939]

Electronic Development Corporation v. Robson, 148 Neb. 526 , 28 N.W. 2 d 130 [1947]

Miller v, Miller, 222 N.W. 2d 71 Minn. [1974] 77 ALR 3d 941 


\section{Curriculum Vitae}

Marjan Koelemeijer werd op 9 augustus 1965 geboren te Doetinchem. In 1984 behaalde zij haar VWO-diploma aan het Christelijk Lyceum Veenendaal. Vanaf 1984 studeerde zij rechten aan de Universiteit Utrecht, waar zij in 1990 het doctoraal-examen Nederlands recht, afstudeerrichting privaatrecht, behaalde. Van 1991 tot 1996 was zij werkzaam als AIO bij de vakgroep privaatrecht van de Universiteit Maastricht. Bij dezelfde vakgroep is zij sinds mei 1996 universitair docent handels- en ondernemingsrecht. 
